\title{
A CATSKILL FLORA AND \\ ECONOMIC BOTANY
}

\section{IV (PART 2.) POLYPETALAE SARRACENIACEAE through LEGUMINOSAE}

\section{Including}

Pitcher-plant, Sundew, Stonecrop, Foam Flower, Currants, Gooseberries, Saxifrage, Witch-hazel, Sycamore, Avens, Hawthorn, Cinquefoil, Cherries, Apple, Roses, Brambles, and Legunes

\author{
KARL L. BROOKS
}

Bulletin No. 454

New York State Museum

The University of the State of New York THE STATE EDUCATION DEPARTMENT

Albany, New York 12230 


\section{LIBRARY}

THE NEW YORK BOTANICAL GARDEN

BRONX, NEW YORK 10458 
A CATSKILL FLORA AND ECONOMIC BOTANY

IV (PART 2). POLYPETALAE

SARRACENIACEAE through LEGUMINOSAE

Including

Pitcher-plant, Sundew, Stonecrop, Foam Flower, Currants, Gooseberries, Saxifrage, Witch-hazel, Sycamore, Avens, Hawthorn, Cinquefoil, Cherries, Apple, Roses, Brambles, and Legumes

Karl I. Brooks

Bulletin No. 454

New York State Museum

The State Education Department does not discriminate on the basis of age, color, creed, disability, marital status, veteran status, national origin, race, or sex in the educational programs and activities which it operates. This policy is in compliance with Title IX of the Education Amendments of 1972. Inquiries concerning this policy may be referred to the Department's Affirmative Action Officer, Education Building, Albany, NY 12234.

The University of the State of New York

The State Education Department

Albany, New York 12230 


\section{DEDICATION}

My studjes of the Catskill flora

are dedicated

to my good wife

MARGUERITE 
Digitized by the Internet Archive in 2017 with funding from IMLS LG-70-15-0138-15 


\section{EDITOR'S PREFACE}

This is the work of an amateur botanist whose many years of collection and study of Catskill plants make him the person most qualified to produce such a treatment in the tradition of the old herbals. We at the Botany Office of the New York State Museum feel that this type of publication is a useful adjunct to our efforts to produce a comprehensive state flora. The author's intimate knowledge of the area and its plants makes this a valuable work for those who are native to the Catskills as well as for the many summer visitors. Medical and food uses of plants, though often only of historical interest, round out the treatment, and make this publication what it is intended to be--a source book for those interested in reading and learning about the Catskill flora. Indeed, since the vast majority of the plants discussed are widely distributed throughout the northeastern states and adjacent Canada, this work should also be of interest far beyond the narrow confines of the Catskill region.

\section{IMPORTANT NOTE}

All economic uses, folklore, medical and pharmaceutical notes, uses as foodstuffs, etc., are compiled from the literature and do not represent an endorsement by the author or the New York State Museum. Some of the uses may, indeed, be dangerous if incorrectly employed. Some are not effective and are presented for historical interest only. 

The Catskills have long been known for their unusual beauty, healthful climate, and their natural resources for recreation, not the least of which is their abundant wildlife and in some respects a unique flora. While it is true that a large percentage of the plants growing naturally in the Catskills also occur throughout most of the northeastern states and adjacent Canada, many species are rare, only locally abundant, or do not occur elsewhere in the eastern states. Some are northern elements found only on the high peaks, and others appear to have been stranded in isolated areas following the retreat of the last glacier some 10,000 years ago. But whether rare in distribution or more abundantly widespread, no plant is completely devoid of interest, and many have had a long and varied association with man that goes back over many millennia.

A study of the flora of any region can be a richly rewarding experience, and that of the Catskills is no exception. Simply getting to know what plants grow in a particular area brings one closer to an understanding of the wonders of nature, but it has long been my contention that just knowing a plant by name is only the beginning. What is its relationship to other plants, both wild and cultivated? Of what value is it to man and to wildlife? Is it edible, a source of dye, useful as a medicine, or is it just an obnoxious weed? How can it be prepared for the table? For what was it prescribed? How can one get rid of it? Answers to such questions not only lead us down many intriguing paths, but also contribute much to our understanding of the intricacies of the biosphere.

My work on the Catskill flora during the last quarter of a century has therefore a three-fold objective: (I) to determine precisely what species grow in this area, (2) to chart the known distribution of each species in the Catskills, and, (3) for each, to collect as much information as possible concerning its value to man and to wildlife. These objectives have led to many hours of work in the field collecting specimens and making observations of the plants seen plus countless others in libraries and herbaria to obtain information on their distribution and use.

This work was written primarily for the serious amateur with a desire to know more about the plants growing in the northeastern states and adjacent Canada, with particular emphasis upon those occurring in the Catskills. In these times of increasing concern for man's impact upon the environment, the dwindling food supply in relation to increased population pressure throughout the world, inflation, and the rising desire of a large segment of the people to return to fundamentals, as it were, it is hoped that the emphasis given to economic botany, and to the importance of our native flora to wildlife, will fill a basic need. So far as the writer is aware, this is the first time that detailed information on food, drug, and dye plants has been assembled in a compilation that includes the common weeds as well as the more obscure components of our flora such as the grasses and sedges, which most popular field guides ignore completely. 
A work of this nature could not have been completed without the help and encouragement of a number of people. My wife, Marguerite, has borne the brunt of my numerous idiosyncrasies, both as a constant companion in the field and as a demanding editor and critic. The late Stanley J. Smith, Curator of Botany at the New York State Museum, not only spent countless hours checking my specimens and graciously permitted access to the state's records on plant distribution but has also been mentor and companion in the field on many occasions, to say nothing of his continuing advice and encouragement for over a quarter of a century. In addition to supplying moral support and companionship in the field, Paul Huth, who fell heir to the Domville-Dunbar records of the Ulster County flora, was kind enough to check through several thousand cards to extract information pertaining to collections and observations made in the Catskill region of that county. In addition, mention must be made of the work of Robert Dirig and Spider Barbour, who have contributed a number of important records.

More than thanks are due to Elizabeth G. Hall, formerly librarian at The New York Botanical Garden, whose vast knowledge of botanical source material seems inexhaustible and whose boundless enthusiasm is infectious. She has been unfailing in digging out elusive books and suggesting sources of information in addition to supplying many details concerning earlier workers in the firld. Special thanks are due to Richard S. Mitchell, State Botanist, for his editorial services and his painstaking work in guiding this series of bulletins through the press, to say nothing of his continued interest and encouragement. Charles J. Sheviak, Curator of Botany at the New York State Museum, has earned the writer's gratitude by making the services of his office readily available. The writer is likewise indebted to $J$. Kenneth Dean, a staff member of the Botany Office at the New York State Museum, for numerous courtesies, including checking out a number of critical specimens. Librarians at both the Horticultural Society of New York and at the New York Botanical Garden have also been most helpful. Last, but in no way least, thanks are due to Patricia Holmgren, herbarium supervisor and administrator of the phanerogamic herbarium at The New York Botanical Garden, and to George Kalmbacher, curator at the Brooklyn Botanic Garden, for permission to check specimens in the herbaria at those institutions.

The writer gratefully acknowledges his debt to the following authors and publishers for permission to reproduce illustrations from their works; the source of each illustration is identified in the caption accompanying the illustration: Ribes rotundifolium, $p .31$ in the following text, is reproduced from Recognizing Native Shrubs by William Carey Grim, copyright 1966, by permission of The Stackpole Company, Harrisburg, $\mathrm{Pa}$.; seven illustrations are reproduced from Trees of New York State by H. P. Brown, copyright 1975, by permission of Dover Publications, Inc., New York, and one figure is reproduced from All About Weeds by Edwin Rollin Spencer, copyright 1957, also by permission of Dover Publications, Inc., New York. To the Cranbrook Institute of Science the writer is indebted for permission to reproduce 19 figures from Shrubs of Michigan by Cecil Billington (Bulletin 20, 2d ed.), copyright 1949, and 12 plates from Michigan Wildflowers by Helen V. Smith, copyright 1979, both publications of the Cranbrook Institute of Science, Bloomfield Hills, Mich. The Macmillan Publishing Company, Inc., New York, has granted permission to reproduce Sedum triphyllum (Sedum telephium ssp. purpureum on $\mathrm{p}$. 15 of the text that follows) from Weeds, rev. ed., by W. C. 
Muenscher. Copyright 1935, 1955 by Macmillan Publishing Co., Inc., renewed 1963 by Walter Conrad Muenscher. The figure of Lotus corniculatus on $p$. 171 of the following text is also used by permission of Macmillan Publishing Co., Inc., from WildIy Successful Plants by Lawrence J. Crockett, copyright 1977 by Lawrence J. Crockett. Last, but by no means least, the writer wishes to acknowledge his indebtedness to The New York Botanical Garden for permission to use five illustrations from Volume II of The New Britton and Brown Illustrated Flora of the Northeastern United States and Adjacent Canada by Henry A. Gleason, copyright 1952.

Karl I. Brooks

Brooklyn, New York

7 May 1983 

CONTENTS

SARRACENIALFS, 1

SARRACENIACEAE, the Pitcher-plant Family. . . . . . . . . . . . . I

Sarracenia (Pitcher-plant) . . . . . . . . . . . 1

DROSERACEAE, the Sundew Family. . . . . . . . . . . . . . . 4

Drosera (Sundew) . . . . . . . . . . . . . . . 4

PODOS TFMALES, 8

PODOSTEMACEAE, the Riverweed Family . . . . . . . . . . . . . 8

Podostemum (Riverweed) . . . . . . . . . . . . . 8

ROSALES, 9

CRASSULACEAE, the Orpine Family ................. . 10

Sedum (Stonecrop)...................... 10

SAXIFRAGACEAE, the Saxifrage Family . . . . . . . . . . . . . 17

Chrysosplenium (Golden Saxifrage). . . . . . . . . . . . 17

Mitella (Bishop's-cap) . . . . . . . . . . . . . . 19

Penthorum (Ditch Stonecrop). . . . . . . . . . . . . 20

Philadelphus (Mock Orange) . . . . . . . . . . . . . . 22

Ribes (Currant, Gooseberry). . . . . . . . . . . . . . 23

Saxifraga (Saxifrage). . . . . . . . . . . . . . . . 33

Tiarella (Foamflower). . . . . . . . . . . . . . 36

HAMAMELIDACEAE, the Witch-hazel Family. . . . . . . . . . . . 37

Hamamelis (Witch-hazel). . . . . . . . . . . . 38

PLATANACEAE, the Sycamore Family. . . . . . . . . . . . . . 41

Platanus (Sycamore)... . . . . . . . . . . . . 44

ROSACEAE, the Rose Family . . . . . . . . . . . . . . . 46

Agrimonia (Agrimony) . . . . . . . . . . . . . . . 52

Amelanchier (Shadbush) . . . . . . . . . . . . . 52

Crataegus (Hawthorn) . . . . . . . . . . . . . . . 59

Dalibarda (False Violet) . . . . . . . . . . . . . 69

Filipendula (Meadow-sweet) . . . . . . . . . . . . . 70

Fragaria (Strawberry). . . . . . . . . . . . . . 72

Geum (Avens) . . . . . . . . . . . . . . . . 77

Potentilla (Cinquefoil). . . . . . . . . . . . 84 
Prunus (Cherry, Peach, Plum) . . . . . . . . . . . 93

Pyrus (Apple, Pear, Chokeberry, Mountain-ash)........ . 109

Rosa (Rose). . . . . . . . . . . . . . . . . 122

Rubus (Bramble)................... . . 134

Sorbaria (False Spiraea) . . . . . . . . . . . . . 150

Spiraea (Spiraea). . . . . . . . . . . . . . 150

Waldsteinia (Barren Strawberry). . . . . . . . . . . 153

IEGUMINOSAE, the Pea Family . . . . . . . . . . . . . 154

Amphicarpa (Hog Peanut). . . . . . . . . . . . 156

Apios (Ground-nut) . . . . . . . . . . . . . 158

Baptisia (Wild Indigo) . . . . . . . . . . . . . 161

Coronilla (Crown-vetch). . . . . . . . . . . . . 162

Desmodium (Tick-trefoil) . . . . . . . . . . . . 163

Lathyrus (Perennial Pea) . . . . . . . . . . . 166

Lespedeza (Bush-clover). . . . . . . . . . . . . 168

Lotus (Deer-vetch) . . . . . . . . . . . . . 170

Lupinus (Lupine) . . . . . . . . . . . . . . . . . 172

Medicago (Black Medic, Alfalfa). . . . . . . . . . . . 173

Melilotus (Sweet Clover) . . . . . . . . . . . . 176

Robina (Locust). . . . . . . . . . . . . . . 180

Trifolium (Clover) . . . . . . . . . . . . . 185

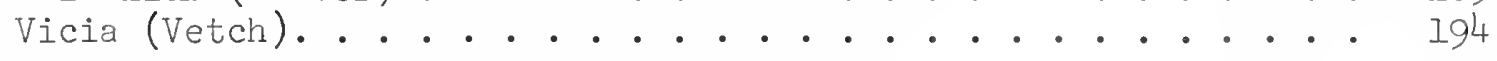

REJECINDAE. . . . . . . . . . . . . . . . . . . . . 199

LIST OF ABBREVIATIONS . . . . . . . . . . . . . . . . 201

GLOSSARY OF TECHNICAL TERMS . . . . . . . . . . . . . . . 203

REFERENCES. . . . . . . . . . . . . . . . . . . . 207

APPENDIX. . . . . . . . . . . . . . . . . . . . 215

ADDENDUM • . . • . . . . . . . . . . . . . . . . . . 277

INDEX. . . . . . . . . . . . . . . . . . . . . 279 


\section{SARRACENIÀLES}

This is an order of herbaceous insectivorous plants comprising three families. In addition to our two families, a third, the Nepenthaceae, a unigeneric family of about 60 old-world species, occurs primarily in tropical Asia and Malaya. They are vines that produce showy pendant pitchers from the ends of alternate leaves, of which a number of species are cultivated in greenhouses and conservatories as novelties. Cronquist (1968) places this order in his subclass Dilleniidae, which also includes such orders as the Malvales, Violales, Salicales, Capparales, Primulales, and Ericales, orders that "evidently hang together as a natural group," even though he admits that the "group cannot be fully characterized morphologically." The Sarraceniales "as here defined consists of three well marked small families, scarcely 200 species in all," including Droseraceae and Sarraceniaceae, both of which are represented in the Catskill flora. He states that while "The mutual affinity of the three families has been affirmed and denied by different authors," he is "more impressed by the similarities than by the admitted differences," and feels that their ancestry "is to be found in the Theales," an order containing 13 families, including the Guttiferae (Hypericaceae).

\section{Key to Catskill Families of Sarraceniales}

1. Style I, umbrella-shaped; leaves modified into large water-holding

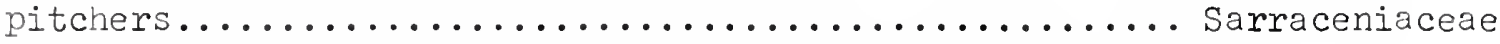

1. Styles as many as the carpels, often deeply divided; leaves covered by stalked glands, not pitcher-shaped or tubular... Droseraceae

\section{SARRACENIÀCEAE, the Pitcher-plant Family}

This is a family of three genera and 14 species of herbaceous newworld bog plants with rosulate tubular leaves forming "pitchers" in which insects become entrapped to drown in the accumulated rainwater at the bottom. The pitchers secrete an enzyme that mixes with the water and hastens the disintegration of the trapped insects. Nine species belong to Sarracenia, a genus of eastern North America. Darlingtonia occurs in California and Oregon, while Heliamphora is restricted to the higher mountains of Venezuela. The family is of special interest because of the insectivorous nature of its plants but is of no significant value, although some species are sometimes cultivated as novelties.

\section{Sarracènia L. Pitcher-plant.}

There are about 10 species of pitcher-plants, a North American genus chiefly of swamps and bogs on the coastal plain from North Carolina to Florida and Texas. The name of the genus commemorates Dr. Michel Sarrasin de I'Étany, 1659-1734, a Canadian physician and naturalist of Quebec who introduced $\underline{S}$. purpurea into Europe some 300 years ago. They are yellowish, green, or purplish bog plants, the radical hollow leaves bearing a wing on one side and a rounded arching hood at the apex. They are curious, yet 
attractive, insectivorous plants sometimes grown in bog gardens and greenhouses for their handsome pitcher-like leaves and curious flowers. In some species the stemless pitchers, attached to slender creeping rhizomes, are only 2 inches high, whereas others may stand more than 2 feet high, the color varying from green to yellow, red, crimson, and purple, often streaked or blotched with contrasting colors. The ornamental flowers, produced when the plant is several years old, are borne on slender leafless stalks that rise from the croms of the plants. The cup-shaped flowers are five-petaled and range in color from greenish-yellow to crimson, greenish-purple, and purple.

Insects alighting on the vividly colored pitchers are enticed to explore by minute drops of a honey-like substance secreted by glands on the lids. Intermingled with the honey glands are downward-pointing hairs, which lead the insect to a slippery area. This offers no foothold and it is thus precipitated into the water at the base of the pitcher. Exit is barred by downward-pointing hairs and it soon perishes, as the fluid in the pitcher has a ready wetting power so that the insect quickly becomes submersed and drowns.

The U.S. Dispensatory of 1865 states that the rizizomes of two southern species, $\underline{S}$. flava and $\underline{\underline{S}}$. variolaris, have long been regarded by the inhabitants of coastal south Carolina as a domestic remedy believed "to possess extraordinary powers in dyspepsia," sick headache, abdominal distension, and other disorders. Invalids chewed the root as they would chew tobacco. From the reports of a physician of that region, the editors of that volume inferrea that "the medicine is a stimulating tonic, with some tendency to act on the brain; and probably well suited to cases of dyspepsia dependent on debility of the stomach." It was thought to stimulate both the stomach and the circulatory system and at the same time to act somewhat as a diuretic as well as being "disposed to operate mildly on the bowel.s."

Sarracènia purpürea I. Pitcher-plant.

Meaning of Species Name. Purple.

Other Names. Sidesaddle-flower, Huntsman's-cup, Indian-cup, Indianjug, Indian-pitcher, Adam's-cup, Adam's-pitcher, Forefathers'-pitcher, Forefathers'-cup, Whippoorwill's-boots, Whippoorwill's-shoes, Skunk Cabbage, Watches, Foxglove, Smallpox-plant, Fly-trap, Meadow-cup, Meadowpitcher, Fever-cup, Fever-pitcher.

Troe or plant. A perennial insectivorous herb.

Habitat. Sphagnum bogs and peaty barrens.

Range. Lab to Sask and Mack, s to INJ, Del, Md, Pa, O, Ind, IIl, and Minn.

Distr in IVIS. Comon across the $n$ part of the state, through the $c$ and $w$ counties; less common southw and absent from those secs where no sphagnum bogs are found.

Distr in the Torrey Range. Common throughout the area in eaphically favorable situations except on the unglaciated portion of the Piedmont plateau, there rare or wanting.

Time of Fl. Late May-Aug; Jun 10-30 at Cornel1.

origin. Native. 


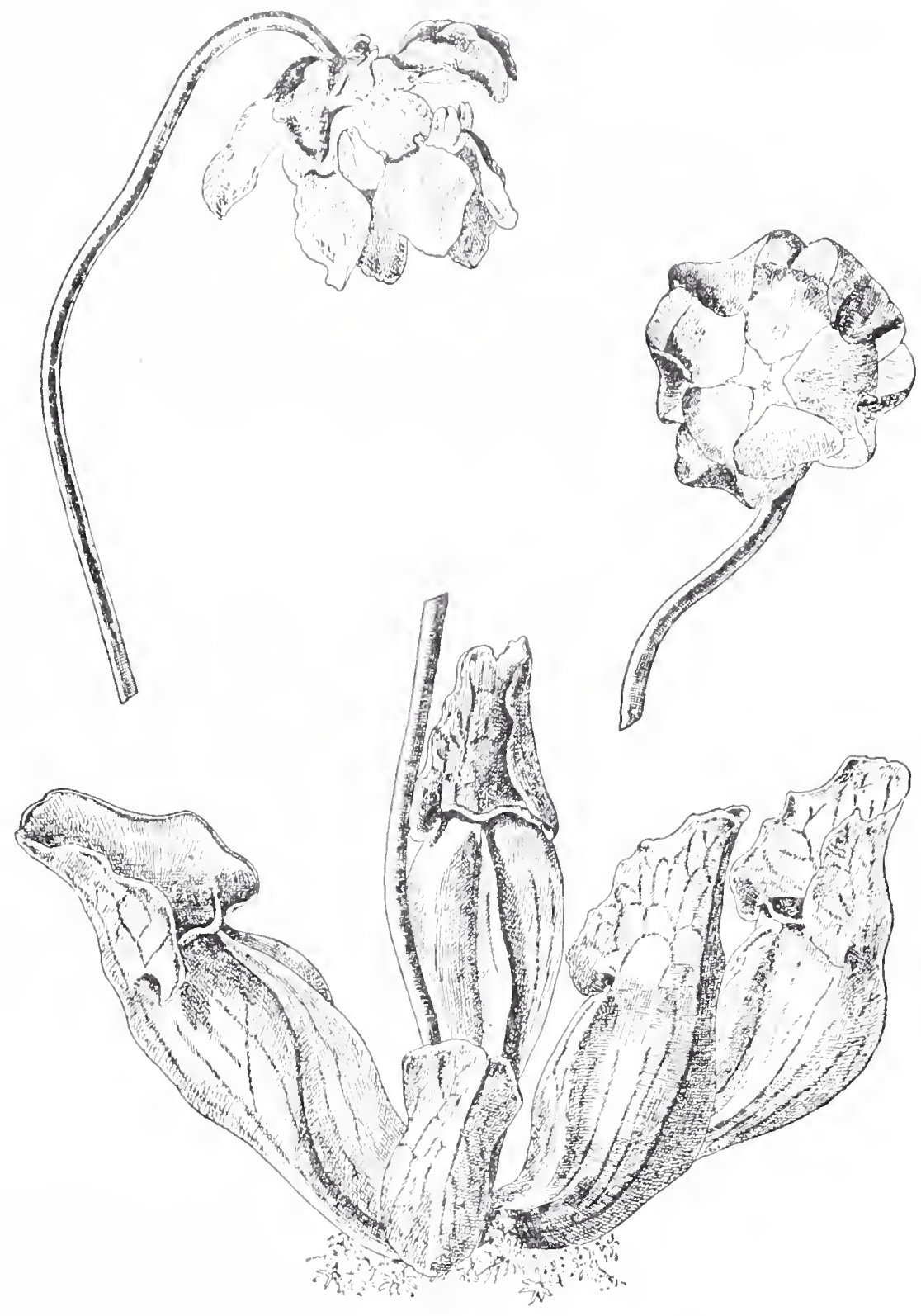

Sarracenia purpurea--Pitcher-plant

[From Dana (1900), Plate 133, p. 304.]

During the last century, and probably before, this plant was regarded by many Indian tribes of Canada and the Great Lakes region as a specific cure for smallpox. They believed that the use of the root not only greatly shortened the run of the disease and checked maturation but prevented deep pitting in convalescence. Millspaugh (1887) reports that when an epidemic of the dreaded disease broke out in Canada during the midale of the last century, the alarm was "greatIy diminished on an old squaw going amongst them, and treating the cases with ... [an] infusion [of the roots of $\underline{S}$. purpurea]. This treatment, it is said, was so successful as to cure every case." A British surgeon corroborated the Indians' view with regard to the effectiveness of this plant in treating smallpox when in 1861 he delivered a paper in London describing his experiences in Canada. 
Nevertheless, physicians of that period did not accept this drug because, as Millspaugh remarks, "in almost all instances," it proved to be "an absolute failure in the hands of the "old school." "The root was also recommended for treating kidney ailments and "torpidity of the organs of the alimentary tract," but it never became an official drug. The editors of the U.S. Dispensatory of 1865 remarked that "subsequent experience has fully determined its entire want of any curative influence over that disease," but Millspaugh concluded his discussion of this plant with the statement that "This ... again corroborates the aborigine's use of the drug, and adds one more proof to the many that are tending to reveal the fact that our American native practice was essentially correct." This species is now protected throughout New York State and should not be disturbed in any way.

\section{DROSERȦCEAE, the Sundew Family}

This is a family of 4 .genera and perhaps 90 or 100 species of annual and perennial glandular herbs or rarely subshrubs of mostly insectiverous bog plants, among which is Dionaea, the Venus Fly-trap, a monotypic genus of North and South Carolina. Drosera is the largest genus, most abundant in Australia but represented by a few species in most regions of all continents. In the United States $\underline{D}$. rotundifolia occurs in all but the southwestern section while $D$. intermedia is more boreal in distribution. Some authors have placed this family in the Parietales but others included it in the Sax ifragaceae. In many respects plants of the Droseraceae are similar to those of the Lentibulariaceae, but the similarity results from parallel development rather than phyletic relationship. This family is of little economic significance, although the Venus Fly-trap is sold in the trade as a novelty. The leaves of Drosera yield a purple or violet dye, once of commercial importance.

\section{Drósera I. Sundew.}

There are about 100 species of sundew, most abundant in Australia and South Africa but occurring also in South America and Eurasia as well as in North America. The name of the genus is derived from the Greek droseros, dewy, referring to the clear glutinous fluid, exuded by the leaf glands, which glitters like dewdrops in the sun. Our species are low perennials or biennials, but the most extraordinary development of this genus is attained in South Africa and Australia where occur tall plants attaining a height of 3 feet with wiry stems that climb by means of adhesive leaf blades. our plants form rosettes of leaves, close to the ground, which vary in shape among the different species, some being round while others are long and narrow. The small white, pink, or crimson flowers are borne in loose clusters at the ends of slender stalks arising from the centers of the leaf rosettes. Reproduction takes place not only by means of seeds but also by leaf buds which normally spring from the bases of the tentacles, particularly on leaves that have become detached.

All species are carnivorous. They catch their prey by means of tentacles that grow in a regular pattern from the upper surface of the leaf blade. As many as 400 have been counted on a single leaf of $\underline{\text {. rotundifolia }}$ less than $1 \mathrm{~cm}$ in diameter. The tentacles stand distinctly separated and 


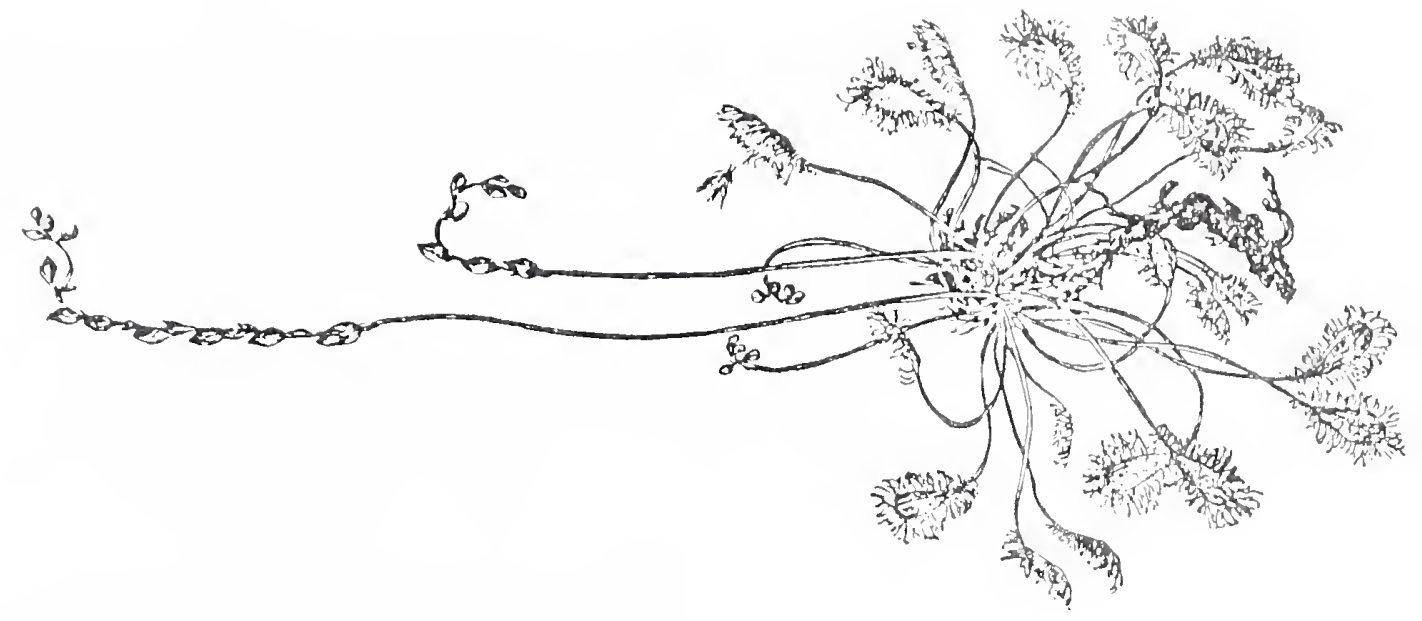

3
0
3
3
0

गें

$\rightarrow \infty$

(1)

ने

홍

엄

ल.

.

त्t

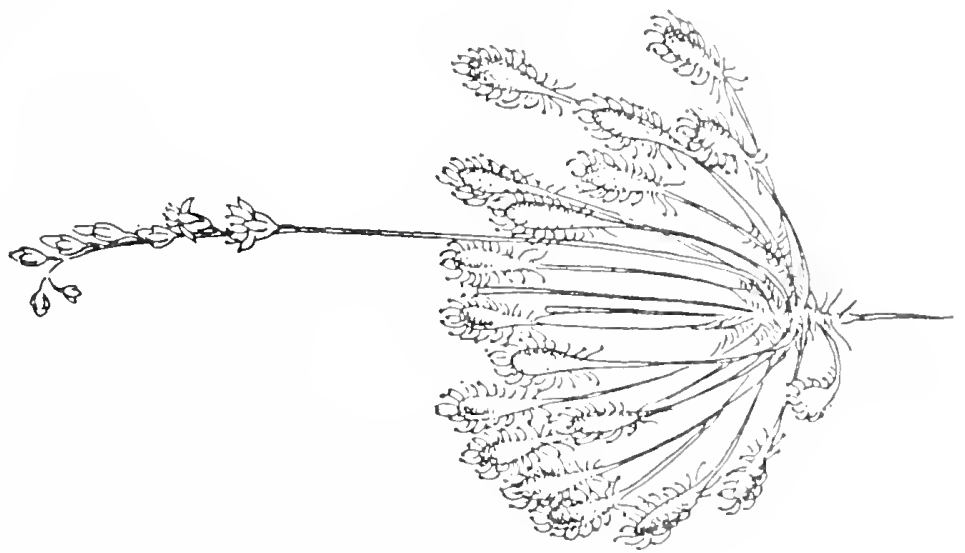


vary in size, those of $\underline{D}$. rotundifolia being shorter in the middle and much longer near the leaf margins. Each gland at the tip secretes and supports a droplet of sticky fluid which, in multiple, gives the leaf a dewy appearance, hence the common name.

These tentacles are capable of motion. Darwin was the first to make extensive experimental studies on the matter. When a small insect alights on a leaf, its escape is prevented by the sticky fluid, which smears and smothers it during its struggles to escape. The presence of an insect acts as a stimulus to neighboring tentacles, which bend toward the prey and attach themselves to it, bringing a larger contact surface to bear. A digestive enzyme is then secreted by stalkless glands which dissolves the content of the prey. The products of this digestion are then absorbed by the same glands. The movements of the tentacles are complex, but the net result is to bring the body of the insect toward the midale of the leaf, which itself can bend to surround its prey.

Some species are sometimes grown as botanical curiosities, either in boggy places out of doors or in the greenhouse. Outside, a sunny positio: is necessary. Unless the atmosphere can be kept constantly moist when growing them inside, it is advisable to cover the plants with a large bell jar.

The leaves of the sundews, like rennet, have the power of "setting" milk to make a sort of custard similar to junket. In the words of Manasseh Cutler, "If the juice [of the leaves] be put into a strainer, through which the warm milk from the cow is poured, and the milk set by for a day or two to become acrescent it acquires a consistency and tenacity neither the whey nor the cream will separate. In this state it is used by the inhabitants of the north of Sweden, and called an extremely grateful food." As another writer remarked, "It makes milk solid, but sour like bonyclabber." Not only are sundews protected by law in New York State, but they are so rare in the Catskills that they should be carefully protected wherever they are found.

\section{Key to Local Species of Drosera}

1. Leaves orbicular or broader than long; petioles hairy; rosette

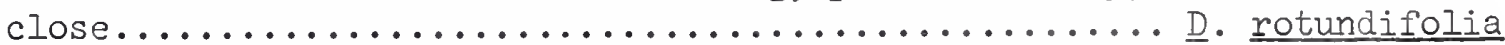

1. Leaves spatulate, tapering into the slender petiole; petioles

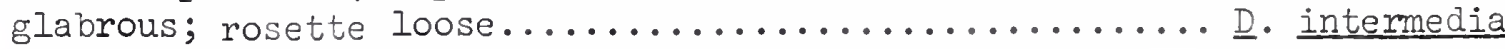

Drósera intermèdia Hayne. Spatulate-leaved Sundew.

Meaning of Species Name. Intermediate.

Other Names. Sundew, Daily-dew.

Type of Plant. A low perennial or biennial insectivorous herb.

Habitat. Wet acid peat and sand.

Range. If to Ont, s to SC, Tenn, O, Ind, Ill, and Minn; on the coastal plain to Fla and Tex.

Distr in NYS. Common across the $n$ part of the state; less frequent southw to Dutchess, Chenango, Tompkins, and Erie co; also on II.

Distr in the Torrey Range. Throughout our area in edaphically favorable places except on the unglaciated part of the Piedmont plateau, there 
rare or wanting.

Time of Fl. (Jun) Jul-Aug; Jul 10-Aug 20 at Cornell.

Qrigin. Native.

Drósera rotundifòlia L. Round-leaved Sundew.

Meaning of Species Name. Round-leaved.

other Names. Round-leaved Dew-plant, Eyebright, Rosc-solis, Youthwort, Moor-grass, Red-rot, Lustwort.

Trpe of Plant. A low perennial or biemial insectivorous herb.

Habitat. Peaty or moist acid soils of bogs and swamps.

Range. Gl and Lab to Ak, s to SC, Ga, Fla, Ala, Tenn, O, Ill, Minn, Mont, and Cal; also in Eurasia.

Distr in NYS. Common northw and on LI, but less frequent in the

Susquehanna reg and not reported from the Chemung valley; frequent westw in the state.

Distr in the Torrey Range. Throughout the range in edaphically

favorable places.

Elevation. Grows to 2500 ft in the Catskills.

Time of $\mathrm{Fl}$. Jun-Aug(Sep); Jul 15-30 at Cornell.

Origin. Native.

Remarks. Parts of the flower are sometimes transformed into small green leaves.

This species, the only one used in medicine, was supposed during the l6th century to be a curative of consumption, but on that score Gerarde remarks that "it hath ... been observed that they have sooner perished that used the distilled water hereof, than those that abstained from it and have followed the right and ordinary course of diet." Later authorities considered it a valuable pectoral, "useful in pulmonary ulceration and in asthma," different kinds of coughs, and other diseases of the lungs. One physician observed that "Drosera is one of the most powerful medicinal agents in our country. It was formerly used externally, but without success, in cutaneous affections, and it seems to have been taken with greater advantage internally. Modern practitioners who, according to custom, have tried only large doses, have not ventured upon giving it internally, fearing to kill their patients, and have therefore rejected it." Millspaugh (1887), on the other hand, stated that "Drosera asserts altogether a peculiar action upon the lungs and, in fact, the whole respiratory tract, thus leading us to value it deservingly in pertussis, bronchial irritation and even phthisis, where in fact it gives many a patient a restiul night and more peaceful day when the disease is too far advanced for still greater benefit." At one time it was used in the treatment of whooping-cough as well as having been advocated as a cure for old age, when an extract was used "together with colloidal silicates in cases of arteriosclerosis." A tincture was prepared by pounding the fresh leaves to a pulp, pressing out the juice, and adding an equal part by weight of alcohol. This mixture was put away in a vell-stoppered bottle and allowed to stand 8 days in a dark, cool place, after which the liquid was filtered out.

Boiled with ammonia, sundew leaves have been used to produce a yellow dye. After straining the dye bath, the wool was boiled in the resulting liquid for half an hour to obtain the desired color. 


\section{PODOSTEMÀIES}

PODOSTEMÅCEAE, the Riverweed Family

Engler treated this taxon as a primitive suborder of the Rosales until 1936, when he considered it to be even more primitive, making it, according to Lawrence (1951), "the terminal order of the line containing the Fagales and Urticales." Most botanists consider it "a highly reduced aquatic ..., presumably with rosalian affinities," but there are many reasons for placing this family in a separate monotypic order, as does Cronquist (1968). Maheshwari concluded in 1945 that it is "almost certain that the Podostemaceae are much reduced apetalous derivitives of the Crassulaceae," while Cronquist observes that "the Podostemales are related to the Crassulaceae and/or the Saxifragaceae, in the Rosales." In any case this is a moderatesized family of between 20 and 40 genera (depending on the authority consulted) and 140 to 200 species of pantropical distribution (most numerous in South America) but with a few extensions into the temperate regions of all continents in both hemispheres. Members of this family can be identified by their occurrence in streams of running water, where they are attached to rocks, and by their mosslike or lichen-like appearance. These plants are of no economic importance, but their unusual life history provides an interesting study.

Podostemum Michx. Riverweed.

This is a genus of about 12 species of aquatic plants growing on stones in running water. Our one species much resembles a lichen. The other species are mostly tropical. The name of the genus is derived from the Greek pous or podos, foot, and stemon, stamen, alluding to the fact that the two stamens are apparently raised on a stalk by the side of the ovary.

Podostèmum ceratoph'jllum Michx. Threadfoot.

Meaning of Species Name. Horn-Ieaf, from the rigid or horny leaves. Type of Plant. A small fleshy, mostly annual, olive-green aquatic herb of firm texture.

Habitat. Firmly attached to loose stones in running water.

Range. NB, Que, and Me to Ont, s to NC, Ga, Miss, and Ark; reported from Minn.

Distr in NYS. Rare.

Distr in the Torrey Range. NY: In 1915 known only from near Newburgh, and then "not recently collected."

Time of $\mathrm{Fl}$. Jul-Sep.

Origin. Native.

Remarks. Rare, but often locally abundant. 


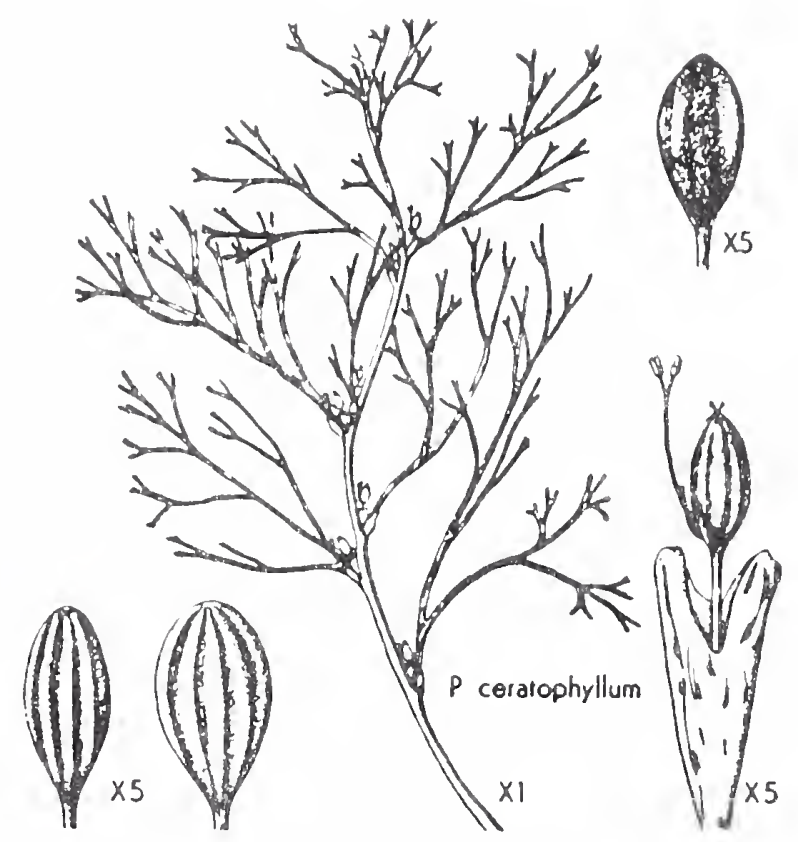

Podostemum ceratophyllum--Threadfoot [From Gleason (1952), Vol. II, P. 254.]

\section{ROSȦLES}

This is one of the largest and most important orders of flowering plants, including 17 families and some 23,000 species, cosmopolitan in distribution. As might be expected from such a large taxon, it exhibits a wide diversity of plant forms, from dwarf arctic herbs and submersed aquatics to woody vines, desert succulents, and tall trees. This order, characterized by the commonly numerous stamens and often numerous pistils, is generally regarded as a primitive one, not far removed from the Ranales, with which it shows many instances of striking parallelism.

This order was considered by Engler and Diels to be composed of 17 families distributed among two suborders, the Catskill families of which were distributed as follows:

\section{Saxifragineae}

Crassulaceae

Saxifragaceae

Hamamelidaceae

\section{$\underline{\text { Rosineae }}$}

Platanaceae

Rosaceae

Leguminosae

Cronquist (1968) places the Rosales in his subclass Rosidae ("evidentIy derived from the Magnoliidae"), which he defines as consisting "of 16 orders, 108 families, and about 60,000 species," comprising more than onethird of all the species of dicots, of which he remarks that "A third of the species in the subclass belong to the single order Rosales." Cronquist places 17 families, including nearly 20,000 species, in this order, about 13,000 of which belong to the Leguminosae, with another 5000 belonging to three other families, the Rosaceae, Crassulaceae, and Saxifragaceae. Other 
families placed in this order include Hydrangeaceae and Grossulariaceae. Cronquist's treatment of the Rosales can be considered as "conservative ... in recognizing only one family of legumes instead of three" and "more liberal in dividing the traditional family Saxifragaceae into three families." "In spite of the diversity of this group," he observes that "it is generally agreed that most of the families here referred to the Rosales are fairly closely related to each other." Adaing that the Rosales are "Clearly the most primitive order in their subclass," they have not only "been a prolific source of diversification within the angiosperms," but "they are directly or indirectly ancestral to some 15 other orders of the Rosidae, and possibly also to the whole subclass Asteridae."

From the traditional point of view, the Hamamelidaceae and the Platanaceae are conspicuous by their absence from the Rosales as conceived by Cronquist. These two families he places in his subclass Hamamelidae, along with the Fagales, Myricales, Juglandales, and Urticales (orders which have been discussed in Volume III of the present work). Of the Hamamelidae, he remarks that they constitute "a loosely knit group of dicots with more or less strongly reduced flowers," adding that although "It is clear that neither any one family nor any one order of the Hamamelidae can be regarded as ancestral to all the others," except for one primitive order, "The remaining orders [in this subclass] may all have been derived from the Hamamelidales."

From an economic standpoint the Rosales are among the most important of plant groups both by reason of the many food plants which it contains as well as its numerous ornamentals, to say nothing of numerous weeds.

CRASSULACEAE, the Orpine Family

This is a family of wide geographical distribution but occurring principally in the drier parts of south-central Asia, the Mexican highlands, South Africa, and the Mediterranean region, being almost entirely absent from Australia, Oceania, and South America. Criteria for the demarcation of genera and species are weak, resulting in the number of genera being estimated from few to 33 and the number of species from 500 to 1500 . Cronquist (1968) assigns about 1400 species to this group. They consist primarily of annul or perennial succulent herbs and shrubs. On the basis of morphological studies it was concluded that the family constitutes a natural group. This family is of economic importance only for its numerous succulents srown as ornamentals, including Sedum, Kalanchoë, Crassula, and Echeveria.

\section{Sèdum I. Stonecrop.}

There are about 500 species of Sedum, chiefly of the north temperate zone, but some extend south beyond the equator, many species favoring rocky or dryish soils. They are mostly smooth, fleshy-leaved perennials with alternate or imbricated leaves and flowers in broad to one-sided cymes. By some authorities the name of the genus is derived from the Latin sedere, to sit, alluding to the fact that many species of low spreading habit affix themselves to rocks or walls, while others derive its name from the Latin 
sedare, to quiet, in allusion to the supposed sedative properties of some species. Many species are cultivated as valued ornamentals, particularly in rock gardens, several of which have a tendency to escape. Other species are sometimes used as substitutes for grassy lawns on sunny slopes, and some make excellent house plants.

A number of species have been used as food plants. The leaves of $\underline{S}$. album, a native of Europe and northern Asia, have served as a salad, while

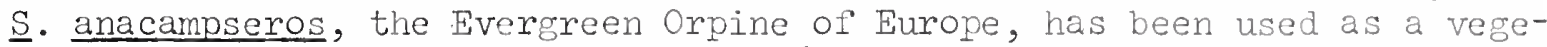
table in soup. Gerarde, writing in 1633, mentions the use of s. rupestre, another native of Europe and adjacent Asia, as a salad plant under the name sengreene, which he reported as having "a fine relish." As late as 1831 H. Philips reported that this plant was cultivated in Holland as a salad plant.

\section{Key to the Catskill Species of Sedum}

1. Flowers dioecious, rarely polygamous, the staminate yellow, the pistillate yellow to purplish; petals very narrow; follicles closely approximate and erect; rhizome thick and deep-seated, the erect or nearly erect flowering stems annual; a boreal or

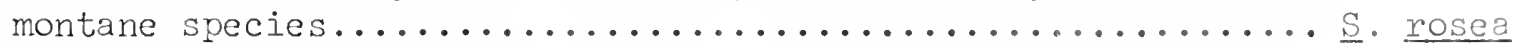

1. Flowers perfect, purplish, pink, white, or yellow; follicles divergent or ascending, 2

2. Leaves of flowering stems or branches terete or subterete and linear-cylindric or thick-ovoid and tightly imbricated, 3

3. Leaves tightly imbricated, narrowly ovoid, thickened at base; flowers yellow; depressed and matted plants....... S. acre

3. Leaves not tightly imbricated, linear-terete or subterete (perennials with evergreen leafy basal offsets; cymes rather compact, corymbiform, terminating simple stems), 4

4. Petals yellow (leaves opposite or whorled)..... S. sarmentosum

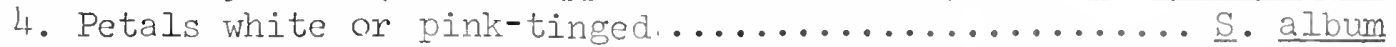

2. Leaves flat and dilated, spatulate to oblong or broader, 5

5. Depressed or matted plants with prostrate basal offshoots and slender upcurving flowering stems $0.5-2 \mathrm{dm}$ high; leaves of flowering stems $0.5-3.5 \mathrm{~cm}$ long (leaves entire; petals white; native woodland plants; lower leaves mostly in whorls

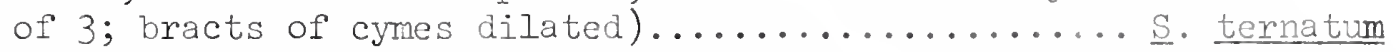

5. Erect or ascending cespitose plants with coarse flowering stems 1.5-8 dm high; larger elliptic, ovate, or obovate leaves 3-10 cm long; introd (petals deep purple to roseate; leaves mostly several-toothed, alternate to whorled) $\underline{S}$. telephium

\section{Sèdum ácre I. Mossy Stonecrop.}

Meaning of Species Name. Pungent-tasting.

Other Names. Wallpepper, Love-entangle(d), Biting Stonecrop, Bird's-bread, Creeping Jack, Creeping Charlie, Pricket, Golden-moss, Little Houseleek, Gold-chain, Wall-madam, Treasure-of-love.

Type of Plant. A matted, creeping evergreen perennial, reproducing

by stems rooting at the nodes, seldom by seeds. 

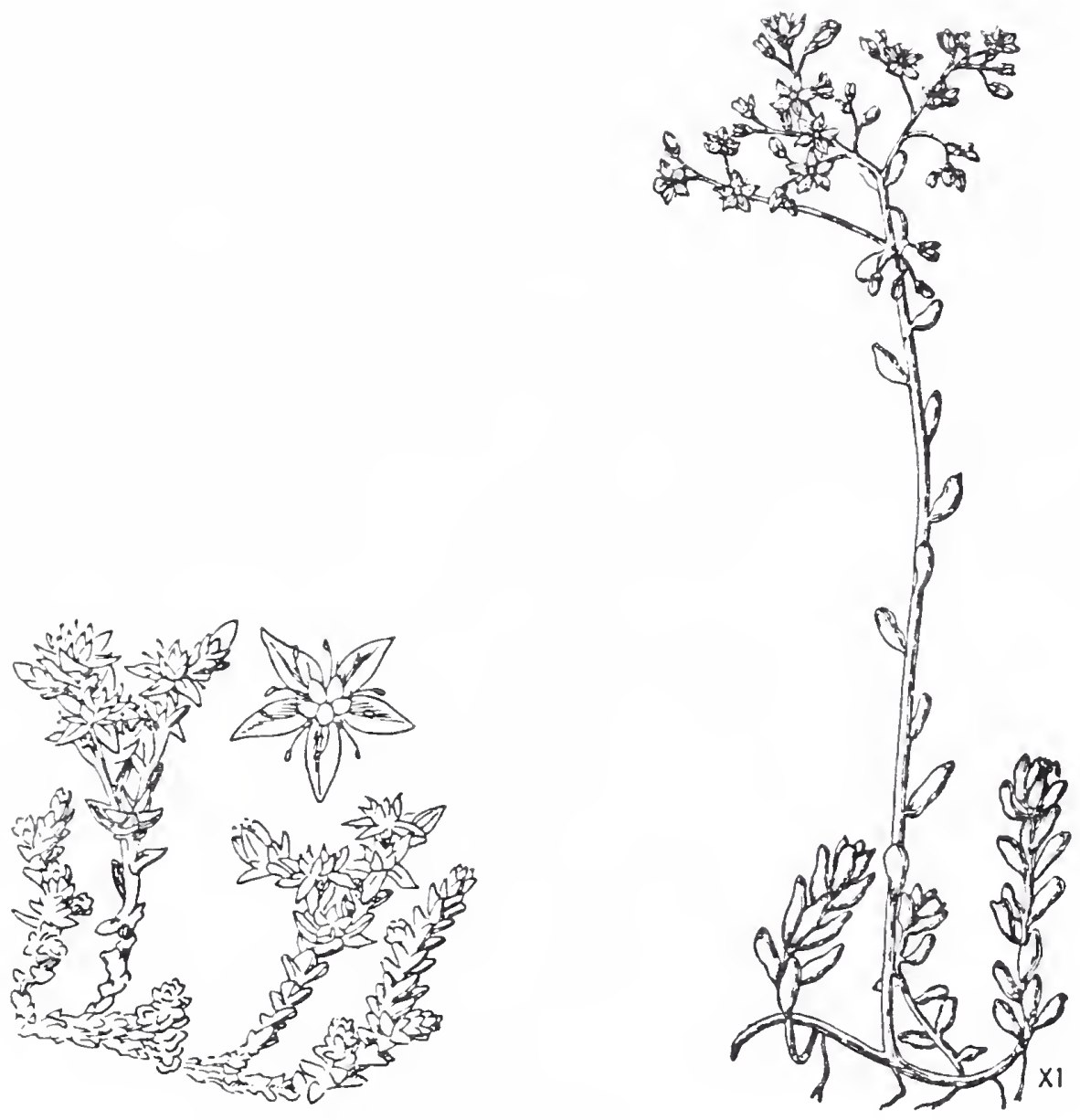

(Left) Sedum acre--Mossy Stonecrop

[From Smith (1966), Plate 74, p. 166.]

(Right) Sedum album--White Stonecrop

[From Gleason (1952), Vol. II, p. 258.]

Habitat. Stony ledges, rocky fields, walls, dry open places, old cemeteries, pastures, roadsides, and waste places.

Range. Que to Wash, s to NC, O, Ind, IIl, etc.

Distr in NYS. Frequent in cult and common in some secs as an esc, especially $w$ of Watertown and in some secs of the Hudson valley.

Distr in the Torrey Range. Occasional in most parts of our range except in the pine barrens, there rare or wanting.

Time of Fl. Jun-Jul(Aug); Jun 20-Jul at Cornell.

Origin. Natzd from Eu.

Remarks. Often cult and commonly esc.

This species is the Wall Pepper or Yellow Stonecrop of European cottage roofs and bears one of the showiest flowers of the genus, a species well worth growing in the rock garden. It was at one time used in medicine; taken internally it induces vomiting and purging, and, on being applied to the skin, it produces inflammation and vesication. The U.S. Dispensatory of 1865 states that "The fresh herb and the expressed juice have been used as an antiscorbutic, emetic, cathartic, and diuretic, and have been applied 


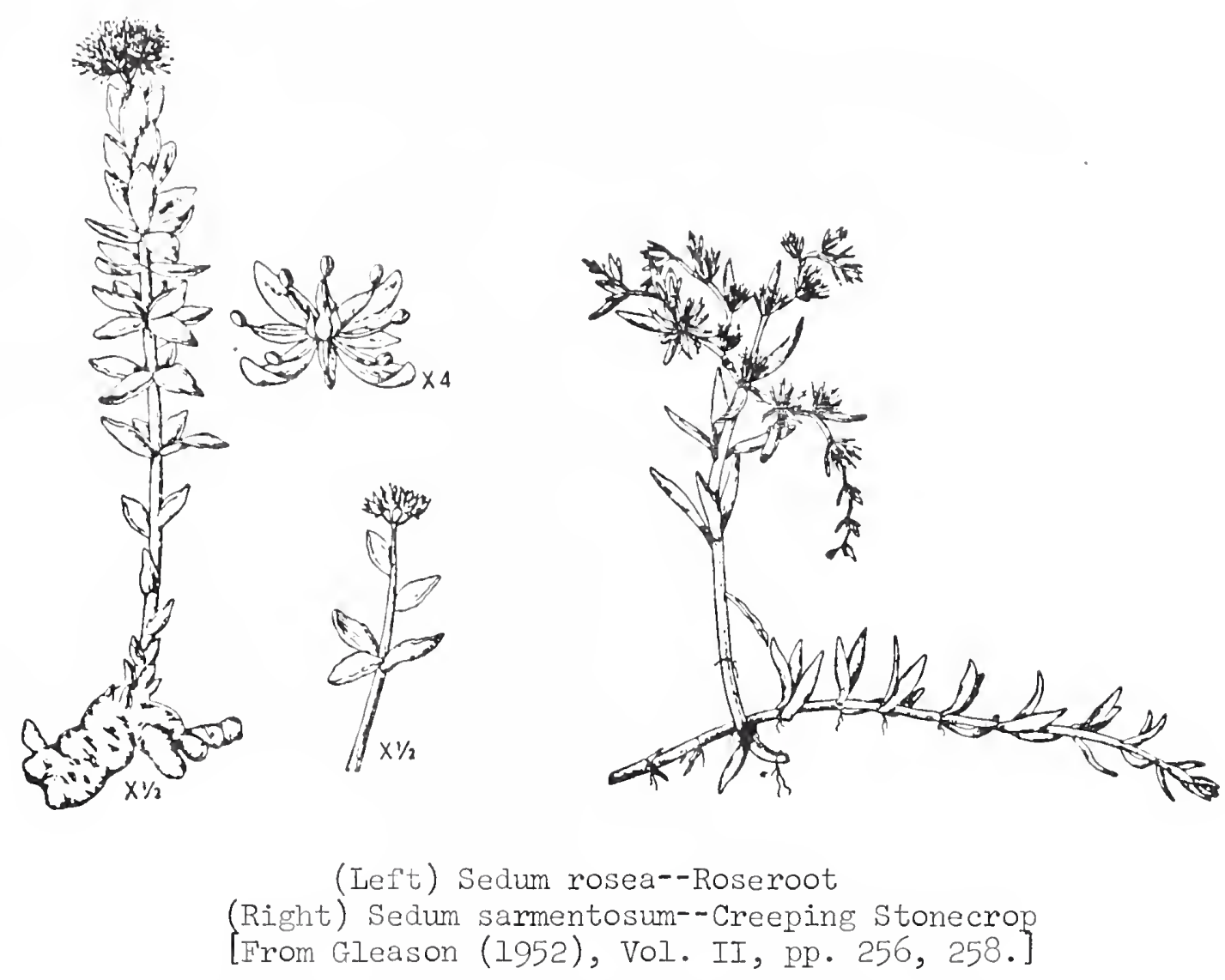

locally to old ulcers, warts, and other excrescences; but the plant is at present little employed." Johnson (1867) remarks that "In some old herbals it is recommended for dropsy, and more modern writers have borne testimony to its good effects in that disease, but it is probably inferior to the more usual remedies of the kind."

In areas where this species has become an obnoxious weed, it can simply be plowed or spaded under to destroy the plant. Muenscher (1952) suggests that the creeping stems can be raked from lawns, followed by an application of ammonium sulfate, after which the lawn should be watered well.

Sèdum álbum L. White stonecrop.

Meaning of Species Name. White, from the color of the flowers. Type of Plant. A perennial herb with creeping stems forming mats. Range. $\mathrm{NY}$ and e $\mathrm{Pa}$ to $\mathrm{O}$. Distr in NYS. Not listed in House (1924).

Distr in the Torrey Range. Not listed in Taylor (1915).

Time of Fl. Jun-Jul.

Origin. Introd from Eurasia.

Remarks. Esc from cult. 
Sèdum ròsea $\left(I_{0}\right)$ Scop. Roseroot.

Meaning of Species Name. An old name referring to the fragrant root, the Rosea radix of early apothecaries.

Other Names. Rosewort, Scurvy-grass.

Type of Plant. A perennial herb.

Habitat. Cliffs and ledges.

Range. Throughout subarctic Am and Eurasia, s, especially along the coast, to Me; inland and s locally to Vt, NY, and ne Pa; Roan Mt, NC; also in the $\mathrm{w}$ to $\mathrm{COI}$ and $\mathrm{BC}$.

Distr in NYS. In 1924 House stated that this species occurred localIy at Chittenango Falls, Madison co, Seneca I, and the Delaware water gap. Distr in the Torrey Range. In 1915 known only from Pike and Bucks co, $\mathrm{Pa}$, both near the Delaware river.

Time of $\mathrm{Fl}$. May-Jul(Aug).

origin. Native.

Remarks. A northern and subarctic species.

Fernald and Kinsey (1943) report that where abundant this species is an important salad plant in northern regions, owing to the scarcity of green vegetables in those areas. The succulent young leaves and stems are used in salads, and the older plants are cooked as greens up to the time they bear young fruits.

Sèdum sarmentòsum Bunge. Creeping Stonecrop.

Meaning of Species Name. Producing lithe runners.

Type of Plant. A slender perennial herb. woods.

Habitat. Dry or rocky soil of roadsides, waste ground, and open

Range. NJ and e $\mathrm{Pa}$ to $\mathrm{O}$.

Distr in NYS. Not listed in House (1924).

Distr in the Torrey Range. Not listed in Taylor (1915).

Time of Fl. Jun .

Origin. Introd from e Asia.

Remaris. Commonly cult for ornament and often esc near gardens.

Sèdum teléphium I. ssp. purpireum (Iink) Schinz \& Keller. Irive-forever.

Meaning of Species Name. For Telephus, son of Hercules; ssp. name, purple.

Synonyms. S. purpureum (I.) Iink in Fernald (I950); . telephium I. ssp. fabaria (Koch) Schinz \& Keller in Gleason (1952).

Other Names. Orpine, Garden-orpine, Frog-plant, Evergreen, Everlasting, Bog-leaves, Iife-of-man, Frog's-mouth, Frog's-bladder, Ireeks, Witches'-moneybags, Iive-long, Aaron's-rod, Midsummer-men.

Type of Plant. A coarse erect perennial herb, reproducing by fleshy tuber-like roots, stems rooting at the nodes, and rarely by seeds.

Habitat. Fields, old stony meadows, pastures, roadsides, banks, open woods, and waste places.

Range. If to Ont and Wis, s to Md and Ind.

Distr in NYS. Frequent or common in many secs of the state. 


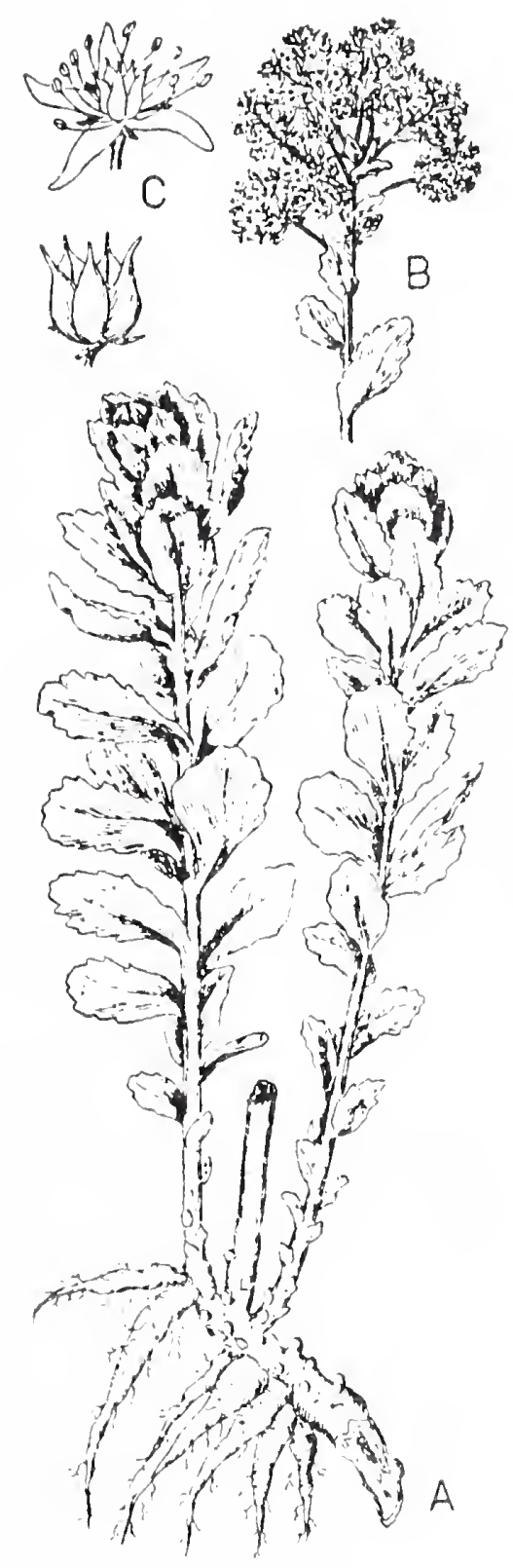

Sedum telephium ssp. purpureum--Live-forever

[From Muenscher (1952), Fig. 54, p. 284.]

Distr in the Torrey Range. A not uncommon adv in most parts of our range except in the pine barrens, there wanting.

Time of $\mathrm{Fl}$. Jul-Sep; Aug-Sep at Cornell.

Origin. Introd and natzd from Eu.

Remarks. Spread from cult and abundantly (often aggressively) natzd; blooms sparingly but spreads freely by means of its rootstocks.

Fernald and Kinsey (1943) report that "It is surprising how few people are familiar with the delicious quality of the tender young leaves and stems as a salad." As a salad plant it should be gathered young; as a potherb of indifferent quality it can be used until July. The crisp, succulent, fingerlike tuberous roots form "a tasty relish" after being marinated for some 


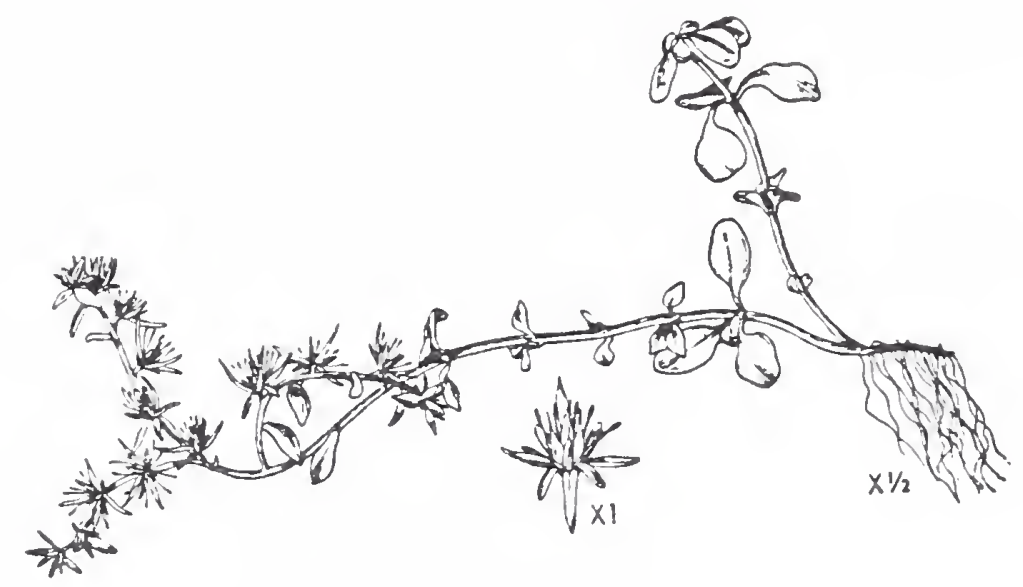

Sedum ternatum--Wild stonecrop

[From Gleason (1952), Vol. II, p. 256.]

days in salted vinegar, poured on the tubers boiling hot. These crisp tubers, available in spring and again in late autumn, "often occur in enormous masses and then furnish an abundant and easily obtained food." This plant has also been used as a vegetable in the preparation of soups.

The U.S. Dispensatory of 1865 states that this plant "was formerly employed externally to cicatrize [promote the growth of fibrous tissue to form a scar] wounds, and internally as an astringent in dysentery and hemoptysis [hemorrhage from the lungs], and is still esteemed by the common people of France as a vulnerary [a substance useful in healing wounds]." of this species Johnson (1867) remarks: "The plant is a common domestic remedy in some parts of the country for diarrhoea and haemorrhoidal diseases. It is mucilaginous, with a slight astringency, and sometimes acts diuretically. Withering states that 'a decoction of the leaves in milk is a forcible diuretic.' The leaves are occasionally put in salads."

In areas where this species has become an obnoxious weed, Muenscher (1952) suggests that scattered clumps can be dug out, taking care to get all the roots. Larger areas should be cultivated for one or two years. Where cultivation is not practicable, close grazing by sheep will bring this weed under control.

Sèdum ternàtum Michx. Wild Stonecrop.

Meaning of Species Name. In three's, from the whorled leaves.

other Names. Iceland-moss, Three-leaved Stonecrop.

Type of Plant. A perennial herb.

Habitat. Damp, often calcareous, rocks, mossy banks, cliffs, woods, and brooksides.

Range. Ct, w Mass, and NY to Mich and Ill, s to Ga, Tenn, and Ark; spread from cult to cool rocks and damp roadsides farther $n$.

Distr in NYS. Rare and sporadic in se NY and perhaps not native in this state; rare as an esc from cult farther northw in the state. 
Distr in the Torrey Range. Rare and sporadic in most parts of our area except in the pine barrens, there rare or wanting.

Elevation. Grows to $3000 \mathrm{ft}$ in Va.

Time of Fl. (Apr)May-Jun; May lo-Jun at Cornell.

Origin. Native.

\section{SAXIFRAĠ̇CEAE, the Saxifrage Family}

This family is composed of about 80 genera and some 1200 species of herbs, shrubs, and small trees. It is nearly cosmopolitan in distribution, but more genera occur in the United States than elsewhere, although species also occur in South America, Australia, New Zealand, South Africa, Oceania, Australasia, and Europe. The family is difficult to separate from related families, particularly from the Rosaceae. Cronquist (1968) divides the family Saxifragaceae as traditionally conceived into three separate families, the Hydrangeaceae, Grossulariaceae, and Saxifragaceae, the last of which, in his conception, contains only 700 species. This family is economically important from the number of ornamentals belonging to it, including Saxifrage, Mock Orange, Coral-bells, Hydrangea, and Astilbe. Currants and gooseberries are fruits of some economic importance.

\section{Key to Catskill Genera of the Saxifragaceae}

1. Plants woody (shrubs), 2

2. Ieaves opposite; stamens 20-40; leaves pinnately veined; fruit a

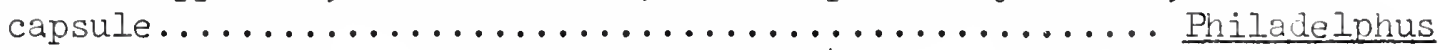

2. Leaves alternate or fascicled; stamens 4 or 5 ; leaves pal-

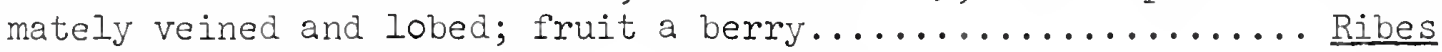

1. Plants herbaceous, 3

3. Petals none, 4

4. Stems decumbent; flowers 4-merous, solitary at the ends of branches; leaves ovate to rotund, $5-15 \mathrm{~mm}$ long, entire or obscurely and irregularly toothed............ Chrysosplenium

4. Stems erect, 2-7 dm tall; flowers 5-merous, borne along a 2-4-branched cyme; leaves lanceolate to narrowly elliptic, 5-10 cm long, sharply serrate, acuminate at both ends.. Penthorum

3. Petals present, 5

5. Petals deeply pinnatifid or fimbriate......................

5. Petals entire or nearly so, 6

6. Capsule bilocular, 2-beaked; pistils in each flower and follicles (fruits) equal in size, 2 -celled........ Saxifraga

6. Capsule unilocular, 2-valved; pistils in each flower and follicles very unequal, 1 -celled.......................

\section{Chrysosplènium L. Golden Saxifrage.}

This is a genus of about 50 species of the north temperate zone. They are small, low herbs with succulent leaves and small solitary or leafy-cymed, often inconspicuous, flowers. The name of the genus is derived from the Greek chrusos, gold, and splen, spleen, of doubtful significance but possibly for some reputed medicinal qualities. C. alternifolium, 


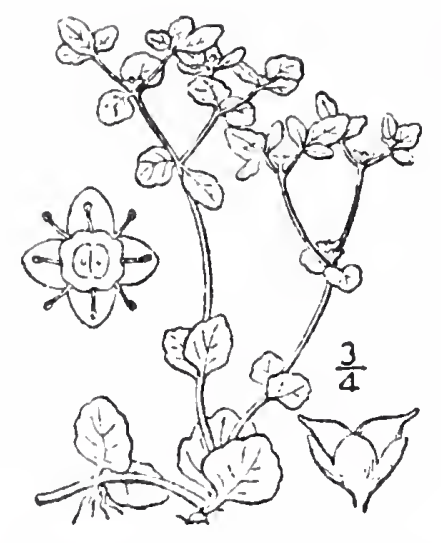

Chrysosplenium americanum--Golden Saxifrage

[From Britton \& Brown (1913), Vol. II, p. 230.]

the Golden Saxifrage of Europe and northern Asia, and C. eppesitifolium, also of Europe and northern Asia as well as the East Indies, are eaten as salad plants. The latter is also used in the preparation of soup.

\section{Chrysosplènium americanum Schwein. Golden Saxifrage.}

Meaning of Species Name. American.

other Names. Water-mat, Water-carpet.

Type of Plant. A perennial herb.

Habitat. Springheads, rills, cold wet places, and muddy soil of swamps.

Range. Que and Ont to Sask, s to $\mathrm{Md}$, Va, upland to $\mathrm{Ga}, \mathrm{O}$, Ind, and I.a.

Distr in NYS. Frequent or common across the state northw; less frequent southw to II, $n$ of the moraine.

Distr in the Torrex Range. NY: Not rare on the s side of LI, not common on the $n$ side and on SI, thence increasing and common northw.

Elevation. Sea level-3970 ft in the Torrey range.

Time of Fl. Apr-Jun; Apr-May at Cornell.

Origin. Native.

Since two of the European species are much esteemed as salad plants, Fernald and Kinsey (1943) suggest that our own species might be equally palatable. It is often abundant in the Catskills and makes rapid growth in early spring, so it is usually easily available and might well be worth trying. One should of course make sure that it is not growing in contaminated water. To be on the safe side a tablet of "chlorazene" should be dissolved in the water it is washed in to serve as a disinfectant; one tablet will purify 2 quarts of water. 

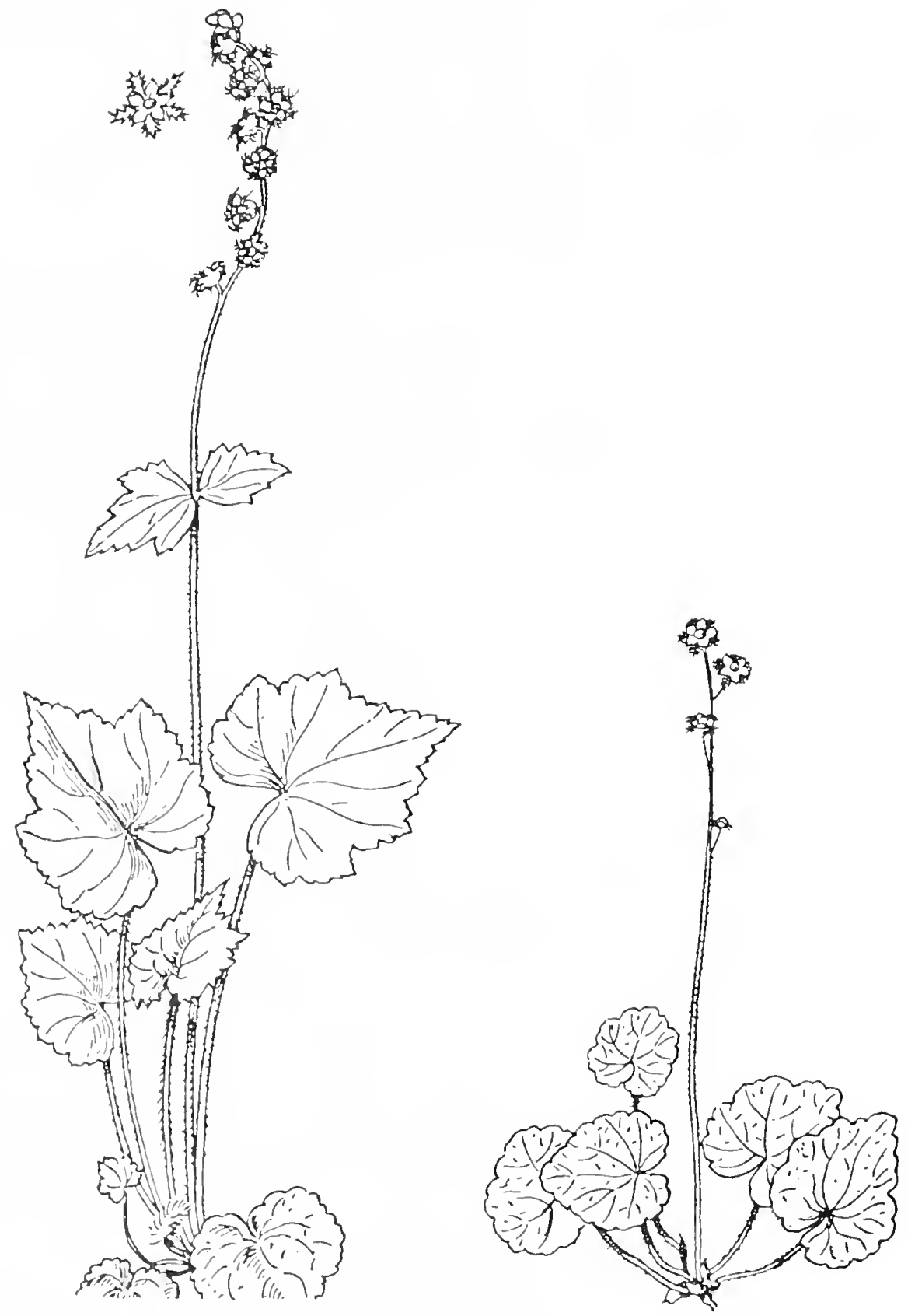

(Left) Mitella diphylla--Two-leaved Bishop's-cap

(Right) Mitella nuda--Naked Bishop's-cap

[From Smith (1966), Plate 76, p. 171.]

\section{Mitélla I. Bishop's-cap.}

There are some 12 species of Mitella, perennial plants of North Ameriica and eastern Asia. They are low, slender plants with round-cordate, alternate, slender petioled leaves and naked or few-leaved flowering stems arising from the rhizome or stolons. The small flowers are borne in simple slender racemes or spikes. The name of the genus is derived from the diminutive of the Latin mitra, cap, in allusion to the shape of the young fruit. 
Mitélı diphýlla I. Two-leaved Bishop's-cap.

Meaning of Species Name. Two-leaved.

other Names. Miterwort, Two-leaved Miterwort, Currant-leaf, False Sanicle, Fringe-cup, Fairy-cup.

Type of Plant. A perennial herb.

Habitat. Rich loamy and rocky woods. and Mo.

Range. Que and Ont to Minn, s to Va, upland SC, Tenn, Ala, Miss,

Distr in NYS. Common northw and westw in the state, less frequent southw to Bronx co, and reported from SI; not known on II.

Distr in the Torrey Range. NY: Reported from but doubtfully on II, rare on SI and in the Bronx and Westchester co, thence increasing and becoming common northw.

Elevation. Grows to $2600 \mathrm{ft}$ in Va; sea level-4020 ft in the Torrey range.

Time of Fl. (Late Apr)May-early Jun; May at Cornell.

Origin. Native.

Remarks. A third leaf is rarely borne on the scape at the base of the inflorescence. This species is suitable for planting in partially shaded areas of the rock garden.

Mitélıa nùda I. Naked Bishop's-cap.

Meaning of Species Name. Naked, from the usually leafless scapes. Other Names. Stoloniferous Bishop's-cap, Stoloniferous Miterwort, Naked Miterwort.

Type of Plant. A perennial herb.

Habitat. Cool or mossy woods, bogs, or swamps, most frequent in arbor-vitae, spruce, and balsam swamps.

Range. Lab to Mack, s to Pa, O, Mich, Wis, Minn, ND, and Mont; also in Asia.

Distr in NYS. Common in the $\mathrm{n}$ part of the state, infrequent in the w counties, and not found $s$ of Greene $c o$ in the e; westw frequent in the cold swamps on the higher hills of Otsego, Herkimer, Madison, Cortland, and Tompkins co.

Distr in the Torrey Range. In 1915 known only from the higher elevations of nw Litchfield co, Ct, and in the mts of Wayne and Monroe co, $\mathrm{Pa}$.

Time of Fl. May-Aug; May 10-Jun 15 at Cornell (-Jul in Ulster co). Elevation. Grows to $3000 \mathrm{ft}$ in the Adirondacks; 1070-4000 ft in the Torrey range.

Origin. Native.

\section{Pénthorum L. Ditch Stonecrop.}

There are four known species of Penthorum, ours of eastern North America and three others in eastern Asia. They are upright weedlike perennials with scattered leaves and yellowish-green flowers "loosely spiked along the upper side of the nalisd branches of the cyme." Some authorities segregate this genus into the monogeneric family Penthoraceae. The name of 


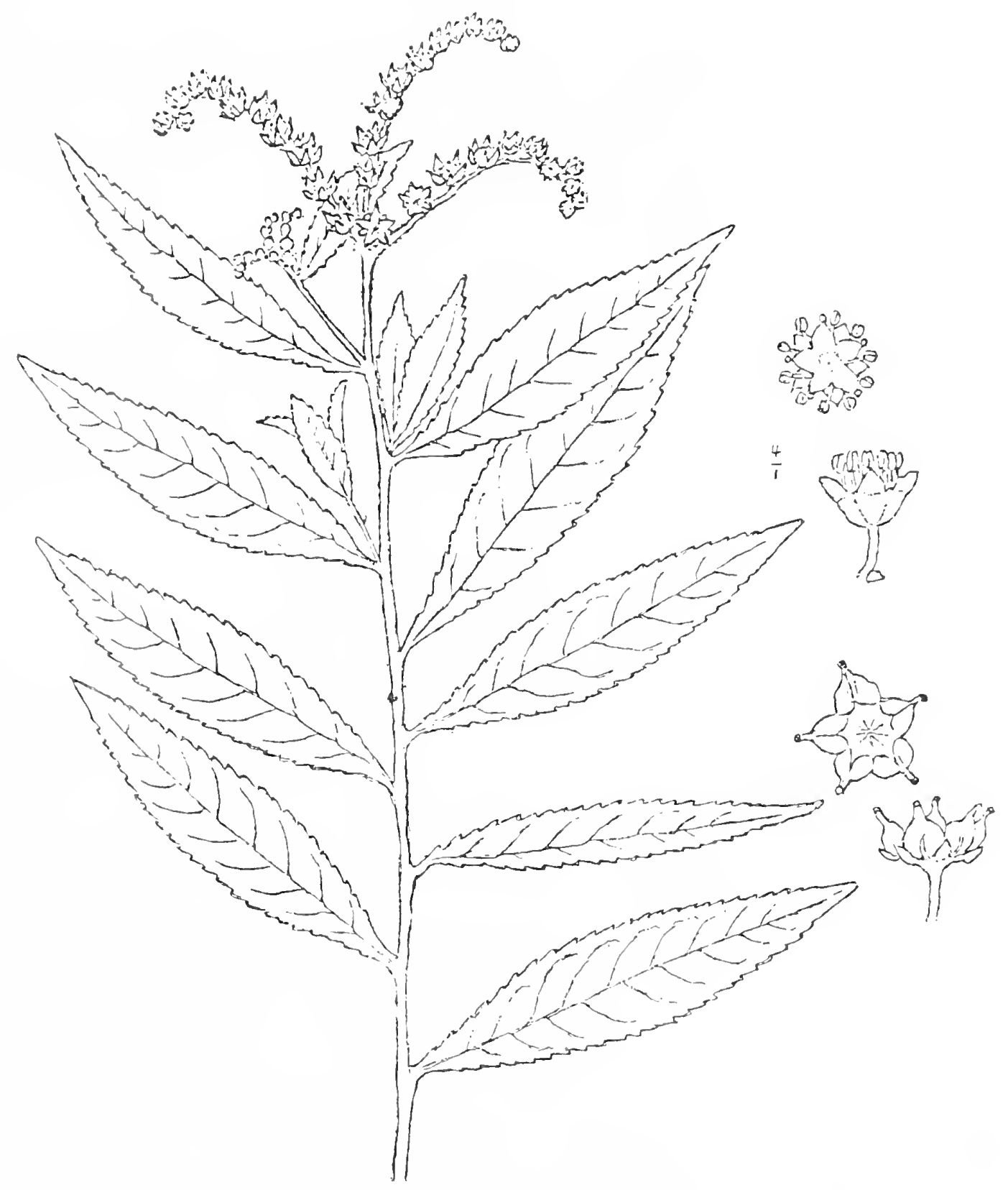

Penthorum sedoides--Ditch Stonecrop

[From Stone (1945), Vol. I, p. 685.]

the genus is derived from the Greek pente, five, and horos, a mark, from the quinary plan of the flowers.

Pénthorum sedoìdes I. Ditch Stonecrop.

Meaning of Species Name. Like Sedum.

Other Names. Virginia Stonecrop.

Type of Plant. An upright, weedlike perennial.

Habitat. Low wet meadows, ditches, marshes, and muddy soil.

Range. Me to Ont, Mich, Minn, and Neb, s to Fla and Tex. 
Distr in NYS. Frequent or common throughout most secs of the state except on II, where it is rare, and absent from the pine barrens; rare or largely absent from the Adirondacks.

Distr in the Torrey Range. Throughout the area except the pine barrens and $e$ and $s$ of them, there rare or wanting.

Time of Fl. Jul-Sep(Oct); Jul-Aug at Cornell.

Origin. Native.

Remarks. The fruit turns reddish at maturity.

Millspaugh (1887) reports that "It has always held a place in domestic practice as an astringent in diarrhea and dysentery. Drs. Briggs and scudder brought it to the notice of practitioners as a remedy, both topic and internal, for irritation of the mucous membranes and various forms of subacute inflammation of the same, as in pharyngitis, vaginitis, tonsillitis, etc. The whole fresh plant was used in the preparation of a tincture."

Philadélphus I. Mock Orange.

There are about 60 species of PhiladeIphus, North American, Asiatic, and southern European shrubs with opposite, often toothed, leaves, no stipules, and solitary, racemose, or cymose-clustered showy white flowers. The name of the genus is said to commemorate King Ptolemy of Egypt, 283-247 B.C., whose agnomen was Philadelphus. Some species have been in cultivation in this country for a long period, while others, including several hybrids, are of comparatively recent introduction. Their usually large white, often very fragrant, flowers make an attractive display in early summer. They are also sometimes called Syringa, an unfortunate choice, for that is the scientific name of the Lilac. No. 6187 Brooks 14 Sep 75, collected in the vicinity of Ashland, Town of Ashland, in Greene County was labeled Philadelphus floridus Beadle by Stanley J. Smith. The writer can find no reference to this species in any of the current manuals for the northeastern states.

Philadélphus coronàrius L. Garden Mock Orange.

Meaning of Species Name. Suitable for a wreath.

other Names. Garden Syringa, Orange-flower Tree.

Type of Plant. A shrub growing to $12 \mathrm{ft}$ in height.

Habitat. Roadside thickets.

Range. Often esc from cult in the ne states.

Distr in NYS. Common in cult and sparingly esc or long persistent in some localities.

Distr in the Torrey Range. Rather a rare esc in most parts of our range.

Time of Fl. Jun-JuI.

Origin. Introd from Eu.

Remarks. For more than 300 years this species has been a favorite garden plant, popular both for its fragrance and its abundant flowers; occasionally spread from cult. 


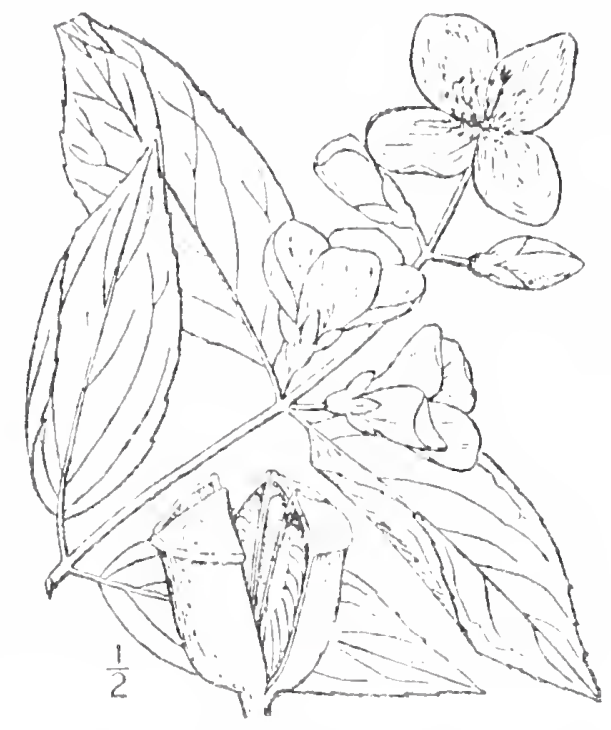

Priladelphus coronarius--Garden Mock Orange [From Britton \& Brom (1913), Vol. II, p. 232.]

\section{Ribes I. Currant, Gooseberry.}

This is a genus of low, often prickly, shrubs of Eurasia and North America, extending also into the Andean region of South America. There are 120 to 140 species, depending upon which authority is followed; Britton and Coville recognized 83 species in North America, most of them native to the western states. By some authorities the gooseberries and currants are segregated into separate genera. Many species of Ribes serve as an alternate host of the white pine blister rust and as a consequence have nearly been exteminated in parts of their range by government agencies. The name of the genus is by one authority said to be derived from the old Danish colloquial ribs, the name of the Red Currant. Another authority states that Ribes takes its name from an Arabic name for Rheum, the generic name of Rhubaxb. It is said that our common name for the currant was given to garden forms of the Red Currant because they resembled in size the southern European currants which grow near corinth. In addition to being cultivated for their familiar fruit, some species make useful ornamental. flowering shrubs, incluaing $\mathrm{R}$. Sanguineum, a plant of western North America (not hardy where winters are severe), R. aureum, the Golden Currant, and $\underline{R}$. odoratum, the Buffalo Currant, another native of the western states.

Fruits of the wild species of both gooseberries and currants are usually small and quite soux, but, when available, they make piquant jellies and jans, by many considered superior to those obtained rrom garden varieties. In her Book of Useful Plants, Julia $\mathrm{B}$. Rogers remarks that "we who have picked the small, but sprightly, green gooseberries of the woods, both the prickly and the smooth ones, know that no cultivated form, no matter how wild it is, can excel in rich flavor the sauce they make." Improved forms of some of our native wild currants have even found their way into cultivation. 
Many species of wild gooseberry were gathered by the American Indians for eating either fresh, cooked, or dried. To remove the bristly spines which are found on some species, the berries were rolled on hot coals in baskets until the spines had been singed off. Some tribes also boiled the young leaves in early spring and ate them with uncooked animal fat. The American Indians also used some species as medicine. The Chippewas combined the berries of Ribes oxyacanthoides with other plants for pain in the back and female weakness, while Blackfoot Indians prepared a decoction from the roots of $\underline{R}$. americanum for use in treating kidney ailments. During World War II when oranges were in short supply in Great Britain, black currants were grown for their high vitamin $C$ content and used in foods for infants and children.

Since both gooseberries and currants have been almost eradicated in many areas by various governmental campaigns, the importance of these plants to wildlife has been considerably reduced. In areas where they are still available, however, they are of considerable value to songbirds, chipmunks, ground squirrels, and other animals.

\section{Key to Ribes Based on Flowers and Fruit}

1. Stems usually with firm spines at the nodes, at least the young stems usually bristly on the internodes; peduncles 1-5 flowered; pedicels not jointed at summit, the fruits not disarticulating from them; calyx with slender to campanulate tube, the lobes longer than broad (gooseberries), 2

2. Calyx lobes much shorter than the campanulate tube; peduncles and pedicels elongate; ovary and. fruit usually covered by glandless prickles (stamens as long as the petals; sepals

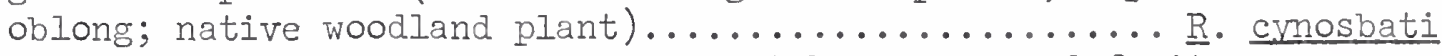

2. Calyx lobes equaling or longer than tube; ovary and fruit not prickly, either smooth, pubescent, or bristly, 3

3. Stamens much exceeding calyx lobes during anthesis; peduncles or pedicels elongate (nodal spines $2-5 \mathrm{~mm}$

long; flowers greenish or purplish, 5-6 mm long;

filaments $4-7 \mathrm{~mm}$ long)........................................

3. Stamens shorter than to barely exceeding calyx lobes; peduncles and pedicels short, 4

4. Calyx glabrous; fruit glabrous or only sparsely setose; indigenous (petioles bearing long plumose hairs $\ldots \ldots \ldots \ldots \ldots \ldots \ldots \ldots \ldots \ldots$. . hirtellum

4. Calyx pilose; ovary closely pilose or glandular; fruit pubescent or glabrate; cultivated plant

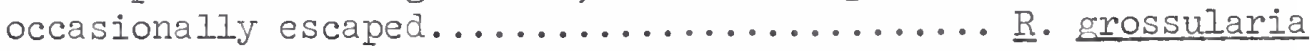

1. Stems with or without spines and bristles; peduncles bearing several to many-flowered racemes; pedicels jointed at summit, the fruits disarticulating from them (currants), 5

5. New and old canes bristly and prickly; pendulous racemes and black fruits glandular-bristly; flowers saucer-shaped... R. lacustre

5. New and old canes without bristles and prickles; racemes ascending to pendulous, 6

6. Calyx salverform, the long slender tube several times longer than the spreading lobes, golden yellow; fruit yellowish or black; leaves convolute in bud......... R. odoratum 
6. Calyx saucer-shaped, rotate or campanulate, without elongate tube; leaves plicate in bud, 7

7. Racemes ascending; ovary and fruit glandular-bristly; flowers

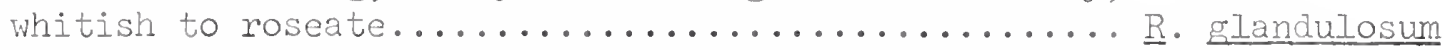

7. Racemes spreading to drooping; ovary and fruit glabrous;

flowers purplish to green or yellowish, 8

8. Decumbent or straggling native shrub; midale lobe of leaf deltoid, the sides of the leaf nearly parallel; pedicels

with capitate glands; flowers purplish.............. triste

8. Erect or ascending cultivated shrub sometimes escaped;

midale lobe of leaf ovate, lateral leaf lobes spreading;

pedicels without glands; flowers yellowish or greenish. R. rubrum

\section{Key to Ribes Based Chiefly on Vegetative Characteristics}

1. Stems and twigs without spines or prickles; fruits in racemes

(currants), 2

2. Erect bushy shrubs, 3

3. Branchlets light brown, puberulent; leaves convolute

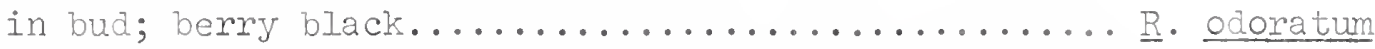

3. Branchlets olive-brown to gray, glabrate; leaves plicate

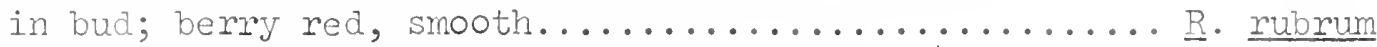

2. Low, prostrate, sprawling, or creeping shrubs, 4

4. Leaves with 5-7 prominent lobes, glabrous beneath; inner bark with fetid odor; buds green or reddish-purple, fusi-

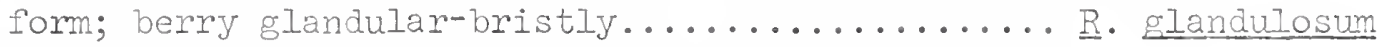

4. Leaves with 3-5 prominent lobes, hairy; inner bark without fetid odor; buds grayish-brown, ovate; berries

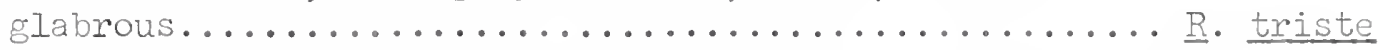

I. Stems and twigs with spines, or prickles, or both; fruits soli-

tary or 2-5 in a cluster (gooseberries, except for $\underline{R}$. lacustre), 5

5. Branches covered with internodal prickles nearly as long as

the nodal spines, 6

6. Branchlets red-brown; berries hairy, black, in racemes;

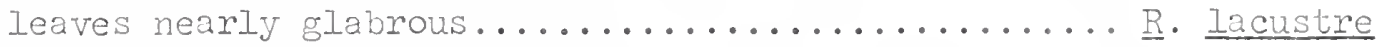

6. Branchlets gray or dark brownish; berries spiny, red, in

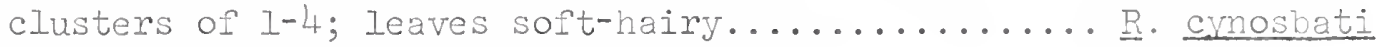

5. Branches without internodal prickles, or, if present, few

and shorter than the nodal spines, 7

7. Spines usually more than $10 \mathrm{~mm}$ long (berries red or green,

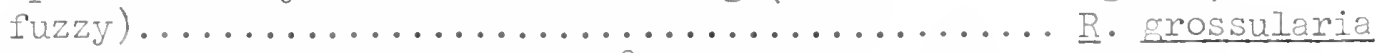

7. Spines less than $10 \mathrm{~mm}$ long, 8

8. Berries red, spiny or hairy (leaves soft-hairy).. R. cynosbati

8. Berries without spines or hairs, dark purple or

black, 9

9. Petiole hairs branched; lobes of leaves acutely

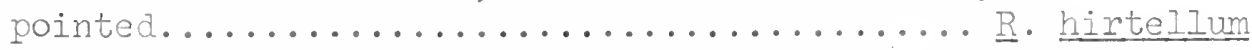

9. Petiole hairs simple, glandular, or absent; lobes of leaves obtuse (spines usually solitary)... R. rotundifolium 


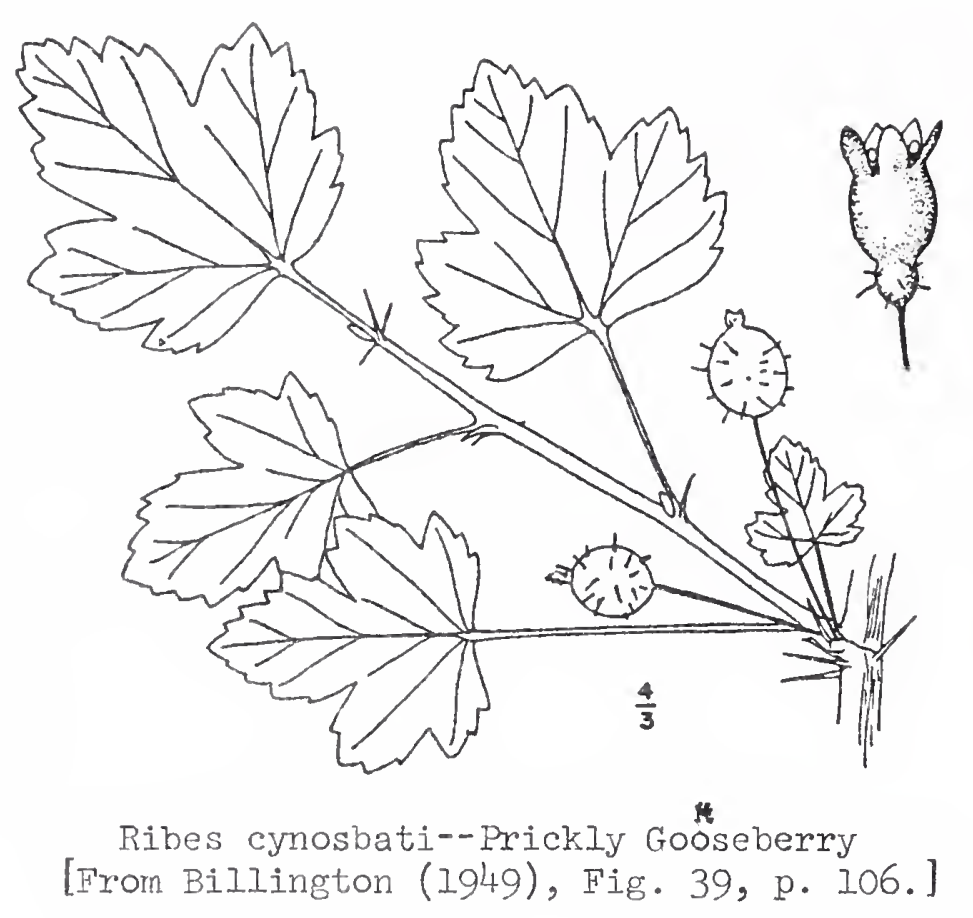

Rỉbes cynósbati L. Prickly Gooseberry.

Meaning of Species Name. Dogberry.

Other Names. Dogberry, Wild Gooseberry, Prickly Wild Gooseberry, Dog-bramble, Pasture Gooseberry.

Type of Plant. A shrub growing 1 I/2 to $4 \mathrm{ft}$ high.

Habitat. Rocky woods, thickets, and clearings.

Range, NB and Que to Minn and Man, s to NC, Ga, Ky, Ala, Ark, Mo, and Okla.

Distr in NYS. Frequent across the state northw and westw; southw to the Catskill mts, the Hudson highlands, and Delaware co; locally on the $\mathrm{n}$ part of $\mathrm{II}$, and rare on SI.

Distr in the Torrey Range. NY: N of the moraine on LI, on SI, unknown in the Bronx, thence increasing and common northw.

Elevation. Sea level-4000 ft in the Torrey range.

Time of II. May-Jun, fr Jul-Sep; fl May at Cornell.

Origin. Native.

Because of their prickly character, these berries have to be eaten with care, but they have a pleasing flavor and a subacid quality which makes them desirable for quenching thirst in the field. This wild fruit makes excellent jellies, preserves, and pies. Gooseberry pie was particularly relished during colonial times.

Rỉbes glandulósum Grauer. Skunk Currant.

Meaning of Species Name. Glandular.

Other Names. Fetid Currant.

Type of Plant. A low, prostrate, sprawling or reclining shrub. 


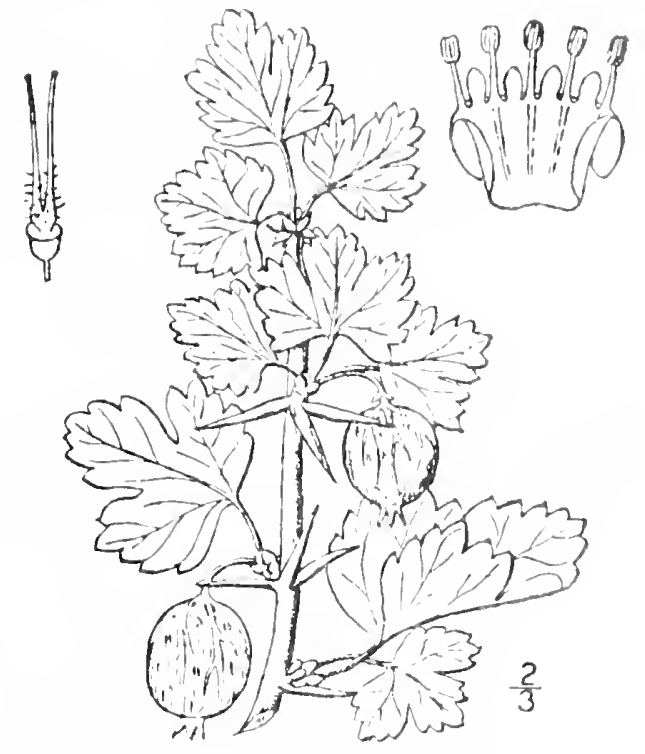

Ribes grossularia--European Gooseberry

[From Britton \& Brown (1913), Vol. II, p. 241.]

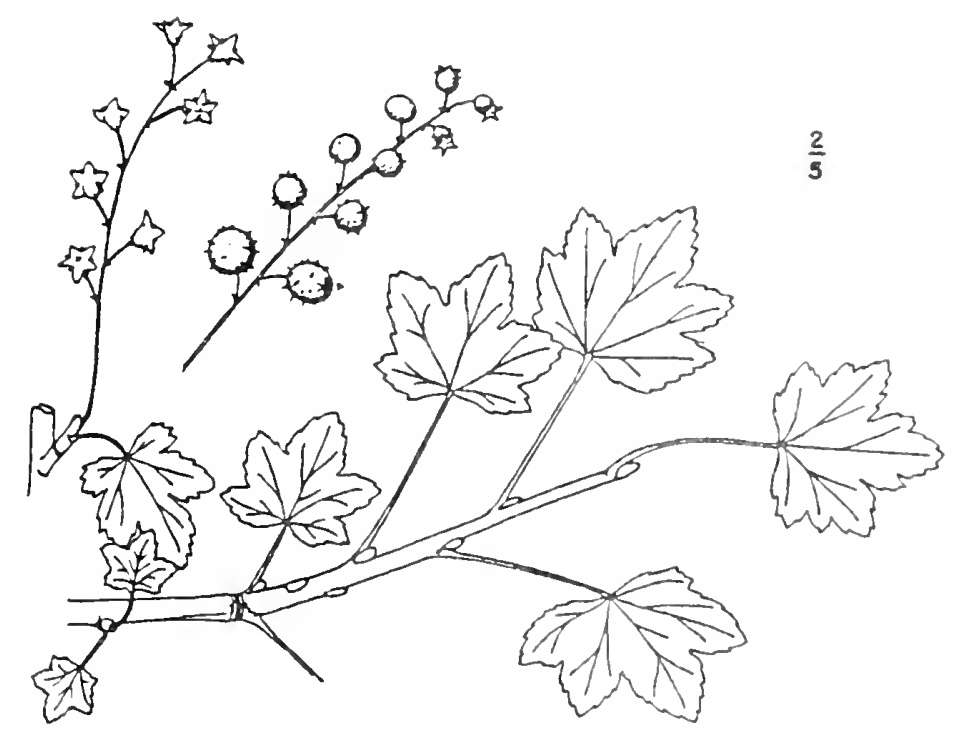

Ribes glandulosum--Skunk Currant

[From Billington (2949), Fig 47, p. 114.] 
Habitat. Cold, damp, rocky woods, swamps, and clearings, often in balsam or spruce swamps.

Range. Lab and $\mathbb{N f}$ to Mack and $\mathrm{BC}$, s to $\mathrm{NE}$, NY, mts to $\mathbb{N C}, 0$, Mich, Wis, Minn, and Sask.

Distr in NYS. Common in the $\mathrm{n}$ and $\mathrm{c}$ parts of the state, less frequent southw to Dutchess co, the Catskill mts, Chenango and Chemung co, and westw to I Erie and Chautauqua co.

Distr in the Torrey Range. NY: The Catskills.

Elevation. Grows to $6000 \mathrm{ft}$ in $\mathrm{NC}$; $100-4020 \mathrm{ft}$ in the Torrey range. Time of Fl. May-Jun(Aug), fr Jun-Sep; fl May 10-30 at Cornell.

Origin. Native.

The bruised shrub and berries have the odor of skunk, but the berries are juicy and palatable, by some consumed with relish in spite of their bristles and odor. The Chippewas used the root of this species in combination with other plants in the treatment of pains in the back and female weakness.

Rìbes grossulària L. European Gooseberry.

Meaning of Species Name. An old generic name derived from the French groseille.

Other Names. Garden Gooseberry.

Type of Plant. A shrub.

Habitat. Roadsides and thickets.

Range. Occasionally esc and considered to be estab in a few places

in the ne states and adjacent Can.

Distr in NYS. Not listed in House (1924).

Distr in the Torrey Range. Not listed in Taylor (1915).

Time of $\mathrm{Fl}$. May.

Origin. Introd from Eu.

This species, the parent of the European gooseberries, long cultivated for their fruit, was brought to this country by the colonists and has spread from cultivation. This native of northern Europe, northern Africa, and the Himalayan region was apparently not known to writers of the classical period; it seems to have been first mentioned by Turner in 1573.

Rỉbes hirtéllum Michx. Bristly Gooseberry.

Meaning of Species Name. Bristly.

Other Names. Low Wild Gooseberry.

Type of Plant. An erect shrub growing 1-3 ft high.

Habitat. Cool, moist, rocky woods, low grounds and clearings, sometimes on cliffs.

Range. Lab and que to Man, s to MD, WVa, O, Ind, Ill, Ind, Minn, and SD.

Distr in NYS. Common northw across the state, especially in the Adirondacks; rare or local southw to Rockland co, Orange co, and westw to L Erie. 


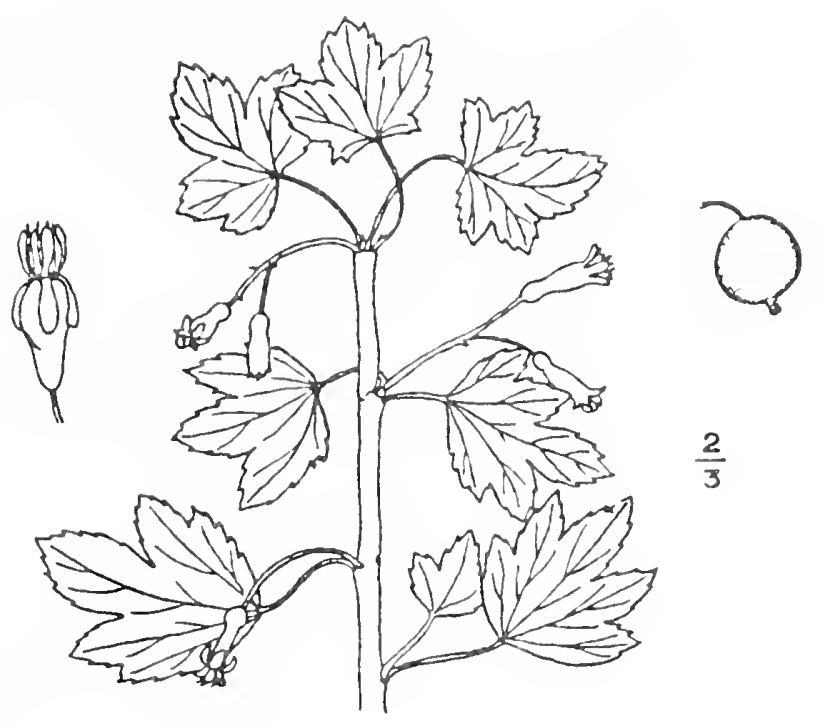

Ribes hirtellum--Bristly Gooseberry From Billington (1949), Fig. 43, p. I10.]

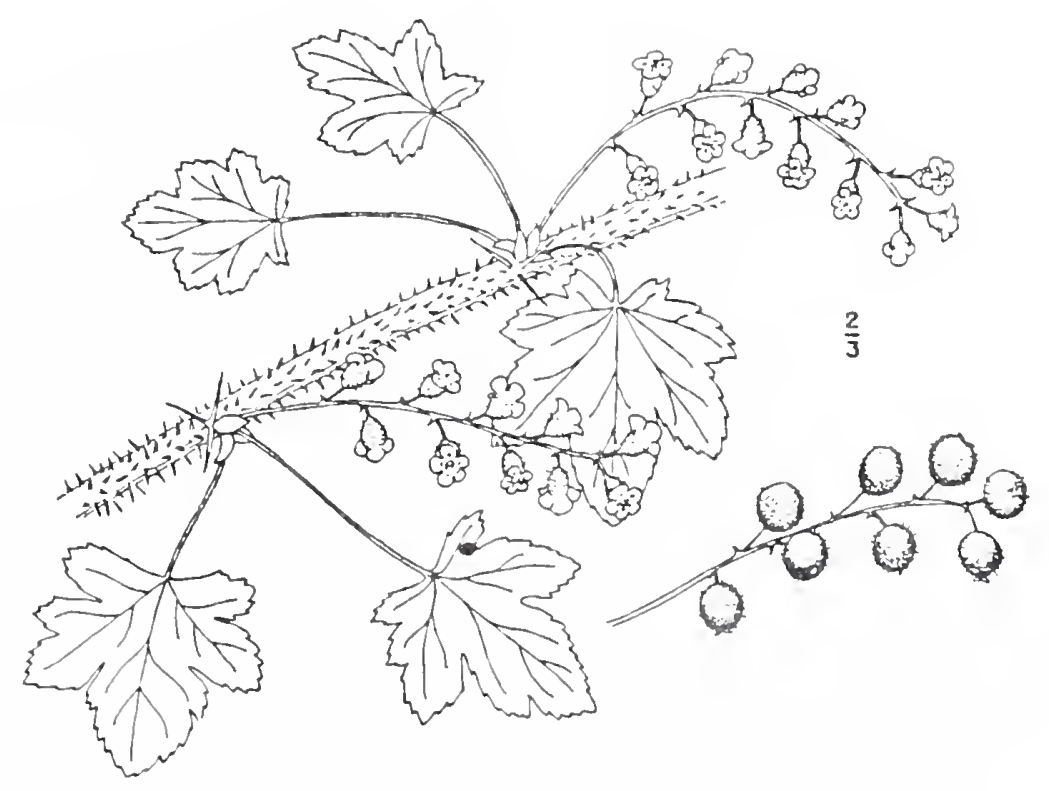

Ribes lacustre--Bristly Black Currant
[From Billington (1949), Fig. 46, p. 112.] 
Distr in the Torrez Range. Nearly throughout the area except in the pine barrens and the area immediately surrounding them, there rare or wanting; not known on LI or SI.

Time of FI. (Iate Apr)May-Jun(JuI), fr Jun-Sep; fl May 12-Jun 10 at Comeli.

Qrigin. Native.

Remarks. Considered superior to the cultivated species for jams and preserves. It is the parent of garden varieties of American gooseberries that are cultivated for their fruits.

Ribes lacústre (Pers.) Poir. Bristly Black Currant.

Meaning of Species Name. Of lakes.

Other Names. Swamp Currant, Swamp Gooseberry, Swamp Black Currant.

Type of Plant. An erect shrub growing l-3 ft high.

Habitat. Cold wet woods and swamps.

Range. Iab to Ak, s to Mass, Pa, mts to Tenn, O, Mich, Wis, and Minn, and in the $\mathrm{w}$ to Col, Utah, and Cal.

Distr in NYS. Common northw across the state; less frequent southw to the Catskill mts, the upland swamps of Chenango, Otsego, and Tompkins co; not reported from the $w$ counties of the state, nor from the $s$ Susquehanna and Chemung valleys.

Distr in the Torrey Range. IV: The summits of the Catskills.

Elevation. 735-4020 ft in the Torrey range.

Time of Fl. Mid-May-Jun(Aug), fr Jul-Sep; fl Jun at Cornell.

Origin. Native.

Remarks. Bruised shrub and berries have a skunklike odor, but the berries are juicy and tart and not offensive when eaten raw. They make a good sauce when cooked.

Ríbes rotundifòlium Michx. Round-Ieaved Gooseberry.

Meaning of Species Name. Round-leaved.

Other Names. Wild Gooseberry, Eastern Wild Gooseberry, Smooth Gooseberry, Mountain Gooseberry.

Type of Plant. A shrub growing 2-3 ft high.

Habitat. Open rocky upland woods and thickets, ascending to the highest crests.

Range. Mass and NY, s to mts of NC, WVa, Ky, and Tenn.

Distr in NYS. Infrequent or locally abundant in the lower Hudson valley and in the catskill mts; reported from II and SI, and northw to the $\mathrm{w}$ side of I Champlain, the s Adirondacks, and westw across the state.

Distr in the Torrey Range. NY: Formerly on II, reported from SI, unknown in the Bronx but in Westchester co, increasing northw.

Time of Fl. Apr-May (early Jun), fr Jun-Sep; fll May 12-25 at Cornell.

origin. Native.

Ribes rubrum I. Garden Currant.

Meaning of Species Name. Red.

Synonyms. R. Sativum Syme in Fernald (1950) and in Gleason (1952). 


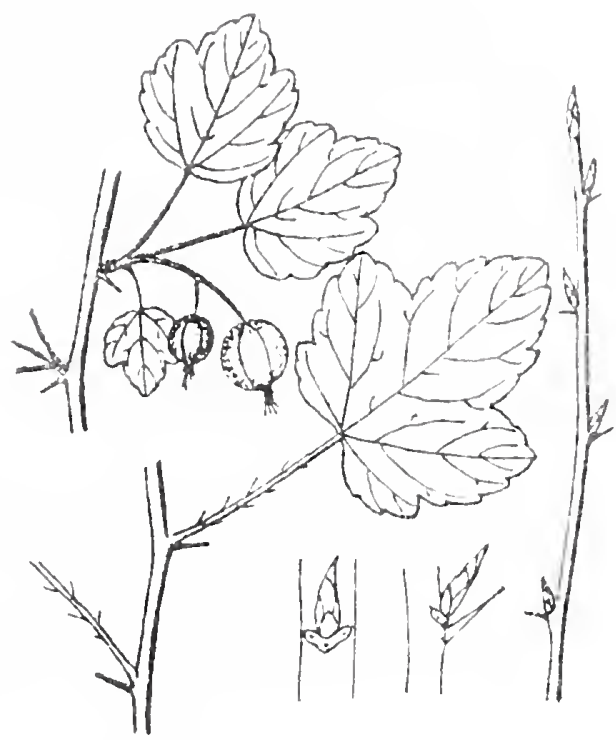

Ribes rotundifolium--Round - leaved Gooseberry [From Grimm (1966), p. 117.]

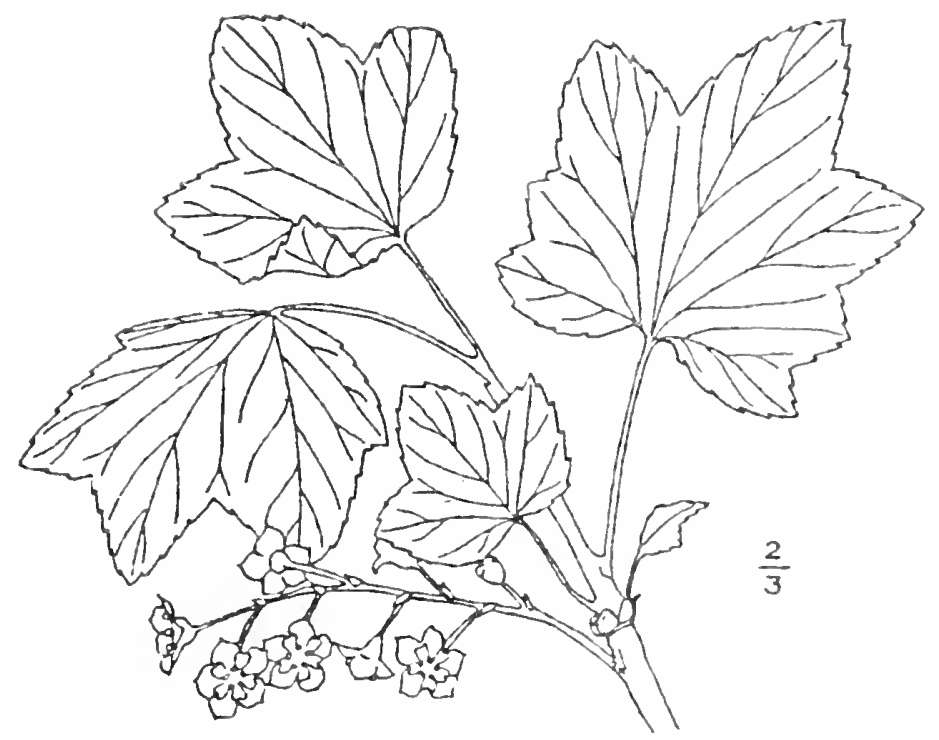

Ribes rubrum-Garden Currant

[From Billington (1940), Fig. 48, p. 114.] 
Other Names. Red Currant, Red Garden Currant, Raisin-tree, Garnetberry, Wine Berry.

Type of Plant. An erect shrub growing 3-4 ft high.

Habitat. Open woods, thickets, and fencerows.

Range. Frequently spread from cult in the ne states and adjacent Can.

Distr in NYS. Occasionally est as an esc.

Distr in the Torrey Range. Not uncommon as an esc in our area.

Time of Fl. May at Cornel.

Origin. Introd and natzd from Eu.

This species has long been common in cultivation in North America. In Europe it seems to have been first mentioned as a horticultural plant by Ruellius in 1536, a French author who praised it as a border plant and its fruit as an appetiser. Gerarde scarcely recognized it as being in general culture in England in 1597, but it soon became popular in that country.

\section{Ribes triste Pall. Wild Red Currant.}

Meaning of Species Name. Sad, probably from the drooping racemes.

other Names. Red Currant, Wild Currant, American Red Currant, American Wild Red Currant, Swamp Red Currant.

Type of Plant. A low sprawling or reclining shrub with stems often rooting.

Habitat. Cool wet woods, bogs, swamps, subalpine ravines, and open marshy places.

Range. Nf and Lab to Ak, s to NJ, Pa, WVa, Mich, Wis, Minn, SD, and Ore; also in $\mathrm{n}$ Asia.

Distr in NYS [as var. albinervium (Michx.) Fern.]. Frequent or 1ocally conmon across the $\mathrm{n}$ part of the state; less frequent southw and westw to Greene, Otsego, Tompkins, and Genesee co.

Distr in the Torrey Range. Known (in 1915) only from Onteora, Greene co, NI, and Bergen co, NJ, in our area.

Time of $\mathrm{Fl}$. (Late Apr)Jun-Jul, fr Jun-Aug; fl May 10-30 at Cornell. Origin. Native.

Racemes are commonly produced at the bases of leafy shoots of the season above leafless branches of the preceding year. The fruit, similar to that of the Garden Currant, has been used for pies and jellies, but it is inclined to drop before maturing.

Not only did the Chippewas use the fruit of this plant as food, eaten raw as well as dried for winter use, but they employed it medicinally. Densmore (1928) reports that the root and stalks from four plants were used to make a decoction in 1 quart of water, "boiled quite a while," to treat "gravel." Combined with the roots of Aralia racemosa and A. nudicaulis (the latter sometimes omitted), stalks of $\underline{R}$. triste were used in decoction to treat stoppage of menstrual periods. This remedy was used "if the difficulty threatened to lead to consumption." 


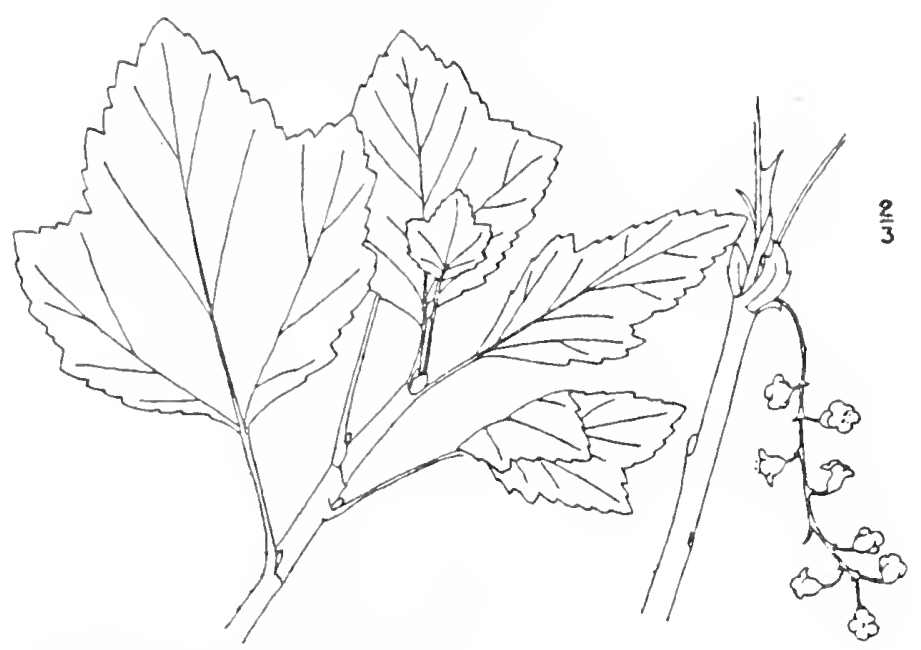

Ribes triste--Wild Red Currant

[From Billington (1949), Fig. 49, p. 116.]

Saxífraga L. Saxifrage.

There are more than 300 species of Saxifraga, chiefly perennial herbs of the north temperate and arctic zones of Eurasia and North America but extending also into South America. About 100 species occur in North America, but only two are native in the Catskills. The name of the genus is derived from the Latin saxum, rock, and frangere, to break, according to one authority, in allusion to the rocky habitat of many species. Fernald (1950), how ever, states that this name was "early applied, through the doctrine of signatures, to European species bearing granular bulblets, which were supposed to dissolve urinary concretions." A number of species are cultivated for ornament, particularly in rock gardens, both for their fine foliage and their lovely flowers, produced over a long blooming period. S. sarmentosa, the Starry Geranium or Strawberry Begonia, iś a popular house plant, only one of several species cultivated for ornament, both indoors and out.

\section{Key to Local Species of Saxifraga}

1. Calyx lobes ovate to broadly deltoid, ascending or only slightly spreading in fruit; leaves $1.5-8 \mathrm{~cm}$ long; petals chiefly white

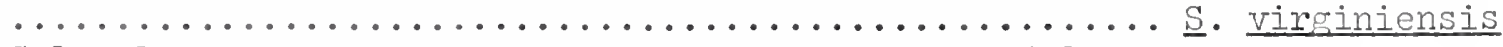

1. Calyx lobes narrower, promptly reflexed; leaves $5-30 \mathrm{~cm}$ long, remotely short-dentate; petals greenish, pearly,

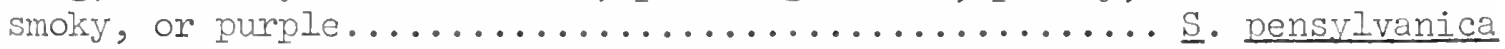




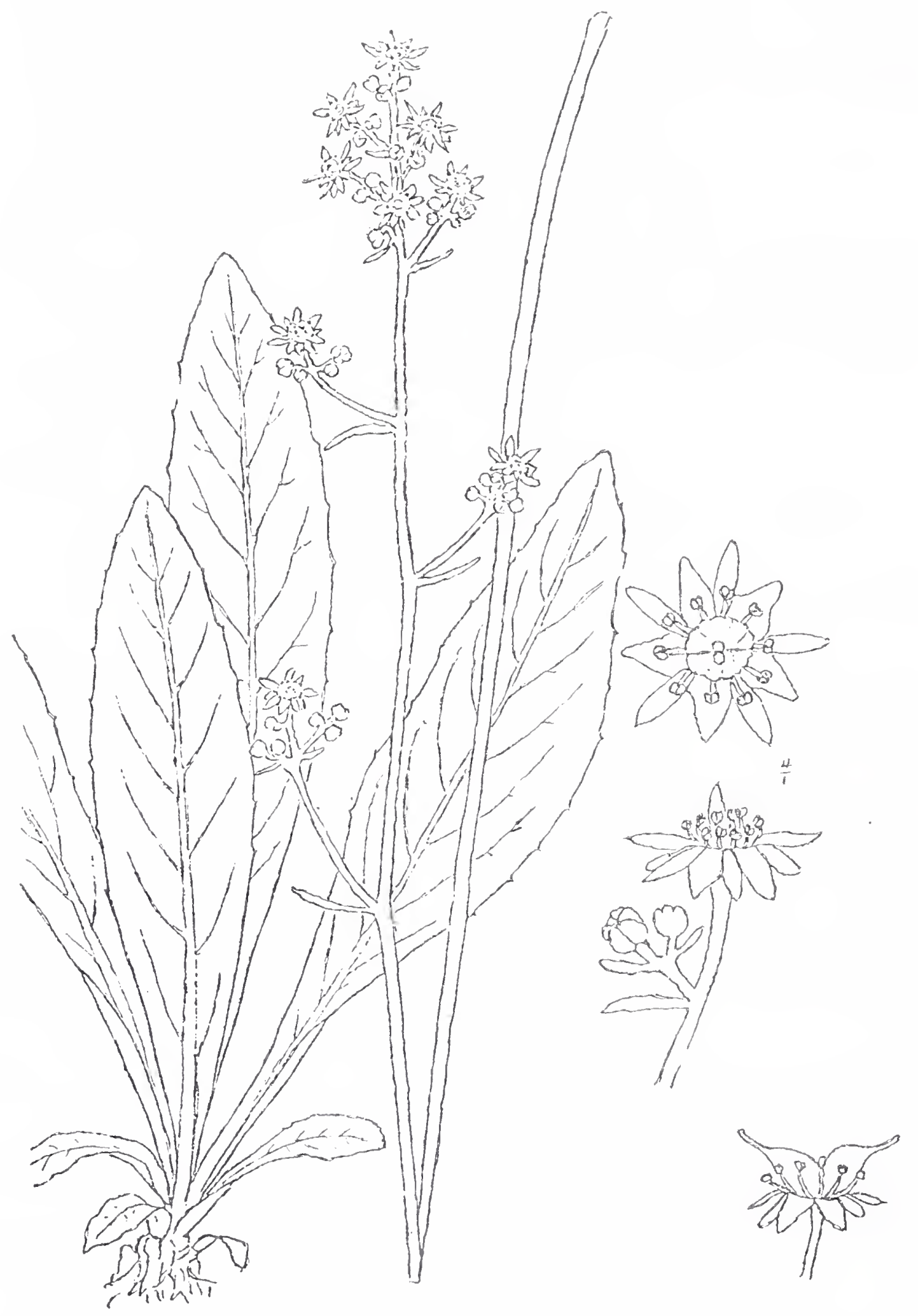

Saxifraga pensylvanica--Swamp Saxifrage [From Stone (1945), Vol. 1, p. 689.] 


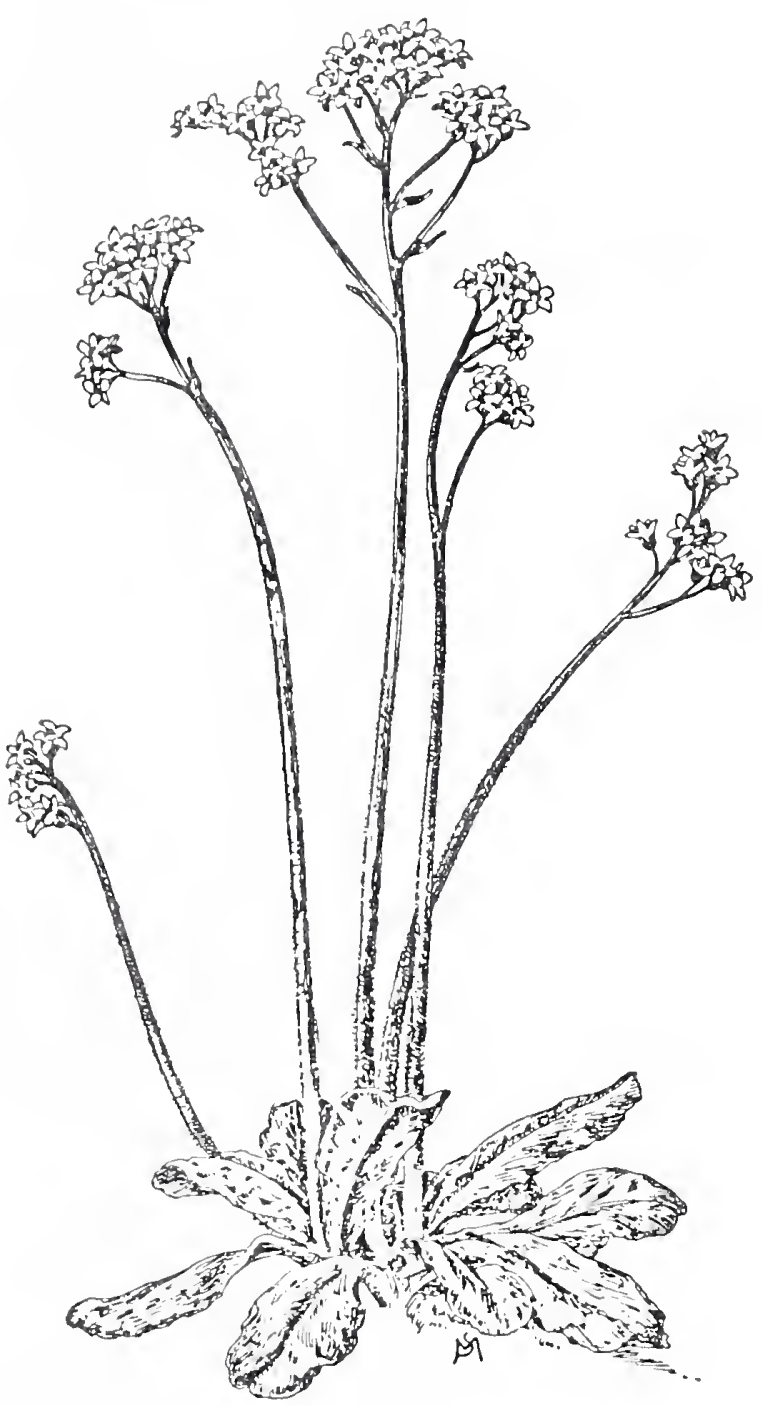

Saxifraga virginiensis--Early Rock Saxifrage

[From Mathews (1912), plate facing p. 182.]

Saxífraga pensylvánica I. Swamp Saxifrage.

Meaning of Species Name. Of Pennsylvania.

other Names. Wild Beet, Pennsylvania Saxifrage.

Type of Plant. A perennial herb.

Habitat. Low meadows, pastures, swamps, boggy thickets, and seeping banks.

Range. Me and Ont to Minn, s to Va, WVa, Ind, Ill, and Mo.

Distr in NYS. Frequent or common across the state outside the higher Adirondacks, and absent from the pine barrens of II.

Distr in the Torrey Range. Throughout the range except in the pine barrens of $\mathrm{NJ}$ and LI, there rare or wanting.

Time of Fl. (Apr)May-Jun; May 15-30 at Cornell.

Origin. Native.

Remarks. Fernald and Kinsey (1943) state that "The young leaves just unrolling, are tender and not unattractive as a salad." 
Saxifraga virginiénsis Michx. Early Rock Saxifrage.

Meaning of Species Name. Of Virginia.

Other Names. Early Saxifrage, Spring Saxifrage, May-flower, Sweet Wilson, Everlasting.

Type of Plant. A perennial herb.

Habitat. Moist or dry open rocky woods, on exposed rock ledges, and gravelly open or shaded slopes.

Range. NB to Ont, Minn, and Man, s to Ga, Tenn, Ark, Mo, and Okla.

Distr in NYS. Common.

Distr in the Torrey Range. Throughout the range except in the pine barrens of $L I$ and $N J$, there rare or wanting.

Time 요 FI. Apr-May(Jun); Apr-May at Cornell.

Origin. Native.

Remarks. Not a common plant in the Catskills.

This species can be grown in rock gardens if given sufficient shade, drainage, and moisture.

Tiarélla I. Foamflower.

There are seven known species of Tiarella, six native to temperate North America and one in eastern Asia. All are perennials with white flow ers. The name of the genus is a latinized diminutive of the Greek tiara, a little turban. Gleason (1952) states that this name is "in fanciful allusion to the fruit," while Fernald (1950) remarks that it refers to "the form of the pistil."

Tiarélla cordifólia I. Foamflower.

Meaning of Species Name. Heart-leaved.

other Names. False Miterwort, Coalwort, Colwort, Coolwort, White Coolwort, Gem-fruit, Allegheny Foamflower, False Bitterwort.

Type of Plant. A perennial herb.

Habitat. Rich woods, usually in moist soil.

Range. INS and NB to Ont and Mich, s to NC, Ga, Tenn, and Ala.

Distr in NYS. Common or frequent in most secs of the state $n$ of

IYC; rare in the Susquehanna valley.

Distr in the Torrey Range. NY: Reported but not definitely known

from Westchester co, thence increasing and common northw.

Elevation. Grows to $5600 \mathrm{ft}$ in $\mathrm{Va}$; sea level-3800 ft in the Torrey range.

Time of Pl. Late Apr-May(Jul); May-Jun at Cornell.

Origin. Native.

Krochmal and Krochmal (1973) state that the entire plant, during the blooming period, and the roots, collected in the fall, have been gathered for medicinal use, observing that "The plant has been used in a tea to increase urine flow, help pass kidney stones, and for other urinary problems." The root was used not only as a diuretic but was also administered to loosen phlegm in the chest. 


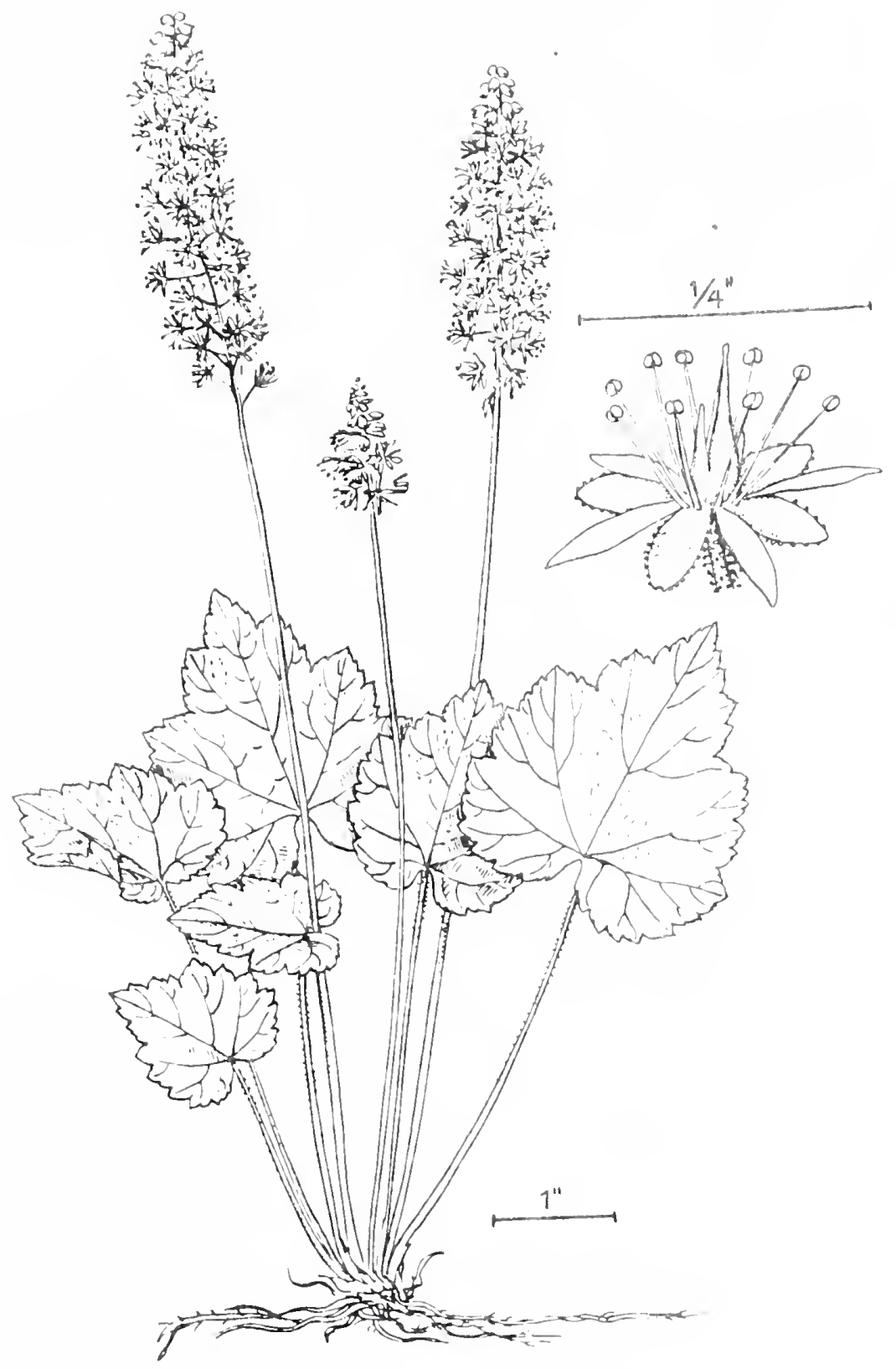

Tiarella cordifolia--Foamflower

[From Krochmal et al. (1971), p. 251.]

This species makes an attractive plant for cool situations in the rock garden or for planting in shaded areas under shrubs.

HAMAMELIDẢCEAE, the Witch-hazel Family

This is a family of 23 genera and about 100 species, best developed in eastern and tropical Asia. They are deciduous or evergreen trees or shrubs, often with stellate hairs, with alternate simple leaves, deciduous stipules, and flowers in heads or spikes. Current data seem to support the 
view that the Hamamelidaceae, Platanaceae, and Myrothamnaceae should be treated as a separate order, the Hamamelidales, which some botanists consider as terminating a line of evolutionary ascent derived from stocks ancestral to the Rosales and derived from the Magnoliales. As mentioned above, Cronquist (1968) places this family in his subclass Hamamelidae, along with the Fagales, Myricales, Juglandales, Urticales, and some other orders not represented in the Catskill flora, all of which "may ... have been derived from the Hamamelidales." Economically the family is important domestically for the. witch-hazel extract prepared from Hamamelis, as well as for a few species grown for ornament.

\section{Hamamèis I. Witch-hazel.}

There are five species of Hamamelis, tall shrubs or small trees, one of eastern North America and the others native to eastern Asia. The hard black seeds are discharged explosively from the capsule when they are ripe. The name of the genus is derived from the ancient Greek name of the Medlar (Mespilus), a European tree, although one authority derives it from the Greek hama, at the same time, and melis, a fruit, alluding to the fact that Witch-hazel flowers appear in late fall at the same time as its fruits, from blossoms of the previous year, are ripening. The Asiatic species are considered more decorative than our native species for horticultural purposes, H. mollis, the Chinese Witch-hazel, and $\underline{H}$. japonica, the Japanese Witchhazel, being the most useful. The flowers of $\underline{H}$. mollis are very fragrant.

\section{Hamamèlis virginiàna I. Witch-hazel.}

Meaning of Species Name. Virginian.

Other Names. Spotted-alder, Tobacco-wood, Snapping-hazel, Winterbloom, Pistachio. high.

Type of Plant. A coarse shrub or small tree, occasionally 20-30 ft

Habitat. Dry or low moist woods, thickets, and swamps.

Range. NS and Que to se Minn, s to Fla, Tenn, Mo, and Tex.

Distr in NYS. Frequent or common throughout most secs of the state, and rare only in some of the $\mathrm{n}$ secs and the higher portions of the Adirondacks .

Distr in the Torrey Range. Common throughout the range except in

the pine barrens, there wanting; rare on the coastal plain of II.

Time of Fl. (Sep)oct-Nov, fr ripe a year later; fl Oct-Nov at

Cornell.

Origin. Native.

Remarks. Wood hard; wt 43 Ib per cu ft.

During the summer few people give the Witch-hazel more than a passing glance, but in autumn, when the other trees seem to have finished their summer's work, the Witch-hazel appears to be just waking up, for it then bursts into bloom, the bright yellow flowers opening in late fall. Often after the leaves have been shed, the Witch-hazel thicket "is veiled with these gold-mesh flowers, as ethereal as the haunting perfume which they exhale." About the same time the seed capsules, which have been developing during the summer from flowers of the previous fall, suddenly snap open and shoot their seeds from 25 to 30 feet from the parent shrub. Rogers 
(1926) feels that this activity is worth going far to see. "Damp weather delays this most interesting little game," she reports, but "Dry frosty weather is ideal for it. Go into a witch hazel thicket on some fine morning in [October or] early November and sit down on the drift of dead leaves that carpet the woods floor. The silence is broken now and then by a sharp report like a bullet striking against the bark of a near-by trunk, or skipping among the leaves.... [This] fusillade comes from the ripened pods, which have a remarkable ability to throw their seeds, and thus do for the parent tree what the winged seeds of other trees accomplish. The lining of the two-celled pod is believed to shorten and produce a spring that drives the seeds forth with surprising force when they are loosened from their attachment." If one takes home a fruiting branch in autumn, he can witness this phenomenon at closer range.

In Great Britain it was often the custom of "superstitious miners" to employ forked sticks of the English Witch Elm as divining rods to locate coal deposits. Somehow this mystical property was early transferred to the Witch-hazel, which in isolated country districts is still often used to locate hidden springs. Sent for before a well is dug, the "water witch" slowly walks over the ground, holding the twig by its two supple forks, one in each hand. When he passes over the spot where a spring is located, the twig goes down of its own volition, thus indicating the location where the well should be dug. Sargent (1891-1902) made short shrift of this practice, stating that "The popular name of this plant is due to the fact that it was early used by impostors to indicate the presence of precious metals in the soil and to discover springs of water."

The colonists learned from the Indians of the medicinal properties of this shrub. As early as $1744 \mathrm{Dr}$. Cadwallader Colden told Gronovius of Leyden that the Mohawk Indians used a decoction of the bark of this shrub to treat with success "allmost total blindness occasioned by a blow" after "other means had for a considerable time prov'd ineffectual." In 1785 the Rev. Manasseh Cutler reported that "the Indians considered this tree as a valuable article in their materia medica" and listed some of its uses: "They applied the bark, which is sedative and discutient, to painful tumors and external inflammations. A cataplasm of the inner rind of the bark, is found to be very efficacious in removing painful inflammations of the eyes." The Menominee Indians of Wisconsin rubbed a decoction of Witch-hazel on the legs of athletes to keep them limbered up and the twigs were steeped for a decoction to cure lame back. This tribe apparently learned the medicinal uses of this plant from the Stockbridge Indians of Massachusetts when the latter group emigrated to Wisconsin. The Potawatomis also used Witch-hazel in sweat baths to relieve sore muscles.

A number of physicians confirmed Indian uses of this shrub during the middle $1800^{\prime} \mathrm{s}$, crediting it with anodyne, sedative, astringent, tonic, and discutient properties and reported its use in the treatment of internal hemorrhage, piles, suppressed menses, pains in the side, and eye inflammation. Hanamelis leaves were official from 1882 through 1955 while the bark and twigs were official in the U.S. Pharmacopeia, 1906-16, for astringent and hemostatic purposes. The distilled extract has been official since 1888 as an astringent for rubbing on the body to relieve congestions, bruises, hemorrhoids, and the like. 
The first settlers thus learned of the manifold uses of Witch-hazel from the Indians, and it soon came to be considered a household necessity, a position it still holds in many areas. But even though it is an official drug, there is far from complete agreement in the medical profession as to its uses and efficacy, some maintaining that none of its present uses can be scientifically justified and that as a botanical drug it is inert and useless. Nevertheless, about a million gallons of distilled Witch-hazel extract is produced and sold every year; on the positive side one can certainly say that it is harmless and perfectly safe to use. This extract can easily be made at home by gathering a quantity of freshly cut twigs and leaves and soaking them in water for 24 hours, using about two parts of water to one of the cut-up plant parts. Strain and reduce this solution by about 25 percent by boiling and to the remainder add 1 part of alcohol to 5 parts of the distillate. Because of its tannin content it is a useful first-aid treatment for minor burns and scalds. Dabbed on the skin with a cotton pad, it will soothe insect stings and mosquito bites, but in all probability alcohol alone would be as effective a treatment.

The Iroquois Indians formerly made a tealike beverage of dried WitchhazeI leaves, which they sweetened with maple sugar. It has a rather austere flavor that is toned down considerably by the addition of milk, and it might make an acceptable camp tea when ordinary tea is not available. Unsweetened, this tea makes an efficacious remedy for diarrhea and a good gargle for sore throat. The Indians also poured hot water over fresh witchhazel leaves and used them as poultices for sprains, bruises, and swellings. This was said not only to aid in eventual cure but also to relieve immediate pain; it might well make a good first-aid treatment on a camping trip. The dried leaves, crushed into a powder, have also been used as a styptic to stop bleeding from small cuts.

Two early writers reported that the seeds were edible, but Asa Gray, writing in 1857, had never heard of the seeds being used as food and attributed the source of such statements to "the Medical Plora of the eccentric Rafinesque, who says the nuts are called pistachio nuts in the southern states." In any case, since these small seeds are hard and bony, few people are likely to consider the experiment worth while.

Although deer browse on the twigs and foliage, and the seeds, available from fall into winter, are eaten by ruffed grouse and squirrels, the wildlife value of Witch-hazel is generally considered to be rather low.

\section{PLATANÁCEAE, the Sycamore Family}

This unigeneric family of monoecious trees, indigenous to the northern hemisphere exclusive of Africa, is characterized by alternate, palmately lobed leaves, sheathing stipules, and exfoliating bark. It was once considered to belong within the Urticales, but Wettstein, Tippo, and others are of the opinion that this family is of closer affinity to the Hamamelidaceae and Rosaceae than to other taxa. Cronquist (1968) places this family in his subclass Hamamelidae, along with Fagales, Myricales, Juglandales, and Urticales. A number of species are cultivated domestically for ornament. 


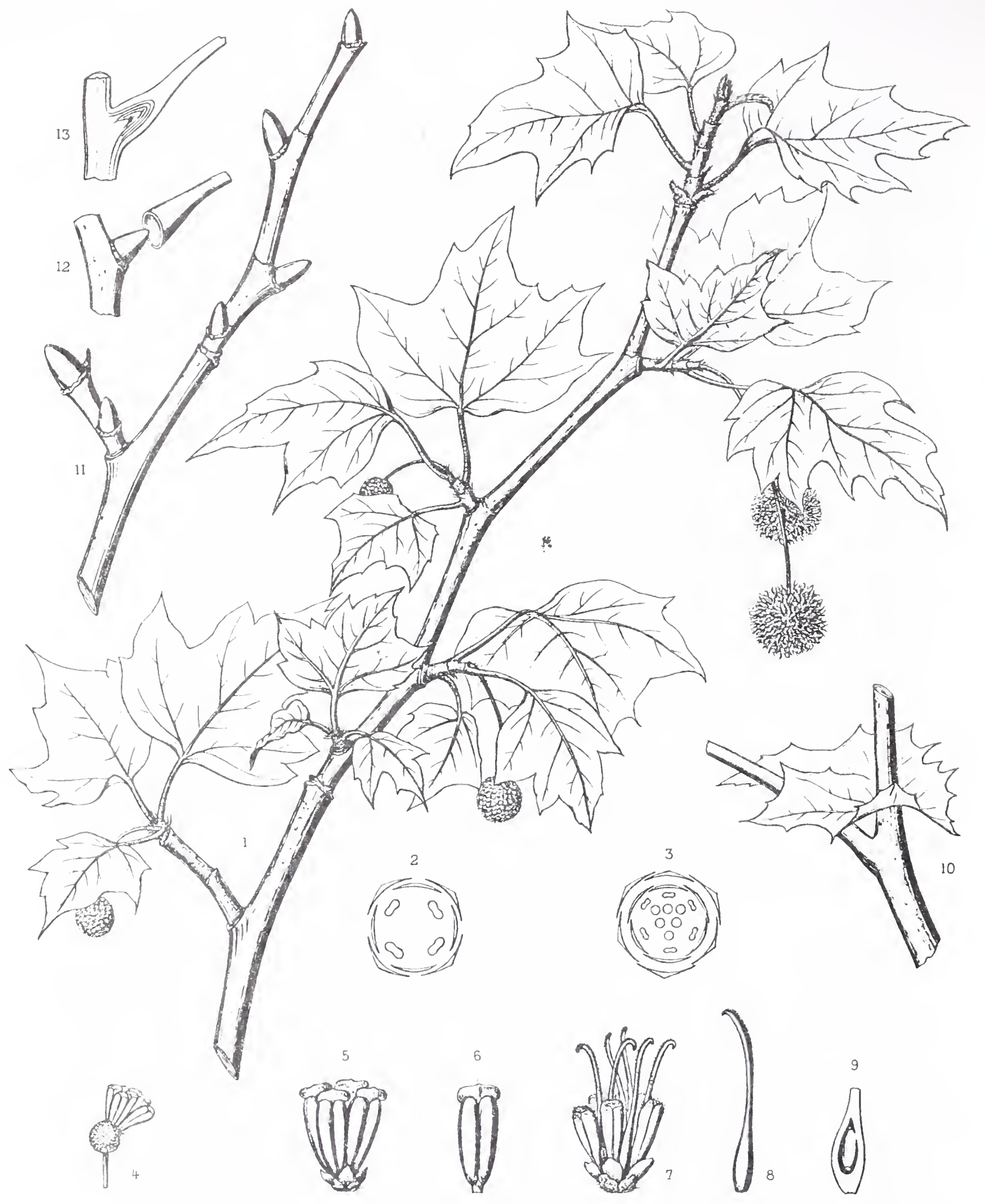

Platanus occidentalis--Sycamore (flowers)

[From Sargent (1891-1902), Vol. VII, PIate 326, p. 103.] 


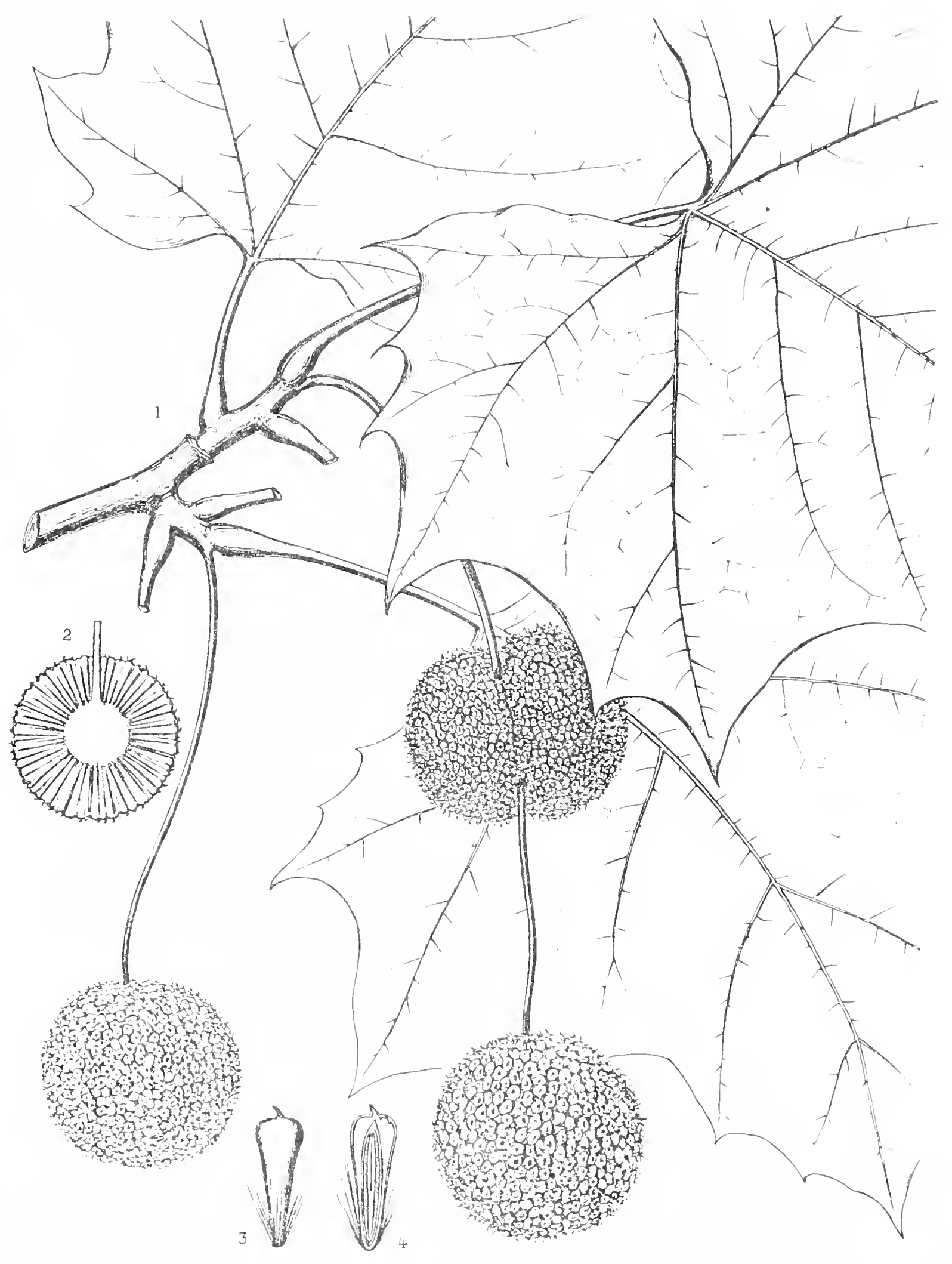

Platanus occidentalis--Sycamore (fruit)

[From Sargent (I891-1902), Vol. VII, Plate 327, p. 103.] 
There are about 10 species of Platanus, one in the old world from southeastern Europe to India, the others native to eastern Iforth America, the southwestern states, and Mexico. They are large trees with bark exfoliating in thin broad plates. The name of the genus, the ancient Latin name of the Plane-tree, is derived from the Greek platys, broad, referring, probably, to the large leaves. The Plane-tree commonly planted as a street tree in our eastern cities is the Iondon Plane, $\underline{P}$. acerifolia, the origin of which is unknown, but Gleason (1952) thought it was "probably a hybrid between our native species and the old World P. orientalis L." It withstands the dust of cities better than most other trees and it tolerates severe pruning extremely well. Everett (1960) remarks that the name Sycamore is traditionally applied to Ficus sycamorus, a species of fig.

This genus is unusual because of the way the various species shed their bark. Some bark shedding is constantly taking place, but every few years more than usual is thrown off. Another interesting feature of this genus is the manner in which the tiny flowers are clustered in dense round heads at the ends of slender stalks, later maturing into the familiar "button-balls" that persist through the winter, breaking up in the spring. The seeds are covered with jointed hairs, which, when observed with a hand lens, resemble mirute stems of Bamboo.

Plätanus occidentàlis L. Sycamore.

Meaning of Species Name. Western, i.e., of the western hemisphere. other Names. Buttonwood, Plane-tree, Buttonball, False Sycamore, Water-beech.

Type of Plant. A large tree which often reaches a height of 100-175 ft with a trunk 3-8 ft in diameter.

Habitat. Moist or wet rich alluvial soil along streams, lakes, ponds, and wet woods.

Range. Me and Ont to Mich, Minn, and Neb, s to Fla, A.la, Miss, and Tex.

Distr in INS. Common from I Champlain and the I George reg westw to the St Lawrence, outside the higher Adirondacks, to about 1000 ft altitude; increasingly abundant southw and westw in the state except in the pine barrens of II and on SI, where it is rare or absent.

Distr in the Torrey Range. Throughout the area except in the pine barrens.

Time of Fl. Late Apr-early Jun; Jun at Cornell.

Origin. Native.

Remarks. Wood hard, weak, difficult to split, reddish brown; wt 35

Ib per cu ft.

This is the largest and most massive (but not the tallest) deciduous hardwood tree of North America, perhaps exceeding all others in the diameter of its trunk. It is characteristically a tree of bottomlands, attaining its maximum development in the lower Ohio and Mississippi valleys, where it was "the outstanding tree of the primeval forest, unsurpassed in picturesque grandeur and in the cooling depth and mighty spread of its shade." It can be recognized as far off as the color of its bark can be seen, for its bark flakes off in irregular plates, giving the upper trunk and branches a 
mottled appearance of light green, pale tan, and greenish or chalky white. In the words of Peattie (1950), "the impression at a slight distance is that of an exquisitely mottled tree, as if dappled with green shade and pale sunlight." Its beauty therefore lies in the body of the tree itself rather than in its flowers or foliage. Rogers (1926) describes this tree as "wayward in its branching habit, its twigs irregular and angular, "and calls it "a distressed-looking object" after the leaves are gone. Its leaves resemble those of the maple in a general way, being as broad as long, with three main lobes. A sheathing stipule, like a small leafy ruffle, grows at the base of each young leaf, but this is shed before midsummer. Its inconspicuous flowers produce "the curious fruits that have given the tree the name of Buttonwood--hanging balls that persist on the tree over winter," dangling in the wind until the central cob is bare, the fruitlets having been borne away on their hairy parachutes to become widely distributed both by wind and water.

Although the wood of this tree is not strong as a beam or column and has little resistance to decay, it is heavy, hard, tough, coarse-grained, and almost impossible to split, qualities much valued by the early settlers. The early French of Illinois are reported to have made large canoes from this tree, one of which was said to be 65 feet long, capable of carrying 9000 pounds. Since trees over 100 years old are likely to be hollow, early settlers often stabled horses, cows, or pigs in the hollow trees. Indeed, sometimes a whole family would take shelter in one until a log cabin could be built. Pioneers also cut trunks of large size into cross-sections for use as primitive solid wheels for ox carts. Hollow trunks, usually not difficult to find, were cut into lengths of 3 or 4 feet and bottoms were nailed on to make stout hogsheads in which to store grain. It later served for the manufacture of barber poles, lard pails, tobacco boxes, ox-yokes, wooden washing machines, Saratoga trunks, piano and organ cases, and broad panels for Pullman cars in the days when they were made of wood. Now considered a timber tree of secondary importance, it is used for crates, boxes, some furniture, interior finish, veneer, piling, brush handles, siding, and musical instruments. But for one use it is unexcelled. Since it can stand endless hacking without splitting, almost all butchers' blocks are made from this wood. When cut radially, the wood is sometimes called lacewood because of its attractive marking.

At least one Indian tribe prepared syrup and sugar from its sweet sap. While it is sometimes planted as an ornamental tree, it is usually the Iondon Plane-tree that finds a place along city streets.

Martin et al. (1961) state that this species seems to be of little appreciable importance to wildlife, for the seeds are utilized by only a few wildife species, the purple finch being the only bird to use the seeds to any great extent, although juncos and chickadees also make use of its fruit. Steyermark (1963) remarks that "It is recorded that the now extinct Carolina Paraquet relished the fruit of this tree as its favorite food." Deer sometimes browse the twigs, fox squirrels eat the seeds, muskrats and beaver consume the bark, and chimney swifts use the hollow trunks as nesting sites.

Steyermark also notes that "It is reported that sycamore pollen [in some areas] is exceeded only by oaks in its importance in being a cause of some cases of hay fever." 
This is a large family of perhaps 115 genera and some 3200 species of herbs, shrubs, and trees of diverse form and habit distributed over most of the earth but most abundant in the temperate regions of eastern Asia, North America, and Europe. The largest genera include Potentilla, Rubus, Rosa, Crataegus, Prunus, and Spiraea, all of which are represented in the Catskill region. As a unit the Rosaceae constitutes a more natural assemblage of plants than some other large families. It is of considerable economic importance not only from the numerous species bearing edible fruit but also from the large number of diverse horticultural and ornamental species. Those bearing edible fruit include apples, pears, quince, cherries, plums, prunes, peaches, nectarines, apricots, almonds, blackberries, raspberries, and strawberries. Many ornamental trees and shrubs also occur within this family, including Spirea, Cotoneaster, Firethorn, Hawthorn, Flowering Quince, Mountain Ash, Japanese Cherry, and Rose. In contrast to a number of other large families, the Rosaceae includes comparatively few weeds. Because of the extreme diversity of the large number of plants included in this family, a number of recent authors have segregated the genera into three families, but most phylogenists seem to prefer dividing the family into several subfamilies or tribes.

\section{Key to the Catskill Genera of Rosaceae}

1. Fruit dehiscent, a follicle or capsule, the superior ovary not inclosed in the calyx tube nor adherent to it, 2

2. Leaves compound, stipulate (suffruticose; leaves odd-pinnate, with 13-21 leaflets; flowers in dense panicles)............ Sorbaria

2. Leaves simple; stipules absent or caducous (carpels splitting down the ventral suture; seeds slender; leaves pinnately veined,

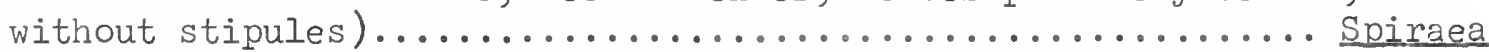

1. Fruit or carpels indehiscent; leaves, at least when expanding, stipulate, 3

3. Ovary inferior, the 2-5 carpels asually connate, borne within and adnate to a cuplike or urnlike depression in the enlarged sumit of the roceptacle, the whole united to form a fleshy fruit (pome or berry); trees or shrubs, the stipules free from the petioles, It 4. Mature carpels hard and bony, 1-5 (spiny shrubs or tress with simple leaves; leaves mostly serrate or dentate)........ Cratagegus

4. Mature carpels papery or soft-cartilaginous, 5

5. Carpels of the compound ovary as many as the styles, without false or partial partitions; leaves simple or pinnate; fruit a pome or berry-like...................... Pyrus

5. Carpels of the compound ovary subdivided by partial (false) partitions projecting inward from the back; leaves simple;

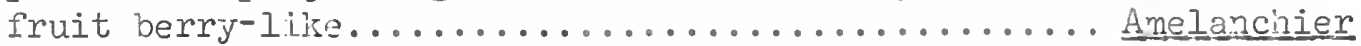

3. Ovary or ovaries superior (in some species inclosed in the calyx ture), 6

6. Ovaries I-many, becoming achenes covered by the calyx, or drupes, 7

7. Ovary free, solitary, becoming a drupe (plum, cherry, etc.);

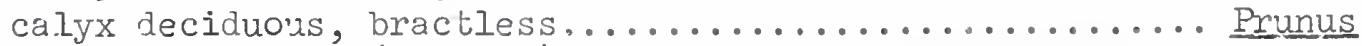

7. Ovary or ovaries (carpels) inclosed in the overtopping calyx; leaves compound or lobed, 8

$$
-46-
$$


8. Carpels numerous, lining the base or sides of the pome; petals large and showy; shrubs, often prickly, the pinnate leaves usu-

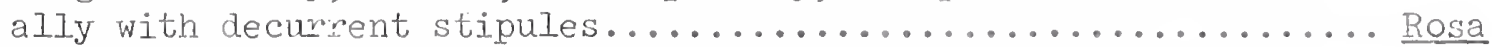

8. Carpels 1-4, completely inclosed in the dry and firm calyx tube, which is constricted or nearly closed at the throat; herbs, 9

9. Calyx beset with hooked bristles, the 5-cleft limb closed after

flowering and persistent; flowers yellow............. Agrimonia

9. Calyx not bristly, the 4 petaloid lobes white or purple, de-

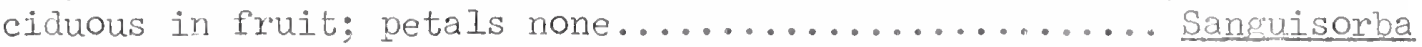

6. Ovaries several to many, borne on a broad to elongate receptacle, not inclosed by the calyx, IO

Io. Carpels ripening into drupelets; ovules 2, pendulous, but seed solitary, II

11. Carpels mostly numerous, ripening into juicy drupelets (raspberries, blackberries); flowers mostly perfect and similar; herbaceous or mostly slightIy woody; leaves mostly compound

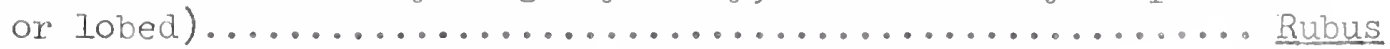

II. Carpels few at the botton of the calyx, nearly dry in fruit; showy flowers with white petals, sterile; fertile flowers apetalous, maturing fruit near the ground; leaves roundish,

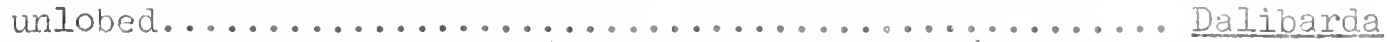

10. Carpels becoming dry achenes (plants herbaceous, or, if woody, having bractlets at the sinuses of the calyx or the styles Iong and plumose), 12

12. Styles persistent and elongating after anthesis, plumose or" jointed (herbs with pinnate or lyrate basal leaves and upright

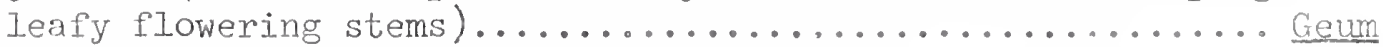

12. Styles not elongate after anthesis, mostly deciduous, 13

13. Receptacle pulpy and greatly enlarged in fruit (bractlets of calyx similar to the narrow calyx lobes; petals

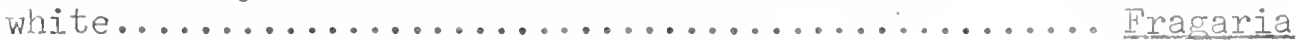

13. Receptacle dry, not greatly enlarged in fruit, I4 14. Carpels 2-ovulate; calyx without bractlets; stipules large, reniform; coarse plants with paniculate-cymose white or pink flowers and large pinnate leaves

14. Carpels 1-ovulate; calyx bracted, or, if bractless, the flowers on a naked scape; stipules elongate, I5 15. Flowering stem scapose; bractlets small, at base of calyx and deciduous or wanting; petals

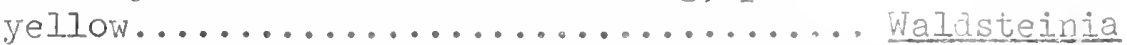

15. Flowering stem bearing leaves; calyx with persistent bracts at sinuses; petals yellow, rare-

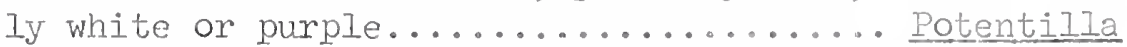

The amateur is likely to find some genera of the Catskill Rosaceae rather confusing, but it may be helpful. to realize that these genera are almost equally divided between those containing herbaceous plants and those consisting almost entirely of woody plants: 
Herbaceous Plants

Agrimonia

Dalibarda

Filipendula

Fragaria

Geum

Potentilla

Rubus

Sorbaria

Walds teinia

\section{Woody Plants}

Amelanchier

Crataegus

Prunus

Pyrus

Rosa

Rubus

Sorbaria

Spiraea

Most country people are actually already familiar with most of the wooky species of this family, starting with the early-blooming juneberries or shadbushes (Amelanchier), and few are those who do not know a Haw, Hawthorn, or simply Thoriapple (Crataezus) at sight. Many occhards contain peaches, plums, and cherries, and the wild species are not markedly different from the domestic varieties, all of which belong to the genus Prunus. It may seem strange to put apples, pears, chokeberries, and mointain-ash in one genus, Pyrus, but all except the choireberries are probably quite familiar to most farmers. And even people born and bred in urban settings are usually well acquainted with various types or roses (Rosa), to say nothing of rasperries and blackberries (Rubus). That leaves only Sorbamia and Sniraea among the woody specias of the Rosaceae; city gardeners are likely to be camiliar wi.th both genera, and who among cointry folk does not know Hardhask and Meadowsweet (Spirara), sometimeis also called Quaker Lady? Sorbaria Oi False Spiraea, is a cultivated ornanental plant that, sometimes escapes in the Catskill region

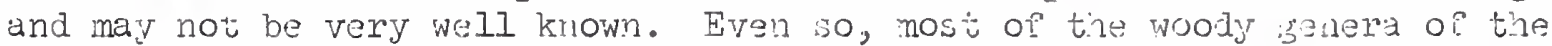
Carskill. Rosaceae should be reasonably familiar to nost laymen and should therefore not present too many problems. The following key may be heloful in determining unfamiliar senera of wooly plants.

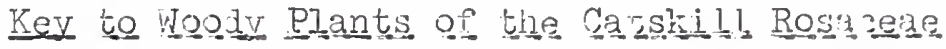

1. Plants with alternate compound leaves (stems with spines or prickles), 2

2. Leaves palmately compound (stems biennial; fruit aggregate)..... Rubus

2. Leaves pinnately compound, 3

3. Spines or thorns present on the stem and often on the midribs

of leaves, 4

4. Stipules adnate to the petiole half their length or more;

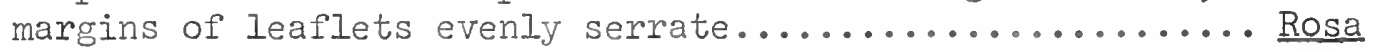

4. Stipules not adnate to the petiole; margin of leaflets usually coarsely toothed or often doubly serrate........... Rubus

3. Spines, thorns, and prickles absent, 5

5. Leaves coarsely serrate; terminal bud present; trees or tall shrubs; fruit red, berry-like.................... Pyrus

5. Leaves doubly serrate; terminal buds absent; low suffru-

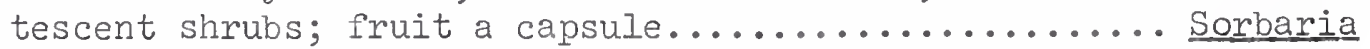

1. Plants with alternate simple leaves, 6

6. Leaves lobed, 7

7. Leaves distinctly palmately lobed and veined (leaves and twigs glandular-clamm; fruit aggregate, berry-like)..... Rubus odoratus

7. Leaves pinnately lobed, or at least not distinctly palmately Iobed, 8 
8. Leaves with 3 main veins from near the base, mostly with 1 or a few lateral lobes (lobes pointed; thorns usually present;

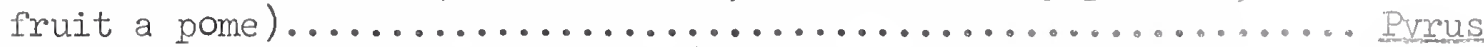

8. Leaves with one large main vein (midrib), variously lobed, 9

9. Leaves pinnately lobed (leaves $4-10 \mathrm{~cm}$ long; buds not clustered at the ends of twigs; fruit a small pome; thorns

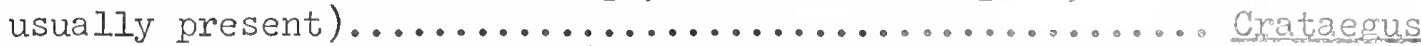

9. Leaves not pinnately lobed (leaves not truncate, irregularly

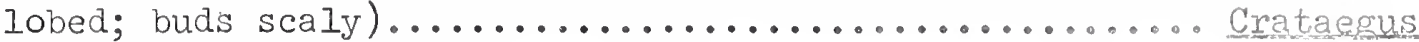

6. Leaves not lobed, 10

10. Margin of leaves entire (leaf blades 8-20 cm long, usually cordate or obtuse at base; fruit a pome)................. Pxrus

10. Margin of leaves not entire (usually serrate, dentate, etc.), Il

11. Plants with spines or thorns on stems, branches, or twigs, 12

12. Petioles with glands near the upper end; fruit a

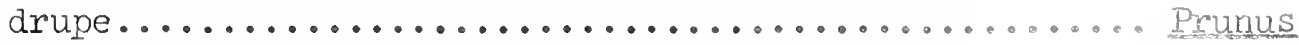

12. Petioles without glands near the upper end; fruit a pome, 13

13. Thorns on twigs and branches; thorns without lateral

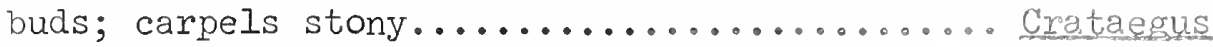

13. Thorns on branches only; thorns usually leafy ox with lateral buds; carpels not stony............ Pyrus

11. Plants without spines and thorns on stems and branches, 14

14. Leaves coarsely dentate or serrate, never doubly serrate

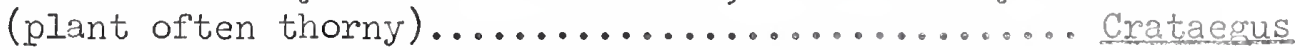

14. Leaves not coarsely serrate or dentate, mostly finely or doubly serrate, serrulate, denticulate, or crenate (sometimes entire near the base), 15

15. Base of leaf broad, cordate, truncate or nearly so, 16

16. Petioles with one or more glands near the upper

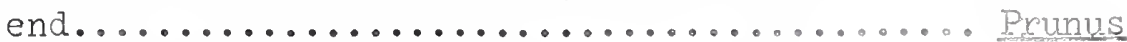

16. Petioles without glands, 17

17. Leaves $5-8 \mathrm{~cm}$ long, waxy on upper surface;

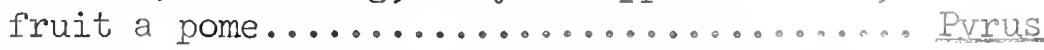

17. Leaves $1-4 \mathrm{~cm}$ long, not waxy on upper sur-

face; fruit a berry-like pome........ Amelanchier

15. Base of leaf' acute or tapering, 18

18. Petioles with one or more glands at the upper end, or the lower surface of leaf waxy and with a dense row of usually rusty hairs along each side of midrib; fruit a drupe................... Prunus

18. Petioles without glands at the upper end; midrib of leaf without rusty hairs as above, 19

19. Midrib of leaf with dark glands on the upper surface; fruit a berry............... Pyrus

19. Midrib of leaf without dark glands on the upper surface, 20

20. Twigs stout, mostly $3-5 \mathrm{~mm}$ in diameter when mature; branches often with stovt spurs (trees or tall shrubs; fruit a porne)... Pvrus

20. Twigs slender, less than $3 \mathrm{~mm}$ in diameter when mature, 21 
21. Fruit fleshy (leaves pale green or whitish on the lower surface; fruit a drupe...$\ldots \ldots \ldots \ldots \ldots \ldots \ldots \ldots \ldots \ldots \ldots$ Prunus

21. Fruit dry, a capsule or follicle (leaves serrate or doubly serrate; fruit folizcular, in corymbs or panicles)............ Spiraea

False Spiraea (Sorbaria) is sometimes considered as a "subshrub," and one species of trailing blackberry (Rubus) is very nearly herbaceous; those two genera therefore appear in both lists. Of the herbaceous genera of the Catskill Rosaceae, strawberries (Fragaria) and the cinquefoils (Potentilla) are doubtless most familiar, with avens (Geum) perhaps running a close third among country people. That leaves only four genera that may cause difficulty. The illustrations that follow, along with the following key, should enable the amateur to segregate the nine herbaceous genera of the Catskill Rosaceae.

\section{Kex to Herbaceous Genera of the Catskill Rosaceae}

1. Leaves simple (petals 5), 2

2. Leaves lobed; flowers terminal; pistils numerous............. Rubus

2. Leaves serrate; flowers on naked scapes; pistils $5-10 \ldots . .$. Dalibarda

1. Leaves compound, 3

3. Leaves 3-foliate or palmately once-compound, 4 4. Ovaries $2-10,5$

5. Petals white to pink (sepals widely spreading or reflexed, lanceolate, nearly or quite as long as the petals)...... Rubus

5. Petals yellow (stamens numerous; leaves with numerous

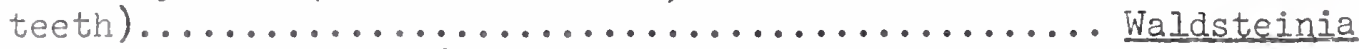

4. Ovaries more numerous, 6

6. Styles filiform, elongate; lower, middle, and upper leaves

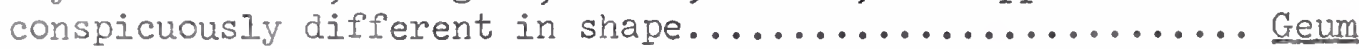

6. Styles short and inconspicuous; leaves all alike or nearly so, except in size, 7

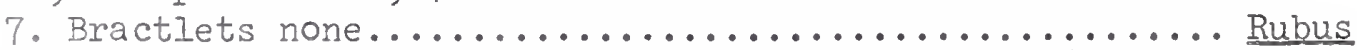

7. Bractlets present, alterrating with the sepals (bractlets entire, or obscurely toothed on the lateral margins only), 8

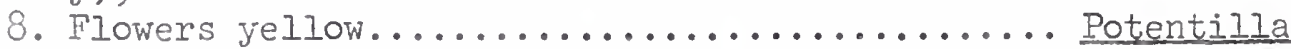

8. Flowers white, 9

9. Leaves with numerous teeth............. Fragaria

9. Leaves 3 -toothed at sumit............ Potentilia

3. Leaves pinnately compound, ternately compound, or dissected, commonly with several leaflets or segments, 10

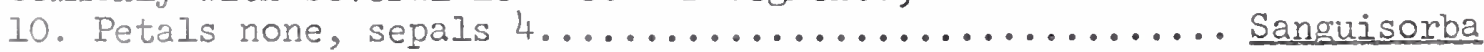

10. Petals 5; sepals 5, Il

11. Hypanthium turbinate, armed with hooked prickles around

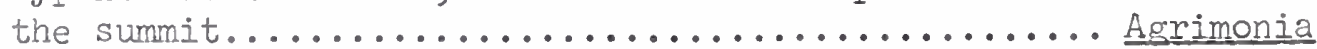

11. Hypanthium flat to saucer-shaped or hemispheric,

unarmed, 12

12. Pistils 5-15, 13

13. Terminal leaflet deeply laciniately toothed to

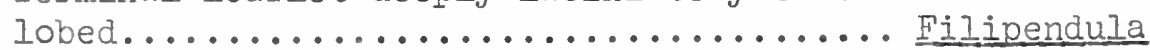

13. Terminal leaflet lanceolate, serrate........ Sorbaria

12. Pistils more numerous, 14

14. Styles short and inconspicuous.......... Potentilia

14. Styles elongate, jointed or plumose........... Geum 


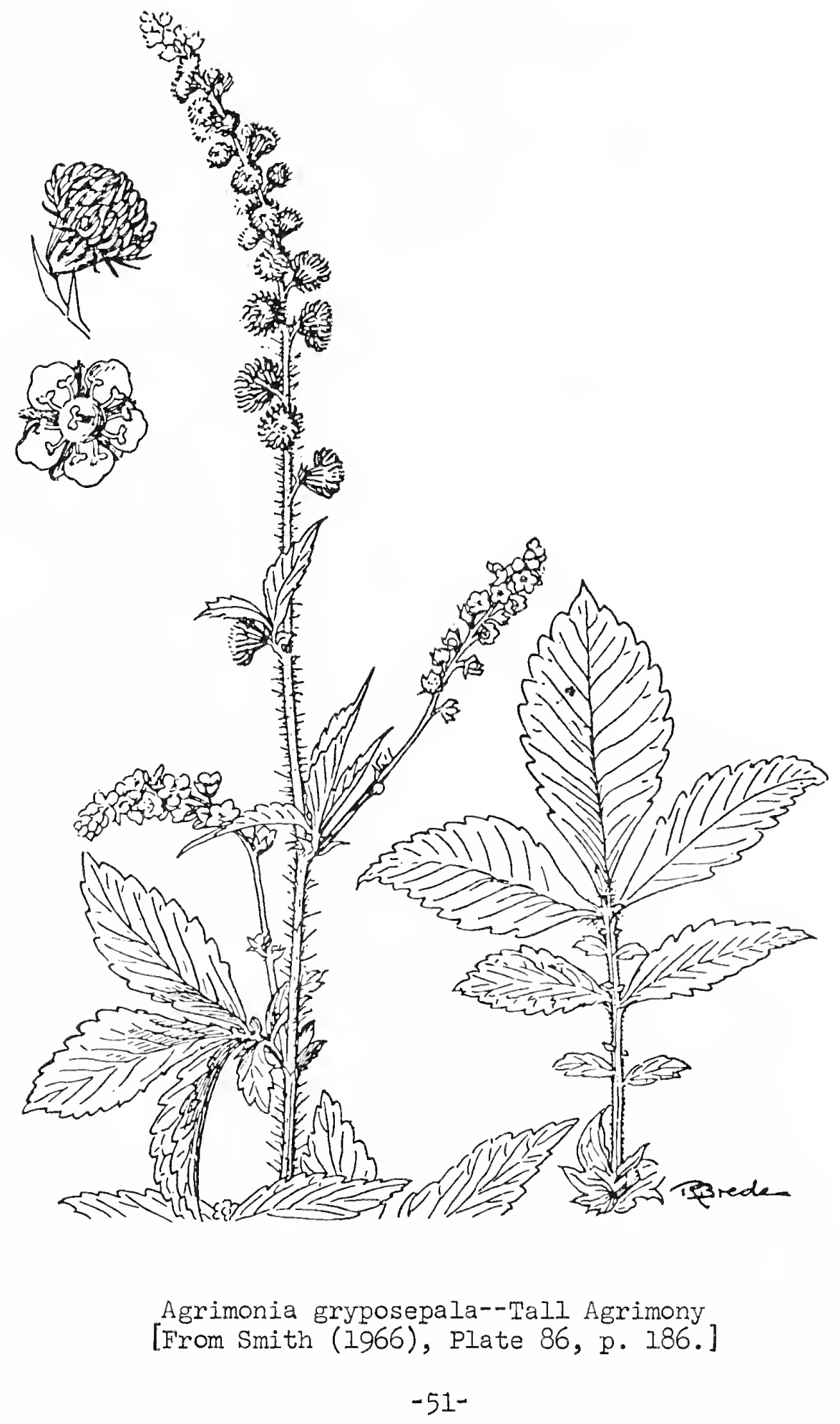


Agrimonia L. Agrimony.

There are about 20 species of Agrimonia, mostly perennial herbs with interruptedly pinnate leaves and small spicate-racemose flowers, widely distributed in the north temperate zone, although a few species grow in the Andes mountains. The name of the genus is a corruption of Argemone, a plant name by Pliny.

Agrimonia eupatoria, a native of Eurasia and North America, not only produces a fine yellow dye but both the herb and the root were once also used medicinally as a mild corroborant and astringent in the treatment of jaundice, chronic afflictions of the mucous membranes, and, in the form of a gargle, in affections of the throat. The Indians of North America also reportedly "employed the root [of species native to the region] with advantage in fevers." In some areas country people also steeped the dried leaves to make a sort of tea, probably mostly for its medicinal properties.

Agrimonia gryposépala Wallr. Tall Agrimony.

Meaning of Species Name. Having hooked sepals.

other Names. Tall Hairy Agrimony, Feverfew, Beggar's-ticks, Cocklebur, Stickweed, Stickseed.

Type of Plant. A perennial herb, reproducing by seeds.

Habitat. On dry soil of open woods, thickets, neglected fields, meadows, and hedgerows.

Range. PEI, Que, Ont, Mich, and ND, s to NJ, NC, Tenn, Mo, and Kan; also $\mathrm{S} \mathrm{BC}$ to $\mathrm{Cal}$ and $\mathrm{NM}$.

Distr in NYS. Frequent or common across the state outside the higher Adirondacks.

Distr in the Torrey Range. Common throughout the range except in the pine barrens and the region immediately surrounding them, there wanting; always increasing northw.

Time of Fl. Jul-Aug; Jul-Aug at Cornell.

Origin. Native.

In areas where this species has become an obnoxious weed, Muenscher (1952) suggests that scattered plants should be pulled up or hoed out as soon as the blossoms appear. Badly infested fields should be plowed and planted with a cultivated crop for a season.

Amelánchier Medic. Shadbush, Juneberry.

There are about 20 species of Amelanchier, trees or shrubs of the north temperate zone with simple leaves and racemes of mostly white or pink flowers, some 18 of which occur in North America. It is often difficult to distinguish the various species. The name of the genus was apparently adapted from the Provencal French name of the European species.

The fruit of A. canadensis, the Grape-pear or Sweet Pear, was eaten in large quantities, both fresh and dried, by Indians of the northwest. It is said to be the finest fruit available in the Saskatchewan country. 
Amelanchier alnifolia, the Western Service Berry, bears larger fruit than any of the eastern species and was also much used as food by the Indians of that region. Amelanchier vulgaris, a European species, is cultivated in England more for its flowers than for its fruit, which is "not highly palatable."

Although juneberries were among the most esteemed of our native fruits by the Indians and by the early European explorers of North America, they are largely ignored by country people of the northeastern states. The Indians gathered the "berries" in large quantities, crushed them to make a paste, which was then moulded into small cakes and dried in the sun. This dried fruit was then mixed with corn meal, made into pemican, and used in puddings, for which use it was considered "nearly equal [to] Zante currants." Fernald and Kinsey (1943) report that "To the European taste the berries are best when made into puddings or pies, the thoroughly cooked seeds giving a flavor suggesting sweet cherry pie." When cooked first, they make excellent muffins, imparting a rich almond flavor. Dried in the sun, they can be used as a substitute for currants.

Only two species of Shadbush are relatively common in the Catskills. One usually has juicier fruit than the other, but otherwise they are so much alike that only a botanist is likely to be concerned with the differences between the two species. Even in the country this fruit is now largely ignored except by an occasional hiker who may sample a few "berries" out of hand when he comes across them. Not only was this fruit eagerly sought by the Indians, who used it in many ways, but the colonists early learned that the dark red, almost purplish berries made good sauce and pies. To make a delicious Shadberry sauce, simply add I cup of sugar to 3 cups of fruit and simmer for 15 to 20 minutes. The most popular use of this fruit, particularly in Appalachia, however, was in the making of "Sarviceberry Pie." A 9-inch pie plate was lined with piecrust then filled generously with washed Juneberries, over which was sprinkled a mixture made up of $3 / 4$ cup of sugar, I/4 cup of flour, and 1 scant teaspoon of salt. The top was then dotted with butter, a top crust was arranged over all and perforated to permit air to escape, then baked for 45 minutes in an oven set at $400^{\circ} \mathrm{F}$. Juneberries also make excellent muffins, but they should be cooked before adding them to any basic recipe for muffins; simply use the recipe for shadberry sauce and drain the berries before adding them to the muffin mix. The cooked seeds add a rich almond-like flavor to the finished product. The Indians used to dry great quantities of Juneberries on flat trays in the sun for out-of-season use. For those who may wish to experiment with the dried fruit, it is very good used like currants in puddings and muffins, or the berries can be stewed to make shadberry sauce. The dried berries taste so different from the fresh fruit, however, that they can almost be considered another kind of food.

While not a timber species, the hard, heavy, strong, close-grained wood is occasionally used for tool handles and in the manufacture of fishing rods. The showy white flowers that appear in dense masses in early spring have ornamental value, but few people in the Catskills make use of its attractive flowers. The fruit is a favorite food of birds.

The Chippewas used the fruit of A. canadensis both fresh and dried for later use. Densmore (1928) states that the dried berries were boiled 
when used and either sweetened with maple sugar or combined with other foods. This species was also used medicinally. A decoction of the roots combined with those of cherry and young oak was taken internally for dysentery and diseases of women. To pregnant women who had been injured, a decoction of the root alone was given to prevent miscarriage. It was also administered to reduce excessive menstrual flow. A decoction of the inner bark, in combination with Pin Cherry, Choke Cherry, and "wild cherry" was taken internally for female weakness.

\section{Key to the Catskill Species of Amelanchier}

1. Petioles stout, 2-10 mm long; leaves imbricated in bud; leaf base acute; flowers solitary ( $1-3$ in a cluster)......... bartramiana

1. Petioles slender, 8-25 mm long; leaves conduplicate in bud; leaves subcordate or rounded at base; flowers in racemes, 2

2. Ieaves pubescent, at least along their midribs or on the

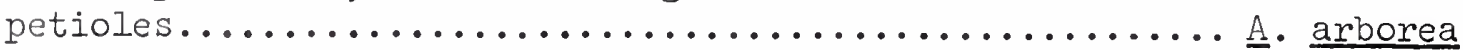

2. Ieaves glabrous from the beginning................ laevis

Amelánchier arbòrea (Michx. f.) Fern. Common Juneberry.

Meaning of Species Name. Treelike.

Other Names. Common Serviceberry, May-cherry, Sand-cherry, Downy Serviceberry.

Type of Plant. A tall shrub or small tree, usually only 15-25 ft high with a trunk 1 ft in diameter but sometimes 50-60 ft tall with a trunk nearly $2 \mathrm{ft}$ in diameter.

Habitat. Rich woods, thickets, pastures, and slopes.

Range. Me to Minn and Ia, s to Fla, Ia, and Okla.

Distr in NYS. Common throughout most secs of the state.

Distr in the Torrey Range. Throughout the range except the coastal

plain of NJ; commoner inland than near the coast.

Time of Fl. Apr-May(Jun), fr Jun-Aug; fl May l-15 at Cornell.

Origin. Native.

The common name of Shadbush was given to this tree by early settlers who associated its blooming in early spring with the runs of shad which ascended the New England rivers to spawn. Commonly associated with borders of woods, streambanks, and fencerows, this species is also found scattered through the forest, particularly on hillsides and mountain slopes, as well as in pastures. Its wood is hard, heavy, and strong, but it tends to warp and check badly during drying. Steyermark (1963) states that "It ranks with Persimmon as the heaviest wood among North American trees, and as fifth in hardness." It is sometimes used locally for tool handles and small turned articles but is otherwise of little value owing to the small size of the tree. It is sometimes planted ornamentally because of its attractive flowers. The Cree Indians used its fruit both fresh and dried and made from it a pudding which Emerson considered very little inferior to plum pudding. The fruit can be served fresh, but many people feel that it has a better flavor when cooked in pies or canned for winter use. 


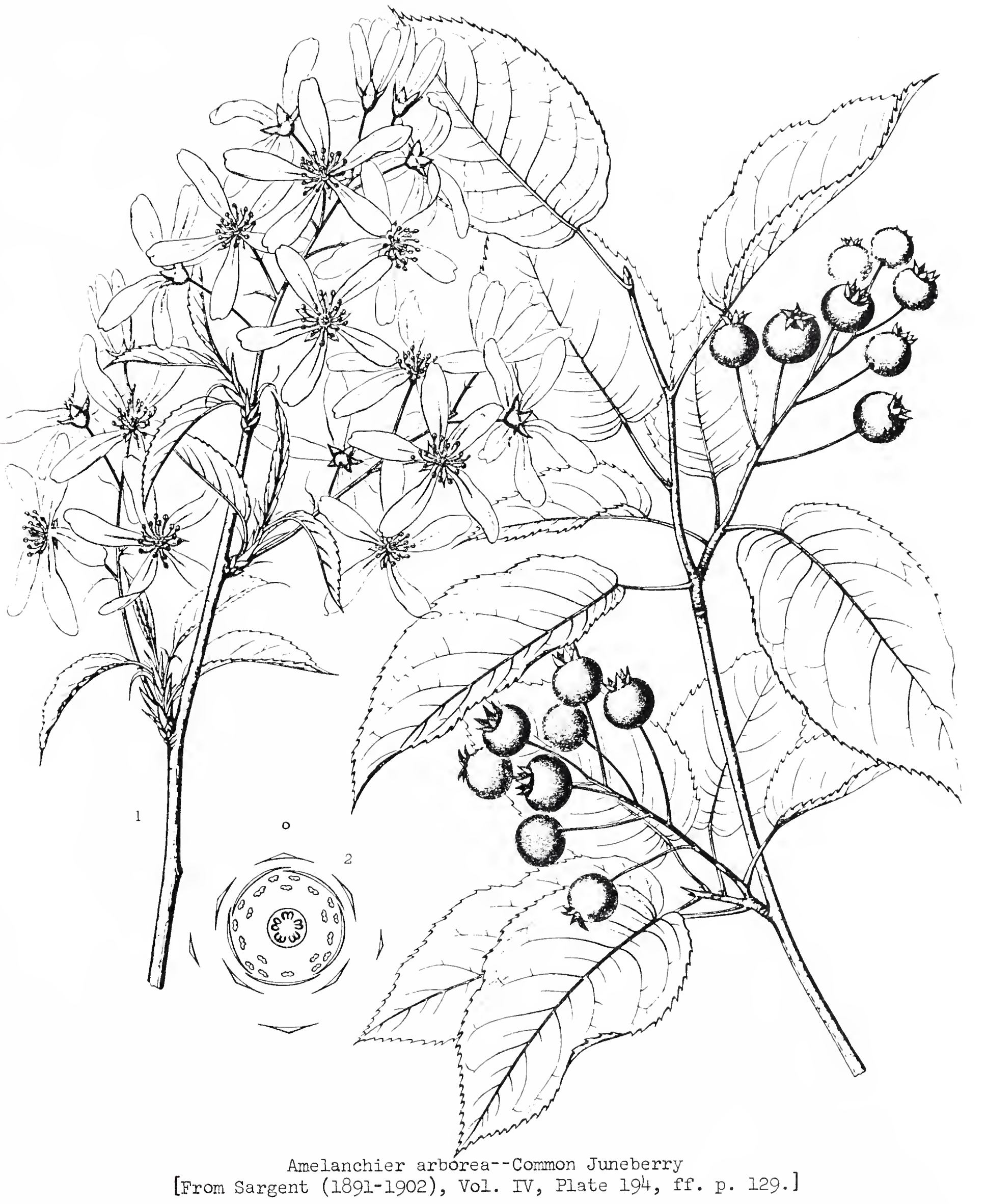


Some 40 species of birds, including ruffed grouse, thrushes, and many other songbirds, consume its fruit, together with such animals as skunks, foxes, chipmunks, squirrels, opossum, raccoon, and even bears. It is therefore an important source of food for many types of wildlife during early summer (June and JuIy). Martin et al. (1951) remark that "Because of its horticultural merits combined with wildlife utility the downy serviceberry is worthy of extensive planting as an ornamental."

Harlow (1957) states that "One of the best features for recognizing the tree is the terminal bud, which is long and tapered like that of beech but with fewer scales. When chewed, the twigs have a faint bitter-almond taste."

Amelánchier bartramiàna (Tausch) Roemer. Mountain Juneberry.

Meaning of Species Name. Named for William Bartram, 1739-1823, who sent seeds to European horticulturists.

Other Names. Mountain Shadbush, Oblong-fruited Juneberry.

Type of Plant. A slender cespitose-fastigiate shrub $11 / 2$ to $8 \mathrm{ft}$ high.

Habitat. Peaty or boggy thickets, mountainous swamps, sphagnous bogs, bushy slopes, and mountain summits (ascending to subalpine areas); also in cold wet rocky woods, swamps, and bogs.

Range. Lab to James Bay and Man, s to $\mathrm{NE}$, the higher mts of $\mathrm{NY}, \mathrm{Pa}$, and WVa, w to Mich, Wis, and Minn.

Distr in NYS. Common throughout the Adirondack reg and locally common across the $\mathrm{n}$ part of the state, southw to Washington. Fulton, Herkimer, and Lewis co.

Distr in the Torrey Range. Confined in our area to peaks of the Catskills and in Monroe and Schuylkill co in $\mathrm{Pa}$. range.

Elevation. Above $1500 \mathrm{ft}$, usually up to $4020 \mathrm{ft}$, in the Torrey

Time of Fl. May-Jun(Aug), fr Jul-Sep.

Origin. Native.

Amelánchier laèvis Wieg. Smooth Shadbush.

Meaning of Species Name. Smooth.

Other Names. Smooth Juneberry, Eastern Serviceberry, Juneberry, Shadbush.

Type of Plant. A fastigiate shrub or small tree.

Habitat. Dry to moist upland woods, thickets, borders of woods, margins of swamps, and clearings.

Range. If to Que, Ont, and Minn, s to Md, $\mathrm{mts}$ to $\mathrm{Ga}$ and $\mathrm{Ala}, \mathrm{O}$, Ind, III, Ia, and e Kan.

Distr in NYS. Frequent across the state northw and throughout the $c$ highlands of the state, the Catskills, and the highlands of the Hudson valley, southw on the Appalachian plateau.

Distr in the Torrey Range. Not listed in Taylor (1915).

Time of Fl. Apr-May, fr Jun-Aug; fl May 1-15 at Cornell.

Origin. Native. 


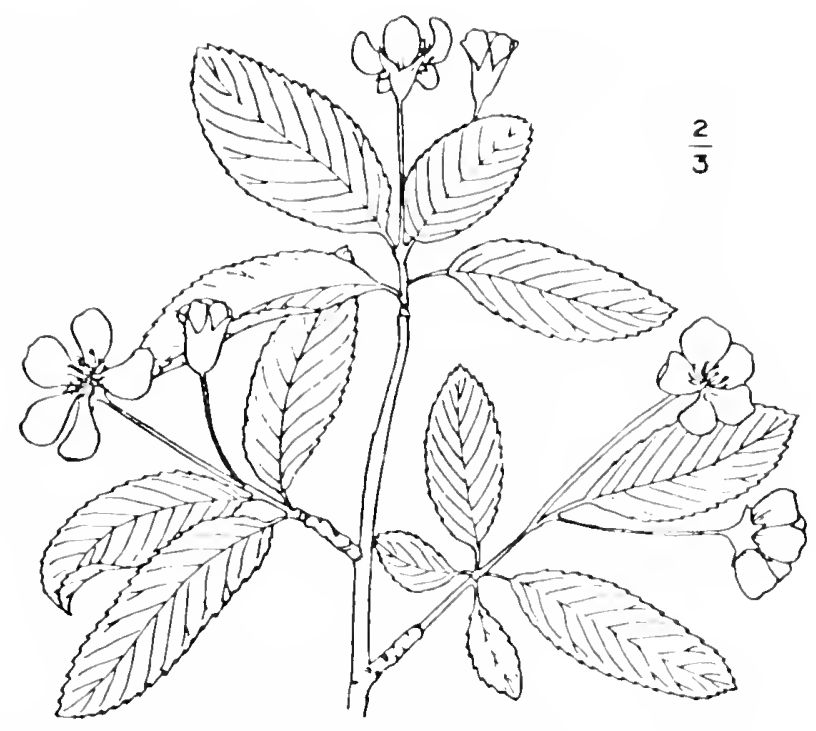

Amelanchier bartramiana--Mountain Juneberry

[From Billington (1949), Fig 62, p. 132.]

This species is often seen in parks and on lawns, for its delicate, purple-brown branches are nearly concealed in April or early May, as the oval leaves are just putting in an appearance, with drooping clusters of attractive white flowers. Rogers (1926) evidently confused this species with $A$. arborea, for of it she states that "Under each [cluster of flowers] is a pair of red silky bracts and the infant leaves are red and silky, all adding to their warmth of color when the tree is white with bloom." It is this species, and not A. arborea, that has bronzy-red expanding leaves; those of $\underline{A}$. arborea are light green and covered with silvery-white hairs, a distinction that makes the two species easy to identify in early spring. Both of these "charming little trees" light up "the river banks with their delicate blossoms, when all the woods around them ... [are] still asleep." The juicy red berries ripen in June, calling all the birds around to a feast, after which "the little tree quite loses its identity, for the forest is roofed with green, and June-berries are quite overshadowed by more self-assertive species."

While the fruit of $\underline{A}$. arborea is usually rather dry and insipid, "practically inedible to all but the birds," that of this species is likely to be sweet and juicy; it took a place among the preferred wild fruits of the American Indians, who gathered them in large quantities wherever they were available. Michaux remarked that in his day the berries often appeared in the markets of Philadelphia, but added that "they were bought only by children." It is from the fruit that it received the name "Sarvissberry," which, according to Peattie (1950), is "a transformation of the sorbus given by the Romans to a related kind of fruit."

The wood of this species is one of the heaviest of our northern sylva, ranking as the fifth hardest of all our woods. It takes a beautiful polish and would make a valuable cabinet wood, but the tree seldom exceeds 


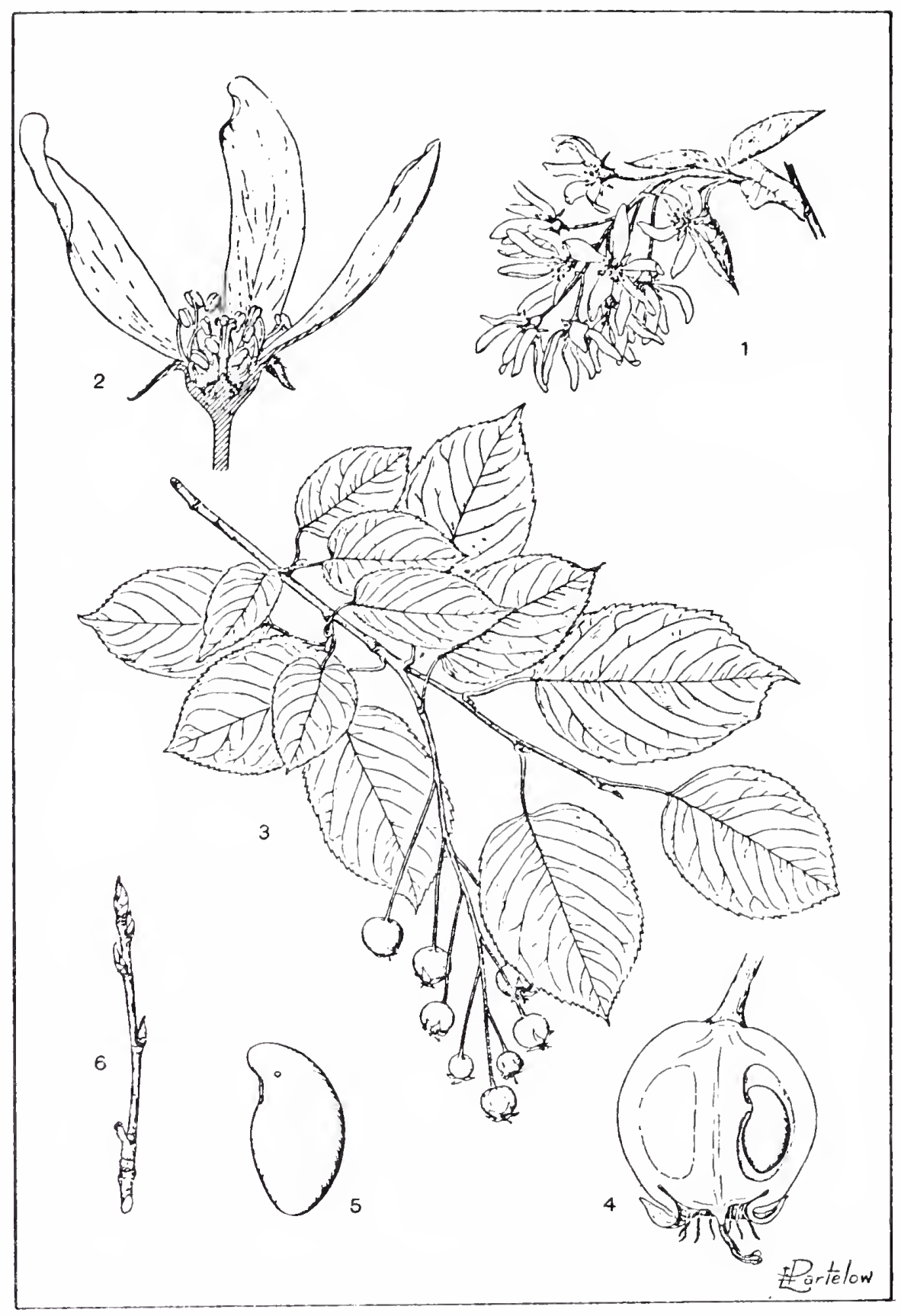

Amelanchier laevis--Smooth-leaved Shadbush
[From Brown (1921), p. 302.]

20 or 30 feet in height. Many species of wild birds, including the ruffed grouse, are fond of its fruit. The fruit is also eagerly devoured by such mammals as the black bear, raccoon, opossum, foxes, and white-tailed deer. 
Crataègus L. Hawthorn.

Hawthorns are most abundant in eastern North America, some 100 species having been described from the northeastern states and adjacent Canada. A few species also occur in the western states, Mexico, and south to the Andean region of South America as well as in temperate parts of Eurasia. The name of the genus is derived from the Greek kratos, strong or powerful. More than 1000 species have been described from North America, but current authorities now regard many of them as hybrids or varieties of variable species. The genus is a most difficult one and most botanists working in the Catskill region have almost completely ignored them, including the present writer. One difficulty is that in order to be able to identify some of the species, it is necessary to collect both flowers and fruit. That requires tagging the shrub or tree in the spring and returning in the fall to obtain fruit from the same plant.

Several Eurasian species bear edible fruit, including $\underline{\mathrm{C}}$. azarolus, a native of Asia Minor and Persia, much cultivated in the Mediterranean region, where it is "sometimes served as dessert, and is much used for preserves." The fruit of $\underline{\mathrm{C}}$. orientalis, another Mediterranean species, is considered in the Crimea to be "an agreeable fruit, much improved by frafting." In Kamchatka the natives make a kind of wine from the fruit of $\underline{\mathrm{C}}$. oxyacantha by fermenting them with water. This species is also said to be cultivated in India for its fruit. The fruits of several other old world species are also relished as food in some areas, including $\underline{C}$. pentagyna, a Eurasian species that grows wild west of Peking, where its large fruits are "collected and an excellent sweetmeat is prepared therefrom."

The English Hawthorn, cultivated primarily for its flowers, bears an inferior fruit, so the English colonists early recognized the superior quality of some of the native American hawthorns. John Josselyn, writing in 1672, considered the haws "very good to eat, and not so astringent as the Haws in England." W. Wood, probably referring to $\underline{\mathrm{C}}$. tomentosa, in his New England's Prospect written in 1634, stated that "The white thorn affords hawes as big as an English Cherrie, which is esteemed above a Cherrie for his goodnesse and pleasantnesse to the taste." The fruits of several native species have a juicy pulp from which delicious jellies and marmalades can be made, but the different species bear such variable fruit that their usefulness can be determined only by experiment, for all the fruits bear large stones and only a minimum of pulp. Jelly from the better species, however, requires comparatively little sugar.

Hawthorns, known locally in the Catskills as thornbrush or thornapples, are quite diverse in appearance, coming in a wide variety of sizes from small shrubs no more than a few feet high to good-sized trees over 30 feet high with a trunk up to a foot in diameter, but most people have no difficulty in recognizing this genus once they become acquainted with it. The fruit resembles a small apple, although that of some species may be oval or pear-shaped, usually bright red in color, except that some species bear greenish or yellowish fruit. Few people except for young boys are tempted to sample the fruit and then conclude that even when they are good, they are not very good, and when they are bad, they are horrid. It is not surprising, therefore, that practically no one ever makes use of this fruit. 
The fruit can be used to make both jelly and marmalade. To make haw jelly, select the best ripe fruit you can find in the neighborhood, crush 3 pounds of the fruit, add 4 cups of water, bring to a boil, simmer covered for 10 minutes, then strain the juice through a jelly bag, discarding the pulp, skins, and seeds. Add 1 package of powdered pectin, the juice of 2 lemons, and 7 cups of sugar to 4 cups of juice, stir well, and bring to a boil. Boil hard for 1 minute, skim off any foam, pour into small glass jars, and seal with paraffin.

To make haw marmalade, cook the haws in very little water for about 15 minutes then force them through a ricer or sieve to remove skins and seeds. To $11 / 2$ cups of the strained haw pulp add the juice and peels from 1 lemon and 1 orange, and, if desired, $I / 2$ teaspoon of powdered rosemary. Stir in 1 package of powdered pectin, return it to the fire, bring to a boil, then stir in 5 cups of sugar and bring once again to a boil, stirring constantly. After this mixture has boiled hard for 1 minute, skim off any foam, pour into sterilized glass jars, and seal with paraffin. To prepare the orange and lemon peels, shave off about half of the white pulp from the inner side of the skins, cut into fine shreds with a pair of kitchen shears, and put them in a saucepan with 2 cups of water and $1 / 8$ teaspoon of soda. Boil for 20 minutes, drain, and add them to the other ingredients.

Various tribes of Indians used one species or another for medicinal purposes, and all doubtless have similar properties. Vogel (1970) remarks that the Flambeau Ojibwas used both the fruit and bark of one species to prepare a medicine for women, while the Meskwakis used the green fruit of another species for bladder ailments and a decoction of the root bark for general debility. The Potawatomis used the fruit of a native species for stomach complaints, while the Kwakiutls chewed the leaves of a different species to make a poultice for application to swellings. In 1737 John Brickell reported that "the Leaves, Flowers, and Haws, are very binding, therefore good to stop all kinds of Fluxes; the Powder of the Stone drank in Rhenish Wine, is of very great service in Stone, Gravel, and Dropsie." Various species of Crataegus were also used by the whites and some were listed in the U.S. Dispensatory for their astringent and tonic properties, useful in the treatment of heart ailments. The inner bark was used for this purpose. A decoction of the astringent ripe haws was once much used both as a cure for sore throat and as a gentle corrective for diarrhea. This medicine was made by crushing 1 cup of the fruit, adding 1 cup of water, and boiling for 10 minutes. The liquid was then strained, sweetened to taste with honey, and administered a tablespoonful at a time for sore throat and a wineglassful at a time for diarrhea.

The Chippewas made use of some species of native hawthorn as food. The fruit was prepared by squeezing it in the hands (presumably to remove the seeds), after which the pulp was made into little cakes without cooking, dried on birch bark, and stored to be cooked in winter. The long thorns of some species made useful awls, used by the women in their sewing.

The dense branching, thorniness, and heavy foliage of these shrubs or small trees make them favorite nesting sites for many birds. Although some 36 kinds of birds sometimes eat the fruit, these small apple-like pomes are not utilized by wildlife to nearly so great an extent as might be expected, fox sparrows and cedar waxwings being the principal songbird 
users, and several species used in ornamental plantings seem to be no more attractive to wildlife than species growing in the wild. Cattle and deer browse the young growth and several mammals, including field mice, gray fox, raccoons, skunks, squirrels, and black bears, occasionally eat the fruit. Both rabbits and beaver.sometimes gnaw the bark.

Thornapples are ubiquitous pasture "weeds" in the Catskills, and a constant battle is necessary to keep them from preempting grazing areas. Scattered small bushes can be grubbed out, but Muenscher (1952) suggests that the only way to get rid of larger shrubs is to pull them out with horses or tractor and chain. Larger trees should be cut in midsummer, piled up to dry, then burned.

Crataegus crus-galli, the Cockspur Thorn, usually found growing in the rich soil of wooded hillsides and old pastures, often attains a height of 25 feet. This species is of note as a horticultural plant, for it has been much used both in Europe and in America (even in colonial times) as a hedge plant. It will withstand heavy pruning and its fierce thorns and intricate twigs form an almost impenetrable barrier. The thorns on the sides of the twigs are 3 to 4 inches long, in age often branching and attaining a length of 6 or 8 inches. Its bright and polished bark shades from reddishbrown to gray. It is an attractive tree, bearing an abundance of flowers in spring. Later, the thick, leathery, lustrous leaves, dark green above and pale beneath, "impart, all summer, an appearance of garden-like formality; in autumn they turn bright orange or deep garnet red," while its red fruits, ripening in october, decorate each twig all winter until spring.

It is not possible to write a key to the Catskill species of Crataegus that will enable the amateur to identify the species he may come across, not only because the genus is such a difficult one but primarily because, in all probability, less than half the species one might expect to occur in that area have been collected. The following key is therefore offered, not so much as an aid in identifying the eight species known to grow in the Catskills but to enable the amateur to note some of the characteristics that serve to separate the various species so that he may more intelligently observe and collect the several species occurring in that area.

\section{Key to Iocal Species of $\underline{\text { Crataegus }}$}

1. Leaves deeply cut or cleft; introduced species (fruit red, styles and nutlets 1$) \ldots \ldots \ldots \ldots \ldots \ldots \ldots \ldots \ldots \ldots \ldots \ldots \ldots \ldots \ldots \ldots \ldots \ldots$. monowna

1. Leaves not deeply cut; native species, 2

2. Leaves broadest toward the apex (also note $3 r d \underline{\text { in key) }}$ (leaves obovate, narrow, dull gray-green, impressed-veined above, dull; calyx lobes lanceolate-acuminate, usually entire;

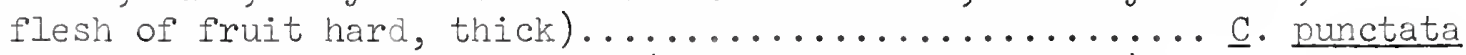

2. Leaves broadest at the middle (also note $3 \mathrm{rd}$ ㄹ in key), 3

3. Leaves not impressed-veined (not acutely lobed; calyx lobes usually lanceolate-acuminate, glandular-margined, reflexed; leaves elliptic ovate; young foliage usually yellow-green)

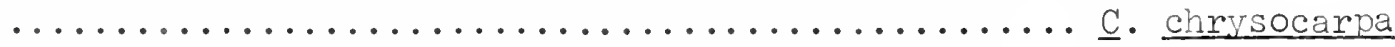


3. Leaves impressed-veined, 4

4. Calyx lobes usually deeply cut; nutlets deeply pitted on the ventral faces; corymbs pubescent (leaves rhombic-elliptic; calyx lobes glandular-laciniate, villous; leaves dark green,

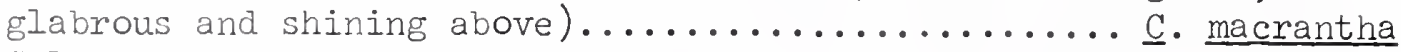

4. Calyx lobes less deeply cut; nutlets with shallow pits on the ventral faces; corymbs and fruit glabrous (leaves elliptic to ovate; calyx lobes remotely glandular ser-

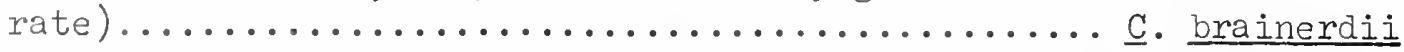

2. Leaves broadest at the base, 5

5. Leaves $1 / 2$ to 2 l/2 in. long; calyx lobes entire (leaves ovate, yellow-green, not conspicuously lobed, often slightly pubescent; young foliage usually bronze-green; fruit large, glabrous, flesh succulent)............... macrosperma

5. Leaves ovate, 1-4 in. long and wide; calyx lobes usually glandular-serrate; fruit usually pubescent, flesh thick, soft, edible, 6

6. Leaves oblong-ovate, sharply lobed; calyx lobes reflexed;

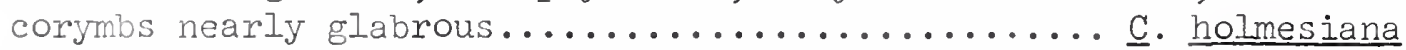
6. Leaves broadly ovate; corymbs and fruit pubescent or tomentose (leaves on vegetative shoots cuneate).... $\underline{\text {. pedicellata }}$

Crataègus brainérdi Sarg. Brainerd's Hawthorn.

Meaning of Species Name. Named for its discoverer, Ezra Brainerd, $1844-1924$.

Type of Plant. A shrub only 6-9 ft high, but sometimes a small tree 18-20 ft tall.

Habitat. Thickets, pastures, and roadsides.

Range. Que, NE, and NY to Mich, s in the mts to NC.

Distr in NYS. Frequent across the state outside the higher Adirondacks, but not recorded from the lower Hudson valley nor from the Catskill and susquehanna regs.

Distr in the Torrey Range. NY: Near Stamford, Delaware co. Time of Fl. May-Jun, fr Sep-Oct. Origin. Native.

Crataègus chrysocárpa Ashe. Round-leaved Thorn.

Meaning of Species Name. Golden fruited. Type of Plant. A stout, intricately branched shrub or rarely a small tree up to $25 \mathrm{ft}$ tall.

Habitat. Thickets and rocky ground along streams.

Range. Nf and Que to NE and NY, w to Man, Col, and NM.

Distr in NYS. Widely distr across the state; common in some secs.

Distr in the Torrey Range. NY: Dutchess, Columbia, Delaware, and

Greene co.

Time of Fl. May, fr Sep-Oct.

Origin. Native. 


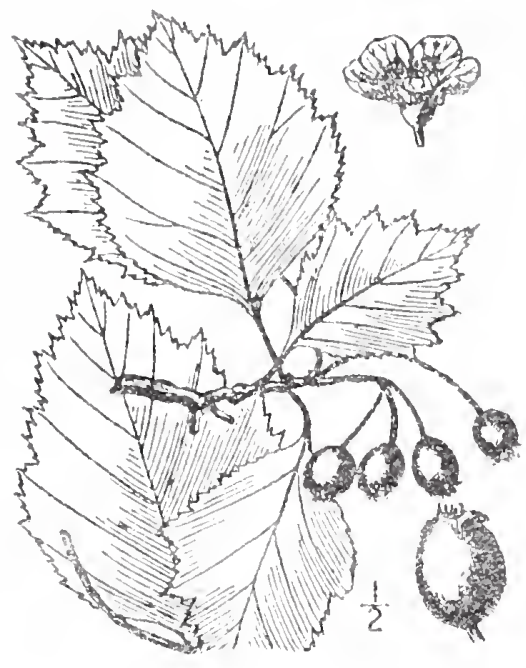

Crataegus brainerdii Brainerd's Hawthorne LFrom Britton

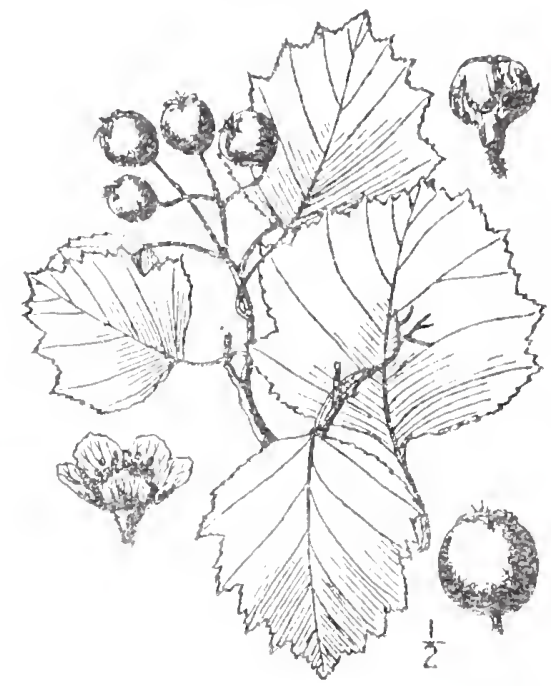

Crataegus chrysocaxpa Round-Ieaved Thorne II: $303,306$.

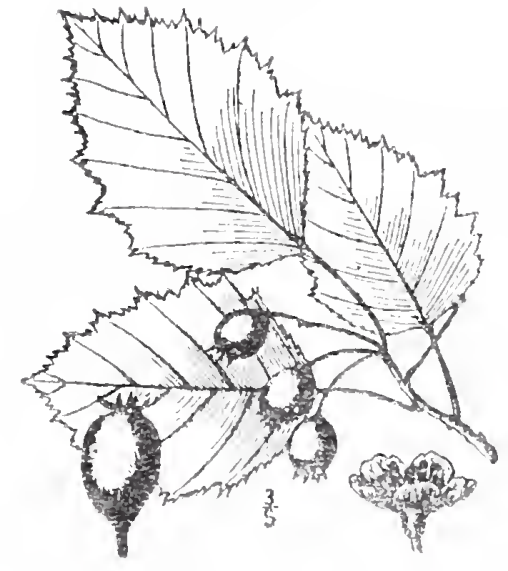

Crataegus holmesiana

Thin-leaved Thom

[From Britton \& Brown (1913), II: 315, 301.]

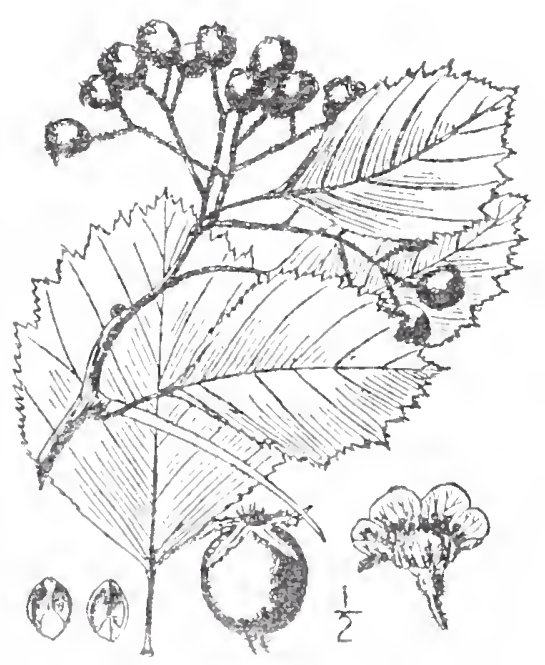

Crataegus macrantha

Long-spine J Thom 


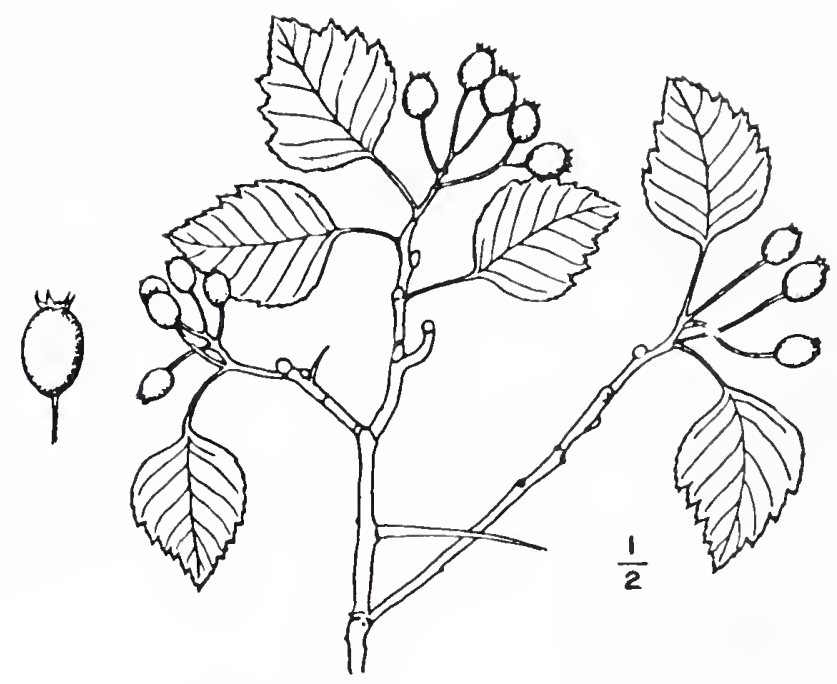

Crataegus macrosperma--Variable Hawthorn

[From Billington (1949), Fig. 67, p. 142.]

Cratàgus holmesiàna Ashe. Thin-leaved Thorn.

Meaning of Species Name. Named for Joseph Austin Holmes, 1859-1915. Other Names. Holmes' Thorn.

Type of Plant. An arborescent shrub or small tree.

Habitat. Thickets, borders of woods, and along streams, usually in moist or fertile ground.

Range. Se Can and $\mathrm{NE}$ to $\mathrm{NY}$ and $\mathrm{Pa}$, w to Wis and ne Minn.

Distr in NYS. Frequent from Albany, Herkimer, and St Lawrence co westw and southw.

Distr in the Torrey Range. NY, under $\underline{C}$. villipes Ashe: Near NYC, increasing northw and common in the Catskills.

Time of Fl. May, fr Sep-Oct; fl May 10-30 at Cornell.

Origin. Native.

Crataègus monógyna Jacq. English Hawthorn.

Meaning of Species Name. Having one ovary, from the solitary nutlet. Other Names. White Thorn, May Thorn, Hedge-thorn, May Bush, Quickset, Quick, Wick, Wicken, Haw-tree, Quickthorn.

Type of Plant. A small tree growing 20-30 ft high.

Habitat. Often cult and spreading to roadsides, open fields, pastures, and borders of woods.

Range. E US.

Distr in NYS. Sparingly esc from cult.

Distr in the Torrey Range. Not very common as an esc in our area.

Elevation. Collected at $2800 \mathrm{ft}$ in Delaware co.

Time of FI. May, fr Oct; fll May 25-Jun 10, fr Sep 20-Oct at Cornell.

Origin. Introd from Eurasia and the Mediterr reg.

Remarks. Wood hard, yellowish-white; wt $50 \mathrm{lb}$ per cu ft. 


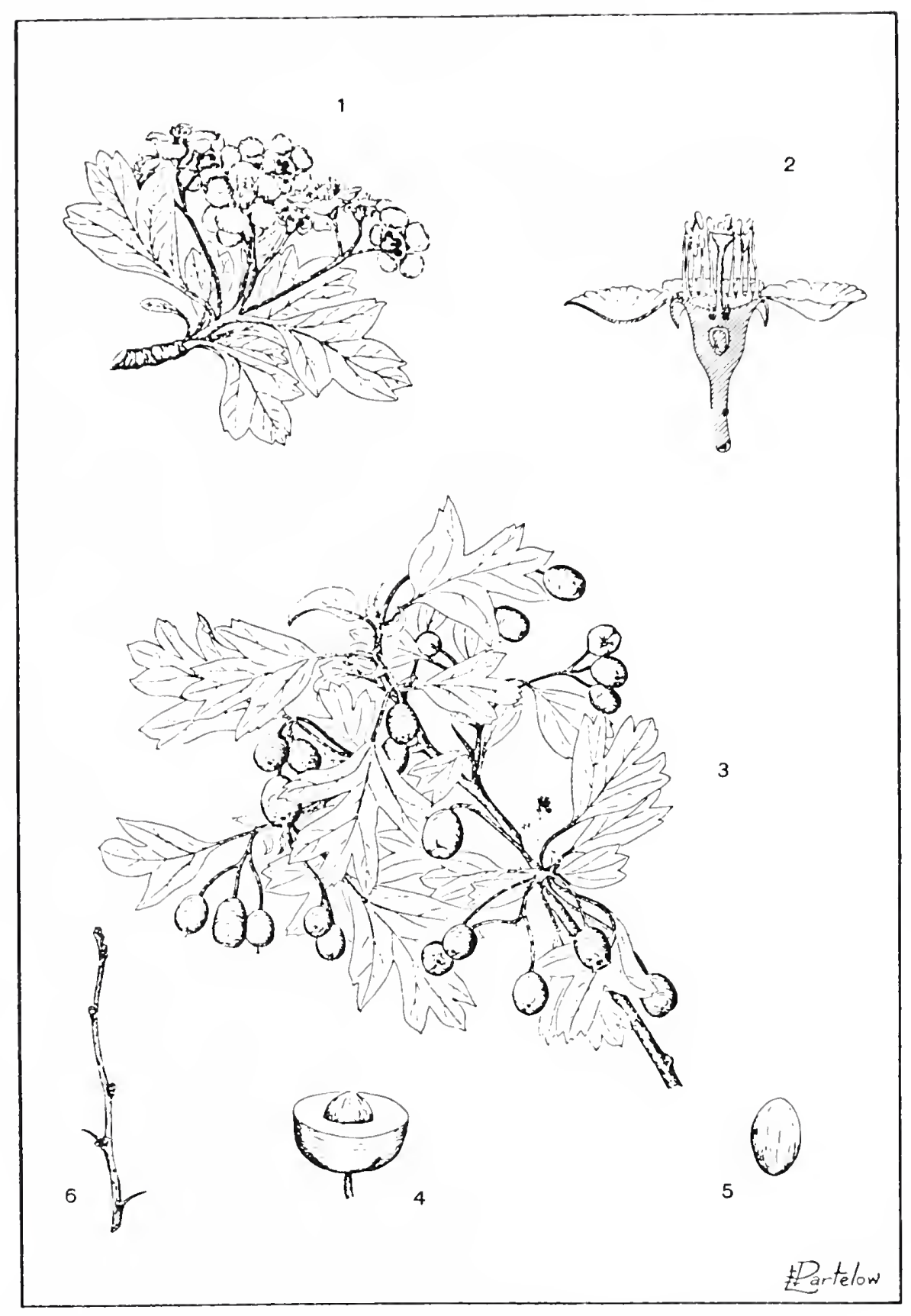

Crataegus monogyna--English Hawthorn

[From Brown (1921), p. 292.]

Crataègus macrospérma Ashe. Variable Hawthorn.

Meaning of Species Name. Large-seeded.

Other Names. Large-seeded Thorn.

Type of Plant. A small tree or sometimes an arborescent shrub.

Habitat. Hillsides, woods, thickets, fields, and along streams, usually in dry or rocky ground. Wis.

Range. S Can and NE to the mts of NC and Tenn, $w$ to IIl, Ind, and

Distr in NYS. A common species but recorded from only a few localities in the Adirondack reg.

Distr in the Torrey Range. Common throughout the range except on the coastal plain of $\mathrm{NJ}$.

Time of Fl. May-Jun, fr Aug-Sep; fl May 10-25, rarely June 5, fr Sep 10 or later at Cornell. 


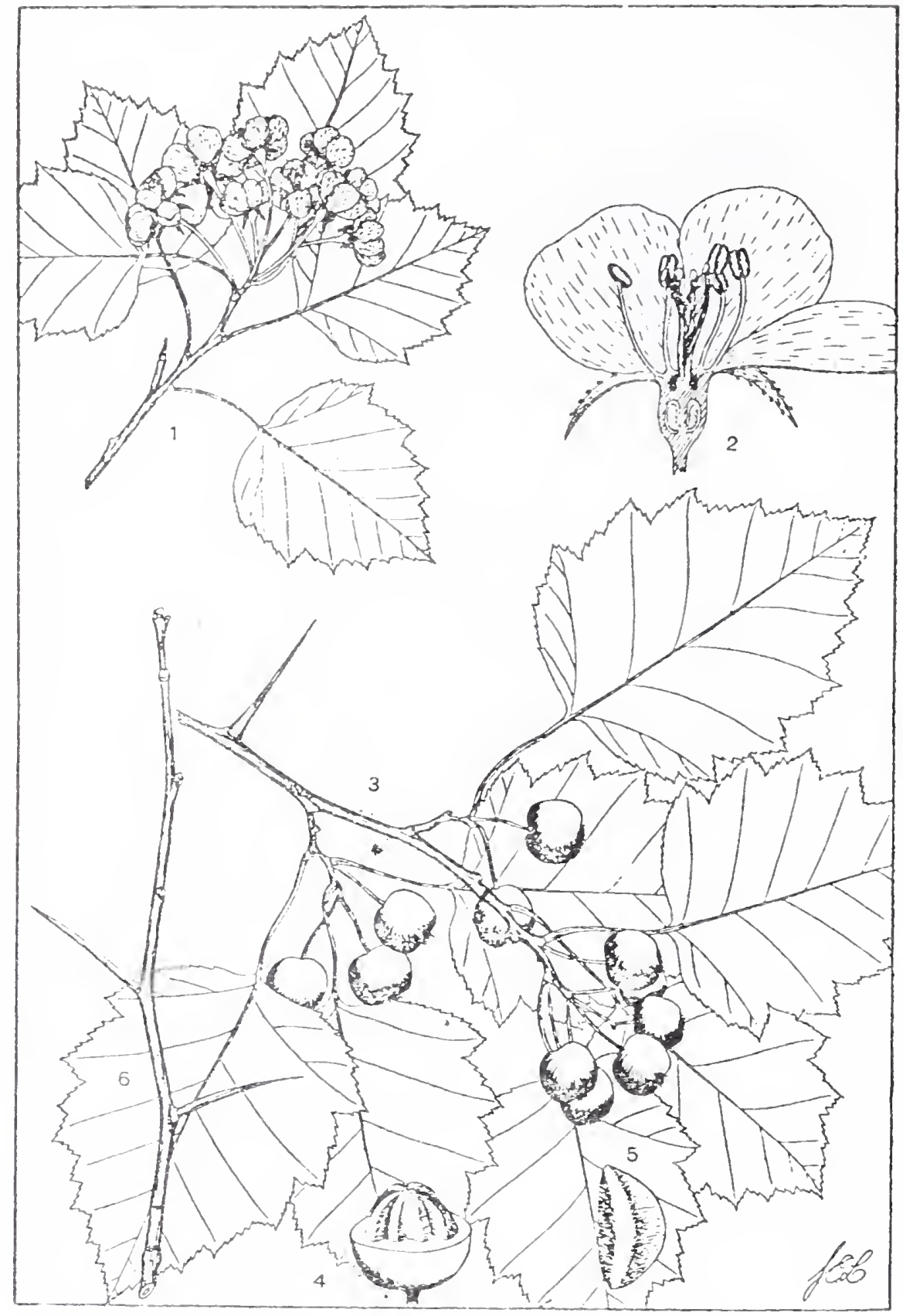

Crataegus pedicellata--Scarlet Haw

[From Brown (1921), p. 290.]

Origin. Native.

Remarks. This species is so variable that early students of the genus described 70 species from this complex, later reducing them all back to one.

Crataègus pedicellàta Sarg. Scarlet Haw.

Meaning of Species Name. Pedicelled.

Type of Plant. A small tree growing 18-24 ft high but sometimes only a stout shrub.

Habitat. Hillsides, borders of noods, thickets, and banks of streams.

Range. INE, Ont, and IVY to Ind and $n$ III. 


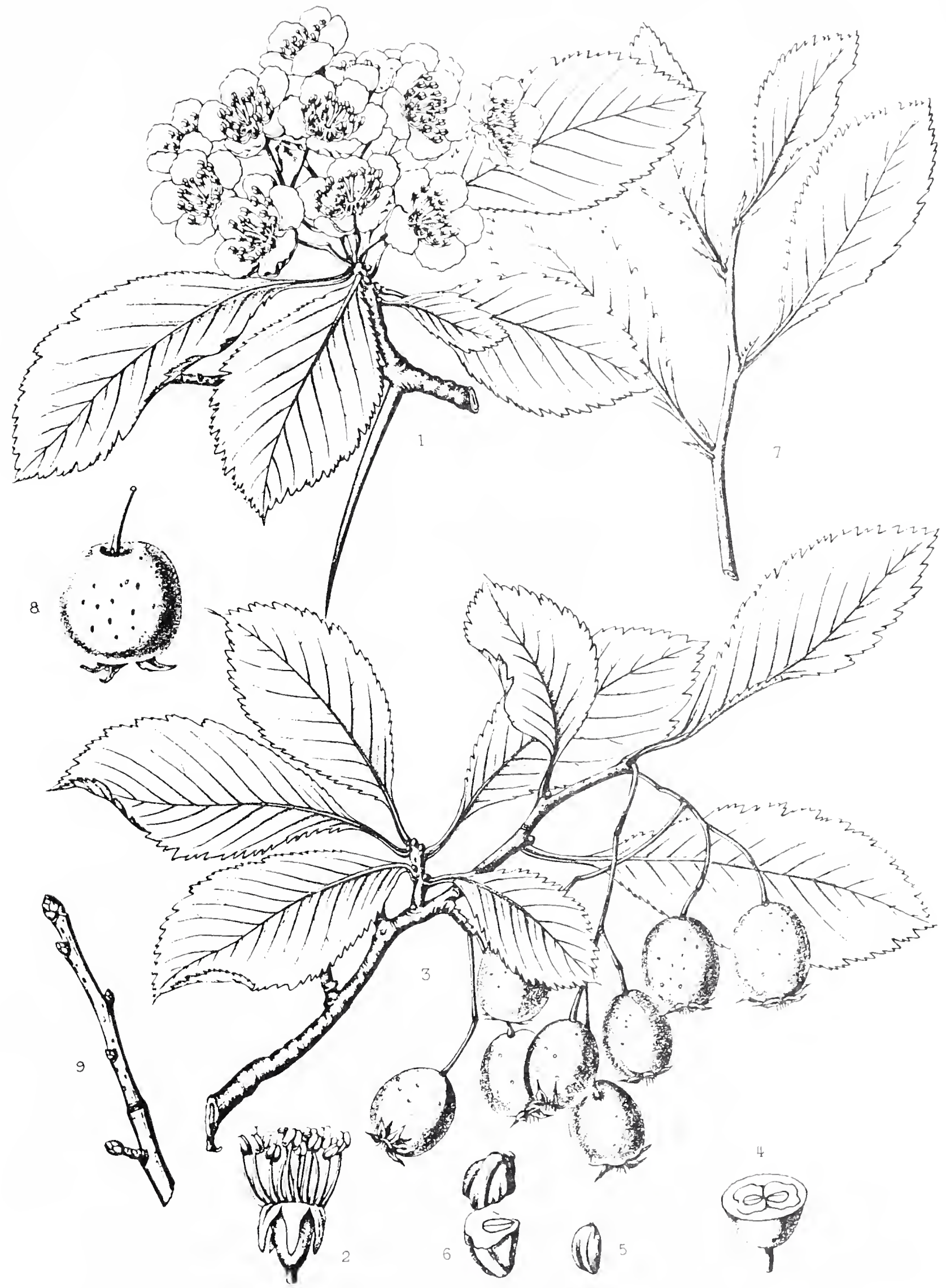

Crataegus punctata--Dotted Haw
[From Sargent (1891-1902), Vol. IV, Plate 184, ff.p. 104.] 
Distr in NYS. Comnon across the state outside and chiefly s of the Adirondacks.

Distr in the Torrey Range. NY: Greene and Dutchess co.

Time of Fl. May, fr Sep.

Origin. Native.

Rogers (1926) states that this species, a native of the northeastern states, is one of the oldest native thorns in cultivation, being a favorite in New England gardens "because of its abundant bloom, deep crimson fruit, and vivid autumn foliage."

There are no Catskill records of this species, but it has been collected in both Greene and Delaware counties just outside the Catskill region and may still turn up in the mountains. For that reason it seems justifiable to retain it in the key to the species and in the text.

Crataègus punctàta Jacq. Dotted Haw.

Meaning of Species Name. Dotted, punctate.

Other Names. Iarge-fruited Thorn, White Thorn, Flat-topped Hawthorn.

Type of Plant. A small tree usually growing 18-20 ft high but some-

times attaining 20-30 ft in height with a trunk 12 in. in diameter.

Habitat. Open rocky ground, thickets, borders of woods, and pastures, usually in rich soil chiefly along streams, shores of ponds, lakes, and bottomlands.

Range. Que and NE to $\mathbb{N C}$ and Ky, w to Minn, Ia, and Ind.

Distr in NYS. Common across the state outside the higher Adirondacks.

Distr in the Torrey Range. Throughout the range except in the pine

barrens of INJ and II, there rare or wanting, but locally unrecorded.

Time of Fl. May-Jun, fr Sep-Oct; fl May 25-Jun 5, fr Sep 20-Oct at Cornell.

Origin. Native.

This species is late in blooming, for its flowers do not put in an appearance until late May or early June, and its inedible fruits do not ripen until late September. Peattie (1950) remarks of this species that "No tree is more active than this in invading the prairie.... And if no stately giraffes are seen browsing upon them, dairy cows do so abundantly, despite the armory of thorns." It is a picturesque tree, "striking at all times of year but especially so in autumn when the heavy crops of fruit are on the tree and the leaves are turning bronze, gradually becoming clear gold, or sometimes deep claret red." One of its common names, Dotted Haw or Dotted Hawthorn, is derived from the small but conspicuous dark dots on the fruit. Both birds and rodents consume its fruit, including a number of songbirds, fox squirrels, and mice. Several species of birds also nest among its branches. It seems also to be a favorite tree of the apple borer, the Dotted Haw becoming a permanent locus of infection for apples. 


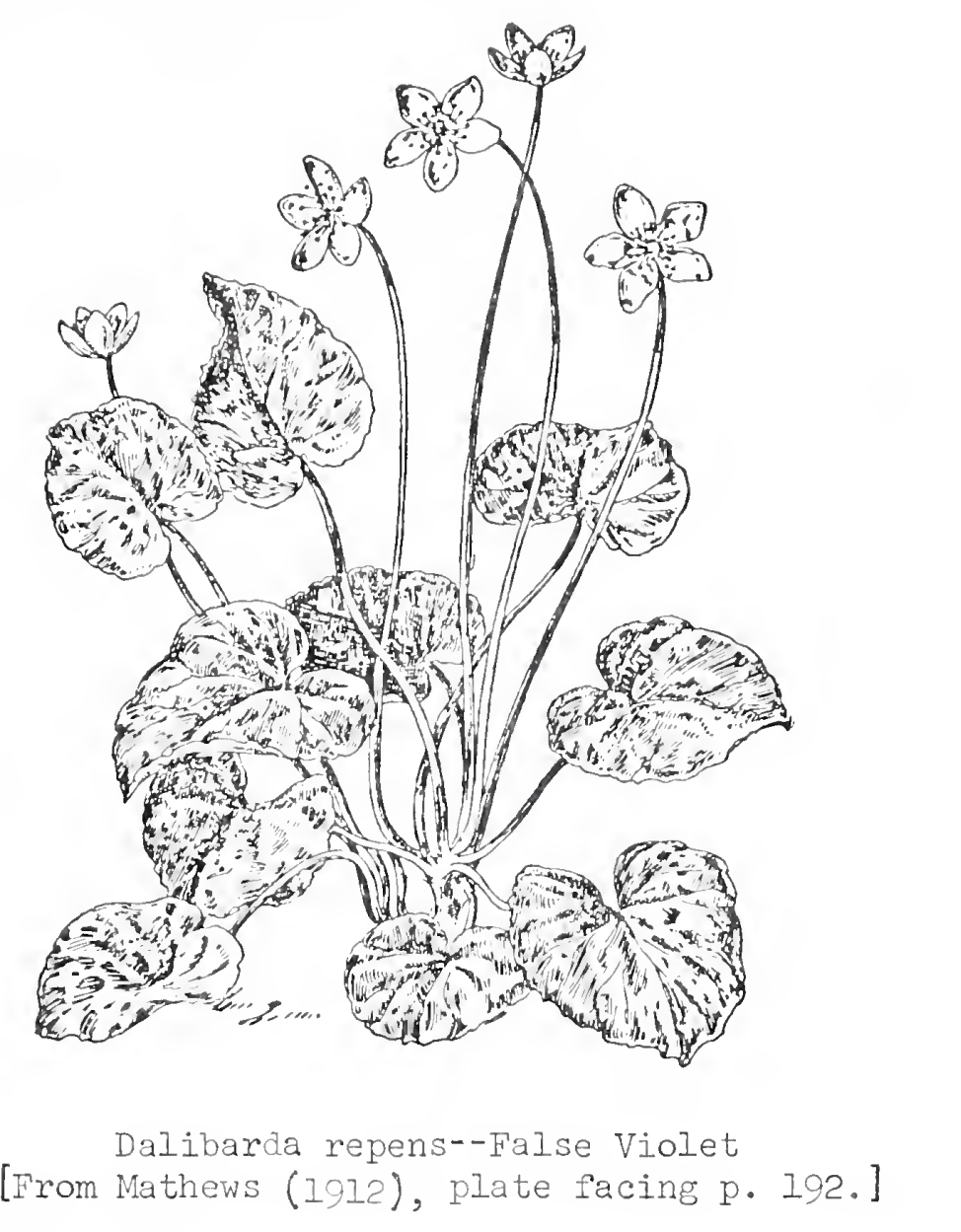

Dalibárda L. False Violet.

This monotypic genus is a low creeping perennial of eastern North America with densely tufted stems and roundish-cordate crenate leaves on slender petioles. It bears two kinds of flowers, a few long-peduncled, usually sterile ones with white petals and numerous fertile apetalous flowers on short, curved peduncles. The name of the genus commemorates Thomas Francois Dalibard, 1703-1779, a French botanist. Some authorities include this species in Rubus, to which it is closely related.

Dalibárda rèpens L. False Violet.

Meaning of Species Name. Creeping.

Other Names. Robin-runaway, Dalibarda, Dewdrop.

Type of Plant. A perennial herb.

Habitat. Moist cool woods and swamps.

Range. Que and Ont, s to Mass, Ct, NY, mts of NC, O, and Mich.

Distr in NYS. Common across the state northw; infrequent in the w counties and rare in the s tier of counties bordering on $\mathrm{Pa}$; local southw to Columbia co and the Catskill mts of Ulster, Greene, and Delaware co. Distr in the Torrey Range. NY: The mts of Ulster, Sullivan, Greene, and Delaware co.

Elevation. Sea level-4050 ft in the Torrey range. 
Time of Fl. Jun-Aug(Sep); Jul-Aug at Cornell.

Origin. Native.

Remarks. A plant somewhat resembling a low violet, hence one of its common names.

\section{Filipéndula Adans. Meadow-sweet.}

There are about 10 species of Filipendula, perennial herbs of the north temperate zone with pinnate leaves, panicled cymose flowers, and reniform stipules. The name of the genus is derived from the Iatin filum, a thread, and pendulus, hanging, in allusion to the roots of the European F. Vulgaris.

\section{Key to the Catskill Species of Filipendula}

1. Terminal leaflet 1-2 dm broad, 7-9-parted; petals deep pink; carpels straightish, erect........................... rubra

1. Terminal leaflets $0.5-1.5 \mathrm{dm}$ broad, 3-5-lobed; petals white; carpels spirally imbricated.......................... un $\underline{\text { umaria }}$

Filipéndula rübra (Hill) Robins. Queen-of-the-prairie.

Meaning of Species Name. Red.

Type of Plant. A perennial herb.

Habitat. Low woods, wet meadows, and prairies, roadsides, and neglected grounds.

Range. NY to Minn, s to NC and Ky.

Distr in NYS. Esc from cult northw to Cleveland, Oswego co, and Aiden Lair, Essex co, and doubtless elsewhere in the state.

Distr in the Torrey Range. Reported only from Hancock, Delaware co, NY; Andover, Sussex co, NJ, and locally in Ct, perhaps nowhere as a wild plant.

Time of Fl. Late Jun-early Aug; Jul at Cornell.

Origin. Native from $\mathrm{Pa}$ westw and southw; esc from cult in the Catskills.

Remarks. Sometimes esc from cult $n$ and e of its range.

Filipéndula ulmària (I.) Maxim. Queen-of-the-meadow.

Meaning of Species Name. An old generic name, from a fancied resemblance of the leaflets to the leaves of EIm, Ulmus.

Other Names. European Meadow-sweet, Meadow-queen, Honey-sweet,

Sweet-hay, Meadow-wort, Herb Christopher, My Lady's-belt, Bridewort.

Tyoe of Plant. A perennial herb.

Habitat. Roadsides and thickets.

Range. $N f$ and e Que to NJ, NY, WVa, and 0 .

Distr in NYS. Occasional as an esc.

Distr in the Torrey Range. A rare esc in our area, and not est.

Time of Fl. Jun-Aug; Jul at Cornell. 

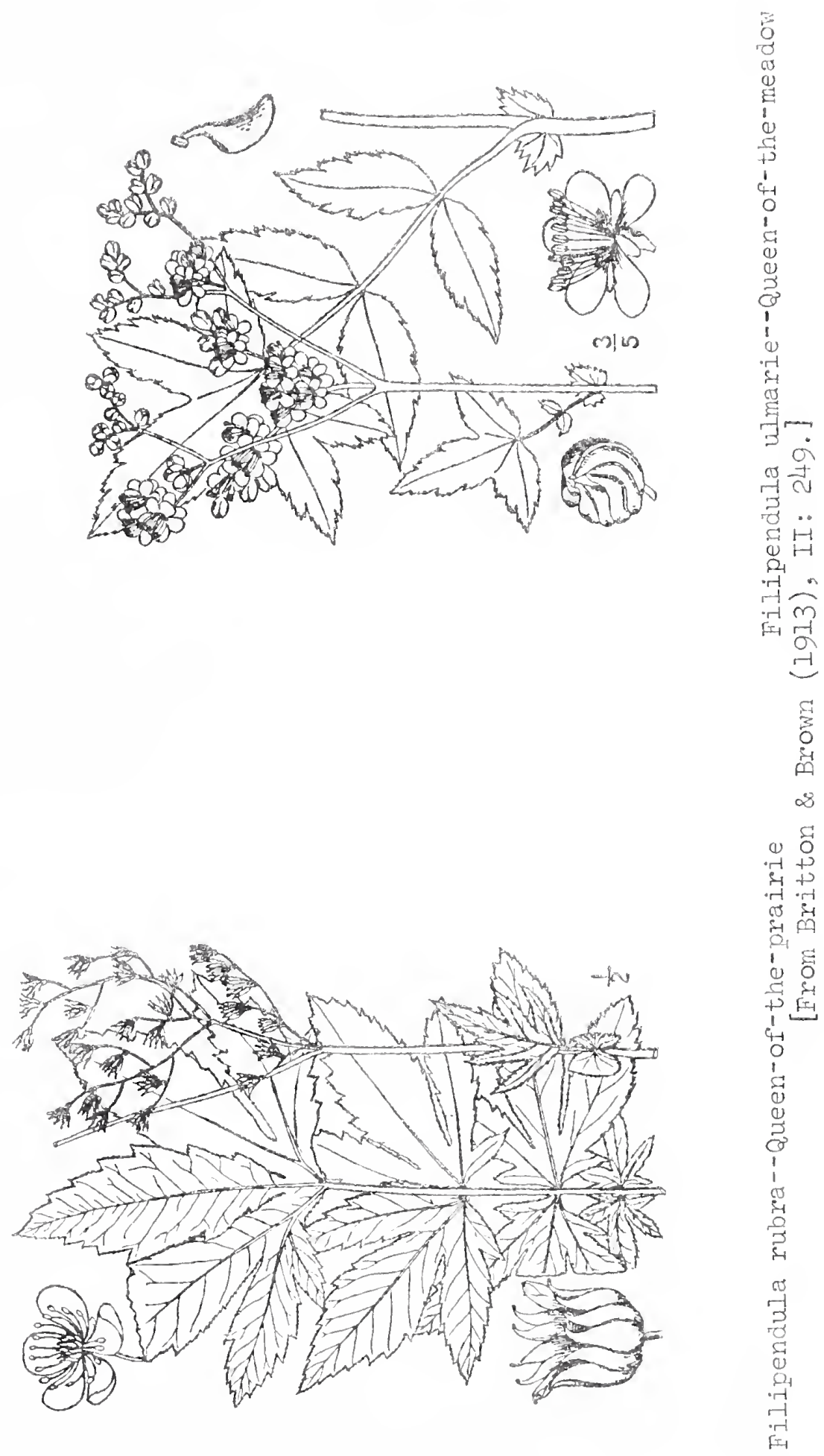
Origin. Introd from Eu.

Remarks. This species seems to be definitely est in several areas of the Catskills.

This perennial plant from Eurasia, sometimes grown in American gardens and occasionally escaped into the wild, is one of several similar plants called Meadow-sweet. It was once used to flavor mead and as a cure for malaria, but it is best known as a source of greenish-yellow, blue, and black dyes. To obtain a greenish-yellow color, a peck of the whole plant was cut up and covered with cold water. This was gradually brought to a boil and simmered for 1 hour, after which the liquid was strained and enough water added to make a dye bath of 4 to $41 / 2$ gallons. One pound of wetted wool mordanted with alum was then put into the likewarm dye bath, heated gradually to the boiling point, and simmered for 1 hour, after which it was rinsed thoroughly and dried in the shade.

A black dye was obtained from the roots collected in July. The roots were washed and boiled, and the liquid strained until it was clear. The wool was then immersed in the liquid and boiled until the required color was obtained, but, according to one authority, this color "does not compare with the beautiful black provided by the bark of the common alder" (Alnus incana ssp. rugosa). A navy blue color was obtained by boiling the stalks and leaves together for 2 hours, straining the liquid, then boiling the wool in the liquid until the desired color was achieved. The wool was then boiled with roots of Garden sorrel (Rumex acetosa) to fix the color. No other mordant was mentioned in this recipe.

\section{Fragària I. Strawberry.}

There are about 15 species of Fragaria, mostly Eurasian and North American perennials, but also extending into the Andean region of South America. They usually develop stolons and have white or pinkish cymose flowers on leafless scapes. The name of the genus is from fraga, the Latin name of the strawberry, so called from the fragrance of the fruit. The Greeks seem to have had no knowledge of strawberries, but Virgil, Ovid, and Pliny all mention $\underline{F}$. vesca as a wild plant furnishing a delicacy for the table. The fruit was known in England at the time of Henry VI, but it appears not to have been cultivated there until around 1542 .

There are at least three taxa of wild strawberries growing rather abundantly in the Catskills, but when one finds the lucious red fruit ready for picking in field or pasture, he is not likely to be much concerned about which species he is gathering. Sometimes in an old meadow one finds the long stems topped by four, five, or six large red berries ripe for picking; it is then possible in a short time to gather a large pail full, stems and all, to be taken home and hulled at leisure. More often, however, it is more practical to pick the berries one by one, hulling them as they are picked, taking care to exclude leaves, parts of hulls, stems, and other debris, for picking over the day's haul at home is a tedious job. It goes without saying that gathering quarts of wild strawberries out in the hot sun can be a time-consuming process, but the rewards are great, for no cultivated strawberry can remotely approach the wild ones for flavor and aroma; 
a shortcake topped with wild strawberries is ambrosia itself. And speaking of strawberry shortcake, it is traditionally made with sweetened biscuit dough--not sponge cake. So many recipes abound for the use of strawberries that there seems no point in repeating them here except perhaps to say that in the writer's opinion, when making jelly or jam, the color and flavor of the fresh fruit is best preserved by using a commercial pectin, following the recipes given on the package, rather than boiling the fruit for hours in an effort to get it to jell.

The American Indians dried quantities of fruit in the sun to store for later use. George W. Carver, the Tuskegee scientist, remarked that "Drying is without doubt the simplest and best method of preserving a number of fruits and vegetables. And it is a source of much regret that few know how to appreciate the delicious taste of home-dried fruits and vegetables," in part because concrete directions are generally not available. Spread out the hulled strawberries on a cookie sheet, cover with fine screening or mosquito netting to keep out flies and other insects, and place in the sun to dry for 3 or 4 days, bringing in the trays at night and turning the larger berries over on successive days. When thoroughly dry, pack in tight containers. A "strawberry leather" can be made by mashing thoroughly ripe strawberries to a pulp, then spreading it out on platters to dry in the sun. When it is dry, dust it with powdered sugar and roll it up like jelly rolls into pieces of suitable size and pack in jars. This can be eaten as a confection or soaked overnight in water for use in making shortcake, sauce, or tarts. If desired, the powdered sugar may be omitted, as the dried fruit keeps perfectly well without it.

Not only are wild strawberries rich in calories but they contain twice as much vitamin $A$ as canned pineapple and three times as much as grapefruit. In addition, a quarter of a cup of strawberries contains as much vitamin $\mathrm{C}$ as one orange. In addition to the usually familiar uses of strawberries, a cooling drink can be made by crushing a handful of berries and adding them to a glass of cold water; half a teaspoon of sugar will serve to enrich the flavor. Few people realize that a refreshing tea can be made from the fresh leaves simply by steeping a handful of leaves for minutes in 2 cups of boiling water. By collecting the leaves in summer and placing them on paper to dry in the sun for a few days, one can have the makings of strawberry tea all through the winter months. Crumbled and stored in an airtight container, the leaves will keep for many months.

The fruit was once thought helpful in treating gout and kidney stones, a tea made from the leaves has been used to cure diarrhea, and an infusion of the root was once used in the treatment of gonorrhea in addition to being considered an excellent bitter to increase the flow of urine. In the words of Johnson (1867), "Strawberries are considered to promote perspiration; they are, undoubtedly, very cooling. Hoffman thought them particularly beneficial to consumptive people. They are likewise said to have had a good effect in urinary complaints, and gouty people are supposed to have received benefit by eating them freely." On the other side of the coin, Millspaugh (1887) remarks that "It is a patent fact that many people with delicate stomach find it almost impossible to eat strawberries and cream--especially early in the season--without suffering from symptoms of disordered digestion; the symptoms often culminating in quite severe attacks." 
Upland gamebirds such as ruffed grouse and pheasant feed on the tender leaves of wild strawberries as well as on the fruit. The varying hare and cottontail rabbit also eat both fruit and leaves, while the cedar waxwing consumes the fruit. Birds, particularly the robin, and other wildife also eat garden strawberries, as almost everyone who owns a strawberry patch can testify, but if suitable precautions are taken, the extent of loss is probably negligible when the total crop is considered.

\section{Key to Local Species of Fragaria}

1. Hairs on main flower stem and petioles spreading; topmost tooth of the leaflets usually shorter and smaller than the ones on either side of it; petals mainly 7-10 mm long; fully grown inflorescence usually shorter than the leaves; inflorescence appearing flat and umbel-like, the main branches more or less equal; calyr lobes pressed against the young fruit; achenes set in pits below the surface of the fruit; leaflets dull glaucous green above, with ascending veins and teeth; surface beneath

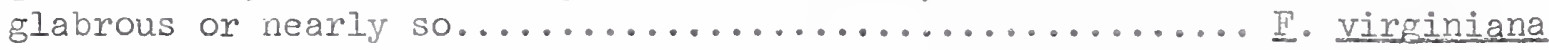

1. Hajrs on main flower stem and sometimes on petioles mostly appressed; topmost tooth of the leaflets higher than the ones on either side of it; petals mainly $4-7 \mathrm{~mm}$ long; fully grown inflorescences often overtopping the leaves; inflorescence appearing raceme-like, the main branches of the few flowers unequal and the leading one elongated as the axis; calyx lobes spreading or reflexed on young fruit; achenes superficial, not set in pits below surface of fruit; leaves bright green above, with spreading veins and teeth, siliky underneath, 2

2. Plants slender, with thin leaves; pubescence sparse and more or less closely appressed................. vesca ssp. americana

2. Plants not slender, more or less villous with spreading hairs on petioles and peduncles............... vesca ssp. vesca

Fragària vésca I. ssp. americana (Porter) Staudt. American Wood Strawberry.

Meaning of Species Name. Weak; ssp. name, American.

Synonyms. Fernald (1950) lists this plant as F. vesca I. var. americana Porter; Gleason (1952) calls it F. americana (Porter) Britt. other Names. American Sow-teat Strawberry.

Type of Plant. A perennial herb, reproducing by seeds and "runners." Habitat. Cool wooded slopes and dry rocky banks.

Range. Que and $N f$ to $M a n$ and SD, s to $\mathrm{Va}, \mathrm{O}$, Ind, IIl, Mo, Neb, and

NM; also in the Rocky Mts.

Distr in NYS. Common northw across the state and westw to I Erie;

less frequent southw to Westchester co.

Distr in the Torrey Range. NY: From the highlands of the Hudson

northw, becoming common in the Catskills; unknown elsewhere.

Elevation. Sea level-3365 ft in the Torrey range.

Time of $\mathrm{FI}$. May-Jun(JuI); May 10-Jun 15 at Cornell.

Origin. Native. 


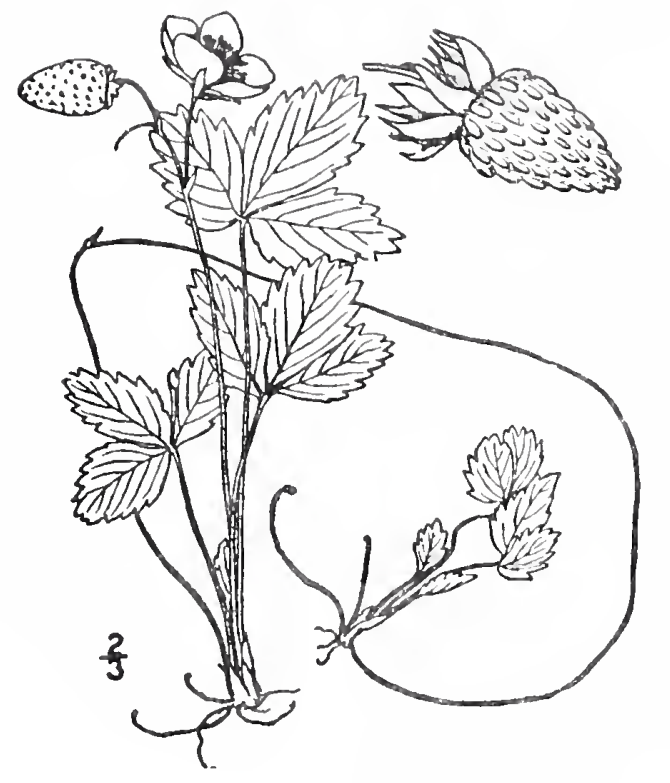

Fragaria vesca ssp. americana American Wood Strawberry From Britton \& Brown

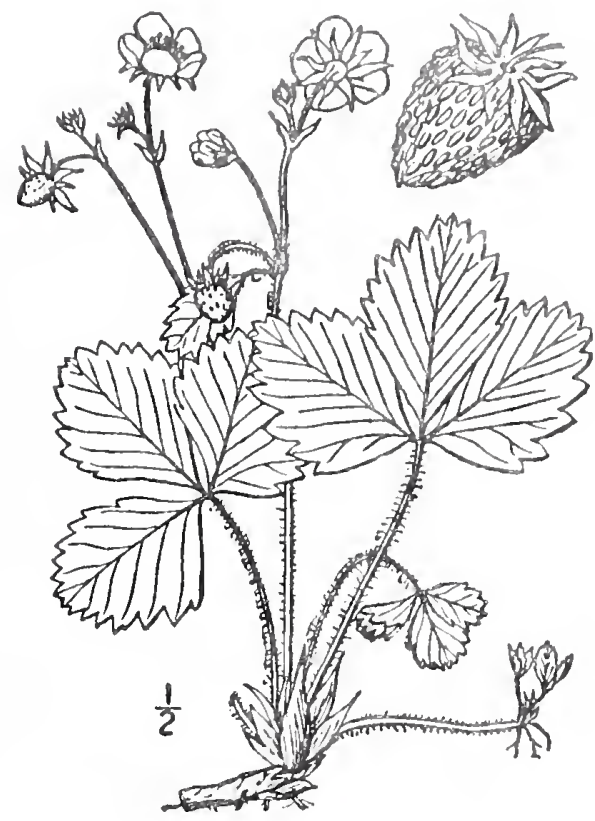

Fragaria vesca ssp. vesca European Wood Strawberry

Fragària vésca I. ssp. vésca. European Wood Strawberry.

Meaning of Species Name. Weak.

Other Names. Sow-teat Strawberry, Hedge Strawberry, Sheep-noses. Type of Plant. A perennial herb, reproducing by seeds and "runners." Habitat. Rocky upland woods, fields, openings, and along roadsides. Range. Que and $\mathrm{Nf}$ to Mich, s to $\mathrm{Pa}, \mathrm{O}$, and Ill.

Distr in NYS. Locally common as an esc or natzd plant in many parts of the state.

Distr in the Torrey Range. Rather a rare esc in most parts of our range.

Time of Fl. May-Jun(Jul); May 10-Jun 15 at Cornell.

Origin. Indig in $\mathrm{Nf}$ and e Que; introd from Eu elsewhere.

Remarks. Formerly frequent in cult.

Fragària virginiàna Duchesne. Field Strawberry.

Meaning of Species Name. Virginian.

Other Names. Virginian Strawberry, Scarlet Strawberry.

Type of Plant. A perennial herb, reproducing by seeds and "runners."

Habitat. Fields, meadows, open slopes, and borders of woods, usual-

ly in rather dry fertile soil. 


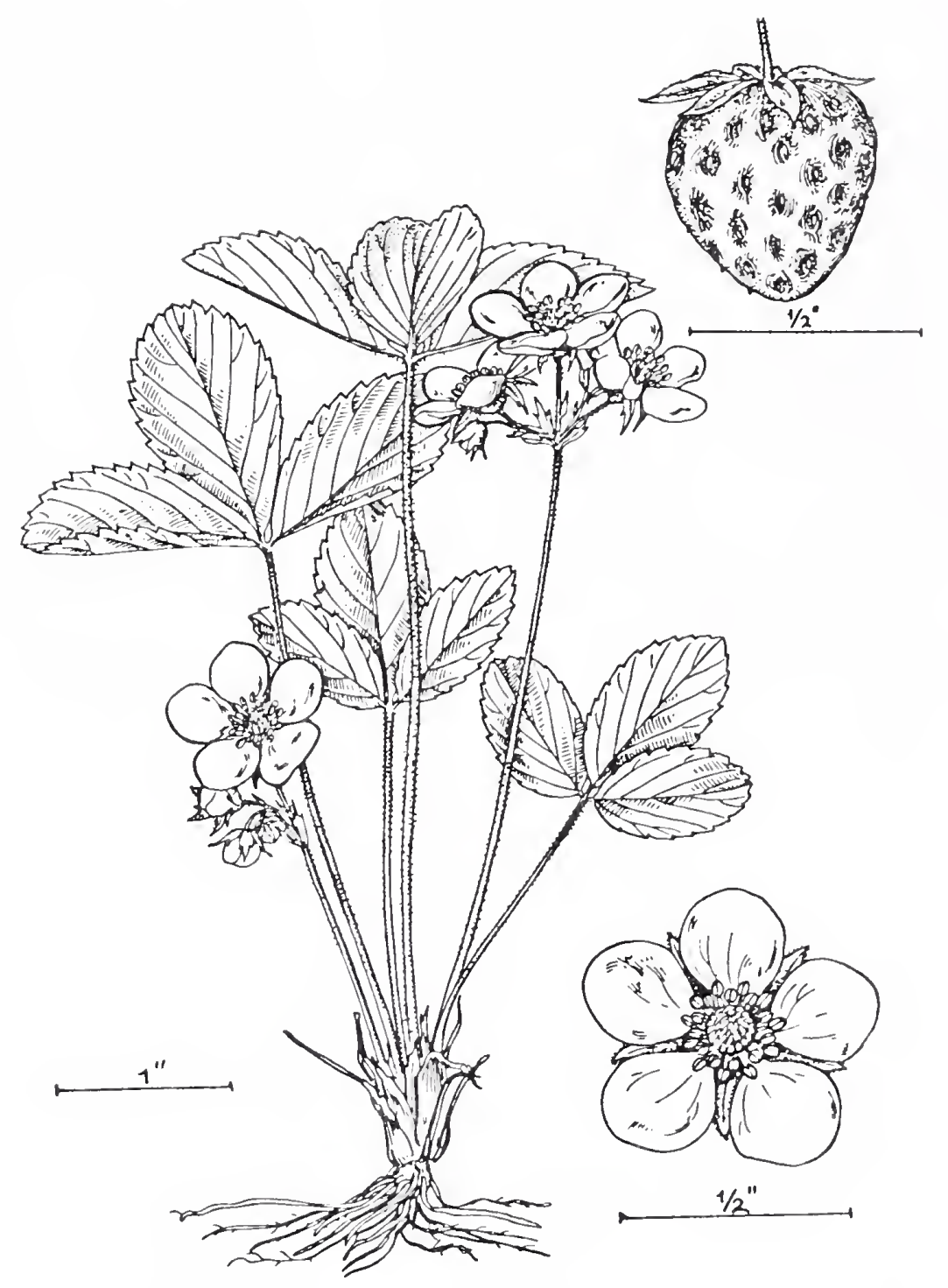

Fragaria virginiana--Field Strawberry

[From Krochmal et al. (1971) p. 123.]

Range. If and Que to Man, s to Ga, Tenn, and Okla.

Distr in NYS. Frequent or common throughout the state except the higher mts and the coastal plain.

Distr in the Torrey Range. Common throughout the range except in the pine barrens, there rare and probably introd.

Time of FI. Apr-Jun(JuI); May 10-Jun 15 at Cornell.

Origin. Native.

Not only did the Chippewas use the raw fruit of this species as food, but two or three roots of this plant, steeped in 1 quart of boiling water was freely administered to children in the treatment of cholera infantum "until the effect is evident." In western medicine the roots were considered to be diuretic. Roger Williams in 1643 reported that "this berry is the wonder of all the fruits growing naturally in these parts.... In 
some parts where the Indians have planted, I have many times seen as many as would fill a good ship, within few miles compass." Not only was it much relished by the early settlers, but the Indians "bruised this strawberry with meal in a mortar and made bread."

Geum I. Avens.

There are about 60 species of Geum, perennial herbs with pinnate or lyrate leaves, chiefly of the north temperate zone but extending also into arctic regions. The name of the genus is an ancient latin name used by Pliny possibly referring to some plant of this genus. G. urbanum, a native of Europe, Australia, and New Zealand, was once much used in Europe as a tonic and astringent in the treatment of hemorrhages, chronic dysentery, and fevers. The root, according to Lindler (1879), was also used as an ingredient in the manufacture of some ales. South American Indians also used a species of Geum as a remedy for intermittent fevers, considering it equal to Peruvian bark.

\section{Key to the Catskill Species of Geum}

1. Calyx campanulate, the usually purple lobes erect or ascending; petals erect, abruptly contracted to a claw; base and summit of style plumose; flowers nodding, fruits erect................ r. rivale

1. Calyx tube saucer-shaped, the lobes soon reflexed; petals spreading, gradually narrowed at base; lower half of style glabrous or merely glandular, upper half not plumose; flowers ascending, 2

2. Key to flowering material, 3

3. Petals white to pale or greenish-yellow, oblong to spatulate, 1-4.5 mro jroad if yellowish, shorter than calyx lobes, 4

4. Peduncles stout and short, copiously hirsute with divergent or reflexed crowded hairs $1-2 \mathrm{~mm}$ long; petals white or pale yellow, 2-5 mm long, 1-2 mm broad, much smaller than calyx lobes.................. laciniatum

4. Peduncles filiform, minutely pilose or puberulent; long hairs, if present, scattered; petals jellow and short or white and $5-9 \mathrm{~mm}$ long by $1-4.5 \mathrm{~mm}$ broad, except in late depauperate flowers, 5

5. Cauline leaves not rapidly reduced in size from base to summit of stem, their tips and teeth mostly acute; petals white, $5-9 \mathrm{~mm}$ long, $2-4.5 \mathrm{~mm}$ broad, about

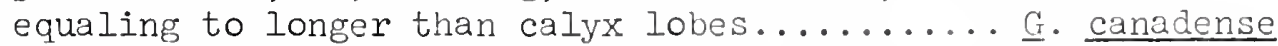

5. Cauline leaves rapidly reduced in size toward summit of stem, their tips and teeth blunt; petals pale or greenish-yellow, 2-4 mm long, 1-2 mm broad, much shorter than calyx lobes..................... virginianum

3. Petals orange or deep yellow, suborbicular or broadly obovate, 3-9 mm broad, equaling or longer than calyx lobes, 6 6 . Terminal segment of some or all basal leaves cuneateobovate to -oblanceolate, incised; calyx lobes lanceolate or lance-ovate, 5-9 mm long; petals 5-10 mm long, 5-9 
$\mathrm{mm}$ broad; base of style glandless................... aleppicum

6. Terminal segment of all basal leaves cordate-reniform or - suborbicular, dentate; calyx lobes broadly deltoid, 2.5-5 $\mathrm{mm}$ long; petals 3.5-5(7) mm long, 3-5(6) mm broad; base of style minutely glandular..................... macrophyllum

2. Key to fruiting material, 7

7. Denuded receptacle glabrous or only minutely pubescent, the pits and scars evident, 8

8. Peduncles thick, mostly $1-5 \mathrm{~cm}$ long, copiously hirsute with divergent or reflexed crowded hairs $1-2 \mathrm{~mm}$ long; calyx lobes lanceolate or lance-ovate, 5-11 mm long; fruiting head $1.7-2.5 \mathrm{~cm}$ in diameter, the drab or brownish styles not glandular...................... laciniatum

8. Peduncles filiform, mostly longer, minutely puberulent; long hairs, if present, scattered; calyx lobes broady deltoid, 2.5-5 mm long; fruiting heads $1.2-1.8 \mathrm{~cm}$ in diameter, the usually purple styles minutely glandular

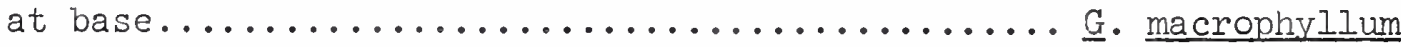

7. Denuded receptacle copiously hirsute, the pits and scars hidden, 9

9. Basal leaves chiefly interruptedly pinnate, with 5-9 incised leaflets and interspersed smaller ones; middle and upper leaves similar, incised; peduncles coarse, clavate at tip; fruiting heads finally globose-obovoid; the styles soon tightly reflexed-appressed and imbricated

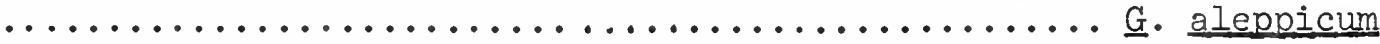

9. Basal leaves chiefly simple or ternately divided, the margins lobed, serrate or dentate; middle and upper leaves simple or 3-cleft, serrate or dentate; peduncles filiform; fruiting heads spherical; upper styles loosely ascending or spreading, only tardily reflexed, 10

10. Cauline leaves not rapidly reduced in size from base to summit of stem, their tips and teeth mostly acute

10. Cauline leaves rapidly reduced in size from base to G. canadense summit of stem, their tips and teeth obtuse.... G. virginianum

Gèum aléppicum Jacq. Yellow Avens.

Meaning of Species Name. Of Aleppo.

Other Names. Herb-bennet, Black-bur, Camp-root. Type of Plant. A perennial herb, reproducing by seeds. Habitat. Open swamps, wet thickets, low meadows, pastures, marshes, and clearings, usually on rich soils.

Range. Nf and Que to Mack, s to NJ, Pa, O, Ind, Ill, Minn, Neb, NM, and Mex.

Distr in NYS. Common across the state northw; less frequent southw, and rare on $L I$ and SI.

Distr in the Torrey Range. NY: Rare on LI, SI, and in the Bronx, thence increasing and common northw.

Elevation. Sea level-2800 ft in the Torrey range. Time of Fl. (May)Jun-Jul(Aug); Jun 15-Jul 15 at Cornell. Origin. Native. 


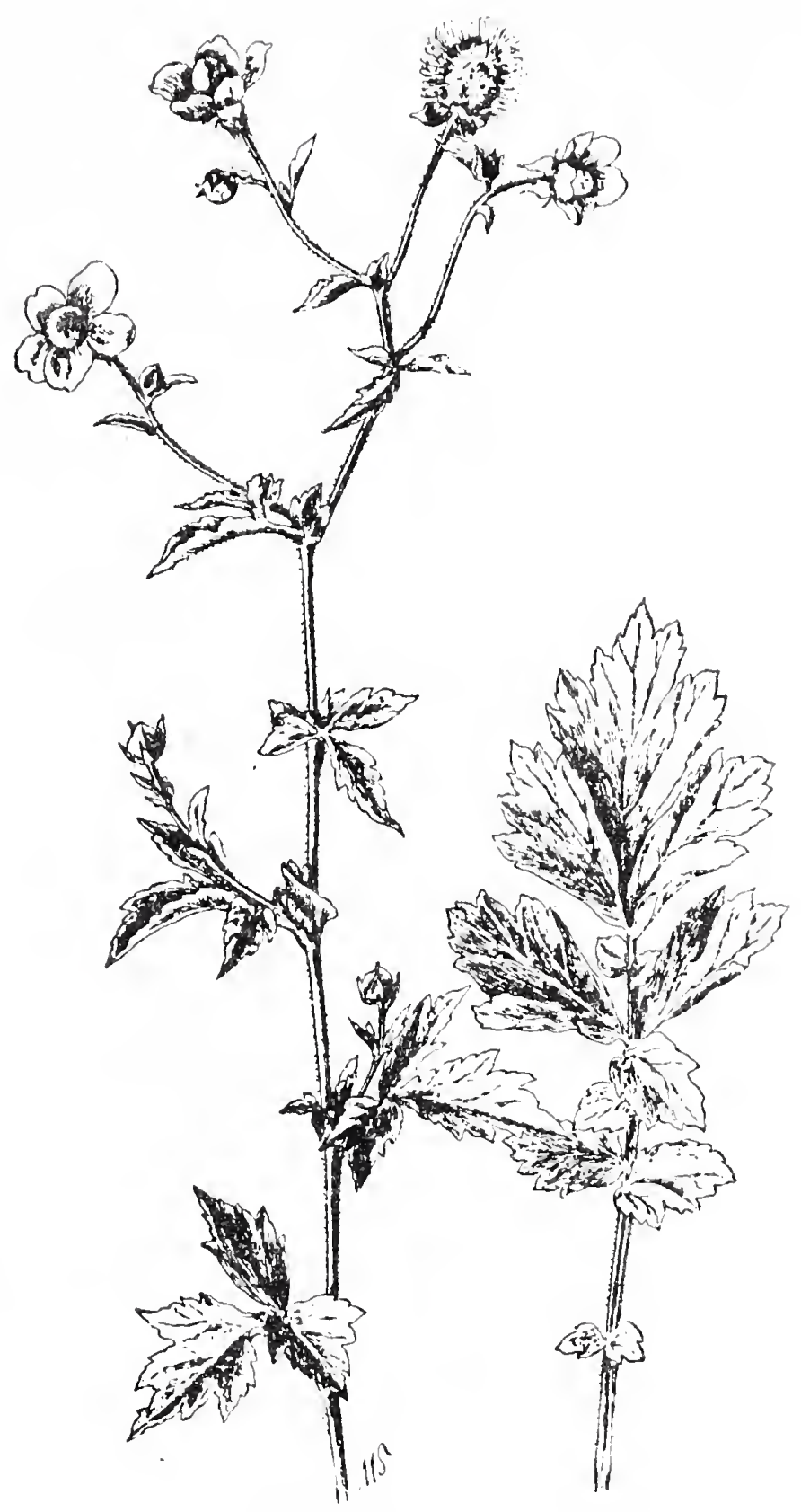

Geum aleppicum--Yellow Avens

[From Dana (1900), Plate 74, p. 173.]

The Ojibwa Indians boiled the roots of this species for a weak decoction taken internally for soreness in the chest and for coughs. In areas where this species may have become an obnoxious weed, Muenscher (1952) suggests that scattered plants should be pulled or hoed out as soon as the blossoms appear. Badly infested fields should be plowed and planted to a cultivated crop for a season.

Gèum canadènse Jacq. White Avens.

Meaning of Species Name. Of Canada. other Names. Red-root, Herb-bennet. Type of Plant. A perennial herb. Habitat. Rich moist thickets and open woods. 


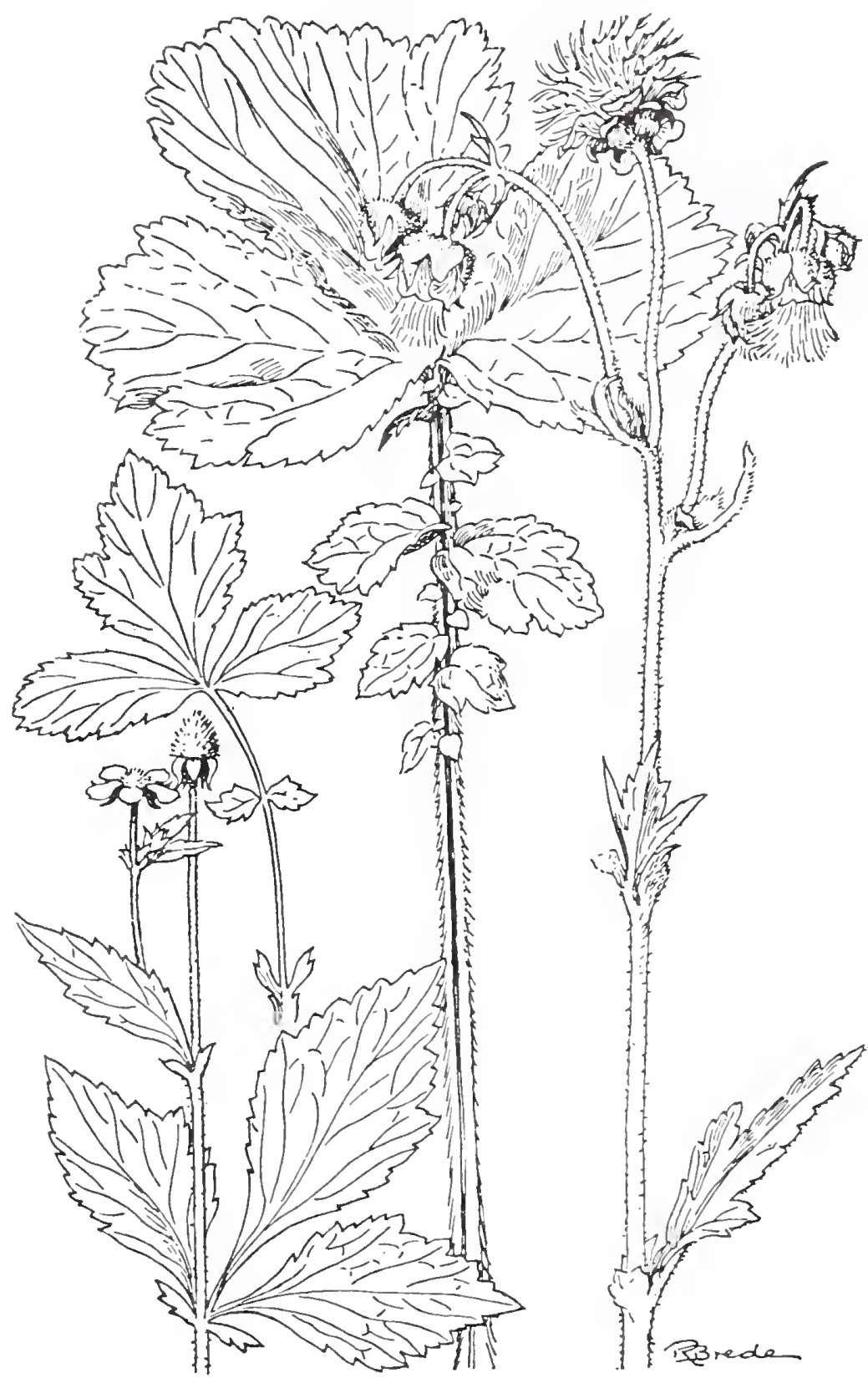

(Left) Geum canadense--White Avens; (right) Geum rivale--Purple Avens [From Smith (1966), Plate 83, p. 182.]

Range. NS to Minn and SD, s to SC, Ga, Tenn, Mo, Kan, and Tex. Distr in NYS. Common in most secs of the state except in the pine barrens of II.

Distr in the Torrey Range. Very common throughout the range except in the pine barrens, there rare or wanting.

Time of Fl. (May)Jun-Jul(early Aug); Jun 20-Jul at Cornell.

Origin. Native.

Remarks. The Chippewas steeped the root of this plant to make a decoction taken internally in the treatment of "female weakness." 


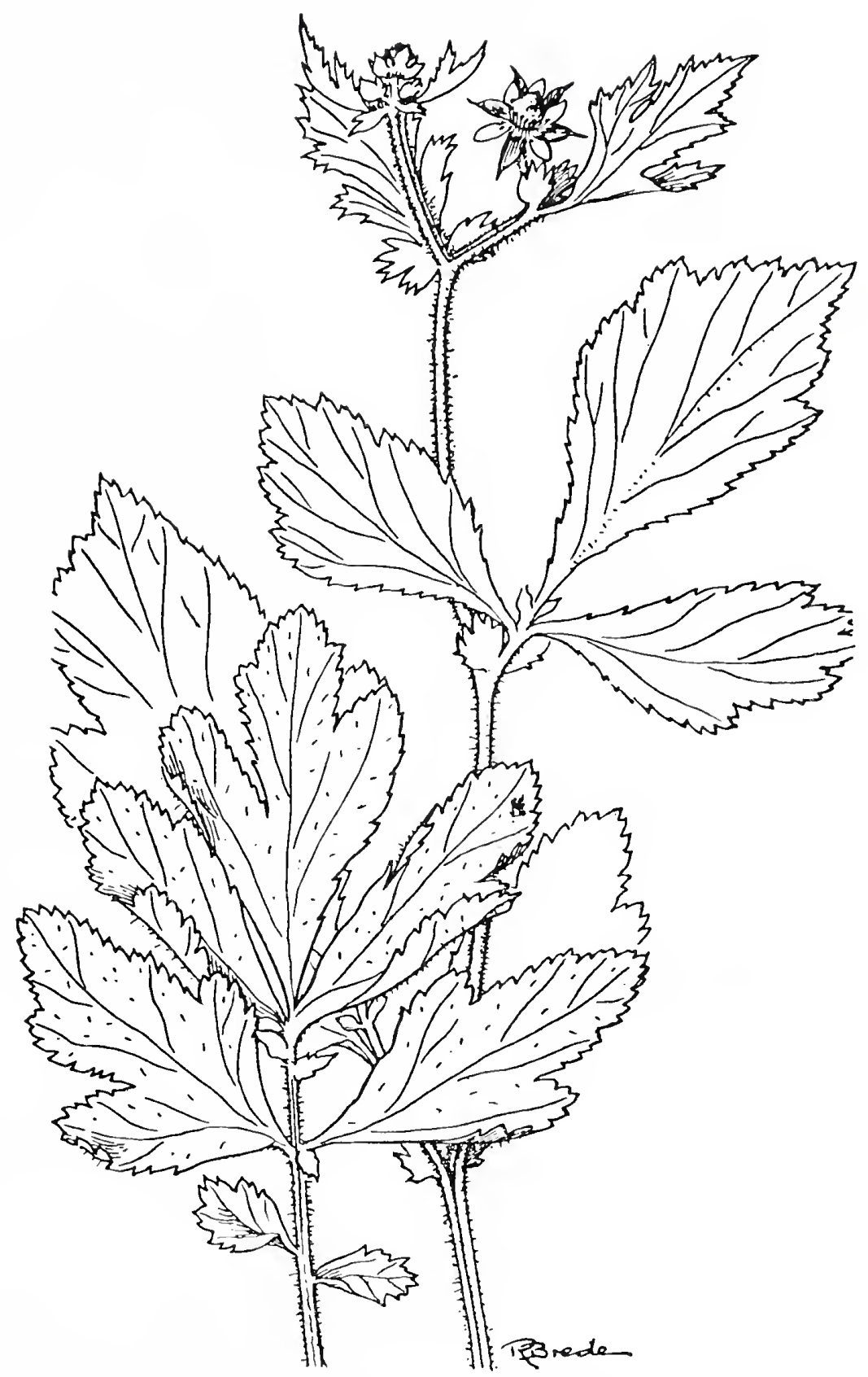

Geum laciniatum--Bristly White Avens

[From Smith (1966), Plate 84, p. 184.]

Gèum laciniàtum Murr. Bristly White Avens.

Meaning of Species Name. Slashed, referring to the leaves.

Other Names. Rough Avens, Bennet, Herb-bennet, White Avens, Throatroot, Chocolate-root.

Type of Plant. A perennial herb.

Habitat. Damp thickets, meadows, and roadsides.

Range. NS to ont and Mich, s to NJ, Md, Pa, WVa, O, Ind, and Mo.

Distr in NYS. Frequent or common, but rare above $2000 \mathrm{ft}$ in the Adirondacks and largely absent from the coastal plain of LI.

Distr in the Torrey Range. Not separated from $\underline{G}$. virginianum in Taylor (1915).

Time of Fl. (May)Jun-Jul; Jun 10-Jul 10 at Cornell. 


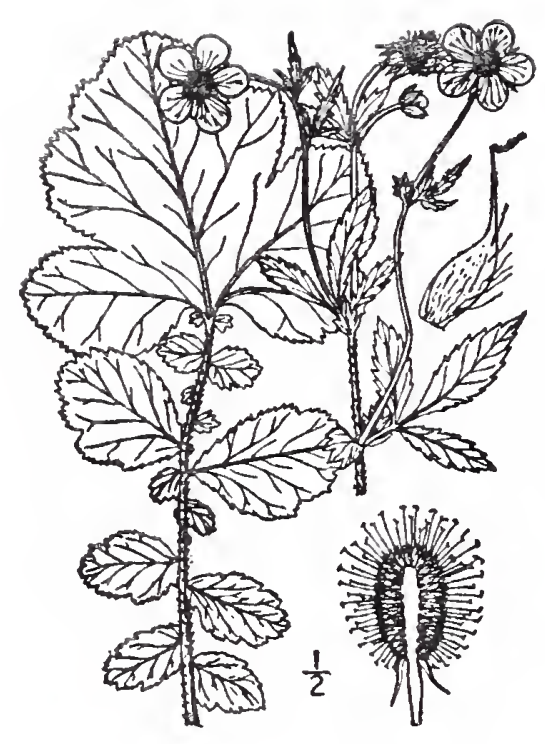

Geum macrophyllum Large-leaved Avens [From Britton \& Brown (1913), II: 270, 271.]

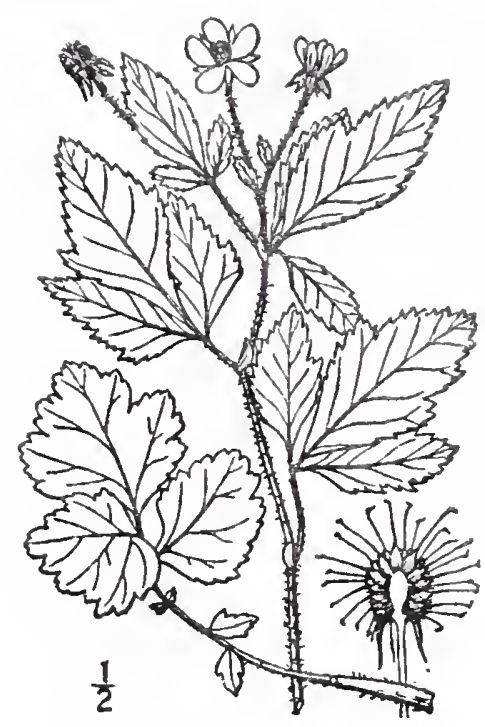

Geum virginianum Rough Avens
$270,271$.

\section{Origin. Native}

Rernarks. Blossoms somewhat earlier than $\underline{G}$. candense; basal leaves becoming very large, the terminal leaflet sometimes 6 in. wide.

Geum macrophýllum Willd. Large-leaved Avens.

Meaning of Species Name. Large-leaved.

Type of Plant. A perennial herb.

Habitat. Rich woods, rocky ledges, low grounds, damp thickets, and operings.

Range. Nf and Lab to Ak, s to the mts of $\mathrm{NE}$ and NY, Mich, Wis, Minn, Mont, Id, and Cal; also in $\mathrm{n}$ Eu and e Siberia.

Distr in NYS. Rare in the $\mathrm{n}$ Adirondacks and not reported elsewhere in the state.

Distr in the Torrey Range. Not listed in Taylor (1915).

Time of Fl. (May) Jun-JuI(Aug).

Origin. Native.

Remarks. The Flambeau Ojibwas used this species in the treatment of female disorders. 
Gèum rivàle L. Purple Avens.

Meaning of Species Name. Of brooksides.

Other Names. Water Avens, Chocolate-root, Indian Chocolate, Evan'sroot, Drooping Avens, Maidenhair, Throatwort, Throat-root, Cure-all.

Type of Plant. A perennial herb.

Habitat. Swamps, marshes, low wet meadows, bogs, and peaty slopes. Range. Nf and Que to Alta and $\mathrm{BC}$, s to $N J$, $\mathrm{Pa}, W V a, O$, III, Ind, Mich, Minn, NM, and Cal; also in Eurasia.

Distr in NYS. Common across the state northw and locally frequent westw to L Erie; less common southw to the Hudson highlands, and rare in the Susquehanna and Chemung valleys.

Distr in the Torrey Range. NY: Unknown s of the highlands of the Iudson, thence increasing northw.

Elevation. Sea level-3365 $\mathrm{ft}$ in the Torrey range.

Time of $\mathrm{Fl}$. May-Jul(Aug); May 15-Jun at Cornell.

Origin. Native.

Mrs. H. K. Morrell, writing on the edible plants of Maine, stated that when boiled, the root of this species "makes a drink like chocolate," a beverage "formerly valued as a tasty home remedy" prescribed for dysentery, colic, dyspepsia, and other ailments of the digestive tract. After the root was "well boiled," sugar and milk were added; even then, however, it was considered rather astringent, "with a slight addition of acid."

Fernald and Kinsey (1943) decided that "In our own experiments we have as yet found no reason to be enthusiastic about this drink." They were more intrigued by Parkinson's remarks to the effect that during the l6th century, "Some use in the spring time to put the roote to steepe for a time in wine, which giveth unto it a delicate flavour and taste, which they drink fasting every morning, to comfort the heart..." In this connection, Johnson (1862) remarks that this plant was "often used in olden times to flavor ale and other liquors."

In 1785 the Rev. Manasseh Cutler recommended a root decoction of this plant as a gargle for sore throat and reported that the Canadians used the powdered root in the treatment of tertian agues. The Thompson Indians of British Columbia used the boiled roots of a closely related species to treat smallpox, an epidemic of which occurred among them some time before 1900, stating that every person who drank a strong decoction made from the boiled roots survived the disease. This same preparation was used for any disease characterized by a rash, such as measles and chickenpox. Other tribes used it for coughs and sore throat. The dried root was official in the U. S. Pharmacopeia, 1820-82, for use as an astringent. The U.S. Dispensatory of 1865 called this species a tonic and a powerful astringent that could with advantage be used in the treatment of hemorrhages, diarrhea, dyspepsia, and stomach disorders. A tincture prepared from the whole plant, gathered before blossoming time in the spring, was also used as a febrifuge. A weak decoction of the root was sometimes used by invalids in New England as a substitute for tea and coffee. 
Geum virginianum I. Rough Avens.

Meaning of Species Name. Virginian.

Other Names. Bennet, Herb-bennet, Cream-colored Avens.

Type of Plant. A perennial herb.

Habitat. Dry woods, thickets, and rocky banks

Range. Mass to Ind, S to SC and Tenn.

Distr in NYS. Infrequent or rare northw from Washington co to I Ontario and I Erie; more abundant southw in the state.

Distr in the Torrey Range. Throughout the range except in the pine barrens and the coastal plain of II, there wanting, and rare and local in the area immediately surrounded by the pine barrens.

Time of $\mathrm{Fl}$. Jun-Aug; Jun 10-Jul 10 at Cornell.

origin. Native.

Potentilla I. Cinquefoil.

There are about 300 species of Potentilla, herbs (sometimes shrubs) with compound leaves and solitary or cymose flowers, widely distributed throughout the north temperate zone. The name of the genus, a diminutive of potens, powerful, originally applied to $\underline{P}$. anserina, alluding to its once reputed medicinal powers.

The leaves of $\underline{P}$. rupestris, Rock Cinquefoil or Prairie Tea, a native of Europe and northern Asia, have been used as a substitute for tea both in Siberia and in Mongolia. J. Lightfoot, writing in 1789, reported that in the Hebrides the roots of $\underline{P}$. anserina, Goose Grass or Goose Tansy, "have often supported the inhabitants for months together. Boiled or roasted, they taste like parsnips." The roots of $\underline{P}$. tormentilla, Tormentil, also a native of Europe and northern Asia, are also reported to have been eaten in times of scarcity. Long boiling is said to have converted the tannin into gum, thereby making them edible. Potentilla reptans, another European plant, was formerly used in the treatment of diarrhea and other complaints for which astringents were usually prescribed. The Chippewas prepared a decoction of half the root of $\underline{P}$. palustris and 1 quart of water for internal use in the treatment of dysentery.

Although several species of Potentilla are common to abundant in many areas, Martin et al. (1961) report that their usefulness to wildlife is relatively low, except in the west, where the rose finch, the least chipmunk, and two species of ground squirrels eat both seeds and foliage, but in the east both grouse and woodcock use the seeds and foliage of some species. 


\section{Key to Local Species of Potentilla}

1. Flowers solitary from naked peduncles from the axils of the foliage leaves or on the stolons, 2

2. First flower from the node above the first well-developed internode; plants small, creeping; leaflets dull, scarcely veiny, narrowly obovate; pubescence of the stem, petioles, and pedicels

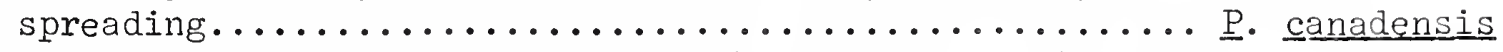

2. First flower from the node above the second or third welldeveloped internode; plants larger, less close to the ground; leaflets brighter green, more veiny, oblanceolate; pubescence of the stem, petioles, and pedicels appressed........... P. simplex

1. Flowers cymose in terminal inflorescences, 3

3. Leaves silvery-tomentose beneath

3. Leaves green beneath, pubescent or smoothish, 4

4. Petals white; leaflets coarsely 3-toothed at apex; plants low, tufted, smooth or essentially so, rather woody at

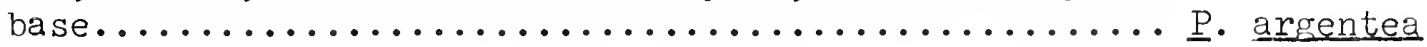

4. Petals yellow; plants coarse, hirsute, erect, $20-90 \mathrm{~cm}$ high, 5

5. Leaflets 3 (petals about equaling calyx lobes).... P. norvegica 5. Leaflets $5-7,6$

6. Flowers $1.5-2.5 \mathrm{~cm}$ broad; stamens 30; petals much ex-

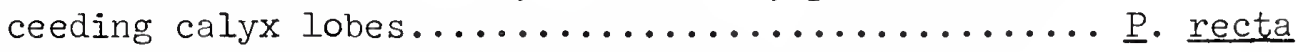
6. Flowers 3-10 mm broad; stamens 5-20; petals about equaling calyx lobes.................... intermedia

Potentilla argéntea L. Silvery Cinquefoil.

Meaning of Species Name. Silvery.

Other Names. Hoary Cinquefoil.

Type of Plant. A perennial herb, reproducing by seeds.

Habitat. Dry or sterile open ground of fields, pastures, roadsides, and waste places; sometimes on rocky ledges.

Range. If to Minn and Mont, s to Md, Va, WVa, O, Ind, and Ill.

Distr in NYS. Frequent or common northw and westw in the state and southw in the lower Hudson valley, and locally on LI, where perhaps adv.

Distr in the Torrey Range. Common as a weed throughout the area.; probably introd into the pine barrens.

Time of Fl. Jun-Aug(Sep); Jun-Jul at Cornell.

Origin. Natzd from Eu.

In areas where this species has become an obnoxious weed, Muenscher (1952) suggests that badly infested fields should be plowed and the plants turned under to increase the organic matter in the soil, then planted with a cultivated crop or a smother crop for a season. 


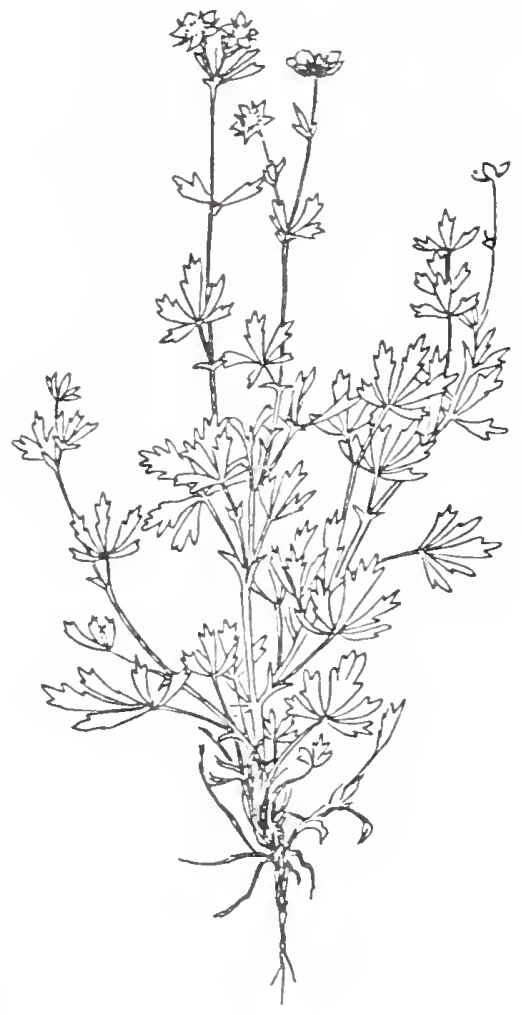

(Ieft) Potentilla argentea--Silvery Cinquefoil [From Smith (1966), Plate 81, p. 179.]

(Right) Potentilla intermedia--Downy Cinquefoil [From Smith (1966), Plate 82, p. 181.]

Potentilla canadénsis I. Dwari Cinqueioil.

Meaning of Species Name. Of Canada.

Other Names. Common Five-finger, Wild Strawberry, Barren Strawberry, Sinkfield, Running Buttercups, Star-flower.

Type of Plant. A perennial herb, reproducing by seeds and runners.

Habitat. Dry soil of open woods, fields, and old meadows.

Range. IS and Me to Ont, s to II, SC, $\mathrm{Ala}$, and $\mathrm{O}$; also in Mo.

Distr in NYS. Common throughout the state except in densely wooded areas.

Distr in the Torrey Range. Throughout the area except in the pine barrens, there rare and local and probably adv, always increasing northw. Elevation. Grows to $6300 \mathrm{ft}$ in NC.

Time of Fl. (Mar)Apr-Jun; May 20-Jul 1 at Cornell. Origin. Native.

This plant is often confused with $\underline{P}$. Simplex (which, in fact, was once called $\underline{P}$. canadensis, so that in older books it is often difficult to 


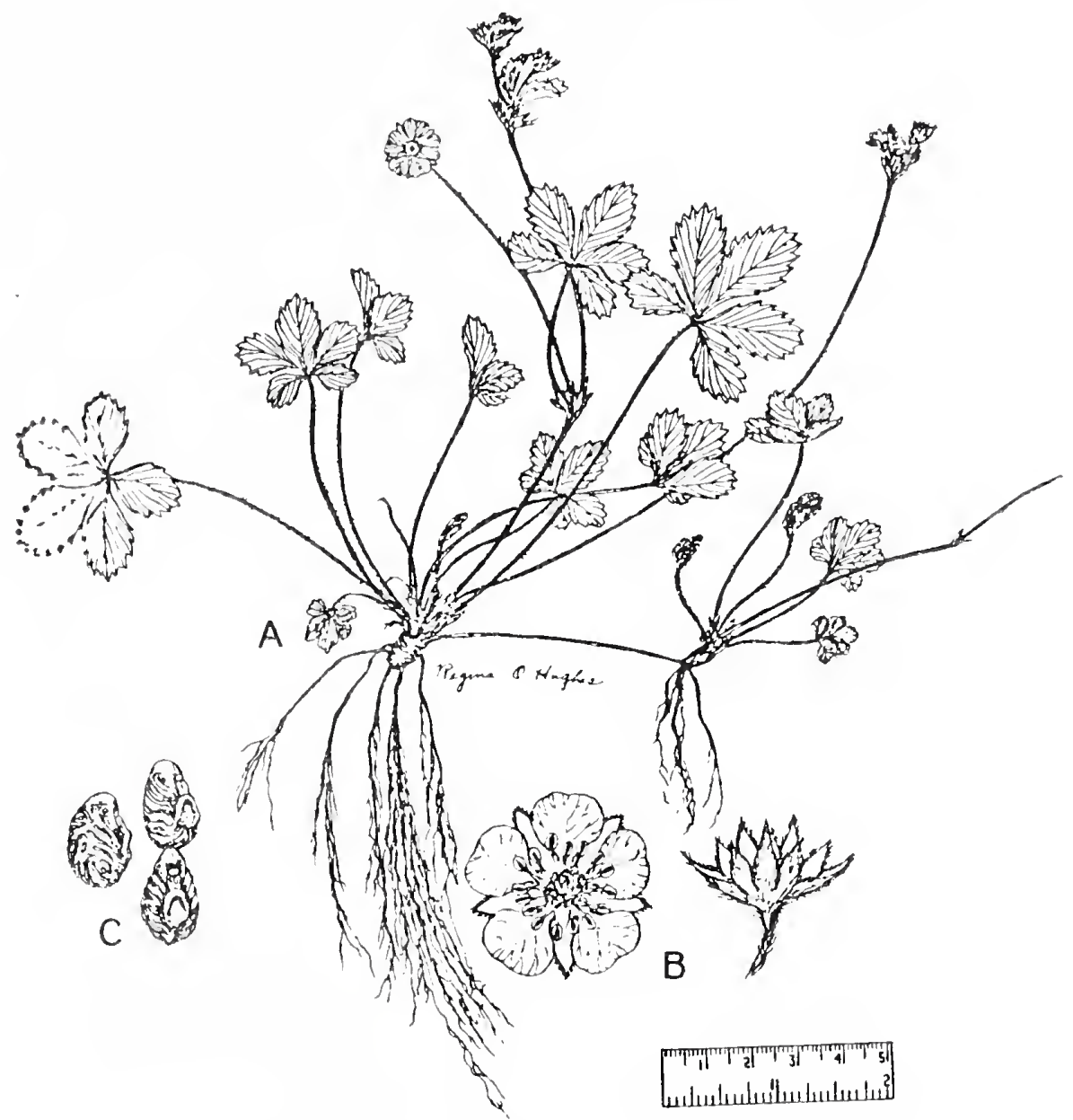

Potentilla canadensis--Dwarf Cinquefoil

[From USDA Agr. Research Sv. (1971), Fig 106, p. 217.]

know which species is under discussion). Peter KaIm was probably referring to $\underline{P}$. Simplex when he noted that an infusion of the common cinquefoil was thought to be a good remedy for fevers, stating that "several persons recovered by this means." The best way to determine which species is at hand is to examine the point from which the first flower on the stem originates. In $P$. canadensis the first flower on the stem springs from the second welldeveloped internode, while in $\underline{P}$. simplex it issues from the third or fourth well-developed internode.

It has been suggested that this species makes a good ground cover on rocky, sterile, acid soils, but the author is probably speaking of $\underline{p}$. simplex, which appears to be a more robust plant and much more widely distributed, at least in the Catskill region. In areas where this species has become a troublesome weed, it can be controlled by the same methods as those outlined for $\underline{\mathrm{P}}$. Simplex.

Potentilla intermèdia I. Downy Cinquefoil.

Meaning of Species Name. Intermediate.

Type of Plant. A biennial, annual, or short-lived perennial herb. Habitat. Roadsides, meadows, dry stony pastures, and waste places. Range. Que to Mich and Va; to be expected elsewhere. 


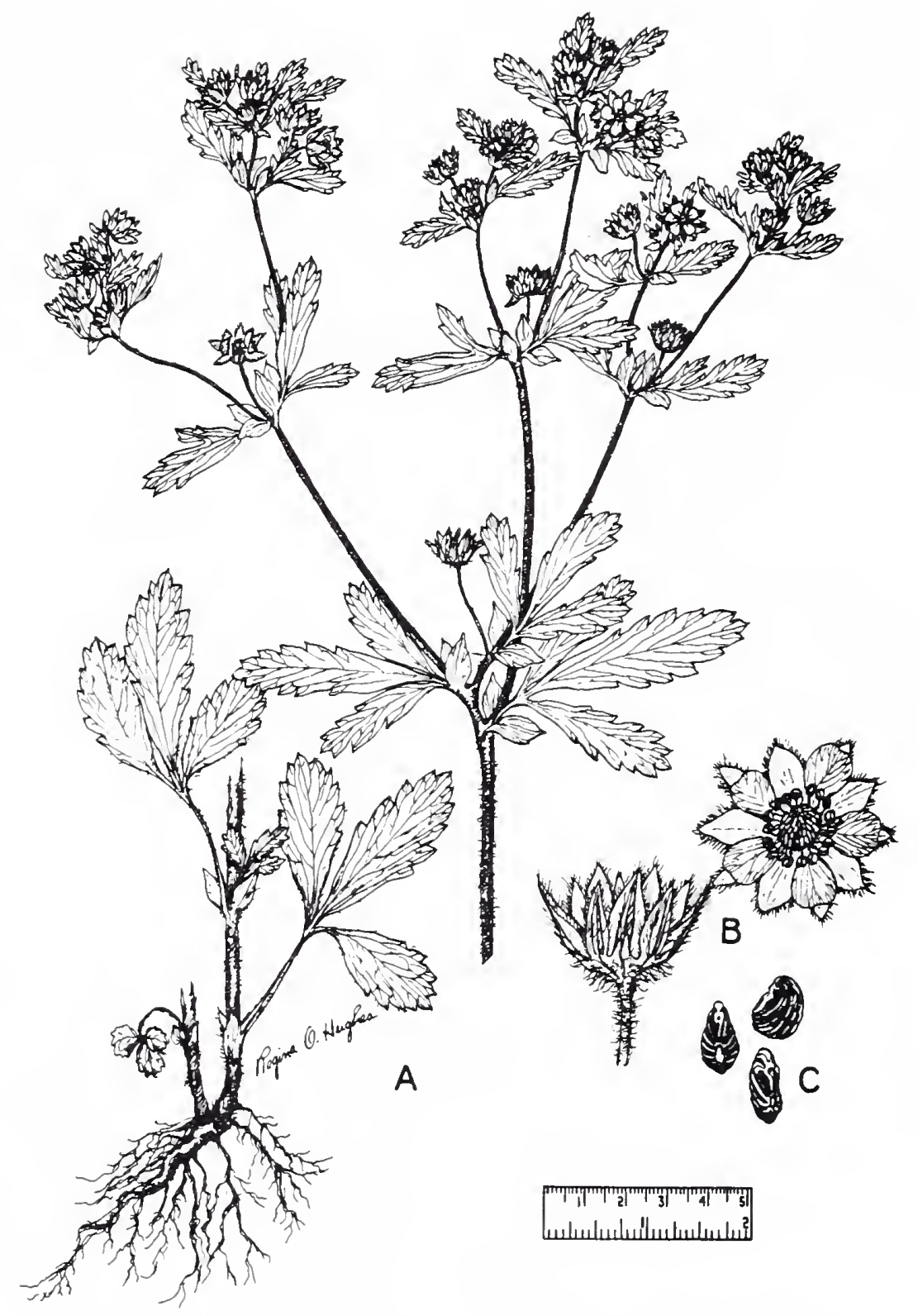

Potentilla norvegica-Norway Cinquefoil
[From USDA Agr. Research Sv. (1971), Fig. 107, p. 219.]

Distr in NYS. Rare as an introd or adv plant in this state. Distr in the Torrey Range. Rare as a ballast plant near the larger cities.

Time of Fl. Late May-Aug.

Origin. Adv and natzd from Eu.

This species, considered by some botanists to be of hybrid origin (possibly containing elements of $\underline{P}$. argentea and $\underline{P}$. norvegica), is in the northeastern states thought of as being "Local but rapidly spreading." It somewhat resembles $\underline{P}$. norvegica but differs in its 5 -foliate leaves. To this

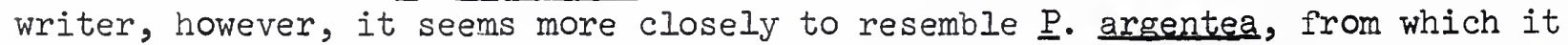
can be distinguished by the long spreading hairs on the stems, petioles, and 
undersides of the leaves; the pubescence on the undersides of the leaves of P. argentea is densely matted.

\section{Potentilla norvégica I. Norway Cinquefoil.}

Meaning of Species Name. Norwegian.

other Names. Barren Strawberry, Rough Cinquefoil, Tall Five-finger. Type of Plant. An annual or biennial herb, reproducing by seeds. Habitat. Thickets, meadows, fields, clearings, roadsides, old pastures, and waste places.

Range. Gl and Iab to Ak, s to NC, Tex, and Ariz; widely distr in Eurasia.

Distr in NYS. Common or frequent throughout the state except in densely wooded secs, into which it appears to migrate with the clearing of the forests.

Distr in the Torrey Range. Throughout the area except in the pine barrens, becoming very common northw.

Time of Fl. Jun-Aug(Oct); Jul(Aug-Oct) at Cornell.

Origin. Native.

Gleason (1952) states that this species may possibly have been introduced from Europe; it often occurs as a weed in cultivated ground. In areas where it has become obnoxious, clean cultivation will destroy this weed. The Chippewas chewed the root and stalk of this species, or prepared a decoction of it, to relieve sore throat.

Potentilla récta I. Rough-fruited Cinquefoil.

Meaning of Species Name. Upright.

Other Names. Sulfur Cinquefoil, Tormentil.

Type of Plant. A perennial herb, reproducing by seeds.

Habitat. Dry fields, roadsides, meadows, pastures, and waste places.

Range. Nf to Ont and Minn, s to Va, NC, Tenn, Ky, Ark, Kan, and Mo.

Distr in NYS. Estab as a locally common plant in several localities across the state; apparently increasing rapidly in abundance and distr in recent years, being first reported from near oswego in 1879.

Distr in the Torrey Range. In 1915 it was considered to be a rare adv in Ct and $\mathbb{N Y}$, hardly persisting.

Time of Fl. (Late May)Jun-Aug; Jun 20-Aug 10 at Cornell.

Origin. Natzd from Eu.

Remarks. This plant is rapidly spreading in the Catskills.

This species has been suspected of being poisonous to livestock both in Europe and in the United States, but Kingsbury (1964) could find "no definite evidence" of its toxic nature. In areas where this species has become a troublesome weed, Muenscher (1952) suggests pulling or hoeing scattered plants from meadows when the first flowers appear. Badly infested meadows should be mowed early to prevent the spreading of seeds. Plowing, followed by clean cultivation for a year, will also destroy this weed. 


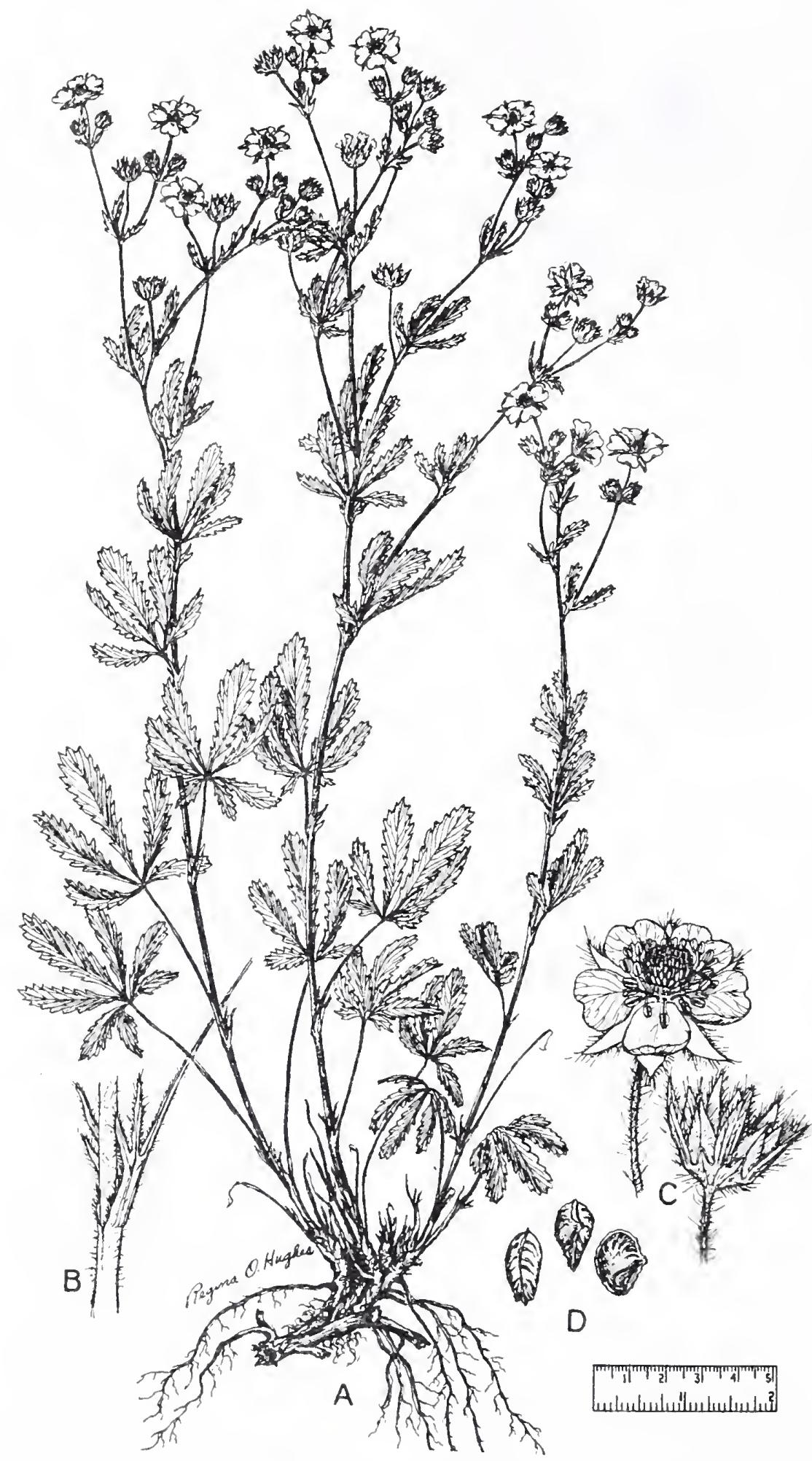

Potentilla recta--Rough-fruited Cinquefoil

[From USDA Agr. Research Sv. (1971), Fig 108, p. 221.] 
Potentilla simplex Michx. Old-field Cinquefoil.

Meaning of Species Name. Unbranched.

Other Names. Decumbent Five-finger, Barren Strawberry, Five-finger. Type of Plant. A perennial herb, reproducing by seeds and runners. sides.

Habitat. Dry or moist woods, thickets, fields, pastures, and roadTex.

Range. Nf and Que to Minn, s to INC, Tenn, Ala, La, Mo, Okla, and

Distr in NYS. Infrequent or locally common across the state outside the Adirondacks.

Distr in the Torrey Range. Common throughout the area except in the pine barrens, there rare and local and probably adv, always increasing northw.

Time of Fl. Apr-Jun; May 20-Jul 1 at Cornell.

Origin. Native.

Where this species has become an obnoxious weed, increase the soil fertility and organic matter, when practicable, by adding fertilizer and plowing under a "green manure" crop such as rye, but Muenscher (1952) observes that "Land infested with this weed is often acid," however, "and otherwise poorly adapted for any purpose except reforestation."

Potentilla tridentàta Ait. Three-toothed Cinquefoil.

Meaning of Species Name. Three-toothed.

other Names. "Sibbaldia."

Type of Plant. A sma.ll tufted creeping perennial $\in$ vergreen with depressed superficial ligneous branches.

Habitat. Dry open sterile rocky, gravelly, sandy, or peaty soils, usually at high elevations and on exposed ridges and ledges.

Range. GI and Iab to Mack, s to NE, NY, Mich, Wis, Ia, and ND, and at scattered stations in the mts to $\mathrm{Ga}$.

Distr in NYS. Frequent or common throughout the Adirondacks and $n$ $N Y$, and in the Catskill mts; less frequent southw to Dutchess co and the Hudson highlands, and not reported from W NY.

Distr in the Torrey Range. NY: Dutchess co, increasing northw.

Elevation. 1000-4020 ft in the Torrey Range.

Time of Fl. (Iate May) Jun-Aug(Oct).

origin. Native.

Raymond H. Torrey (1930), quoting Dr. Wherry, remarks of this species that "It seems to grow on gravelly soils irrespective of their derivation, although always acid in reaction.... this plant is absent on some mountains where one might expect it because it is so intolerant of shade and competition. It evidently survived the glacial period on the peaks of the Blue Ridge in Virginia and North Carolina ... and then gradually migrated northward when the ice retreated. Carrying seeds by the wind seems out of the question, so birds are the only likely means of transportation." 

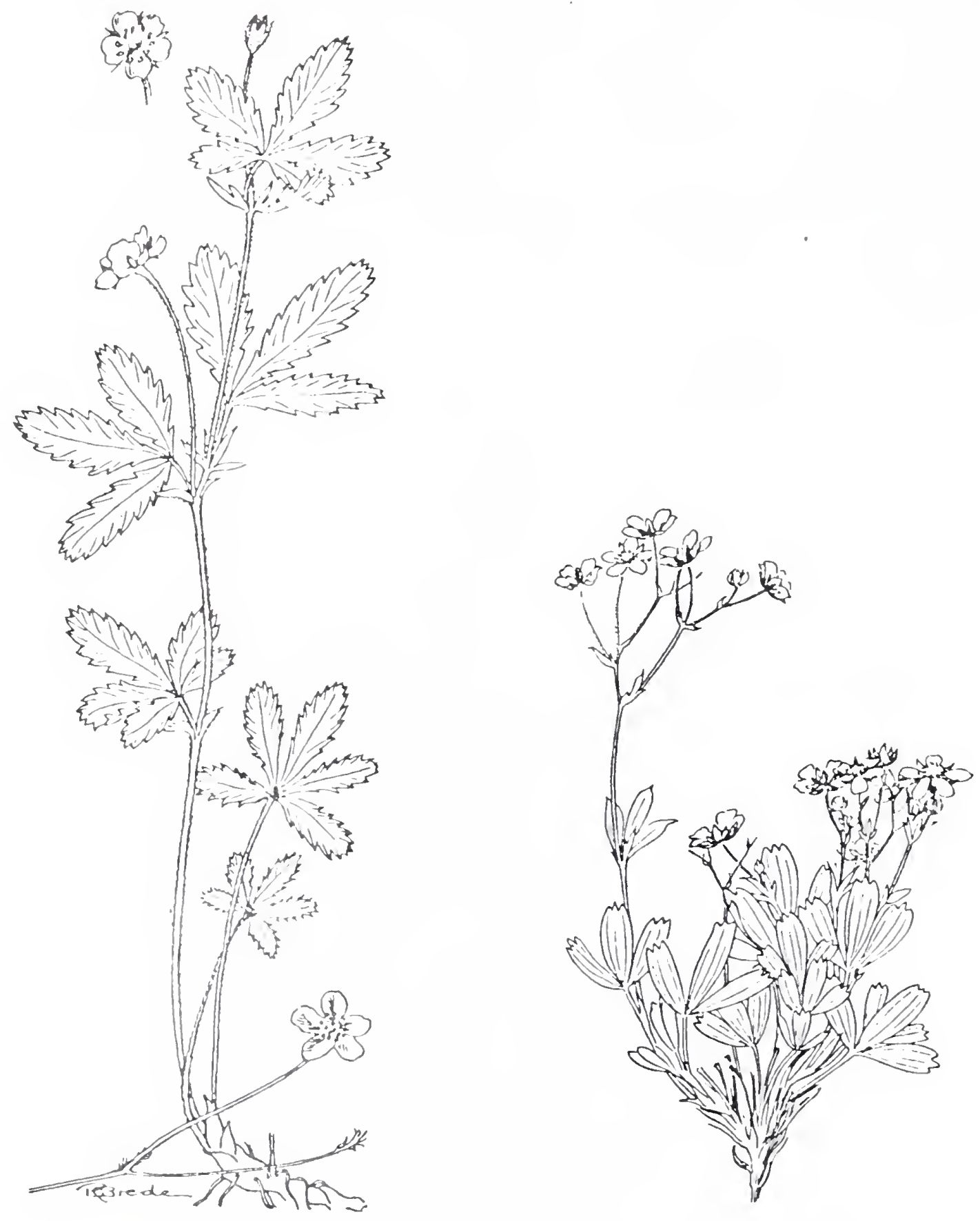

(Ieft) Potentilla simplex--old-field Cinquefoil [From Smith (1966), Plate 82, p. 181.]

(Right) Potentilla tridentata--Three-toothed Cinquefoil [From Smith (1966), Plate 81, p. 179.] 
Prunus L. Cherry, Peach, Plum.

There are about 200 species of Prunus, a genus of small trees or shrubs bearing fruits containing a hard pit or "stone," growing chiefly in the north temperate zone but extending also into the Andean region of South America. The name of the genus is the ancient latin name of the plum. Most of the species bear edible fruit and all have attractive flowers. This genus has therefore contributed much both to economic and ornamental horticulture. In addition to the Plum, other well-known species include the Flowering Almond, garden cherries, peaches, apricots, the Japanese Cherry, and the Almond, one member of the genus whose flesh is dry and woody and whose pit is an edible nut, now widely grown commercially in California.

One of the simplest ways to identify native species of this genus at any season of the year is to nibble on the inner bark of a twig. If it tastes bitter and astringent with a flavor of hydrocyanic acid (the flavor of peach pits or bitter almonds), there can be little doubt that the genus Prunus is involved (although $\underline{P}$. virginiana may be an exception). The wood of this genus is close-grained, solid, and durable, and some species are important timber trees. Many of our cultivated plums are imported varieties of the woolly twigged, thick-leaved European $\underline{P}$. domestica, a species that, according to Rogers (1926), "[has] found a congenial home in the mild climate of the West Coast." In addition, she states that "Japan has furnished to the Middle West and South a hardy, prolific species, . triflora, generally immune to the black knot, a fungous disease which attacks native plums. Crosses between the Japanese and American native plums promise well. California now ranks first in prune raising as an industry, with France a close second. Prunes are the dried fruit of certain sweet, fleshy kinds of plum. Many cultivated varieties of Japanese plums have enriched the horticulture of our West Coast."

Martin et al. (1961) report that the wild cherries furnish an important source of food for wildlife. More than 70 species of birds, including important gamebirds and common songbirds, consume the fruits as they ripen in the surnmer and fall, and sometimes even before they are ripe. Outstanding in importance are the widespread wild Black Cherry, the Chokecherry, and the Pin Cherry, all of which are common in the Catskill region. In addition to their use by birds, wild cherries are also relished by many fur and game mammals as well as by a number of small mammals. Bears break down the bushes to get at the fruit, and skunks, raccoons, and foxes also seek them out. The branchlets and foliage are browsed by deer, and rabbits chew the bark of some species. Often these animals feed on the cherries that have fallen to the ground after the birds have taken their harvest. The flowers likewise furnish pollen and some nectar to honey bees.

In both Europe and Asia the bark of a number of native species of Prunus has been used as the source of reddish- and yellowish-brown, black, bluish-black, gray, and yellow dyes.

It has long been known that at times some of the wild cherries may cause fatal poisoning when eaten by farm animals, as the eastern wild cherries have been responsible for much loss in livestock under conditions which make their foliage available to pastured animals. Black Cherry is 
frequently the cause of poisoning in cattle eating the wilted leaves, but all wild cherries are subject to suspicion. Muenscher (1949) observes that while the Black Cherry appears to be the most dangerous, the Chokecherry and the Pin Cherry are also dangerous. Both wilted and fresh leaves are poisonous, but vigorous succulent leaves from young shoots contain far more hydrocyanic or prussic acid than foliage from mature trees. Cherry leaves occurring in well-cured hay, however, yield only very small amounts of prussic acid. Cherries are not relished by cattle and sheep when more palatable forage is abundant; fatal poisoning therefore occurs on ranges where drought and overgrazing have considerably reduced the amount of grass and other forage. Death appears to be due to the depressant effect of the prusic acid on the respiratory and cardiac centers of the brain.

\section{Key to the Catskill Species of Prunus}

1. Flowers sessile or subsessile, pink to lark pink; ovary velvety or tomentose; exotic species escaped from cultivation........ P. persica

1. Flowers distinctly pediceled; native species, 2

2. Flowers numerous, distinctly racemose, terminating leafy branches of the current year (racemes with 20 flowers or more; leaves below the raceme of ordinary size), 3

3. Sepals entire or inconspicuously glandular-erose, usually

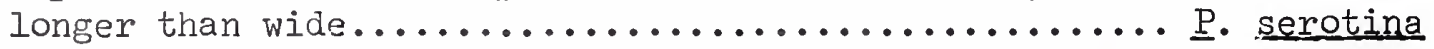

3. Sepals conspicuously glandular-erose, often wider than

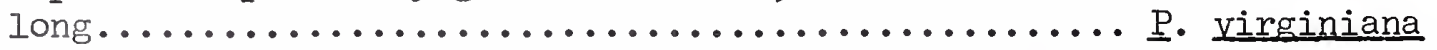

2. Flowers few or solitary, in small umbels, short corymbs, or rarely few-flowered racemes, 4

4. Sepals without marginal glands (sepals glabrous on the

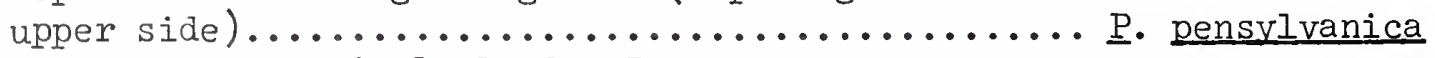

4. Sepals with marginal glands, 5

5. Sepals glabrous on the upper [inner] side........... P. pumila

5. Sepals pubescent on the upper side, at least at base (petals 8-15 mm long; sepals glabrous on the lower

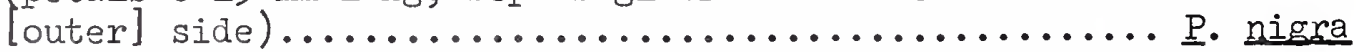

\section{Key to Plants Bearing Leaves and Fruit}

1. Fruit sessile, velvety or tomentose................... persica

1. Fruit pediceled, glabrous, ?

2. Plums; stone flattened to turgid, more or less 2-edged (leaf teeth tipped with a gland, or a minute scar marking the former presence of a gland; leaf teeth triangular to ovate, ascending or salient, the gland distinctly terminal, not adjacent to the sinus; leaves obovate or broally oblong-obovate,

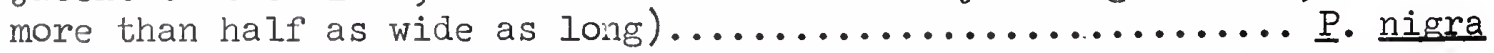

2. Cherries; stone globose or subglobose, 3

3. Inflorescence distinctly racemose, 6-15 cm long, bearing numerous fruits (if all develop), the pedicels much shorter than the axis; fruit blackish or red-purple, 4 
4. Ieaves, or at least some of them, with prominent pubescence along both sides of midrib on lower surface; sepals persistent under the fruit; leaf teeth very short, appressed

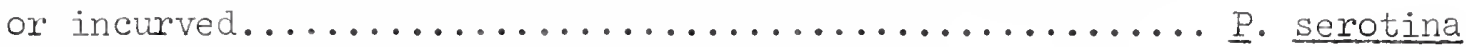

4. Leaves usually glabrous on the back; sepals soon deciduous; leaf teeth triangular, ascending............. v. virginiana

3. Inflorescence of few-flowered umbel-like clusters or of short racemes, the pedicels much exceeding the length of the axis (clusters of flowers and fruits bractless, or bracted only by the bud scales), 5

5. Teeth at the middle of the leaf margin 1-4 mm apart, less than $0.5 \mathrm{~mm}$ high; leaf margin cartilaginously thickened; fruit

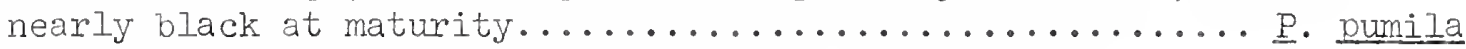

5. Teeth at the middle of the leaf margin $0.5-1 \mathrm{~mm}$ apart, irregular in size; margin not thickened; fruit bright red at

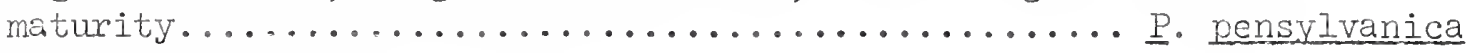

Prunus nigra Ait. Canada PIum.

Meaning of Species Name. Black, from the dark branches. Other Names. Wild Plum, Red Plum, Horse-plum, Pomegranate. Type of Plant. A small tree sometimes attaining a height of 20 to 30 f't but often only a coarse shrub.

Habitat. Thickets, borders of woods, streambanks, and fencerows. Range. NE, NY, and s Ont to Mich, Wis, Minn, s Man, Wyo, and Utah, S to Fla and INM.

Distr in NYS. Frequent in the Adirondacks up to $2000 \mathrm{ft}$ in elevation, less frequent southw to the higher hills of Dutchess co, the Hudson highlands, Ulster and Otsego co, and locally westw across the state.

Distr in the Torrey Range. Sometimes found as an adv; not common. Time of 티. Mid-Apr-early Jun, fr Aug-Oct; fl May 5-20 at Cornell. Origin. Native.

This shrub much resembles $\underline{P}$. americana, the wild Red Plum, in many respects, but the latter is a more southern species. The Indians are reported to have given supplies of the Canada Plum to Jacques Cartier when he sailed into Chaleur Bay in 1534, for this rare species of the Catskill region is more abundant northward and is said to be "commonly cultivated in the gardens of French Canada," both for its handsome flowers (which turn pink before they fall) and its edible fruit, which, according to Peattie (1950), is still "sold in the markets of Canadian cities." Rogers (1926) remarks that "This tree furnished the settler with a'relish for his hard fare, and the horticulturist a hardy stock on which to graft scions of tenderer and better varieties of plums," but "It is a tree well worth bringing in from the woods to set in a bare fence corner that will be beautified by the blossoms in the spring, and in late summer by the bright orangecolored fruit against the ruddy foliage." Its wood is strong, enabling the tree to survive heavy snows and ice storms with much less injury from breaking than most trees. In Peattie's opinion, "the Canada Plum deserves more cultivation than has ever been given it," for "horticulturists have given this Plum little attention and as yet few named varieties have been bred from it," in contrast to the Wild Red Plum, which "has given rise to more 


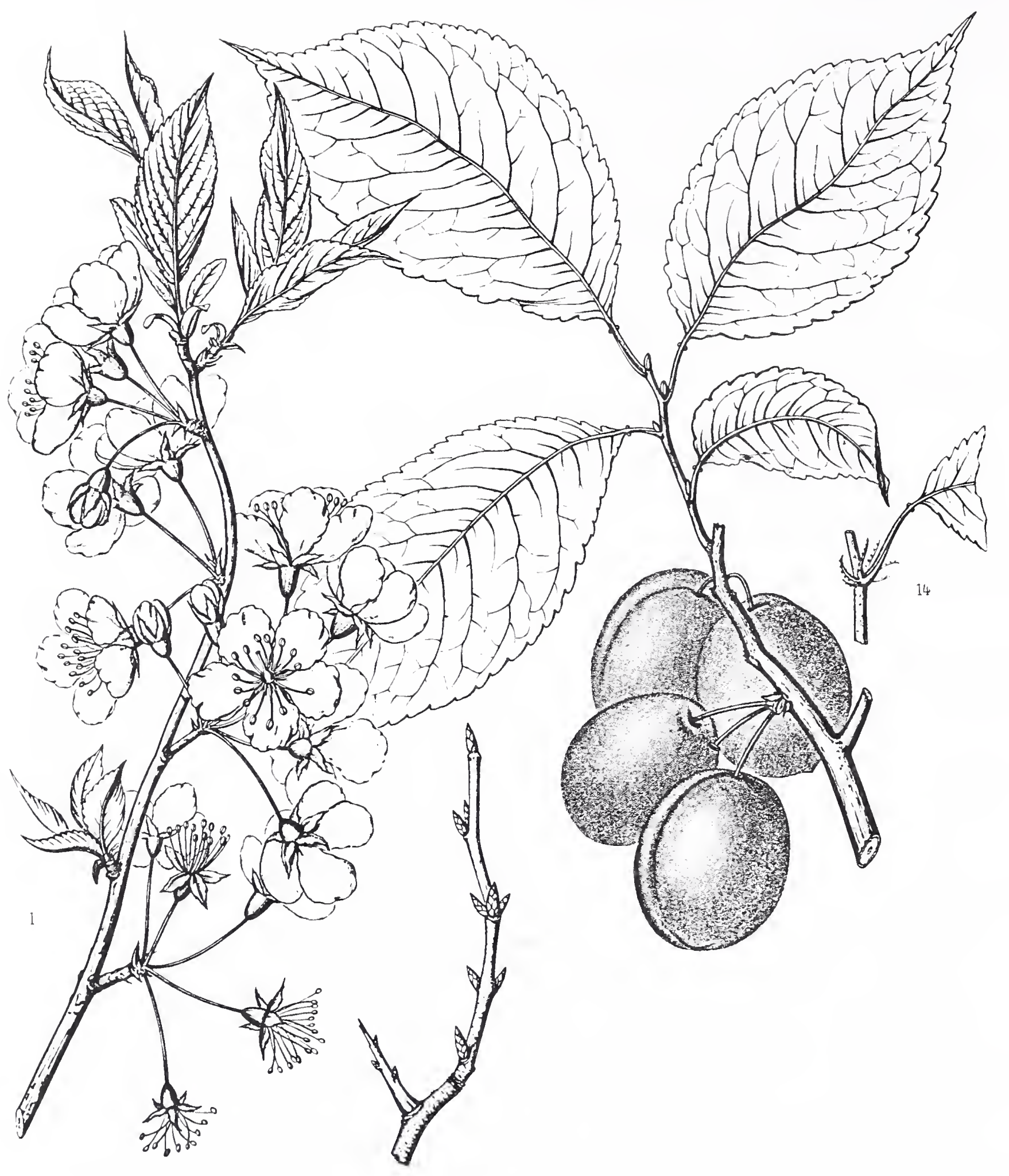

Prunus nigra--Canada Plum

[From Sargent (1891-1902), Vol. IV, Plate 149, ff. p. 16.] 
pomological varieties than any other native species," some 300 cultivars having been derived from it.

Prüus pensylvánica L. f. Pin Cherry.

Meaning of Species Name. Of Pennsylvania.

Other Names. Bird Cherry, Fire Cherry, wild Red Cherry, Pigeon Cherry, Dogwood, Red Cherry.

Type of Plant. A slender shrub or a small tree, occasionally attaining a height of 30-40 ft with a trunk up to 1 ft in diameter.

Habitat. Dry rocky woods, recent burns, clearings, neglected fields, and fencerows.

Range. Lab and $\mathrm{N} f$ to $Q u e$ and $\mathrm{BC}$, s to $\mathrm{NJ}$, Va, upland to $\mathrm{NC}$, Tenn, Ill, Ia, SD, and Col.

Distr in NYS. Common throughout most secs of the state $n$ of the coastal reg.

Distr in the Torrey Range. NY: At Hewlett and $\mathrm{n}$ of the moraine on II, rare on SI, and thence increasing up the Hudson valley and becoming very common northw.

Elevation. Sea level-4020 $\mathrm{ft}$ in the Torrey range.

Time of Fl. Apr-May (early Jun), fr Jul-Sep; fll May 10-25 at Cornell. Origin. Native.

Remarks. Often abundant after fires; wood soft, light brown, wt 31 lb per cu ft.

This is a small, short-lived tree; not without charm when in full flower, it is generally considered a "forest weed," since it usually dies when the trunk reaches 4 to 6 inches in diameter. With the aspens it forms a pioneer association on cut-over or burned-over forest lands, particularly in areas formerly dominated by White Pine, Hemlock, and northern hardwoods. Its chief value from the forester's standpoint, therefore, is to prevent erosion and to furnish a light shade for other seedling trees growing underneath, acting as a nurse tree until larger and more permanent species occupy the site. It cannot withstand shade and soon dies when overtopped by other trees. Its wood is of no commercial value, but the fruit is consumed by some 23 species of birds; they are almost wholly responsible for the dissemination of its seeds. Chipmunks and deer mice utilize the "pits" or seeds as food, and the fruits are eaten by several other species of animals. Deer seem not to be overly fond of it as browse, but the bark is sometimes eaten by beaver when more preferred food is not available.

This species is known to every country boy for its pleasantly sour fruit, which is sometimes eaten raw. Although its pulp is thin compared with the large stone, mixed with currants or apple to make it jell, it makes a delicious jelly (use the recipes given under $\underline{\mathrm{P}}$. serotina or $\underline{\mathrm{P}}$. virginiana). The gum exuled from the trunk is also sought by some people as a substitute for chewing-gum. 


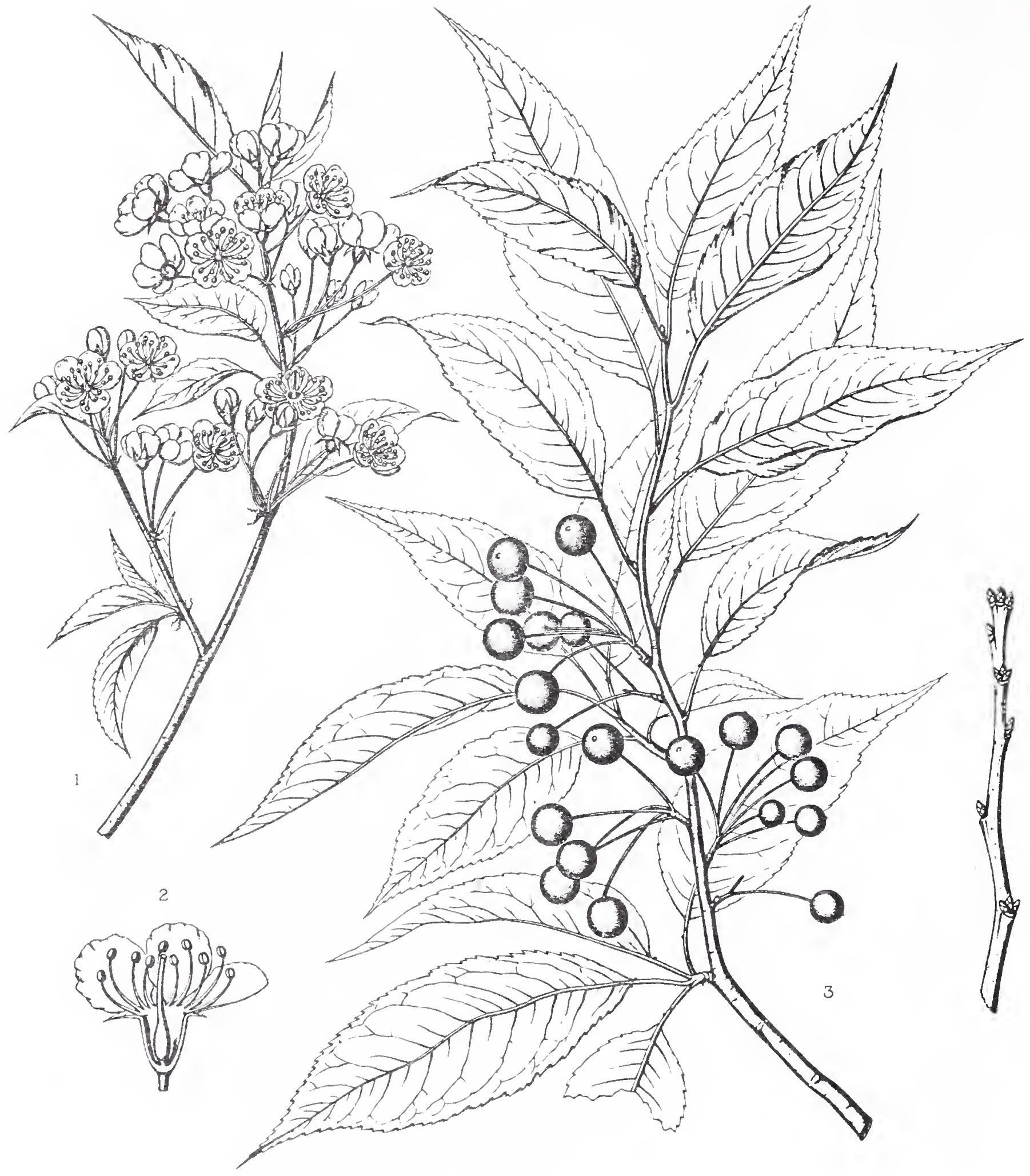

Prunus pensylvanica--Pin Cherry

[From Sargent (1891-1902), Vol. IV, Plate 156, ff.p. 36.] 
Prunus pérsica (L.) Batsch. Peach.

Meaning of Species Name. An old generic name, an ancient name for the Peach, which reached Europe from China via Persia.

Type of Plant. A small tree.

Habitat. Roadside thickets and waste places.

Range. NE to Mich and southw.

Distr in NYS. Occasionally esc from cult or spontaneous in waste ground $s$ of the Adirondacks.

Distr in the Torrey Range. An esc in many parts of our range.

Time of Fl. Apr-May, fr Jul-Oct; fl Apr 20-May 20 at Cornell.

Origin. Introd from Asia.

Remarks. Long in cult and occasionally adventive from discarded seeds; certainly little more than a waif in the Catskill region, where it has so far been collected only once.

The numerous varieties of this species produce the peaches of commerce, from which two well-marked strains, "cling-stones" and "free-stones," have evolved. Double-flowered dwarf forms are grown for ornament. During both World Wars I and II, Hill (1952) states that "peach stones were used as a source of charcoal" in the manufacture of filters "for gasmasks."

The bark of the twigs, the inner bark of the trunk, and the leaves have been used in medicine. Lighthall (n.d.), an Indian "medicine man," remarked that "No family should be without a sack of leaves in their house," for he felt that they had "a wonderful power in quieting irritation of the stomach and the ... small bowels." He prescribed an infusion of the leaves in tablespoonful doses every 10 or 15 minutes to quiet obstinate cases of vomiting and considered it a mild tonic in small doses. A hot poultice of the leaves or bark laid on the pit of the stomach would ease stomach cramps. He also boiled the leaves with bread and milk to make a poultice for cuts and wounds "where the inflammation runs too high."

A "sour" yellow color can be obtained by covering I bushel of peach leaves with 10 gallons of water and letting them stand in a warm place completely covered for a week or two. One pound of light gray wool was then mordanted with potash alum, boiled, drained, wrapped in a cloth, and set aside for several days, after which the yarn was rinsed and boiled for 1 hour with the fermented peach leaves.

Kingsbury (1964) states that of the various species of Prunus cultivated in North America, the Peach seems to be the only one to have caused much trouble among farm animals. While all parts of the plant contain cyanide, the pits are particularly rich in that compound and have caused mortality in hogs in Maryland and Indiana. "Lethal amounts of peach seeds may accumulate from home peach canning projects," he observed, "but the leaves are also potentially dangerous." 


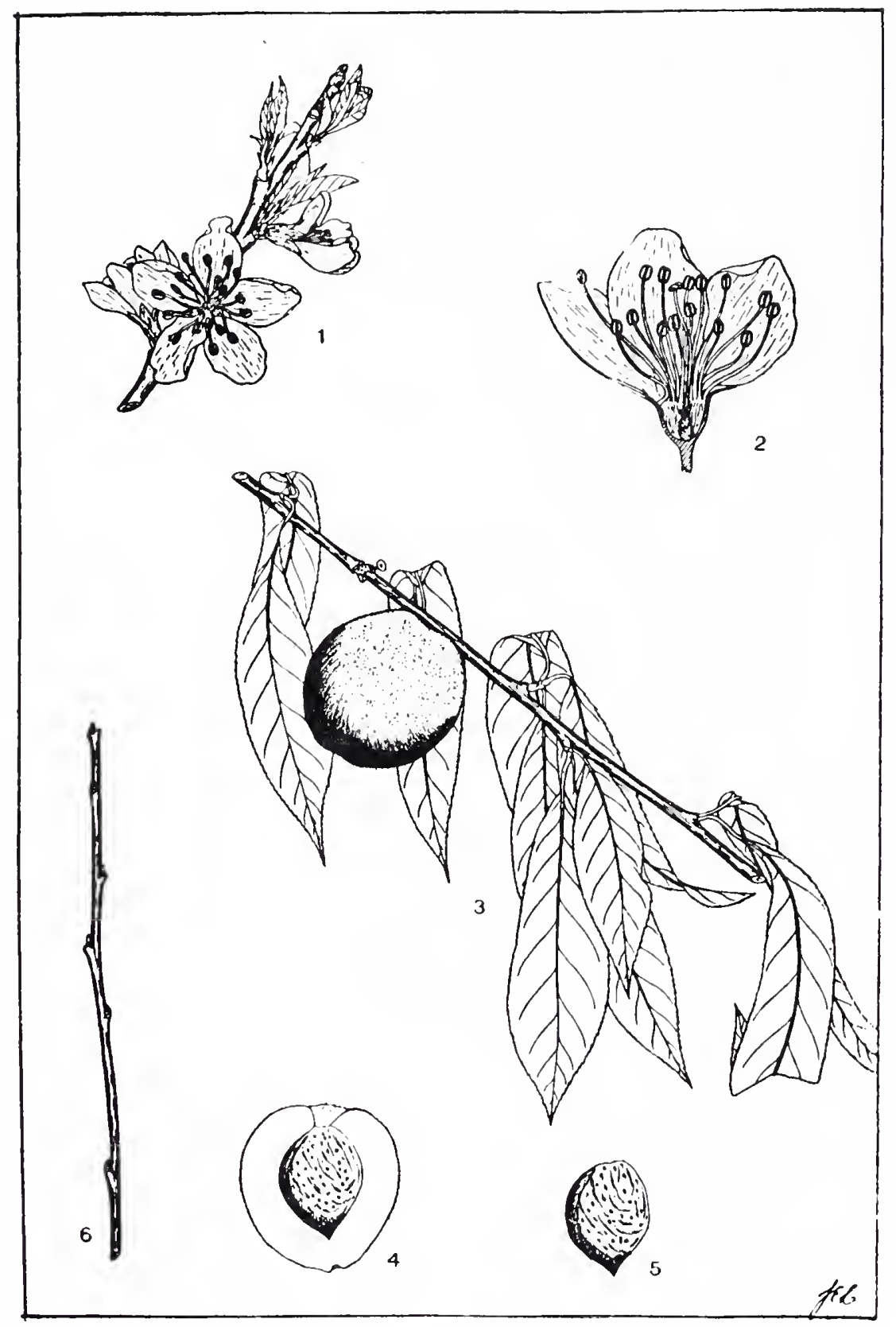

Prunus persica--Peach

[From Brown (1921), p. 264.]

Prunus pumila I. var. depréssa (Pursh) Gleason. Sand Cherry.

Meaning of Species Name. Small; var. name, low, depressed. Synonyms. Fernald (1950) refers only to $\underline{P}$. pumila I. Other Names. Dwarf Cherry.

Type of Plant. A small shrub with prostrate stems. Habitat. Sands, dunes, and rocky calcareous shores. Range. NB and e que to Minn, s to Ont, Mass, NY, and e Pa. 


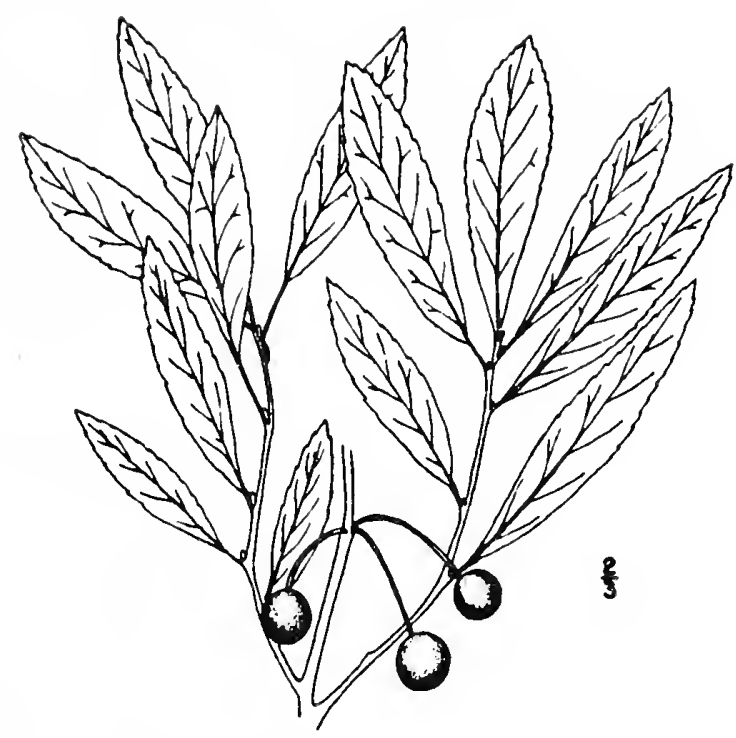

Prunus pumila--Sand Cherry

[From Billington (1949), Fig. 98, p. 182.]

Distr in NYS. Uncommon on sand dunes, sandy shores, and fields of the Great Lakes reg.

Distr in the Torrey Range. NY: Unknown on LI or SI, rare in Westchester co, thence increasing and common northw.

Elevation. Sea level-4020 ft in the Torrey range.

Time of $\mathrm{Fl}$. May-early Jun, fr Jul-Sep.

Origin. Native.

Remarks. While Taylor (1915) states that this species is "common northward" and suggests that it grows on the surmit of Slide Mountain, Catskill records of $\underline{\underline{P}}$. pumila are extremely rare.

Prunus seròtina Ehrh. Black Cherry.

Meaning of Species Name. Late-ripening.

Other Names. Rum Cherry, Wild Cherry, Whiskey Cherry, Wild Black Cherry, Cabinet Cherry.

Iype of Plant. A medium-sized to large tree, commonly 50-60 ft high with a trunk 1 1/2 to $3 \mathrm{ft}$ in diameter, but it sometimes attains $100 \mathrm{ft}$ in height with a trunk diameter of 4-5 ft.

Habitat. Dry woods, roadsides, fencerows, waste land, and forest margins.

Range. NS, Que, Ont, and Minn to ND, a to Fla, Tex, and Mex.

Distr in NYS. Frequent or common in most secs of the state.

Distr in the Torrey Range. Common throughout the range except in

the pine barrens, there rare or wanting.

Time of Fl. May-Jun, fr Jul-Sep; fl May 20-Jun 10 at Cornell, about 2 weeks later than $\underline{P}$. virginiana.

Origin. Native.

Remarks. Wood hard, strong, reddish-brown; wt $36 \mathrm{lb}$ per cu ft. 
In the forest this species, the tallest of all cherries and the most precious native cabinet wood in the Rose family, develops a tall straight trunk with a relatively small crown, making its best growth on deep, moist, fertile soils, but it is often found growing on drier soils. Michaux reported that trees growing on the banks of the Ohio grew from 80 to 100 feet high, with trunks 3 to 5 feet in circumference, undivided to a height of 25 or 30 feet. In the field the Chokecherry is sometimes confused with young specimens of the Black Cherry, but the relatively more pointed leaves of the latter species, together with the rusty hairs along the midrib (particularly on the leaves of vigorous shoots), will serve to distinguish the two species.

The many virtues of the wood of this species have found high favor, ranking it with mahogany and rosewood in the esteem of cabinet-makers. While it is weak when used as a beam, it is heavy, compact and fairly hard, with a beautiful smooth grain that takes a handsome finish and a light red tint that deepens with age. In addition it shrinks but little in seasoning and does not warp. It therefore came to rank second only to Black Walnut as the finest cabinet wood of temperate North America. Peattie (1950) remarks that "In the days of wooden Pullmans, wooden streetcars, and fine carriage-making, Cherry was of utmost importance." Among many other things it was also much used for furniture; many families are still the proud possessors of fine drop-leaf cherry tables that have been handed down through several generations. The drains upon this species were such that by the beginning of the present century, hardwood buyers were cruising the country in search of Black Cherry trees of fine dimensions. So successful were they that Peattie (1950) states that it now ranks at the bottom of the available cabinet wood in the United States. Whenever it can be obtained, it is currently used for show-cases, counters, cabinets, bars, weighing apparatus, spirit levels, paneling, interior finish, precision instruments, musical instruments, and furniture, both solid and as a veneer.

This species also makes a desirable ornamental. In the words of Rogers (1926), "A worthy shade and park tree, Black Cherry is charmingly unconventional, carrying its mass of drooping foliage with the grace of a willow, its satiny brown bark curling at the edges of irregular plates like that of the Cherry Birch."

The fruit of this species has a sweetish, astringent, somewhat bitter taste, but it makes an especially rich dark jelly with a delicious winey flavor. To 3 quarts of washed, unpitted Black Cherries, add 3 cups of water, bring to a boil, and simmer for 20 minutes. When cool enough to handle, squeeze out the juice: Because cherry juice contains no pectin, one can then follow the recipe for sour cherry jelly found accompanying any package of commercial pectin, but for variety and an excellent flavor, this cherry juice can be mixed half and half with a wild apple juice. Collect about a peck of wild apples (they need not be ripe), cut out any parts damaged by insects, quarter them, and put them into a kettle (peels, cores, and all), barely cover with water, and simmer for 30 minutes or until the apples are tender, then drain off the juice without crushing the fruit. To 2 cups of cherry juice add 2 cups of apple juice and 4 cups of sugar, stir, and bring to a boil. Continue to boil hard until it passes the jelly test (see the account under Pyrus malus). Pour immediately into jelly glasses and seal with paraffin. 


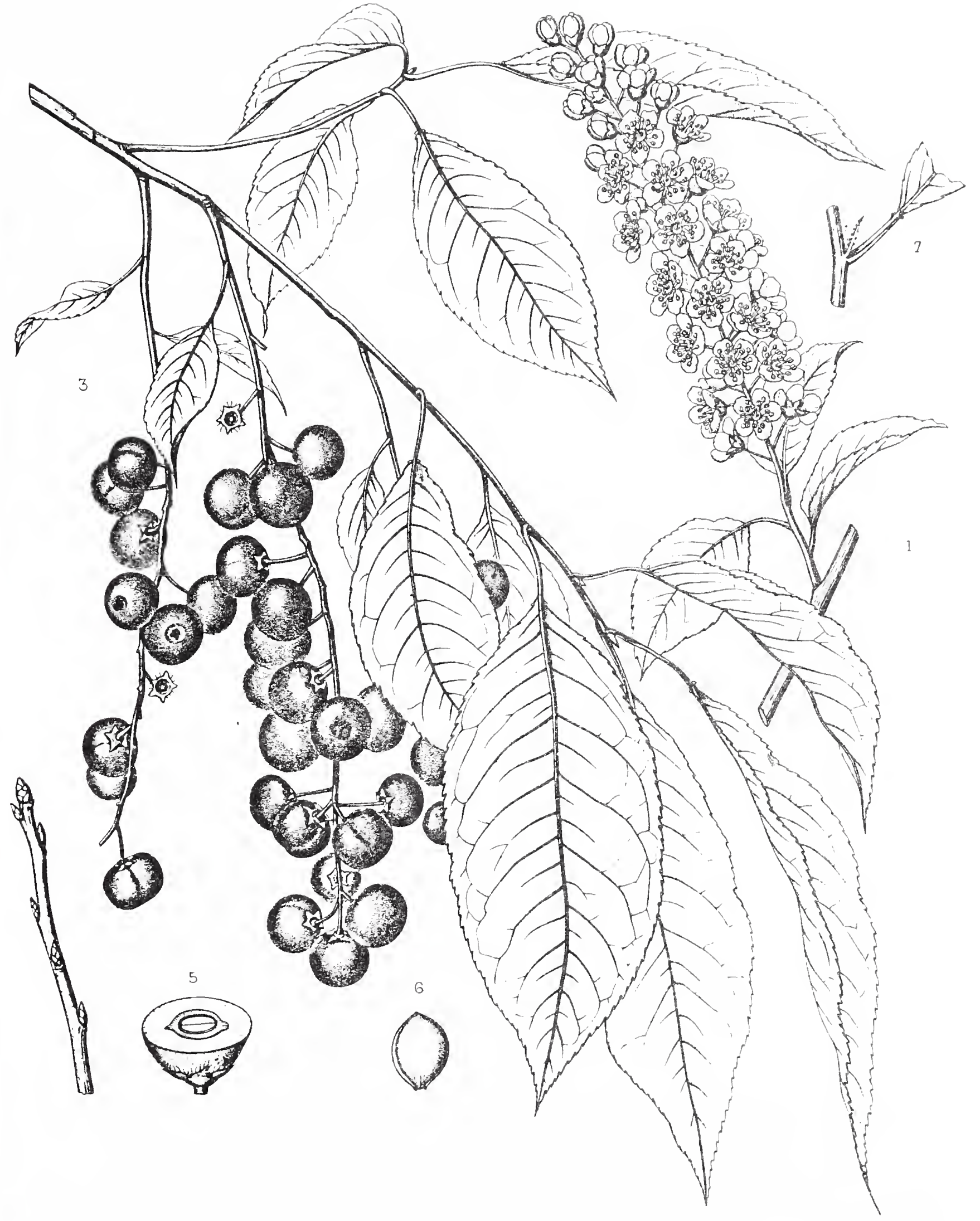

Prunus serotina--Black Cherry

[From Sargent (1891-1902), Vol. IV, Plate 159, ff. p. 47.] 
The name "Rum Cherry" was acquired because this species was used by early New Englanders to convert the raw rum they obtained from the West Indies into a sweet, beautifully colored cherry liqueur. To I quart of Rum Cherries add about 1 dozen crushed seeds and 1 cup of water, then simmer for 15 minutes. When cool enough to handle, strain the juice through a jelly bag, return to the fire, add 1 cup of sugar to each cup of juice, and bring to a full boil again, then pour into bottles or jars, and seal tightly. Add 1 part juice to 2 parts of rum, whisky, or brandy for a fine-flavored drink. The fruit is still occasionally used for flavoring alcoholic liqueurs. Rum Cherries were also once much used to make brandied cherries or cherry bounce. Fill a quart jar three-fourths full of uncooked Rum Cherries, add 1 cup of sugar, then fill the jar to the top with commercial brandy. Seal the jar and set it in a dark place for at least 3 months.

Cherry soup can likewise be made from Rum Cherries. Wash 1 quart of unpitted cherries, then crush and pound them until the seeds are broken. Add $I$ quart of water and a pinch of salt, then simmer for 30 minutes. Put through a sieve to remove skins and seeds, return to the fire, and thicken with 2 tablespoons of instant mashed potatoes. Simmer for a few minutes more, then add sugar to taste. This soup can be served hot or cold; when served cold, it can be dressed up a bit with a spoonful of sour cream on top of each serving. For those who may be interested in further exploring the uses of Black Cherries, Gibbons (1962) gives a recipe for Blushing Betty, a pudding, and directions for making cherry wine.

North American Indians made much use of the fruit of this species, eating it both fresh and dried for future use. The fruits were pulverized in a stone mortar and combined with dried pulverized meat to make pemmican. The fruit was also added to soups, and some tribes enjoyed a tea made from the twigs as an invigorating beverage.

Black Cherry was likewise much used by the Indians as a medicine. Cherokee women used a warm infusion of the bark to relieve the pains of childbirth, while the Ojibwas used the inner bark of this species, boiled, bruised, or chewed, as an application to external sores and wounds. An infusion of the inner bark was also sometimes given to relieve pains and soreness in the chest. Densmore (1928) reports that the Chippewas used the twigs of this species to prepare a beverage as well as eating the fruit both raw and dried for winter use. A decoction of the root was also used medicinally to expell worms, and a decoction of the inner bark was used in the treatment of ulcers, cholera infantum, and scrofulous neck; a handful of the prepared roots was boiled in about 1 quart of water. The roots of this plant were also used in combination with those of Ledum groenlandicum (Labrador Tea) in the treatment of burns, ulcers, or any condition in which the flesh was exposed. The roots were dried, powdered, and mixed, but not cooked. This powder was applied to the raw flesh. When it became damp, it was removed, the sore washed, and a fresh application made. The fresh roots mashed were also sometimes used as a poultice, or the inner bark was scraped and boiled for use as a disinfectant wash for sores and scrofulous neck.

The Poncas treated diarrhea either with a decoction of the bark or an infusion of the dried and pulverized fruit. Among some tribes the bark was used in the treatment of coughs and colds and as a seasoner for other medicines, while the steeped fruit was used as a bitter tonic. The 
Meskwakis made a tea of the root bark as a sedative and a stomach remedy, a drink that became popular in domestic medicine. The Mohegans put the ripe fruit in a bottle and let it ferment in its own juice for about a year, after which it was used in the treatment of dysentery. For colds, the leaves were steeped with Boneset (Eupatorium perfoliatum).

A medicine so widely used by the Indians could not fail to impress the early settlers, and the inner bark of this species was soon adapted by them for use in the treatment of fever, intestinal worms, indigestion, and tuberculosis. In Appalachia a bark tea is still used to treat coughs, colds, and measles. The U.S. Dispensatory of 1865 stated positively that "This bark is among the most valuable of our indigenous remedies. Uniting with a tonic power the property of calming irritation and diminishing nervous excitability, it is admirably adapted to the treatment of diseases in which debility ... of the system ... is united with general or local irritation." John Iloya, writing at a somewhat later date, reported that "No more popular bark of a native tree, excepting Sassafras, is known to home medicine." He was speaking both of Black Cherry and Chokecherry, which were not only used interchangeably in American medicine but were treated as synonymous in some editions of the U.S. Pharmacopeia. Wild Black Cherry bark from the dried stems has been official from 1820 to the present time for use as a sedative and as a pectoral in cough medicines. A syrup made from the bark has likewise been much used as a flavoring agent and a wine made from the syrup also once had wide use in medicine. All parts of the plant yield hydrocyanic acid when steeped in water, the medical properties of which are destroyed by boiling, so the plant is steeped in warm water only. For use in medicine the bark is collected in autumn, when it contains the largest concentration of the precursors to hydrocyanic acid. Since the bark deteriorates with age, the supply must be renewed each year.

Since Black Cherry produces its fruits prolifically, it is a singularly dependable source of food for wildlife. The cherries are eaten by many species of wild birds, including ruffed grouse. Such mammals as the black bear, raccoon, skunk, and foxes also consume the fruit, and the "pits" are a favorite food of chipmunks and deer mice, the former often storing large quantities for its winter food supply.

This species is the most dangerous of the eastern wild cherries with respect to farm animals; less than $1 / 4$ pound of leaves prove toxic to a 100-pound animal. All classes of livestock have died as a result of eating the leaves of this species. Children have also died after ingestion of the seed kernels.

\section{Prunius virginiàna I. Chokecherry.}

Meaning of Species Name. Of Virginia. Type of Plant. A large shrub or small tree; usually only 6-8 ft tall, it may grow 20-30 ft high with a straight trunk 6-8 in. in diameter. Habitat. Thickets, roadsides, borders of woods, pastures, shores, dunes, and borders of swamps.

Range. Nf to Man and Sask, s to Va, uplands of NC, Ky, Tenn, Mo, Ark, and Kan.

Distr in NYS. Common or frequent in most secs of the state. 
Distr in the Torrey Range. IV: Occasional on II, very rare and local on SI, unknown in the Bronx, rare in Westchester co, thence increasing and becoming very common northw.

Time of $\mathrm{El}$. (Iate Apr)May(early Jun), fr Aug-oct; fl May 5-30 at Cornel1, about 2 weeks earlier than $\underline{P}$. serotina.

origin. Native.

Sargent (1891-1902) states that this is the most widely distributed "tree" in North America, extending from the Arctic Circle to the southern states and Mexico and from the Atlantic to the Pacific. While usually only a large shrub, in some areas it often becomes a small tree. The flowers appear in late spring, usually 2 weeks earlier than those of the Black Cherry, with which it is sometimes confused. The leaves of this species are oval and short-pointed. or nearly obtuse instead of long-pointed, and they lack the rusty hairs usually found along the midrib of the Black Cherry. In addition the inner bark of the twigs of the Chokecherry has a rank, disagreeable odor, and the fruit of the Black Cherry is crowned with the persistent remains of the calyx while that of the Chokecherry is not. The wood of this species is similar to that of the Black Cherry, but it is of no commercial value owing to the small size of the tree.

Chokecherry is usually regarded as a weed tree associated with roadsides, fencerows, and waste places, but it has many qualities which should make it useful in soil-erosion control and game management. Most people who have tested. the edibility of its fruit have concluded without hesitation that the Chokecherry is indeed well named. In his New England Prospects, published in 1634, William Wood remarked that these cherries "so furre the mouth that the tongue will cleave to the roofe, and the throate wax hoarse with swallowing those red Bullies (as I may call them, ) being little better in taste," concluding that "they are as wilde as the Indians." The quality of the fruit differs much on different plants, however, and one can sometimes find plants bearing pleasant, juicy fruit with little astringency. Its defects have been corrected in a limited way by propagation of the most promising strains, some of which produce fruit as much as an inch in diameter. Peattie (1950) reports that "In Quebec this species has long been cultivated and selected strains bear fruit that may be eaten out of hand, like the best orchard cherries, or as preserves or jelly." It holds its fruit better than the cultivated cherries of European origin and ripens late in the season long after other cherries are no longer available. A cultivar, "Shubert," with reddish-purple mature foliage, is sometimes still planted for ornament.

The Chippewas and other northern Indians gathered quantities of Chokecherries and pounded them between two stones, pits and all, leached out the harmful hydrocyanic acid from the kernels of the stones before drying, then dried the mass in the sun without cooking and stored it for winter use or used the dried paste as an ingredient in their pemmican. They also used a bundle of twigs of Chokecherry and Black Cherry about 4 inches long and $I$ inch in diameter to prepare a beverage. This bundle was tied together by a strip of bark long enough to permit the lifting of the bundle and dropping it into about 1 quart of hot water without burning the hand.

In the Catskills Chokecherries are among the most abundant and easily gathered of fruits, yet few people make any use of them, although old recipes 


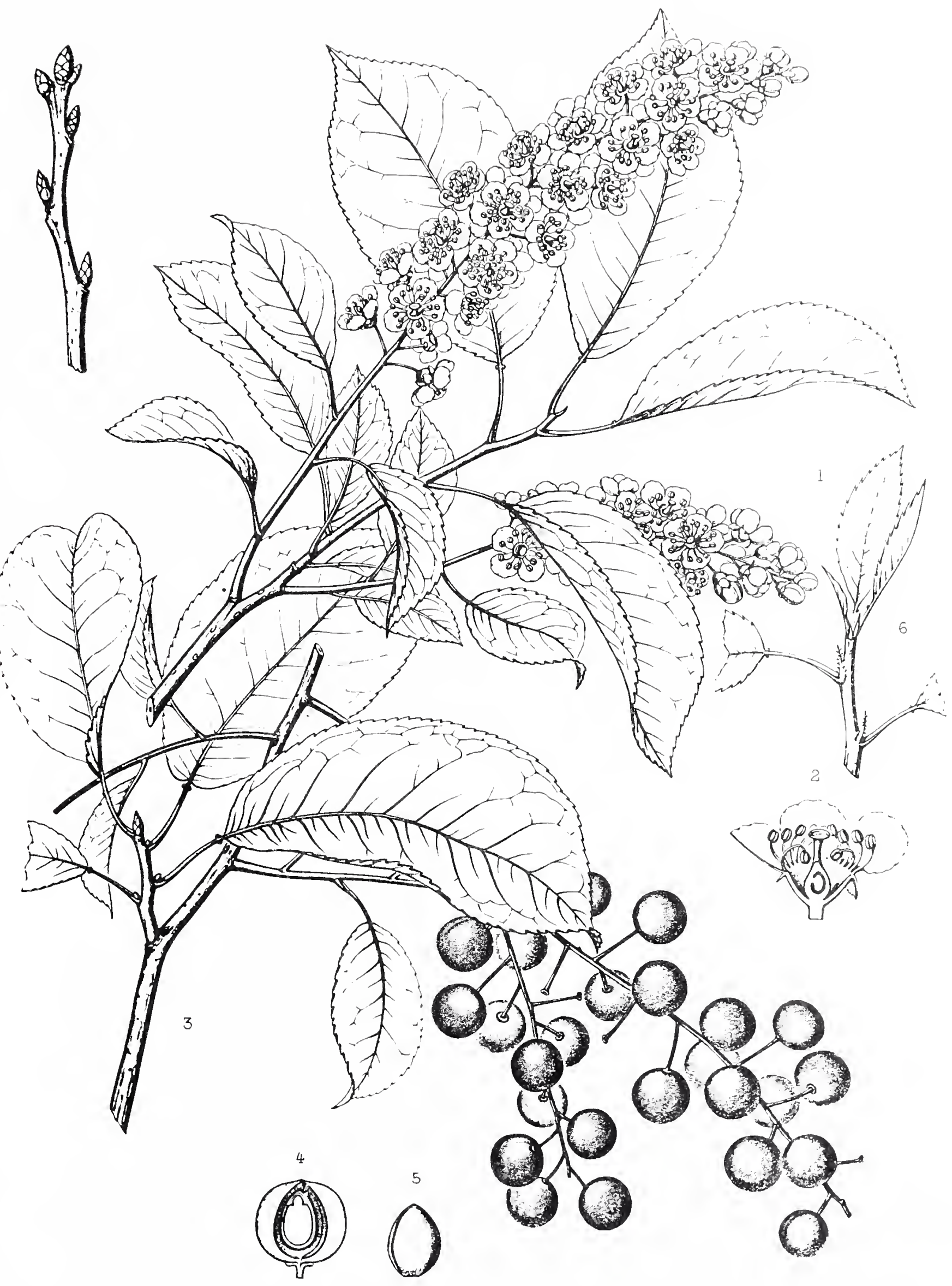

Prunus virginiana--Chokecherry

[From Sargent (1891-1902), Vol. IV, Plate 158, ff.p. 43.] 
indicate that the fruit of this species played an important role in the early settlers' diet. The fact that most people are "turned off" by the mere mention of Chokecherries is perhaps not surprising when one considers the very astringent, "puckery" taste of the ripe fruit, yet some bushes bear quite juicy, palatable fruit, the chief fault of which lies in the thinness of the flesh in proportion to the size of the pits; selected bushes can supply material for a most delicious jelly. Gather about 4 quarts of ripe cherries from bushes bearing the largest, juciest fruit you can find. Stem and wash the cherries and put them, unpitted, into a large kettle, add 3 cups of water, bring to a boil, and simmer, covered, for 15 minutes. When cool enough to handle, strain out the juice through a jelly bag. Put 3 cups of juice into a large kettle, add $6 \mathrm{l} / 2$ cups of sugar, mix well, place over high heat, and bring to a boil, stirring constantly. Stir in 1 bottle or package of commercial pectin, bring to a full rolling boil, and boil hard for 1 minute. Remove from the stove and skim off the foam with a metal spoon. For a stronger cherry flavor, add $1 / 4$ teaspoon of almond extract, pour into sterilized jelly glasses, and seal with $1 / 8$ inch of paraffin. Berglund and Bolsby (1971) give recipes for Chokecherry Cake with Vanilla Sauce, Cold Sour Chokecherry Soup, and Cold Buttermilk and Chokecherry Soup for those who may wish to experiment further with chokecherries.

The Chippewas also employed a decoction of the inner bark, said to be very astringent, as a gargle for sore throat and as a rub for treating cramps. The inner bark was steeped with Corylus root, White Oak root, and the heartwood of Ostrya virginiana for internal use in the treatment of hemorrhages. A decoction made from four roots of Leptandra virginica (CuIver's Root) and a large handful of the inner bark of $\underline{P}$. virginiana in $I$ pint of water was taken betore breakfast and at frequent intervals during the day as a mild cathartic to cleanse the blood. It was also used with an external poultice of the root or inner bark of $\underline{P}$. serotina in the treatment of sores. A decoction of Chokecherry root was also used as a wash to strengthen the hair and make it grow. Fresh leaves of this species were held in the mouth and stuffed in the nostrils as a protection when "working over the dead."

Other tribes of American Indians also made medicinal use of this species, both alone and in combination with other ingredients. The Penobscots steeped Chokecherry bark to make a tea used in the treatment of diarrhea, while the Pillagers used such tea in the treatment of lung troubles. The Potawatomis not only used an infusion of the bark as an eyewash but made a tonic drink from the berries. Iighthall (n.d.), an Indian "medicine man," considered the bark of this species a fine tonic that reduced nervous excitability and calmed "the force of cardiactive action," a "fine remedy for debility of the stomach, ... a good remedy for revers, and for consumption," particularly when the patient was "troubled with night sweats, and is fretful and nervous, and wakeful at nights." He made a tincture simply by cutting the inner bark into fine pieces, filling a bottle half full of the pieces, and adding good whiskey. After standing for 2 weeks, it was ready to use in doses of 1 tablespoonful every 3 or 4 hours. He preferred a cold water preparation, however, which he made by cutting up the fresh bark into fine pieces and soaking it in cold water for 24 hours, of which he prescribed "a common swallow every 3 or 4 hours." To treat fevers he combined this bark in equal proportions with dogwood bark (Cornus florida). 
The early colonists were also quick to recognize the medical virtues of wild cherries. In 1663 John Josselyn considered the fruit of wild cherry a good remedy for fluxes, and in 1785 the Rev. Manasseh Cutler recommended an infusion or tincture of the inner bark for jaundice. In 1810 Benjamin Barton ascribed bitter, astringent, narcotic, and stimulant powers to the bark, especially that of the root, and considered it most useful for intermittent fevers, worms, dyspepsia, and consumption, but it is often difficult to know whether the bark of $\underline{P}$. Serotina or $\underline{P}$. virginiana is meant, as they were used interchangeably.

In his American Medical Botany, published in Boston 1817-20, Dr. Jacob Bigelow called the bark of $\underline{P}$. Virginiana "undoubtedly a useful tonic, [which] appears to possess, in some degree, a narcotic and antispasmodic property." When Captain Meriwether Lewis was ill with abdominal cramps and fever on the upper Missouri, he took a strong tea made from Chokecherry twigs boiled in water and was well the next day. The Pennsylvania Dutch frequently used a tea of the outer bark of the young branches or the inner bark, sometimes combined with the fruit, soaked in whiskey, as a remedy for colds. Southern mountaineers used a tea made from the bark not only for colds but also in the treatment of measles. The dried ground bark has also been smoked as a treatment for headaches and colds and used as a powder to dry up open sores. The fruit was likewise used to make a crude wine used in the treatment of dysentery. Wild cherry bark has been official in the U.S. Pharmacopeia from 1820 to the present time, listed both under P. virginiana and $\underline{P}$. serotina. In the 1882 edition the first was the official name, but the drug was defined as the bark of the second species.

Roots of the Chokecherry were used with an alum mordant to produce a reddish-purple dye, 2 pounds of the roots being required to dye one pound of wool. The bark, on the other hand, produced a range of colors from yellow through orange and tan.

Many species of wild birds and mammals also consume the fruit of this species, making it of considerable value to wildlife during the late summer.

The seeds of this species are widely distributed by birds along fences, hedgerows, and the borders of fields, where they soon produce extensive thickets that are difficult to eradicate owing to the formation of numerous sucker shoots from the roots. Muenscher (1952) suggests that small bushes can be grubbed out, but large bushes must be pulled out with a team of horses or tractor and chain. More extensive areas should be cut in midsummer and the bushes burned.

Pyrus L. Apple, Pear, Chokeberry, Mountain-ash.

There are over 130 species of Pyrus, trees and shrubs largely confined to the north temperate zone. The name of the genus is the ancient Latin name of the Pear. Not only does this genus provide a wide variety of apples and pears, but several species are highly regarded ornamentals. This genus has sometimes been separated into Pyrus (pears), Malus (apples), Aronia (chokeberries) and Sorbus (mountain-ashes), but, in the words of Fernald (1950), these genera are "less strongly or constantly marked than 
our very few species would suggest." When one looks at mountain-ashes, for example, it would seem that they are distinct enough from apples and pears to warrant generic status, but Fernald states flatly that "Cytologically there is no justification for separating them as genera and none in the wood-anatomy."

\section{Key to Local Species of Pyrus}

1. Leaves odd-pinnate; cymes very compound (styles distinct, fruit berry-like--mountain-ashes), 2

2. Inner bud scales glabrous or merely ciliate; leaveś yellowgreen above; leaflets lanceolate to lance-oblong, longattenuate, the larger ones three and one-half to 5 times as long as broad; flowers $5-6 \mathrm{~mm}$ broad; fruits $4-6 \mathrm{~mm}$ in

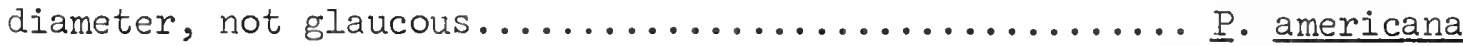

2. Inner bud scales villous; leaves blue-green above; leaflets oblong to oblong-ovate, short- to long-acuminate, the larger ones twice to thrice as long as broad; flowers about

I cm broad; fruits $8-12 \mathrm{~mm}$ long, glaucous............... . decora

1. Leaves simple or merely lobulate; fllowers and fruits few in subumbellate or racemose inflorescences, or, if paniculate-corymbose, in inflorescences rarely $6 \mathrm{~cm}$ broad, 3

3. Trees or coarse shrubs often with spinescent branchlets; leaves not glandular along midrib; cyme simple and umbelliform or simply racemose; petals large ( $1-2 \mathrm{~cm}$ long, $0.8-1.5 \mathrm{~cm}$ broad); fruit $0.8-3 \mathrm{~cm}$ or more in diameter, 4.

4. Leaves involute in bud and before expanding; petals white; anthers reddish; orifice of concave receptacle partly or nearly closed by disklike cushion; styles free to base; flesh of fruit (in ours) with grit cells (pear)...... P. communis

4. Leaves convolute or folded lengthwise in bud and before expanding; petals roseate to white; anthers yellow; orifice of receptacle open; styles united at very base; fruit in ours subglobose and without grit cells (apple) (lower surface of leaves, petioles, young shoots, and outside of persistent calyx with whitish or gray tomentum).. P. malus

3. Shrubs with slender ascending to spreading branches; leaves glandular along the midrib on upper side; inflorescence simple to more or less compound; petals mostly less than $1 \mathrm{~cm}$ long and $7 \mathrm{~mm}$ broad; fruit small and berry-like (chokeberries), 5

5. Lower surfaces of leaves, new shoots, rachis and pedicels

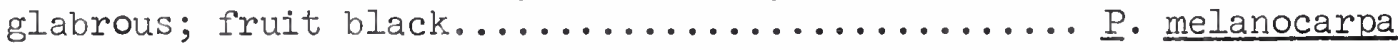

5. Lower surfaces of leaves, young shoots, rachis and pedicels soft-pubescent; fruit dark purple or purple-black.... F. floribunda

In the following discussion it seems advisable to break away from the usual alphabetical arrangement of species so as to present them in more "Iogical" groups under the headings Apple, Chokeberry, Mountainash, and Pear. 


\section{Apple}

Apples, originally native to the forests of temperate Europe and Asia, have been cultivated for many millennia. Small carbonized apples much resembling those that still grow wild in the Swiss forests have been found in the ancient lake habitations of Switzerland. Not only were they cultivated by the Phoenicians, but they are also mentioned by Theophrastus, Cato, and Pliny. Early cultivated in Great Britain, the apple was brought to Massachusetts from Europe shortly after the landing of the Pilgrims in 1620 and promptly became naturalized as a wild tree, the seeds having been scattered both by mammals and birls. Since commercial apples are highly developed hybrids, they seldom breed true from seed, the wild trees usually reverting to something closer to the original stock. In adaition to the introduced fruit, the Wild Crabapple, native to eastern North America, soon became a highly prized ornamental.

Pyrus màlus I. Apple.

Meaning of Species Name. The Greek name of the Apple tree.

Other Names. Scarb-tree, Wilding-tree, Crab-tree, Crab-stock.

Type of Plant. A small tree.

Habitat. Roadsides, borders of woods, clearings, fencerows, and pastures.

Range. Well estab in the ne states and adjacent Can and probably elsewhere.

Distr in NYS. Frequent or common in many secs of the state.

Distr in the Torrey Range. A common esc in our area, but, according to Taylor (1915), "hardly persisting."

Time of Fl. Late Apr-early Jun; May 1-25 at Cornell.

origin. Introd and natzd from Eurasia.

Remarks. Wood hard, reddish-brown; wt 50 lb per cu ft.

Johnson (1867) remarks that "The Apple is mentioned by the most ancient Greek writers, and in Pliny's time was cultivated in abundance in the villages around Rome ... The practice of grafting ... is [Iikewise] of very ancient origin ..., now in universal use as a means of perpetuating the varieties originally obtained from seed." To the many well-known uses of the fruit of this tree he adds one that time seems to have passed by during the last century: "The pulp of the fruit, boiled, and dried in the oven, and mixed with two-thirds of its weight of flour, is said to form a wholesome bread."

Wild apple trees are found scattered along roadsides and in pastures throughout the Catskills, despised by most as not worth any further attention since the fruit is likely to be both hard and sour. Occasionally, however, particularly after they have been touched by frost, one comes upon a tree bearing Iruit that is quite delicious eaten out of hand. But the very qualities that make wild apples a poor fruit to eat raw make them superior for cooking. Their firmness and wild sour taste, with a hint of bitter, make them far better cooking apples than those avilable on the market. Even when they are wormy or otherwise damaged by insects, it is possible to cut away the undesirable sections and in a short time accumulate a good supply . 


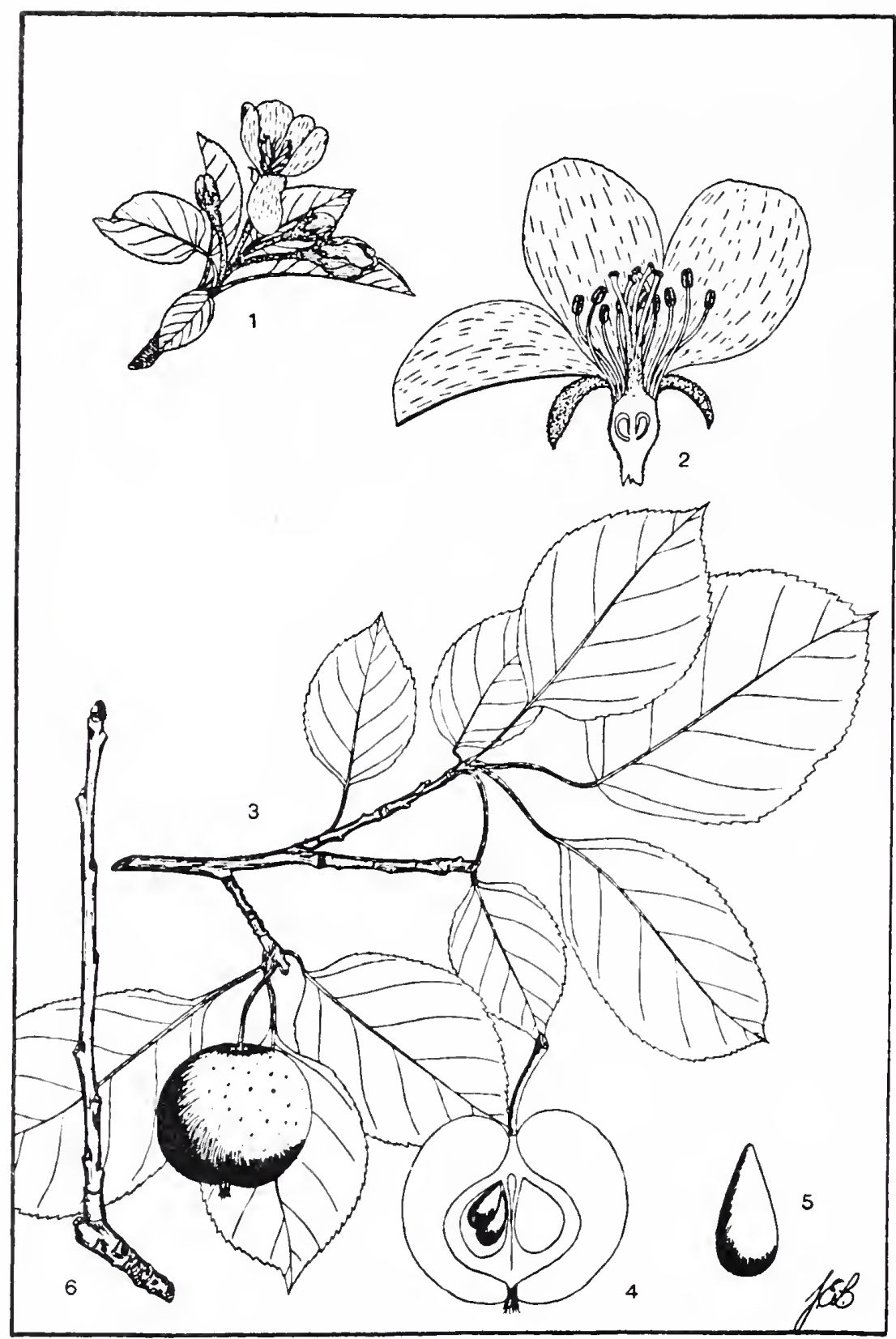

Pyrus malus--Apple

[From Brown (1921), p. 234.]

Pared and sliced wild apples can be substituted for cultivated ones in almost any recipe, but they make an apple jelly superior to any that can be bought at the store; the process is simplicity itself. Gather about a peck of wild apples in early fall, making sure to include as many as possible with red skins. Cut them in quarters, including skins and cores except where damaged by insects. Put the apples in a large kettle, barely cover with water, simmer for 20 minutes, let cool, and strain off the juice. This juice is so rich in pectin that it can either be used alone or combined half and half with other flavorful fruit juices. To 4 cups of juice, plain or mixed, add 4 cups of sugar and boil until it approaches the "jelly point." If the juice runs off the spoon like water when poured from it, the jelly is nowhere 
near ready; if it drips off the spoon in two places, it is approaching the jelly point. When the last two or three large drops run together, sheet off the spoon, and seem to break below the edge when they drop, the jelly is done. Pour the jelly into sterilized half-pint jars and seal with paraffin. You will marvel at its delightful flavor.

Even the remaining cooked apples have plenty of flavor left in them after the juice is extracted. Put them through a food mill or ricer to remove the skins and seeds. From the resulting pulp one can make a flavorful apple butter by adding 6 cups of sugar and 1 teaspoon of pumpkin pie spice to 2 quarts of pulp. Heat this mixture gently until the sugar melts then boil, stirring constantly until it gets thick and starts "plopping." Store in straight-sided jars so it can be unmolded when served. It can then be sliced like cranberry jelly and served in much the same manner. This tangy, spicy product will add zest to any meal.

Apple wood is hard, strong, and close-grained, but it is not a timber species. It is sometimes used for firewood, however, and occasionally for tool handles. Its chief importance lies in its horticultural value as the stock from which varieties of cultivated apples have been derived and for the ornamental value of its dwarf and double-flowered forms.

Dried apples were much used in pioneer days since they could not only be stored until the next season but could also be easily transported long distances. When apples were not considered good enough for other purposes, they were made into cider either for drinking as such or for conversion into vinegar. Another type of apple butter was made by boiling apple cider in a large kettle until it was reduced by about one-third its original volume. To this liquid was added (about half by volume) a measure of carefully pared, cored, and sliced apples, sweet ones being preferred. This mixture was brought to a boil, the mass being constantly stirred with a long-handled wooden spoon until it thickened to the "right consistency." Usually no sugar was added but it could be kept all through the year.

The inner bark, either fresh or dried, produces a dye of shades varying from dull yellow to pure gold or brass, different trees usually producing different shades of yellow. For 1 pound of wool, I peck of bark was soaked overnight in 2 gallons of soft water. The next morning the mixture was boiled for several hours, water being added from time to time to replace that which evaporated so as to maintain a constant volume. When cooled until lukewarm, the mixture was strained to remove the pieces of bark and enough soft water was added to make a dye bath of 4 gallons. The wool was then immersed in the dye bath, slowly brought to a boil, and boiled for half an hour. With an alum mordant the bark makes a yellow-tan color; the leaves alone result in a honey yellow.

Cattle, horses, and mules sometimes gain access to orchards after the apples have fallen in autumn and may consume large quantities. Cows particularly then stagger around as if they were drunk. Death can result from eating excess quantities of such apples. Poisoning may also result from eating the cyanogenetic foliage. Apple seeds also are cyanogenetic. One man who found apple seeds a delicacy once saved a cupful, which he consumed at one time, resulting in death from cyanide poisoning. 
There are two species of chokeberries in the Catskills, neither of which can be called common. Although, as a group, the fruits are widely available through much of the winter, Martin et al. (1961) report that they appear to be of minor importance to wildlife. Ruffed grouse, chickadees, meadowlarks, and cedar waxwings sometimes consume the fruits, as do black bears and red foxes. White-tailed deer occasionally browse on twigs and foliage, while rabbits and white-footed mice also sometimes eat both fruit and foliage.

Pirus floribunda Lindl. Purple Chokeberry.

Meaning of Species Name. Free-flowering.

Synonyms. Aronia prurifolia (Marsh.) Rehd.

Other Names. Red Chokeberry.

Type of Plant. A shrub 3-6 ft high. like.

Habitat. Peats, low thickets, swamps, wet to dry clearings, and the

Range. Nf and Ont, s to NC, O, Ill, and Ind.

Distr in NYS. Frequent or common throughout most secs of the state except the higher Adirondacks.

Distr in the Torrey Range. Throughout the area, more common southw

than elsewhere; perhaps wanting in the pine barrens.

Time of Fl. May-Jun(mid-Jul), fr Sep-Nov; fl Jun at Cornell.

Origin. Native.

Pìrus melanocárpa (Michx.) Willd. Black Chokeberry.

Meaning of Species Name. Black-fruited.

Synonyms. Aronia melanocarpa (Michx.) Ell.

Other Names. Chokepear.

Type of Plant. A shrub 2-6 ft high.

Habitat. In acid soil of low thickets, roadsides, clearings, rocky

pastures, and bluffs, often in drier habitats than $\underline{P}$. floribunda.

Range. Nf to Ont and Minn, s to SC, Ga, and Tenn.

Distr in NYS. Common throughout the state.

Distr in the Torrey Range. Common throughout the area.

Elevation. Grows to 6000 ft in NC.

Time of Fl. (Apr)May-Jun(early Jul), fr Aug-oct; fl May 20-Jun 15

at Cornell.

Origin. Native.

American Indians are reported to have gathered the fruits of both species, the very puckery quality of which was destroyed by cooking. Fernald and Kinsey (1943) state that they "yield a splendid, heavy and sweet jelly, dark-carmine and very solid." They lament the fact that thousands of bushels of this fruit, which contains "so much juice and such an abundance of pectin," goes to waste every autumn when it could at least "be used to supply pectin which is often deficient in some fruits." This species is often cultivated as an ornamental shrub for its showy clusters of white flowers. 


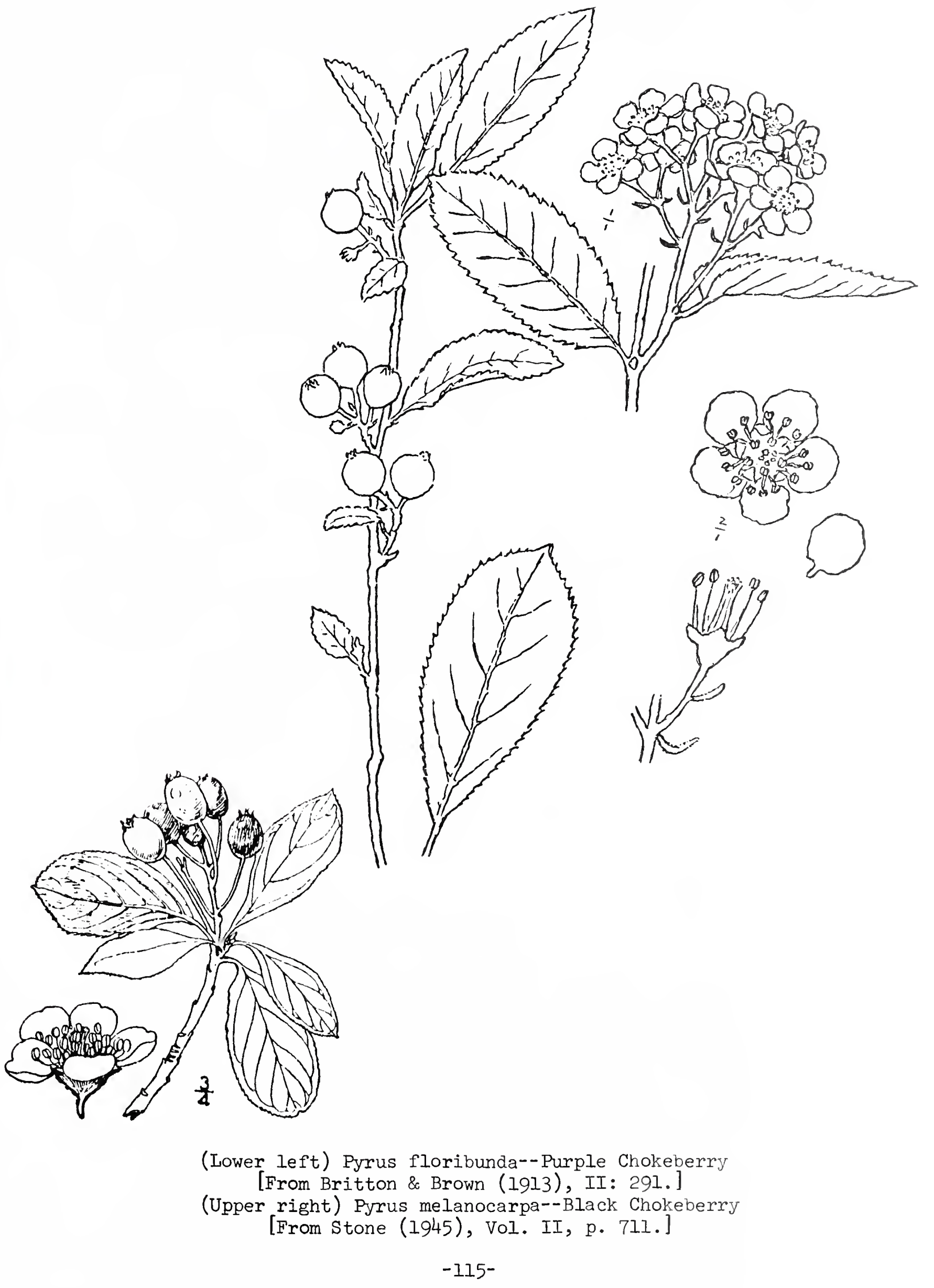




\section{Mountain-ash}

The handsome foliage and showy flower and fruit clusters have long made the mountain-ashes a favorite group of small trees for ornamental planting as yard trees. The foliage is almost fernlike in its delicacy, its spreading whorls making a most attractive setting for the white flowers in spring and the scarlet clusters of fruit in autumn. In addition, the berries persist far into the winter, not only supplying food for such birds as grosbeaks, cedar waxwings, and ruffed grouse at a time when their need is greatest but brightening dull thickets of bare twigs on dreary days. Ground squirrels likewise consume the fruit and moose browse both foliage and twigs. One mountain-ash of Japan is hardly distinguishable from our western species, and some authorities believe that our two native species are varieties of one circumpolar complex.

Pyrus aucuparia, the European Mountain-ash, is much planted for ornament in the Catskill region. While it is reported as "freely spread from cultivation," the writer has seen no specimens that were not growing in someone's dooryard, nor, except for its occurrence on the Platt list of 1840, are there any records of its growing spontaneously in that region. The name of the species is an old generic name meaning "attractive to birds," derived, according to Johnson (1867), "from the use made of the berries by German fowlers, who bait their nets with them." Both the inner bark and the fruit possess medicinal qualities, once used in the treatment of scurvy and "as a remedy in hemorrhoids and strangury." The fruit has likewise been used in the preparation of a jam, an alcoholic drink, and as a bread-food in times of scarcity. "In Norway the inner bark has been used as the source of a gray dye.

\section{Pirus americàna (Marsh.) DC. American Mountain-ash.}

Meaning of Species Name. American.

Synonyms. Sorbus americana Marsh.

Other Names. Roundwood, Dogberry, Missey-moosey, American Rowantree, American Service-tree, Witch-wood, Round-tree, Wine-tree, Elderleaved Mountain-ash, Elder-leaved Mountain-sumac, Moose-missy, Indian Mozamize, Life-of-man.

Type of Plant. A small tree or coarse shrub 15-20 ft high.

Habitat. Low woods and slopes in moist or wet soil.

Range. Nf and Que to Man, s to $N J, P a, M d$, upland to $N C, G a$, and e Tenn, WVa, Mich, and Ill.

Distr in NYS. Common northw across the state and throughout the Adirondack and Catskill mts; less common or local southw to Westchester co, the upper Susquehanna valley, and westw to the upland swamps of Tompkins, Yates, Wyoming, and Erie co.

Distr in the Torrey Range. NY: Unknown on II and SI, rare and locaI

in $\mathrm{n}$ Westchester co, thence increasing and becoming common northw.

Elevation. 800-3365 $\mathrm{ft}$ in the Torrey range.

Time 으 Fl. Late May-Jun(Jul), fr late Aug-Oct; fl Jun at Cornell.

Origin. Native.

Remarks. Wood soft, light brown; wt 34 lb per cu ft. 


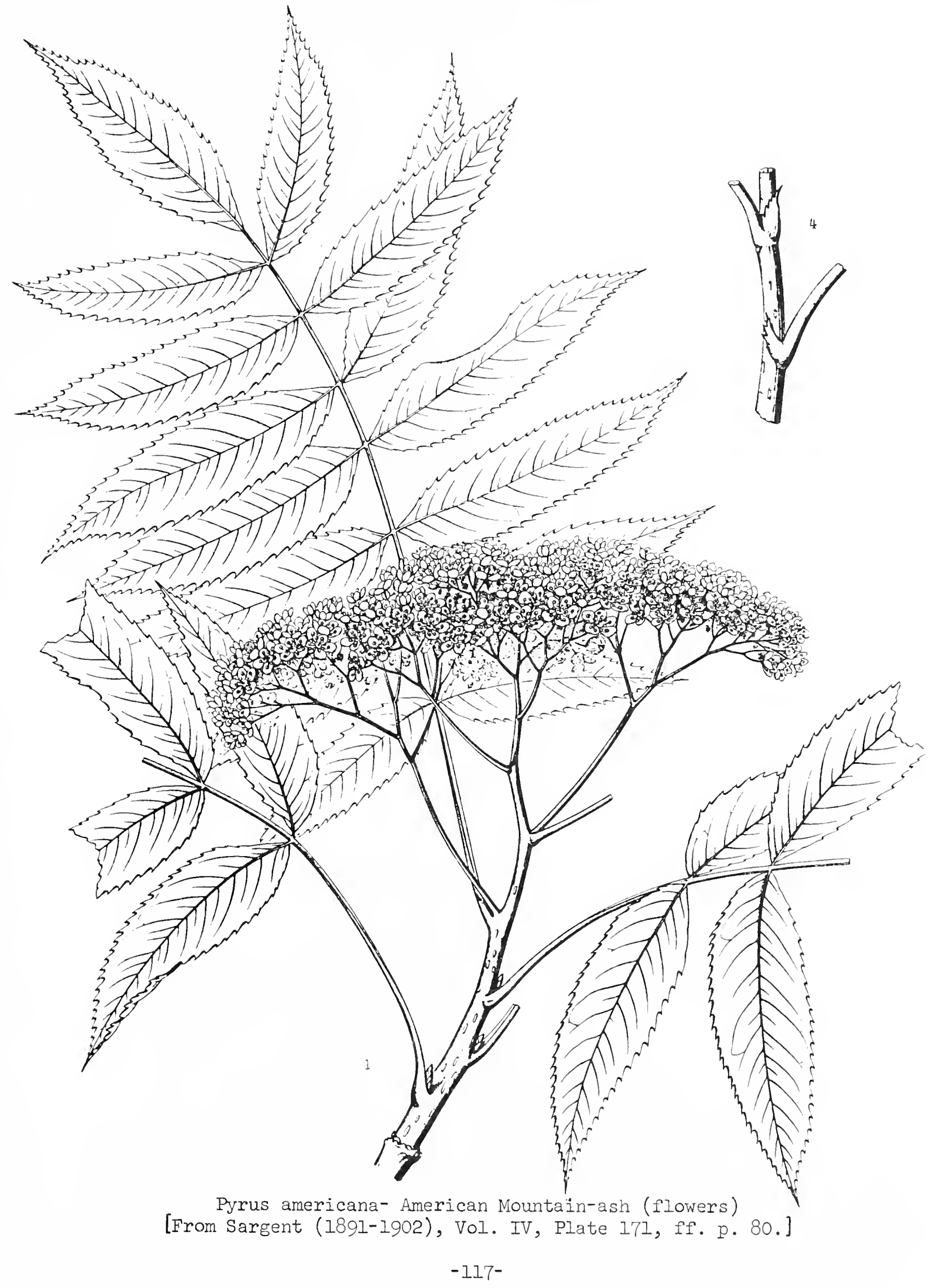




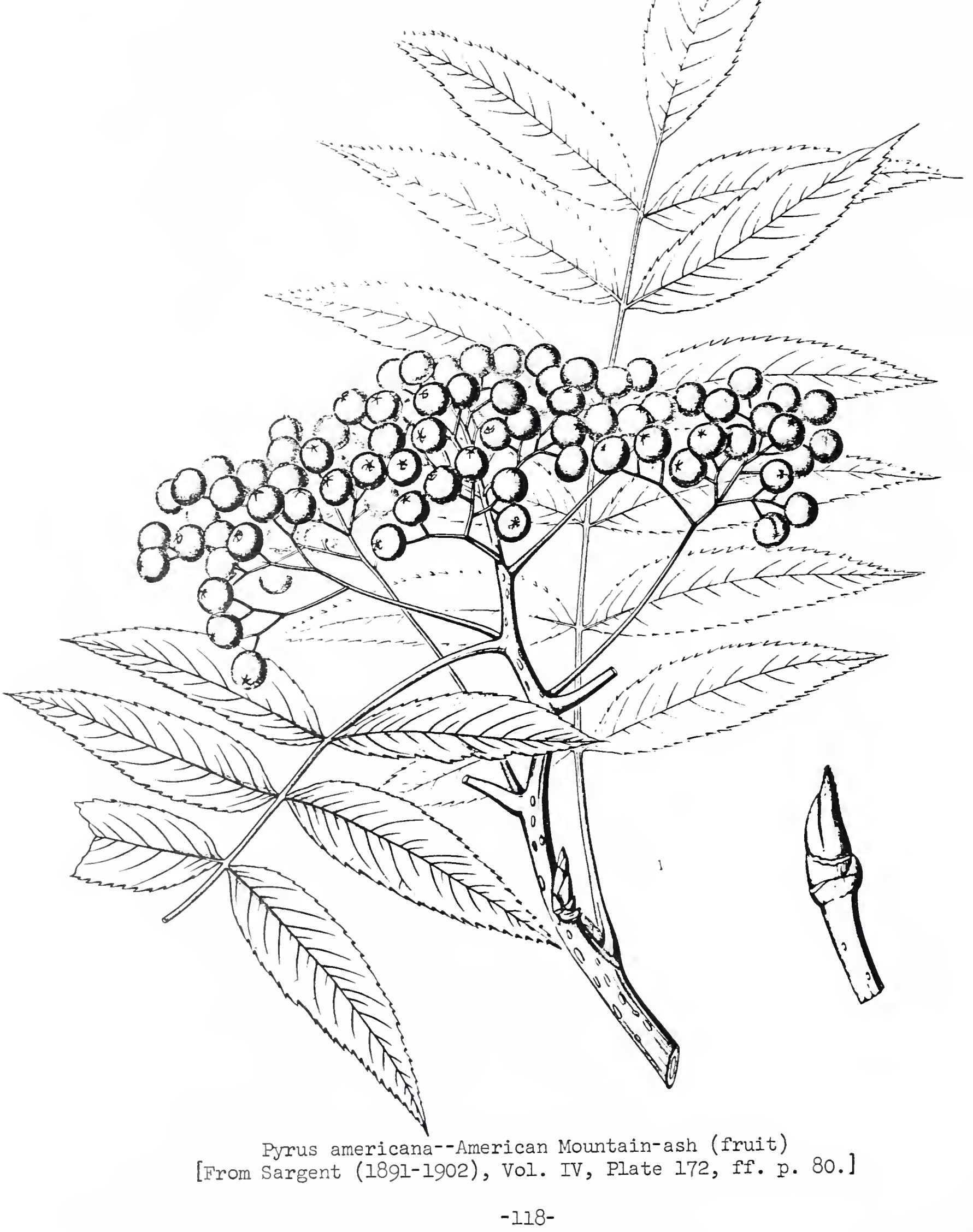


This small tree is distinctly a northern species, attaining its best development north of Lakes Huron and Superior; in our region it prefers the borders of cold swamps and bogs or rocky mountain ridges. This rather uncommon tree of the Catskills is both slow-growing and short-lived and of no commercial value, but it is an attractive ornamental producing large flat-topped clusters of white flowers in May or June followed by brilliant orange-red fruits in fall. These fruits are both very acid and unpleasant in taste, but they seem to be eaten with relish by many species of birds. Harlow (1957) reports that when this species and the European Mountain-ash are grown together, the birds eat the fruit of the native species first.

The American Indians are reported to have used bark preparations of this species in the treatment of heart disease. The fruit is rich in vitamin $\mathrm{C}$ and has been used "fresh and in tea, to treat scurvy." Pioneers also used the bark in a tea for nausea and "to cleanse the blood in spring." In some areas this species is called Peruve, no doubt a reference by analogy to Peruvian bark or quinine, for in early days any bitter and aronatic bark was considered an acceptable substitute for use in treating malaria and other fevers as well as for use as a tonic. The inner bark has also been used as an astringent and antiseptic.

Pýrus decòra (Sarg.) Hyland. Showy Mountain-ash.

Meaning of Species Name. Handsome.

Synonyms. Sorbus decora (Sarg.) C. K. Schneider

Other Names. Roundwood, Dogberry, Northern Mountain-ash.

Type of Plant. A small tree or coarse shrub.

Habitat. Woods, rocky slopes, fencerows, and shores.

Range. S Gl, lab and $\mathrm{Nf}$ to Minn, s to Mass, NI, O, Ind, Ia, Wis,

and Minn, ascending to subalpine areas.

Distr in NYS. Rare on the subalpine mt slopes and summits of $n$ NY.

Distr in the Torrey Range. NY: The highest mts in Sullivan and Greene co.

Elevation. 1800-4020 ft in the Torrey range.

Time of Fl. (May) Jun(Jul), fr Sep-Nov; fl May 25-Jun 10 at Cornell. Origin. Native.

Fernald and Kinsey (1943) report that the unripe fruit of this species is "very austere and has an unpleasant flavor, but when thoroughly ripe and mellowed by frost it becomes palatable." An infusion of the berries has sometimes been used for a drink.

\section{Pear}

The common Pear, a native of Europe and northern Asia, has been in cultivation for millennia, for a small-fruited kind has been found in the debris of the earliest lake villages of Switzerland. It was also cultivated in the gardens of the Phoenicians, but the Romans seem to have been the first to develop some of its numerous horticultural varieties. 


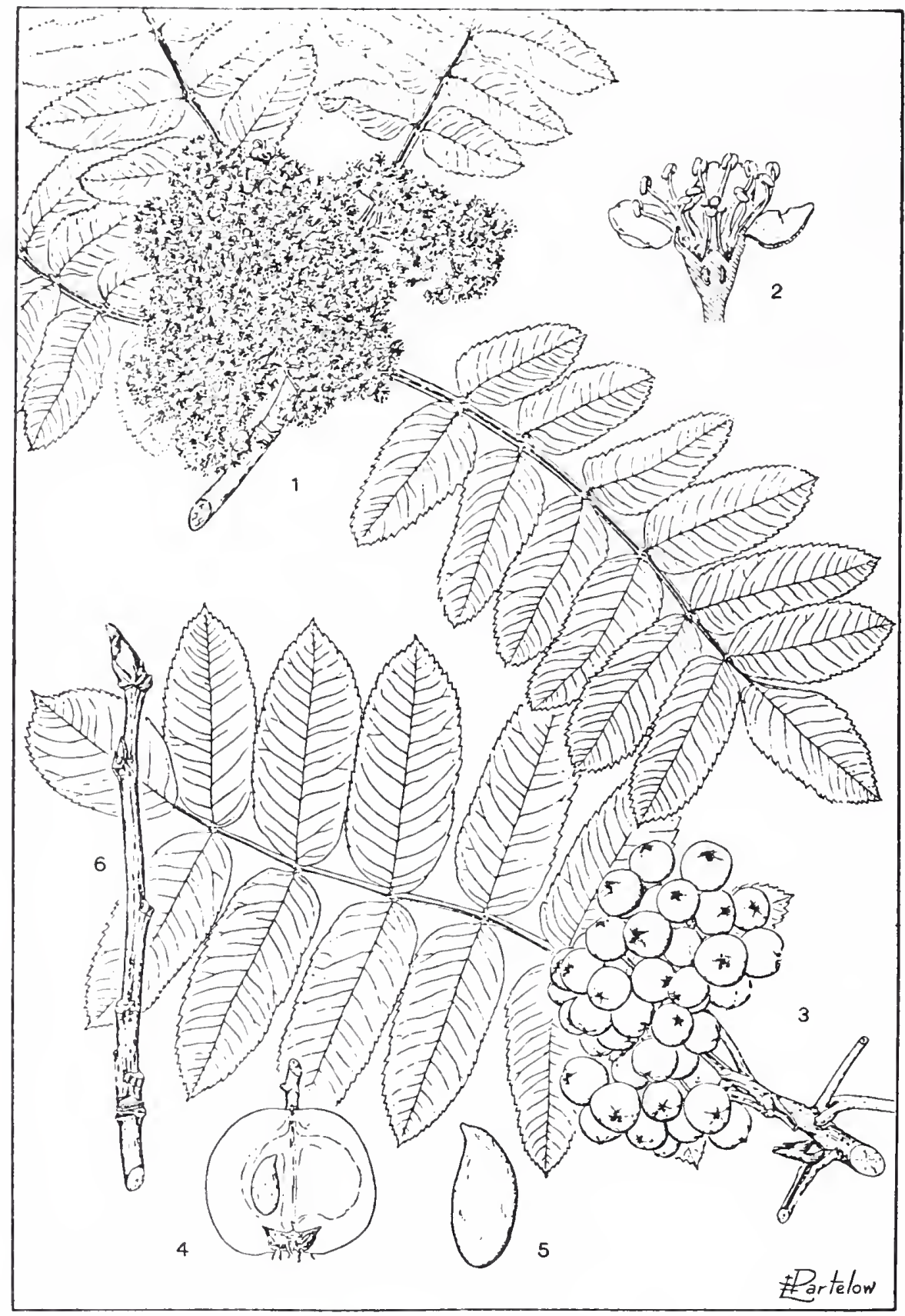

Pyrus decora--Showy Mountain-ash

[From Brown (1921), p. 296.]

Pyrus communis I. Pear.

Meaning of Species Name. Common.

Other Names. Choke Pear.

Type of Plant. A small tree.

Habitat. Thickets, borders of woods, roadsides, pastures, and clearings.

Range. A not uncommon esc in the ne states and $s$ Can.

Distr in NYS. Rare or local as an esc from cult.

Distr in the Torrey Range. A rare esc locally est. 


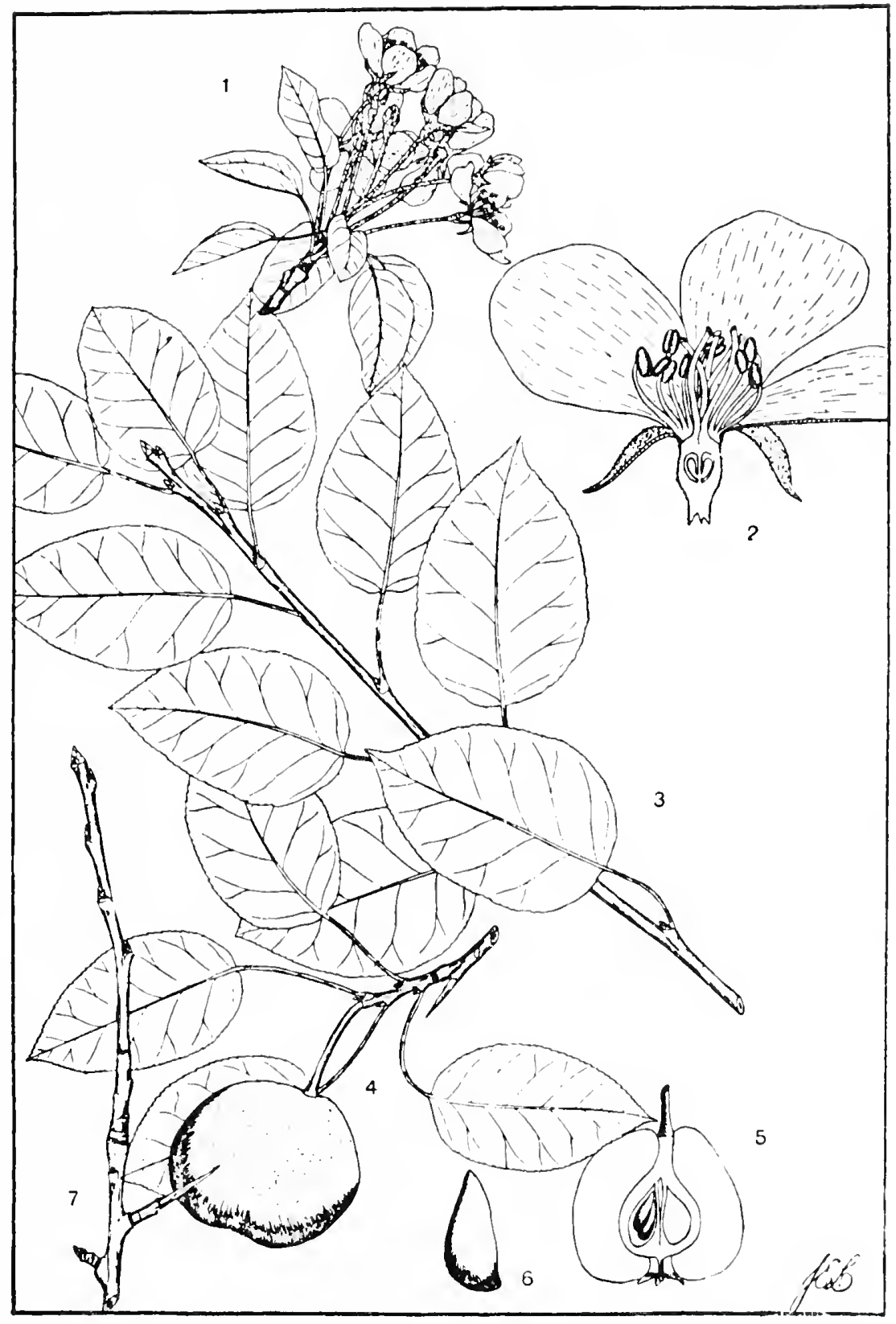

Pyrus communis--Pear

[From Brown (1921), p. 230.]

Time of Fl. Apr-May; May $1-20$ at Cornell.

Origin. Introd from Eurasia.

Remarks. Long in cult and spread from cult or from rejected cores; Gleason (1952) reports that it rarely esc, but it is locally common in some secs of the Catskills. Wood hard, fine-grained, reddish-brown; wt $51 \mathrm{lb}$ per cu ft.

Johnson (1867) was of the opinion (possibly erroneously) that "The Pear was one of the first fruit trees broldght under cultivation, "stating that "The earliest notice of it extant is probably that of Homer." He likewise remarks that "Pears have been grown in China from time immemorial," 
and states that many kinds were known to the Romans, who "perhaps introiuced it into this island [Great Britain]," although he thought it "more likely that the monks were its first cultivators here." He states that "it is more durable than the apple ... and often grows for centuries without showing symptoms of decay."

This species is not a timber tree, but its hard, heavy, strong, close-grained wood has occasionally been used for tool handles, knife handles, wood engraving, and for fuel, but its chief value lies in its numerous horticultural and ornamental varieties. With respect to its use for wood engravings, however, Johnson (1867) remarks that "it is not even enough in texture to be fit for the finer purposes of the art." Fruit of the wild species is generally not particularly useful in the raw state although one occasionally comes across a tree bearing edible raw fruit. One can make excellent preserves from it, however, and the hard, solid flesh makes it desirable for use as pickled or spiced pears. In adaition, the leaves have been used as the source of "a moderately good yellow dye."

Rósa L. Rose.

There are more than 100 species of roses (although many times that number have been described). All species are natives of the northern hemisphere, with Anatolia being considered a major center of rose differentiation. They are usually prickly shrubs with odd-pinnate leaves often bearing aromatic glands and stipules chiefly adnate to the petiole. The name of the genus is the ancient latin name of the rose. Most of the roses in cultivation are of hybrid origin. Only a few of our native species, notably $\underline{R}$. setigera, are commonly cultivated.

Man seems to have been associated with roses since prehistoric times. Rose seeds have been found at an early Neolithic site in the Netherlands dating about 5000 years ago, suggesting that humans were then collecting rose fruits for food, along with other fruits and nuts, including. Corvlus, Pyrus, Crataegus, and Rubus. Masses of rose seeds have also been found at Swiss lake dwellings, dated about 2500 years ago, and at sites in Britain. But, according to Widrlechner (1981), "The oldest known tangible historic evidence for the existence and possible use of roses comes to us from the Monoan civilization ... in the form of remains of a fresco from the palace at Knossos, Crete," dated some 3700 years ago, which, according to one authority, bears a "striking resemblance to the Holy Rose of Abyssinia, Egypt, and Asia Minor." Roses are also pictured in the murals of Pompeii. The rose was commonly mentioned in literary works in the time of Herodotus (around 500 B.C.), but the oldest surviving horticultural literature on roses is that written by Theophrastus about 300 B.C., in which he not only described the different types of roses growing in the eastern Mediterranean but also distinguished wild roses from cultivated types. He also stated that "sesameoil... receives rose-perfume better than other oils," a practice still employed in India today in extracting rose perfume.

The Romans continued the literary tradition of the rose established by the Greeks, Pliny giving the most comprehensive description of the roses cultivated during his time (around 50 A.D.). He likewise listed 32 remedies 
derived from roses and spoke of the astringent and laxative properties of the petals. Wiarlechner (1981) states that "In Spain their use for such effects is still common." Pliny also supplied a recipe for making rose wine. Widrlechner observes that "The rose industry was quite advanced in Rome at the time of Pliny; roses decorated houses, and were occasionally strewn through the streets," to say nothing of their use at banquets. The Romans even had a rose festival, presumably annual, "to celebrate and honor the rose." The flowers were used in such quantities that the marketing of roses became a "big business," so much so that they were introduced into Egypt, where they flowered 2 months earlier than in Greece. They were grown in Egypt in increasing quantities after 300 B.C. to supply the large demands for them in Rome.

Rose hips, the fruit of these shrubs, form an important survival food, not only because they are easily recognized and the chances of getting the wrong plant are almost nonexistent, but also because they are usually available almost all year long. American Indians often ate these fruits raw in times of scarcity. In the field an easy way to dry this fruit is to place handfuls of it in a kettle and put it over a slow fire or set it overnight on the coals of a campfire.

Few people know that roses are highly regarded for their flavor and food value in many parts of the world; they can be made into many delicious and luxurious dishes, including delicate desserts and delicious jams and jellies. To make a delightful uncooked rose petal jam, gather freshly opened roses, then, since the white base of the petal contains a bitter substance, grasp as many petals as you can hold between your finger and thumb, pull them from the rose and snip off the white bases with a pair of shears. Wild roses are best, but any fragrant rose can be used, provided it has not been sprayed with poisonous insecticides. Put 1 cup of rose petals into a blender with $3 / 4$ cup of water and the juice of $I$ Iemon. Blend until smooth, then gradually add $21 / 2$ cups of sugar with the blender still running and blend until all the sugar has dissolved. Stir in 1 package of commercial powdered pectin, such as Sure Jell, into 3/4 cup of water, bring to a boil, and boil hard for 1 minute, stirring constantly. Pour the pectin into the rose-sugar mixture and blend at low speed until the pectin has been thoroughly incorporated with the other ingredients. Pour immediately into small sterilized jars and seal with paraffin. The jam will be nicely jelled in about 6 hours. This jam will keep for a month in the refrigerator; store it in the freezer if you wish to keep it for a longer time. This jam is not only excellent on toast or hot biscuits, but it can also add a delightful flavor to ordinary muffins flavored with a pinch of mace. When the muffins are nearly done, make a small depression in the top of each one, fill it with rose jam, and finish baking until the muffins are lightly browned and the jam is glazed. Serve piping hot.

To make a rose omelet, break 4 eggs into the blender, add $1 / 3$ cup of rose petals, $1 / 2$ teaspoon of celery salt, and a pinch of marjoram. Blend at medium speed until the eggs are fluffy and the petals practically liquefied. Pour this mixture into a greased iron skillet and cook over medium. heat until the bottom is Iightly browned, then place the pan under the broiler to brown the top. For those who may wish to experiment further with rose petals, Gibbons (1966) gives recipes for candied rose petals, 
Harem Kisses, and for making rose water and rose syrup, useful flavoring agents.

To prepare rose hip jam, gather the largest bright-red hips you can find, cut off both the stem and blossom ends, make a slit down the side, and remove the seeds. Put 1 cup of prepared hips in the blender, add $3 / 4$ cup of water and the juice of 1 lemon and blend until perfectly smooth. Gradually add 3 cups of sugar while the blender is running at slow speed and blend for about 5 minutes or until all the sugar is completely dissolved. Next prepare 1 package of powdered pectin as directed above, pour into the blender, and blend for 1 minute more, then pour the mixture into small sterilized jars and seal with paraffin. If this jam is to be kept for more than a month, store it in the freezer. Gibbons (1966) likewise gives a recipe for making rose hip soup, a fruit soup that can be served either hot or cold as an appetizer at the beginning of a meal or as a dessert at its close.

Rose petals can also be used either fresh or dry in the preparation of "a rather tasty tea," a delightful drink when sweetened with a little honey or sugar to help bring out the fragrance. Dark red roses are more flavorful than others; the aroma and taste become more delicate as the colors lighten. Tea can be made from the dried flowers by covering 2 tablespoons of the petals with boiling water and letting them steep for 5 minutes. The petals also make a pleasant nibble and are sometimes candied or prepared as a salad.

Rose hips are extremely rich in vitamin C, the juice containing 25 times more than orange juice. They are also richer in calcium, phosphorus, and iron than oranges. During World War II rose hips were an important source of vitamins and minerals in the scandinavian countries and elsewhere when the German blockade cut off imports of all citrus fruit. Millions of pounds of rose hips were gathered each year and dried for use in soup, hot or cold drinks, and many other ways. Members of the Swedish Air Force were even taught to carry a handful of rose hips in their pockets for use as a stimulant when under heavy physical strain. In England the people were encouraged to gather these fruits from the hedges. They were then pulverized and distributed throughout the country by the Ministry of Health for their important vitamin and mineral content. The seeds, which many people discard, contain an abundant supply of vitamin $E$. Separate the seeds from the rest of the fruit, grind them up, and boil in a small amount of water. After carefully straining out the "hulls" and the fine hairs through a triple layer of cheesecloth, the resulting liquid can be substituted for most syrups called for in recipes.

The Chippewas employed a decoction of the root of Rosa arkansana in the treatment of convulsions. The fresh or dried root was also chewed to make a poultice for hemorrhages from wounds. The root was likewise employed as a tonic and in the treatment of diseases of women. The Apaches boiled wild rosebuds and drank the resulting tea to cure gonorrhea.

Rosa gallica, the French Rose, a native of southern Europe, was formerly much cultivated in the United States as an ornamental. The unexpanded petals, both fresh and dried, were used in medicine. The petals were gathered before the flower opened, separated from their claws, and dried in the sun or by the fire. They are slightly astringent and tonic and were once thought to possess peculiar virtues. During the 1800's, however, they were 
chiefly employed in infusion "as an elegant vehicle for tonic and astringent medicines."

The origin of the Cabbage-rose ( $\underline{R}$. centifolia), widely cultivated in gardens all over the world, is not known with certainty. The extremely fragrant petals, collected when the flower was fully expanded but before they began to fall, were once much used in the preparation of medicines. They were often dried, but they could be preserved fresh for a considerable time "by compressing them with alternate layers of common salt in a well-closed vessel, or [by] beating them with twice their weight of that substance." According to the U.S. Dispensatory of 1865, "The petals are slightly laxative, and are sometimes administered in the form of syrup combined with cathartic medicines," but they were chiefly used in the preparation of rose water, which, because of its "agreeable odor," was one ingredient of lotions.

The production of rose water, one of the important products of the rose, is, according to Widrlechner (1931), "not recorded in history; the first reference to it is found after its production was already an established industry," when, between 810 and 817 A.D., the province of Faristan in Iran was required to give a tribute of 30,000 bottles of rose water annually to the Caliph of Bagdad. By that time Faristan was not only supplying the Islamic world with rose water but was also exporting it to China. The Moors probably brought the technology for rose water to spain during the tenth century A.D. along with their territorial expansion. Widrlechner adds that "The distillation of the attar from rose water came later and probably arose independently in Europe and the Arab world." The cultivation of roses for attar spread both east and west from Persia and by the close of the 1600's distilleries in Iran were a major industry. The rose most often grown for attar production was the Damask Rose, $\underline{R}$. damascena, or a similar species, the specific name of which refers to Damascus. At the close of the 1600's a Turkish merchant introduced rose culture into what is now Bulgaria and began the largest rose plantations in the world. India, Jericho, and Jerusalem were also important centers of rose culture during the middle ages, at which time "the Islamic world was first enjoying vast quantities of rose water and later small, but increasing, amounts of attar." Rose water "became a favorite flavoring material for desserts and beverages, which it remains today," as well as in preserves. The attar has been used almost exclusively in the manufacture of expensive perfumes. One kilogram (about 2 pounds) of Bulgarian attar cost $\$ 5,000$ in 1980. The Turks started large-scale processing in 1926, but Bulgaria remains a world leader in the production of the attar of the Damask Rose.

Rose hips likewise constitute an important source of food for wildlife. In addition to the fleshy exterior of the fruits, both birds and mammals eat the numerous bony seeds inside. Since the fruit remains on the shrubs throughout the winter and into the following spring, it is available as food when other sources of nourishment are covered with snow. Although probably not the choicest of food, it is important to upland gamebirds during times of scarcity. Thickets of wild roses are also excellent nesting sites and furnish protective cover for both birds and mammals. The fruits and other parts of the plants are also utilized by mammals, particularly moose and white-tailed deer. Hedges and living fences of $\mathrm{R}$. multiflora make particularly valuable plantings for those who wish to encourage wildlife. 


\section{Key to the Catskill Species of Rosa}

1. Styles united into a column, protruding from the orifice of the hypanthium and about half as long as the stamens; plants of vinelike habit; flowers white; inflorescence many-flowered;

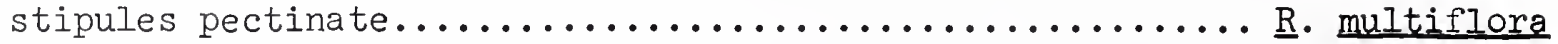

1. Styles distinct, scarcely exsert or not at all; plants usually erect; flowers usually red or pink; inflorescences fewerflowered; stipules not pectinate (flowers solitary or corymbose; when solitary, the pedicel bracted near its base), 2

2. Sepals of each flower unlike in size and shape, the outer pinnatifid with several lateral lanceolate segments; orifice of the hypanthium about $1 \mathrm{~mm}$ in diameter, styles short-exsert; exotic species occasionally escaped, chiefly in the vicinity of civilization, 3

3. Leaves not stipitate glandular beneath except rarely on the veins; wall of the hypanthium conspicuously thickened

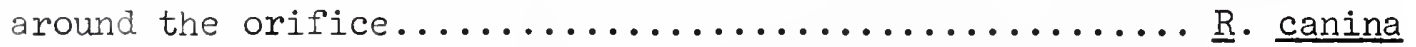

3. Leaves conspicuously stipitate-glandular beneath on both surface and veins; wall of the hypanthium not thickened around the orifice, 4

4. Styles pubescent; leaves all or mostly rounded at

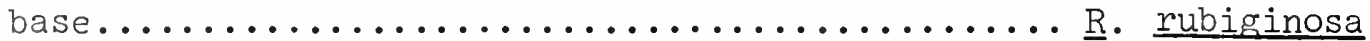

4. Styles glabrous; leaves mostly narrowed to an acute

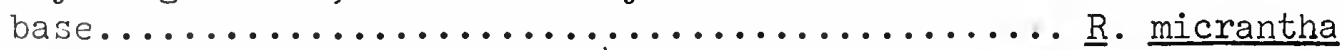

2. Sepals all entire, or some with 1-4 linear, scarcely foliaceous, appendages rising near the base; orifice of the hypanthium 2-4 mm wide; styles mostly included, the orifice of the hypanthium closed and covered by the head of the stigma; native species, 5

5. Leaves finely toothed, the teeth near the widest part of the leaf $0.3-1.2 \mathrm{~mm}$ high (average about $0.5 \mathrm{~mm}$ ), measured along their distal margins (infrastipular thorns at base of or just below the stipules present at many nodes, stout, conic, more or less decurved; internodal thorns

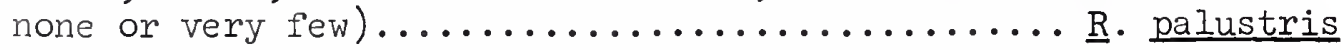

5. Leaves coarsely toothed, the teeth near the widest part of the leaf $0.6-2 \mathrm{~mm}$ high, averaging about $1 \mathrm{~mm}, 6$

6. Infrastipular thorns stout, often decurved, flattened toward the base; internodal thorns commonly

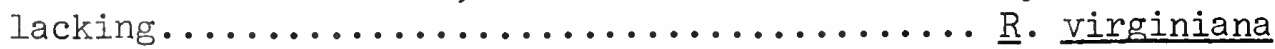

6. Infrastipular thorns straight, slender, terete; stems commonly with numerous internodal thorns.. ‥ ‥ carolina

Since Rosa is a rather complex and difficult genus, an alternate key to the Catskill species is provided:

1. Upper and/or lower surface of leaflets bearing small, round, rustcolored glands, 2

2. Both upper and. lower surfaces of leaflets abundantly glanddotted; leaflets quite fragrant when bruised; styles hairy; calyx lobes persisting and long-lasting until ripening of

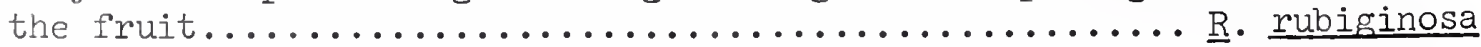


2. Upper surface of leaflets very sparsely glandular or nearly or quite without glands; foliage slightly or scarcely fragrant when bruised; styles glabrous or nearly so; calyx lobes promptly falling after flowering, not long-lasting..... R. micrantha

1. Neither surface of leaflets with resinous glands, but with

or without hairs, 3

3. Stipules at base of petioles deeply dissected, fringed and comblike; flowers white, small, $1.5-2.8 \mathrm{~cm}$ across...... R. multiflora

3. Stipules not as above; flowers pink or red, medium to large, 2-8 cm across, 4

4. Outer calyx lobes or some of them pinnately cut into several narrow segments; mouth of receptacle (through which the styles protrude) about $1 \mathrm{~mm}$ in diameter; styles shortly or long-protruding from mouth of hypanthium; chiefly introduced cultivated shrubs (receptacle smooth; petioles

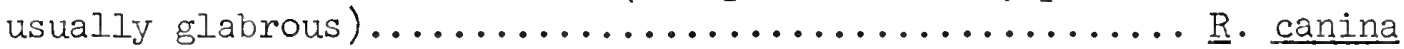

4. All calyx lobes entire or with simple shallow teeth, or some of them with 1-4 narrow, elongated lobes arising from the upper or lower half; mouth of receptacle $2-4 \mathrm{~mm}$ in diameter; styles not protruding, forming a dense brush or disk in the mouth of the receptacle and closing it; native species, 5

5. Iarge shrubs of swamps or wet ground, mostly $5-81 / 2$ ft tall; leaves finely toothed, 12-25 teeth above the midale of each margin, the teeth near the widest part of the leaf $0.3-1.2 \mathrm{~mm}$ high; stipules more or less con-

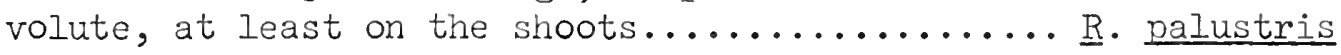
5. Plants mainly of dry or rocky ground, usually less than $3 \mathrm{ft}$ tall in $\underline{\mathrm{R}}$. carolina, but up to $6 \mathrm{l} / 2 \mathrm{ft}$ tall in $\underline{\mathrm{R}}$. virginiana; leaves coarsely toothed, usually 5-15 teeth above the middle of each margin, the teeth near the widest part of the leaf $0.6-2 \mathrm{~mm}$ high; stipules flat, 6 6. Infrastipular prickles (those at base of or just below the stipules) slenderly needle-like and straight, terete; dilated portion of base of larger thorns usually less than half the length of the thorn; prickles usually numerous between nodes of the stem; flowers arising from the new growth of the season......

6. Infrastipular prickles stout, flattened and broadened near the base, often curved or hooked but sometimes straight; dilated portion of base of larger thorns usually longer than half the length of the thorn; prickles usually absent between nodes of the stem; flowers usually arising from the branches of wood of the previous season.............. virginiana 
Rósa carolina I. Low Pasture Rose.

Meaning of Species Name. Of Carolina. Rose.

Other Names. Wild Rose, Hip-tree, Low Rose, Carolina Rose, Pasture

Type of Plant. An erect shrub 1 to $3 \mathrm{ft}$ high.

Habitat. Dry open woods, thickets, pastures, and dry sandy, rocky, or open habitats.

Range. NS to Minn and Neb, s to Fla and Tex.

Distr in NYS. Frequent or common across the state outside the higher Adirondacks.

Distr in the Torrey Range. Throughout the range except in the pine barrens, there rare or wanting.

Time of Fl. (Mid-May)Jun(early Jul); Jun 20-Jul at Cornell.

Origin. Native.

This species is easily confused with $\underline{R}$. Virginiana; it is best distinguished by the shape of its thorns and by its habit of blooming on oneyear stems, while $\underline{R}$. virginiana rarely blooms except on branches from old wood. The aerial stems arise from long underground stems and often die back from year to year.

Rósa canina I. Dog Rose.

Meaning of Species Name. Of a dog; i.e., mean, from the abundant prickles.

Other Names. Canker Rose, Wild Brier, Hip-rose, Hip-tree, Cat-whin, Canker-blooms, Bramble-brier, Brere-rose, Lawyers (i.e., an old thorny stem), Soldiers, Hedge-peak, Dog-thorn, Horse-bramble, Bird-brier, Bedeguar.

Type of Plant. A tall shrub.

Habitat. Dry banks, thickets, waste places, roadsides, old fields, and neglected grounds.

Range. NS to $\mathrm{w} N \mathrm{~N}$, s to $\mathrm{Va}$ and Tenn.

Distr in NYS. No distr given in House (1924).

Distr in the Torrey Range. Rare as an occasional esc from gardens; natzd in the valley of the upper Delaware $r$.

Time of Fl. Mid-May-Jul.

Origin. Introd and natzd from Eu.

Remarks. Occasionally planted for ornament and locally esc from cult.

The fruit of this species, a native of Europe and temperate Asia, is fleshy, smooth, oval, red, and of a pleasant, sweet, acidulous taste. In addition to sugar, it contains vitamins and uncombined citric and malic acids. In Europe it has been collected since ancient times for use as food when garden fruits were few and scarce. Galen remarked that they were gathered by country people in his day, as they still are in Europe. Gerard stated that "the fruit when it is ripe makes most pleasant meats and banqueting dishes, as tarts and such like." J. Lightfoot, writing in 1789 , observed that the pulp of the fruit, separated from the seeds and mixed with wine and sugar, "makes a jelly much esteemed in some countries." Johnson (1867) gives more details concerning the uses of this species in 


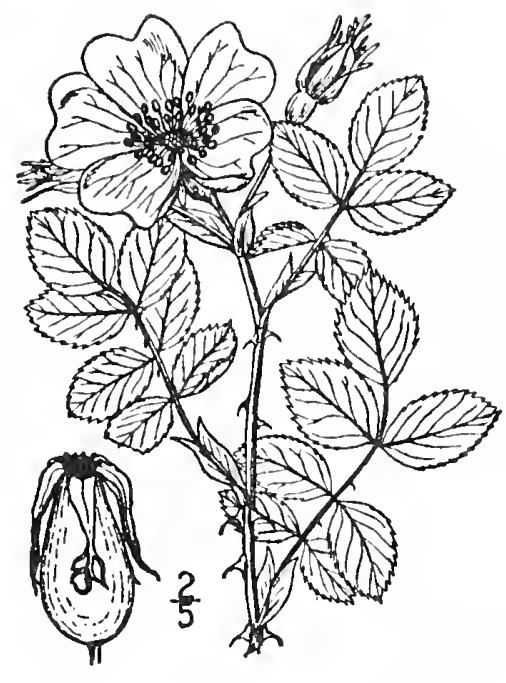

Rosa canina

Dog Rose

[From Britton \& Brown (1913), II: 284, 285.]

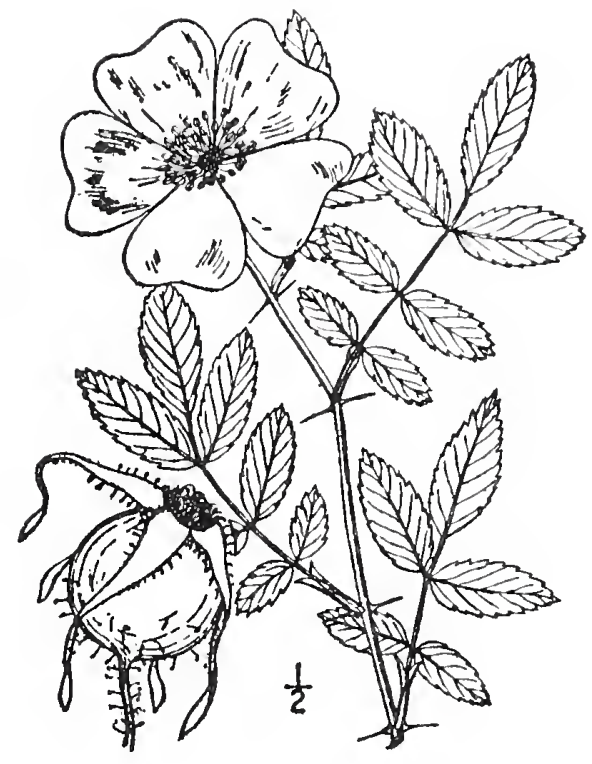

Rosa virginiana

Tall Pasture Rose

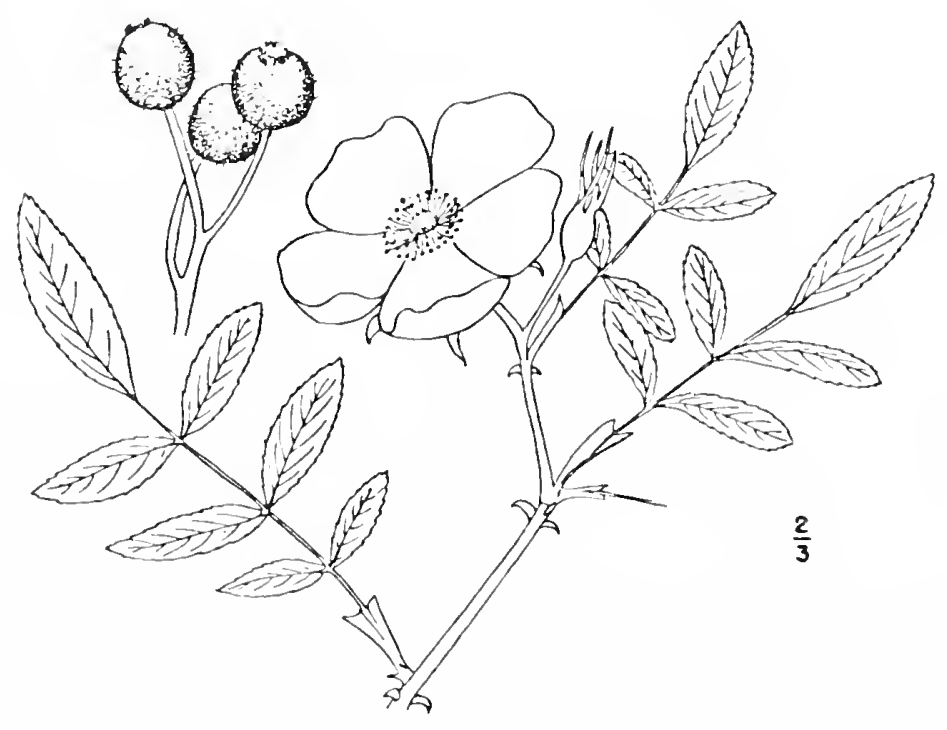

Rosa carolina--Low Pasture Rose

[From Billington (1949), Fig. 95, p. 178.] 
Europe: "The fruit of the Dog Rose ... has long been used to form a conserve with sugar, much employed in pharmacy. It ... acts as a refrigerant and very slight aperient; but is chiefly applied as a vehicle for other medicines, especially for children, though sometimes given in pectoral disorders. An infusion of the crushed fruit in hot water forms an agreeable cooling drink. In some parts of Europe the 'Hips' are collected, and sold in the markets for the purpose of mixing with wine. They are often eaten raw by children, and are not unwholesome, but care should be taken to remove all the bristle-like hairs that surround the seeds ... In former times, when garden fruits were scarce, they were much esteemed for dessert. ... Their taste when cooked is not particularly pleasant to modern palates, but in Germany a preserve like our conserve of hips is often made of them. Gerarde recommends the flower of the garden Rose as a culinary vegetable, and Roses are largely eaten in that manner in China." He adds that "The leaves have been used as a substitute for tea." This species has likewise often been used as stock for grafting purposes. The U.S. Dispensatory of 1865 notes that the pulp of the ripe fruit has also been used in this country chiefly as "an agreeable vehicle for other medicines."

Ròsa micrántha Sm. Small-flowered Sweetbrier.

Meaning of Species Name. Small-flowered.

other Names. Small-flowered Eglantine.

Type of Plant. An erect shrub.

Habitat. Thickets, clearings, roadsides, pastures, etc.

Range. Anticosti I to s Ont and Wis, s to $\mathrm{NY}, \mathrm{NC}, \mathrm{Ky}$, and Tex.

Distr in NYS. Rarely esc from cult in this state.

Distr in the Torrey Range. Very rare as an occasional esc from gardens.

Time of $\mathrm{Fl}$. Jun.

Origin. Introd and natzd from Eu.

Remarks. Often cult and frequently esc; similar to R. rubiginosa, with which it is sometimes confused.

Rósa multiflöra Thunb. MuItiflora Rose.

Meaning of Species Name. Many-flowered.

Other Names. Japanese Rose.

Type of Plant. A sprawling shrub.

Habitat. Clearings, roadsides, borders of woods, wasteland, and thickets along rivers.

Range. S NE, southw and westw.

Distr in NYS. Not listed in House (1924).

Distr in the Torrey Range. Not listed in Taylor (1915).

Time of $\mathrm{F}$ l. May-Jun.

Origin. Introd and natzd from e Asia.

The Multiflora Rose is frequently planted as a "Iiving fence" to keep out trespassers and livestock as well as to provide shelter and cover for birds and other wildlife. This recent introduction is spreading rapidly in the Catskill region and promises to become quite pestiferous; animals spread the seeds and it becomes an aggressive weed, invading natural habitats and replacing native species. 


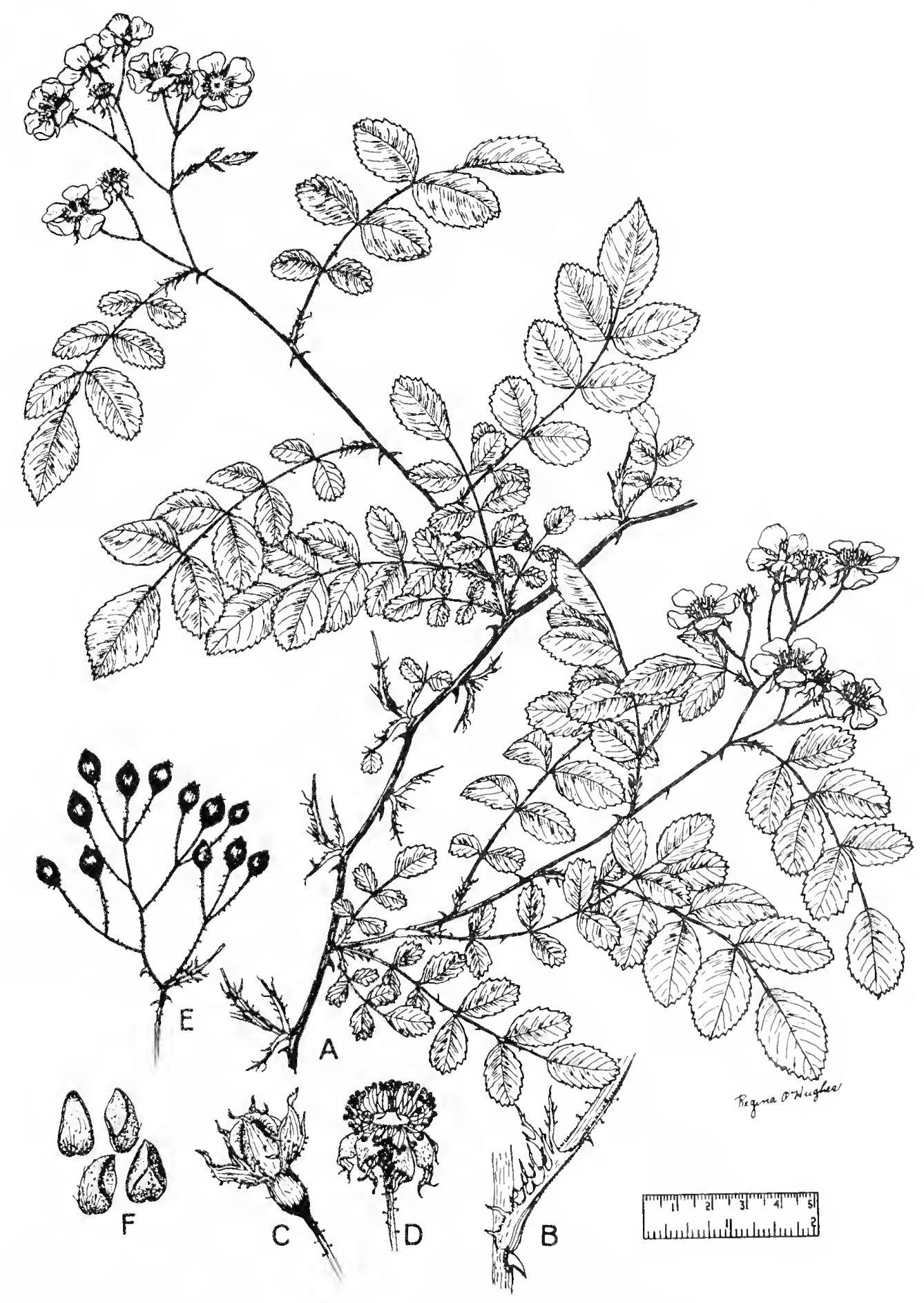

Rosa multiflora--Multiflora Rose

[From USDA Agr. Research Sv. (1971), Fig. I09, p. 223.] 
Ròsa palustris Marsh. Swamp Rose.

Meaning of Species Name. Of marshes.

Other Names. Wild Rose, Hip-tree.

Type of Plant. A much-branched shrub.

Habitat. Wet thickets, swamps, marshes, streambanks, and shores.

Range. NS to Mich, Wis, and Minn, s to Fla and Ark.

Distr in NYS. Frequent or common across the state.

Distr in the Torrey Range. Common throughout the range except in

the pine barrens, there wanting.

Time of Fl. (Jun) Jul(Iate Aug); JuI 10-Aug I5 at Cornell.

Origin. Native.

Ròsa rubiginòsa L. Sweetbrier.

Meaning of Species Name. Rusty.

Synonyms. R. eglanteria L.

Other Names. The Eglantine of Chaucer, Spenser, and Shakespeare;

Hip-rose, Hip-brier, Bedeguar, Primrose, Kitchen Rose.

Type of Plant. A coarse shrub (sometimes treelike).

Habitat. Thickets, clearings, roadsides, etc.

Range. Throughout the ne states, adjacent Can, and beyond.

Distr in NYS. Common in cult and frequently esc to roadsides, etc.

Distr in the Torrey Range. Common as an esc from cult in our area. Time of Fl. (Mid-May)Jun-JuI; JuI at Cornell.

Origin. Introd and natzd from Eu.

Ròsa virginiàna Mill. Tall Pasture Rose.

Meaning of Species Name. Virginian.

Other Names. Pasture Rose.

Type of Plant. An erect shrub.

Habitat. Damp to dry thickets, clearings, swamps, and shores.

Range. Nf to ont, s to NE, Va, upland NC to Ala, Tenn, and Mo.

Distr in NYS. Frequent or common across the state outside the higher Adirondacks.

Distr in the Torrey Range. Common throughout the range except in the pine barrens, there only sparingly introd; more common northw than elsewhere.

Time of $\mathrm{Fl}$. (Jun) Jul(Aug).

Origin. Native.

Remarks. Easily confused with $\underline{R}$. carolina. 


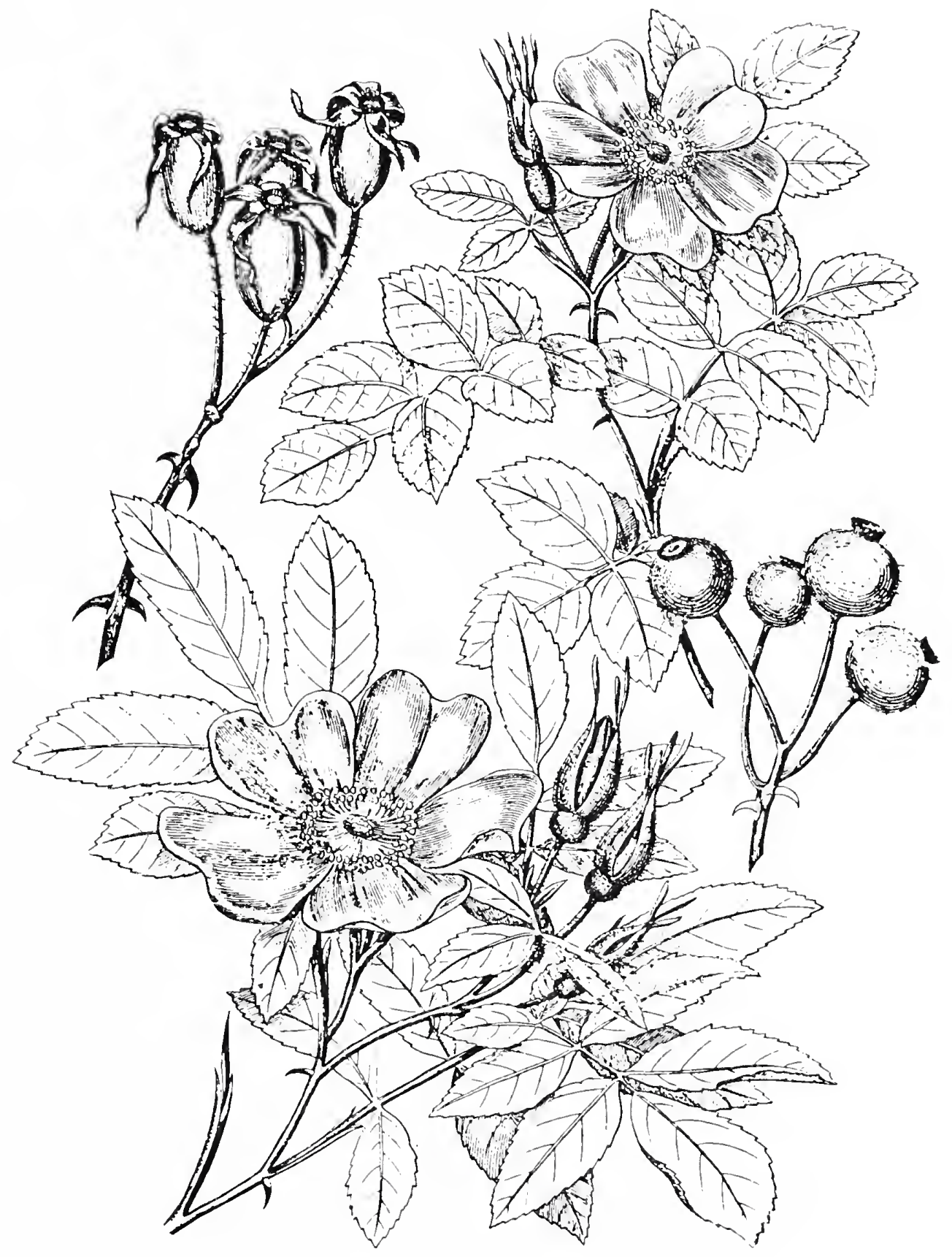

(Top) Rosa rubiginosa--Sweetbrier

(Bottom) Rosa palustris--Swamp Rose

[From Emerson (1878), Vol. II, plate ff.p. 488.] 
Rùbus L. Bramble.

This is a large genus of usually shrubby, often prickly, perennial herbs, usually bearing edible fruit, now almost cosmopolitan in distribution but best represented in the north temperate zone and the mountains of South America. The number of species in this complex genus is difficult to estimate owing to differences of opinion among students of the genus, but Fernald (1950) lists 205 species for the northeastern states and adjacent Canada, only 9 of which grow in the Catskills (plus two hybrids). Several species or hybrids are commonly cultivated, including the Youngberry, Ioganberry, Boysenberry, and Himalaya-berry. The name of the genus is the Roman name, derived from the Latin ruber, red, probably referring to the fruit of the Raspberry.

As with practically all edible native fruits, the American Indians made much use of blackberries and raspberries, both fresh and dried in the sun. The dried berries were sometimes pounded and mixed with pulverized meat and other ingredients to which boiled animal fat was added, the dried mass forming their famous pemmican, an important Indian survival food that could easily be carried on long journeys. This type of food was adopted by the early settlers and soon formed an important part of their wilderness food supply. The dried berries were also soaked in water and slowly heated with maple sugar, eaten either as a sauce or mixed with ground corn. The high vitamin $C$ content makes these berries an excellent survival food, particularly since they are easily recognized by everyone. In the field the tender young peeled shoots are also edible and make a pleasant nibble.

In Scotland an orange dye has been obtained from the roots of native species of Rubus, while in other areas the young shoots of blackberries with an alum mordant were used as the source of a light gray dye. To dye 1 pound of wool, I pound of young blackberry shoots was boiled for 45 minutes, after which the liquid was strained and enough water added to make 4 gallons. When the dye bath was lukewarm, the mordanted wool was immersed, brought to a boil, and simmered for I hour. If a darker gray was desired, the wool was taken out and I/2 ounce of ferrous sulfate was added to the dye bath and mixed well. The wool was then returned to the dye bath and simmered until the desired shade was obtained, after which the wool was rinsed and dried.

The genus Rubus furnishes many familiar wild berries, all of them with pulpy fruits consisting of many small, mostly juicy drupelets, each containing a hard seed. Both blackberries and raspberries are so familiar to everyone that they require little discussion. Both kinds of fruit have always been picked by those fortunate enough to be near where they grow, not only to use fresh but also to preserve in quantity for winter use. The dewberries or trailing blackberries, which grow close to the ground, however, are often overlooked, but many of them often have superior fruit. The leaves of both blackberries and raspberries are sometimes used, both fresh and dried, as a substitute for tea. Those of the Black Raspberry, R. occidentalis are best avoided, however, as they may be harmful.

The Chippewas ate blackberries raw as well as dried and stored for winter use. Densmore (1928) observes that when preparing them for winter use, they cooked the berries without sugar, spread them on birch bark in 
little cakes to dry in the sun, and stored them in birch-bark containers for winter use. The leaves of $\underline{R}$. frondosus were combined with other ingredients to make a decoction taken internally in the treatment of lung troubles. A decoction of the root alone was taken internally for stoppage of menstrual periods.

Blackberries have long been used in medicine. As early as 1737 John Brickell found blackberry fruit cooling and astringent; the juice, mixed with honey, alum, and red wine, he reported, "fastens loose Teeth." The root bark of both the high and low blackberries was quite generally praised by 19th century physicians for its astringent properties and it was recommended for the treatment of diarrhea and chronic dysentery. (In the Catskills the low, trailing blackberries are represented by $\mathrm{R}$. flagellaris and $\underline{R}$. hispidus, while $\underline{R}$. allegheniensis, $\underline{R}$. canadensis, and $\underline{R}$. laciniatus are "high-bush" blackberries.) The American Indians were also well aware of the astringent properties of blackberry root, for Wooster Beach reported in 1857 that when members of the Oneida tribe were attacked by dysentery in one season, all recovered following treatment with blackberry root while their white neighbors "fell before the disease." Other tribes also boiled blackberry roots for use in the treatment of flux and diarrhea, but in some areas blackberries were used for other purposes as well. Vogel (1970) observes that the Alabamas used blackberries as a toothache remedy and as a poultice against pneumonia, although the part used was not specified.

other tribes boiled both canes and roots for a drink used to treat vomiting and spitting of blood, as an eye wash to cure sore eyes, as a diuretic, to treat stomach troubles, and as a poison antidote. Krochmal and Krochmal (1973) report that in Appalachia a tea made from blackberry roots is used to dry up runny noses and to stop dysentery, while the juice of the fruit is used to control dysentery in children. The dried root bark of the genus Rubus was official in the U.S. Pharmacopeia, 1820-1916, and in the National Formulary, 1916-36, for use as an astringent and tonic; the berries were official in the National Eormulary, 1916-26, for use in syrup as a flavoring agent. Vogel (1970) reports that a proprietary "blackberry balsam" is currently advertised as a remedy for diarrhea "since 1846."

Martin et al. (1961) remark that as a group blackberries rank at the very top of summer foods for wildlife, in part because of their widespread availability in most parts of the country. While their principal use is while the fruit is juicy, even the dried or drying berries are eaten to some extent in late fall or winter. Birds are particularly prominent among the long list of wildlife users, some 97 species making quite extensive use of their fruit. Blackberry fruits are also popular with raccoons, chipmunks, and squirrels as well as with some other rodents, and the leaves and stems are extensively browsed by deer and rabbits. In addition to their value as a source of food, the thorny brambles often make impenetrable thickets where birds, rabbits, and other animals find comparative safety. Blackberry patches also commonly provide nesting sites for small birds.

\section{Kex to the Catskill Species of Rubus}

1. Principal foliage leaves simple and lobed (leaf lobes broadly triangular, acute); flowers rose-purple................ 1. Principal foliage leaves compound; flowers white, 2 
2. Stems herbaceous or nearly so, not well differentiated into primocanes and floricanes, spineless, occasionally with very weak bristles; stipules oblanceolate to ovate, blunt or rounded to

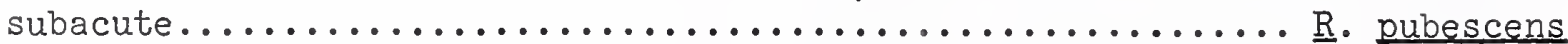

2. Stems woody, biennial, persisting through the winter and bearing flowers the second year, usually more or less spiny or bristly; stipules linear or setaceous, 3

3. Fruit separating from the receptacle, which is persistent on on the pedicel (raspberries), 4

4. Pedicels beset with stout, curved, or hooked spines, not

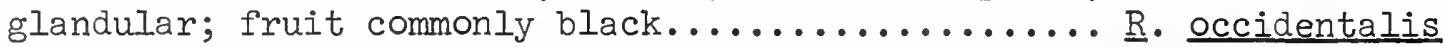

4. Pedicels more or less beset with straight and rather weak bristles, also copiously but minutely glandular; fruit

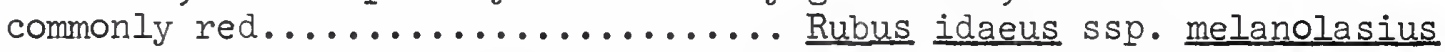

3. Fruit separating from the stem with the central receptacle included (blackberries and dewberries), 5

5. Primocanes prostrate or low-arching, rooting at the tip, 6

6 . Armature largely or wholly of slender small-based

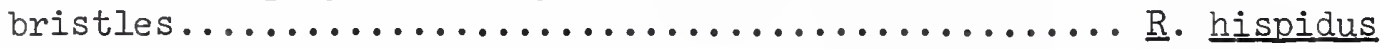

6. Armature of stout, stiff, often hooked spines with expanded bases; bristles none, 7

7. Leaves (when fresh) with strongly plicate leaflets puckered at the edge, the main veins forming furrows above and very prominert beneath....... R. plicatifolius

7. Leaves not as above (leaves 3-foliate, the terminal one often coarsely or doubly serrate, commonly sharply

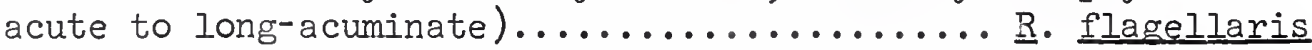

5. Stems tall, normally erect or ascending; thorns of the primocanes straight or barely reflexed, 8

8. Leaves deeply cut or laciniate, often dissected nearly

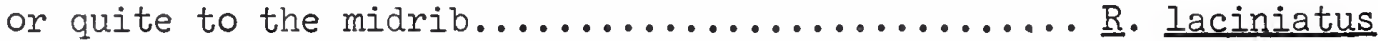

8. Leaves serrate-dentate, but not deeply dissected, 9

9. Corymbs leafy-bracted to or above the middle, the bracts overtopping the flowers................ frondosus

9. Corymbs not leafy-bracted, 10

10. Glandular hairs abundantly present on the pedicels, commonly also on the stipular bracts and petioles,

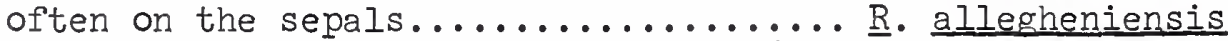

10. Glandular hairs essentially lacking (leaves softly pubescent to the touch beneath)..... R. canadensis

\section{Ribus allegheniénsis Porter. Mountain Blackberry.}

Meaning of Species Name. Of the Alleghenies.

other Names. Sow-teat Blackberry, Common Blackberry, High-bush Blackberry

Type of Plant. A shrub with erect or arching, often stout, angled, purplish-red canes 3-6 ft high armed with stout, straight, broad-

based prickles.

Habitat. Clearings, wayside thickets, and open woods.

Range. NB and $s$ Que to Minn, s to Md, in the mts to Ga, Tenn, and Mo. 


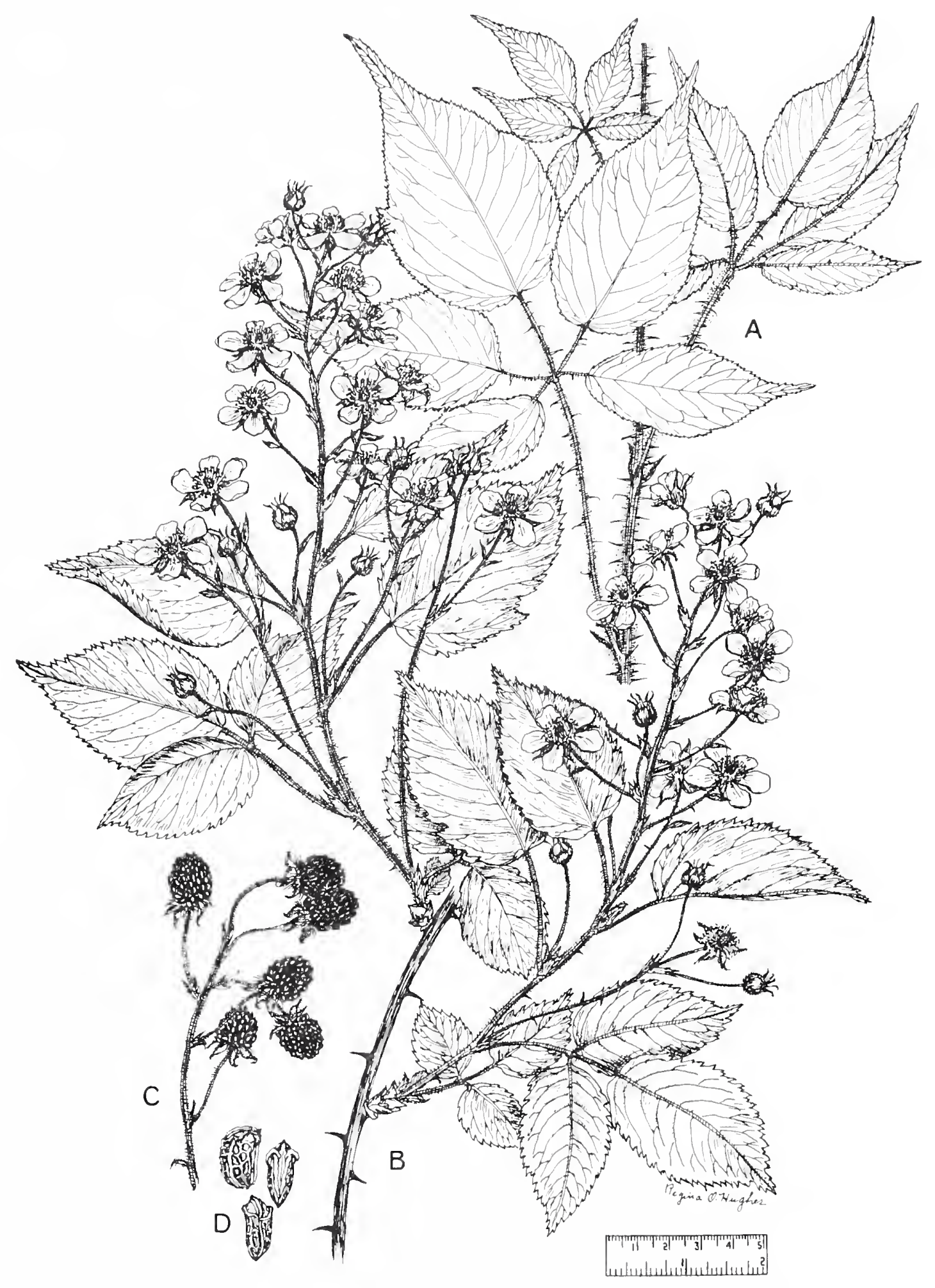

Rubus allegheniensis--Mountain Blackberry

[From USDA Agr. Research Sv. (1971), Fig. I10, p. 225.] 
Distr in NYS. Locally abundant from I Champlain and I George westw and southw across the state outside the higher Adirondacks; apparently rare or absent on much of the sandy coastal plain reg.

Distr in the Torrey Range. Under $\underline{R}$. nigrobaccus Bailey: Common everywhere except the coastal plain of $N J$.

Time of Fl. May-Jul, fr Aug-Sep; fl Jun at Cornell.

Origin. Native.

Remarks. Usually abundant; our commonest tall blackberry.

This species, the most abundant blackberry in the Catskills, is probably our most valuable wild fruit. It grows over almost the entire eastern United States and southern Canada and the annual crop is probably worth millions. Several cultivated forms have been derived from this wild species.

Throughout the northeastern states country people make such extensive use of wild blackberries for pies, jellies, jams, and puddings, to say nothing of eating them fresh, that giving recipes here would be like carrying coals to Newcastle. Most people, however, are not generally aware that in early spring the young sprouts of the primocanes, gathered before the prickles harden, can be peeled and sliced as an ingredient in tossed salads. Expressed juice from the ripe berries can also be mixed half and half with lemonade to make a refreshing summer drink. Used as a medicine, blackberry juice was once a favorite remedy for diarrhea or "summer complaint." The juice can likewise be used to make blackberry liqueur and wine. To make blackberry wine add 6 cups of water to 6 quarts of berries and boil gently for 15 minutes, then press out the juice. To each quart of juice add 2 cups of sugar, pour into a large crock, spread 1 cake of yeast on a slice of toasted rye bread, and float it on top of the juice. Cover the crock and let stand for 1 week, then carefully pour off the wine into gallon jugs and stop loosely with wads of cotton. Keep in a cool place until the wine clears and shows no further sign of fermentation, then carefully decanter into sterilized bottles and cap tightly. Let it age at least until cold weather. Some people prefer to serve this wine as a mulled drink, prepared by pouring 1 bottle of blackberry wine into a glass or enameled saucepan, adding 6 sticks of cinnamon and sugar to taste, then heating the wine to a temperature as hot as one can drink it, taking care not to let it boil.

The entire plant contains an active principle which is one of the best known cures for diarrhea, a fact long known to both Indians and whites. The roots (and the leaves as well) of this species were dug, dried, and stored until needed. One teaspoon of the crushed root (or leaves) was steeped in a cup of boiling water. When cool, one or 2 cups were taken a day until the condition was remedied. Eating a large quantity of the fresh fruit would have about the same result.

\section{Rubus canadénsis I. Smooth Blackberry.}

Meaning of Species Name. Canadian.

Other Names. Millspaugh's Mountain Blackberry, Thornless Blackberry.

Type of Plant. A stout shrub 3-6 ft high similar to $\underline{R}$. allegheniensis but armed with only occasional weak prickles. 


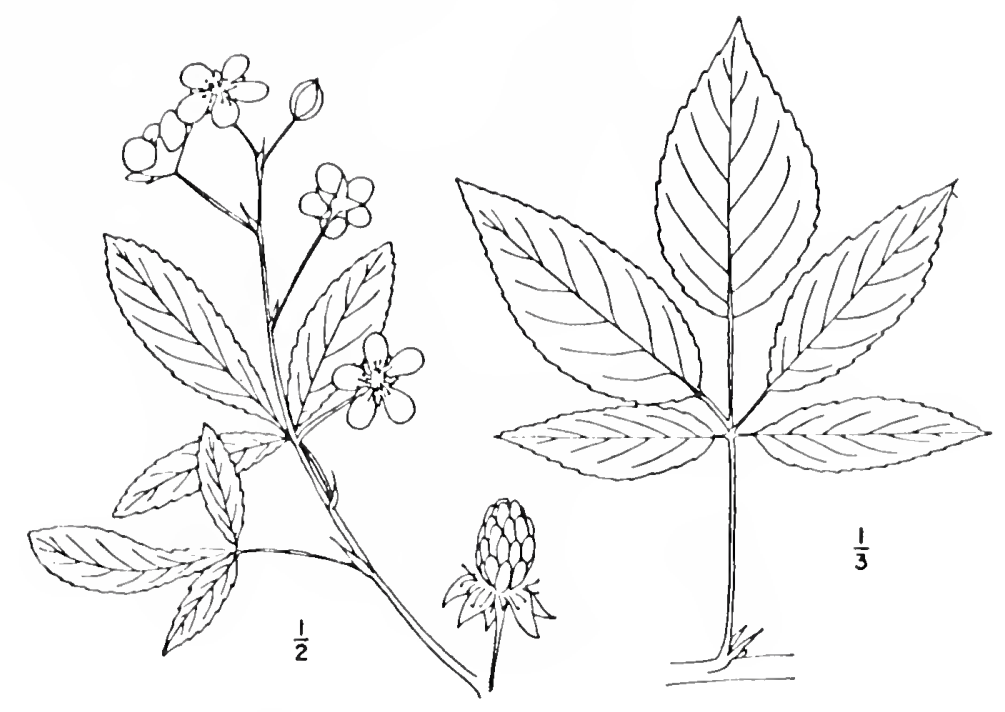

Rubus canadensis--Smoo'in Blackberry

[From Billington (1949), Fig. 83, p. 162.]

Habitat. Woods, thickets, and clearings.

Range. Nf and Ont to Minn, s to $\mathrm{Pa}$ and upland to $\mathrm{n} \mathrm{Ga}$ and Tenn.

Distr in NYS. Frequent or common northw across the state, apparently outside the higher Adirondacks, southw to LI and SI, and westw to I Erie; rare or absent on the coastal plain.

Distr in the Torrey Range. Confined so far as now known to the mts of Ulster, Greene, Columbia, Sullivan, and Delaware co, NY, and Monroe and Iuzerne co in $\mathrm{Pa}$; locally very common.

Time of Fl. Jun-Jul, fr Aug-early Sep; fl Jun at Cornell. Origin. Native.

The berries of this species, as well as those of $\underline{R}$. allegheniensis, have long been much used for the making of pies, jellies, jams, and puddings. The roots of this and $\underline{R}$. villosus were also used as a remedy for dysentery. The roots only were official. As suggested by the U.S. Dispensatory of 1865, "The smaller roots should be selected for use; or, if the thicker pieces are employed, the cortical part should be separated, and the wood rejected. Their virtues are extracted by boiling water, and by diluted alcohol, and depend chiefly, if not exclusively, upon tannin, which is an abundant constituent. These roots are tonic and strongly astringent. They have long been a favorite domestic remedy in bowel affections, and from popular favor have passed into regular medical use. Given in decoction, they are usually acceptable to the stomach, without being offensive to the taste; and may be employed with great advantage in cases of diarrhea from relaxation of the bowels, either in children or adults." The decoction was prepared by boiling 1 ounce of the roots in $11 / 2$ pints of water until it was reduced to 1 pint, of which 1 to 2 fluid ounces were administered to an adult 3 or 4 times during a period of 24 hours. 


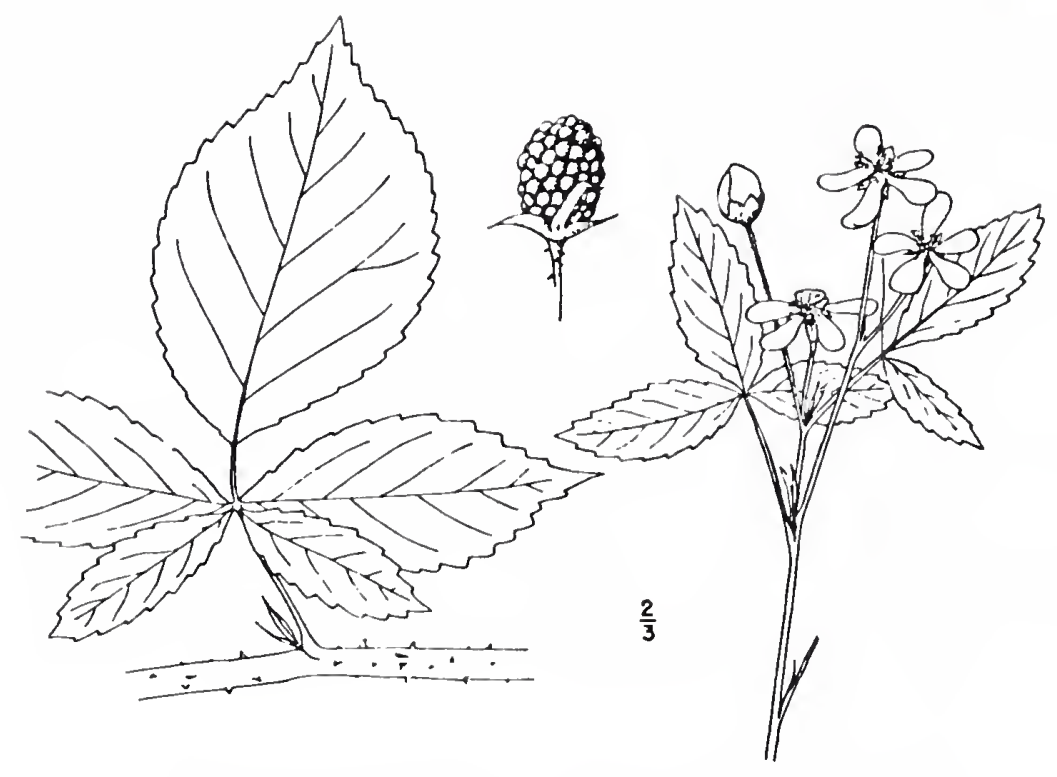

Rubus flagellaris--Northern Dewberry

[From Billington (1949), Fig. 87, p. 168.]

Rùbus flagellàris Willd. Northern Dewberry.

Meaning of Species Name. Like a whip-lash.

Other Names. Running Blackberry, Low Running Blackberry, Dewberry, Trailing Bramble.

Type of Plant. A deciduous shrub with long trailing stems armed with scattered, broadbased, often slightly curved prickles, reproducing by seeds and runners.

Habitat. Dry fields, open woods, meadows, pastures, borders of thickets, and rocky places.

Range. Me and Que to Ont and Minn, s to Md, $\mathrm{n} \mathrm{Ga,} \mathrm{Mo,} \mathrm{and} \mathrm{Ark.}$

Distr in NYS. Common across the state southw and locally northw to Albany co, c NY, and doubtless elsewhere.

Distr in the Torrey Range. Under $\underline{R}$. procumbens Muhl.: Common everywhere.

Time of Fl. May-Jun, fr Jun-Aug; fl Jun at Cornell.

Origin. Native.

Remarks. A highly variable species chiefly northern in distrib.

In areas where this species has become a troublesome weed, Muenscher (1952) suggests that it can be brought under control in meadows by plowing in autumn, disking several times, and planting a smother crop the following spring. Follow with a cultivated crop before reseeding. Scattered clumps can be grubbed out, but more extensive areas should be mowed and burned. 


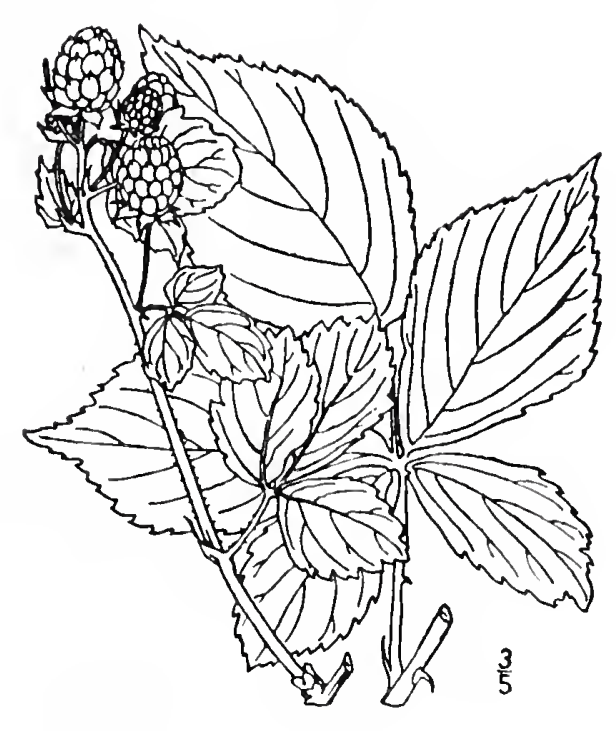

Rubus frondosus--Leafy-flowered Blackberry

[From Britton \& Brown (1913), II: 279.]

Rủbus frondósus Bigel. Leafy-flowered Blackberry.

Meaning of Species Name. Leafy.

Type of Plant. A perennial shrubby plant growing $21 / 2$ to $4 \mathrm{ft}$ high. Habitat. Thickets, hillside pastures, and borders of rocky woods, mostly in dry or stony soil.

Range. Mass to Ind, $s$ to Va.

Distr in NYS. Frequent in the se part of the state and on LI; less frequent northw to Saratoga co and across the state westw.

Distr in the Torrey Range. Throughout the range except in the pine barrens, there wanting; very rare in the reg surrounding the pine barrens.

Time of Fl. May-Jun, fr late Jun-Sep; fl Jun at Cornell. Origin. Native. 


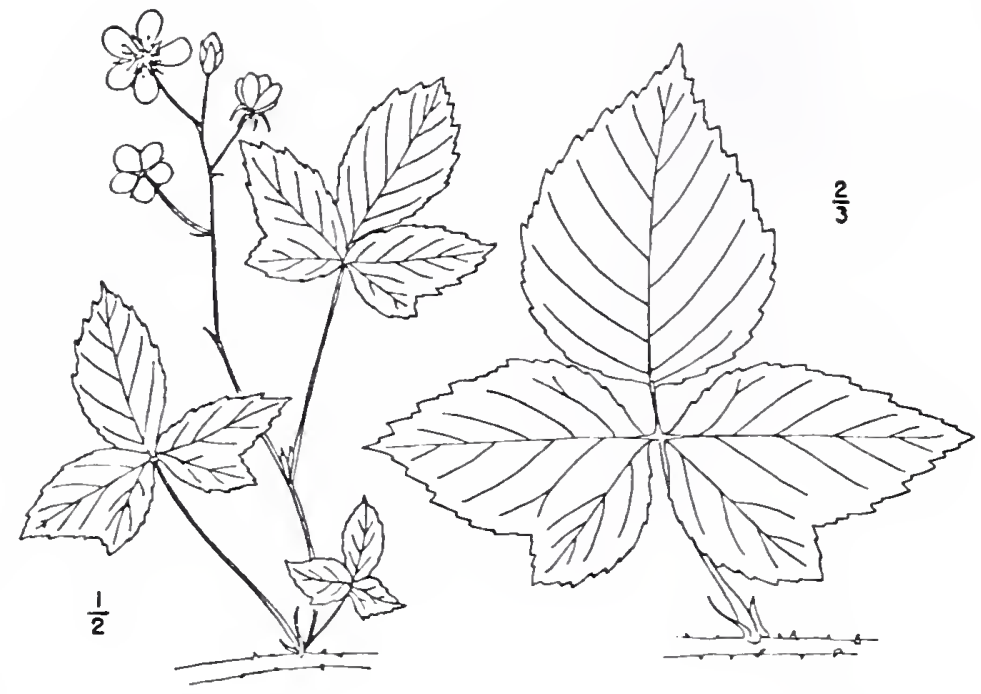

Rubus hispidus--Bristly Dewberry

[From Billington (1949), Fig. 60, p. 118.]

Rübus hispidus I. Bristly Dewberry.

Meaning of Species Name. Bristly.

Other Names. Hispid Blackberry, Running Swamp Blackberry, Swamp Dewberry.

Type of Plant. A semi-evergreen perennial shrub with long trailing stems usually copiously armed with stiff bristles.

Habitat. Moist open soil of ditches, swales, open woods, and low grounds, rarely in drier soil.

Range. NS to Wis, s to Md, NC, Ga, WVa, and Mo.

Distr in NYS. Common or frequent across the state except in some portions of the Adirondack reg, particularly at high elevations.

Distr in the Torrey Range. Common throughout the range.

Time of Fl. Jun-early Sep, fr mid-Aug-Oct; fl Jun 25-Jul 25 at Cornell.

Origin. Native.

Remarks. Abundant throughout the northeastern states and adjacent Can.

Although American Indians used blackberries primarily as a remedy for diarrhea, the Mohegans drank an infusion of the berries of this species as a remedy for worms.

Rübus idaèus I. ssp. melanolàsius Focke. Wild Red Raspberry.

Meaning of Species Name. Of Mt Ida; ssp. name, beset with dark hairs.

Maxim.

Svnonums. B. strigosus Michx.; R. idaeus I. var. strigosus (Michx.)

Other Names. Red Raspberry. 
Type of Plant. A biennial shrub with round, arching canes 2-6 ft high, often whitened when young and usually bristly but with few or no prickles; while the canes are biennial, the plant is long-lived.

Habitat. Dry or moist thickets, fields, rocky slopes, clearings, and roadsides.

Range. Lab and $\mathrm{Nf}$ to $\mathrm{Ak}$ and $\mathrm{BC}$, s to $\mathrm{NC}$, Ga, Ind, Ia, Wis, Minn, Neb, Wyo, Col, and Ariz.

Distr in NYS. Common northw across the state; less frequent southw and apparently not native $s$ of the Hudson highlands.

Distr in the Torrey Range. NY: From the highlands of the Hudson, northw.

Elevation. Grows to $5500 \mathrm{ft}$ in NC.

Time of Fl. May-Jul; Jun at Cornell.

\section{Origin. Native.}

Remarks. The original of the Cuthbery and Hansall Raspberries. A hybrid between this subspecies and $\underline{R}$. allegheniensis has been collected in the Town of Kortright.

Our Red Raspberry is a subspecies of the Eurasian circumpolar $\underline{R}$. idaeus complex, long used for food in that area, for its fruit has been found in the debris of the ancient lake villages of Switzerland. Rubus idaeus furnished European varieties of the cultivated raspberry as well as those cultivated in American gardens prior to 1865. Early settlers also made use of the native raspberry and by 1887 had developed at least six varieties for cultivation. The fruits of ssp. melanolasius were likewise much relished by the American Indians wherever they were to be found, not only as food but also for medicinal purposes. Several tribes used the ripe fruit simply as a flavoring agent for bad-tasting medicines, but at least one tribe used a decoction of the root bark in the treatment of sore eyes. The Omaha Indians scraped and boiled raspberry and blackberry roots, combined, to make a tea used to treat children afflicted with bowel trouble.

The wild Red Raspberry is so well known in the Catskill region that it seems unnecessary to dwell at length on its uses for jam, jelly, and pie, or as a fresh fruit served with cream and sugar. This fruit lacks pectin, however, so that ingredient must be added when making jam or jelly. The juice can either be mixed half and half with apple juice (see the account of Pyrus malus) or commercial pectin can be added; good recipes for both raspberry jam and raspberry jelly are found on the packages or bottles of commercial pectin. Many people are not aware, however, that the dried leaves of the Red Raspberry have long been used as a substitute for tea. The leaves are gathered when the plants are in flower and thoroughly dried indoors out of the sun at room temperature. They can be spread out on the floor on newspapers or tied in bundles and hung from the rafters in the attic. These leaves should be thoroughly dried before using them for tea, as the wilted leaves have been known to poison cattle. This poison is driven off or altered in composition as the leaves get thoroughly dry and cause no ill effects either in well-cured hay or when used for making tea. The dried leaves can be crumbled, the coarser stems removed, and the residue packed in glass jars with tight lids to store for winter use. To make raspberry tea, pour boiling water into a teapot and let it stand for 10 minutes. Discard the water, add the equivalent of five or six dried and crumbled raspberry leaves, pour boiling water over them, let steep for 5 minutes, and serve with milk or cream and sugar. This tea contains tannin, as does oriental tea, and has a pleasant aroma that makes an acceptable 


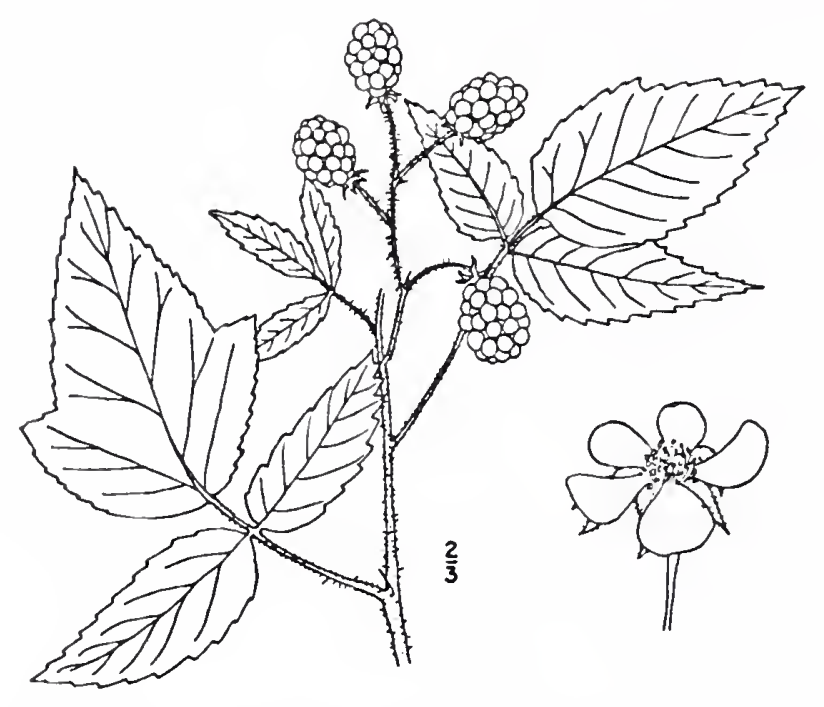

Rubus idaeus ssp. melanolasius--Wild Red Raspberry [From Billington (1949), Fig. 74, p. 150.]

substitute for tea. A similar tea can also be made from blackberry leaves, but it has a somewhat different flavor.

A raspberry-ade can be made by packing a jar with ripe berries, filling in the spaces with white vinegar, capping the jar, and letting it stand for a month. Then strain off the juices through a fine sieve lined with a double layer of cheesecloth and store in sterilized jars or bottles until wanted. To serve, sweeten to taste with sugar and dilute with ice water.

The leaves, roots, and fruits of our wild raspberry were also used by the early settlers as medicine. The leaves and roots particularly are astringent and were therefore considered by the laity as specifics in the treatment of dysentery, while the fruits were used for their refrigerant and laxative properties. In "official medicine," however, only the berries were used and then only as a flavoring agent. The fruit and/or the juice has been official since 1882 only for the preparation of raspberry syrup to serve "as a pleasant disguising agent in pharmaceutical mixtures, especially those of an adiculous nature."

Rübus Iaciniàtus Willd. Cut-leaved Blackberry.

Meaning of Species Name. Slashed, from the leaf shape.

Type of Plant. A biennial shrub.

Habitat. Esc from cult to roadsides, borders of woods, and waste places.

Range. Mass to Mich and southw.

Distr in NYS. Occasional in cult and esc or estab in se NYS.

Distr in the Torrey Range. A rare, hardly persisting esc in our range.

Time of Fl. Jun-Aug, fr Jul-Sep; fl Jul at Cornell.

origin. An old world species, probably introd from Eu. 


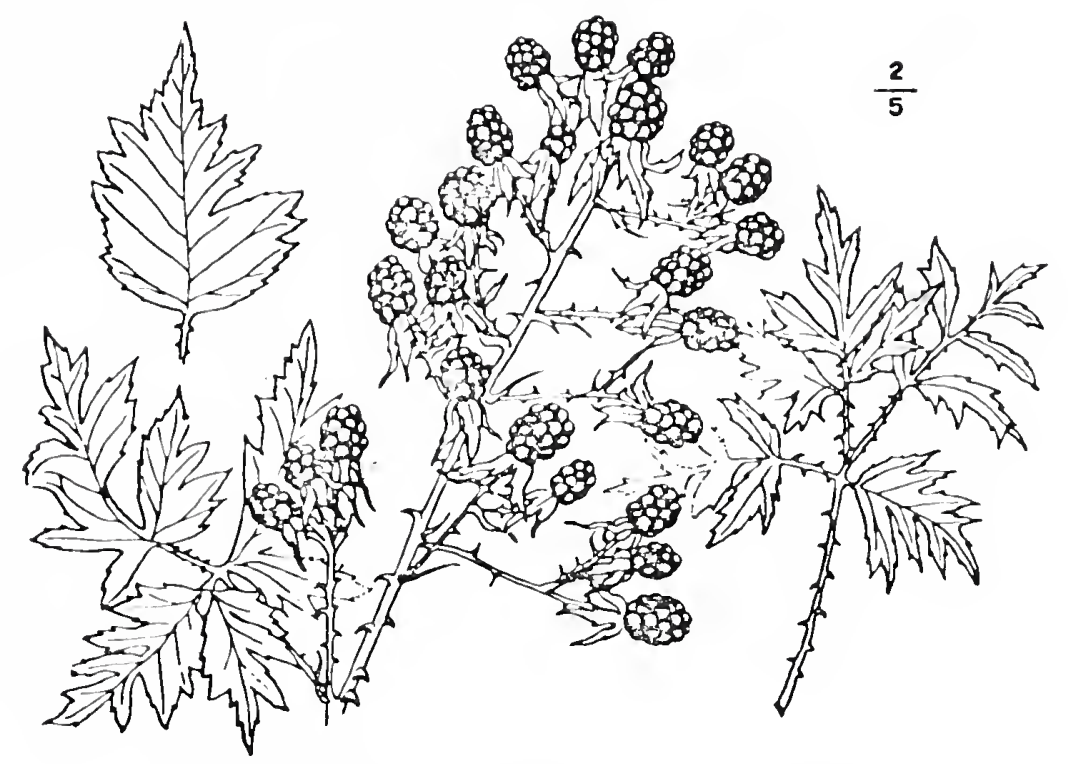

Rubus laciniatus--Cut-leaved Blackberry [From Billington (1949), Fig. 84, p. 162.]

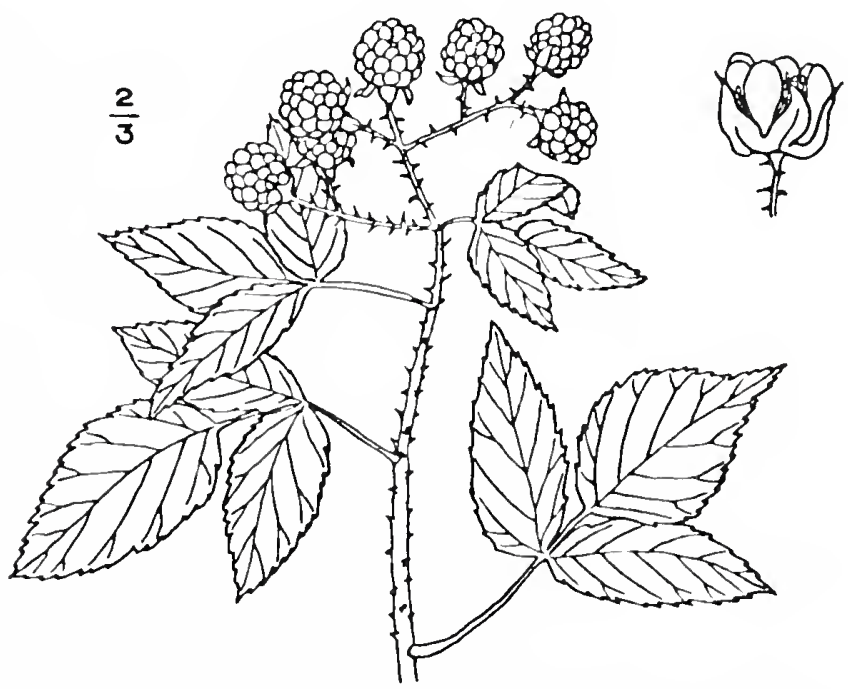

Rubus $\mathrm{x}$ neglectus--Purple Raspberry [From Billington (1949), Fig. 75, p. 154.]

Billington (1949) describes the pedicels of Rubus $\mathrm{x}$ neglectus as being "erect or ascending, closely covered with slender prickles and stiff glandular hairs," while the calyx is "hispid and glandular." The pedicels of Rubus idaeus ssp. melanolasius, which, to the writer, this hybrid much resembles, on the other hand, are "pubescent and more or less bristly"; no mention is made of glandular hairs. The calyx of ssp. melanolasius likewise is "bristly hispid," but not glandular. 
Rübus x negléctus Peck. Purple Raspberry.

(․․ idaeus ssp. melanolasius $\times \underline{R}$. occidentalis)

This taxon, intermediate between $\underline{R}$. idaeus $\mathrm{ssp}$. melanolasius and $\underline{\mathrm{R}}$. occidentalis, is probably a self-perpetuating hybrid. The berries have a fine flavor, although they are a little more tart than those of its parents. This hybrid is the parent of several cultivated varieties.

Rübus occidentàlis L. Black Raspberry.

Meaning of Species Name. Western; i.e., of the western hemisphere. Other Names. Blackcap, Thimbleberry, Scotch-cap, Purple Raspberry, Blackberry.

Type of Plant. A biennial shrub with long arching, usually glaucous, canes often rooting at the tip and armed with scattered hooked prickles. Habitat. Dry or moist open woods, fields, roadsides, thickets, and recent clearings.

Range. Que to Minn, ND, and e Col, s to Ga and Ark.

Distr in NYS. Common in most secs of the state except the pine barrens of LI, and infrequent or rare above $1600 \mathrm{ft}$ in the Adirondacks.

Distr in the Torrey Range. Throughout the range except in the pine barrens.

Elevation. Grows to $3000 \mathrm{ft}$ in Va.

Time of Fl. May-Jun(Jul), fr Jun-Aug; fl Jun at Cornell

Origin. Native.

Remarks. Often cult in many horticultural varieties; the original

of the Gregg, Hilborn, and other raspberries.

There is no question but that for many people the Black Raspberry, a native of eastern North America, is one of the finest of our wild fruits, for few surpass its distinctive flavor. Not only was it valuable to the early settlers, in part because it could easily be dried or preserved, but it is much sought after today for use either fresh as a dessert served with sugar and cream or for making pies, jellies, and jams, to say nothing of its popularity as a flavoring agent in ice cream and soft drinks, giving them a flavor quite unlike anything else. Although its fruits are full of seeds, "they offer a high reward for the palate." While Emerson (1875) felt that in the wild state it was "an inferior fruit," not everyone agrees; in the wild it practically always produces fruit of good quality, by many considered superior to the cultivated varieties, although $\mathrm{A}$. J. Downing, writing in 1857, reported that when cultivated "its fruit is much larger and finer than in the uncultivated state, and its rich, acid flavor renders it, perhaps, the finest sort for kitchen use." While the fruit can be used in many ways, either fresh or cooked, the leaves should not be used for making tea, as some have suggested; there is a strong suspicion that they may be unwholesome. For the same reason one should avoid chewing on the tender young shoots of the plants.

The American Indians also made much use of this species, both as food and as an ingredient in medicine. Vogel (1970) states that the Ojibwas prepared a decoction of the dried roots of this species for use in treating pains in the stomach, while the Menominees combined the roots of Black Raspberry with St. John's-wort (Hypericum ascyron) for treating the 


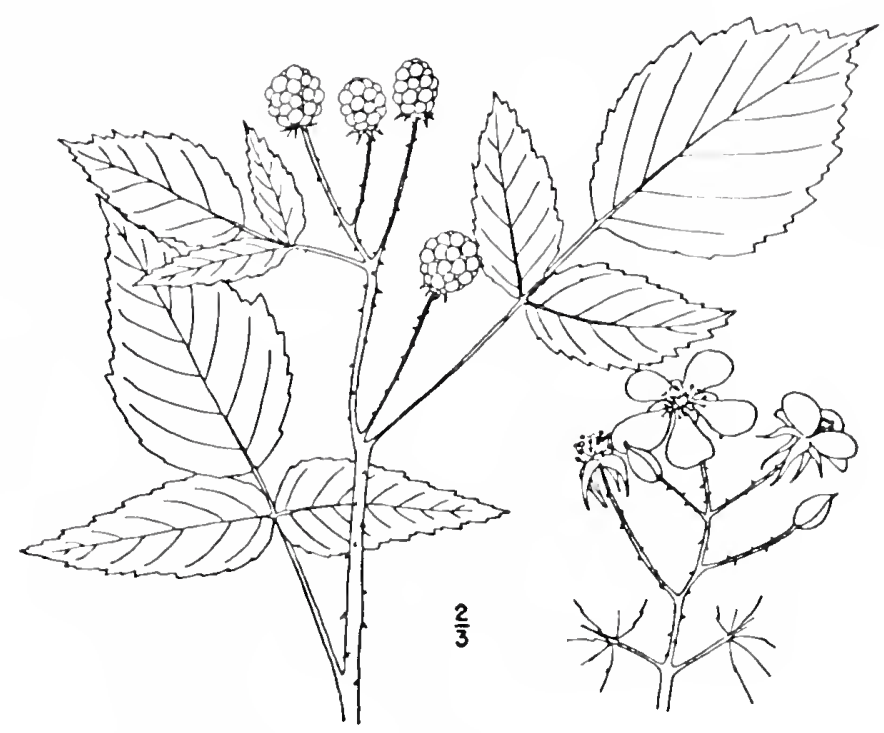

Rubus occidentalis--Black Raspberry

[From Billington (1949), Fig. 76, p. 154.]

early stages of consumption, as tuberculosis was then called. The Chippewas used a decoction of the root of this species in combination with other plants for use in the treatment of pains in the back and for female weakness. The Omahas scraped and boiled the roots of both the Red and Black Raspberry, combined, to make a tea for children afflicted with bowel. trouble, and the Pawnee, Omaha, and Dakota tribes made a decoction of the root bark of this species for use in the treatment of dysentery. While the laity also sometimes used the root bark of the Black Raspberry for similar purposes, it has never been listed as an official medicine in the United States.

Rủbus odoràtus I. Flowering Raspberry.

Meaning of Species Name. Fragrant.

Other Names. Purple-flowering Raspberry, Thimbleberry, Scotchcaps, Mulberry, Rose-flowering Raspberry, Canadian Raspberry, Virginia Raspberry.

Type of Plant. A straggling, unarmed shrub 2-5 ft high.

Habitat. Moist shady ravines, rocky woods, borders, and fencerows. Range. NS and Me to Ont and Mich, s to NC, Ga, and Tenn. Distr in NYS. Common throughout most secs of the state except on LI, where rare or local.

Distr in the Torrey Range. NY: RosIyn, LI; unknown on SI, rare and local in Bronx and Westchester co, thence increasing northw. Time of Fl. Jun-Sep, fr Jul-Sep; fl Jun-Jul at Cornell. Origin. Native.

Although the fruit of this species is generally considered as scarcely edible because it is rather insipid, it is not unpleasant. Cathered with Black Raspberries or Red Raspberries, they can be mixed together for use in pies, jams, and jellies, thus at least increasing the bulk if other fruit should be in short supply. 


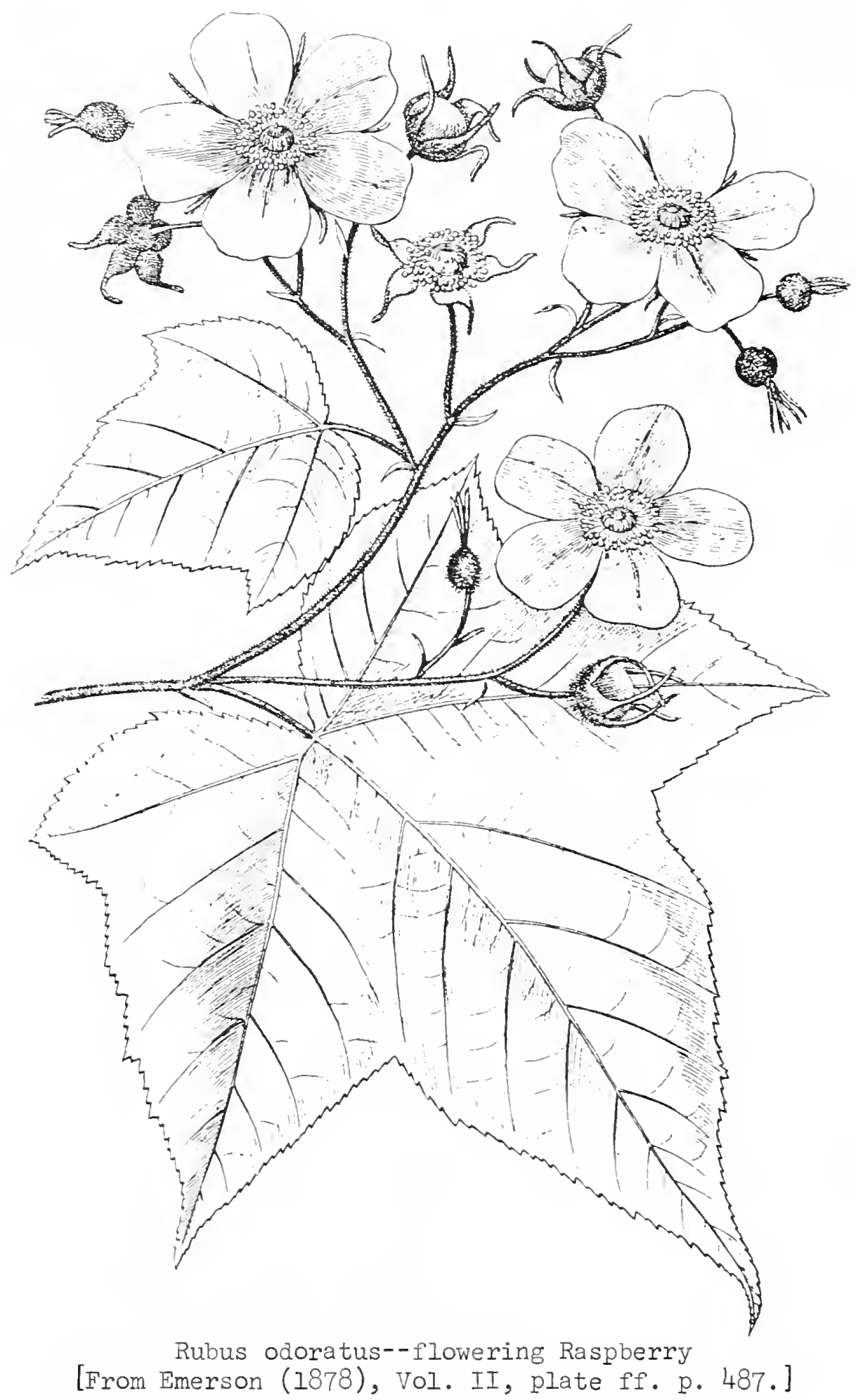

Rübus plicatifòlius Blanch. Plaited-leaved Dewberry.

Meaning of Species Name. With plaited Leaves.

Type of Plant. A trailing or soon recurving and prostrate, tiprooting shrub.

Habitat. Dry open soil.

Range. NS and Me to Que, $s$ to $C t$ and $\mathbb{N}$.

Distr in NYS. Not listed in House (1924).

Distr in the Torrey Range. In 1915 known definitely only from the 


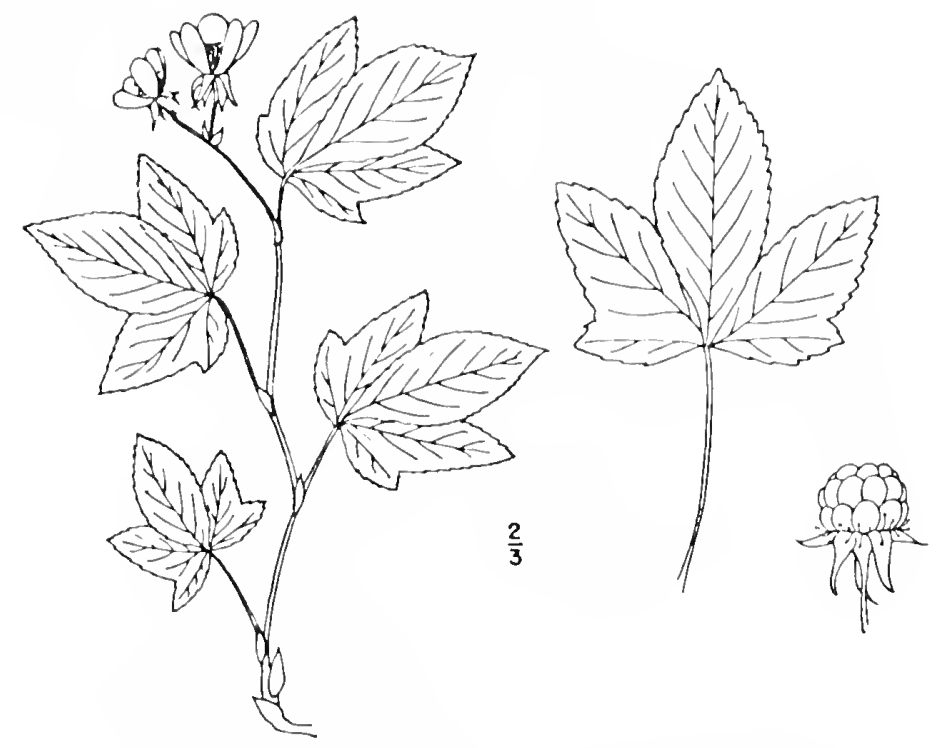

Rubus pubescens--Dwarf Red Blackberry

[From Billington (1949), Fig. 79, p. 158.]

mts in Greene co, NY, and Luzerne co, $\mathrm{Pa}$.

Time of Fl. Jun-Aug.

Origin. Native.

Rubus pubéscens Raf. Dwarf Red Blackberry.

Meaning of Species Name. Hairy.

Other Names. Dwarf Red Raspberry, Running Raspberry, Mulberry,

Plum-bog-berry, Swamp-berry, Pigeon-berry, Dewberry.

Type of Plant. A perennial herb.

Habitat. Damp mossy woods, slopes, swamps. bogs, rocky shores, and thickets.

Range. Lab to Yuk and $\mathrm{BC}$, s to NJ, WVa, O, Ind, Wis, Ia, SD, Col, and Wash.

Distr in NYS. Common northw across the state and westw to L Erie; less common or rare southw to Bronx co; reported from II; frequent only in swamps of the higher hills in the s tier of counties bordering on $\mathrm{Pa}$.

Distr in the Torrey Range. NY: Unknown on LI and SI, rare in Westchester and Bronx co, thence increasing northw.

Time of Fl. May-Jul, fr Jun-Aug; fl May at Cornell.

Origin. Native.

Remarks. Intermediate between blackberries and raspberries.

Rủbus signätus Bailey

Stanley Smith observed this plant in the vicinity of Hancock in Delaware County on a foray to that area 17-19 June 1954. It is not listed by either Taylor (1915) or House (1924). Furthermore, Fernald (1950) includes this taxon in his $\underline{R}$. adjacens and Gleason (1952) places it in his collective species $\mathrm{R}$. hispidus $\mathrm{L}$., where it is given a range from quebec to Michigan, south to Virginia and Illinois. 


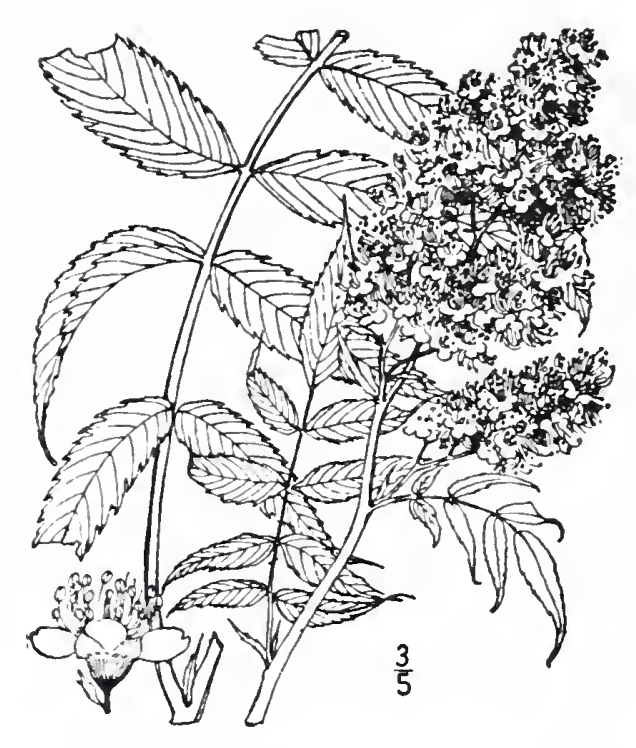

Sorbaria sorbifolia--False Spiraea

[From Britton \& Brown (1913), II: 247.]

Sorbària R. Br. False Spiraea.

This is a genus of about five species of shrubs, all natives of eastern Asia. The name of the genus is derived from the Latin Sorbus, an early name for the mountain-ashes, which have similar foliage.

Sorbària sorbifòlia (I.) A. Br. False spiraea.

Meaning of Species Name. With leaves of Sorbus.

Other Names. Sorb-leaved Schizonotus.

Type of Plant. Shrubby to nearly herbaceous.

Habitat. Roadsides, fencerows, wasteland, and copses.

Range. NB to $\mathrm{Pa}$, $\mathrm{w}$ to Ind and Minn.

Distr in NYS. Frequent in cult and locally esc or persistent in some localities.

Distr in the Torrey Range. A rare esc known definitely only from Ct and NY in our area.

Time of $\mathrm{Fl}$. Jul-Jul.

Origin. Introd and natzd from e Asia.

Remarks. Commonly cult and frequently esc, especially in the e states and e Canada.

Spiraèa L. Spiraea.

There are nearly 100 species of Spiraea, all shrubs of the northern hemisphere with simple leaves and corymbs or panicles of white or rosecolored flowers. The name of the genus is derived from the Greek speira, a wreath. Most of the species are attractive flowering shrubs and nearly 50 species are cultivated for ornament in the northeastern states, some of which have escaped and apparently become established in some areas. 


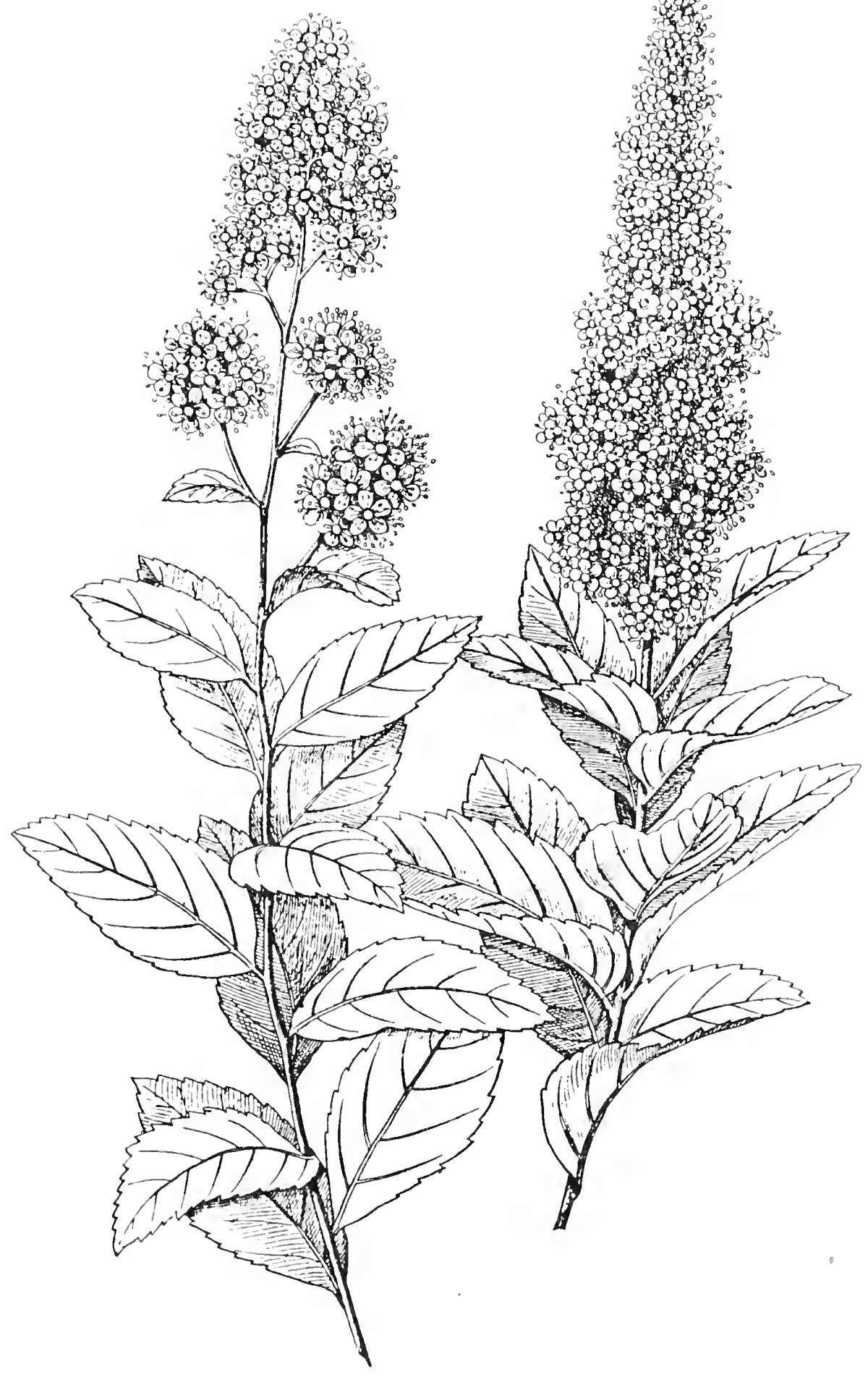

(Left) Spiraea Iatifolia--Broad-leaved Meadowsweet (Right) Spiraea tomentosa-Harahack [From Emerson (1878), Vol. II, plate ff.p. 485.] 
Key to the Local Species of Spiraea

1. Leaves green on both sides (branchlets of panicle glabrous, not puberulent or tomentulose $\ldots \ldots \ldots \ldots \ldots \ldots \ldots \ldots \ldots$. Iatifolia

1. Leaves closely felted beneath with white or tawny to-

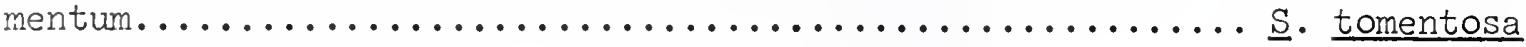

Spiraèa latifòlia (Ait.) Borkh. Broad-leaved Meadowsweet.

Meaning of Species Name. Broad-leaved.

Other Names. American Meadowsweet, Quaker Lady, Queen-of-theMeadow, Spice Hardhack.

Type of Plant. A shrubby perennial 2-5 ft high, reproducing by seeds and rootstocks.

Habitat. Moist or dry, usually upland or rocky soil of old fields, pastures, roadsides, and meadows.

Range. If and Que to Mich, s to NY, Pa, and interior NC.

Distr in NYS. Frequent or locally common throughout most secs of the state.

Distr in the Torrey Range. Throughout the range except the reg e and $s$ of the pine barrens in NJ.

Time of $\mathrm{Fl}$. Jun-Aug(Sep); Jul 15-Aug at Cornell.

Origin. Native.

In areas where this species has become an undesirable weed, Muenscher (1952) suggests that small clumps can be grubbed out with a mattock, while it is best to pull out large clumps with a team or tractor and chain. Dense growths should be cut with a brush hook and burned. Where possible the land should then be plowed, disked or harrowed several times, and followed by a clean cultivated crop for a year before reseeding.

\section{Spiraèa tomentòsa L. Hardhack.}

Meaning of Species Name. Tomentose.

Other Names. Steeplebush, Silver-leaf, Silver-weed, White-cap, Woolly Meadowsweet, Poor-man's-soap, Spice-hardhack, Rosy-bush.

Type of Plant. A simple or sparsely branched shrub growing $1-4 \mathrm{ft}$ high, reproducing by seeds and shoots from creeping roots.

Habitat. Sterile pastures and old fields.

Range. NS and NB to Que and Man, s to Va, NC, Ga, Tenn, and Ark. Distr in NYS. Frequent across the state northw, and in the Adirondacks to $2000 \mathrm{ft}$; common in C NY, the Ontario lowlands, and on II and II SI; less frequent or rare in the w NY highlands.

Distr in the Torrey Range. Throughout the range in favorable localities; usually very common.

Time of Fl. Jul-Sep; Jul-Aug at Cornell.

Origin. Native.

Vogel (1970) states that the Mohegans steeped the leaves of Hardhack to make a tea for use in the treatment of dysentery, while the Flambeau Ojibwas made a tea of the leaves and flowers for "morning sickness" during pregnancy and to aid parturition. In 1849 Dr. Francis P. Porcher reported 


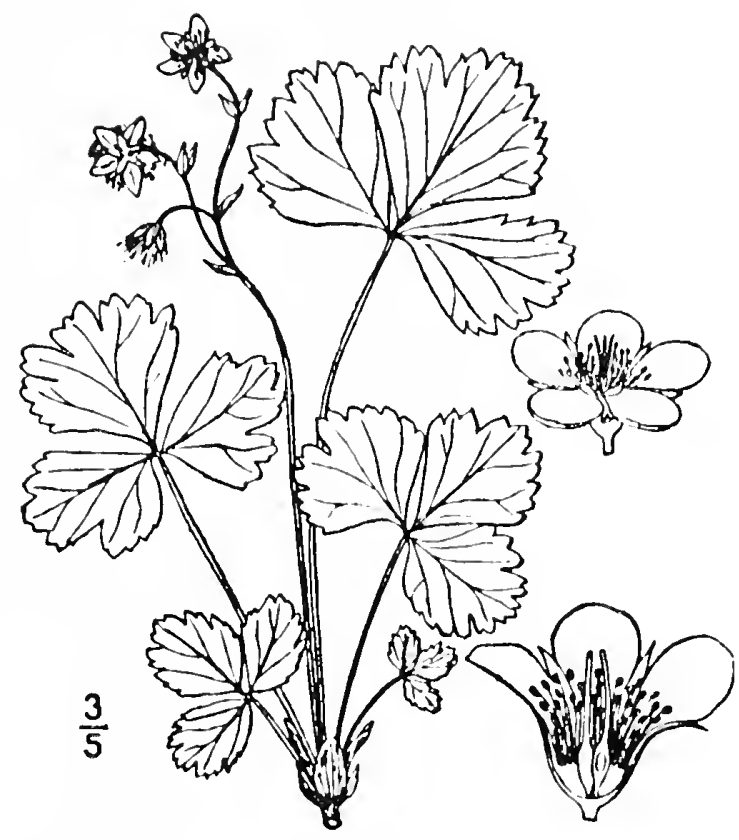

Waldsteinia fragarioides--Barren Strawberry

[From Britton \& Brown (1913), II: 269.]

that the Indians made use of this plant and that Dr. Cogswell of Connecticut had brought it to the attention of the medical profession. It was then considered a valuable tonic and astringent useful in the treatment of diarrhea and cholera infantum. Dr. A. Clapp considered the bark and leaves more efficient than the root, which was the official part; it was thus listed in the U.S. Pharmacopeia, 1820-82, for its astringent and tonic properties, considered usefuz in the treatment of diarrhea, hemorrhage, gonorrhea, and ulcers. The U,S. Dispensatory of 1865 considered that "In consequence of its tonic powers it is peculiarly adapted to cases of debility; and, from the same cause, should not be given during the existence of inflammatory action, or febrile excitement."

In areas where this species has become an undesirable weed, it can be controlled by the same methods as those outlined for $\underline{S}$. latifolia.

Waldsteinie Willd. Barren Strawberry.

There are five species of Waldsteinia, low perennial herbs of the north temperate zone with chiefly radical 3-5-lobed or -divided leaves and bracted scapes of small yellow flowers. The genus was named to honor Graf Franz de Paula Adam von Waldstein-Wartenburg, 1759-1823, a German botanist.

Waldsteinia fragarioides (Michx.) Tratt. Barren Strawberry.

Meaning of Species Name. Like Fragaria, Strawberry.

Other Names. Dry Strawberry.

Type of Plant. A low perennial herb.

Habitat. Open rocky woods, thickets, clearings, and shaded hillsides. 
Range. Me and w Que to Minn, s to Pa, uplands of $\mathrm{Ga}$ and Tenn, and locally to Ind and Mo.

Distr in NYS. Frequent or common across the state, especially in the mountainous and hilly secs, s to Ulster, Columbia, Greene, and Sullivan co; infrequent or rare in the $s$ tier of counties bordering on $\mathrm{Pa}$.

Distr in the Torrey Range. NY: Ulster, Sullivan, Dutchess, Delaware, and Greene co.

Elevation. 800-4020 ft in the Torrey range.

Time of Fl. Late Apr-May(Jun); Apr 25-May 20 at Cornell. Origin. Native.

This plant is a handsome species for the woodland wildflower garden or a shaded rock garden, where it spreads over rocky slopes having good drainage; it prefers an acid soil.

\section{LEGUMINOSAE, the Pea Family}

This family is considered to be one of the three largest families of flowering plants. The Compositae is the largest family, with the Orchidaceae and the Leguminosae competing for second place. The Ieguminosae include about 550 genera and perhaps 13,000 species, cosmopolitan in distribution. They are herbs, shrubs, or trees with mostly alternate, compound leaves. The family is divided into three subfamilies, treated by some authorities as separate families comprising a separate order. Lawrence (1951) remarks that "many botanists, perhaps with undue conservatism and adherence to tradition, have held the Ieguminosae to comprise a single family rather than 3 or 4 families." Although comparative studies of wood anatomy produced "no sharp lines separating the three subfamilies," elevation of this taxon to a separate order should perhaps be deserving of more thought.

Economically the Leguminosae constitute one of the most important families of flowering plants. Not only are many species grown ornamentally, but many others provide food, fodder, dyes, gums, resins, and oils. Among the important food plants are garden peas, lentils, peanuts, beans, cowpeas, and soybeans. Important fodder and forage plants include clover, alfalfa, soybean, vetch, bird'sfoot trefoil, and sweet clover, while among the more outstanding ornamentals are wisteria, sweet pea, lupine, redbud, royal poinciana, broom, and senna. Some trees are also much valued for their lumber.

\section{Key to the Catskill Genera of Leguminosae}

1. Trees, shrubs, or woody vines; leaves compound, 2

2. Leaflets 3 ; flowers purple to white; erect or spreading

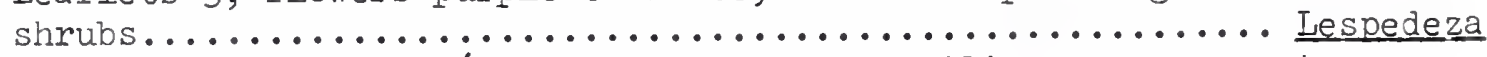

2. Leaflets more than 3 (flowers distinctly papilionaceous; erect or ascending trees or shrubs; flowers white to pink or rose color; flowers in racemes; lower calyx lobes acute to acuminate)..... Robina 
1. Herbaceous plants, or only slightly woody at base, 3

3. Leaves simple, or I-foliate, or represented by their stipules only, or none, 4

4. Leaf blade none; leaves represented by a pair of foliaceous stipules bearing a tendril between them; flowers

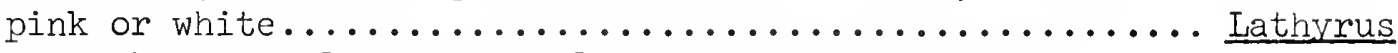

4. Leaf blade developed, much larger than the stipules; tendrils none; flowers yellow, in racemes (leaves

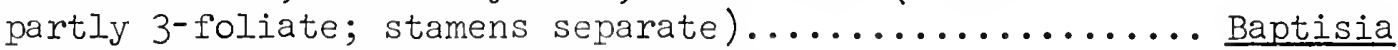

3. Leaves compound, 5

5. Leaves evenly pinnate, or the terminal leaflet represented by a tendril, 6

6. Tendrils none; leaflets 2-6; flowers white and violet,

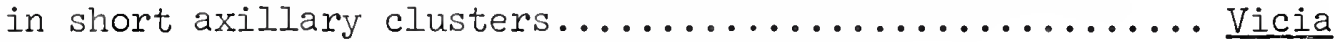

6. Tendrils present, terminating all or most of the leaves, 7

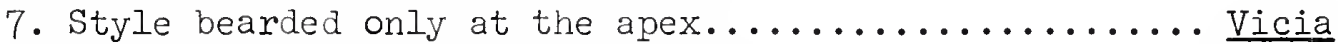

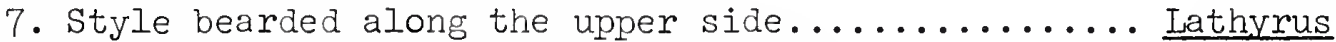

5. Leaves odd-pinnate, palmate, or trifoliate, 8

8. Leaflets on ordinary well-developed leaves more than

3, 9

9. Flowers in heads or umbels or solitary, 10

10. Flowers yellow; heads subtended by entire bracts.. Lotus 10. Flowers white to pink; leaflets entire; flowers 10-15 mm long, 10-15 in each head........ Coronilla

9. Flowers in terminal, axillary, or lateral spikes

or racemes, 11

11. Leaflets $7-18$, palmately compound........... Lupinus

11. Leaves pinnately compound (calyx with 5 unequal

lobes, the upper 4 short, nearly equal, the

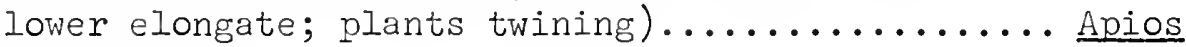

8. Leaflets 3,12

12. Leaflets serrulate, 13

13. Terminal leaflet sessile or nearly so...... Trifolium

13. Terminal leaflet distinctly stalked, 14

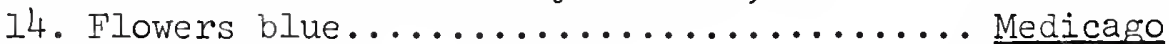

14. Flowers white or yellow, $15 \ldots \ldots \ldots$ Melilotus

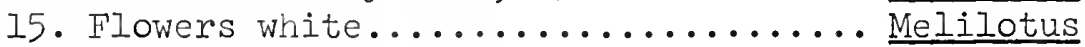

15. Flowers yellow, 16

16. Flowers in slender elongate racemes

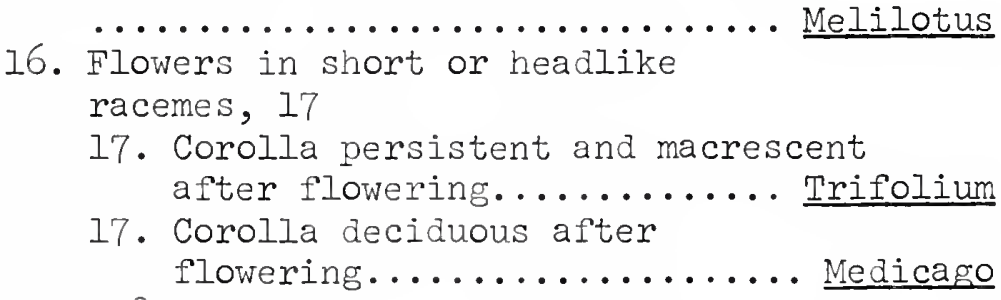

12. Leaflets entire, 18

18. Flowers yellow or cream color, 19

19. Flowers in open peduncled racemes (racemes

terminal; terminal leaflet sessile or

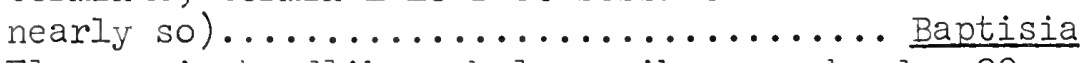

19. Flowers in headike umbels, spikes, or heads, 20 
20. Flowers cream color, usually with a purple spot on the standard; calyx lobes about equal................. Lespedeza

20. Flowers bright yellow; calyx lobes distinctly unequal in size (flowers few, in long-peduncled headlike umbels). Coronilla 18. Flowers blue or purple to pink or white, 21

21. Stems normally twining, or in the absence of support trailing, but then usually twining on themselves, 22

22. Calyx lobes 5 (flowers 10-12 mm long, numerous,

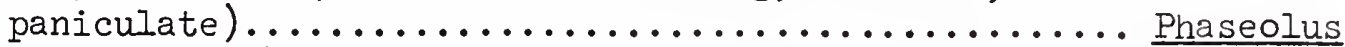

22. Calyx lobes 4 , by the fusion of the upper 2, 23

23. Keel petals strongly curved upward (flowers in

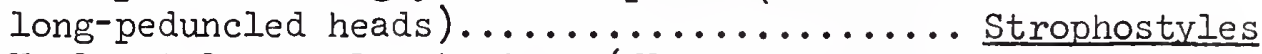

23. Keel petals nearly straight (flowers without bracteoles; bracts at base of the pedicel per-

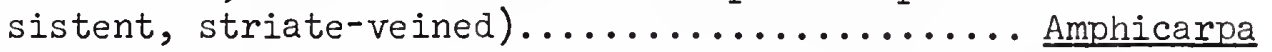

21. Stems erect, ascending, spreading, or prostrate, but with no tendency to twine, 24

24. Flowers in terminal racemes, 25

25. Terminal leaflet distinctly stalked.......... Desmodium

25. Terminal leaflet sessile, or with a stalk no longer than the stalks of the lateral leaflets......... Baptisia 24. Flower clusters axillary, 26

26. Stems prostrate; leaflets with stipellules (often deciduous in age)................. Desmodium

26. Stems erect, ascending, or spreading; stipellules none..................... Iespedeza

Amphicárpa Ell. Hog Peanut.

There are seven known species of Amphicarpa, the other six all natives of eastern Asia. They are low, slender, perennial herbs with twining stems, 3-foliate leaves, and mostly purplish flowers. The name of the genus is derived from the Greek amphi, both or of both kinds, and karpos, fruit, referring to the two kinds of fruit often produced--3seeded pods and 1-seeded pods. Fruit of the Wild Bean of the Himalayas, A. edgeworthii, has been gathered while green for use as food.

Amphicárpa biracteàta (I.) Fern. Hog Peanut.

Meaning of Species Name. Bracted.

other Names. Wild Peanut, Pea-vine, American Licorice.

Type of Plant. A perennial herb.

Habitat. Damp woodlands, thickets, and open marshy spaces.

Range. Que and NS to Man and Mont, s to Fla, La, and Tex.

Distr in NYS. Common throughout the state.

Distr in the Torrey Range. Common throughout the range except in

the pine barrens of NJ, there rare or wanting; always decreasing southw. Time of $\mathrm{Fl}$. Aug-Sep; Aug at Cornell.

Origin. Native. 


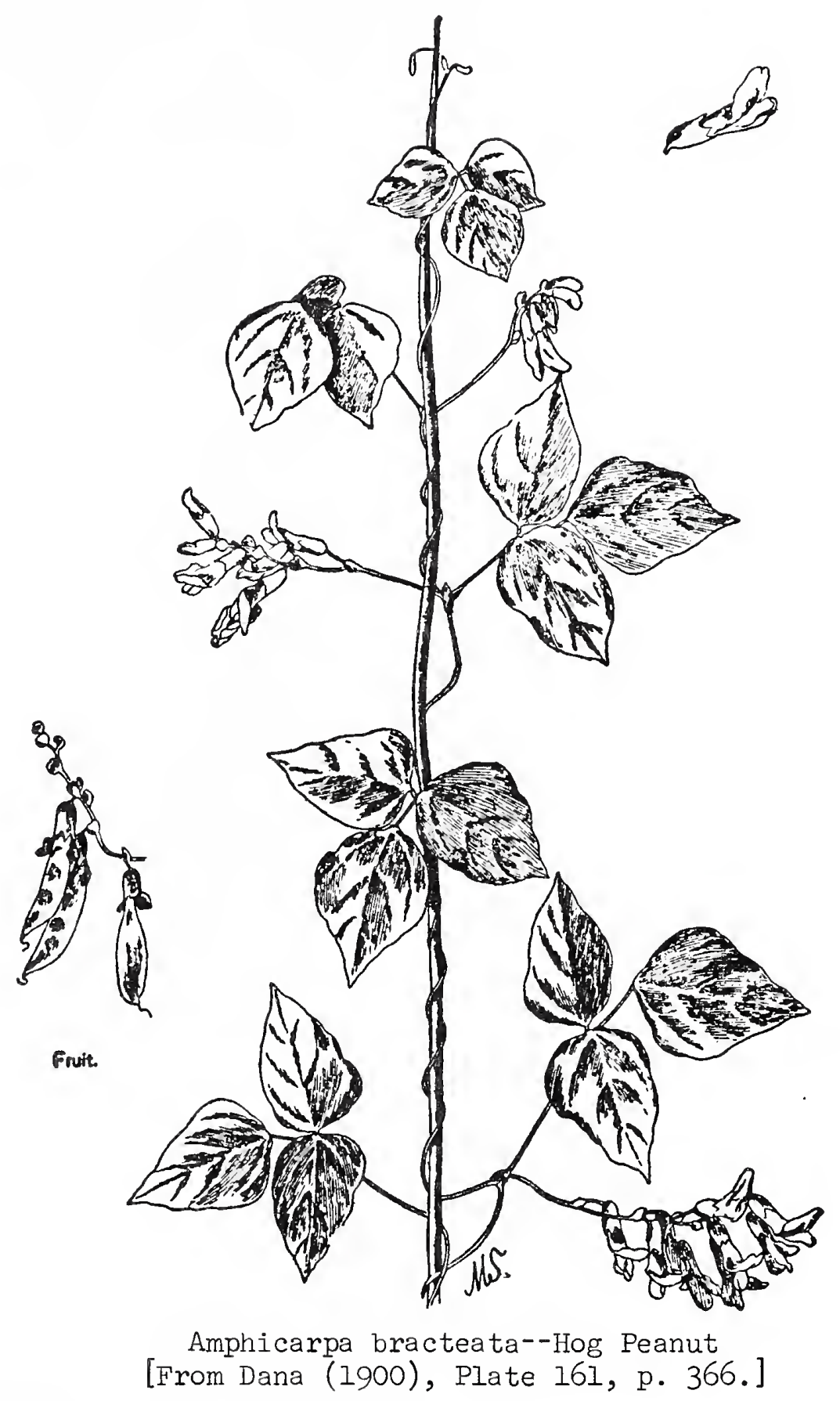

Near the roots of this plant tiny blossoms without petals appear on threadlike branches. These self-fertile flowers produce pods that develop one large light brown seed about the size and shape of a peanut. Hogs running about in the woods often root up the leaves and soil in search of them, hence the common name of Hog Peanut. These large seeds appearing beneath the dead leaves or just under the surface of the ground are often quite abundant. They can be gathered without destroying the plant and even when raw make very pleasant eating. According to Porcher, this species was once cultivated in the south for its nutritious seeds.

These subterranean fruits were well known to the Indians, particularly in the central states, where they were gathered in large quantities. 
The "skin" or shell is somewhat leathery, but it cracks off in boiling, exposing the nutritious bean. Weiner (1972) reports that these fruits contain approximately 25 percent protein, "the highest protein yield of any wild plant consumed by the Indians." The Indians sometimes ate these beans raw, removing the shell by soaking the fruit in warm water or in water to which hardwood ashes was added, after which the shells could be removed by rubbing. These beans are often sufficiently abundant to repay the time spent in digging them up. When boiled and seasoned with salt, pepper, and butter or cream, they much resemble shelled beans from the garden, although they are of a rather dry quality. Voles, white-footed mice, and other rodents often gather quantities of these beans, their nests often containing several quarts of them. It is reported that in autumn and early winter Indian women were not averse to robbing the rodents of their winter stores, securing "big piles of them." Father De Smet, a missionary to the tribes of the upper Missouri, wrote that "The earth pea and bean are also delicious and nourishing roots found commonly in low and alluvial lands. The above-named roots form a considerable portion of the sustenance of these Indians during the winter. They seek them in places where the mice and other little animals, in particular, the ground squirrel, have piled them in heaps." In their defense, however, Gilmore states that the Dakota Indians, at least, "always replaced them" with "an equivalent amount of corn or other food." The Chippewas also used this plant medicinally, preparing a decoction of five roots in 1 quart of water to be taken internally as a physic and to purify the blood.

These underground fruits, available in late fall and early spring, should be remembered as an important survival food should one become lost in the wilderness. Quail and other birds eat both the aerial and subterranean seeds of this plant, and white-tailed deer are reported to browse on the leaves, but since they are locally abundant at best, they are of limited significance to wildlife, at least in the Catskill region.

Àpios Medic. Wild Bean, Ground-nut.

There are about seven species of Apios, two in North America, the others native to eastern Asia. They are twining herbaceous perennials with compound leaves, flowers in dense, often branching, short racemes, and rootstocks bearing tuberous enlargements. The name of the genus is derived from the Greek apios, pear, alluding to the somewhat pyriform shape of the tuberous enlargements of the rootstock.

Ápios americàna Medic. Ground-nut.

Meaning of Species Name. American.

Other Names. Wild Bean, Ground-pea, Trailing-pea, Potato-pea, Pigpotato, Dacotah-potato, Indian Potato, White Apple, Traveler's-delight.

Type of Plant. A perennial herb.

Habitat. Rich woods and thickets, especially in alluvial thickets along streams.

Range. NB and que to Minn, SD, and Col, s to Fla, La, and Tex. 


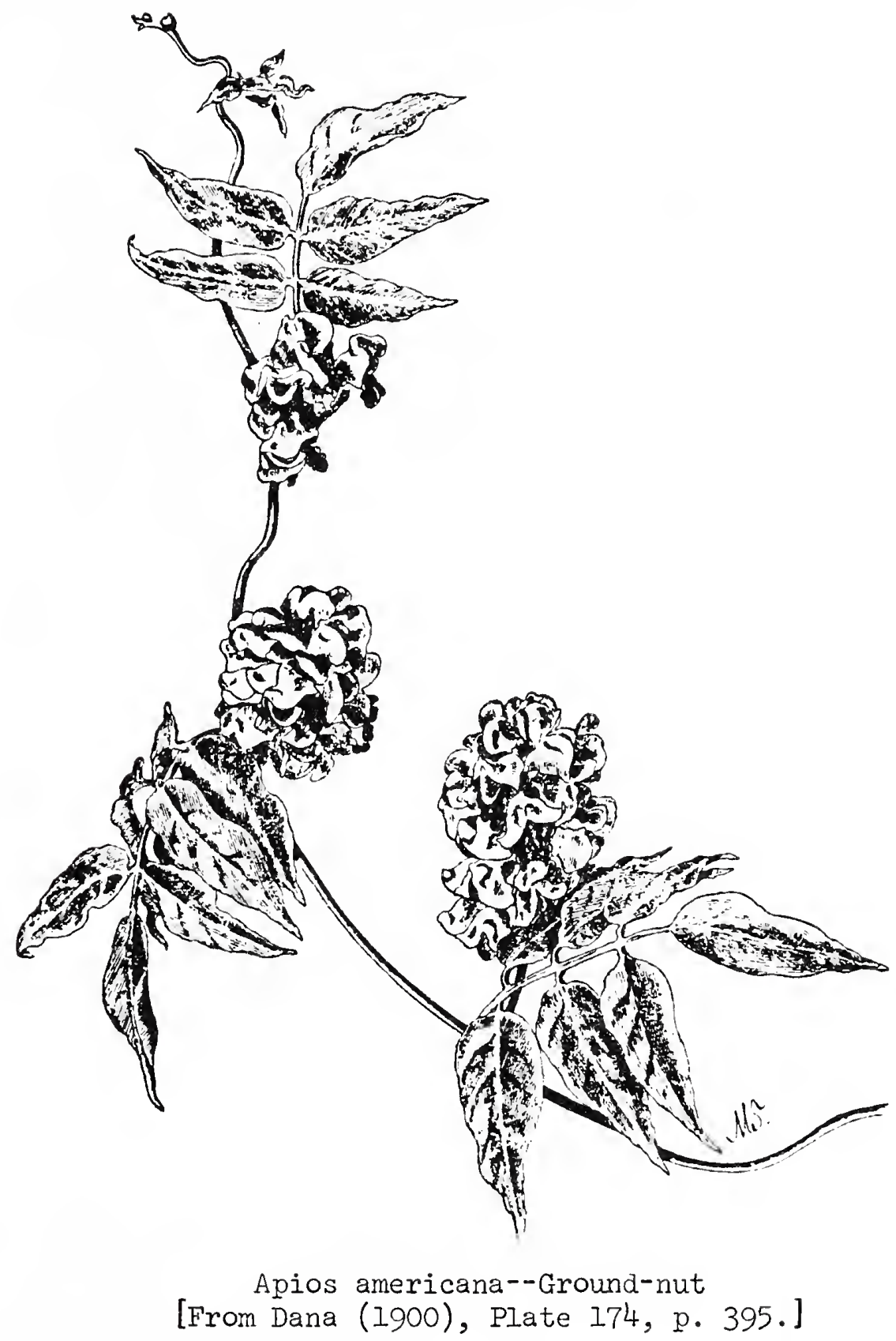

Distr in NYS. Frequent or common in most parts of the state but rare in most secs of the Adirondacks and apparently absent from the $n$ portion of the Adirondacks.

Distr in the Torrey Range. Common throughout the range.

Time of Fl. Jul-Aug(Sep); Aug-Sep 10 at Cornell.

Origin. Native.

Remarks. The stem contains a milky juice.

The Ground-nut or Indian Potato, found throughout much of eastern North America, was one of the few native plants held in high repute by the Indians. It therefore soon attracted the attention of the European colonists, who wrote with enthusiasm of its virtues and possibilities in their early chronicles. Thomas Hariot's $A$ briefe and true report of the new 
found land of Virginia, published in 1590, probably contains the first account of this plant in the English language: "Openavk are a kind of roots of round forme, some of the bigness of walnuts, some far greater, which are found in moist and marish grounds growing one by another in ropes, or as thogh they were fastened with a string, being boiled or sodden they are very good meate."

It is reported that the Indians showed this species to the Pilgrims of Massachusetts; during that first hard winter they were forced to subsist largely upon the edible tubers of this plant for want of other supplies. Ironically enough, by 1654 they passed a law forbidding the Indians from digging these tubers on "English land." For a first offense, the guilty Indian could be jailed; for a second, whipping was the reward. Peter Kalm, an early visitor to North America, reported that "Mr. Bartram [of Philadelphia] told me that the Indians who live farther in the country do not only eat these roots, which are equal in goodness to potatoes, but likewise take the peas which lie in the pods of this plant and prepare them like common peas." Ordinarily, however, the fruits are too scarce to provide much food.

The Indians rightly considered these tubers among the finest of foods available to them, for in so far as nutritive value is concerned, they contain 18 percent protein by weight. Not only did the Pilgrims make use of them, but the Finns and Swedes who first settled the Delaware valley gathered and ate them "for want of bread." Even during the Civil War they supplemented scanty food supplies in some areas. This plant was cultivated in France as early as 1635, but it was soon forgotten. Another attempt was made to introduce it in Europe in 1845 as a possible substitute for the potato, which was becoming subject to disease, but attempts to cultivate it were soon abandoned as impracticable. Not only did it require two or three years for the tubers to reach a size fit for use, but its habit of producing strings of tubers just beneath the surface of the soil made weeding the field practically impossible.

The raw tubers have been described as being "somewhat tough, with a very viscid milky juice, but of a pleasant sweetish, turnip-like taste." They can be eaten raw, "but the viscid juice leaves an unpleasant rubberlike coating on the teeth and lips." This disagreeable quality is removed by roasting or parboiling with salt. They can be boiled in salted water and eaten with butter like potatoes, but a more satisfactory method of preparation is to slice the tubers, skin and all, and fry them in bacon fat like fried potatoes, for which they make a "satisfactory substitute." These fried slices should be eaten hot, for upon cooling they become "tough and uninteresting." Leftover Ground-nuts will regain their flavor if they are greased and then roasted in the oven for a while. Some people may not regard their sweet, turnip-like taste as anything special, but they can at least add novelty to a meal. 


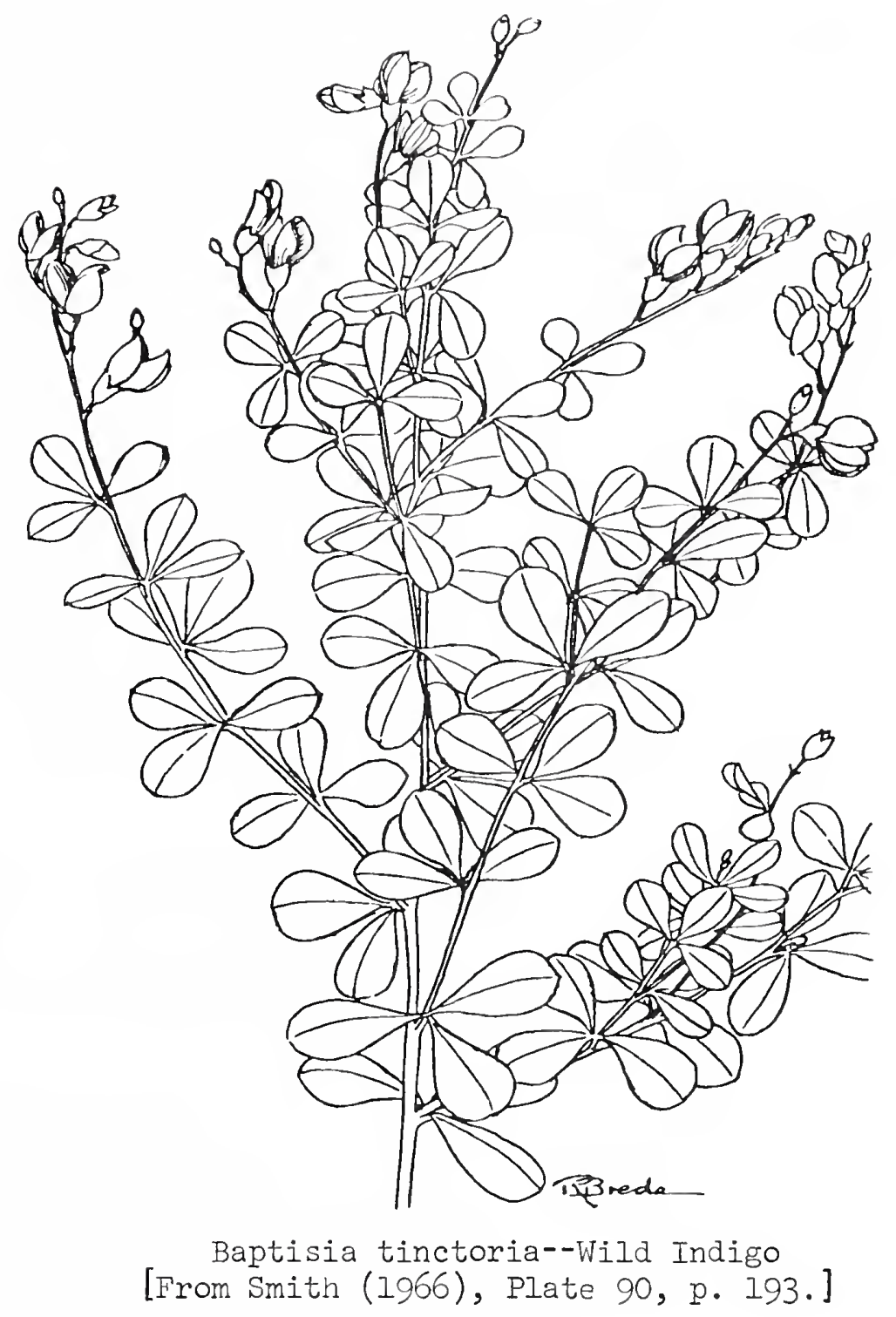

Baptisia Vent. Wild Indigo.

There are about 30 species of Baptisia, perennial eastern and southern North American herbs with palmately 3-foliate (rarely simple) leaves and racemose flowers. The name of the species is from the Greek baptizein, to dye, in allusion to the use of some species as a poor substitute for indigo. Some species turn black in drying. The Meskwakis used B. leucantha in combinations with other herbs for several purposes, including the treatment of eczema, wounds, sores, catarrh, and snakebite, as well as for its emetic properties. In Iowa this species was also used by the whites as an emetic and cathartic.

Baptisia tinctoria (L.) R. Br. Wild Indigo.

Meaning of Species Name. Used for dyeing.

Other Names. Rattleweed, Horsefly-weed, Yellow Broom, Indigo Broom, Clover Broom, Indigo-weed, Shoofly, Rattlebush, Horse-fleaweed. 
Type of Plant. A perennial herb. soil.

Habitat. Dry open woods and clearings, usually in sandy or gravelly

Range. Me to s Ont, Mich, and se Minn, s to Fla, Ga, and Tenn.

Distr in NYS. Frequent or locally common across the state $s$ of the Adirondack reg, becoming more abundant or common southw.

Distr in the Torrey Range. Common throughout the coastal part of the range, always decreasing inland, but locally common in sandy places northw.

Time of Fl. (Late May) Jun-JuI(Aug).

Origin. Native.

Remarks. More common southw.

Vogel (1970) remarks that the Creek Indians boiled the roots of this species in water and administered the decoction both internally and externally to children who seemed listless and on the point of becoming ill. other tribes steeped the root and used the liquid to bathe cuts and wounds. This species was official in the U.S. Pharmacopeia, 1831-42, and in the National Formulary, 1916-36, for use as an emetic, cathartic, stimulant, astringent, and antiseptic.

Coronilla I. Crown-vetch.

There are about 25 species of Coronilla, glabrous herbs or shrubs, natives of western Eurasia and northern Africa, with pinnate leaves and flowers in umbels on axillary peduncles. The name of the genus is a diminutive of the Latin corona, a crown, alluding to the inflorescence.

\section{Coronilla vària L. Crown-vetch.}

Meaning of Species Name. Variable.

other Names. Coronilla, Axseed, Axwort, Hive Vine.

Type of Plant. A perennial herb.

Habitat. Roadsides, waste places, and old house-sites.

Range. Abundantly but locally estab from NE to SD, s to $\mathrm{Va}, \mathrm{NC}$, WVa, Ky, and Mo.

Distr in NYS. Infrequent, but when estab becoming abundant; natzd in many parts of the state.

Distr in the Torrey Range. In 1915 considered uncommon as a roadside weed throughout the area except in $\mathrm{Pa}$, there reported only from Chester co.

Time of Fl. (May) Jun-Aug(Sep); Aug at Cornell.

Origin. Introd and natzd from Eu.

Remarks. Originally cult. Since 1960 much planted on roadside banks in the Catskills to prevent soil erosion.

This perennial plant forms large clumps of spreading stems with showy umbellate clusters of rose-colored flowers. It does well as a cultivated plant, making an attractive addition to the perennial border. It is much planted by county and town officials in the Catskill region to help bind the soil on roadside cuts and banks and as a consequence is quite abundant in that area. Muenscher (1949) reports that this plant, 


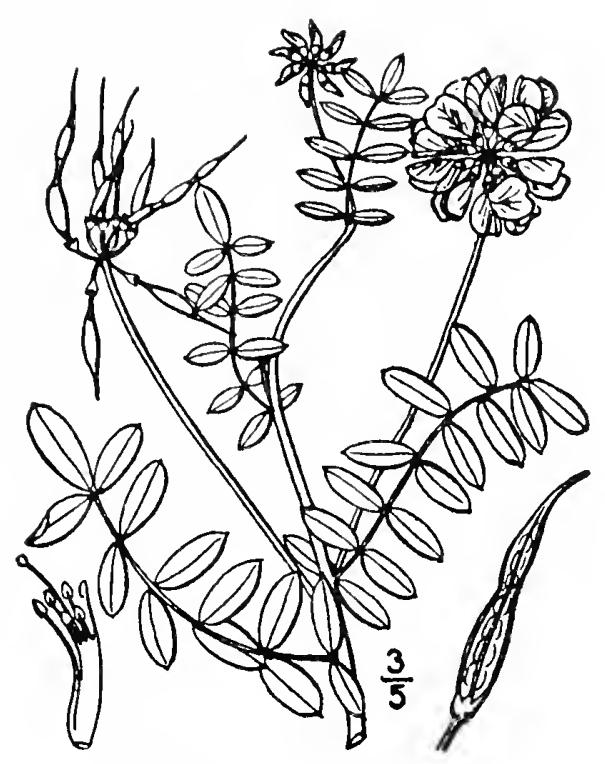

Coronilla varia Crown-vetch

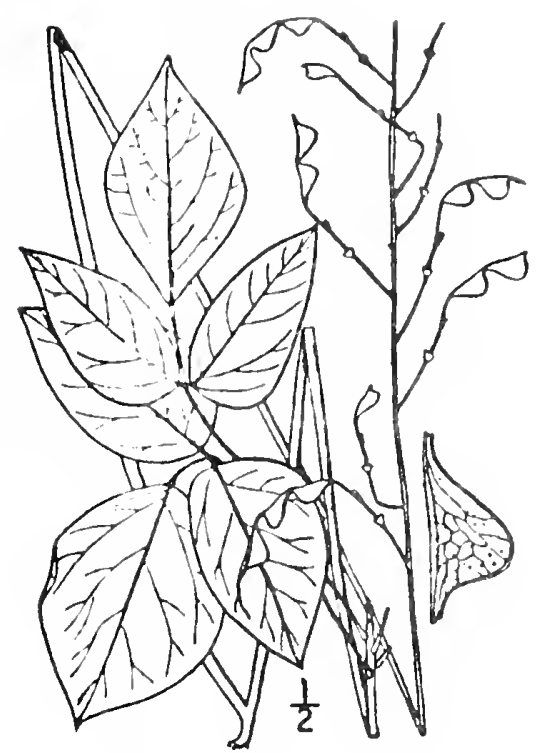

Desmodium nudiflorum Naked-flowered Tick-trefoil

[From Britton \& Brown (1913), Vol. II, pp. 392, 395.]

"especially the seed, has been considered poisonous in Europe," but little seems to be known about its toxic action.

Desmòdium Desv. Tick-trefoil.

There are more than 200 species of tick-trefoil, herbaceous to almost arborescent plants of cool temperate to tropical regions of the Americas, southern Africa, eastern Asia, and Australia. The name of the genus is derived from the Greek desmos, a bond or chain, in allusion to the jointed seed pod. Although the tick-trefoils or beggarweeds are in some areas common in fields, along fencerows, and in open woods of the eastern United States, they have only limited value for wildlife. Martin et al. (1961) report that "The bobwhite quail is the only species known to feed on them to any extent." Although Desmodium is considered both by TayIor (1915) and House (1924) to be "common throughout the range" or "Frequent or common across the state," this is an uncommon genus in the Catskill region.

\section{Key to Local Species of Desmodium}

1. Peduncles very long and leafless; fruit on a long stalk within the calyx; leaves all crowded at summit of stem (leaves and flowers on separate stems, the raceme on an ascending naked branch from near

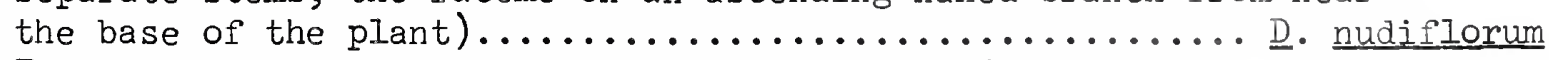

1. Peduncles not conspicuously elongated; stalk of fruit never more than twice the length of the calyx, 2

2. Plants trailing, prostrate, soft-hairy all over; leaflets orbicular; racemes simple, axillary and terminal..... D. rotundifolium

2. Plants more or less erect, glabrous or hairy; racemes panicled; leaflets somewhat elongated, not orbicular, 3 


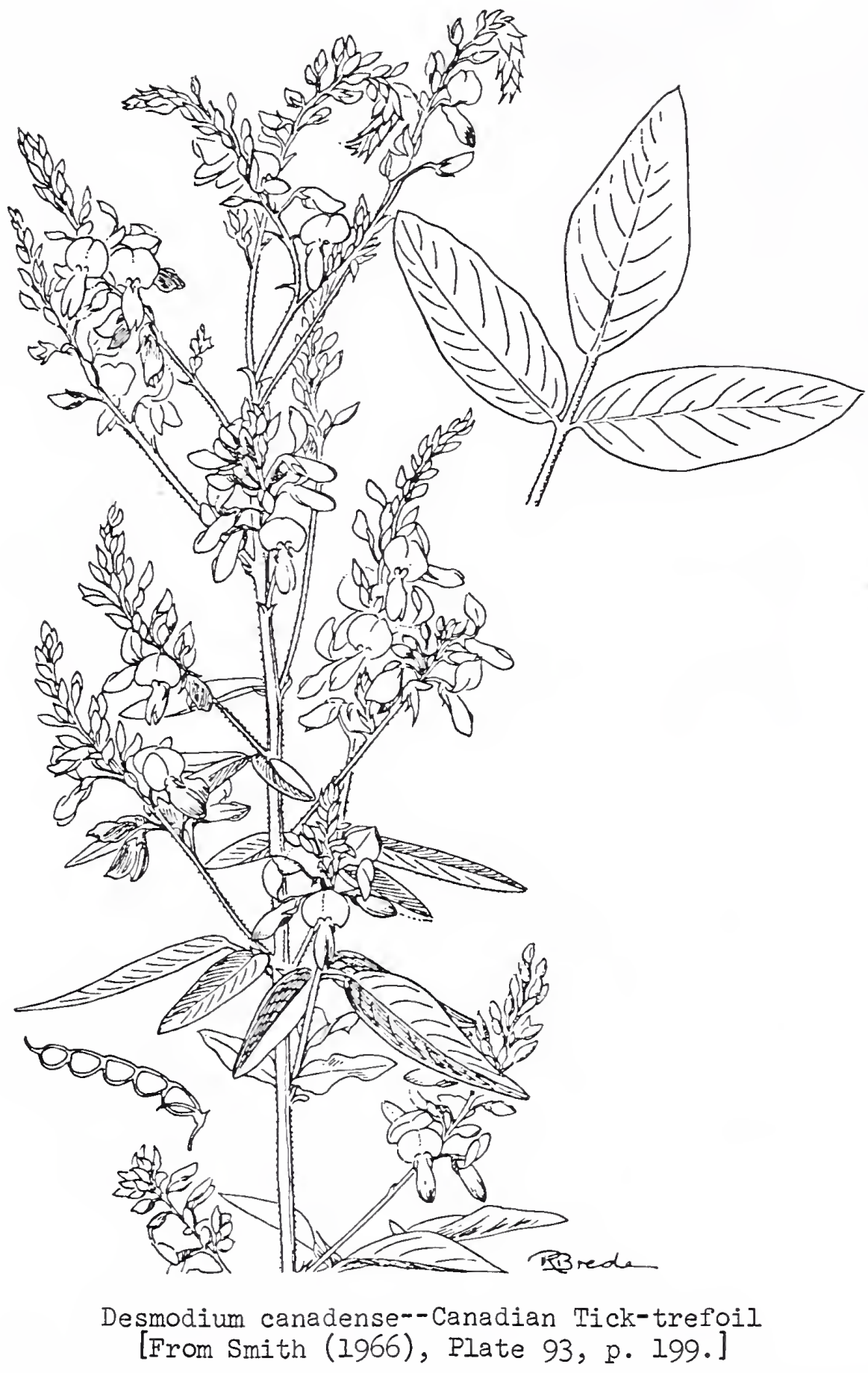

3. Fruit sessile in the calyx, or essentially so; flowers 10-13 mm long (rose-purple, changing to blue); calyx 5-7 mm long; stem

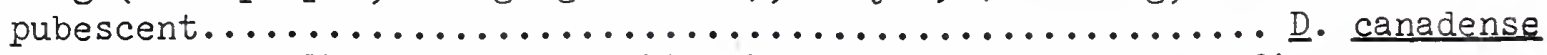

3. Fruit on a stalk equaling or slightly exceeding the surrounding calyx; flowers usually 6-8 mm long; calyx 2.5-3.5 mm long; plant essentially smooth throughout.................... paniculatum 


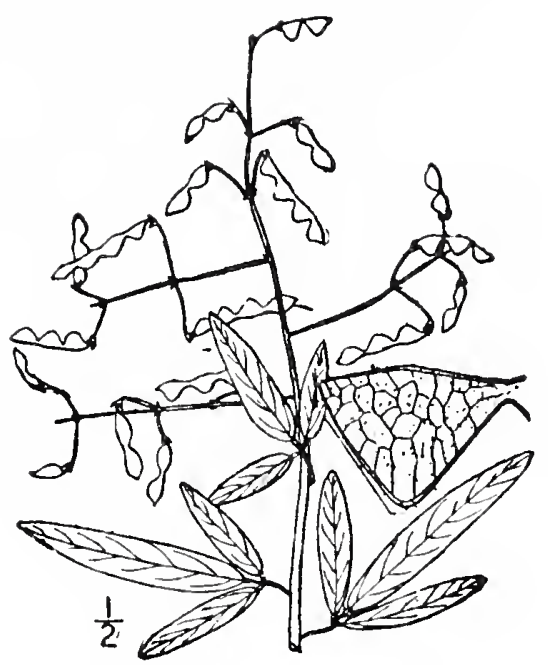

Desmodium paniculatum Panicled Tick-trefoil [From Britton \& Brown (1913), Vol. II, pp. 399, 397.]

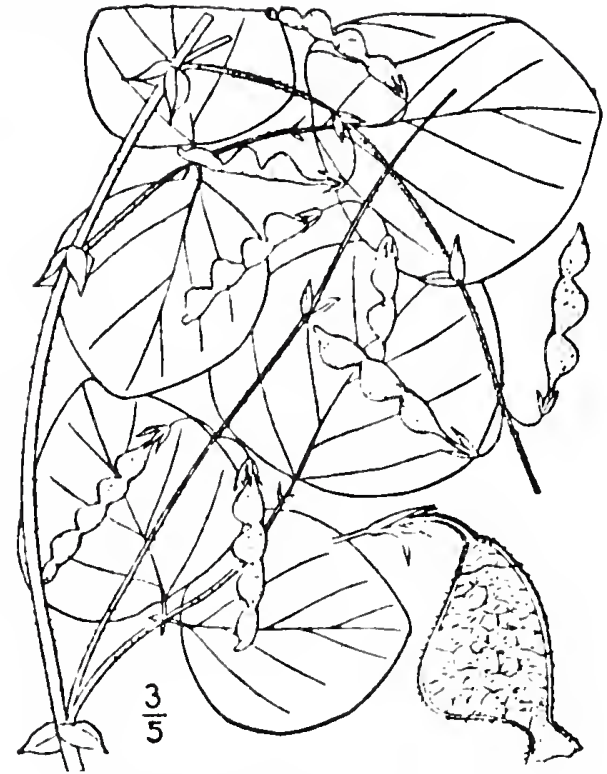

Desmodium rotundifolium Round-leaved Tick-trefoil

Desmòdium nudiflórum (I.) DC. Naked-flowered Tick-trefoil.

Meaning of Species Name. With naked flowering scapes.

Type of Plant. A perennial herb.

Habitat. Rich or dry woods and openings.

Range. Me to Wis and Minn, $s$ to Fla and Tex.

Distr in NYS. Frequent or common throughout most secs of the state outside the higher Adirondacks.

Distr in the Torrey Range. Throughout the area except in the pine barrens of $\mathrm{NJ}$, there wanting.

Time of Fl. Jul-Aug; Jul 20-Aug at Cornell.

Origin. Native.

Desmòdium rotundifòlium DC. Round-leaved Tick-trefoil.

Meaning of Species Name. Round-leaved.

Other Names. Prostrate Tick-trefoil, Trailing Tick-trefoil, Hivevine, Dollar-leaf.

Habitat. Dry woods, barrens, and borders of thickets.

Type of Plant. A perennial herb.

Range. Vt and Mass to Mich and Mo, s to Fla, Ga, La, and Tex.

Distr in NYS. Frequent or common across the state southw; less conmon or local northw to Saratoga, Oneida, Oswego, Monroe, and Erie co.

Distr in the Torrey Range. NY: Uncommon on LI and SI, decreasing northw to the highlands; in 1915 unknown elsewhere.

Time of Fl. Jul-Sep; Aug at Cornell.

Origin. Native.

Remarks. Taylor (1915) observes that this is "A rare and very local species about whose distribution little is known." 
Desmódium canadénse (L.) DC. Canadian Tick-trefoil.

Meaning of Species Name. Of Canada.

Other Names. Showy Tick-trefoil, Beggar's-lice, Sainfoin.

Type of Plant. A perennial herb.

Habitat. Open woods, thickets, and riverbanks.

Range. Que and NS to Sask and Alta, s to SC, WVa, O, Ind, III, Mo, Orla, and Ark.

Distr in NYS. Frequent or common across the state, but rare or absent on the coastal plain of LI.

Distr in the Torrey Range. Throughout the range except in the pine barrens, there rare and local and probably introd, always increasing northw.

Elevation. Grows to $2000 \mathrm{ft}$ in the Adirondacks.

Time of Fl. Jul-Aug; Aug-Sep at Cornell.

Origin. Native.

Remarks. In many places the commonest and most conspicuous species; our most showy-flowered species.

Desmòium paniculàtum (I.) DC. Panicled Tick-trefoil.

Meaning of Species Name. Paniculate.

Type of Plant. A perennial herb.

Range. Me to Ont, Mich, Ia, Neb, and Kan, s to Fla and Ter.

Distr in NYS. Frequent or common across the state outside the Adirondacks but extending, in sandy secs, well into the e, s, and $w$ foothills.

Distr in the Torrey Range. Common throughout the range except in the pine barrens of $N J$, there rare or wanting; not abundant on the coastal plain of $L I$.

Time of 피. Jul-Aug; Aug 10-30 at Cornell.

Origin. Native.

Remarks. Often abundant. The seeds are eaten by bobwhite and wild turkey.

Muenscher (1952) remarks that "Several of the native Desmodiums of the eastern United States may encroach upon pastures, especially those bordering on woodlands. He suggests mowing or close grazing the pastures; clean cultivation of fields will rid them of these weeds.

\section{Läthyrus L. Vetchling, Perennial Pea.}

There are about 160 species of Lathyrus, natives of the north temperate zone and temperate South America, our species perennial and mostly smooth herbs. The name of the genus is derived from the Greek lathyros, a leguminous plant of Theophrastus. The name is often said to be composed of the prefix la, very, and thuros, passionate, the original plant reputed to be an aphrodisiac. This genus is closely related to Pisum, which includes the Garden Pea.

Poisoning of both human beings and livestock after eating large amounts of the seeds of $I$. Sativus, the Grass Pea or Indian Pea, I. cicera, 


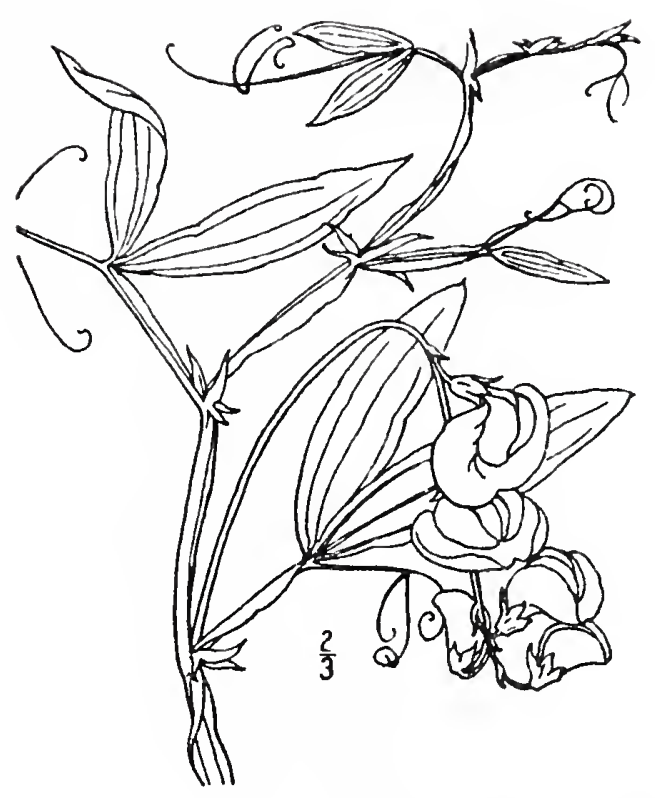

Lathyrus latifolius--Perennial Pea

[From Britton \& Brown (1913), II: 416.]

Flatpod Pea, and I.clymenum, Spanish Vetch, has been known since the time of Hippocrates and has accounted for much loss of life in Europe, India, and northern Africa. In human beings poisoning is associated with conditions of poverty or drought resulting in a diet composed largely of the seeds of these species and is now primarily of historical interest only. Moderate amounts of these peas are not harmful, but consuming large quantities produces a paralytic syndrome in both man and lifestock. Death ensues if the diet is not corrected. Lathyrus sylvestris and I. latifolius have also been reported as toxic to cattle and other farm livestock.

\section{Làthyrus latifòlius L. Perennial Pea.}

Meaning of Species Name. Broad-leaved.

other Names. Everlasting Pea.

Type of Plant. A perennial herb.

Habitat. Esc from cult to roadsides, thickets, and waste places. Range. NE to Ind, $\mathrm{s}$ to $\mathrm{Va}$, Mo, and Kan.

Distr in NYS. Occasionally esc from cult and est in waste places and along roadsides.

Distr in the Torrey Range. In 1915 it was known only from Ct as a waif.

Time of Fl. Jun-Aug(Sep); Aug-Oct at Cornell.

Origin. Introd from Eu.

Remarks. Popularly cult for ornament. 


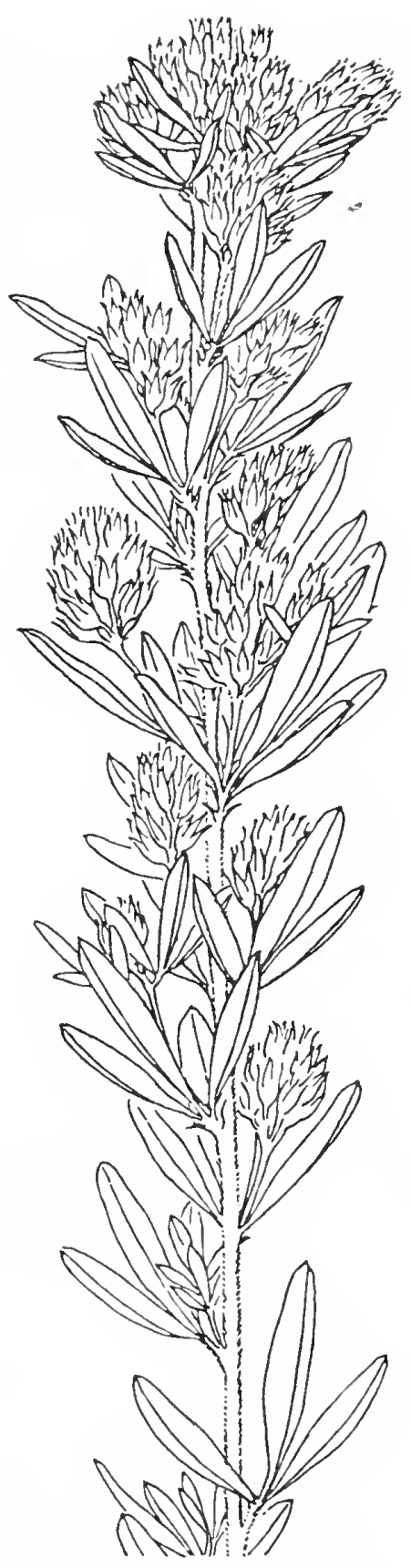

Lespedeza capitata--Round-headed Bush-clover [From Smith (1966), Plate 95, p. 202.]

Lespedèza Michx. Bush-clover.

There are about 40 species of Lespedeza, natives of eastern North America, eastern Asia, and Australia. They are mostly annual or perennial herbs or half-shrubs bearing small trifoliate leaves and spicate, racemose, or solitary flowers, purplish to yellowish-white in color, in sessile or peduncled axillary clusters, each flower subtended by 2 or 4 small bractlets. The fine, straightish veins of the leaves are almost horizontally divergent. The name of the genus honors Vicente Manuel de Cespedes, the Spanish governor of East Florida, 1784-1790, during Michaux's explorations 


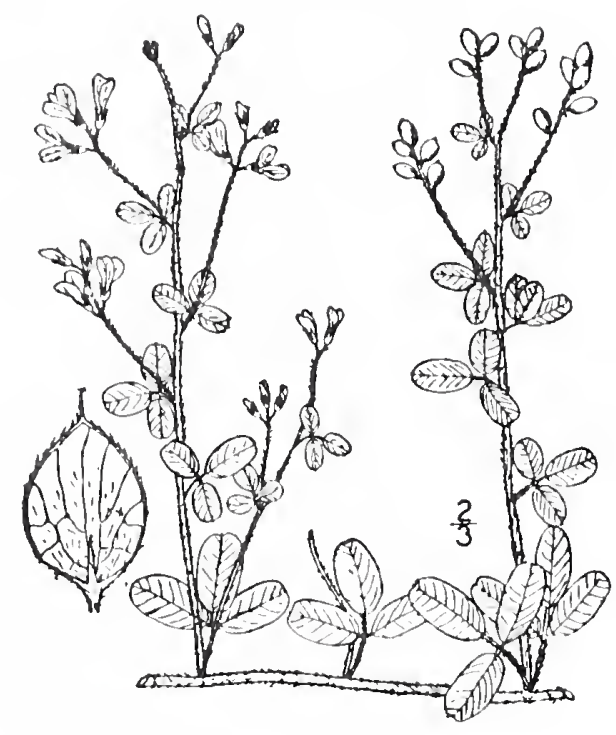

Lespedeza procumbens--Trailing Bush-clover

[From Britton \& Brown (1913), II: 403.]

there. The name was later misspelled, "probably by Michaux's editor," according to Fernald (1950), as de Lespedez.

\section{Key to Local Species of Lespedeza}

1. Flowers all alike, petaliferous, in dense spikes or heads, whitish or cream color with a purple spot; calyx 5-7 mm long, scarcely shorter than the corolla; stems upright, 0.6-1.2 $\mathrm{m}$ high (leaflets silky, elliptic-oblong or narrower; spikes nearly sessile)... I. capitata

1. Flowers of 2 kinds, petaliferous and apetaliferous, in irregular or loose clusters, the former violet with a dark spot; calyx 4 $\mathrm{mm}$ long, much shorter than the corolla; stem prostrate, downy,

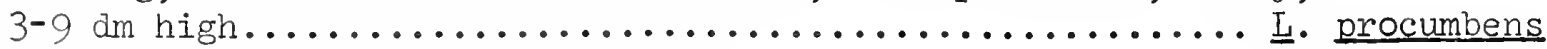

Lespedèza procumbens Michx. Trailing-Bush-clover.

Meaning of Species Name. Trailing.

Type of Plant. A trailing perennial herb.

Habitat. Dry sandy or rocky upland woods and clearings.

Range. NH, Mass, and NY to Ind and Wis, s to Fla, Okla, and Tex.

Distr in NYS. Frequent in the se part of the state; rare or local northw to Schenectady $c o$ and $w$ to Yates co.

Distr in the Torrey Range. NY: Common on LI and SI, decreasing up the Hudson valley to Dutchess and Ulster co, but, in 1915, not reported from the Catskills.

Elevation. Sea level--1000 ft in the Torrey range.

Time of Fl. Mid-Aug-early Oct; fl Aug at Cornell.

Origin. Native.

Remaris. Fernald (1950) suggests that this species might perhaps be better considered as a variety of $\underline{I}$. repens. 
Lespedèza capitäta Michx. Round-headed Bush-clover.

Meaning of Species Name. In heads, referring to the manner of flowering.

Type of Plant. A perennial herb.

Habitat. Dry open, usually sandy, soil of woods, prairies, roadsides, and waste places.

Range. NE to Wis, Minn and Neb, s to Fla and Tex.

Distr in NYS. Frequent or common across the state outside the Adirondacks from I Champlain and Jefferson co westw; increasingly common southw.

Distr in the Torrey Range. Common throughout the area.

Time of FI. Late JuI-Sep; Aug 20-Sep 20 at Cornel1.

Origin. Native.

Remarks. One of our most variable species.

Lòtus I. Deer-vetch.

There are about 140 species of Lotus, herbs primarily of western North America and the old world, with pinnate leaves and small yellow or reddish flowers, either in umbels or solitary upon axillary leafy-bracteate peduncles. The name of the genus is derived from Iotos, an ancient Greek name applied to several kinds of plants but restricted by Linnaeus to these clover-like plants.

Young pods of I. edulis and I. gebelia, both plants of the Mediterranean region, have in the past been used as substitutes for string beans by the poorer inhabitants. I. tetragonolobus, the Winged Pea, also a plant of the Mediterranean region, was cultivated as a garden vegetable in France as late as 1883 as a substitute for Asparagus. It was also "formerly employed as an esculent by the poor of Sicily and Spain" and was likewise cultivated in some of the northern counties of England. It was "reported as being in American gardens in 1863."

The deer-vetches are locally abundant in some areas of the western states, where they have forage value for livestock. As with the clovers, both the seeds and foliage are relished by wildiffe. The seeds are particularly important to western species of quail and small rodents.

Lòtus corniculàtus I. Bird's-foot Trefoil.

Meaning of Species Name. Horned.

Other Names. Bastard Indigo, Ground Honeysuckle, Bloom-fell, Crowtoes, Cross-toes, Cat's-clover, Sheepfoot, Bird's-eye, Iadies'-fingers, Devil's-fingers, Shoes and Stockings, Claver.

Type of Plant. A perennial herb.

Habitat. Fields, roadsides, meadows, and waste places. 


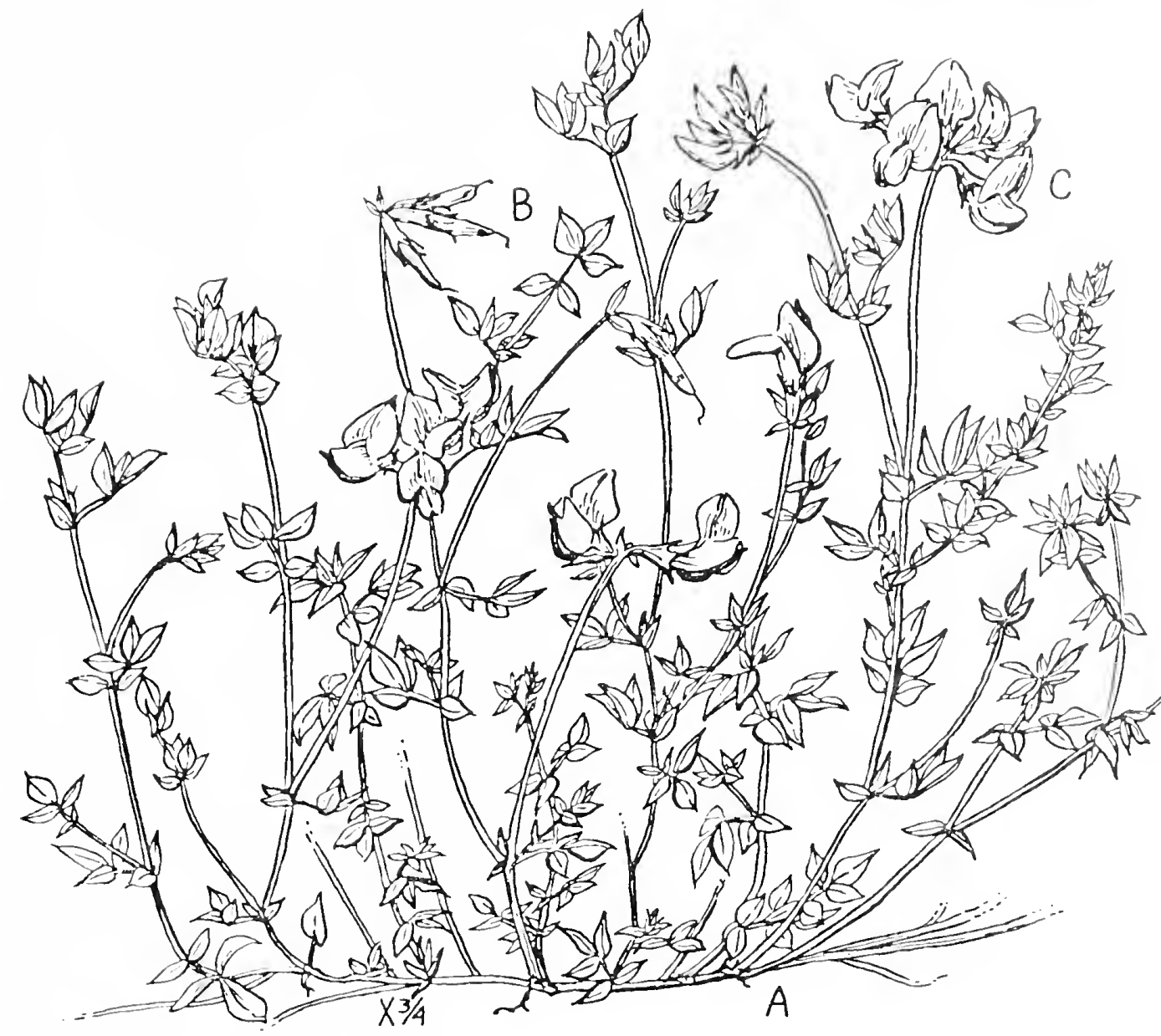

Lotus corniculatus--Bird's-foot Trefoil

From Crockett (1977), p. 158.]

Range. Local, $\mathrm{Nf}$ to Minn, s to $\mathrm{Va}$ and $\mathrm{O}$; also on the Pacific coast. Distr in NIS. Locally common about NYC, Albany, and other cities. Distr in the Torrey Range. In 1915 not very common as an adv. Time of $\mathrm{Fl}$. Jun-Aug(Sep).

origin. Adv from Eu.

Remarks. This is a comparatively recent introduction to the Catskill region, where it is now quite widespread; it was something of a rarity some 50 years ago.

This legume is sometimes cultivated for its pasturage value, succeeding on poor and dry soils where alfalfa and clover do not flourish. It is believed likely that this species may have future importance as a pasture legume in this country. Johnson (1867) remarks of this plant in Great Britain that "The Bird's-foot Trefoil is a valuable plant in meadows and pastures when mixed with grasses and other nutritious herbs, and may be sown with advantage with the ordinary meadow grasses for permanent pasture ... It makes very good hay, but in this, as in other points, cannot bear comparison with the clovers and other plants of the kind in general use."

Kingsbury (1964) states that "This popular forage crop has been shown occasionally to produce potentially toxic amounts of a cyanogenetic 
substance in Europe, Britain, Australia, and the United States, "but cases of livestock loss "have not been reported except possibly in Australia."

\section{Lupinus I. Lupine.}

This is a genus of some 225 species chiefly of North America but represented also in South America and the Mediterranean region, several species of which are cultivated for ornament. They are herbs with palmately 1-18-foliate leaves and showy flowers in terminal racemes or spikes. The name of the genus is derived from the Latin lupus, a wolf, "of uncertain significance" in connection with these plants according to one authority, but "because of a belief that it destroys the soil" according to Fernald (1950).

Lupinus albus, the Field Lupine or Wolf-bean, a plant of the Mediterranean region, has been cultivated since the days of the ancient Egyptians. The Romans cultivated it as a legume but it seems not to have reached the Rhine region until the l6th century. It is still cultivated in Italy and some other countries both as a plant for green manure and for its seeds, which, when boiled to remove their bitterness, are still an article of food in some areas. Lupinus hirsutus, Blue Lupine, and I. luteus, two other Mediterranean plants, have also long been cultivated and still serve as food for the poorer classes of people in that area. The tough, branching roots of $\mathrm{I}$. Iittoralis, a plant of northwestern North America, were dried by the Indians of the Columbia River region for use as food during the winter. After being roasted they become farinaceous.

While the bitter seeds of $\underline{L}$. perennis are reported to have been used as food by the Indians from Canada to Florida, many lupines contain a well-recognized alkaloid, lupinine, and many cases of poisoning have been recorded from eating the pods and seeds. It is therefore wise to avoid using these plants as articles of food.

\section{Lupinus polyphýllus Lindl. Garden Lupine.}

Meaning of Species Name. Many-leaved.

other Names. Lupine.

Type of Plant. A stout perennial herb.

Habitat. Dry or wet roadsides and banks.

Range. PEI, NS, NE, and NY.

Distr in NYS. Not listed in House (1924).

Distr in the Torrey Range. Not listed in Taylor (1915).

Time of Fl. Iate Jun-early Aug.

origin. Introd and natzd from nw Am.

This species has been observed as a waif in the Catskill region and can be expected to grow around dumps that have served as repositories for garden refuse. It should be noted that the accompanying illustration is of I. perennis, the native Wild or Perennial Lupine, a plant not yet known to occur in the Catskills, although it should be looked for along the Delaware valley below Hancock. Aside from the fact that the Garden Lupine is a more 


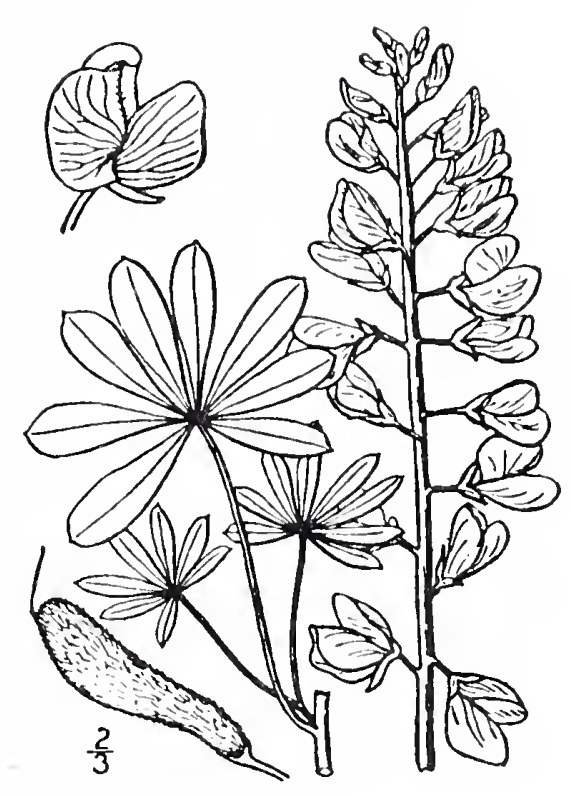

Lupinus perennis--Wild Lupine

[From Britton \& Brown (1913), II: 348.]

robust plant, the chief field characteristic to note in distinguishing the two species lies in the number of leaflets that make up the palmate leaf. The lower leaves of $\mathrm{I}$. polyphyllus are made up of $12-18$ leaflets, while $\mathrm{I}$. perennis has only 7-ll leaflets.

\section{Medicàgo L. Black Medic, Alfalfa.}

There are about 50 species of Medicago, herbs with pinnately 3foliate leaves chiefly of the Mediterranean region but extending north through Europe and east into western and central Asia. The name of the genus is derived from medice, the ancient name of Alfalfa, because it came to the Greeks from Media. A broad-leaved variety of $\underline{M}$. denticulata, Shanghai Trefoil, was reported to be much used by the Chinese as a winter vegetable, while M. platycarpa furnishes a food in Siberia. Medicago scutellata, a plant of the Mediterranean region known as Snails, on the other hand, is grown in some areas because of the singular shape of its seed pods. More abundant on the Pacific coast than elsewhere, bur-clovers in that area are of major value to some kinds of wildlife, among which is the California quail, which makes extensive use of the herbage.

\section{Key to the Local Species of Medicago}

1. Flowers $2-5 \mathrm{~mm}$ long, yellow; fruit subreniform, slightly spiral only at summit; a low or diffuse annual................ Iupulina

1. Flowers 6-12 mm long, blue-violet or purple; legume spiraled through 2 or 3 revolutions; an ascending perennial.......... M. sativa 


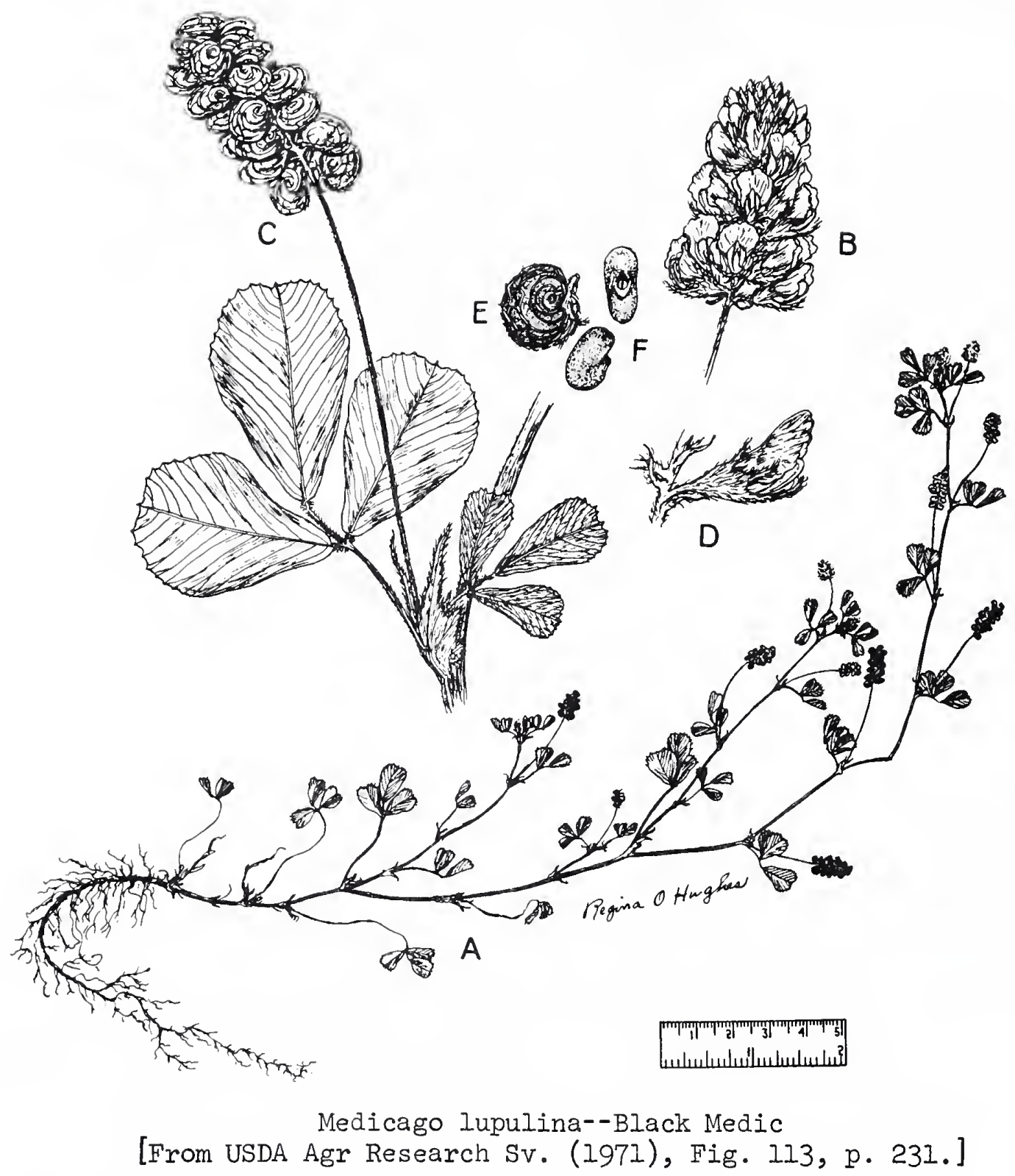

Medicàgo Iupulina L. Black Medic.

Meaning of Species Name. Hoplike, from the spiciform racemes. Other Names. Nonesuch, Hop Medic, Blackseed, Hop-clover, Trefoil, Melilot-trefoil, Black-grass, Black Nonesuch, Black Clover, Natural Grass, Horned Clover, Shamrock, Sainfoin.

Type of Plant. An annual or winter annual herb reproducing by seeds.

Habitat. Roadsides, fields, gardens, lawns, and waste places.

Range. NS to BC, S to Fla, Haiti, and Mex; also in SAm. Distr in NYS. Common throughout most secs of the state. Distr in the Torrey Range. Common everywhere as a weed. Iime of Fl. (Mar)May-Sep(Dec); May-Sep at Cornell. Origin. Natzd from Eu. 


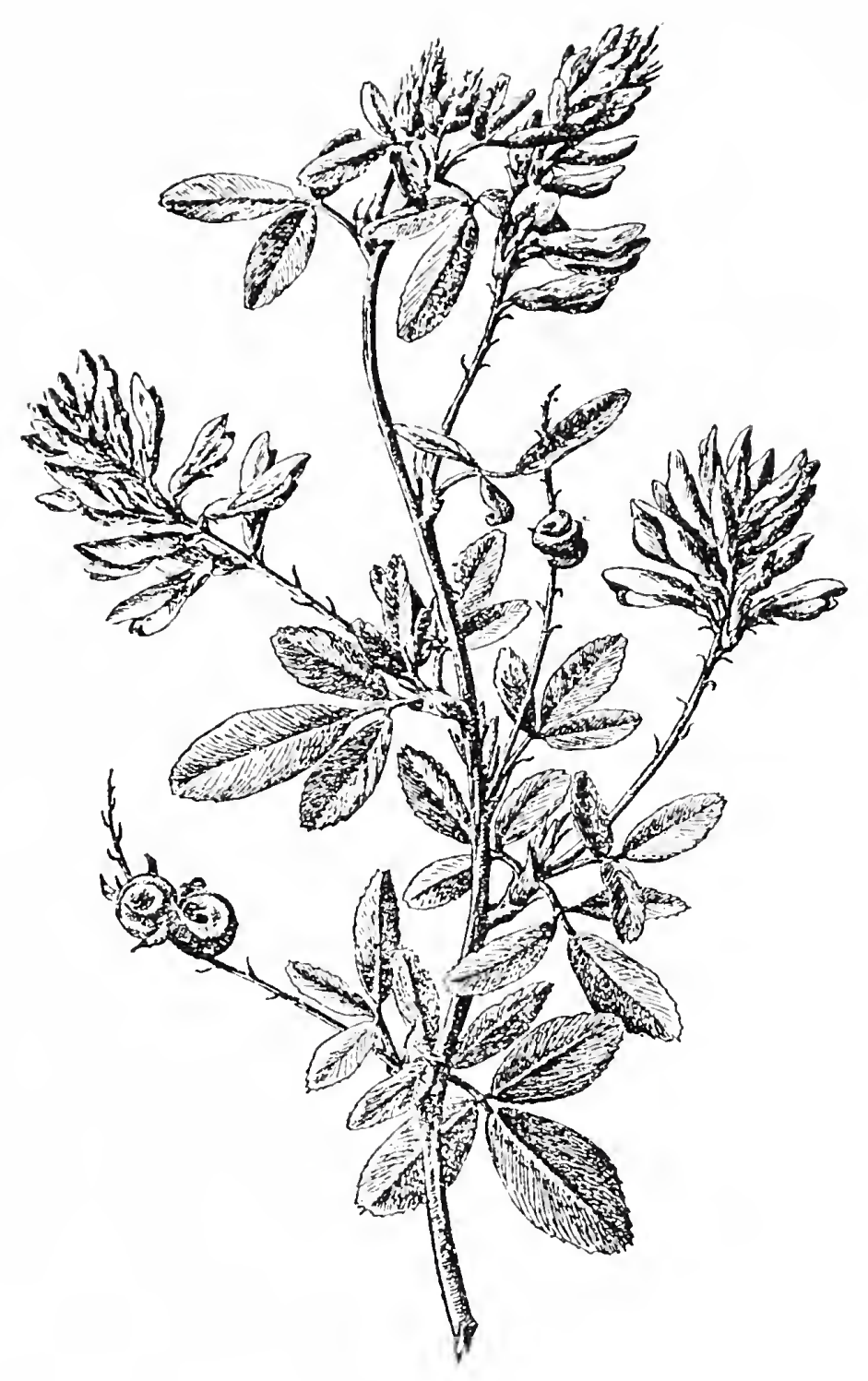

Medicago sativa-Alfalfa
[From Parsons (1907), p. 333.]

The seeds of this plant are said to be greatly relished by the Indians of southern California, according to a USDA report of 1870 . Johnson (1867) states that "when cultivated, it attains a much larger size, and yields a moderate crop. It is now seldom grown, being inferior to the clovers, though it affords very good food for sheep and cattle," while Steyermark (1963) observes that "In Hawaii Black Medic is highly valued for forage, but in the continental United States it has not assumed importance and is used only to a slight extent as a cover crop and for winter pasturage." In areas where this species has become an undesirable weed, it can be controlled by clean cultivation.

Medicàgo sativa L. Alfalfa.

Meaning of Species Name. Sown.

Other Names. Purple Medic, Lucerne, Burgundy Clover, Chilian Clover, Brazilian Clover, Snail Clover, Great Trefoil, Spanish Trefoil, Holy-hay, Sainfoin. 
Type of Plant. A perennial herb.

Habitat. Almost throughout the US and $s$ Can.

Distr in NYS. Common in cult and often esc or estab in many secs

of the state.

Distr in the Torrey Range. Frequent in fields and waste places in

most parts of our area.

Time of Fl. (May) Jun-Sep(Oct); Jun-Jul at Cornell.

Origin. Introd and natzd from Eu.

Remarks. Iong in cult as a valued fodder crop.

According to a report of 1882, Alfalfa leaves were then eaten by the Chinese as a vegetable. Indians of Utah are also reported not only to boil the new shoots as greens but also to grind the seeds between stones and cook the "flour" as mush or for use as cakes. Alfalfa leaves likewise constitute one ingredient in Pablum, a popular infants' cereal. Alfalfa, particularly rich in vitamins $A, D$, and $K$, has been used in medicine as a valuable "natural" cure for jaundice and to encourage the clotting of blood. The leaves are best collected in the spring or early summer to be eaten fresh in salads or steeped in hot water as a tea.

Even as early as 1867 Johnson remarked that Alfalfa "has been for ages cultivated in southern Europe as a fodder plant.... The stems spring up more rapidly after mowing than those of any other fodder plant, so that it may be cut in favourable seasons four or five times. It is said that cattle thrive better on Lucerne than on any other food of the kind, and it forms a most nourishing fodder for horses ... It makes good hay, but being very juicy takes a long time drying." Steyermark (1963) calls this species "the number 1 legume forage crop in the United States," not only for hay and pasturage but valuable also for "silage and feed concentrates," particularly in the western states. In addition, "It is one of three commercial sources for the extraction of Carotine, a vitamin A synthetic product, and in the form of a meal is added to many of the prepared baby foods and cage bird foods as a source of vitamin A." He adds, however, that "Cases are on record of persons who have suffered hay fever from sensitivity to alfalfa pollen."

\section{Melilótus Mill. Sweet Clover.}

There are about 20 species of Melilotus, annual or biennial herbs with pinnately 3-foliate leaves, natives of central and southern Europe, northern Africa, and western Asia. The name of the genus is derived from the Greek meli, honey, and lotos, the name of some.leguminous plant.

Both M. alba and M. officinalis have been widely used as forage crops and as soil builders since about 1920, particularly in the northwestern states. Kingsbury (1964) states that in 1921 they were recognized as the agents responsible for a severe hemorrhagic disease of cattle in the United States and Canada. Subsequent investigation revealed that this disease was associated with feeding moldy or spoiled sweet-clover hay or moldy silage, of which a large amount is required to induce the disorder. Sweet-clover poisoning is restricted almost exclusively to cattle, as only very minor loss in sheep and horses has occurred. Death by bleeding either internally or externally follows within a very few days after the appearance

$$
-176-
$$


of symptoms. Further experiment culminated in the development of the medically valuable anticoagulant dicoumarin and the highly useful rodenticide Warfarin.

Both of these species occur throughout much of the country, but they are more abundant in the western states, where the seeds are of moderate value to some upland game birds. Melilotus alba is likewise regarded as a particularly valuable honey plant.

\section{Key to the Catskill Species of Melilotus}

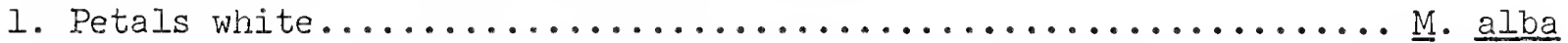

1. Petals yellow (standard much longer than wing petals).... M. officinalis

Melilotus álba Desr. White Sweet Clover.

Meaning of Species Name. White.

Other Names. Melilot, White Melilot, Corn Melilot, White Millet, King's Clover, Honey-lotus, Cabul-clover, Plaster Clover, Sweet Lucerne, Tree-clover, Honey Clover, Bokhara-clover, Wild Laburnum, Hart's Clover. Type of Plant. A biennial herb, reproducing by seeds.

Habitat. Fields, roadsides, and waste places.

Range. NS to $B C, S$ to $W I$ and Mex.

Distr in NYS. Frequent or common in most secs of the state.

Distr in the Torrey Range. Common as a weed nearly throughout our area.

Time of Fl. May-Oct; Jun-Oct at Corneli.

Origin. Natzd from Eu.

In many respects this species might be called the king of weeds, for nitrogen-fixing bacteria that live in nodules on its roots have the ability to use nitrogen from the air rather than taking it from the soil, thereby increasing the available supply of nitrogen in the soil even if the plants are not plowed under as "green manure." Sweet clover thus always leaves the soil somewhat better than it was. White Sweet Clover is also one of the best "Bee pastures" and is often called Bee Clover. Steyermark (1963) was of the opinjon that it was equally as valuable as M. officinalis "as green manure, and for grazing and fodder," but that because it produced "a somewhat higher yield than Yellow Sweet Clover," it was probably planted more often for hay and pasturage. In their early stages of growth sweet clover and alfalfa look very much alike, but the crushed leaves of the latter lack the sweet aroma of the sweet clovers. In some areas this species is grown rather extensively for forage, pasture, and as a "green manure" crop.

This plant can be a bad weed, particularly in recently cleared or disturbed ground. Muenscher (1952) suggests that it can be brought under control by pulling or hoeing scattered plants. More extensive stands in fields should be plowed under then planted with a clean cultivated crop. 
Melilòtus officinàlis ( I.) Lam. Yellow Sweet Clover.

Meaning of Species Name. Of the shops, various preparations of it being formerly used in medicine and for flavoring.

Other Names. Yellow Melilot, Yellow Millet, Balsam-flowers, Hart'sclover, King's-clover, King's-crown, Heartwort, Plaster-clover.

Type of Plant. An annual or biennial herb reproducing by seeds.

Habitat. Neglected fields, pastures, roadsides, and waste places.

Range. Throughout the northeastern states and s Can, w to the Pacific.

Distr in NYS. Frequent or common.

Distr in the Torrey Range. Common throughout our area, but not so common as $\underline{\text { M. }}$ alba.

Time of Fl. Late May-Oct; Jun-Jul at Cornell.

Origin. Natzd from Eu.

Remarks. Not common southw.

Over 100 years ago Johnson (1867) stated that this species "was formerly much grown as a fodder plant in England, but is now very little cultivated here, being much inferior to lucerne, clover, and many other herbs of the kind in nutritive qualities.... In Switzerland, and some parts of Germany, it is much grown, and in the former country has acquired celebrity from being used to give the peculiar flavour to the Gruyere cheese, so highly esteemed in Continental Europe. For this purpose the flowers and seeds are bruised and mixed with the curd before processing ... A water distilled from the flowers is used as a perfume. The plant, like most other wild herbs, was once esteemed for its supposed medicinal properties, which appear to have been imaginary."

Some 20 years later Millspaugh (1887) reported that the sweet-scented flowers of this species have been used as a flavoring agent in Gruyere cheese, snuff, and smoking tobacco. When packed with furs and woolens, it was claimed that they protected them from moths in addition to giving them a pleasant odor. Boiled with lard, the flowers were once extensively used with much success by the laity as a salve for ulcers, indolent sores, and "broken breasts," but the editors of the U.S. Dispensatory of 1865 likewise felt that it had. Iittle medical power. Although it was formerly recommended in the treatment of various diseases, it was not then employed internally. It was not discovered until the 20th century that a medically useful anticoagulant could be derived from this plant.

During the last half century, however, there has been occasion to re-evaluate this species, for of it steyermark (1963) states that not only is it "highly regarded as a bee plant for honey production," but that it is also much "used as a green manure, for hay, and pasture," continuing with the observation that "Its chief advantage over alfalfa and red clover lies in its ability to withstand dry sterile soils, and in this role it plays an important part, especially in the southeastern United States, in reclaiming poor or impoverished soils and at the same time being used for hay." One disadvantage is that when improperly cured or spoiled hay is fed to domestic animals, the coumarin contained in it may become toxic, "but varieties ... lacking coumarin have been developed recently." In any case, "It matures earlier and is a better seed producer than $\underline{M}$. alba," and it grows better under unfavorable conditions. 


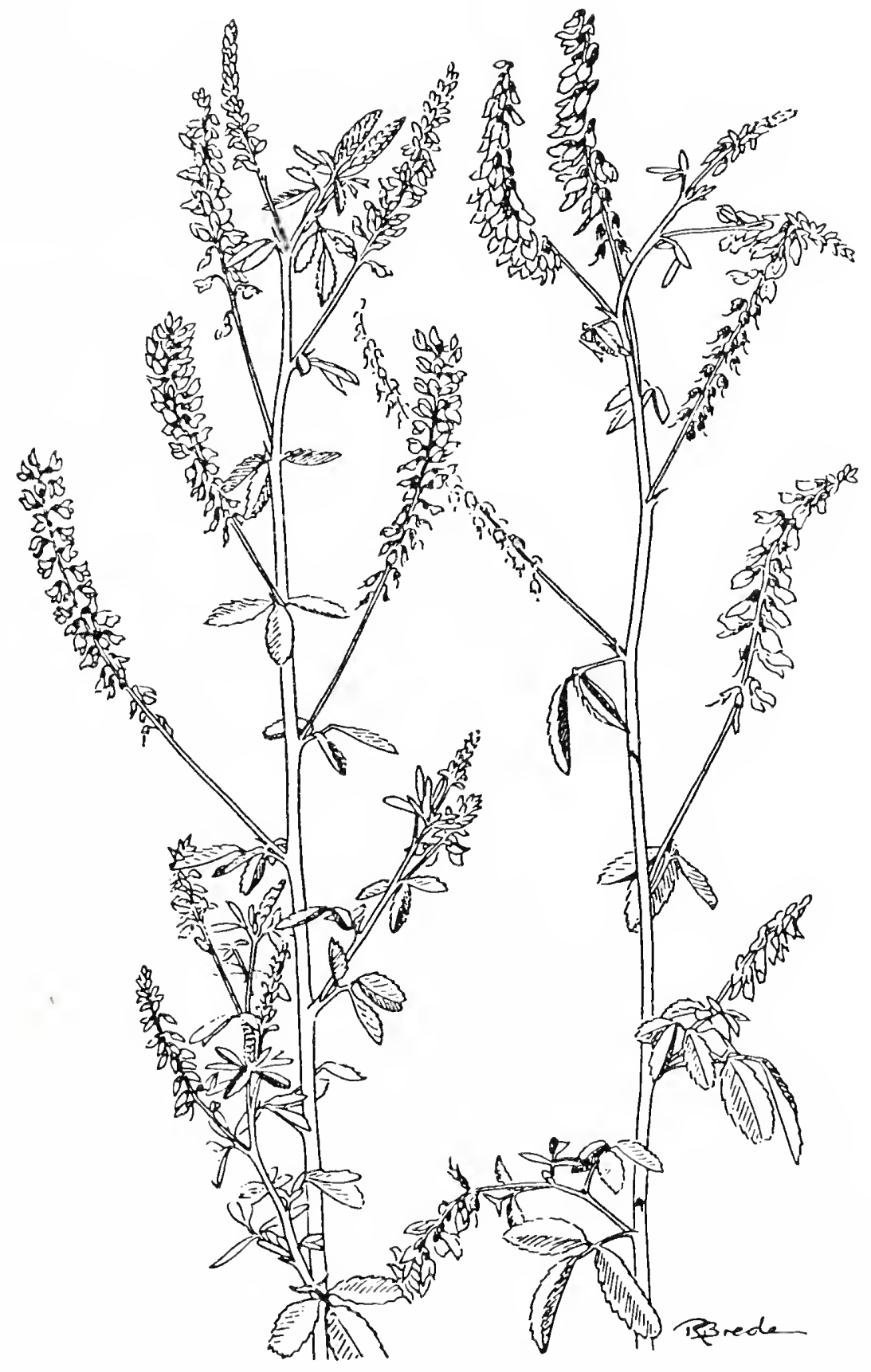

(Left) Melilotus alba--White Sweet Clover

(Right) Melilotus officinalis--Yellow Sweet Clover [From Smith (1966), Plate 92, p. 197.] 
Robina I. Locust.

There are about 20 species of Robina, all trees or shrubs native to North America, often with spines for stipules and with odd-pinnate leaves and showy flowers in drooping axillary racemes. The genus was named to honor John Robin, 1550-1629, herbalist to Henry IV of France, and his son Vespasian Robin, 1579-1662, who first cultivated the locust tree in Europe.

\section{Robína pseùdo-acàcia I. Black Iocust.}

Meaning of Species Name. An old generic name, False Acacia.

other Names. Locust-tree, Acacia, False Acacia, Bastard Acacia, Common Locust, White Locust, Yellow Locust, Red-flowering Locust, Green Locust, Honey-locust, Pea-flower Locust, Post-locust, Silver-chain.

Type of Plant. A large shrub or medium-sized tree from 30-70 or 80 ft high with a trunk 2-3 ft in diameter.

Habitat. Roadsides, fencerows, open woods, and waste places. Ont.

Range. $\mathrm{Pa}$ to Ind and OkIa, s to $\mathrm{Ga}$ and $\mathrm{La}$; natzd $\mathrm{n}$ to $\mathrm{NS}$, Que, and

Distr in NYS. Commonly natzd from long cult northw to L ontario, St Lawrence co, the Adirondack foothills, and I Champlain.

Distr in the Torrey Range. Doubtfully indigenous in any part of our area but common as an esc from cult.

Time of Fl. May-Jun; Jun 1-15 at Cornell.

Origin. Originally native from $\mathrm{s} \mathrm{Pa}$ along the mts to $\mathrm{n} \mathrm{Ga}$ and in the Ozarks of $\mathrm{No}$ and Ark; now natzd over a more extensive range, including most of the Catskill region.

Remarks. Much planted for lumber and ornament, now natzd in many countries. Wood strong, very durable, greenish-brown, the sapwood yellow; wt 46 Ib per cu ft. Much used for posts, in ship-building, and especially for tree-nails.

This species makes its best growth in the deep, rich, moist soils of bottomlands, but it is often found growing on drier soils. Sprouts from the roots often form thickets of smaller trees about larger ones. One unusual fact concerning the foliage of this tree is that at nightfall the leaflets "fold up for the night," in a sense seeming to go to sleep, a phenomenon caused by the loss of sap pressure in the petioles of the leaflets, the purpose of which has yet to be explained. In late May the tree bursts into a bloom that is often so profuse as to make a notable display. Bees lead the insect host that swams about the very fregrant, nectarladen flowers with their characteristic "butterfly-like" blossoms reminiscent of small pea blossoms. As a matter of fact, the fragrant flowers are an important source of honey. Originally this species ranged along the Appalachians from southern Pennsylvania to northern Georgia. It is supposed that the Indians used its wood for bows and eventually spread it beyond its natural range. It was found planted near their villages along the Virginia coast. They also made a blue dye from the leaves.

Early American pioneers early learned that the wood of this tree has many fine qualities. It is the seventh hardest of all our trees and as a beam it is the strongest of all North American woods outside the tropics. 
It is also the stiffest of all our woods, exceeding hickory by 40 percent, and it shrinks less in drying than any other, losing only 10 percent in volume. In addition, it is the most durable of all our hardwoods, exceeding that of White Oak by 250 percent. The wood takes a high polish, and it has a high fuel content, one cord almost equaling a ton of anthracite coal. Yet Black Locust is not even mentioned in the usual lumbering statistics, the chief reason being that in many areas the locust borer has ruined most of the trees and too few are found in sound condition. It is also subject to attack by the locust leaf-miner, causing premature browning and death of the foliage. In former days it was much in demand for ship-building. "Tree-nails" (dowels) of this wood were stronger and longer-lasting than the strongest hulls. Very durable in contact with soil or water, it was also used for ships' bottoms, mill cogs, and wheel hubs. Since locust boards are now almost unknown, it is likely to be used only for fence posts, railway ties, mine props, insulator pins, and such small articles as rake teeth, tool handles, and ladder rungs.

This species is often planted as an ornamental, but Rogers (1926) was not enthusiastic about such use. In addition to its being subject to insect attacks, "The angled twigs ... break easily in windy weather," so "its symmetry is soon destroyed unless the tree grows in a sheltered situation. An old locust is usually an ugly, broken specimen, ragged looking for three-fourths of the year," while in winter "the pods chatter querulously, as the wind plays among the tree tops." In the Catskills this tree seems not yet to be subject to insect attack, however, and one frequentIy sees fine specimens. It has also been planted extensively for erosion control in gullies and ravines since it tolerates poor soil and grows rapidly. The parent tree often sends up a host of sucker shoots, however, which are almost impossible to eradicate; this also precludes its use as a lawn tree. Steyermark (1963) states that "Black Locust has been used extensively for reforestation purposes, especially covering newly exposed ground, such as mine excavations and dumps, and eroded areas," as well as being "used extensively in some prairie states as a shelter belt." In addition, its extensive root system not only keeps the soil from washing away, but it also enriches the soil through the nitrogen-fixing bacteria found in granular nodules on its roots.

Martin et al. (1961) state that the Black Locust "rates low as a wildlife plant. Its seeds are consumed to a limited extent by quail, other gamebirds, and also by squirrels, but the small extent of wildlife use stands out in contrast with its widespread availability." Birds seem to eat its seeds only if nothing better is available, but the bark is often eaten by cottontail rabbits during the winter months.

The U.S. Dispensatory of 1865 states that this species is "supposed by some to possess remedial properties. The bark of the root is the most active part, and is said to be tonic, and in large doses purgative and emetic," while Millspaugh (1887) remarks that "A tincture of the fresh bark from the young twigs was used medicinally." The inner bark, however, contains a poisonous principle and not only have horses, cattle, sheep, and poultry been fatally poisoned from eating it but several. cases of human poisoning have been recorded from eating the seeds, roots, or the inner bark. Kingsbury (1964) states that horses are most commonly poisoned when they strip and eat the bark of the trees to which they have been tethered, 


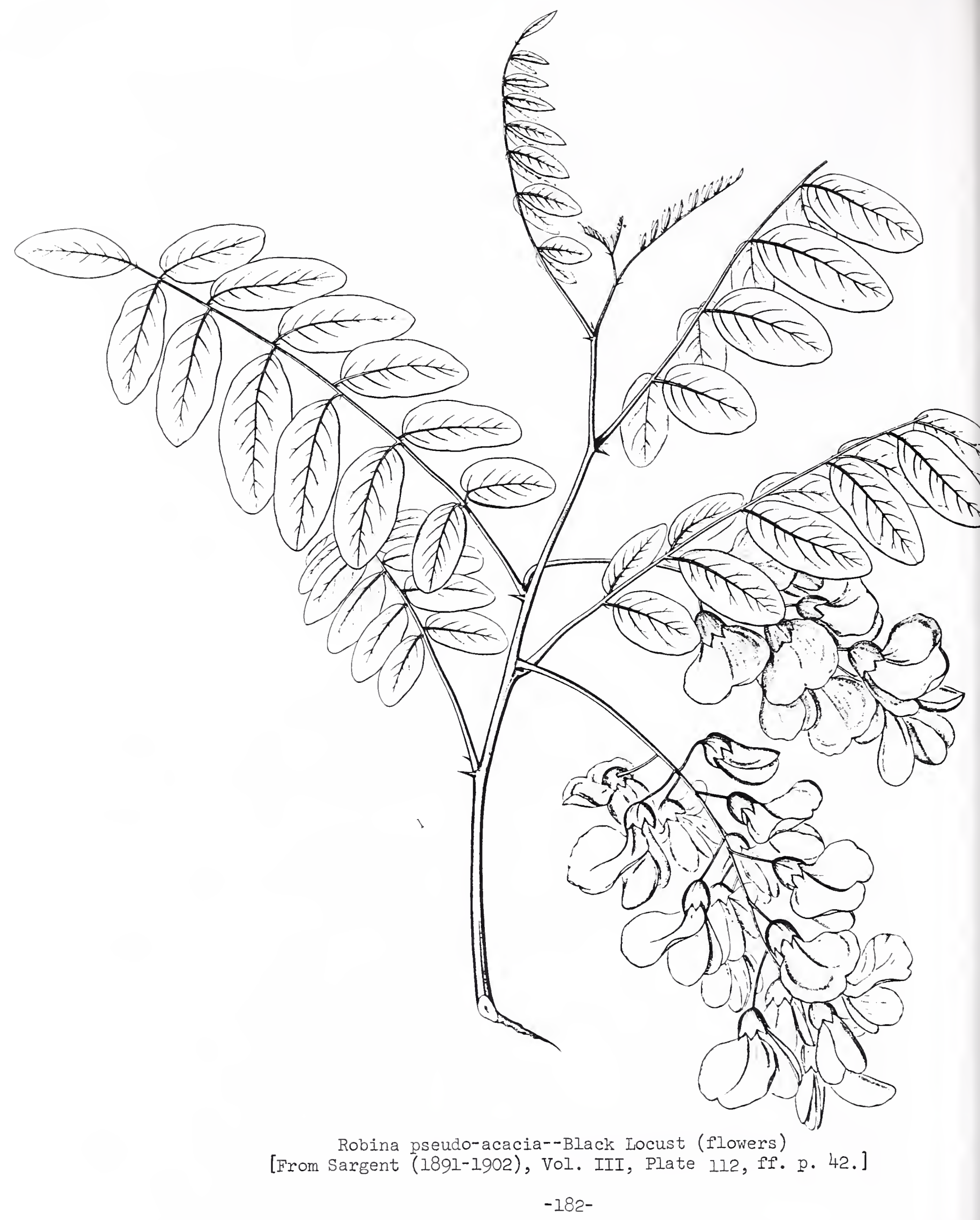




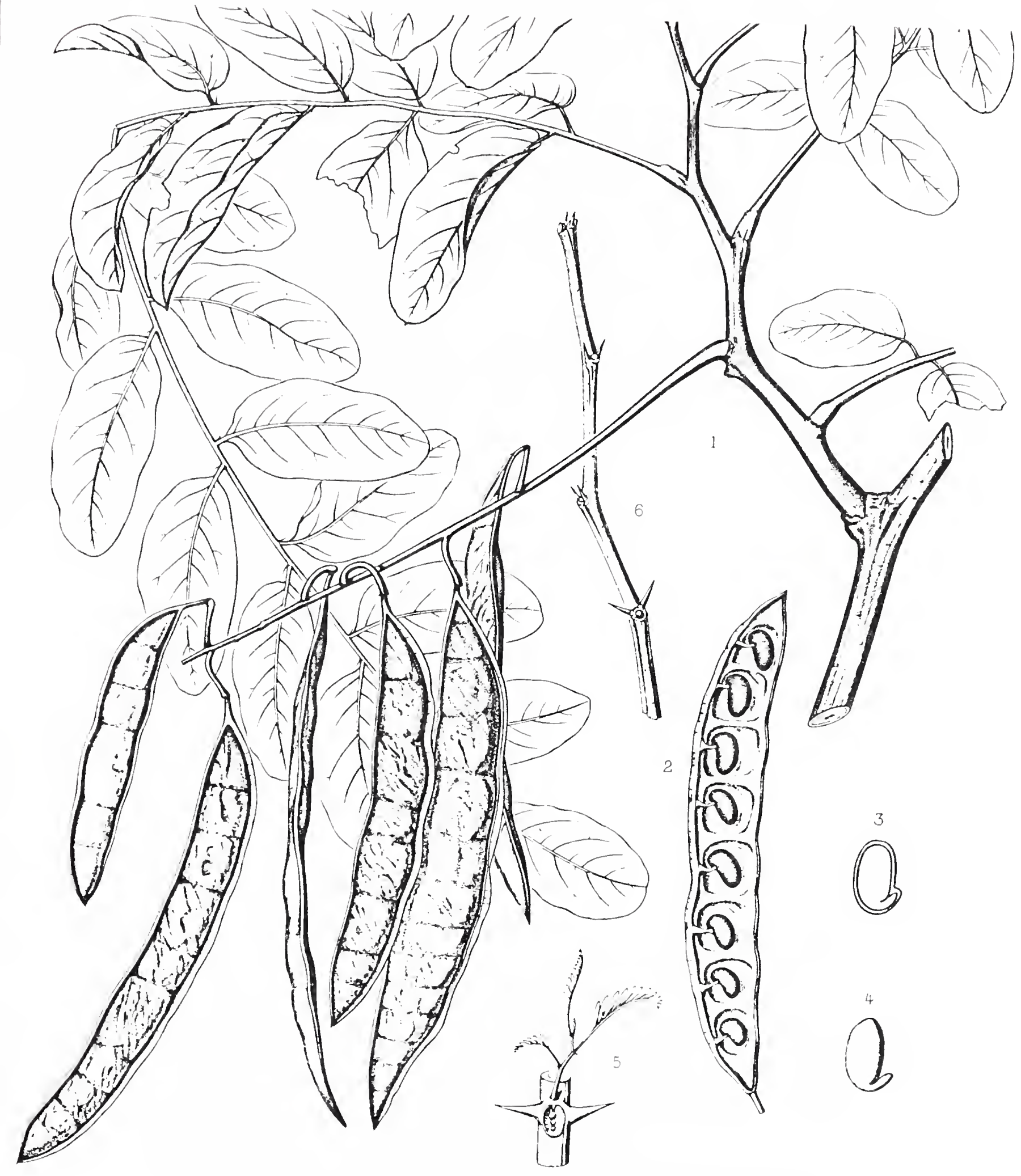

Robina pseudo-acacia--Black Locust (fruit)
[From Sargent (1891-1902), Vol. III, Plate 113, ff. p. 42.] 
and both cattle and horses have been poisoned from grazing sprouts on cutover lands. Symptoms include purging, stupor, weakened pulse, and gastroenteritis.

Millspaugh (1887) further reports that while the seeds are quite acrid, they "Iost this quality upon boiling; they then furnish a pleasant, nutritious article of food, much esteemed by the aborigines." The seeds, upon pressure, also "yield a large quantity of oil." In New Mexico the flowers of a related species were eaten fresh.

Since the bark, roots, leaves, and seeds have a reputation for being poisonous, it is wise to avoid their use either as food or medicine, although it is possible that cooking the seeds may make them edible. The flowers, on the other hand, have been used both to make a pleasant drink by infusing them in water and to make fritters. For the latter purpose, gather the clusters at the height of bloom, remove the coarse stems, and dip the clusters in a batter made from 1 cup of flour, 1 tablespoon of sugar, 1 teaspoon of baking powder, 2 eggs, and $1 / 2$ cup of milk. Fry these clusters in deep fat heated to $375^{\circ} \mathrm{F}$ for about 4 minutes or until they are golden brown. Drain them on a paper towel, squeeze some orange juice over them, roll in granulated sugar, and serve while piping hot. 
Trifólium L. Clover.

There are about 300 species of clover, annual and perennial herbs chiefly of the north temperate zone with leaves mostly palmately 3-foliate, stipules united with the petiole, and flowers in heads or headlike racemes. The name of the genus is derived from the Latin tres, three, and folium, leaf. Trifolium is the most valuable of the legumes for forage and several species are widely cultivated. Clover is also highly valued as a source of honey.

Western Indians have used the young herbage of various species of clover either raw as a salad or cooked as a potherb. Vogel (1970) remarks that the Indians of northern California ate the fresh foliage from April through July, picking it from plants before they flowered. The Digger tribe cooked Red Clover by placing several moistened layers on one another in a stone oven. The Apaches boiled clover with dandelions, grass, and "pigweed." Sturtevant (1919) remarks that "Where clover is found growing wild, the Indians practice a sort of semicultivation by irrigating it and harvesting it." The Pomo tribe held special feasts and dances in early spring to celebrate the appearance of this food plant. At that time "The people moved out into the fields and reveled in the abundance of these greens, eating great quantities as they gathered them, and bringing them back to the village by the basketfull." Although the leaves contain many essential food elements, they have been known to cause bloating both in human beings and in cattle, particularly when consumed in large quantities. Some Indian tribes ate peppernuts or dipped the clover in salt water to aid its digestion and to prevent bloating.

The seeds and dried flowers of various clovers have long been used in Europe in times of famine as a bread-food, usually as an "extender" of whatever flour might be available. Writing of the use of the common White Clover, $\underline{T}$. repens, in Scotland, Lightfoot reported that bread made from it was very nutritious and wholesome. Among settlers of the eastern states clover tea, made by brewing the dried flower heads, was esteemed as a wholesome and supposedly medicinal drink, for many years prescribed as a soothing medicine for people suffering from bronchitis, asthma, and coughs. It was particularly recommended in the treatment of whooping-cough.

Martin et al. (1961) report that wild animals, like domestic livestock, relish clover foliage, and the small hard seeds of western clovers are important to quail and other birds. Ruffed grouse, wild turkey, and bobwhite consume both seeds and foliage, but most upland game birds limit their use of clover almost entirely to the foliage. The varying hare, woodchuck, porcupine, cottontail rabbit, raccoon, and skunk, as well as some other mammals, consume both pods and foliage.

Trifolium arvense and $\underline{T}$. incarnatum may cause mechanical injury to farm animals by forming "hair balls" in the digestive system. Trifolium hybridum produces a dermititus in some individuals, and cases of photosensitization in domestic animals have been ascribed to this species in Europe. 


\section{Key to the Catskill Species of Trifolium}

1. Flowers sessile or subsessile in the dense head, the middle and upper ones not strongly reflexed in age, 2

2. Heads subtended by a pair of opposite leaves or their dilated stipules, either sessile or slightly elevated above them (heads subglobose, ovoid, or obovoid; calyx teeth setaceous; corolla much exceeding calyx; corolla roseate or creamy

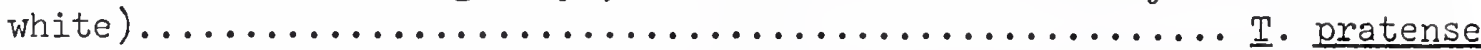

2. Heads on naked peduncles, not subtended by paired leaves or stipules; leaves all alternate (petioles of lower and median leaves shorter than the narrowly oblanceolate or linearoblong leaflets; corolla pale, macrescent, overtopped by the calyx teeth; heads drab or grayish)............... a . arvense

1. Flowers distinctly pedicellate, in loosening heads; pedicels reflexed in age, 3

3. Corolla yellow, becoming brown and macrescent; heads 0.5-1.5 $\mathrm{cm}$ thick; petioles mostly shorter than leaflets (leaflets all sessile or subsessile; stipules elongate, not dilated at base; style and legume subequal; seed globose)....... T. agrarium

3. Corolla white, roseate, or purple; heads $1.2-4.5 \mathrm{~cm}$ in

diameter; lower petioles longer than leaflets, 4

4. Stems widely creeping or with long basal runners (peduncles rising from the creeping stems, scapiform; calyx teeth shorter than the tube; corolla white)...... I. repens

4. Stems erect or ascending, without basal runners (calyx 3.5-5 mm long, its teeth only slightly longer than the campanulate tube; corolla pink and white or roseate throughout..$\ldots \ldots \ldots \ldots \ldots \ldots \ldots \ldots \ldots \ldots \ldots \ldots$. hybridum

Trifòlium agràrium I. Hop-clover.

Meaning of Species Name. Of fields.

other Names. Yellow Clover, Hop Trefoil, Field Hop Clover.

Type of Plant. An annual or biennial herb, reproducing by seeds. Habitat. Roadsides, waste places, meadows, pastures, and old fields. Range. Nf to $\mathrm{BC}, \mathrm{s}$ to $\mathrm{SC}$ and Ark, commoner eastw. Distr in NYS. Frequent or locally common. Distr in the Torrey Range. Common as a weed throughout our area. Time of Fl. (May)Jun-Sep; Jun-Aug at Cornell. Origin. Natzd from Eu.

Both flowers and foliage are edible. Western Indians often eat the flowers, stems, and seeds of this plant after they have been washed and dipped in salted water. As a vegetable it can be prepared by cutting the clover into small pieces and frying them in bacon fat and draining on a paper towel. For those who may wish to experiment with this and other clovers, Berglund and Bolsby (1971) give recipes for clover omelet, clover soup, clover caramel custard, deep-fried clover-blossom fritters, clover and wine lemonade, pork chops baked with yellow clover, braised yellow clover blossoms, and yellow clover salad. 


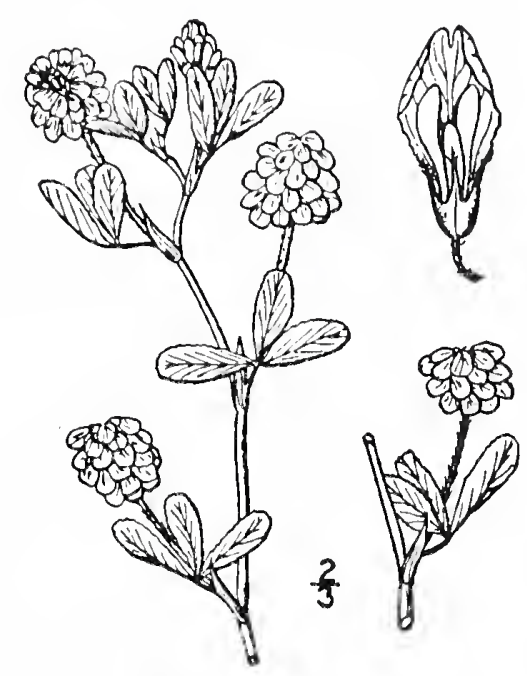

Trifolium agrarium--Hop Clover

[From Britton \& Brown (1913), II: 354.]

In areas where this species has become an undesirable weed, Muenscher (1952) suggests that it can be controlled by close pasturing to prevent seed formation. In meadows it should be plowed under and followed by a clean cultivated crop.

Trifólium arvénse L. Rabbit's-foot Clover.

Meaning of Species Name. Of cultivated fields.

Other Names. Old-field Clover, Stone Clover, Hare's-foot Clover, Pussy Clover, Calf Clover, Poverty-grass, Bottle-grass, Dogs and Cats, Pussies, Pussy-cats.

Type of Plant. An annual herb, reproducing by seeds.

Habitat. A weed of sterile soil, roadsides, old fields, meadows, and waste places, especially in dry, sandy, or rocky soil.

Range. Que to Fla, w to the Pacific coast.

Distr in NYS. Locally common in many parts of the state outside the higher Adirondacks.

Distr in the Torrey Range. Common everywhere.

Time of Fl. May-Oct; Aug 15-Sep 15 at Cornell.

Origin. Natzd from Eu.

(1952) In areas where this species has become an undesirable weed, Muenscher to improve the soil or by planting a green manure crop and plowing it under, followed by a clean cultivated crop. 


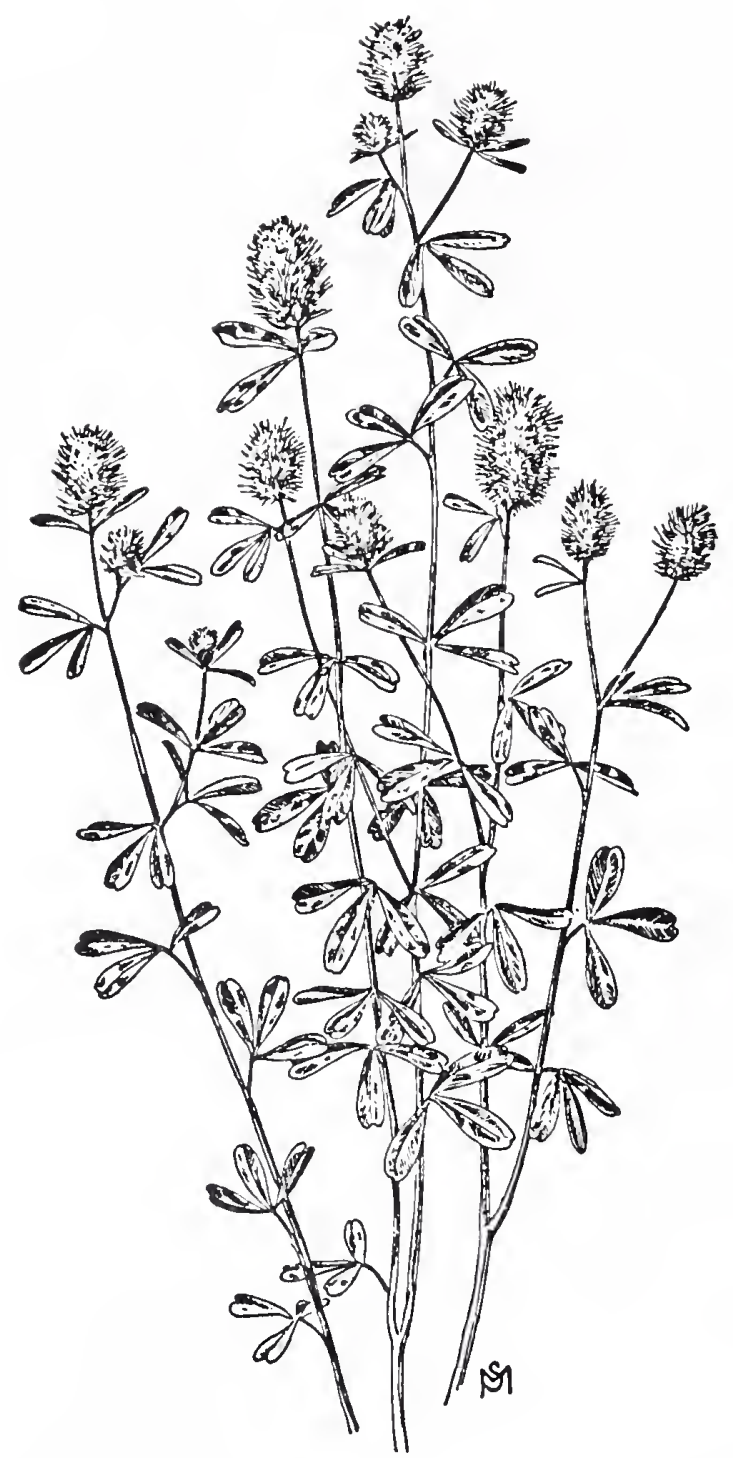

Trifolium arvense--Rabbit's-foot Clover [From Mathews (1912), plate between pp. 212-213.]

Trifòlium hýbridum I. Alsike Clover.

Meaning of Species Name. Hybrid, from an early misconception. Other Names. Pink' Clover, Alsatian Clover, Swedish Clover. Type of Plant. A perennial herb.

Habitat. Much cult, spreading to roadsides and clearings. Range. Nf to $\mathrm{Ak}$, $\mathrm{s}$ to $\mathrm{Fla}$ and $\mathrm{Cal}$.

Distr in NYS. Often cult and locally common as an esc or natzd plant in many parts of the state.

Distr in the Torrey Range. Common in most parts of our range as a weed, but often locally wanting.

Time of Fl. Jun-Oct; Jun-Aug at Cornell.

Origin. Introd from Eu.

Remarks. More abundant northw; sometimes cult for fodder. 


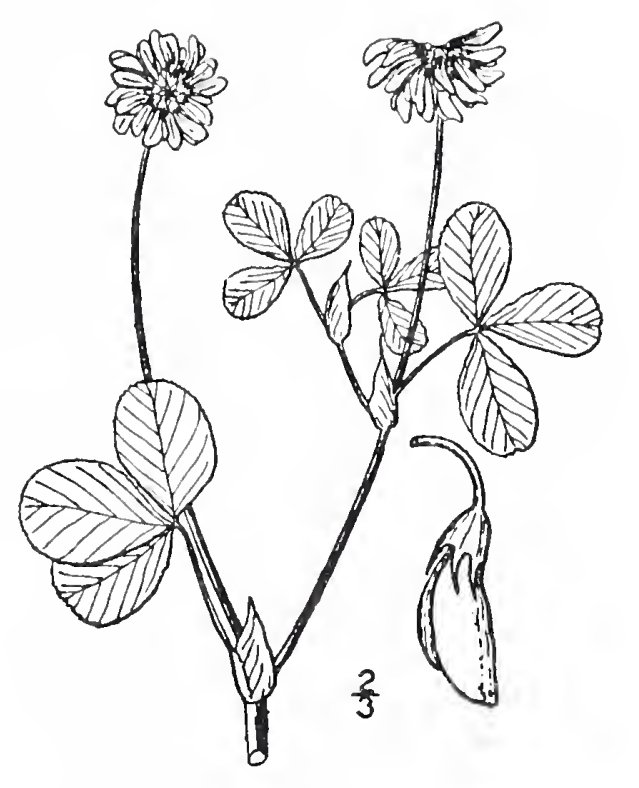

Trifolium hybridum--Alsike Clover

[From Britton \& Brown (1913), II: 357.]

This species is a good source of honey in some areas. Steyermark (1963) observes that "Alsike Clover is sown as a pasture and fodder plant primarily as a substitute for red clover in wet or sour soils," particularly in the north-central, eastern, and Pacific northwestern states.

Kingsbury (1964) reports that photosensitivity caused by eating this species has been recognized in hogs, sheep, cattle, and horses. The latter seem to be particularly susceptible, poisoning usually occurring among animals on alsike pasturage during bright sunny weather. Animals usually make a prompt recovery on being removed from the clover pasturage. Some individuals likewise get a dermatitis from handling this species.

Prifolium praténse L. Red Clover.

Meaning of Species Name. Of meadows.

Other Names. Purple Clover, Meadow Clover, Sweet Clover, Marlgrass, Cow-grass, Cow-clover, Broad-leaved Clover, Common Clover, Sugar-pl.ums, Honeysuckle-clover, Knap, Suckles, Cleaver-grass.

Type of Plant. A biennial or short-lived perennial herb.

Habitat. Fields, roadsides, meadows, and clearings.

Range. Lab to BC, s nearly throughout temp NAm.

Distr in NYS. Very common.

Distr in the Torrey Range. Common throughout the area.

Time of Fl. May-Aug(Sep); Jun-Oct at Cornell.

Origin. Natzd from Eu.

Remarks. Commonly planted for forage.

As an agricultural plant, Red Clover, a native of Europe and temperate Asia, seems to have first attracted attention in England around 1635. It was introduced into America at an early period, for Bartram 


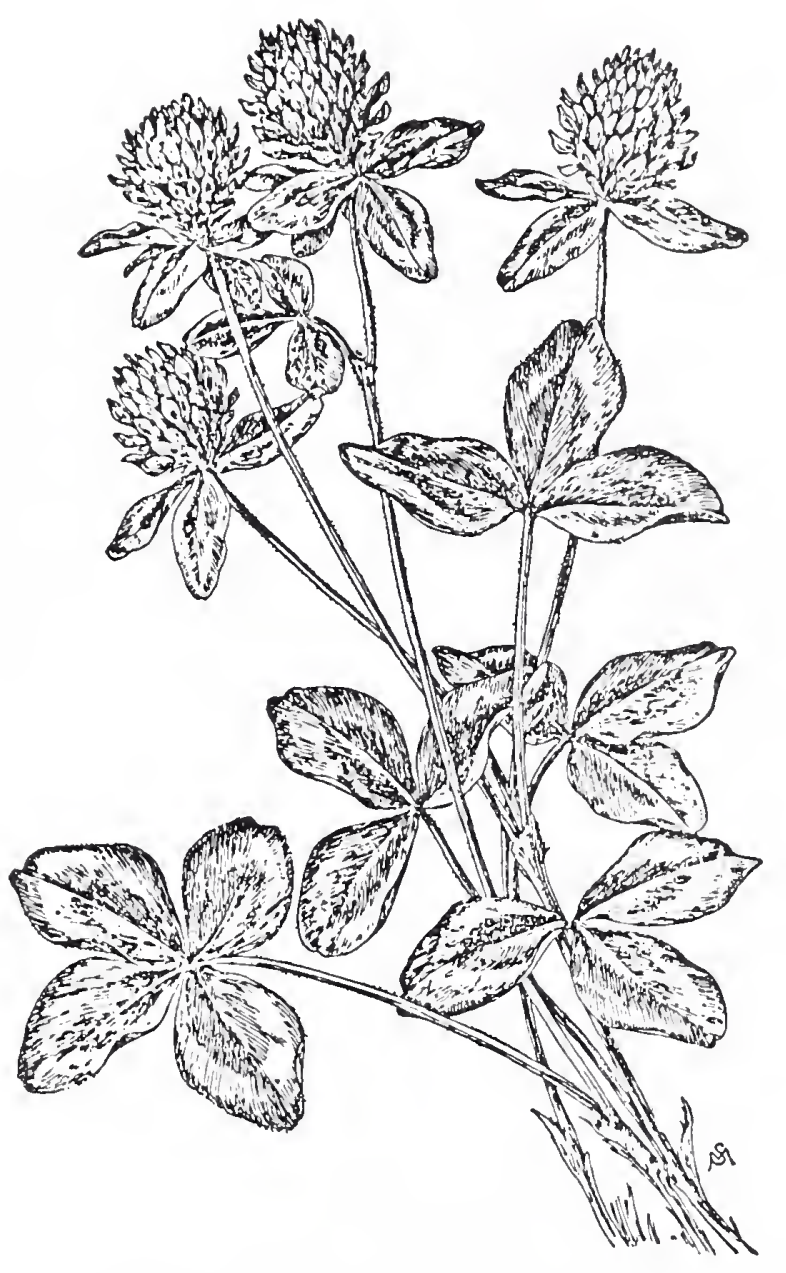

\section{Trifolium pratense--Red Clover \\ [From Mathews (1912), plate between pp. 212-213.]}

mentioned it before the American Revolution and Samuel Deane in 1797 spoke of it as a plant highly valued in New England. While it is among the most generally cultivated fodder plants, it seems not to have been used as a food plant in Europe until about 1875, when J. Lightfoot reported that in Ireland the powdered flowers were "mixed with bread and eaten" in times of scarcity, presumably by adding the flowers to flour to increase its bulk before baking.

Johnson (1867) has much to say concerning the usefulness of this plant to the British farmer: "The Clover is perhaps the most important to the farmer of all the plants cultivated for fodder in this country. In the wild state it is a perennial, but when grown artificially it rarely lasts many years. It is usually sown with corn [wheat or rye] in the spring, and allowed to grow up after the crop is reaped, pastured by sheep or cattle, and either cut for hay the following season, or mowed several times like lucerne [Medicago sativa], and employed for a 'soiling,' or feeding in the farmstead....

"On good soils fitted for its production Red Clover will often yield upwards of three tons of hay per acre, and sometimes considerably more. 
Like most plants of the kind, it is very succulent, and requires long drying before it is fit for stacking. In Courland and other parts of Russia it is commonly fermented in heaps before drying, and cattle are said to relish it in that condition. To obtain Clover-hay in its most nutritive state, as well as to insure a vigorous after-growth, it should always be cut before it is in full flower ...

"The nutritive qualities of Clover are exceeded by very few plants, and it is so productive that ... one acre is equal to three of ordinary pasture ..., and the hay is reckoned more valuable ... than the same weight yielded by the best meadow land...

"The introduction of this plant and that of the turnip, have caused a revolution in British husbandry. It seems to have been first grown here by Sir Richard Weston, in 1645, being introduced by him from Belgium, where he had observed its large and successful cultivation; but it appears to have been sown on the Continent long before, the want of the fine natural pastures that we possess having, at a very early period, directed the attention of the German and French farmers to the cultivation of those herbs that yield their best substitute.

"The seeds and dry flowers of the Red Clover, like those of the white species, have been occasionally used as a substitute for flour in bread making, and those of all the native species might probably be so employed.

"The heads are gathered in the north of Europe for dyeing wool green, being boiled with alum or sulphate of iron."

Steyermark (1963) was of the opinion that "After alfalfa, red clover is considered to be the most important forage legume crop in the United States," particularly in the north-central, northeastern, and Pacific northwestern states.

The redish-purple blossoms are currently more likely to be used to make a tea much relished by some people than are other species of clover. The flower heads are gathered on a dry day when in full bloom and dried indoors at room temperature, either by spreading them out on newspapers on the floor or by hanging them up to dry. When fully dry the flowers can be crushed, then packed and stored in tightly covered glass jars. Herbs to be used in cooking or for making tea should never be dried in the sun or in an oven, for the flavoring oils are usually highly volatile and easily dissipated by heat. Clover tea is prepared by pouring boiling water over a heaping teaspoonful of the dried blossoms and letting them steep for a few minutes. A more flavorable tea mixture can be made by mixing four parts of crushed dried clover blossoms with one part of crushed dried peppermint or spearmint leaves, used in about the same amount as in preparing regular tea.

Among the laity during the $1800^{\prime}$ 's, a strong clover tea was very likely to be consumed as a sedative and for its demulcent action, deemed particularly valuable in treating such respiratory ailments as asthma, hoarseness, colds, persistent coughs, and irritations of the respiratory tract. Iighthall (n.d.) suggested a "common swallow" of the hot tea "every hour or two." A cough syrup was also made by adding strained honey to a 


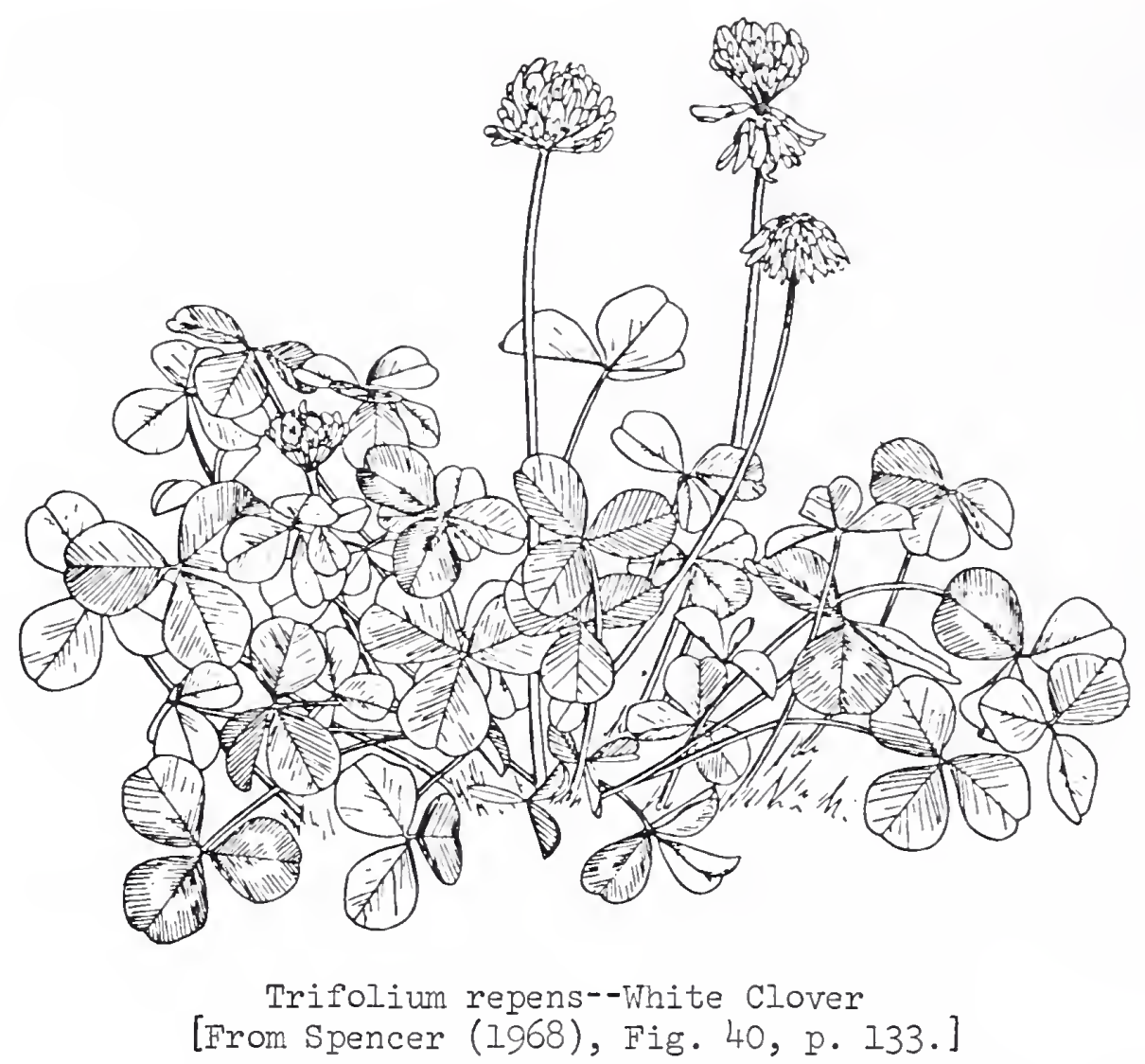

strong infusion of the blossoms, considered useful for croups, colds, bad coughs, and hoarseness. An infusion of the entire plant at full bloom was likewise a component of salves used to treat skin sores and ulcers. American Indians used the plant for sore eyes and in a salve for burns, but they could not have done so until the plant had been introduced from Europe. In central Europe this species was used medicinally to improve the appetite, relieve digestive distress, and to treat liver ailments.

Kingsbury (1964) reports that "Hay containing large or moderate amounts of second-cutting or late-season red clover produces a syndrome characterized by slobbering in cattle, horses, and sheep," the symptoms being "likely to continue with increasing severity as long as the hay is fed."

Trifólium rèpens I. White Clover.

Meaning of Species Name. Creeping.

Other Names. Dutch Clover, Honeysuckle Clover, White Trefoil, Purple-grass, Purplewort, Sheep's Gowan, Honeystalks, Lamb-sucklings, Shamrock, White Dutch Clover.

Type of Plant. A perennial herb.

Habitat. Iawns, roadsides, fields, and open pastured woods.

Range. Throughout the US and $\mathrm{n}$ into Can and Ak.

Distr in NYS. Common.

Distr in the Torrey Range. Common throughout our range as a weed. Time of Fl. May-Oct; Jun-Oct at Cornell. 
Origin. Introd and natzd from Eu.

Remarks. Commonly planted.

Trifolium repens and other clovers have long been considered highly valuable as forage crops, either alone or mixed with grass. Millspaugh (1887) states that "Its nutritive ratio is lower by nearly one-half than that of timothy, yet ruminants seem to eat it more greedily and with a fuller sign of satisfaction." White Clover is also greatly prized as a green manure to improve the soil, an element of importance in crop rotation because of its large percentage of potash, lime, and phosphoric acid. Johnson (1867) observes that "The chief value of this species is for pasturage. All kinds of domestic cattle thrive upon it. It forms a most valuable addition to the grasses in permanent pastures, and is often sown alone, or with rye-grass, for more temporary use. In this latter way it will last and continue to yield good crops for many years." He also remarks that "The seeds retain their vitality for a long period when buried in the ground, and hence the plants often appear abundantly on land freshly brought under cultivation."

It is reported that in Ireland during times of scarcity the powdered flowers of this species were mixed with flour to make a bread considered wholesome and nutritious. It was also much used as one component of a salve for sores and ulcers, "to which it proves peculiarly soothing." A strong infusion was also "often used in half-ounce doses, to suspend the spasm of whooping-cough." A tincture was prepared by pounding the fresh blossoms to a pulp, adding two parts by weight of alcohol, stirring well, and letting the mixture stand at least 8 days in a dark, cool place, after which the tincture was strained and stored until needed.

It is reported that in the United States between 2 and 3 million pounds of White Clover seeds are marketed annually, most of which is mixed with grass seeds for lawns. Some strains of White Clover have "a moderately cyanogenetic capacity," but no actual cases of loss of livestock have been attributed to this species.

This species comes in various sizes. Steyermark (1963) states that "T. repens $\mathrm{f}$. giganteum, Ladino Clover, is a giant form which originated from Lodi, Italy', and was introduced about 1900 into the northeastern states," adding that "various other strains of White Clover are in cultivation, differing from one another in size," with the English White Clover being the smallest and the White Dutch Clover intermediate in size. In addition to its usefulness in pastures and lawns and for its palatable hay and silage value, "It is also employed for soil improvement, erosion control, and food for wildlife," as well as being a source of clover honey. 
Vícia I. Vetch.

There are about 200 species of vetch, more or less climbing herbs with half-sagittate stipules and flowers on axillary peduncles, widely distributed on all continents but particularly in the northern hemisphere and temperate South America. The name of the genus is the classical Latin name of the vetch. Fernald and Kinsey (1943) report that the seeds of $\underline{V}$. sativa have been tried as human food but that they proved to be both unpalatable and indigestible. The fact that this species is invaluable as a forage crop for domestic animals is no indication that it is suitable as food for man. It is reported that the starchy seeds of several species of native vetches were eaten by the Indians. Martin et al. (1961) remark that both the seeds and foliage "are eaten to a limited extent by birds and rodents, including mourning dove, ruffed grouse, ring-necked pheasant, bobwhite quail, wild turkey, and some sparrows," particularly in the eastern states where they are most common.

Vicia faba, the Broad, English, or European Bean, is among the most ancient of cultivated plants, one variety having been found in the lacustrine deposits of Switzerland ascribed to the Bronze Age. It was likewise cultivated by the ancient Egyptians, by the Hebrews, and by the ancient Greeks and Romans. One of the noble families of Rome, the Fabii, derived their name from this plant. It is said to have been introduced into China in the year 2822 B.C. No one knows when it reached Great Britain, but in 1597 Gerarde appears to have known only two varieties.

\section{Key to Iocal Species of Vicia}

1. Flowers 1-8, 3-8 mm long (legume nearly equally rounded from both sutures to the blunt tip, beakless, $1-1.3 \mathrm{~cm}$ long).. V. tetrasperma

1. Flowers $20-40$ or more, $0.8-2 \mathrm{~cm}$ long; if less than 20 flowers in well-developed racemes, $1.5-2 \mathrm{~cm}$ long, 2

2. Appressed-pubescent perennial; upper side of calyx gradually rounded, not gibbous at base, the lower teeth lance-attenuate, the upper very short and broad; limb of standard as long as

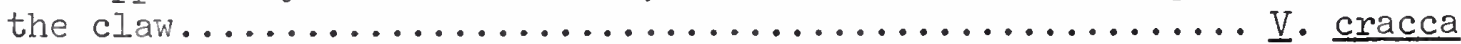

2. Spreading villous annual or biennial; upper side of calyx gibbous or saccate at base, the lower teeth linear-acicular, long-ciliate, the upper lanceolate; limb of standard less than half as long as claw...................... villosa

Vicia crácca L. Tufted Vetch.

Meaning of Species Name. The Latin name applied by Rivinius to this plant, the Italian name being Cracca.

Other Names. Canada-pea, Cow Vetch, Blue Vetch, Bird Vetch, Tinegrass, Cat Peas, Wild Vetch.

Type of Plant. A perennial herb, reproducing by seeds.

Habitat. Fields, meadows, roadsides, thickets, shores, and waste places.

Range. Nf to BC, s to Del, Va, Ind, Mich, and Ill; also in Eurasia. 


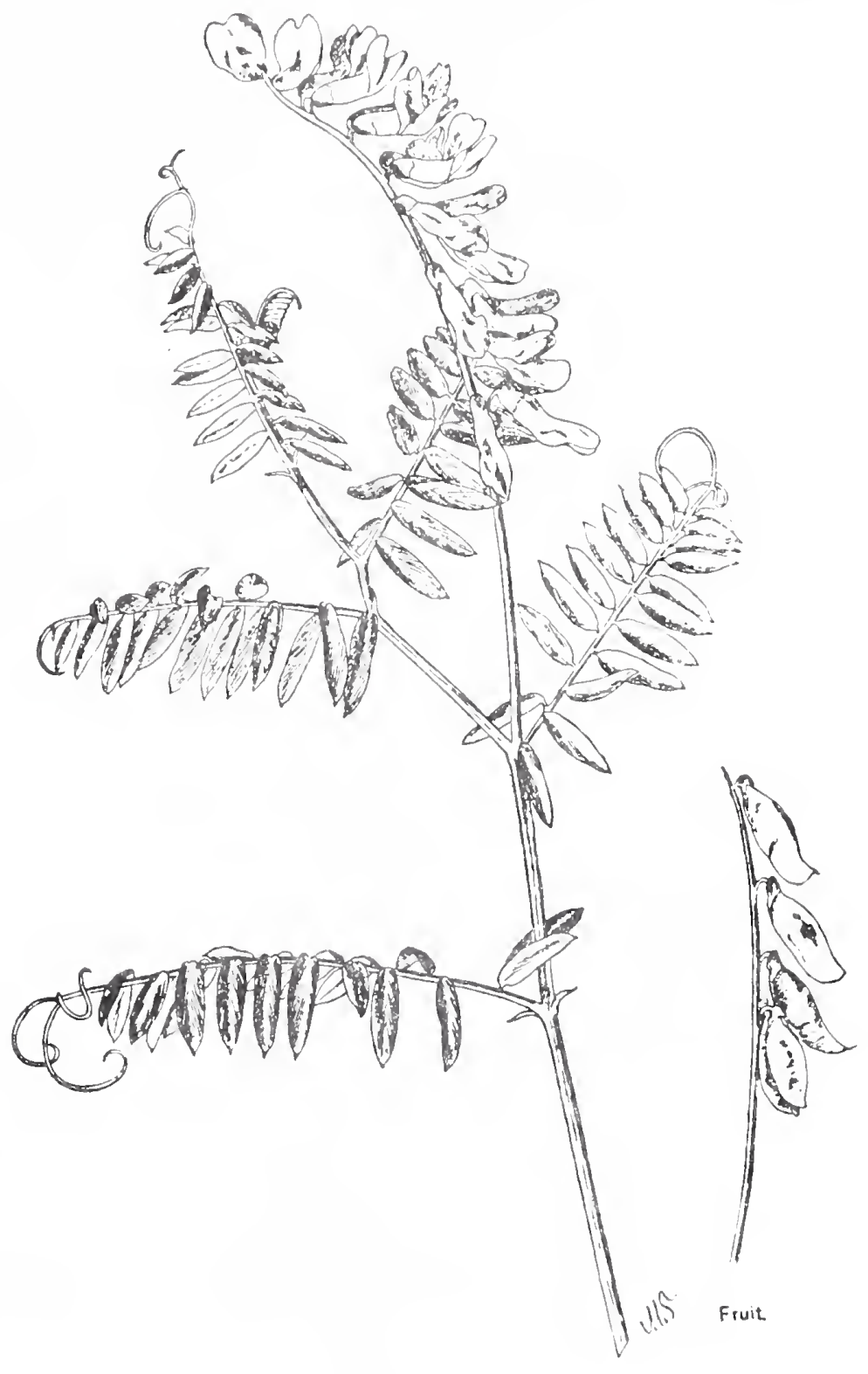

\section{Vicia cracca--Tufted Vetch \\ [From Dana (1900), Plate 155, p. 351.]}

Distr in NYS. Frequent across the state northw, where apparently native; locally abundant southw to the vicinity of NYC, where it appears to be adv.

Distr in the Torrey Range. Rather common as a weed throughout the range except the coastal plain of NJ.

Time 오 티. May-Aug; Jun 10-Jul 15 at Cornell.

Origin. Native in the $\mathrm{n}$ part of its range but apparently natzd from Eu from Mass to Ind and southw.

In areas where this species may have become an undesirable weed, Muenscher (1952) suggests mowing infested fields before the seeds ripen. Plow and fallow with a cultivated crop for one season. 


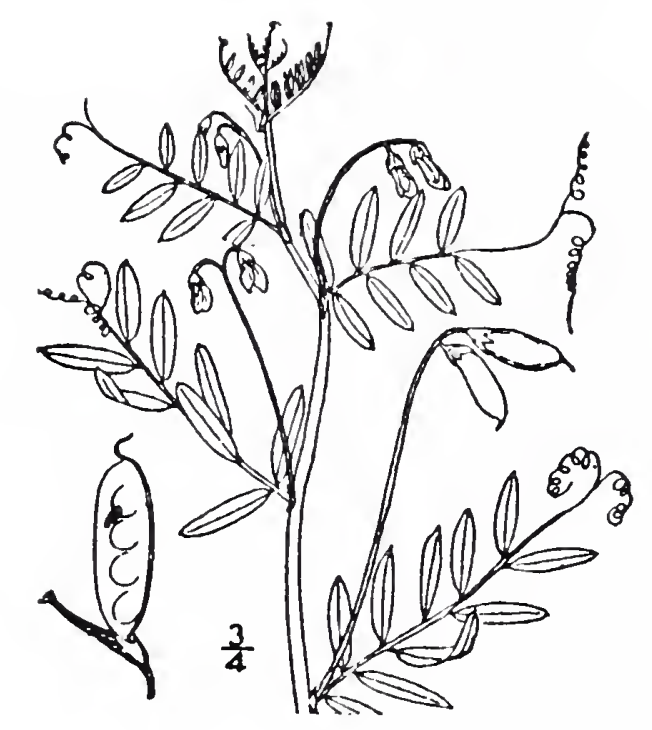

Vicia tetrasperma--Four-seeded Vetch

[From Britton \& Brown (1913), II: 411.]

Vícia tetraspérma (I.) Moench. Four-seeded Vetch.

Meaning of Species Name. Four-seeded.

Other Names. Slender Vetch, Smooth Tare, Lentil Tare.

Type of Plant. An annual herb, reproducing by seeds.

Habitat. Fields, meadows, roadsides, and waste places.

Range. Nf to Ont and Wis, s to Fla and Tex.

Distr in NYS. Frequent or common in many secs of the state.

Distr in the Torrey Range. Not uncommon as a weed near the larger cities and towns.

Time of Fl. May-Aug(Sep); Jun at Cornell.

Origin. Natzd from Eu.

Remarks. In areas where this species may have become an undesirable weed, it can be controlled by the same methods as those outlined for $\underline{V}$. cracca.

Vícia villòsa Roth. Hairy Vetch.

Meaning of Species Name. Iong-hairy.

Other Names. Winter Vetch, European Vetch.

Tyrpe of Plant. An annual or biennial herb.

Habitat. Fields, meadows, roadsides, and waste places.

Range. NS to $\mathrm{BC}$, s to $\mathrm{Ga}$, Tex, and $\mathrm{Cal}$.

Distr in NYS. Infrequent or locally abundant throughout the state outside the densely wooded areas.

Distr in the Torrey Range. Collected from time to time as a waif; doubtfully thoroughly est.

Time of Fl. (May)Jun-Aug(Sep); Jun-Sep at Cornell.

Origin. Introd and natzd from Eu.

Remarks. Cult as a forage crop. 


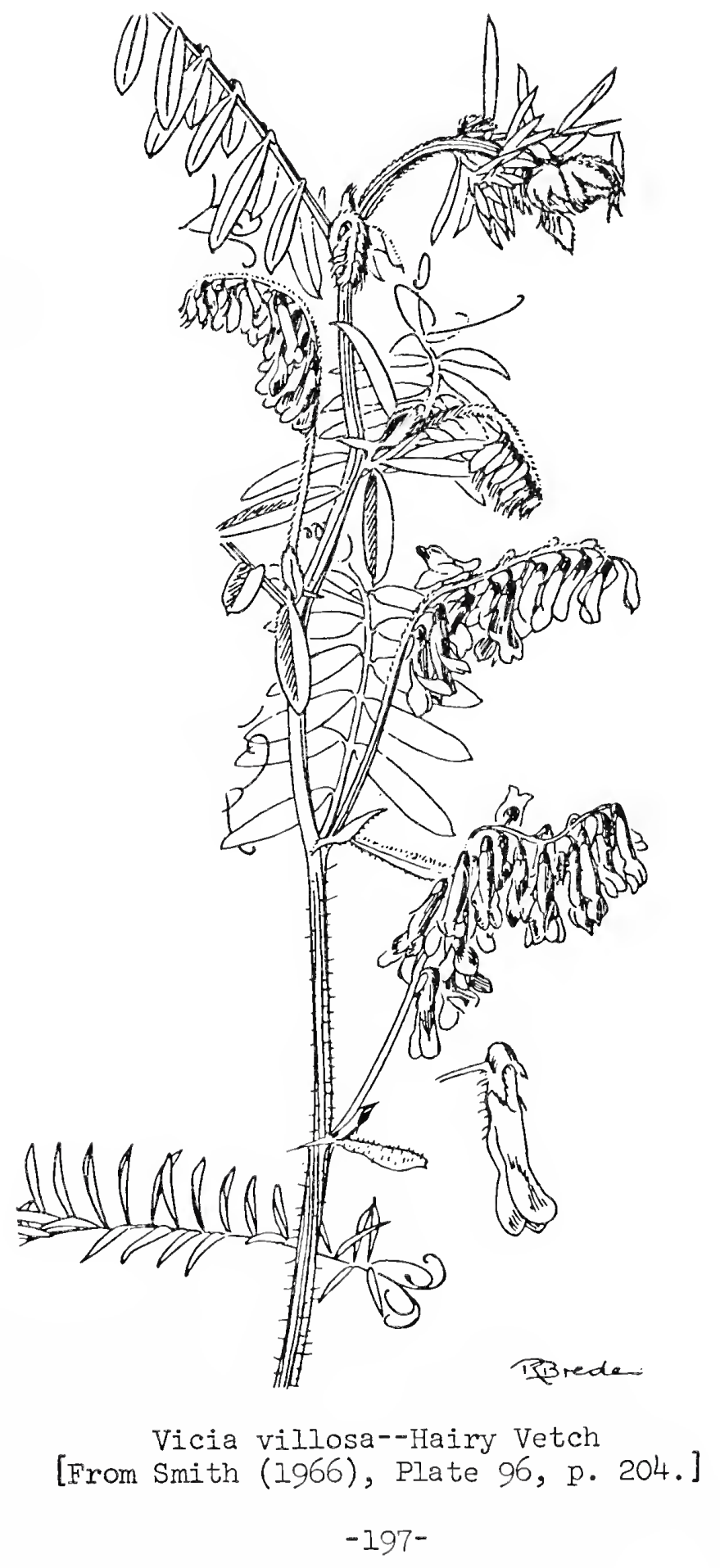


In some areas this species is extensively grown as a cover crop for plowing under as a green manure. It sometimes escapes or persists but does not survive long under cultivation. Steyemark (1963) observes that this species frequently escapes to fallow fields and roadside banks; in flower it is "quite conspicuous" with its "dark lavender to purple, many flowered racemes." Kingsbury (1964) reports that at least one instance is on record in wich this plant caused loss of life in cattle in Europe and that the seed was held responsible for the loss of five cows in Alabama. 


\section{REJECINDAE}

The botany office at the New York State Museum has for years maintained for each of the counties making up New York State an informal, upto-date checklist of all plants known to occur in the county. Admittedly, these checklists are not complete, in part because there has not been time to check all herbaria where specimens from the state have been filed and in part because botanical exploration constantly turns up species previously unrecorded, but these lists do provide all the information currently available on what plants grow in each of the several counties of the state.

As mentioned in the introduction to Volume 1 of this series, however, the Platt list of 1840 was used as one of the sources in compiling a checklist of the plants occurring in Delaware County, although none of the Platt specimens has survived and there is no evidence that the plants studied were confined to those collected in Delaware County. The Platt list, comprising 380 species, contains 36 species from this section of the Catskill flora, 7 of which have neither since been collected in Delaware County, nor are there any records of their occurrence elsewhere in the Catskill region:

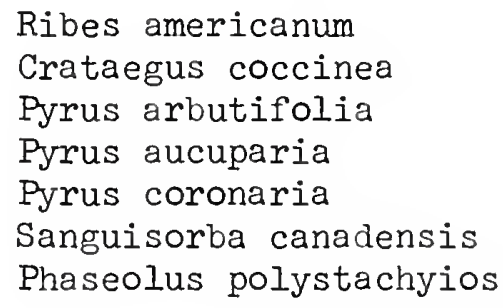

These species are therefore rejected both from the checklist for Delaware County and as elements constituting part of the Catskill flora until such time as more specific evidence is found that they occur in this area. 

The following abbreviations are used primarily in the "plant biographies" and in the Appendix, for the most part without periods:

adv, adventive

Afr, Africa, African

Ak, Alaska

Ala, Alabama

alt, altitude

Alta, Alberta

Am, America, American

Apr, April

Ariz, Arizona

Ark, Arkansas

Aug, August

Austr, Australia

BC, British Columbia

$B W$, black-and-white photograph

$c$, central

Cal, California

$\mathrm{cm}$, centimeter

Co, county, counties

Col, Colorado

Ct, Connecticut

cu, cubic

cult, cultivation, cultivated

DC, District of Columbia

Dec, December

Del, Delaware

distr, distribution

dm, decimeter

$e$, east, eastern

eastw, eastward

esc, escape, escaped

estab, established

Eu, Europe

Feb, February

Il, flower, flowering

Fla, Florida

fr, fruit, fruiting

frag, fragmentary

it, foot

Ga, Georgia

GI, Greenland

$I$, island

Ia, Iowa

Id, Idaho

III, IIlinois

in., inch

Ind, Indiana

introd, introduced
Jan, January

Jct, junction

Jul, July

Jun, June

Kan, Kansas

Ky, Kentucky

I, lake

La, Louisiana

Lab, Labrador

Ib, pound

II, Long Island

$\mathrm{m}$, meter

Mack, Mackenzie District

Man, Manitoba

Mar, March

Mass, Massachusetts

Md, Maryland

Me, Maine

Mex, Mexico

Mich, Michigan

Minn, Minnesota

Miss, Mississippi

$\mathrm{mm}$, millimeter

Mo, Missouri

Mont, Montana

Mt (s), Mount, mountains

$n$, north, northern

$\mathrm{NAm}$, North America(n)

natzd, naturalized

$\mathrm{NB}$, New Brunswick

NC, North Carolina

n.d., no date

ND, North Dakota

$\mathrm{NE}$, New England

ne, northeast, northeastern

Neb, Nebraska

Nev, Nevada

NI, Newfoundland

$\mathrm{NH}$, New Hampshire

NJ, New Jersey

NM, New Mexico

n.n., no name

northw, northward

Nov, November

n.p., no place

IS, Nova Scotia

nw, Northwest, northwestern 
NY, New York

NYC, New York City

NYS, New York State

0 , Ohio, Ohio State University

Oct, October

Okla, Oklahoma

Ont, Ontario

Ore, Oregon

$\mathrm{Pa}$, Pennsylvania

Phil, Philadelphia Acadeny of Sciences

Que, Quebec

$R$, river

reg, region, regions

RI, Rhode Island

Rt, route

$s$, south, southern

SAm, South America(n)

Sask, Saskatchewan

SC, South Carolina

SD, South Dakota

$\sec (s)$, section(s)

Sep, September

SI, Staten Island

southw, southward southwestw, southwestward

ssp, subspecies

St, saint

sw, soutbwest, southwestern

T, transparency; i.e., a 35-m slide in color

Tenn, Tennessee

Tex, Texas

Trop, tropics, tropical

US, United States

$\mathrm{Va}$, Virginia

var., variety

vic, vicinity

$v t$, Vermont

w, west, western

Wash, Washington

westw, westward

$W I$, West Indies

Wis, Wisconsin

wt, weight

WVa, West Virginia

Wyo, Wyoming

$x$, a cross between two species, indicating a hybrid

Yuk, Yukon Territory 
Unhappily for the amateur, botanical literature is so rife with technical terms that it almost seems necessary to learn a new language in order to be able to read some of it with any degree of comprehension. The writer has tried (but probably not always succeeded very welI) not only to keep the use of technical terms to a minimum but also to define those he does use when they first occur. Since glossaries of botanical terms are readily available in most of the field guides, to say nothing of the two more comprehensive ones given in Fernald (1950) and in Gleason (1952), the writer has made no attempt to compile a glossary of botanical terms for this work. In any case, recourse can always be had to Webster's Seventh New Collegiate Dictionary (1965), where most of them are defined. Should one wish to go further afield, George Usher's (1966) A Dictionary of Botany is an excellent reference.

This work contains many references to the medicinal applications of plants, in the course of which the use of a number of medical terms has been necessary. Such words are perhaps likely to be even more unfamiliar to the laymen than are those relating more or less strictly to botany. While the definitions of most of the medical terms are likewise given in the dictionary, the following list, compiled in part from Krochmal et al. (1971), may be helpful.

Ague, an old word for fever, usually malaria.

Allergenic, produces an allergy.

Alterative, an old-fashioned medical term meaning a medicine that cures an

illness by gradually restoring general bodily health.

Amenorrhea, an abnormal absence or suppression of the menstrual discharge. Anodyne, relieves or quiets pain.

Antacid, neutralizes excess acidity in the alimentary canal.

Anthelmintic, capable of expelling or destroying intestinal worms.

Antiasthmatic, relaxes bronchial muscles and relieves labored breathing.

Antibiotic, an organic chemical substance, derived from living things, that

will work selectively against harmful microorganisms.

Antidote, counteracts the action of a poison.

Antipruritic, prevents or relieves itching (antipsoriatic).

Antipyretic, any medicine for checking or preventing fever; also called

"Pebrifuge" and "refrigerant."

Antiscorbutic, a food or medicine that can prevent or cure scurvy; any plant

that contains significant amounts of vitamin $C$ is an antiscorbutic.

Antiseptic, checks or inhibits the growth of the microorganisms that cause

infection.

Antitussive, relieves or prevents coughing.

Aperient, a mild and gentle-acting laxative

Aromatic, a plent, drug, or medicine with a spicy scent and purgent but

pleasing taste.

Astringent, causes the contraction or shrinkage of body tissues. Ataxia, an inability to coordinate voluntary muscular movements. Calculous, a mineral deposit or "stone," usually in the bladder or kidney. Carcinogenic, causing cancer.

Carminative, used to discourage the formation of gas after eating. 
Catarrhal, related to inflamation of the respiratory tract.

Cathartic, causes an evacuation of the bowel.

Caustic, destroys tissue.

Cholagogue, increases the flow of bile

Consumption, an old term for tuberculosis.

Corroborant, an invigorating agent.

Counterirritant, causes irritation of the surface of an area with the object of relieving a deep-seated congestion.

Cystic, relating to the urinary bladder or to the gall bladder.

Cystitis, inflammation of the urinary tract.

Cytotoxic, poisonous to cells.

Decoction, an extract obtained by boiling.

Demulcent, a substance used to protect or soothe the gastro-intestinal tract.

Deobstruent, a medicine that has the power to clear obstructions Irom the natural ducts of the body.

Depurative, removes impurities and waste materials from the blood.

Diaphoretic, used to increase perspiration.

Disinfectant, destroys or inhibits the growth of harmful microorganisms.

Diuretic, increases the volume and flow of urine.

Drastic, an agent that acts rapidly or violently.

Dropsy, edema, an abnormal accumulation of serous fluid in bodily tissues (excess "water" in the common tongue).

Dysentery, a disease characterized by severe diarrhea with passage of mucus and blood, usually caused by infection.

Dyspepsia, a disturbed digestive condition characterized by nausea, gas, and heartburn; indigestion.

Emetic, an agent that causes vomiting.

Emenagogue, an agent that induces menstrual slow.

Emollient, used externally to soothe or soften the skin and protect it.

Excoriation, a peeling or wearing off of the skin.

Expectorant, an agent that causes expulsion of phlegm from the respiratory tract.

Febrifuge, an agent that reduces fever.

Flatulence, stomach discomfort caused by gas.

Flux, an excessive abnormal discharge from the bowels.

Gastritis, inflamation of the mucous membrane, particularly of the stomach.

Hemoptysis, expectoration of blood from some part of the respiratory tract. Hemorrhage, a copious discharge of blood from the blood vessels; bleeding.

Hemostatic, an agent used to stop internal hemorrhage.

Hepatic, of or pertaining to the liver.

Herpetic, pertaining to reptiles.

Hygroscopic, having the ability to attract and absorb moisture from the surrounding environment.

Hypnotic, an agent that induces sleep without delirium.

Infusion, an extract obtained by steeping or soaking in water, usually hot but not boiling.

Irritant, causes inflamation of, or stimulation to, the tissues.

Jaundice, a diseased condition that causes the skin, eyes, and body fluids

to turn a yeilowish-green color.

Lumbago, painful muscular rheumatism usually involving the lower back.

Menorrhagia, an abnomally profuse menstrual flow.

Nephritis, inflamation of the kidneys. 
Nervine, a redicine that will quiet nervousness or act as a tonic to nerve tissue; a relaxant or calmative.

Ophthalmiatric, used in the treatment of eye diseases.

Pectoral, usually an expectorant, used for diseases of the chest and lungs.

Peritonitis, inflamation of the tissues lining the abdominal cavity.

Poultice, a soft, usually heated, medicinal substance spread on cloth and

applied to the skin.

Pressor, raising or tending to raise blood pressure.

Pulmonary, pertaining to the lungs.

Purgative, increases peristalsis (contraction of the bowel).

Pustulant, causes severe irritation of the skin, especially the sweat glands. Refrigerant, allays thirst and gives a sensation of coolness to the body.

Rheumatism, a sort of catch-all term that includes almost any pain and stiffness of the joints.

Rickets, a childhood disease characterized by defective deposition and utilization of calcium and phosphorus owing to inadequate sunlight or vitamin $D$.

Rubifacient, causes reddening and mild irritation of the skin.

Scorbutic, relating to or resembling scurvy.

Scurvy, a disease marked by swollen and bleeding gurns, loosening of teeth, and bleeding into the skin and mucous membranes, resulting from a lack of ascorbic acid (vitamin C).

Sialagogue, causes an increase in flow of saliva.

Somnifacient, produces sieep without delirium; a soporific.

Soporific, tending to induce sleep.

Stimulant, a substance that increases the activity of some part of the body, but not all stimulants bring a feeling of well-being; stumulants must be carefully distinguished from narcotics, which often bring a feeling of euphoria by depressing certain nerve centers.

Stomachic, stimulates appetite and increases secretion of digestive juices.

Styptic, an agent to check or stop bleeding; most herbal styptics are strong astringents that staunch the flow of blood by shrinking the surrounding tissues, thus closing the exposed blood vessels.

Sudorific, increases perspiration.

Thoracic (pertaining to the chest), a medicine used to treat complaints of the lungs and bronchial tubes.

Tincture, a solution of a medicinal substance in alcohol.

Tonic, stimulates the restoration of strength or tone to the muscles; bitter tonics achleve this by stimilating the flow of gastric juices, which increases the appetite, enabling the patient to consume more nourishing food.

Urethritis, infection of the urethra, the duct by which urine is discharged from the bladder.

Vermicide, an agent that destroys worms.

Vermifuge, a substance used to destroy or expel parasitic intestinal worms. Vesicant, causes irritation to the skin, resulting in blisters.

Vulnerary, an agent that promotes healing of open wounds. 



\section{REFERENCES}

Adrosko, Rita J. 1968. Natural Dyes in the United States. U. S. National Museum Bulletin 281. Smithsonian Institution Press, Washingdon, D. C. Reprinted by Dover Publications, Inc., New York, 1971, as Natural Dyes and Home Dyeing.

Alexander, E. J. 1936. "An Unsought Adventure in the Southern Catskills," Jour. N. Y. Bot. Gard. 37: 42-46.

Bailey L[iberty] H. 1949. Manual of Cultivated Plants, Rev. Ed. Macmillan Publishing Co., Inc., New York.

Bartram, William. 1792. Travels Through North and South Carolina, Georgia, East and West Florida. A facsimile of the 1792 London ed. The Beehive Press, Savannah, 1973.

Benson, Lyman. Plant Classification, 2d ed. D. C. Heath \& Co., lexington, Mass.

Berglund, Berndt, and Clare E. Bolsby. 1971. The Edible Wild. Charles Scribner's Sons, New York.

Bigelow, Jacob. 1817-20. American Medical Botany ... 3 vols. Cummings \& Hilliard, Boston.

Billington, Cecil. 1949. Shrubs of Michigan. Cranbrook Institute of Science, Bulletin No. 20, 2a ed. Bloomfield Hills, Mich.

Britton, Nathaniel L. 1908. North American Trees. Henry Holt \& Co., New York.

, and Addison Brown. 1913. An Illustrated Flora of the Northern United States, Canada and the British Possessions ..., 2d ed. 3 vols. Charles Scribner's Sons, New York. A reprinted edition is available from Dover Publications, Inc., New York.

Brooker, S. G., and R. C. Cooper. 1961. "New Zealand Medicinal Plants," Econ. Bot. 15: 1-10.

Brooklyn Botanic Garden. 1964. Dye Plants and Dyeing. A special printing of Plants \& Gardens, Vol. 20, No. 4. Brooklyn Botanic Garden, Brooklyn.

Brooks, Karl I. 1962. "New Records for Delaware County, New York," Torreya 89: 190-191.

Brown, H.P. 1921. Trees of New York State. New York State College of Forestry at Syracuse University, Technical Publication No. 15. Syracuse, N. Y. Reprinted by Dover Publications, Inc., New York, 1975. 
Burns, G. P., and C. H. Otis. 1916. Trees of Vermont. Vermont Agric. Exp. Sta. Bul. 194. Free Press Printing Co., Burlington, Vt.

Clute, Willard N. 1898. The Flora of the Upper Susquehanna and Its Tributaries. Willard N. Clute \& Co., Binghamton, N. Y.

Coon, Nelson. 1960. Using Wayside Plants, 3d rev ed. Hearthside Press Inc., New York.

Core, Earl L. 1967. "Ethnobotany of the Southern Appalachian Aborigines," Econ. Bot. 21: 199-214.

Creevey, Caroline A. 1912. Harper's Guide to Wild Flowers. Harper \& Bros., New York.

Crockett, Lawrence J. 1977. Wildly Successful Plants: A Handbook of North American Weeds. Macmillan Publishing Co., Inc., New York

Cronquist, Arthur. 1968. The Evolution and Classification of Plants. Houghton Mifflin Co., Boston.

- 1981. An Integrated System of Classification of Flowering Plants. Columbia University Press, New York.

Cutler, Manasseh. 1785. An Account of Some of the Vegetable Productions, Naturally Growing in this Part of America, Botanically Arranged. Mem. Am. Acad. I: 396-493.

Dana, Mrs. William Starr. 1900. How To Know the Wild Flowers. Reprinted by Dover Publications, Inc., New York, 1963.

Densmore, Frances. 1928. "Uses of Plants by the Chippewa Indians," 44th Annual Report of the Bureau of American Ethnology to the Secretary of the Smithsonian Institution, 1926-1927, pp. 279-397. U. S. Government Printing Office, Washington, D. C. Reprinted by Dover Publications, Inc., New York, 1974, as How Indians Use Wild Plants.

Dispensatory of the United States of America, 12th ed. 1865. J. B. Iippincott \& Co., Philadelphia.

Emerson, George B. 1878. A Report on the Trees and Shrubs Growing Naturally in the Forests of Massachusetts. 2 vols. Little, Brown \& Co., Boston.

Encyclopaedia Britannica. 1957. 2'+ vols. Encyclopaedia Britannica, Inc., Chicago.

Everett, T. H., ed. 1960. New Illustrated Encyclopedia of Gardening, Unabridged. 14 vols. Greystone Press, New York

Fenneman, Nevin M. 1938. Physiography of Eastern United States. McGrawHill Book Co., New York. 
Fernald, Meritt L. 1950. Gray's Manual of Botany, 8th ed. American Book Co., New York. Corrected Printing, 1970.

and Alfred C. Kinsey. 1943. Edible Wild Plants of Eastern North America. Idlewild Press, Cornwall-on-Hudson, N. Y. (An edition revised in 1958 by Reed C. Rollins is available from Harper \& Row, New York.)

Fogg, Join M. 1945. Weeds of Lawn and Garden. University of Pennsylvania Press, Philadelphia.

Foster, Gertrude B. 1965. Herbs for Every Garden. E. P. Dutton \& Co., Inc., New York.

Fox, Helen M. 1933. Gardening with Herbs for Flavor and Fragrance. The Macmillan Co., New York. Reprinted by Dover Publications, Inc., New York, 1970.

Frankton, Clarence, and Gerald A. Mulligan. 1971. Weeds of Canada. Canada Department of Agriculture [n.p.]

Fyles, Faith. 1920. Principal Poisonous Plants of Canada. Department of Agriculture Bulletin 39, 2d Series. J. de Labroquerie Tache, Ottawa.

Georgia, Ada E. 1914. A Manual of Weeds. The Macmillan Co., New York.

Gerard, John. 1633. The Herbal or General History of Plants. Revised and enlarged by Thomas Johnson. Reprinted by Dover Publications, Inc., New York.

Gibbons, Euell. 1962. Stalking the Wild Asparagus. David McKay Co., Inc., New York.

1966. Stalking the Healthful Herbs. David McKay Co., Inc., New York.

Gleason, Henry A. 1952. The New Britton and Brown Illustrated Flora of the Northeastern United States and Adjacent Canada. 3 vols. The New York Botanical Garden, New York.

Going, Maud. 1901. With the Wild Flowers, red ed. The Baker \& Taylor Co., New York.

Grieve, M. 1967. A Modern Herbal. 2 vols. Hafner Publishing Co., New York.

Grimm, William C. 1962. The Book of Trees. The Stackpole Co., Harrisburg, $\mathrm{Pa}$.

- 1966. Recognizing Native Shrubs. The Stackpole Co., Harrisburg, $\mathrm{Pa}$.

1967. Familiar Trees of America. Harper \& Row, Publishers, New York. 
Harlow, William M. 1942. Trees of the Eastern United States and Canada. McGraw-Hill Book Co., New York. Reprinted by Dover Publications, Inc., New York, 1957, as Trees of the Eastern and Central United States and Canada.

Hedrick, U. P., ed. 1919. Sturtevant's Edible Plants of the World. Reprinted by Dover Publications, Inc., New York, 1972.

Hellquist, C. Barre. 1972. "Range Extensions of Vascular Aquatic Plants in New England," Rhodora 74: 138.

Hill, Albert F. 1952. Economic Botany: A Textbook of Useful Plants and Plant Products, 2d ed. McGraw-Hill Book Co., New York.

House, Homer D. 1923. Wild Flowers of New York. 2 vols. New York State Museum Memoir 15. The University of the State of New York, Albany, N. Y. (A one-volume edition is available from The Macmillan Co., New York, 1934, 1961.)

1924. Annotated Iist of the Ferms and Flowering Plants of New York State. New York State Museum Bulletin No. 254, Albany, N. Y.

Illick, Joseph H. 1919. Pennsylvania Trees. Commonwealth of Pennsylvania, Department of Forestry, Bulletin No. 1l. Harrisburg, Pa.

Johnson, C. Pierpont. [1867.] The Useful Plants of Great Britain. Robert Hardwicke, London.

Johnston, Alex. 1970. "Blackfoot Utilization of the Flora of the Northwesturn Great Plains," Econ. Bot. 24: 301-324.

Kalm, Peter. 1770. Travels in North America. 2 vols. William Eyres, Warrington, England. Reprinted by Dover Publications, Inc., New York, 1966.

Kingsbury, John M. 1964. Poisonous Plants of the United States and Canada. Prentice-Hall, Englewood Cliffs, N.J.

Krochmal, Arnold. 1968. "Medicinal Plants and Appalachia," Econ. Bot. $22: 332-337$.

Russell S. Walters, and Richard M. Doughty. 1971. A Guide to Medicinal Plants of Appalachia. Agriculture Handbook No. 400, Forest Sv., U.S. Department of Agriculture.

, and Connie Krochmal. 1973. A Guide to the Medicinal Plants of the United States. Quadrangle, the New York Times Book Co., New York.

Kudish, Michael. 1971. Vegetational History of the Catskill High Peaks. University Microfilms, Ann Arbor, Mich.

Lawrence, George H. M. 1951. Taxonomy of Vascular Plants. The Macmillan Co., New York. 
Li, Hui-Lin. 1969. "The Vegetables of Ancient China," Econ. Bot. 23: $253-260$.

Lightfoot, John. 1789. Flora Scotica... 2 vols. London.

Lighthal], J.I. [n.d.] The Indian Folk Medicine Guide. Popular Library, New York.

Long, H. C. 1938. Weeds of Arable Land. Ministry of Agriculture and Fisheries, Bulletin No. 108. London.

McVaugh, Rogers. 1958. Flora of the Columbia County Area, New York. New York State Museum and Science Service Bulletin No. 360, Albany, N. Y.

Martin, Alexander C., Herbert S.Zim, and Arnold L. NeIson. 1961. American Wildlife and Plants. Reprinted by Dover Publications, Inc., New York.

Mathews, F. Schuyler. 1912. Field Book of American Wild Flowers. G. P. Putnam's Sons, New York.

Medsger, Oliver P. 1917. "Two Months in the Southern Catskilis," Mem. Torr. Bot. Club 17: 294-300.

- 1927. [Flora of the Catskills--Abstract of a lecture before the Torrey Botanical Club 9 Nov 26], Torreya 27: 13-14.

- 1947. Edible Wild Plants. The Macmillan Co., New York.

Mellichamp, T. Lawrence. 1983. "Cobras [DarIingtonia] of the Pacific Northwest [with some observations on Sarracenia]," Natural History 92 , No. 4, April 1983: 46-51.

Michaux, F[rançois] Andrew. 1851. The North American Silva ... 3 vols. Robert P. Smith, Philadelohia; G. P. Putnam, New York. First published in Paris, 1810-13.

Millspaugh, Charles F. 1887. American Medicinal Plants ... Boericke \& Tafel, New York \& Philadelphia. (The 1892 edition of this work has been reprinted by Dover Publications, Inc., New York, 1974.)

Mohlenbrock, Robert H., and Dan K. Evans. 1974. "Illinois Field and Herbarium Studies," Rhodora 76: 460-470.

Morrell, H. K. 1901. "Some Maine Plants and their Uses ...," Rhodora 3: $129-132$.

Muenscher, W[alter] C. 1936. "Aquatic Vegetation of the Susquehanna and Delaware Areas" in State of New York Conservation Department, A Biological Survey of the Delaware and Susquehanna Watersheds, Biological Survey (1935), No. 10, Supplemental to Twenty-fifth Annual Report, 1935, pp. 205-221. 
Muenscher, Walter C. 1944. Aquatic Plants of the United States. Cornell University Press, Ithaca, N. Y.

1949. Poisonous Plants of the United States. The Macmillan Co., New York.

- 1950. Keys to Woody Plants, 6th ed., rev. Comstock Publishing

Co., Inc., Ithaca, N. Y.

- 1952. Weeds. The Macmillan Co., New York.

Pammel, I[ouis] H. 1911. Weeds of the Farm and Garden. Orange Judd Co., New York

- 1913. The Weed Flora of Iowa. Iowa Geological Survey Bulletin No. 4. Des Moines.

Parker, Arthur C. 1910. Iroquois Uses of Maize and Other Food Plants. New York State Museum Bulletin No. 482, Albany, N. Y.

Parsons, Frances T. 1924. How To Know the Wildflowers. Charles Scribner's Sons, New York.

Parsons, Mary E. 1907. The Wild Flowers of California. Cunningham, Curtis \& Welch, San Francisco. Reprinted by Dover Publications, Inc., New York, 1966.

Peattie, Donald C. 1950. A Natural History of Trees of Eastern and Central North America. Houghton Mifflin Co., Boston.

Perkins, Anne E. 1930. "Comon Plants as Domestic Remedies in Maine," Torreya 30: 63-68.

Peterson, Roger T., and Margaret McKenny. 1968. A Field Guide to the Wildflowers of Northeastern and Northcentral North America. The Peterson Field Guide Series. Houghton Mifflin Co., Boston.

Petrides, George A. 1958. A Field Guide to Trees and Shrubs. The Peterson Field Guide Series. Houghton Mifflin Co., Boston.

Philbrick, C. Thomas. 1982. "New Locations for Podostemum ceratophyllum ...," Rhodora 84: 301-303, No. 838, April 1982.

Platt, M. 1840. "Plants Collected and Examined by the Botanic Class ... During the Summer Term of 1840," Fifty-fourth Annual Report of the Regents of the University of the State of New York, 227-231, 1841.

Porcher, Francis P. 1863. Resources of the Southern Fields and Forests, Medicinal, Economical, and Agricultural ... Evans \& Cogswell, Charleston.

Power Authority of the State of New York. 1980. Terrestrial Ecology in the vicinity of the Prattsville Pumped Storage Project, pp. 44-53. Prepared by Charles J. Burt, Ichthyological Associates, Inc. 
Proctor, George R. 1947. "Some Noteworthy Catskill Plants," Rhodora 49: 53-54.

Rafinesque Clonstantine] S. 1828-30. Medical Flora ... of the United States... 2 vols. Atkinson \& Alexander, Philadelphia.

Rogers, Julia E. 1926. Trees. Doubleday, Page \& Co. for Nelson Doubleday, Inc., New York.

Rydberg, Per Axel. 1932. Flora of the Prairies and Plains of Central North America. The New York Botanical Garden, New York. Reprinted by Dover Publications, Inc., New York, 1971.

Sargent, Charles S. 1891-1902. The Silva of North America ... Exclusive of Mexico. 14 vols. Houghton, Mifflin \& Co., Boston.

Saunders, Charles F. 1934. Useful Wild Plants of the United States and Canada. Robert M. McBride \& Co., New York. Reprinted by Dover Publications, Inc., New York, 1976, as Edible and Useful Wild Plants of the United States and Canada.

Smith, Helen V. 1966. Michigan Wildflowers. Bulletin No. 42. Cranbrook Institute of Science, Bloonfield Hills, Mich.

Spencer, Edwin R. 1957. Just Weeds. Charles Scribier's Sons, New York. Reprinted by Dover Publications, Inc., New York, 1974, as All About Weeds.

Steyermark, Julian A. 1963. Flora of Missouri. Iowa State University Press, Ames, Ia.

Stone, Hugh E. 1945. A Flora of Chester County Pennsylvania. 2 vols. The Academy of Natural Sciences, Philadelphia.

Sturtevant, Edward L. 1919. See Hedrick, U. P. 1919.

Svenson, H. K. 1931. "Trip of August 22-29," Torreya 31: 154-157.

Taylor, Norman. 1909. "The Botanical Symposium at Stamford, Delaware County, July 3-10, 1909," Torreya 9: 188-189.

1915. Flora of the Vicinity of New York: A Contribution to Plant Geography. Mem. of the N. Y. Bot. Gard., Vol. V.

Torrey, Raymond H. 1930. "Columbus Day Week-End in the Catskills," Torreya 30: 24-25.

- 1931. "Catskill Trip, May 30-31," Torreya 31: 121-123.

1932. Rhodora 44: 13-15.

U.S. Department of Agriculture. 1949. Trees: the Yearbook of Agriculture. U.S. Government Printing Office, Washington, D. C. 
U.S. Department of Agriculture, Agricultural Research Service. 1971. Common Weeds of the United States. Dover Publications, Inc., New York.

Usher, George. 1966. A Dictionary of Botany. Constable \& Co., Ltc.., Iondon.

Vogel, Virgil J. 1970. American Indian Medicine. Ballantine Books, New York.

Webster's Seventh New Collegiate Dictionary. 1965. G. \& C. Merriam Co., Springfield, Mass.

Weiner, Michael A. 1972. Earth Medicine--Earth Foods: Plant Remedies, Drugs, and Natural Foods of the North American Indians. The Macmilian Co., New York.

Widrlechner, Mark P. 1981. "History and Utilization of Rosa damascena," Econ. Bot. 35: 42-58.

Wiegand, Karl M., and Arthur J. Eames. 1925. The Flora of the Cayuga Lake Basin, New York. Vascular Plants. Cornell University Agric. Exp. Sta. Memoir 92.

Wiley, Farida. 1936. "Catskills Trip, September 12-14," Torreya 36: 152154.

Wood, Alphonso. 1870. American Botany and Flowers. A. S. Bames \& Co., Inc., New York.

Wood, William. 1634. New England Prospects, 3d ed. Thomas \& John Fleet, Boston, 1764 . 


\section{APPENDIX}

The first three sections of my Flora carried detailed documentation for each dot shown on the distribution maps for each species, whether they referred to actual collections made, a reference in the literature, a photograph taken by the writer, or to an observation made in the field. The end result was an Appendix that not only frequently overwhelmed the text but also greatly increased the length of each volume. Another factor to be considered is the fact that few people are likely to be interested in anything more than a general indication of the rarity of a given species or its overall distribution. Clearly a change in procedure seemed advisable. Few distribution maps found in the literature carry extensive documentation, yet that information represents countless hours of research in addition to much time spent in the field. In fact the writer has spent as much, if not more, time compiling distribution records and keeping them up to date as he has spent on research and writing the accompanying text. Such information should not be entirely thrown to the winds. It has therefore been decided to publish the distribution maps with the text but to file the documentation for those maps with the Botany Office of the New York State Museum as well as with the Bailey Hortorium at Comell University, where they can be made available to the general inquirer upon request.

Families of plants in the data that follow are in general arranged in the order given in Fernald (1950) and in Gleason (1952), with the genera in alphabetical order under the several families, followed by the species in each genus, also in alphabetical order. Following a device used by a number of other writers, the township grid has been used as the basis for the distribution maps that follow, where a solid dot (•) represents a collection made in that township, while an open circle (0) refers to an observation, a reference in the literature, or a photograph taken by the writer. No effort has been made to show the approximate location within the township of collections or of observations; the solid dots and open circles simply indicate the occurrence of that taxon somewhere within the township. 


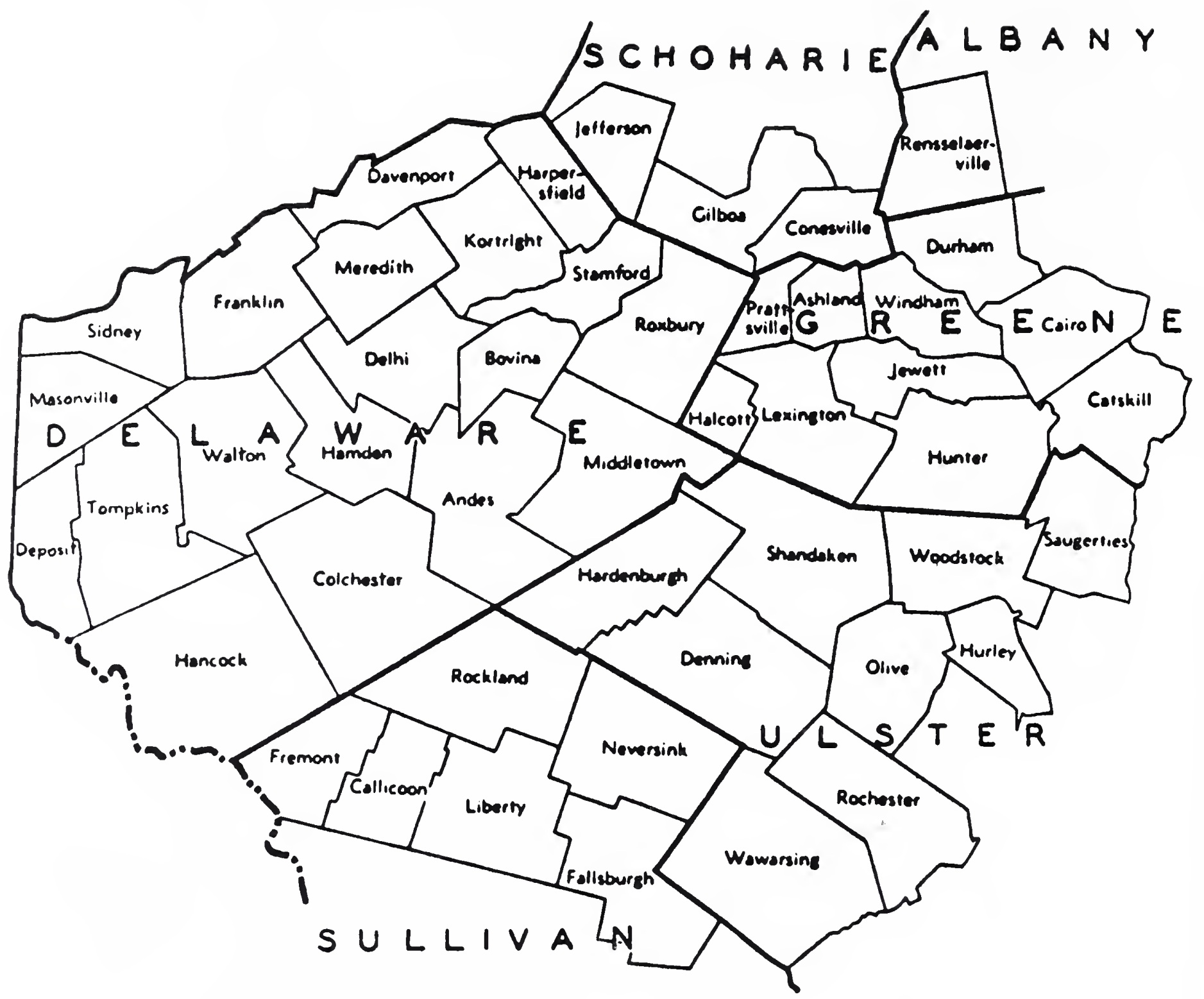

Counties and townships of the Catskill mountain region. 


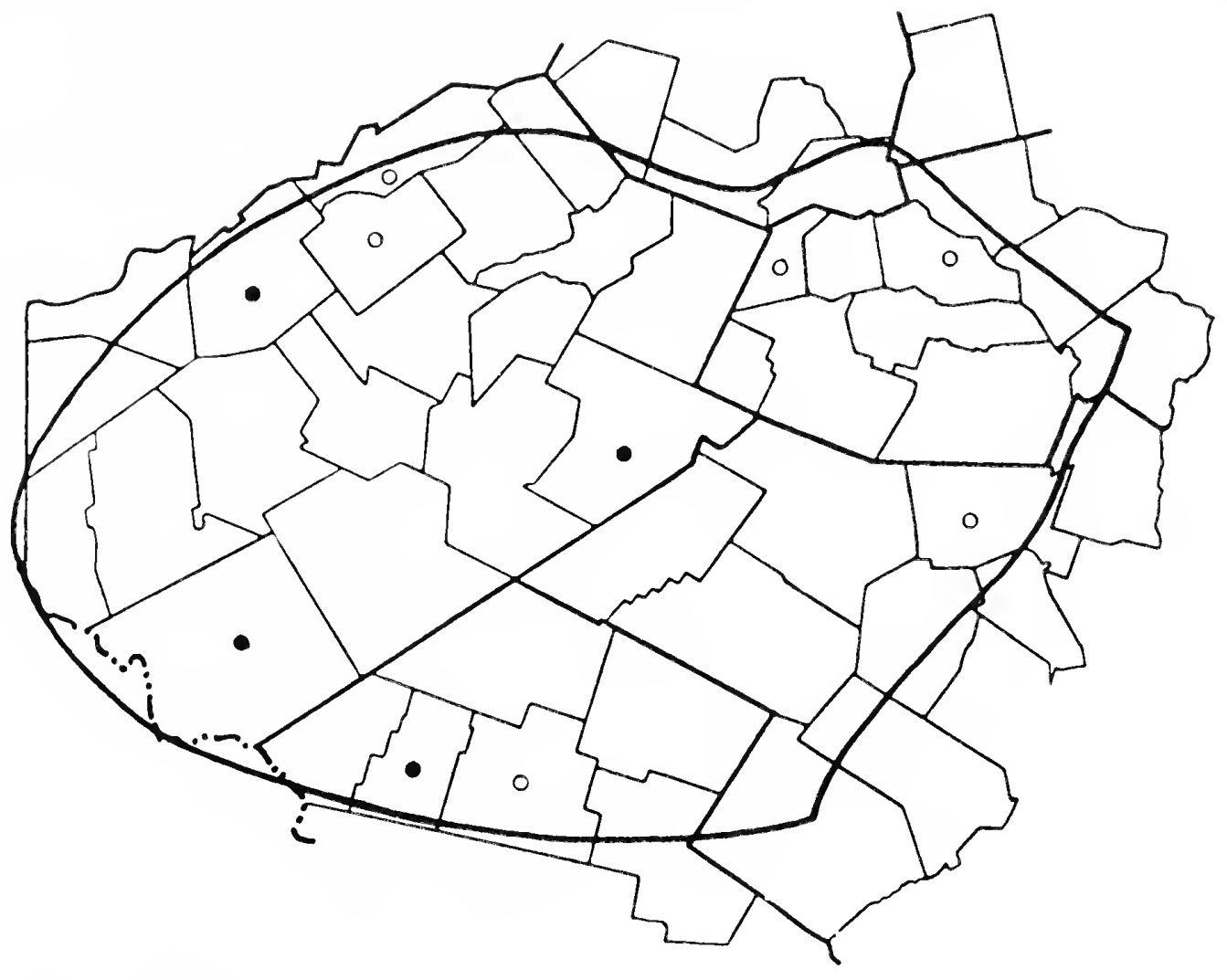

Drosera intermedia Hayne

Spatulate-leaved Sundew

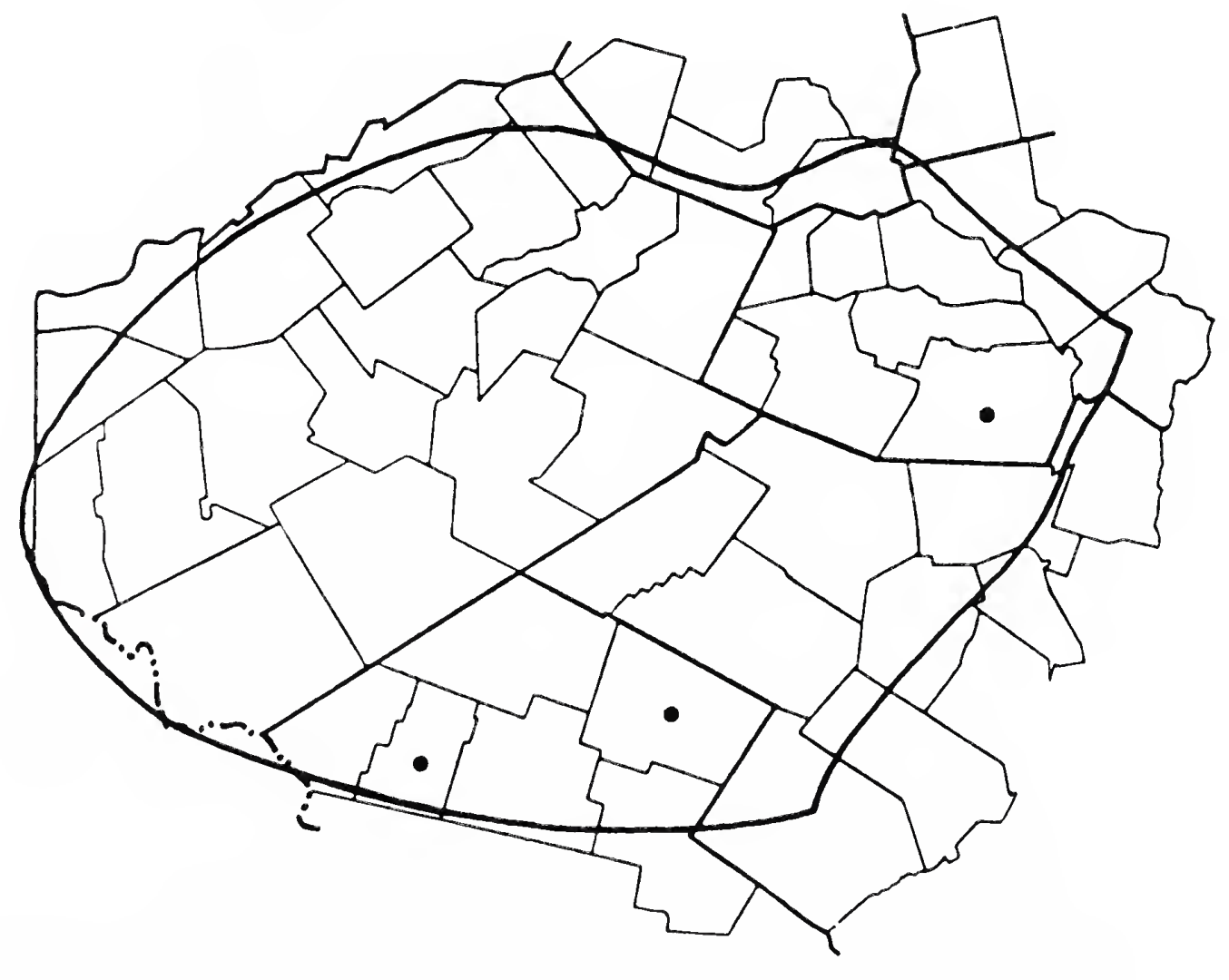




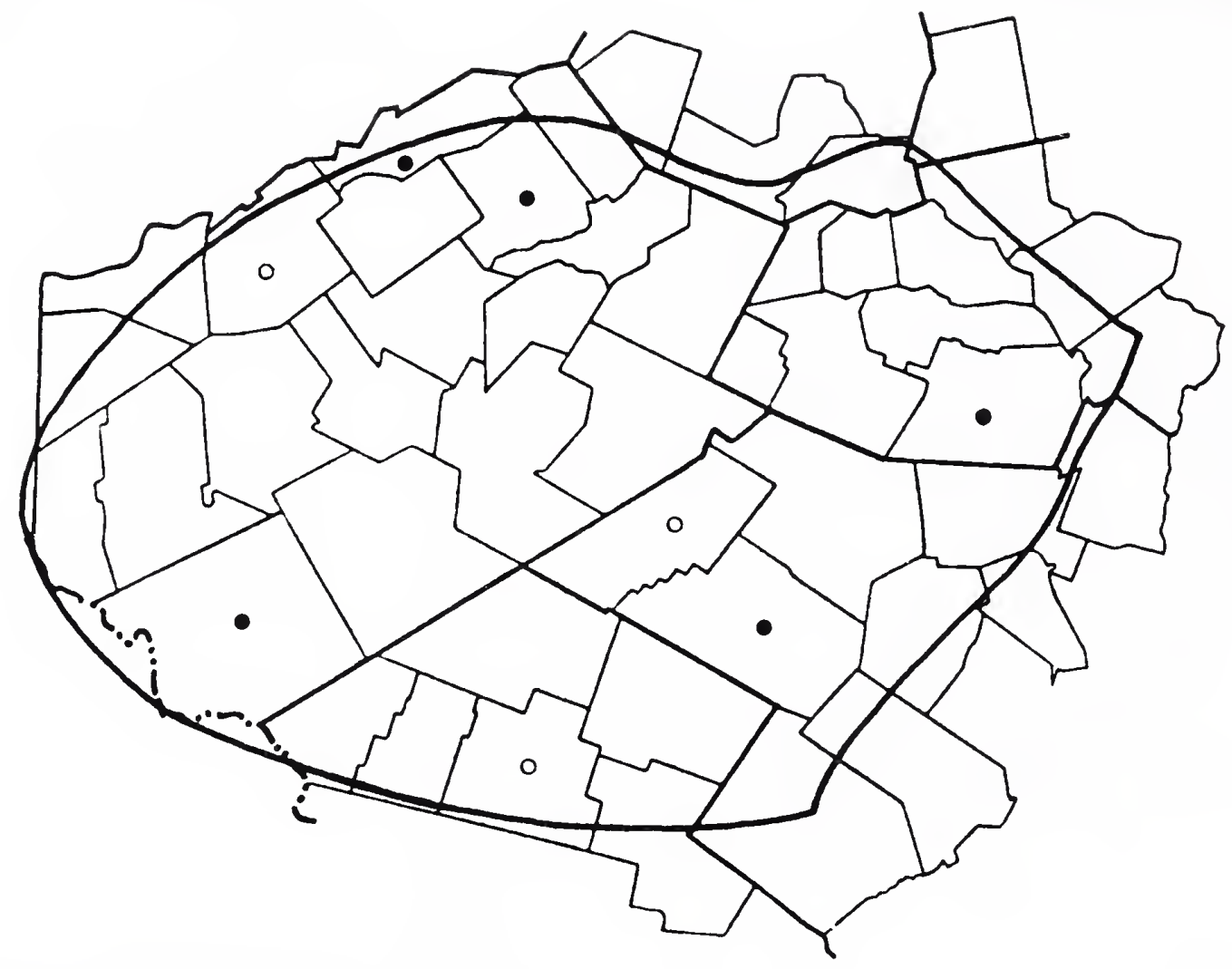

Podostemum ceratophyllum Michx.

Threadfoot

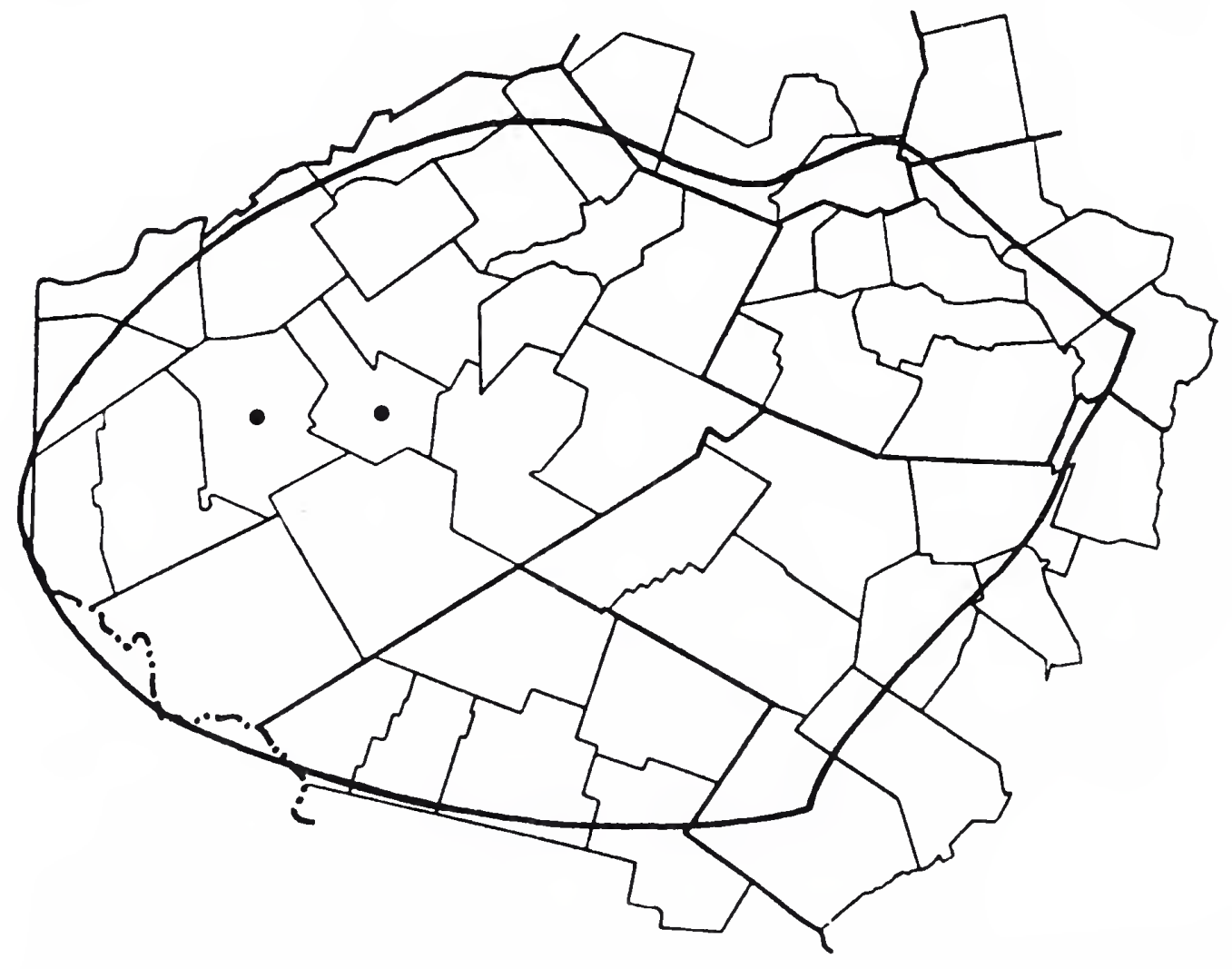




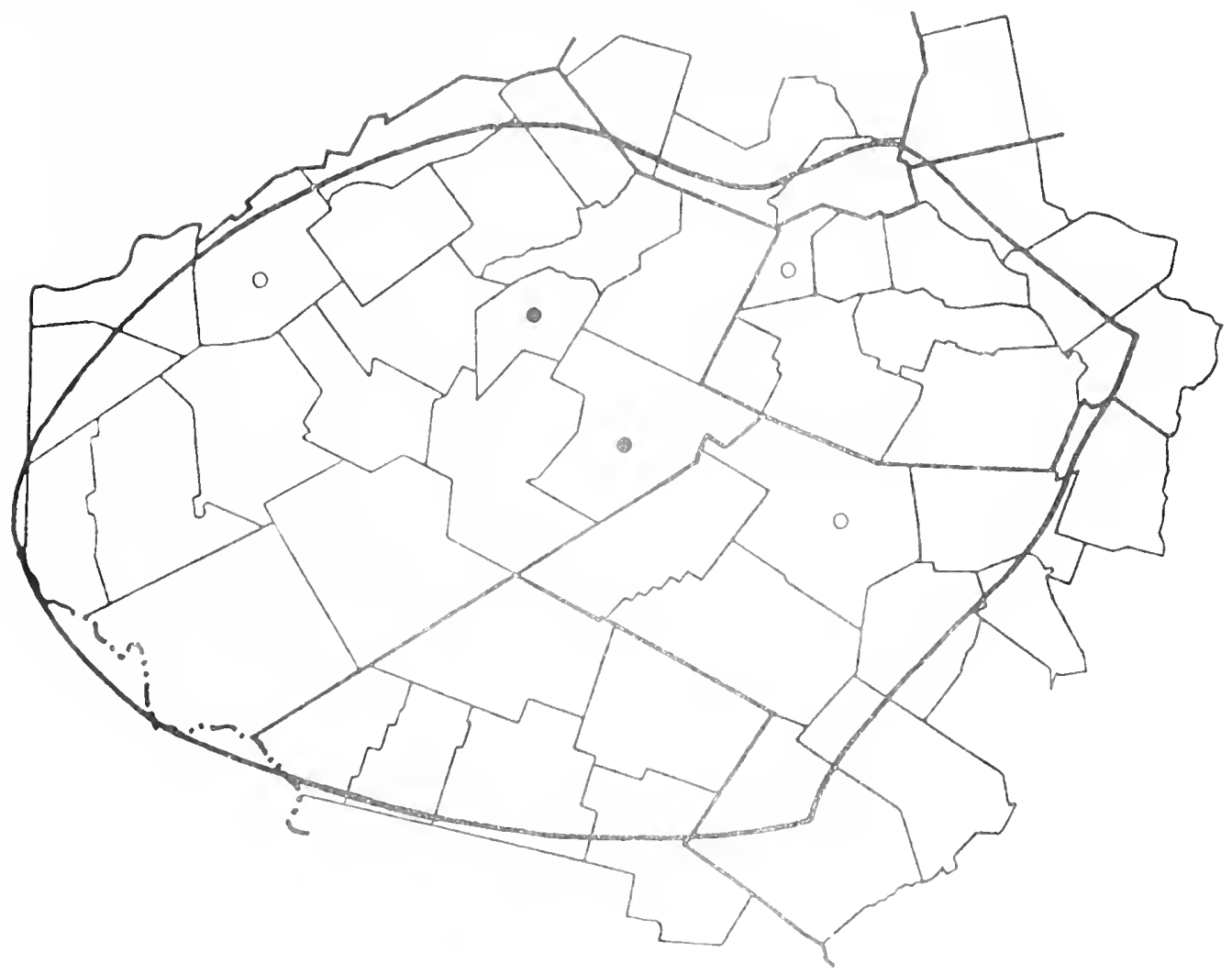

Sedum album I.

White Stonecrop

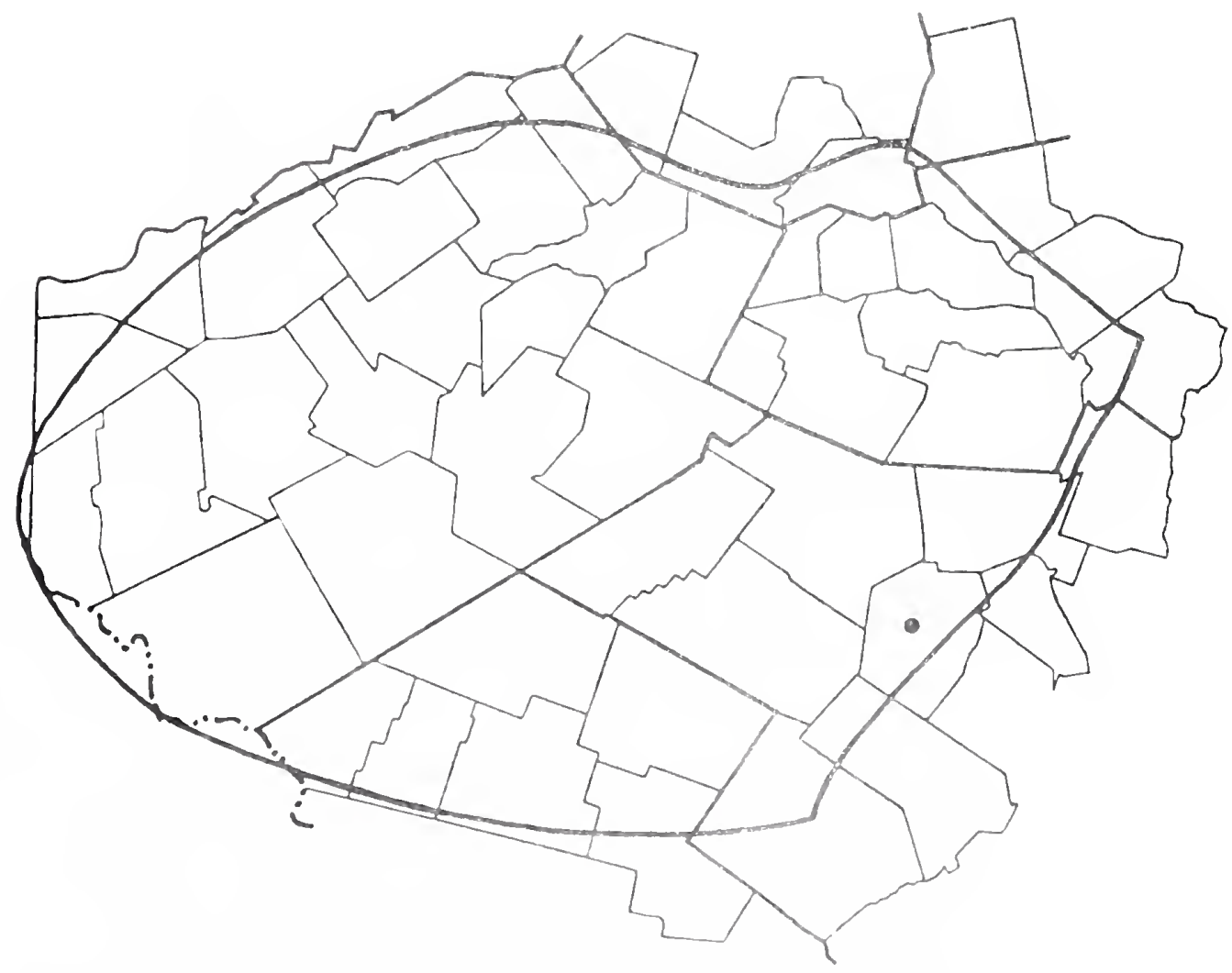


Flora of

Sedum rosea (I.) Scop.

THE CATSKILLS

Roseroot

New York State

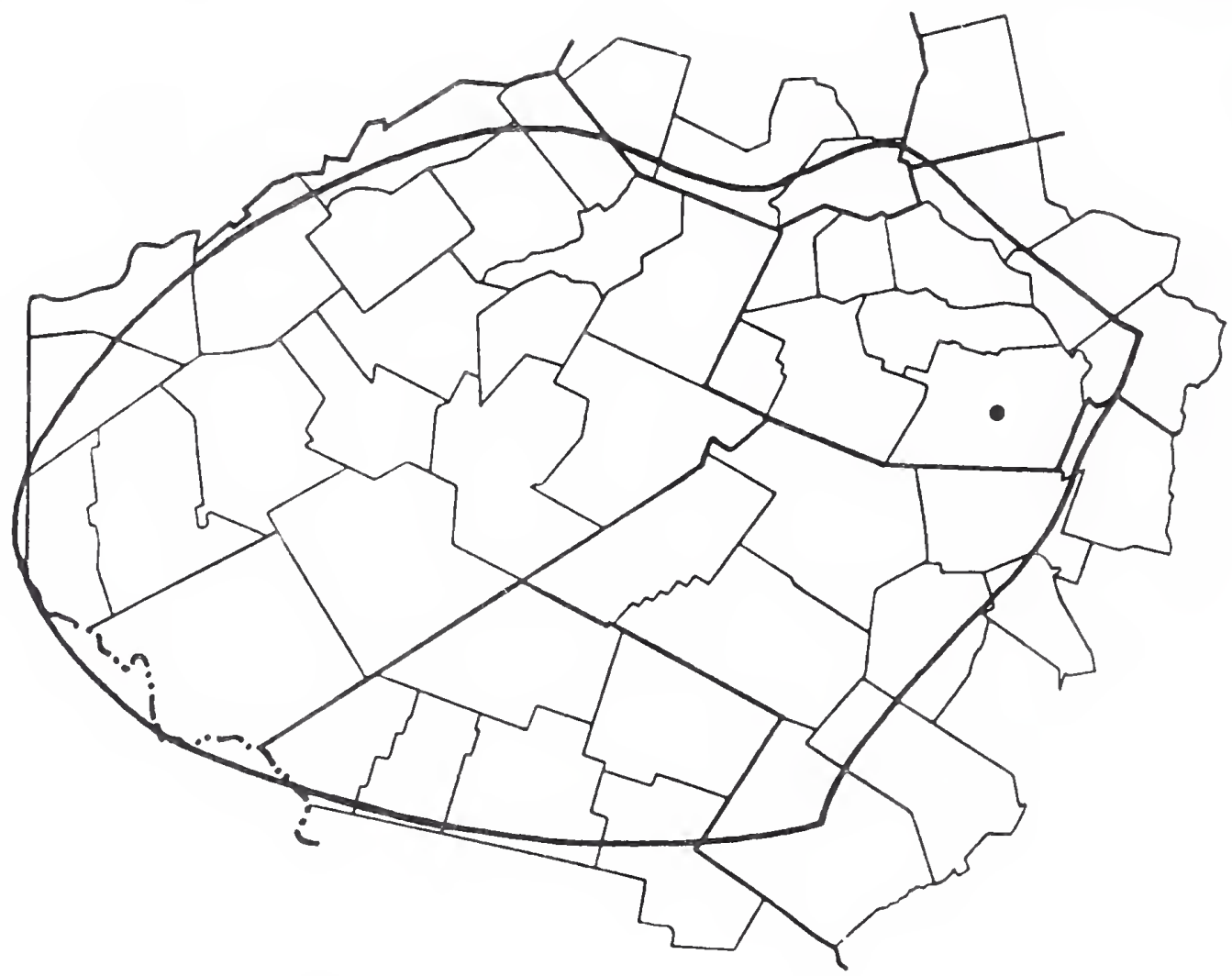

Sedum sarmentosum Bunge

Creeping Stonecrop

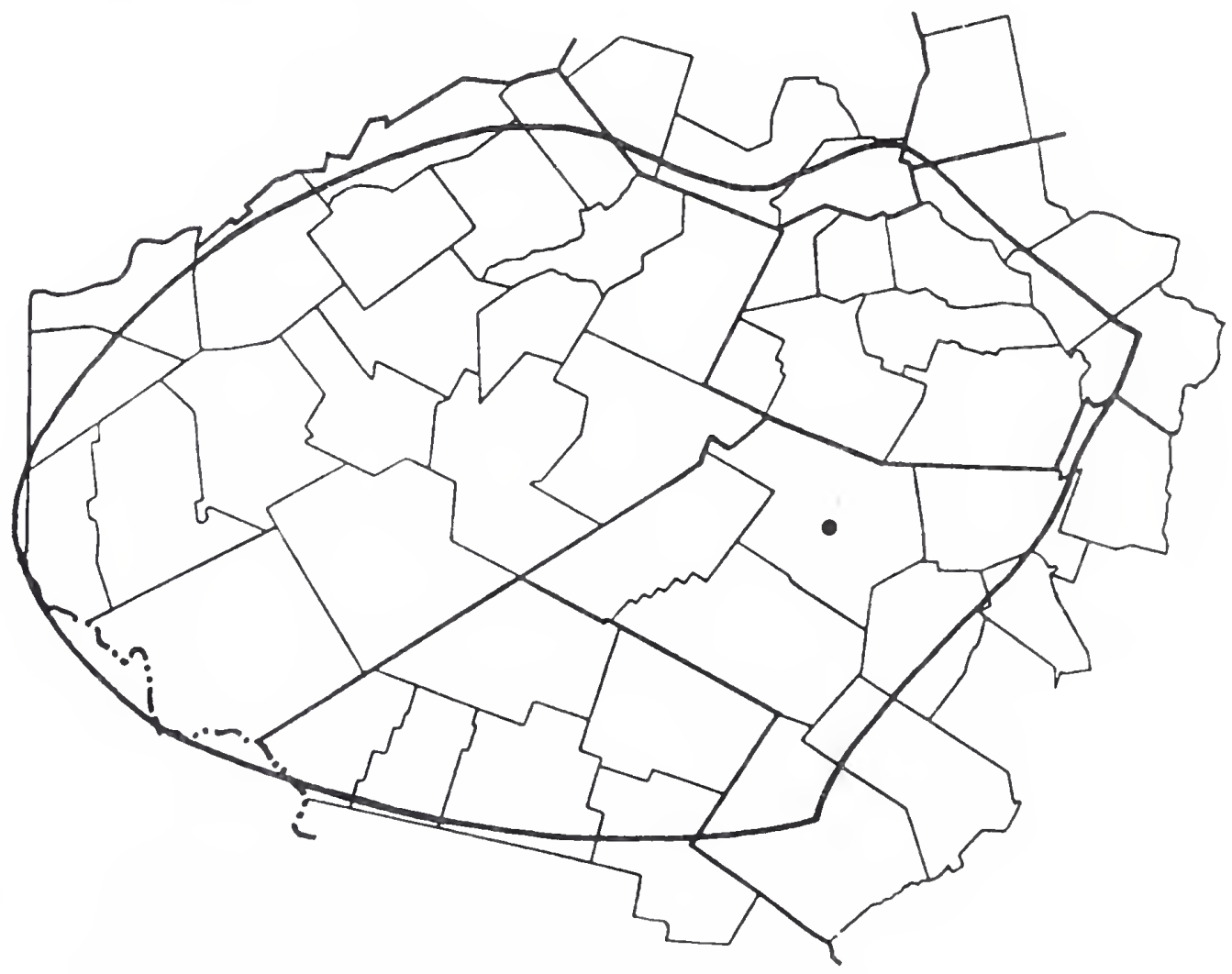




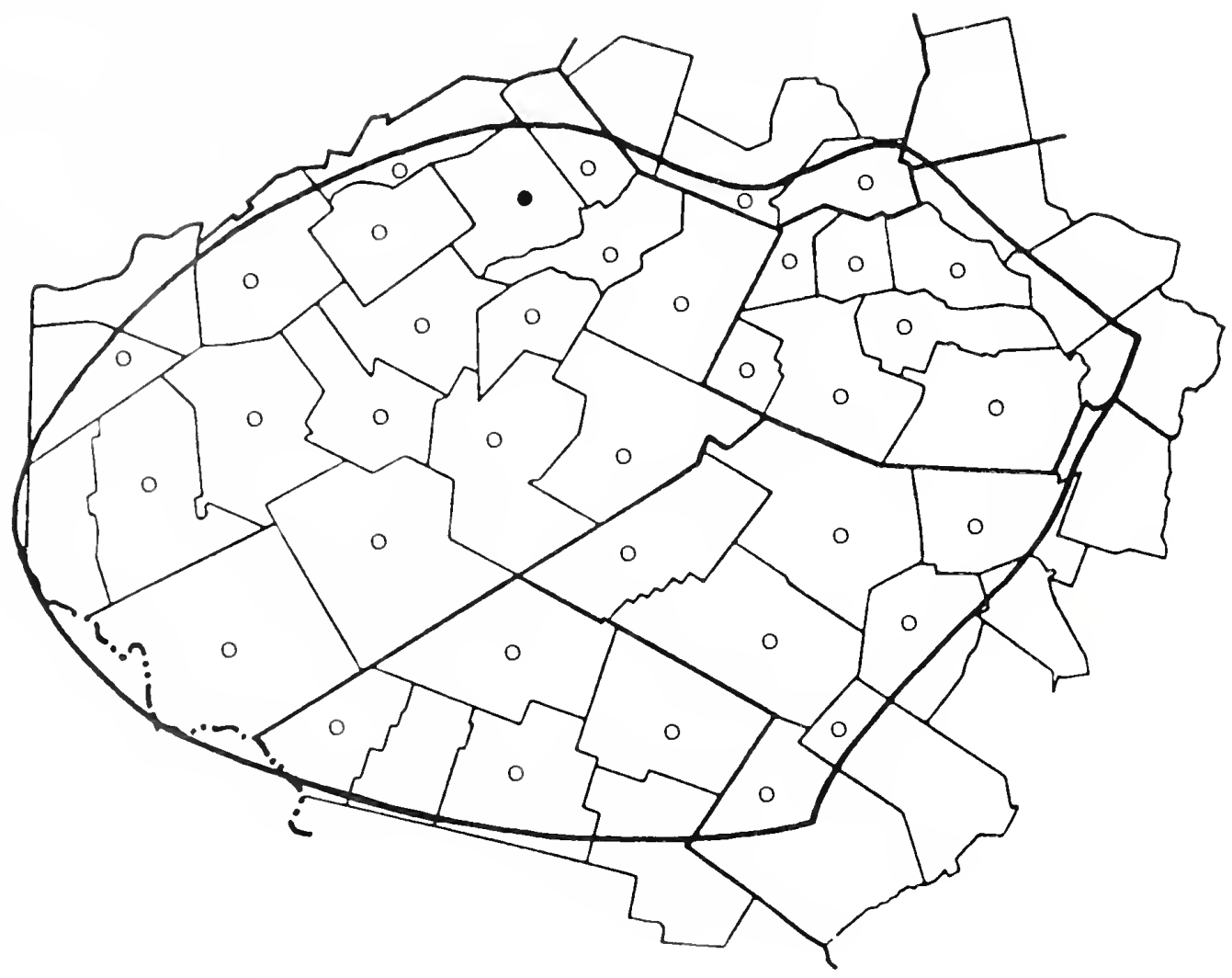

Sedum ternatum Michx.

Wild Stonecrop

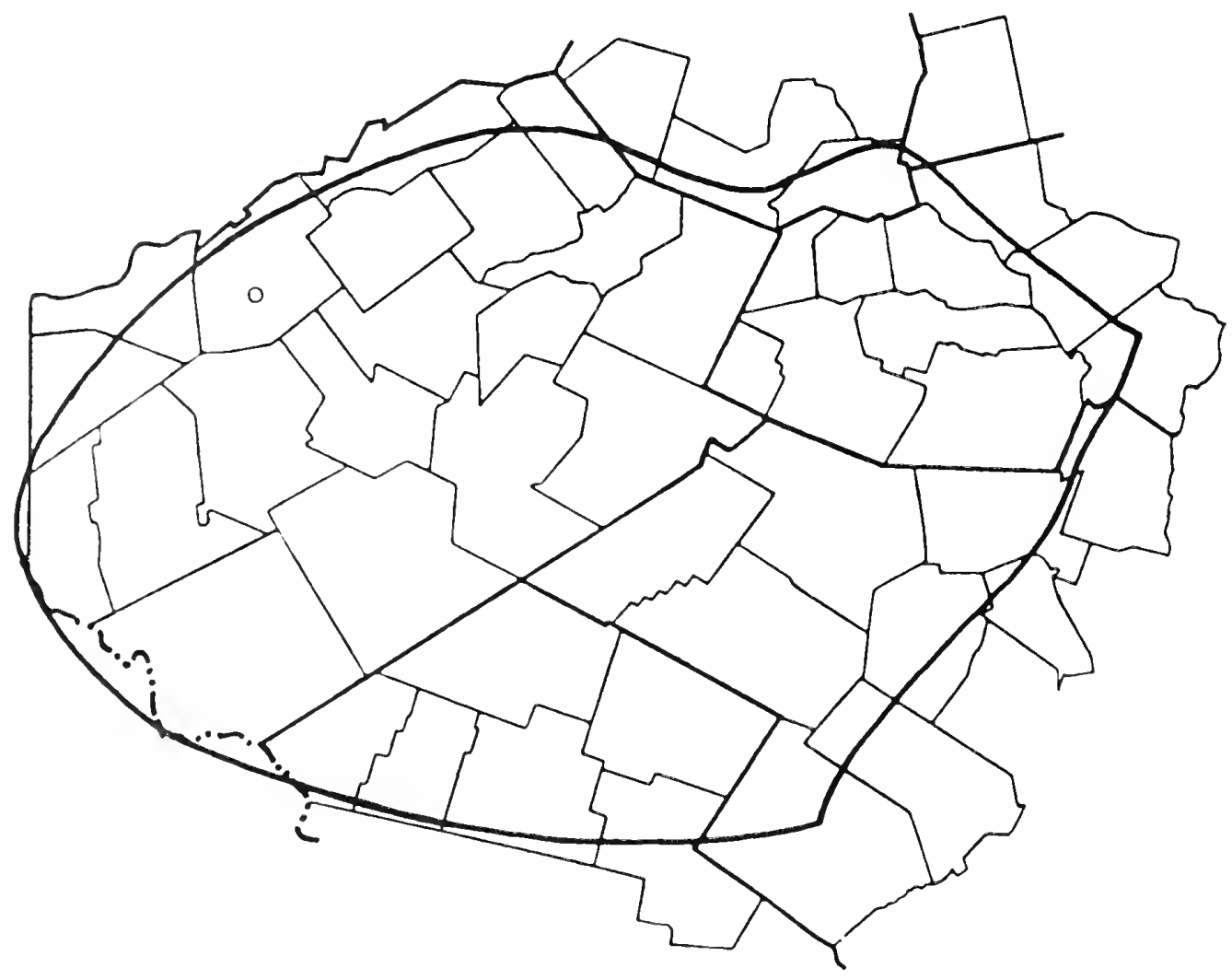




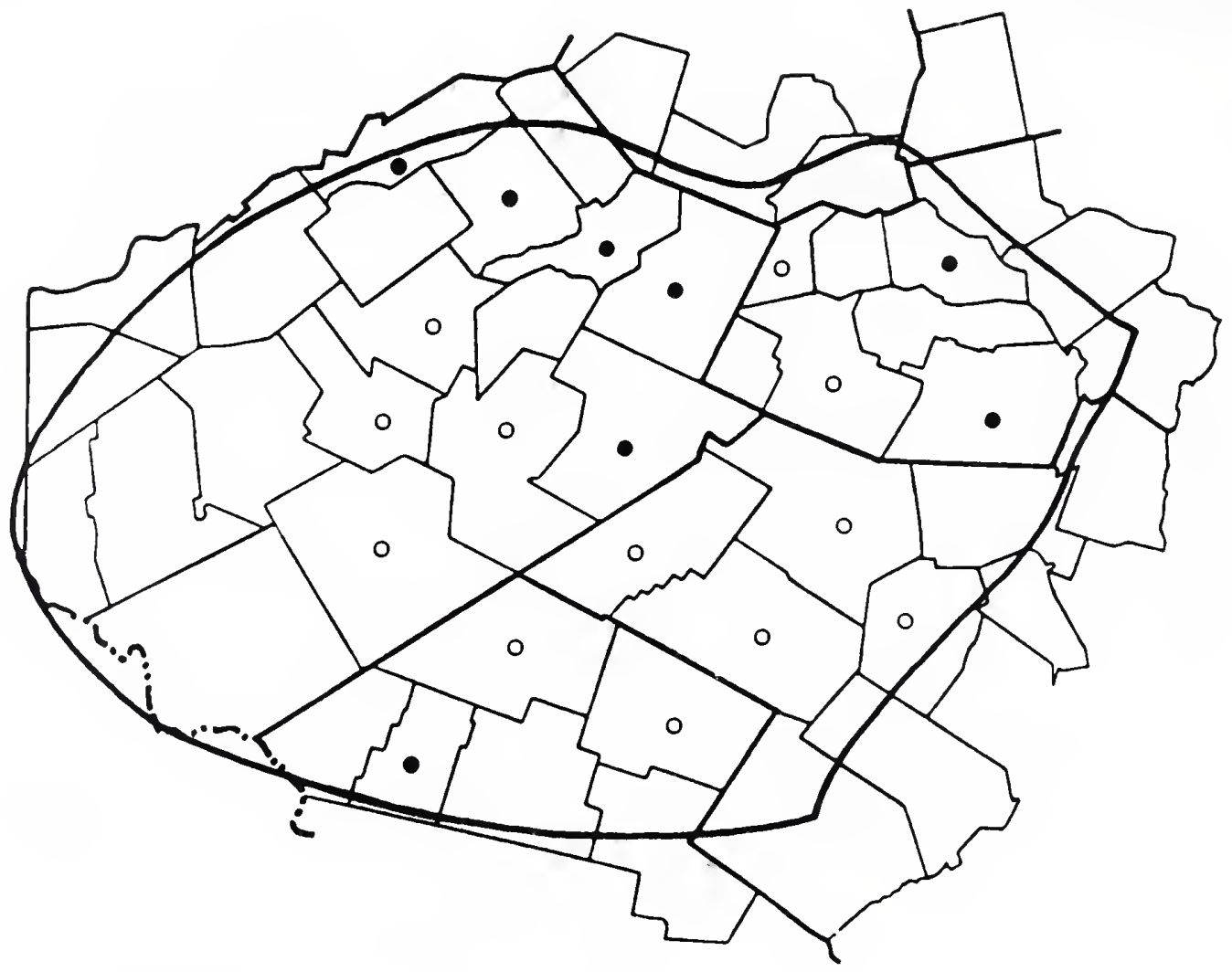

Mitella diphylia I.

Two-leaved Bishop's-cap

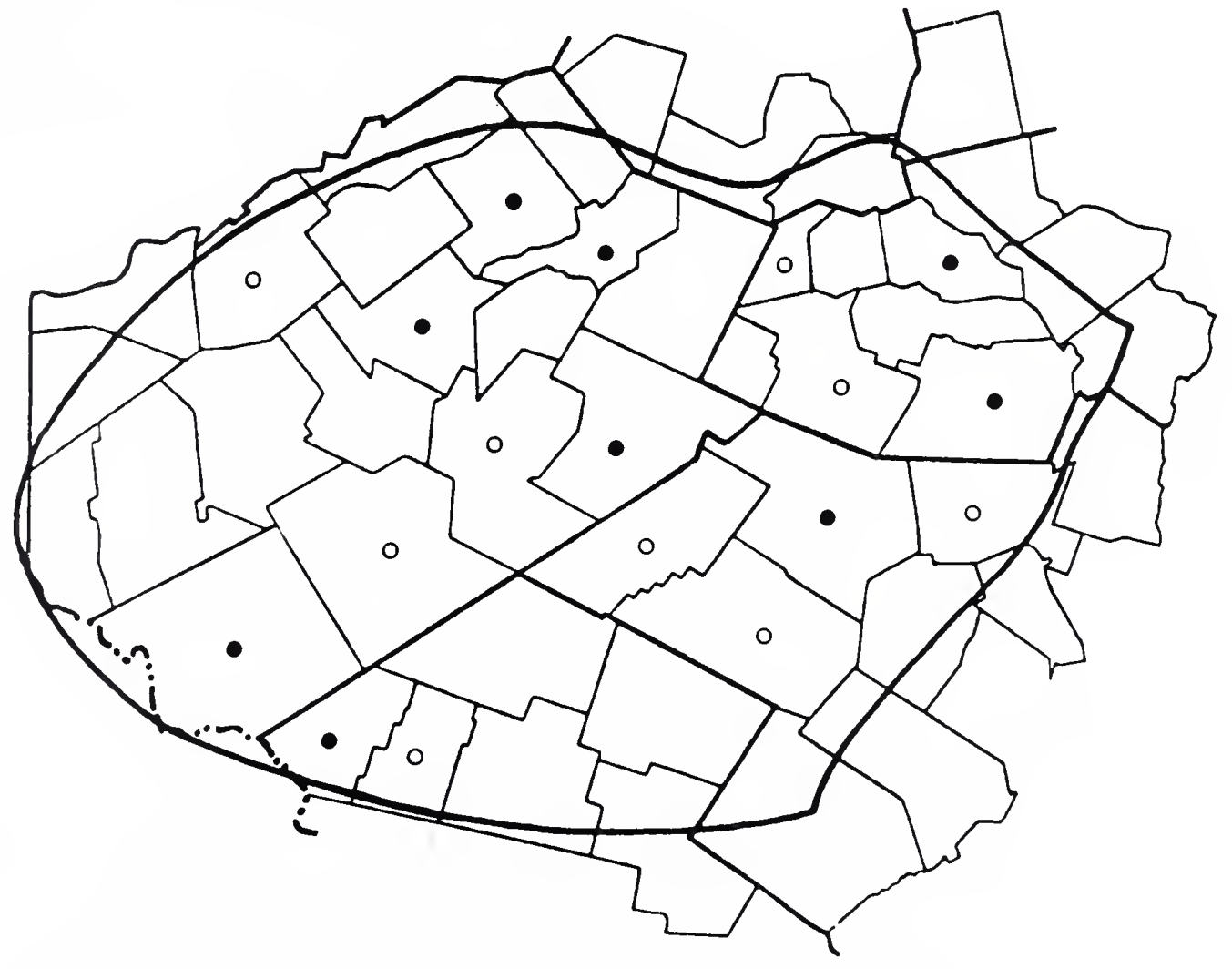




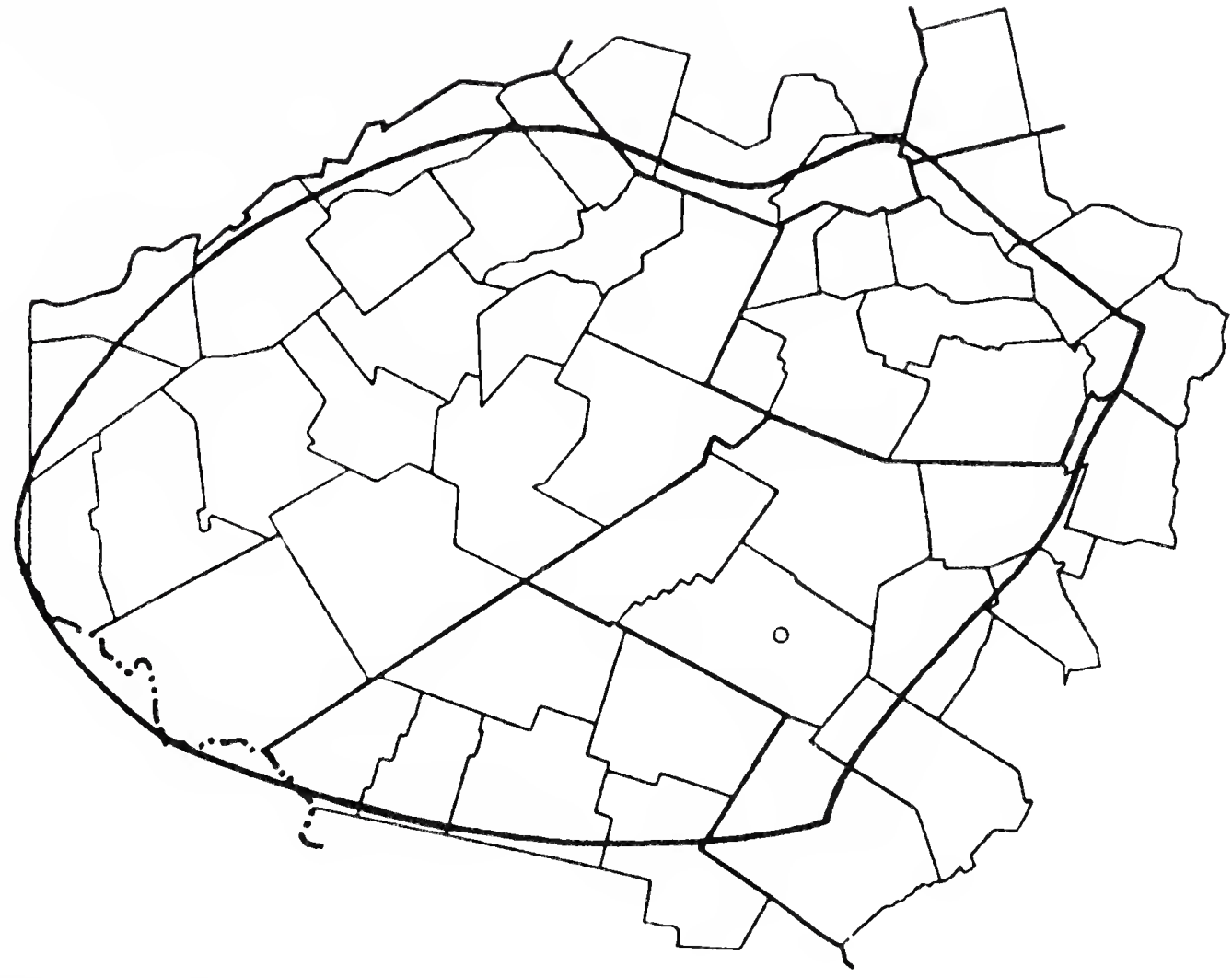

Penthorum sedoides L.

Ditch Stonecrop

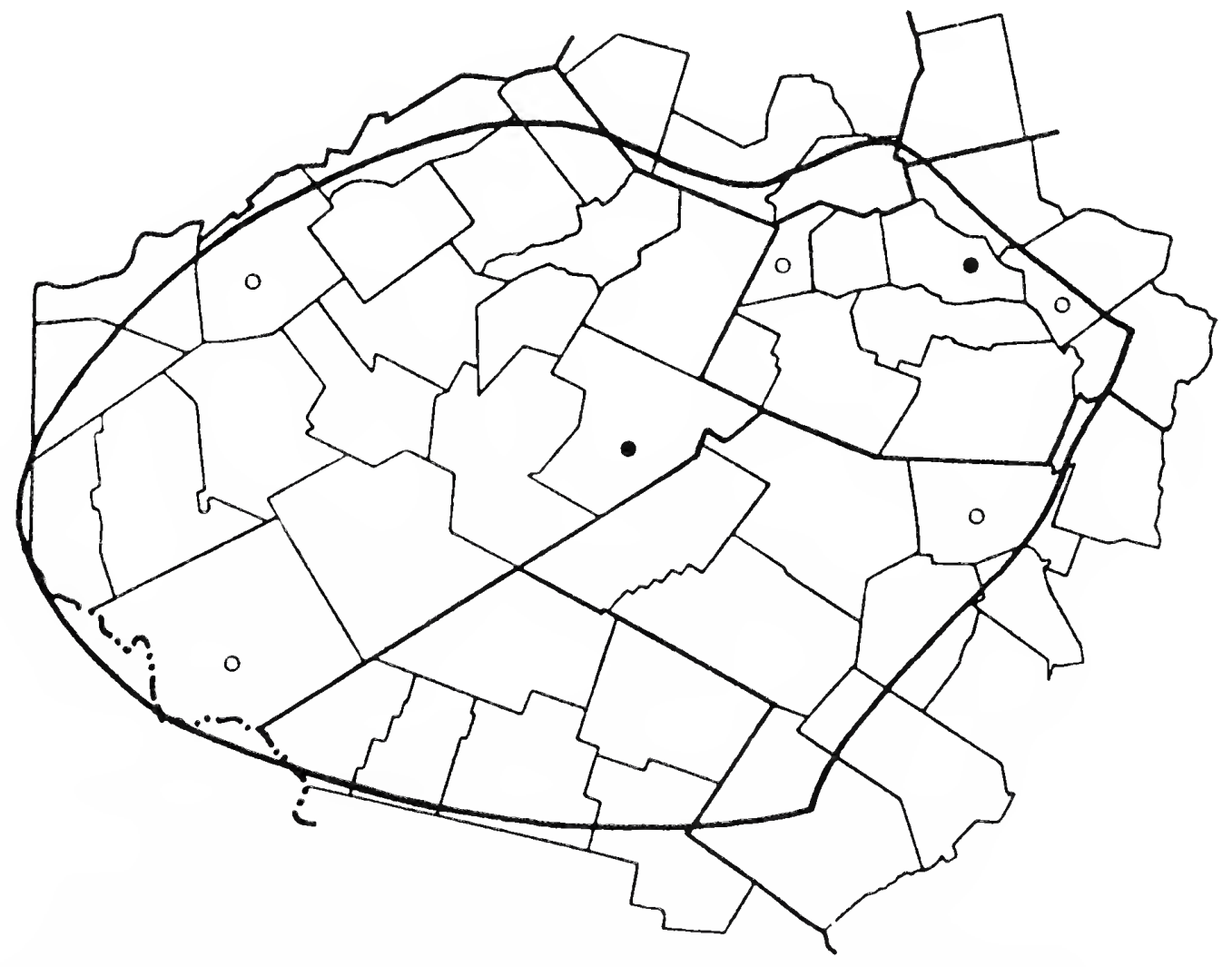




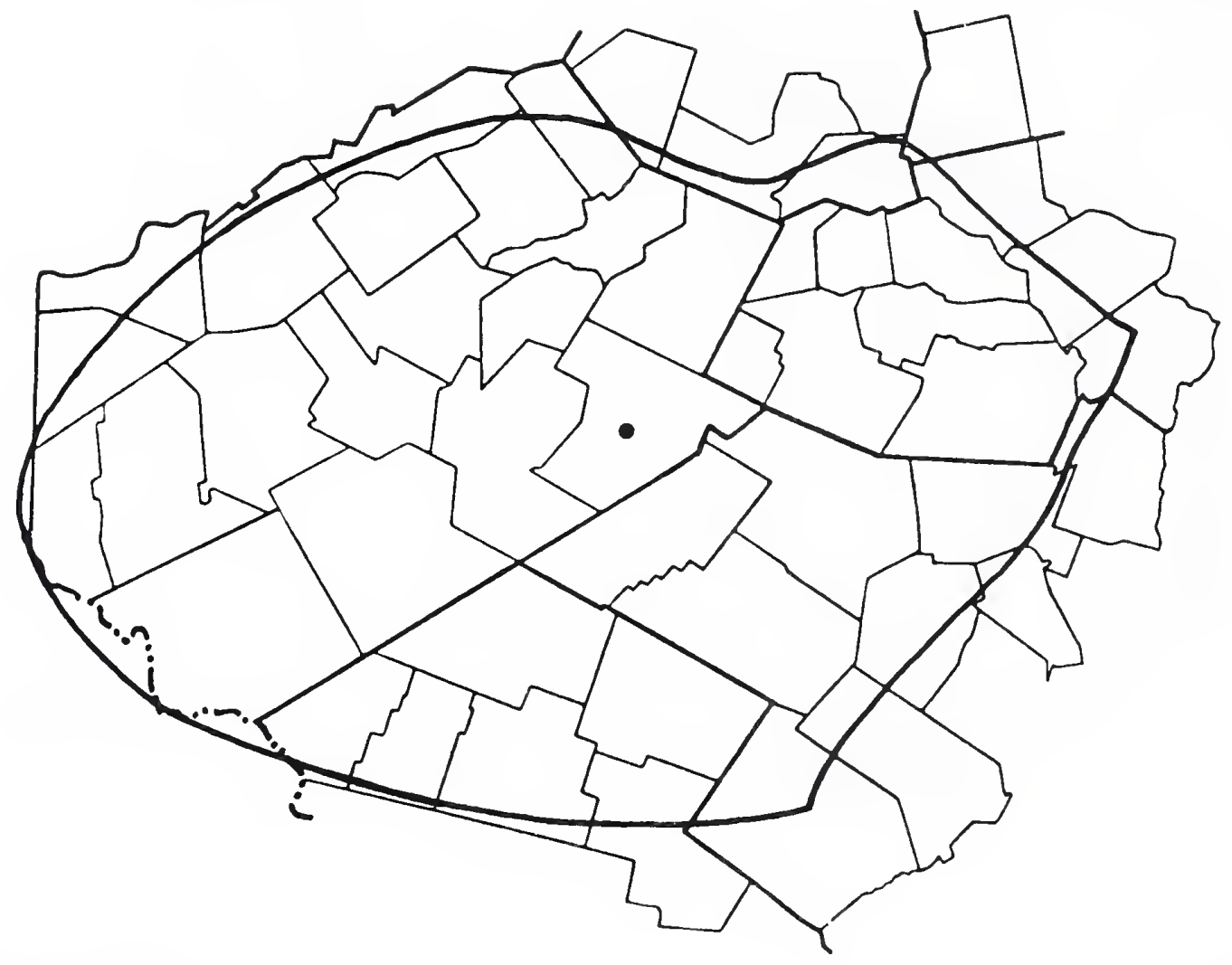

Ribes cynosbati I.

Prickly Gooseberry

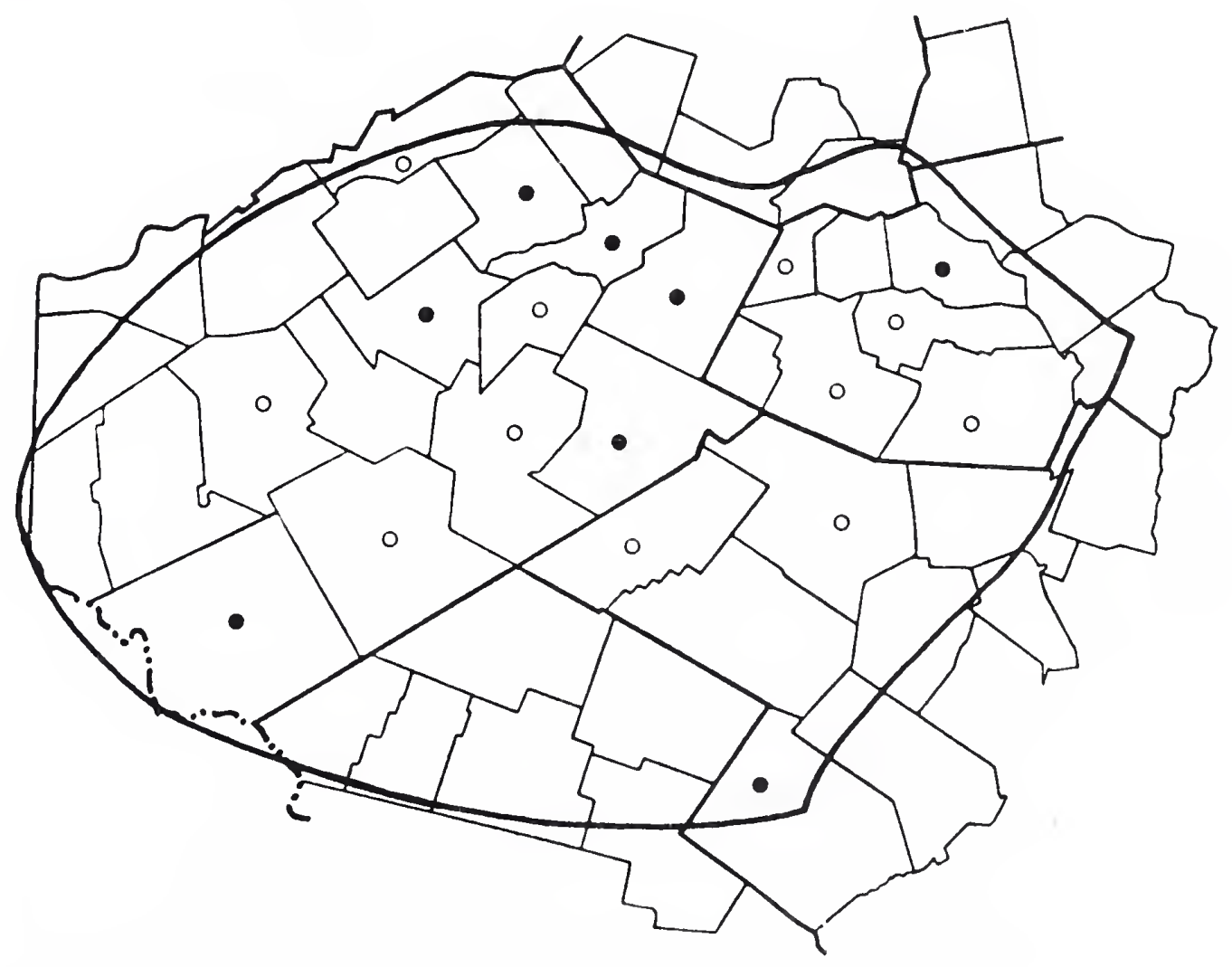


Flora of

Ribes glandulosum Grauer

THE CATSKILLS

Skunk Currant

New York State

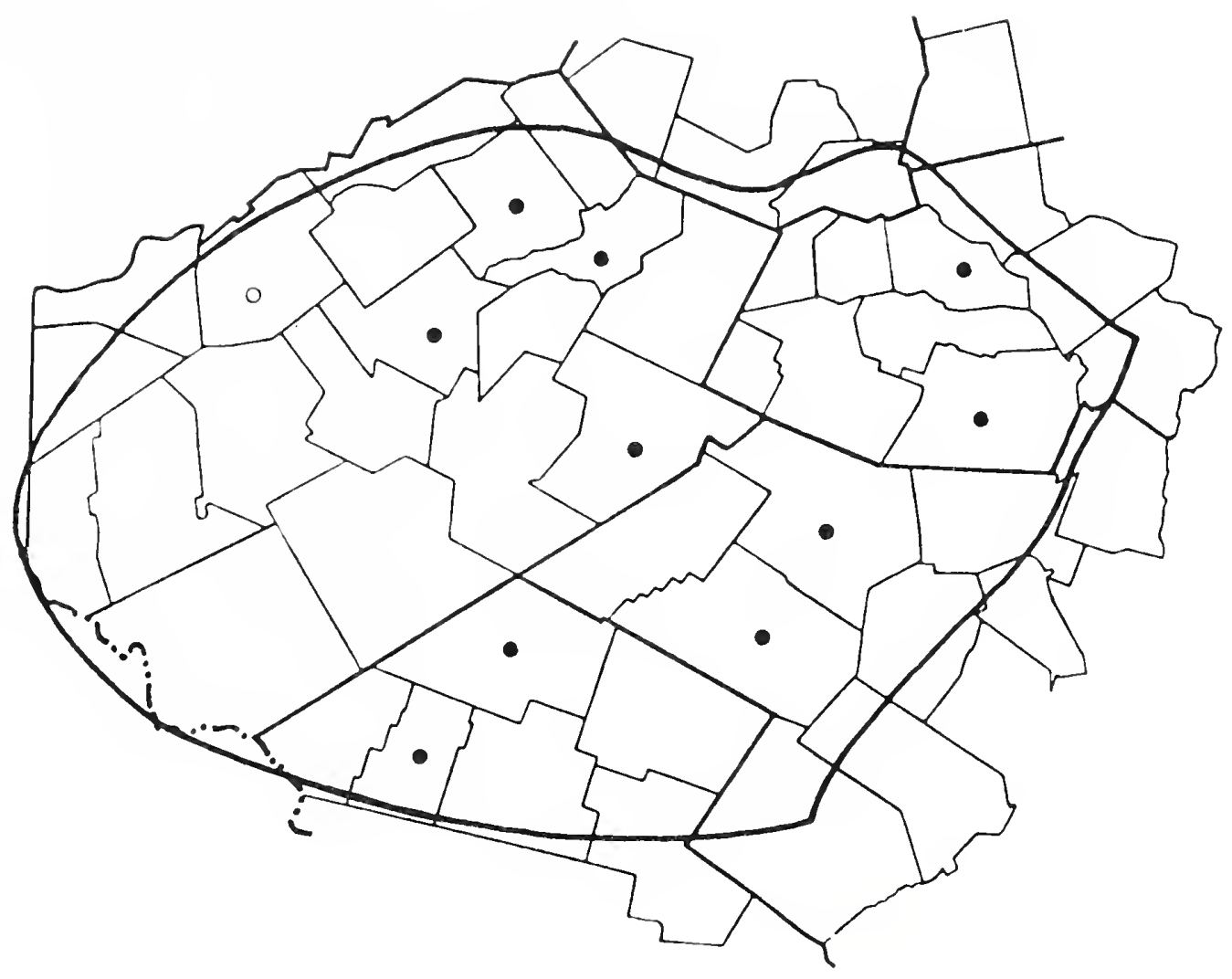

Ribes grossularia I.

European Gooseberry

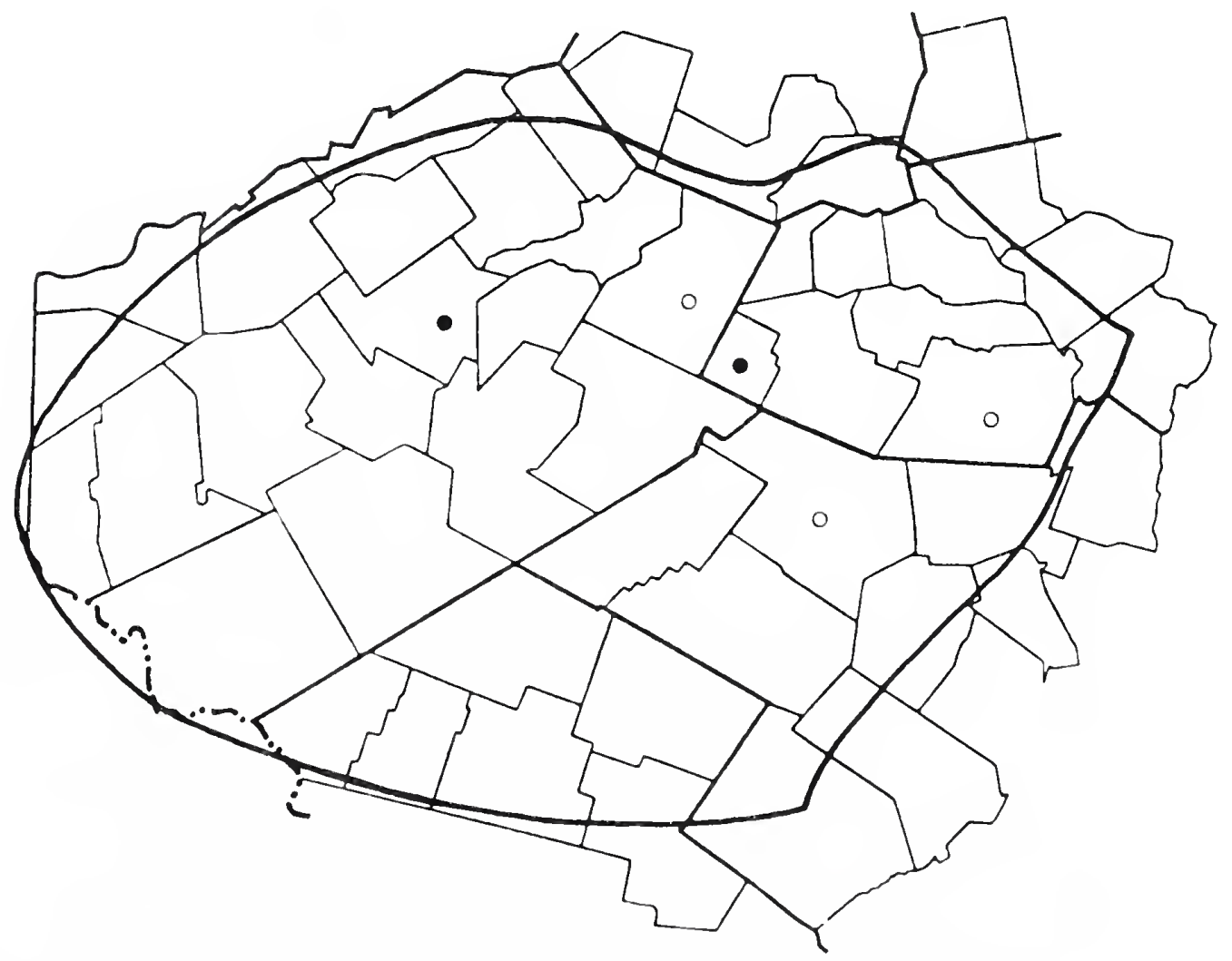




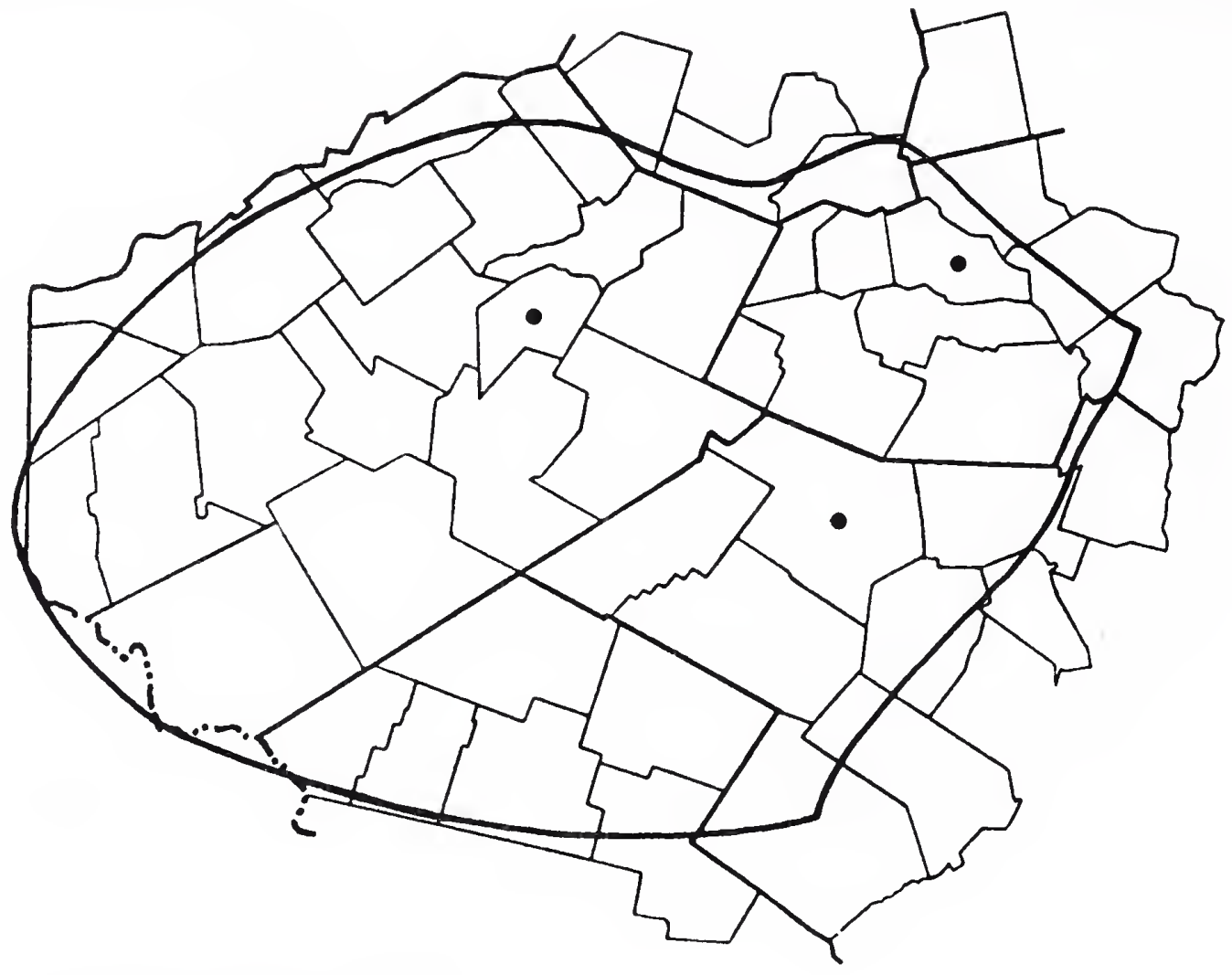

Ribes lacustre (Pers.) Poir.

Bristly Black Currant

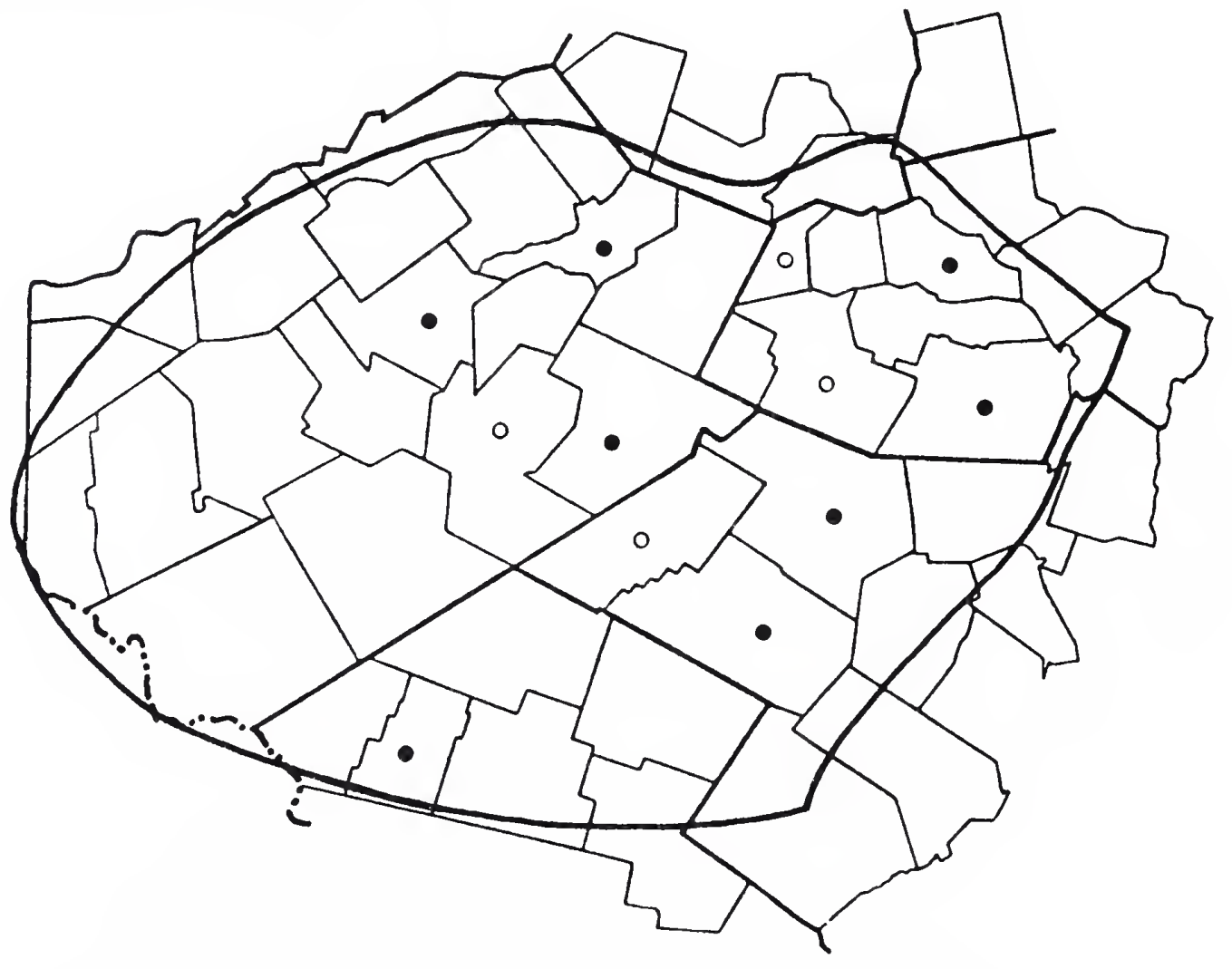




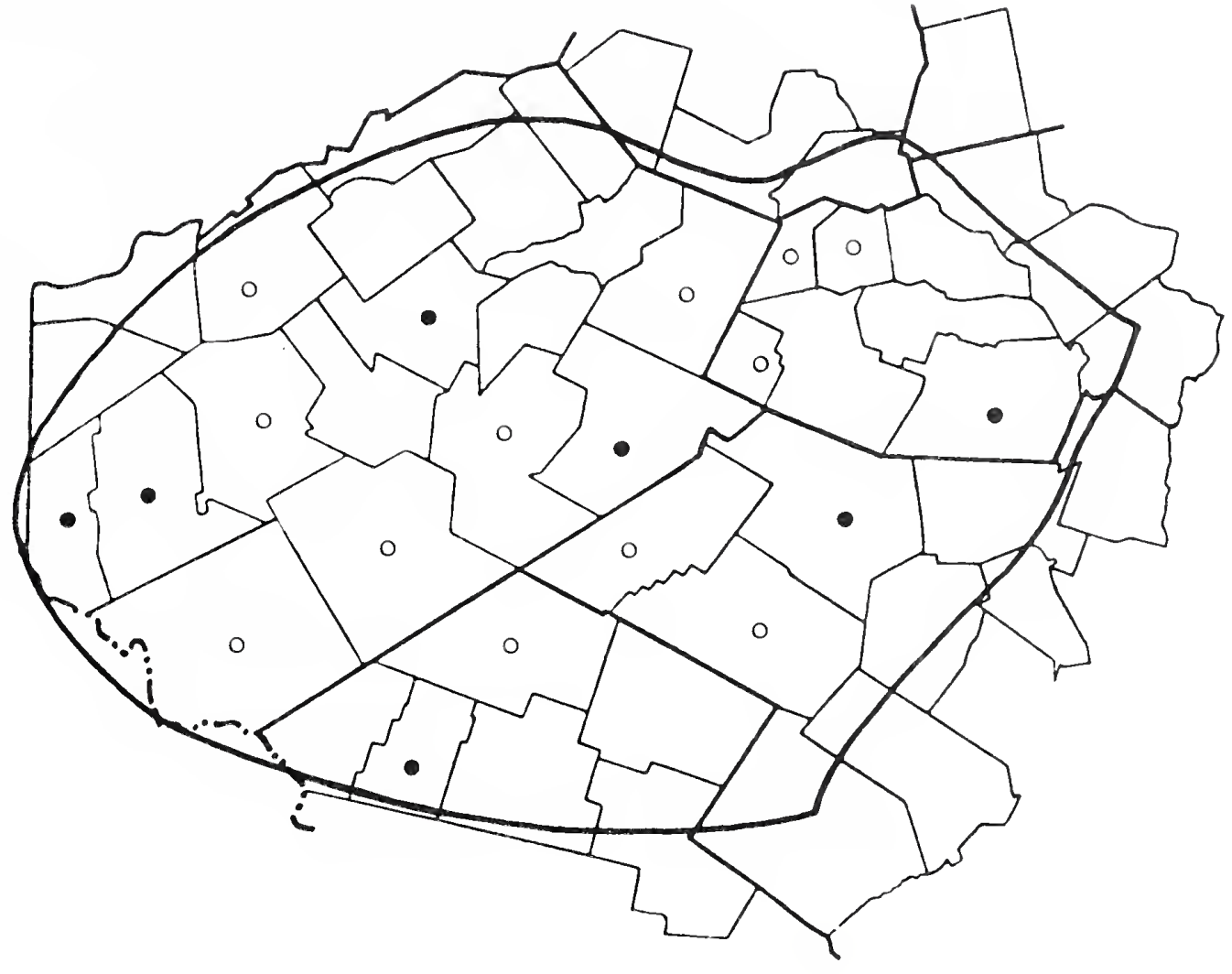

Ribes rubrum $I$.

Garden Currant

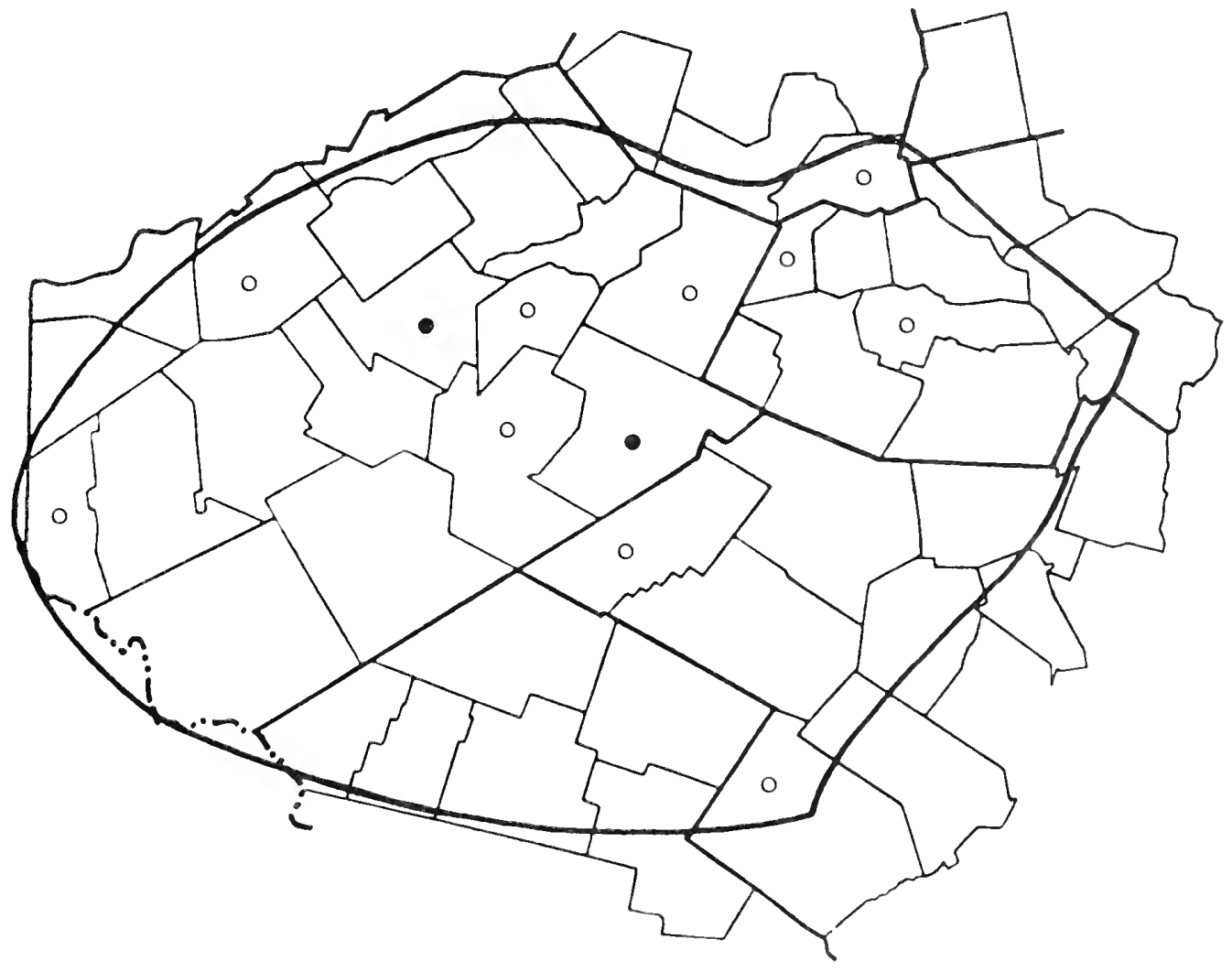




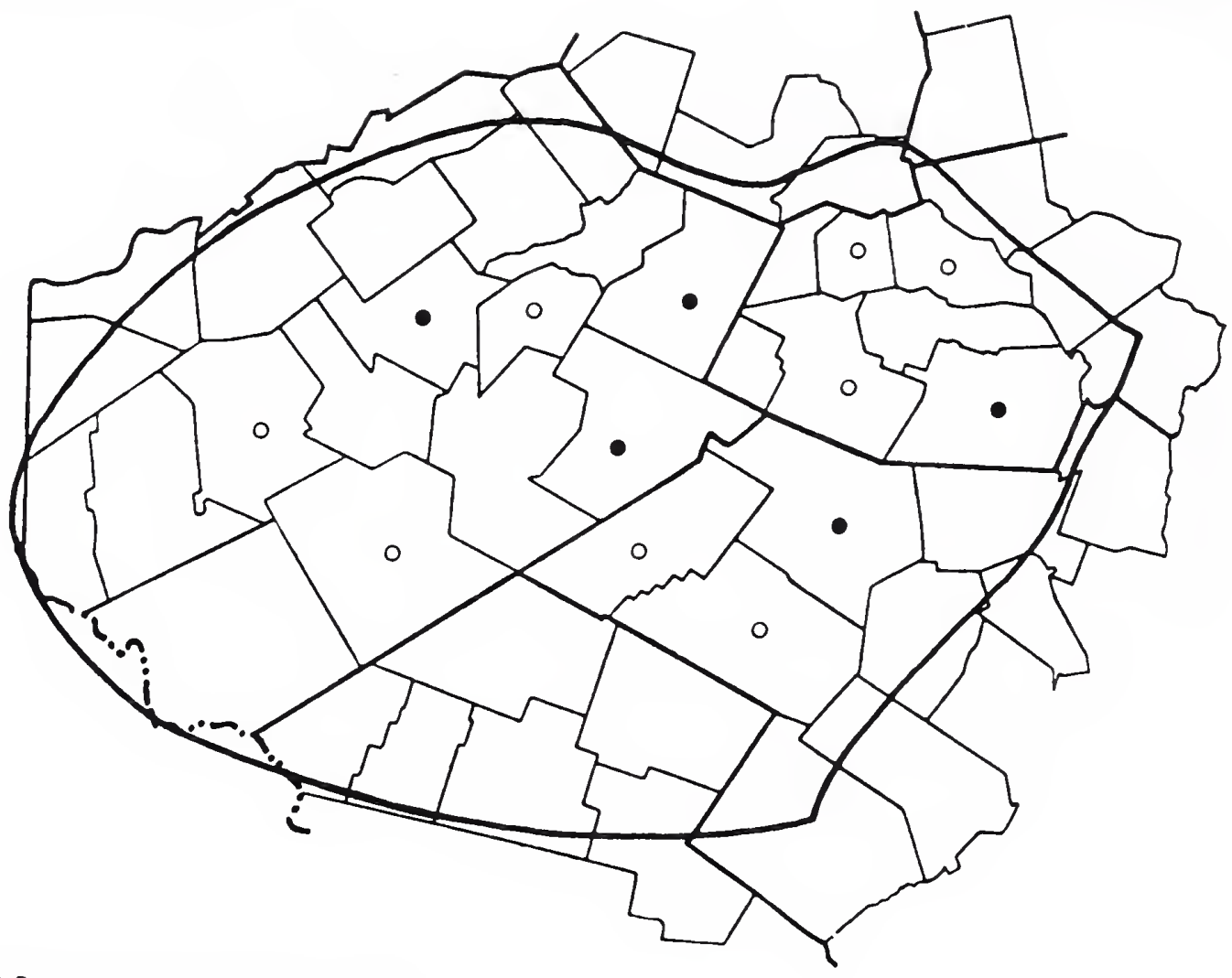

Saxifraga pensylvanica I.

Swamp Saxifrage

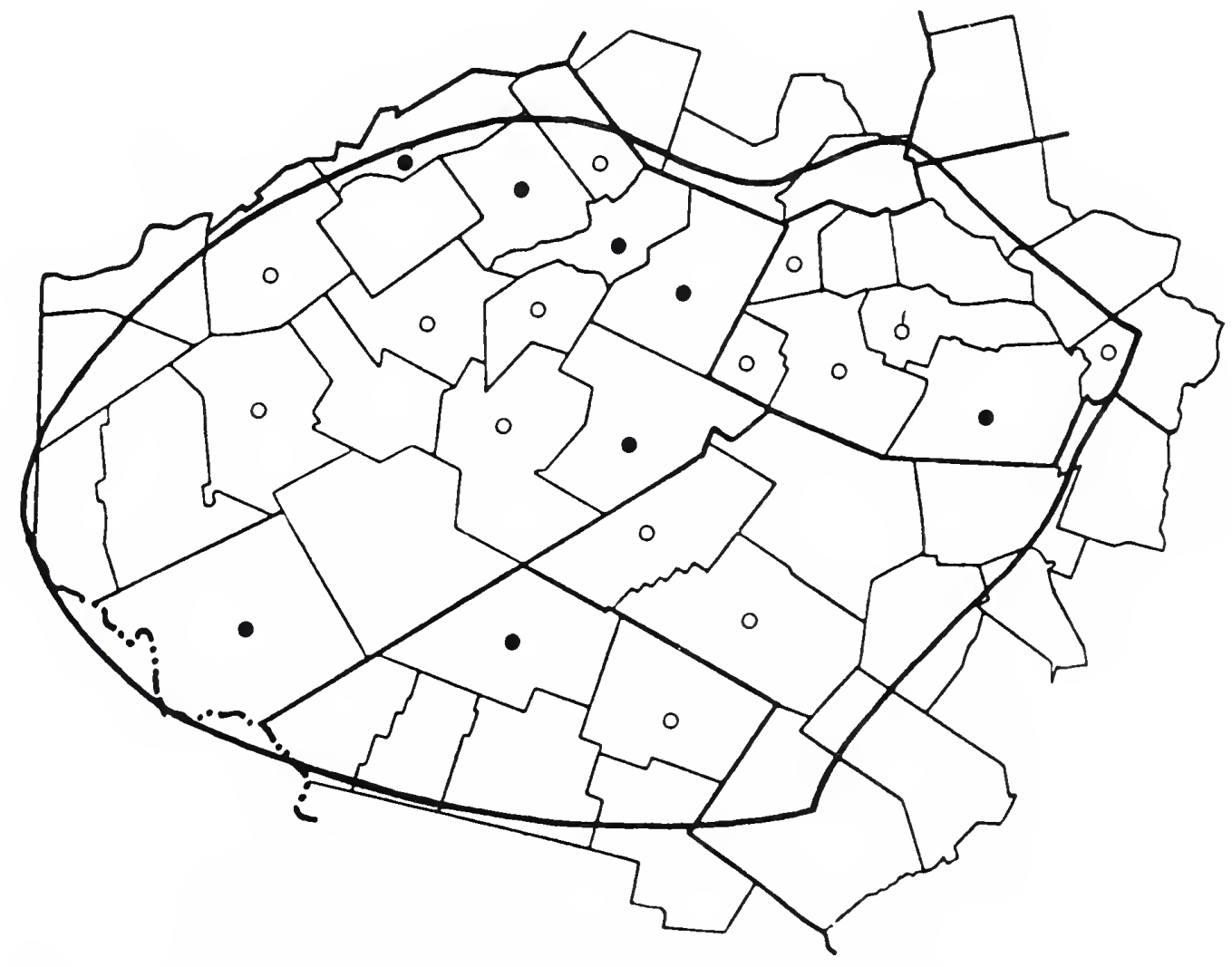


Flora of

Saxifraga virginiensis Michx.

THE CATSKILLS

Early Rock Saxifrage

New York State

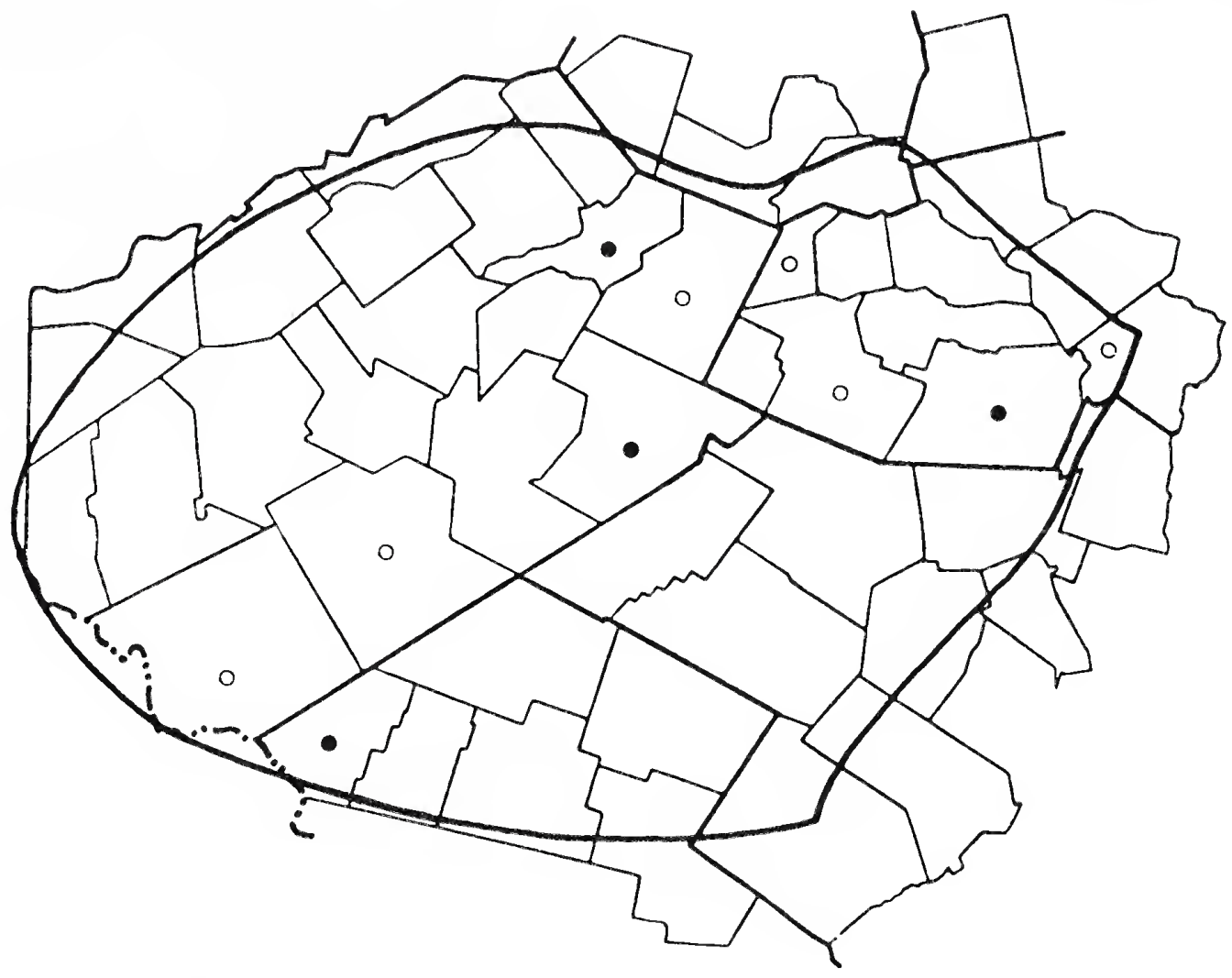

Tiarella cordifolia I.

Foamflower

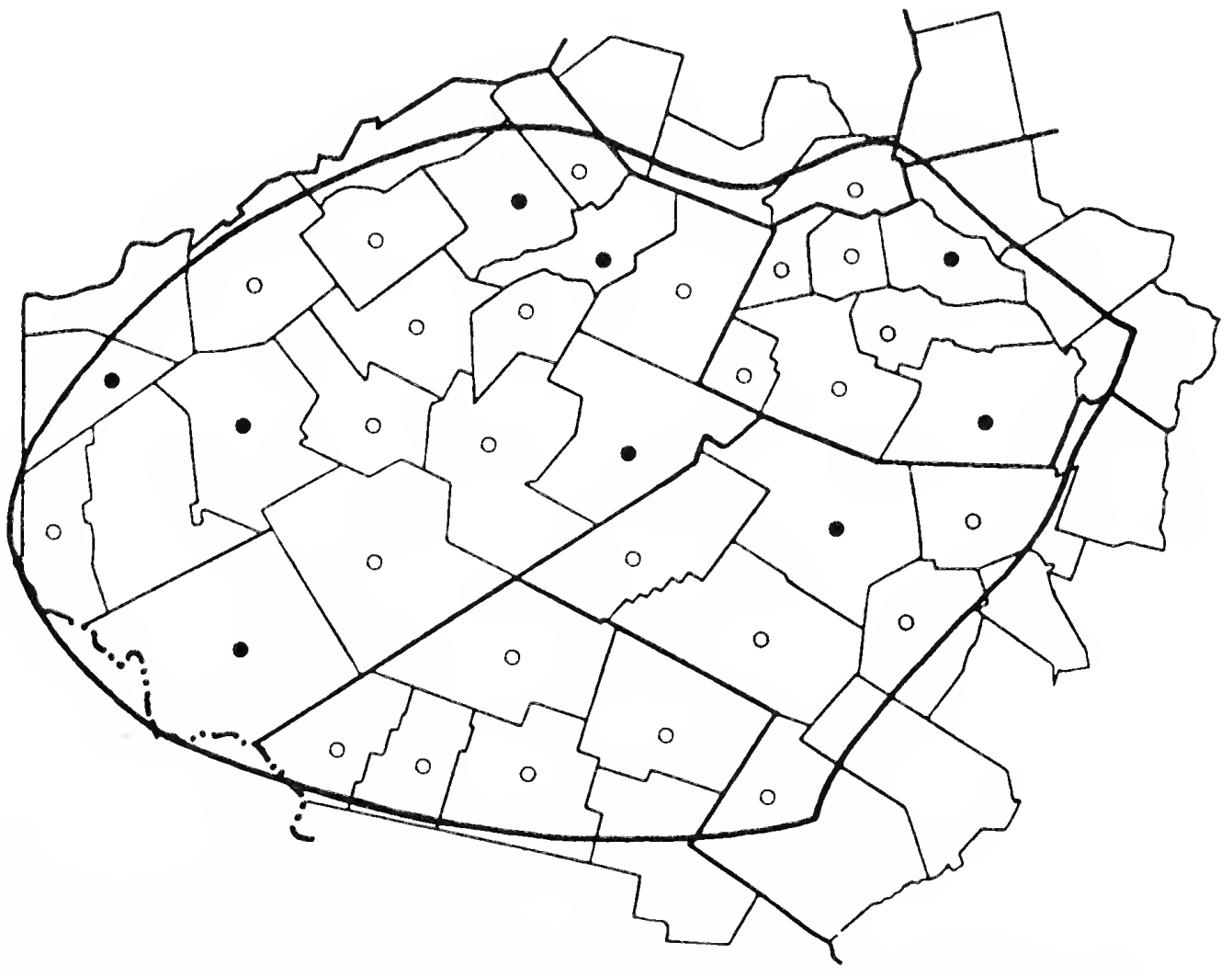


Flora of

Hamamelis virginiana L.

THE CATSKILLS

Witch-hazel

New York State

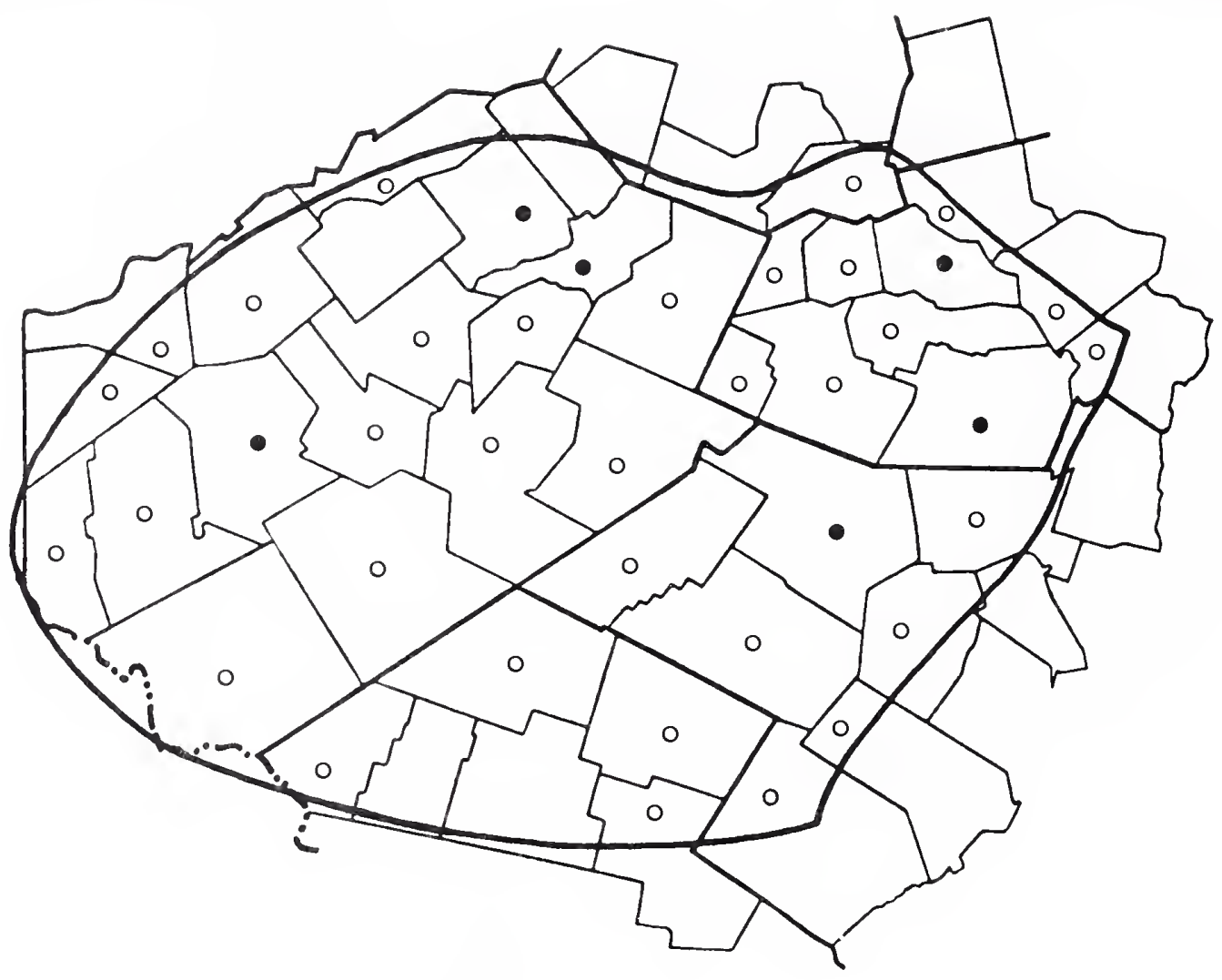

Platanus occidentalis I.

Sycamore

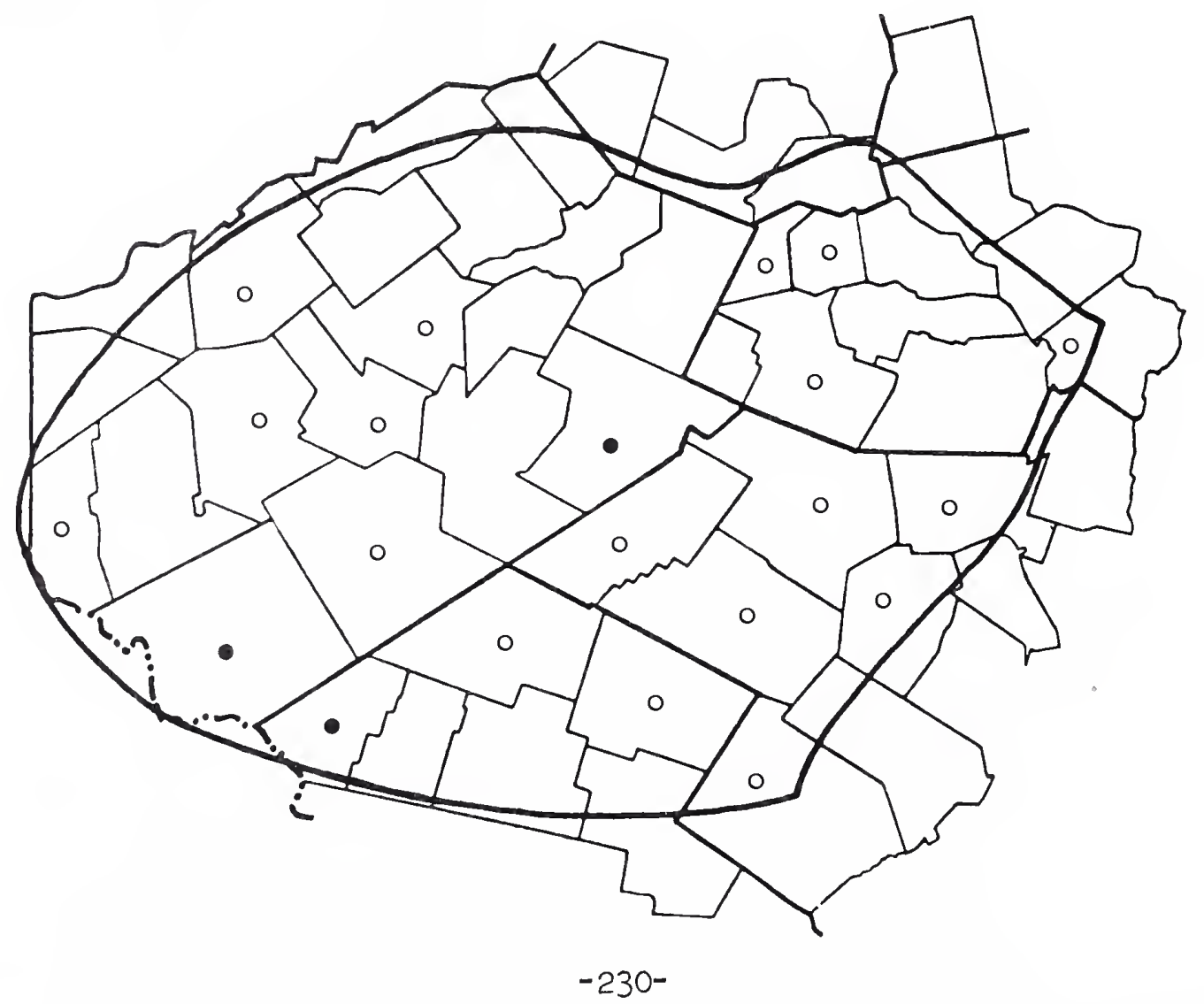


Flora of

Agrimonia gryposepala Wallr.

THE CATSKILLS

Tall Agrimony

New York State

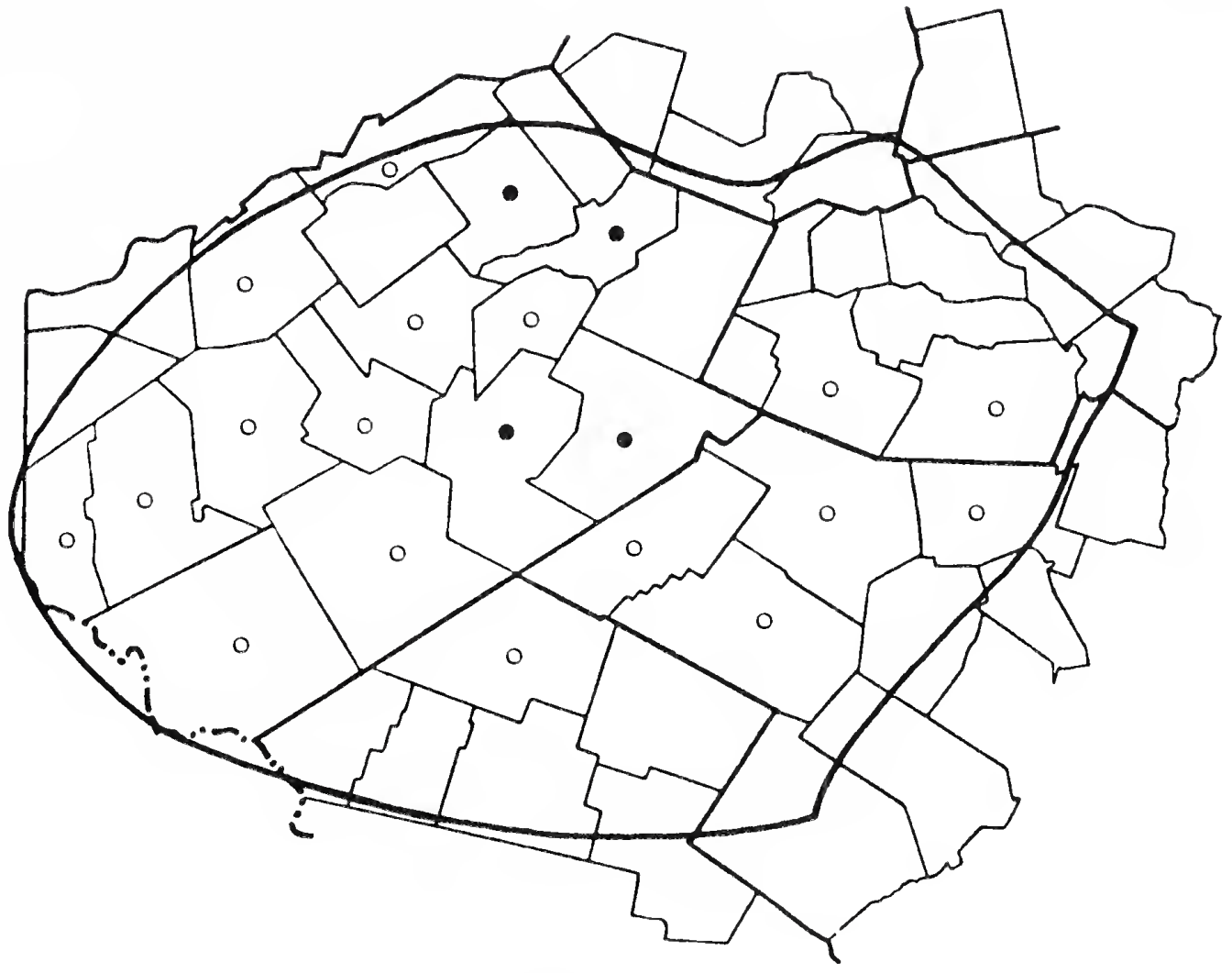

Amelanchier arborea (Michx. f.) Fern.

Common Juneberry

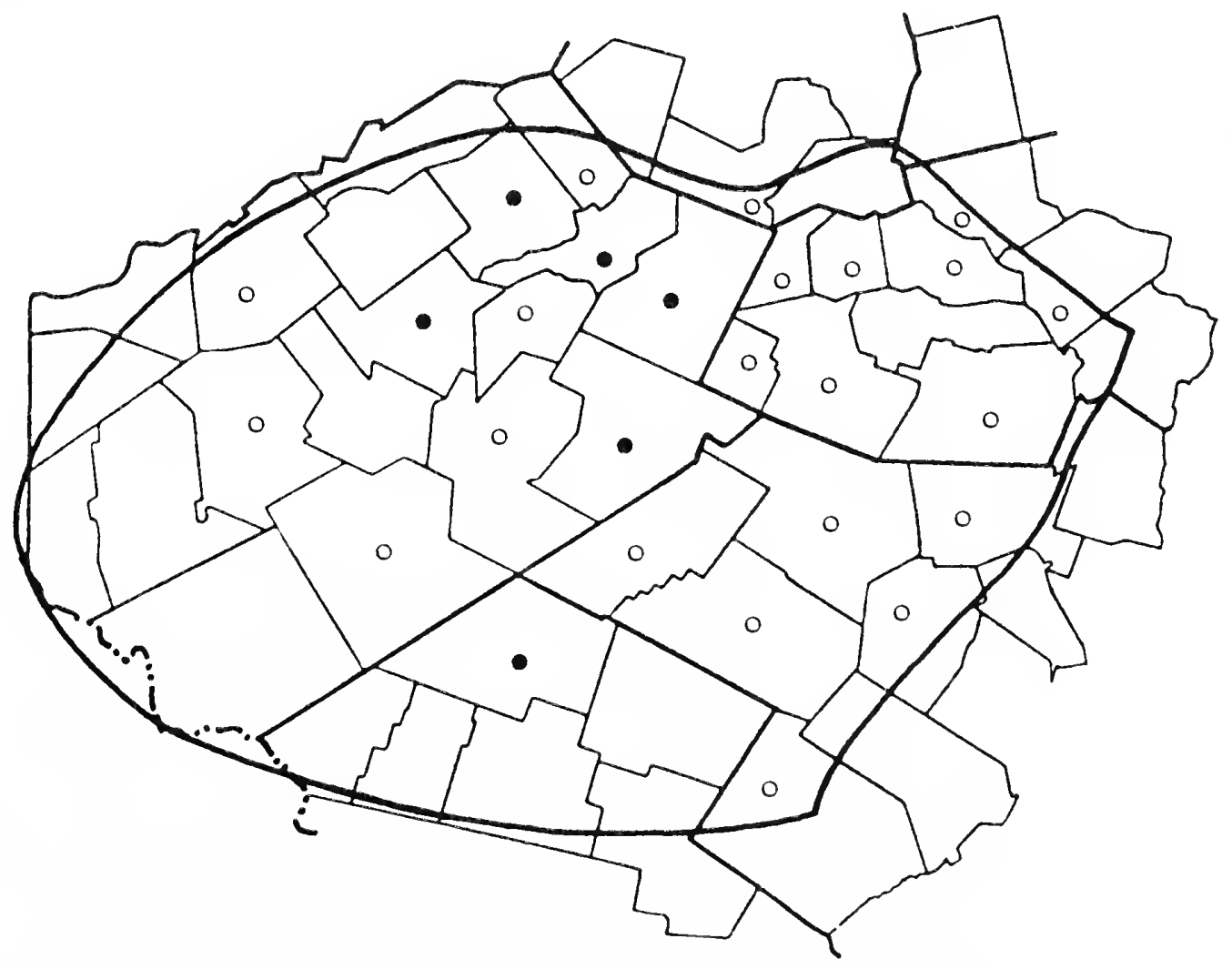




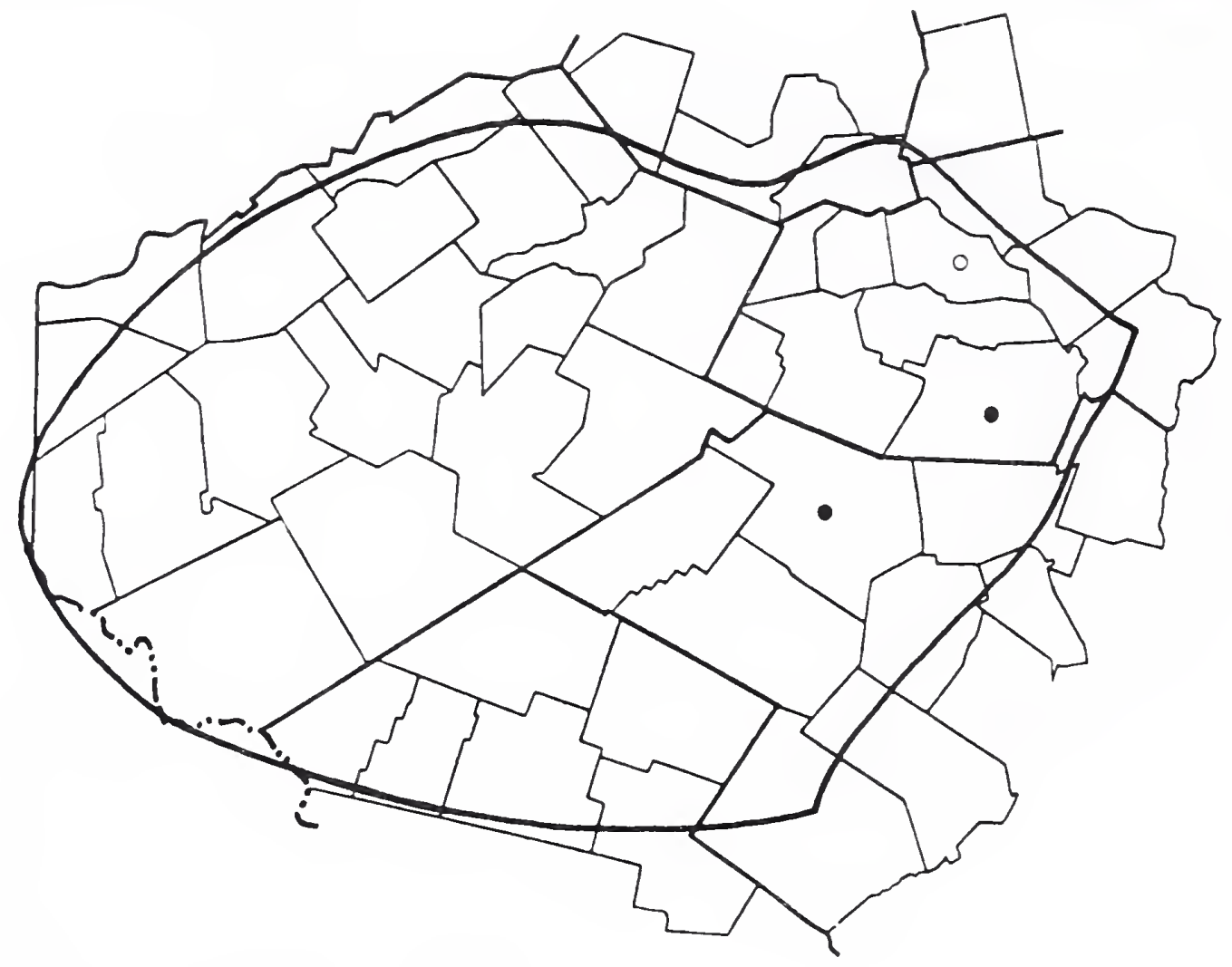

Amelanchier laevis Wieg.

Smooth Shadbush

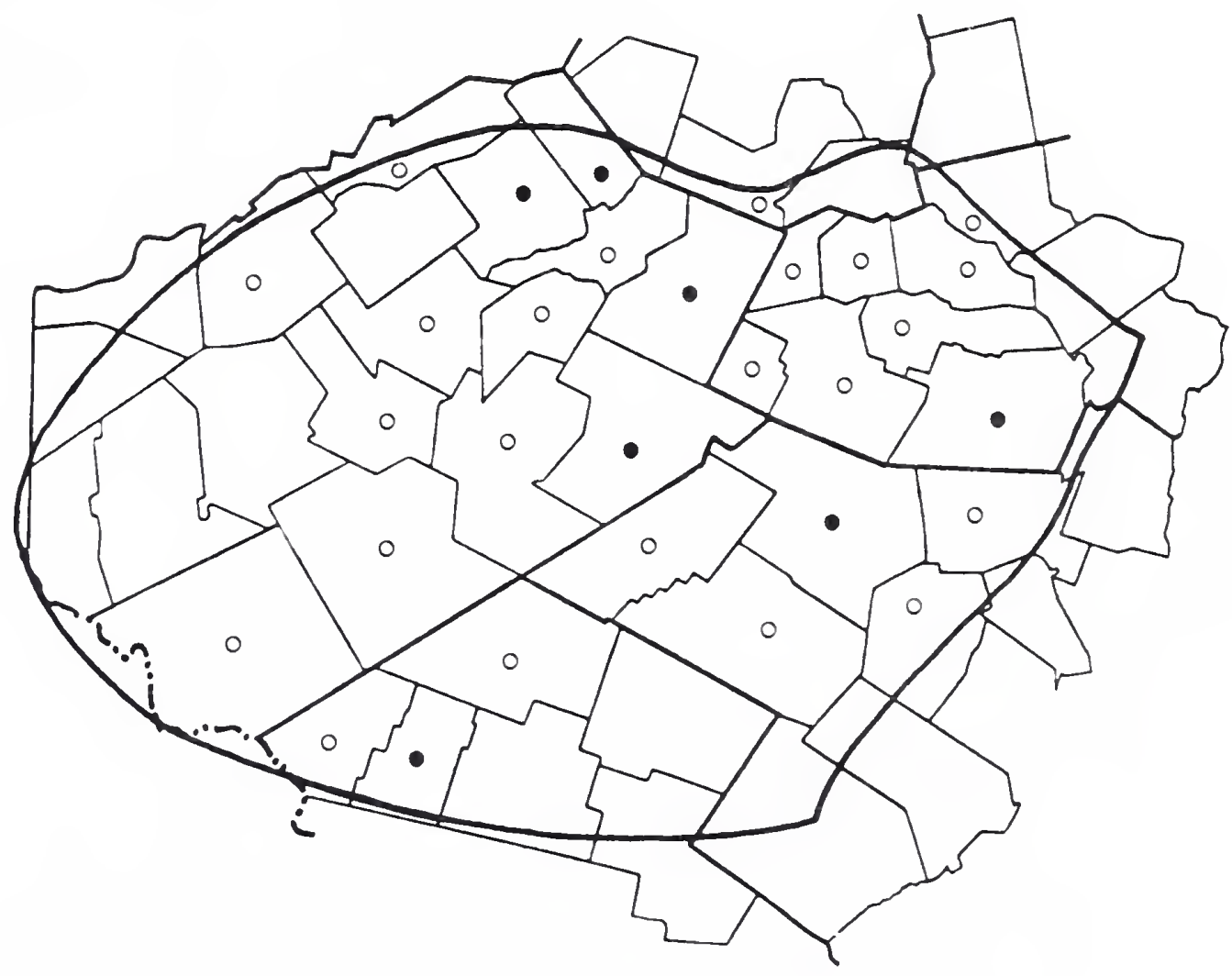




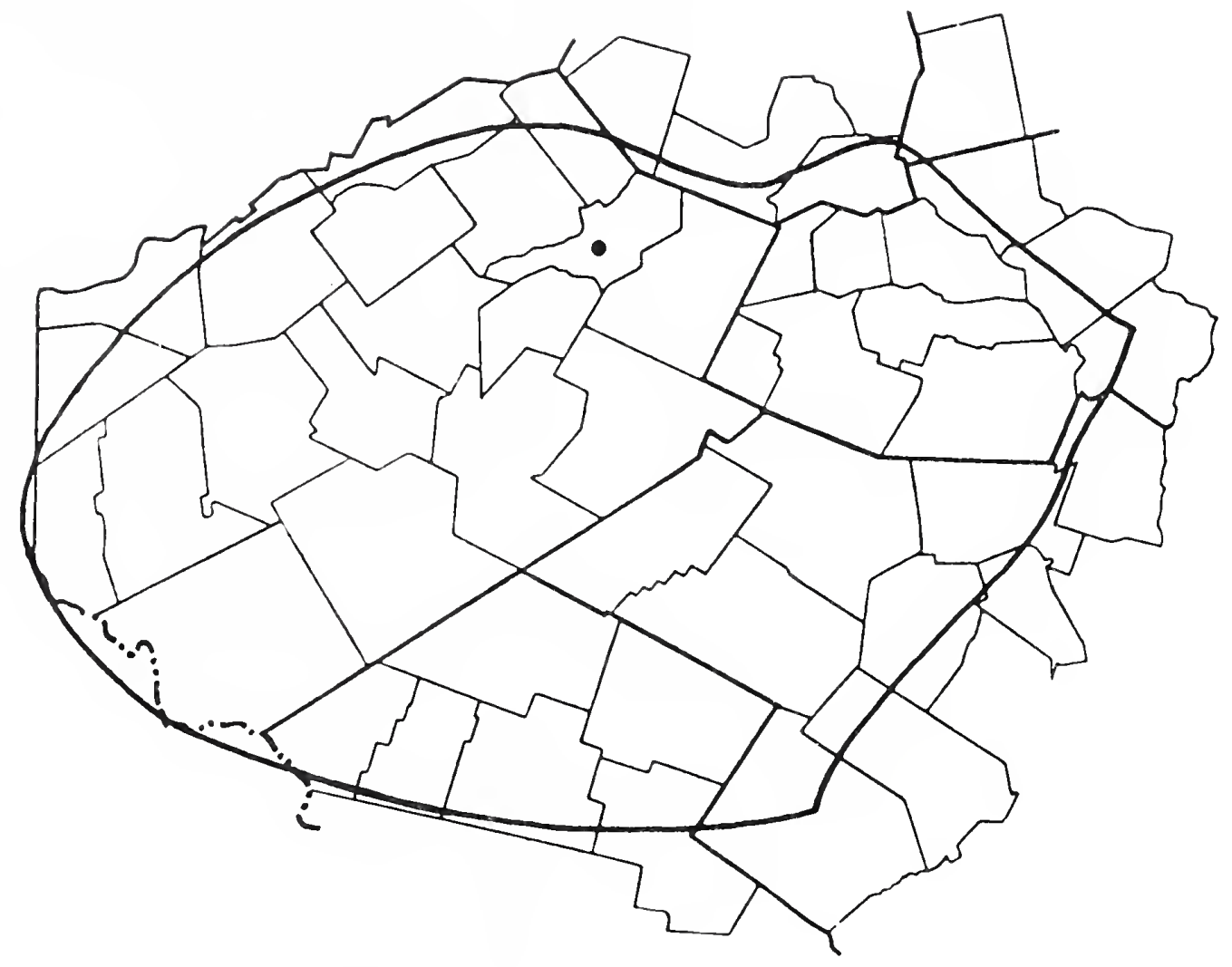

Crataegus chrysocarpa Ashe

Round-leaved Thorn

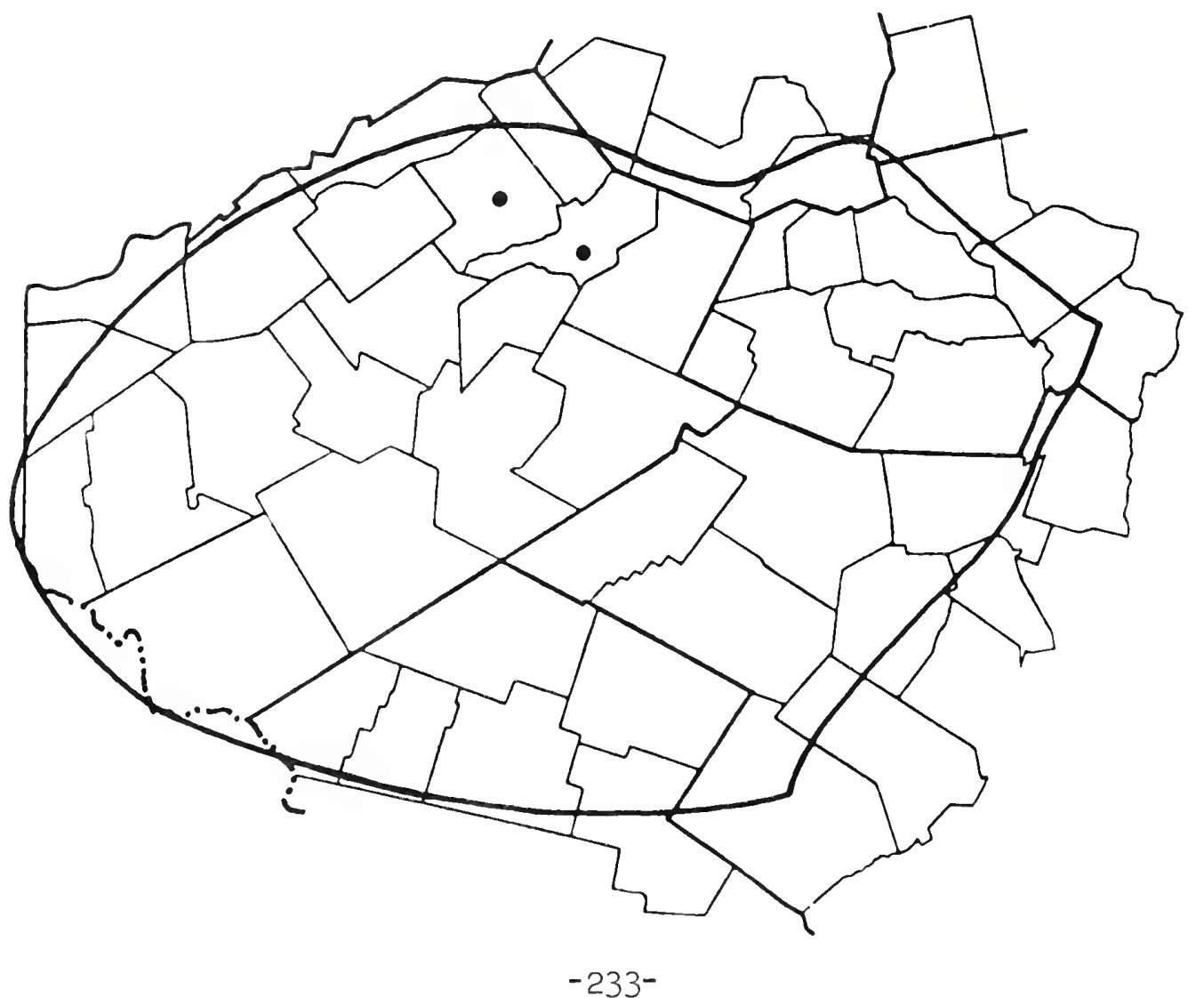


Flora of

Crataegus holmesiana Ashe

THE CATSKILLS

Thin-leaved Thorn

New York State

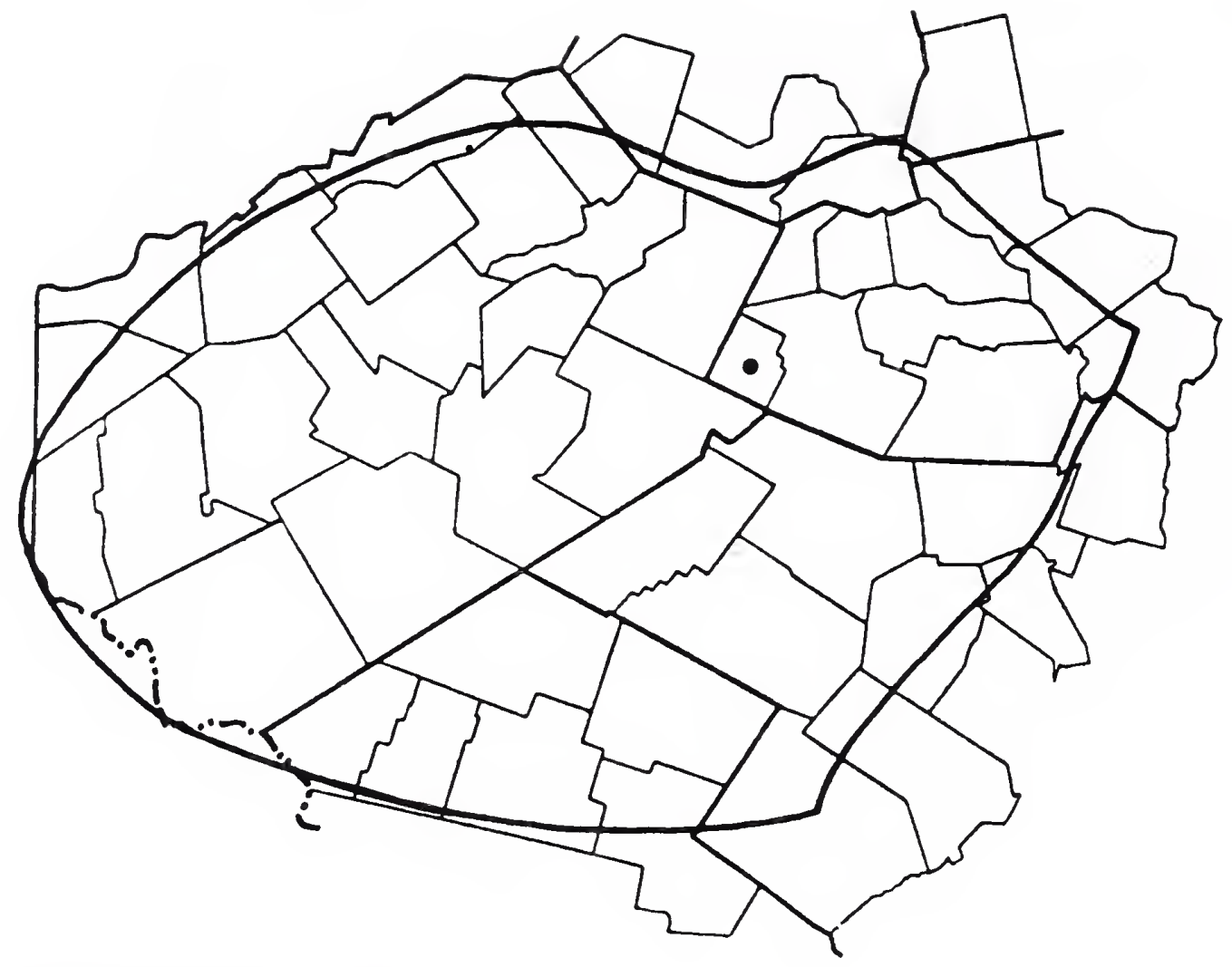

Crataegus macrosperma Ashe

Variable Hawthorn

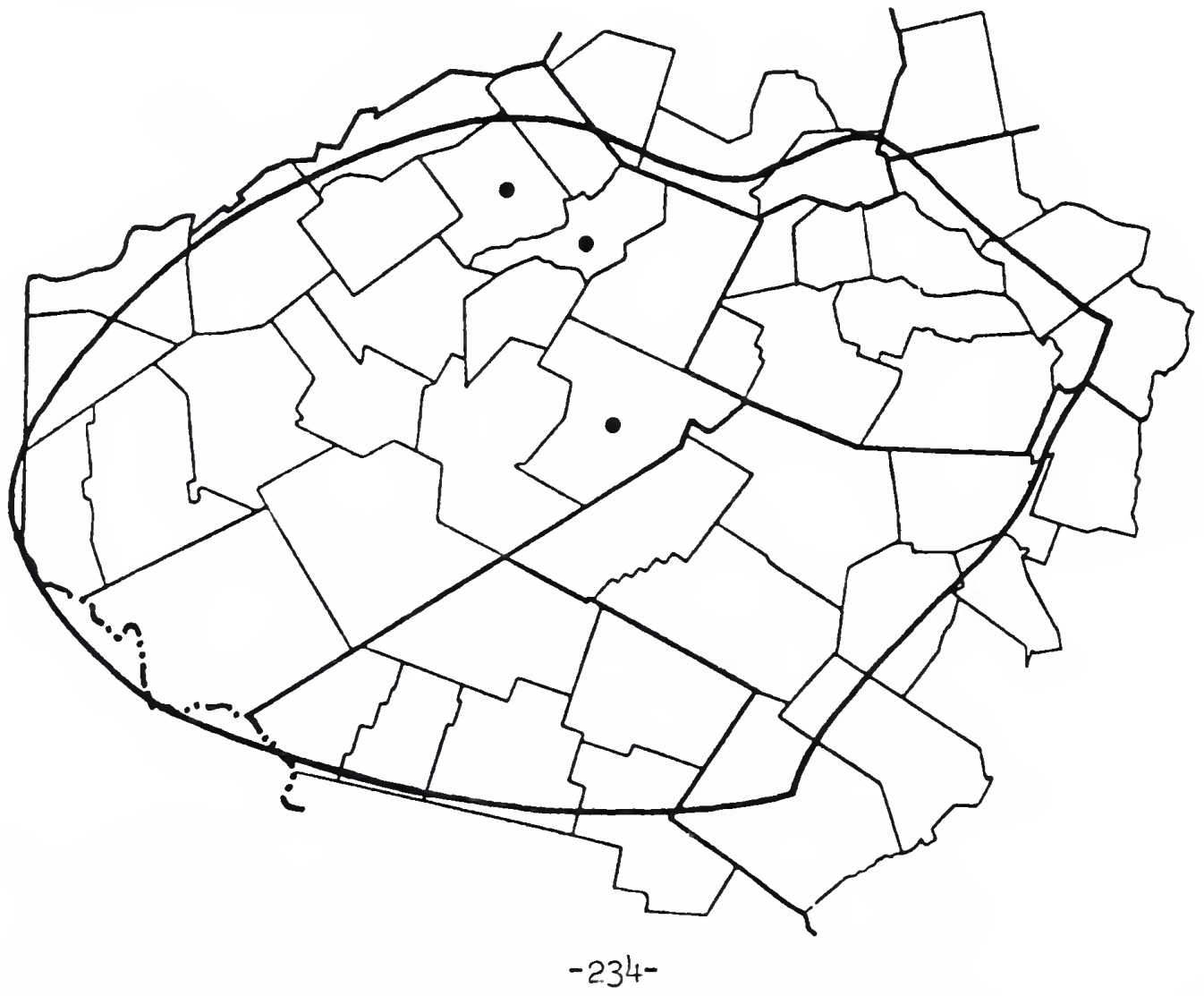




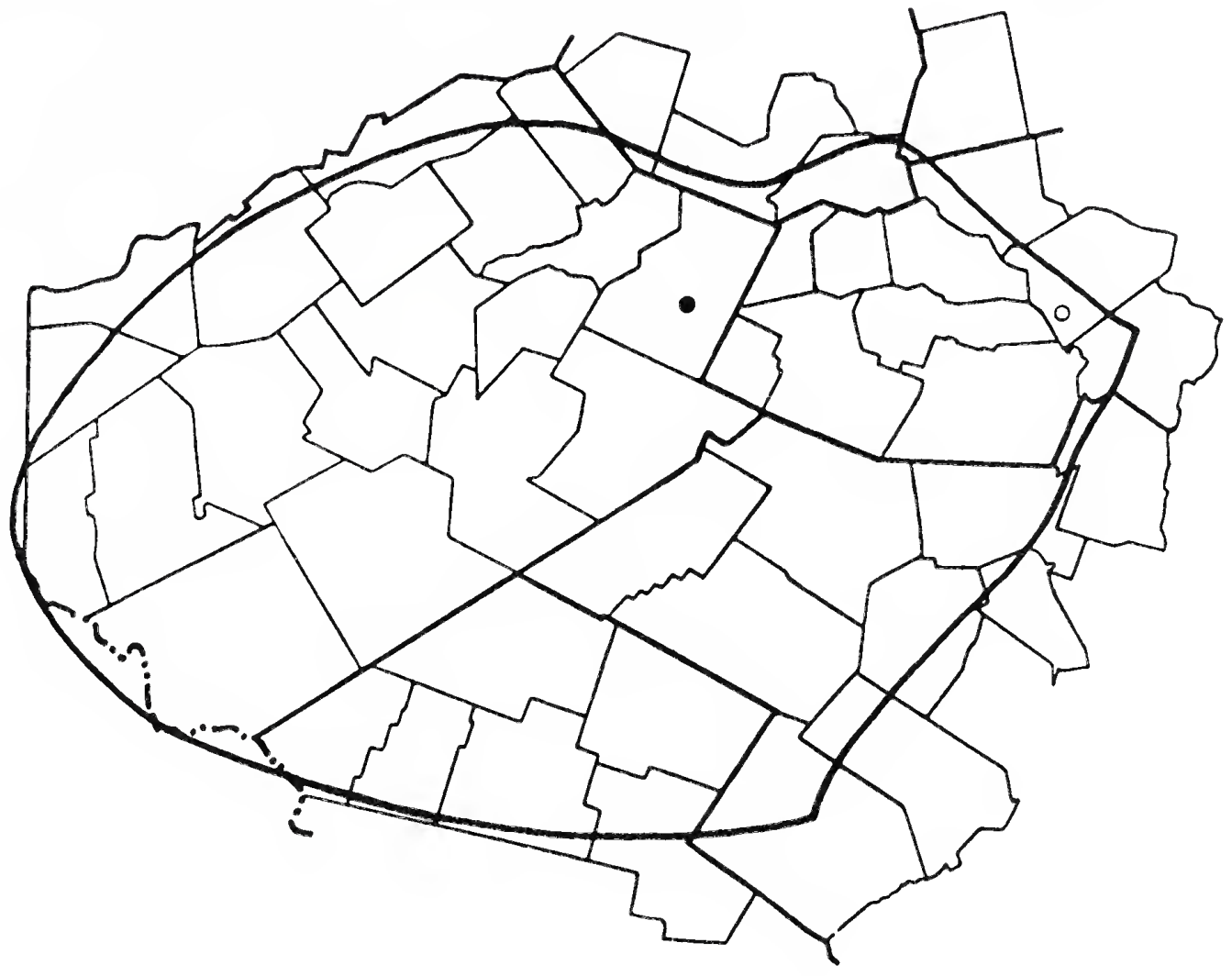

Crataegus punctata Jacq.

Dotted Haw

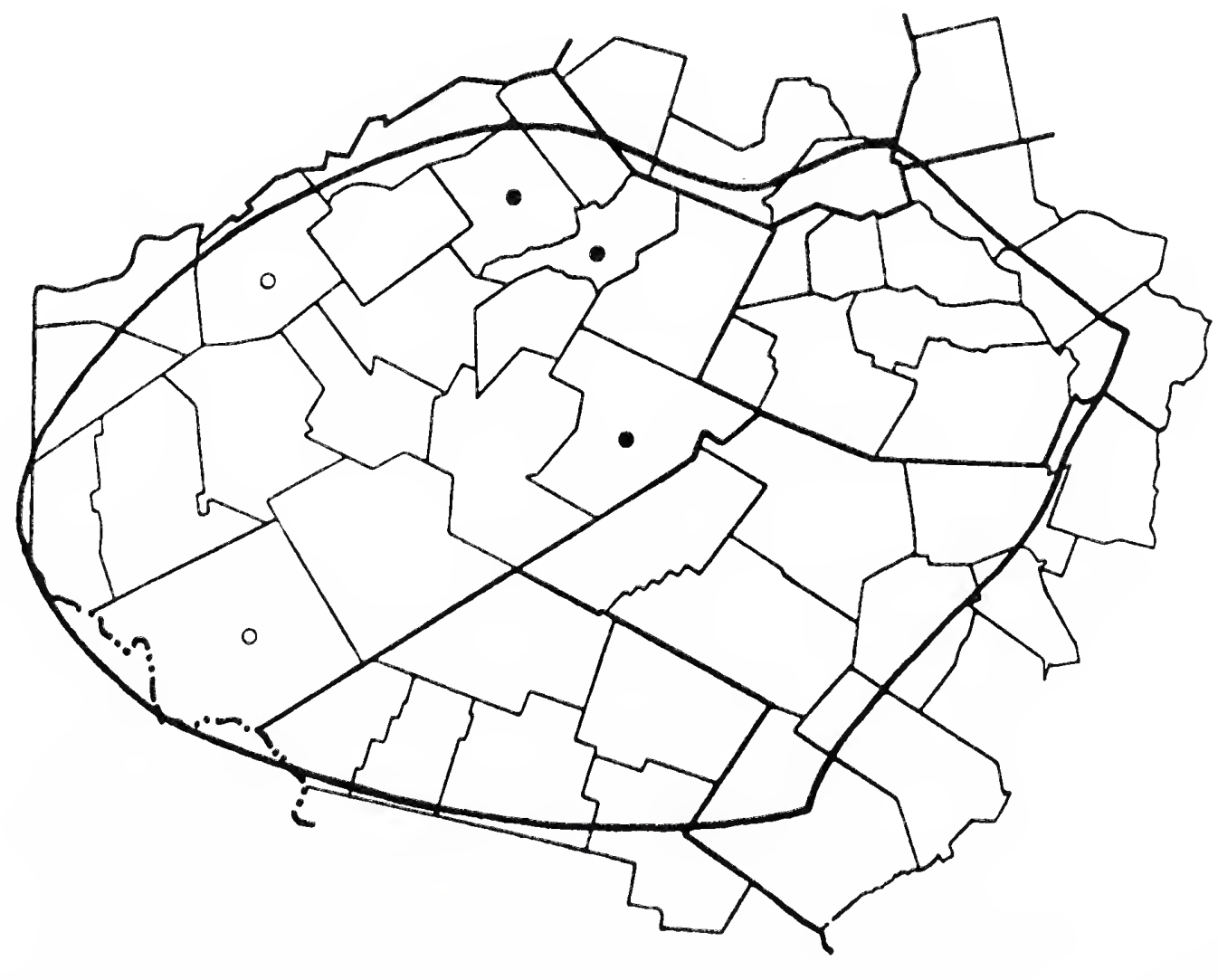




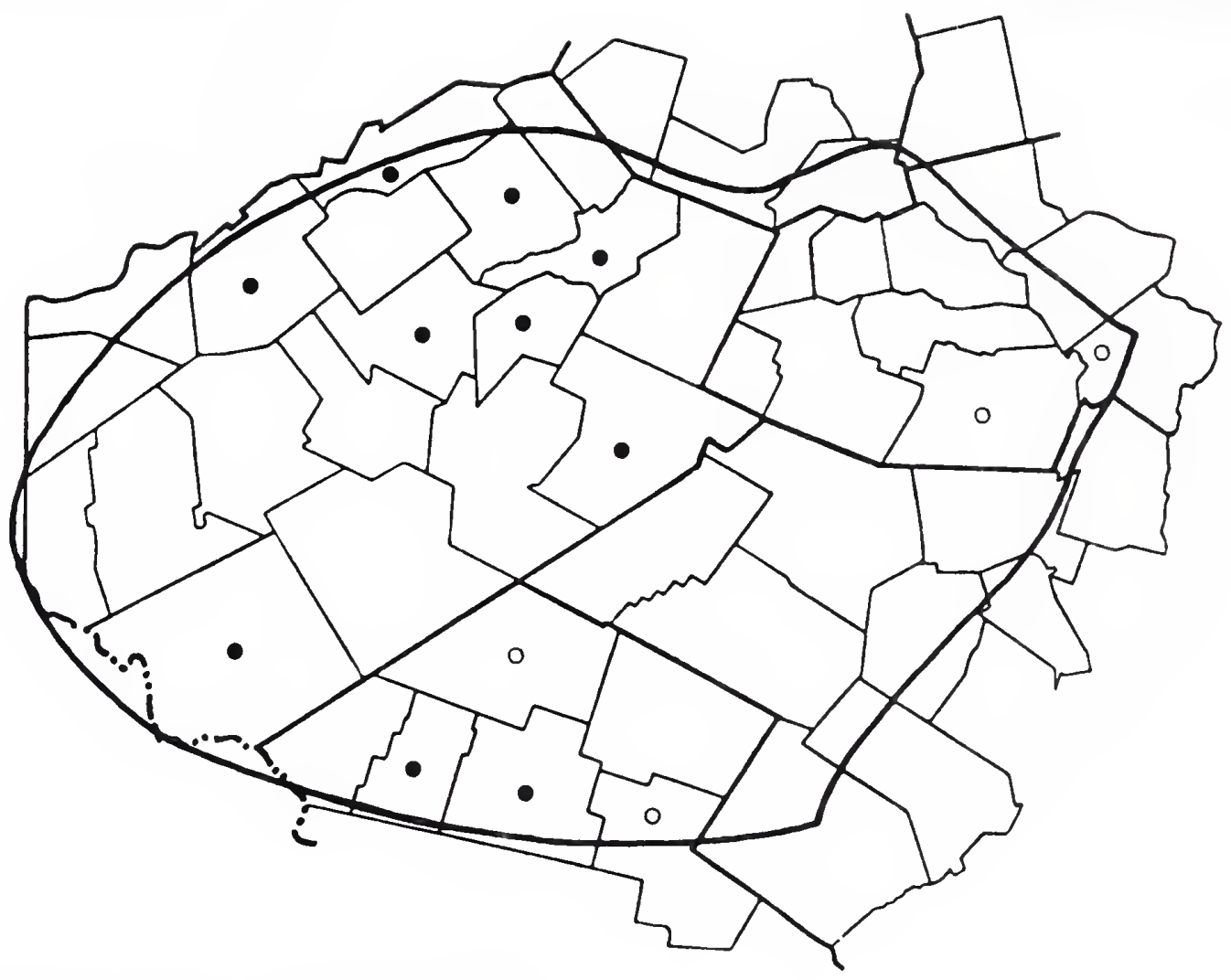

Filipendula rubra (Hill) Robins.

Queen-of-the-prairie

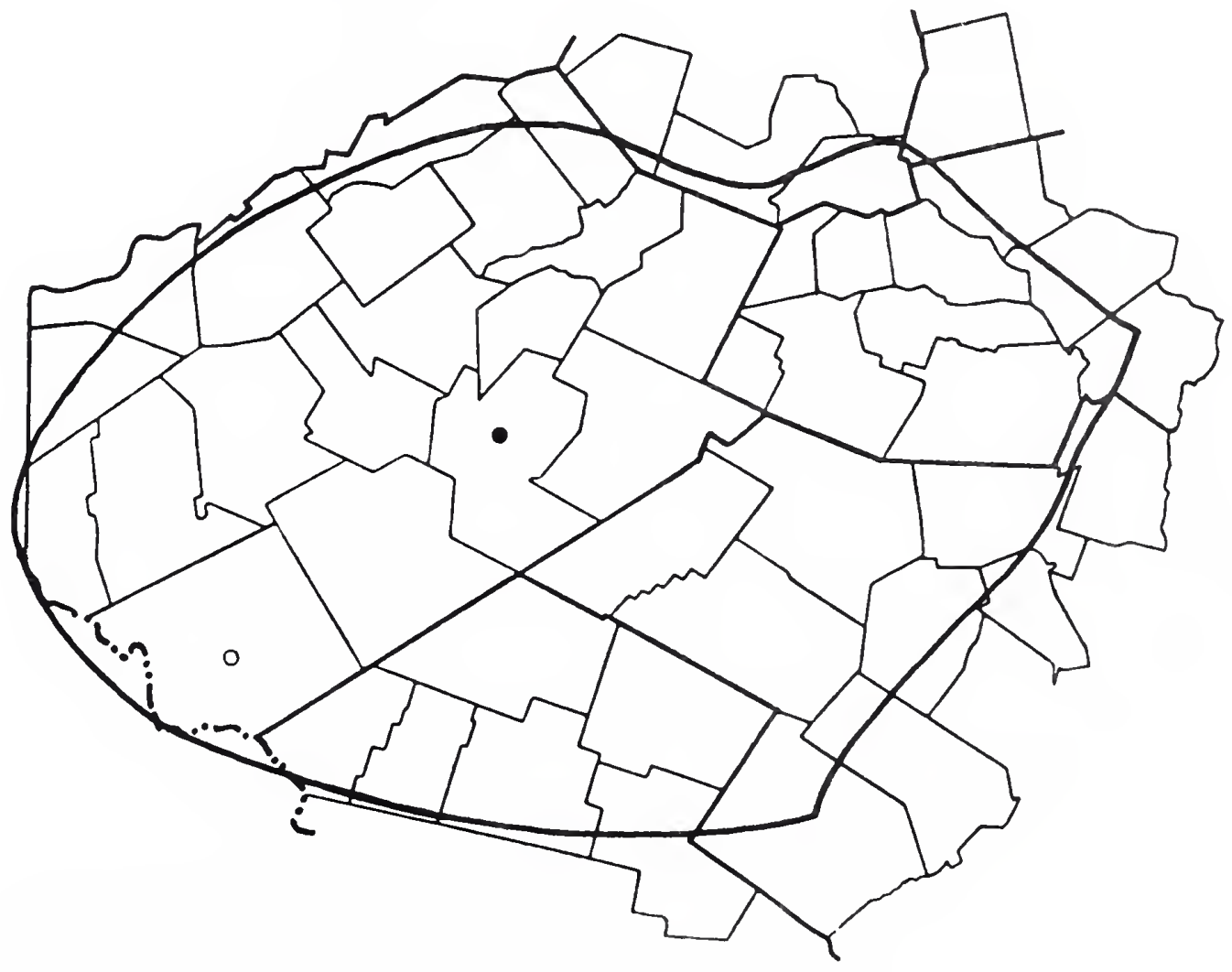


Flora of

Filipendula ulmaria (L.) Maxim.

THE CATSKILLS

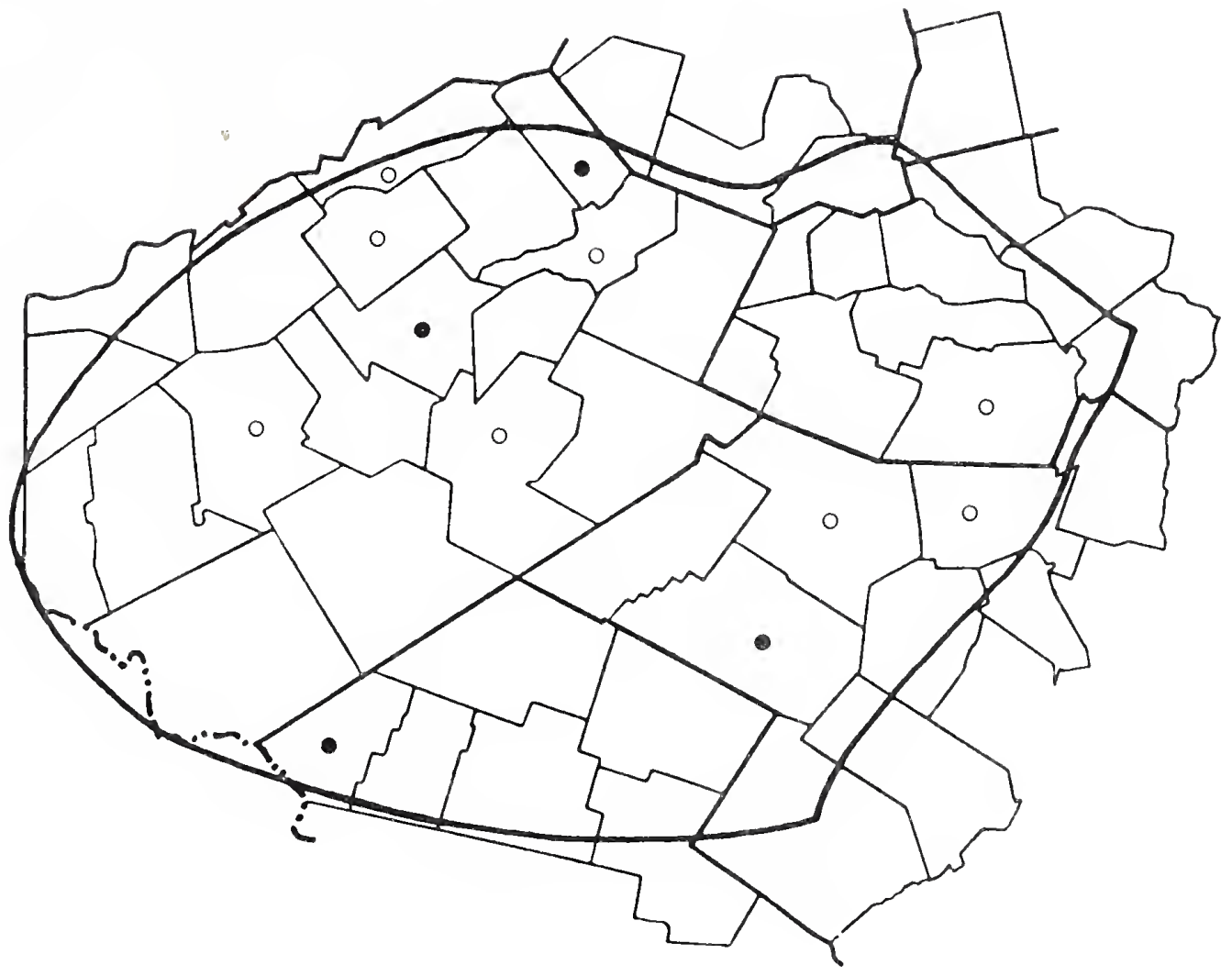

Fragaria vesca I.

ssp. americana (Porter) staudt.

American Wood Strawberry

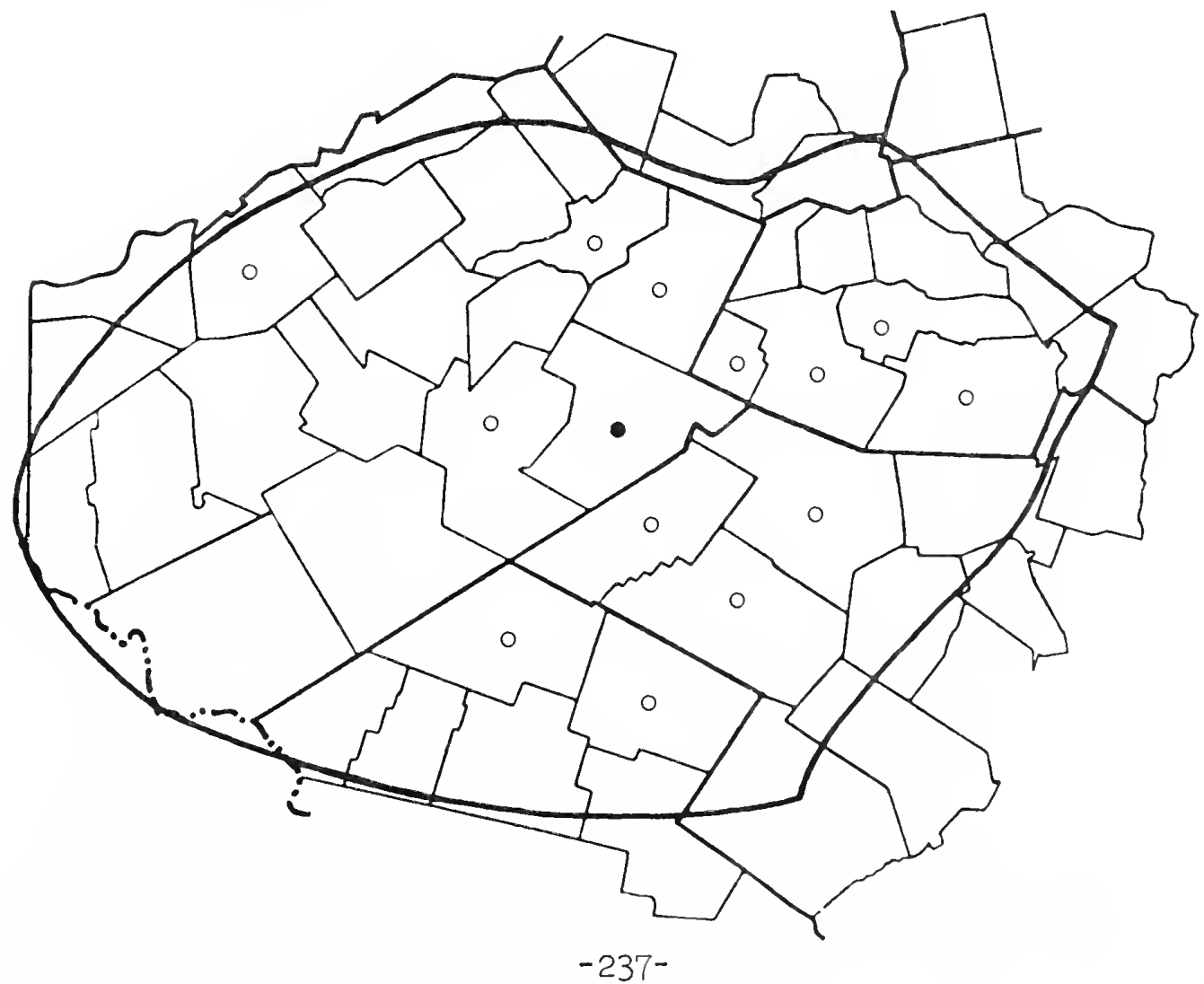




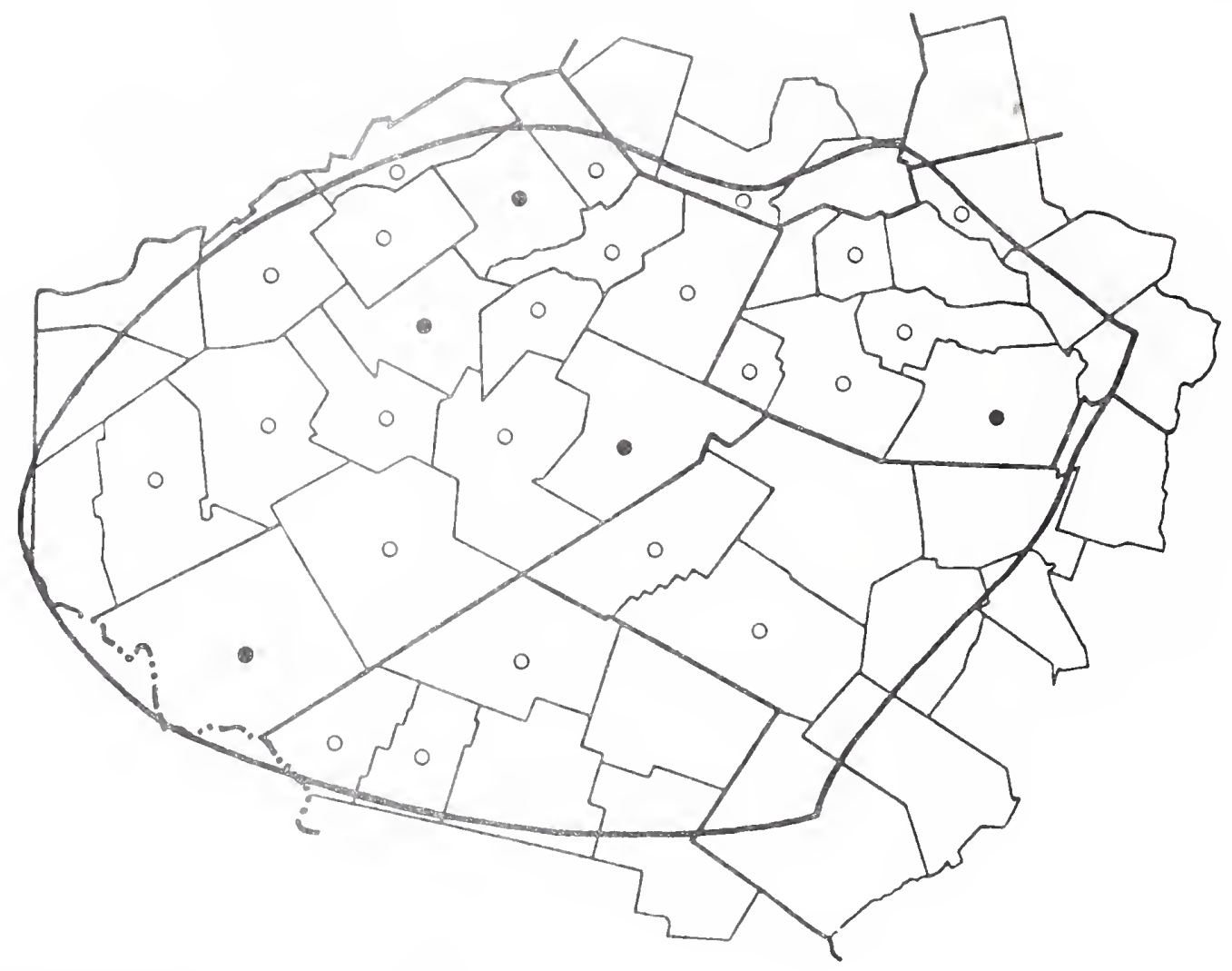

Fragaria virginiana Duchesne

Field Strawberry

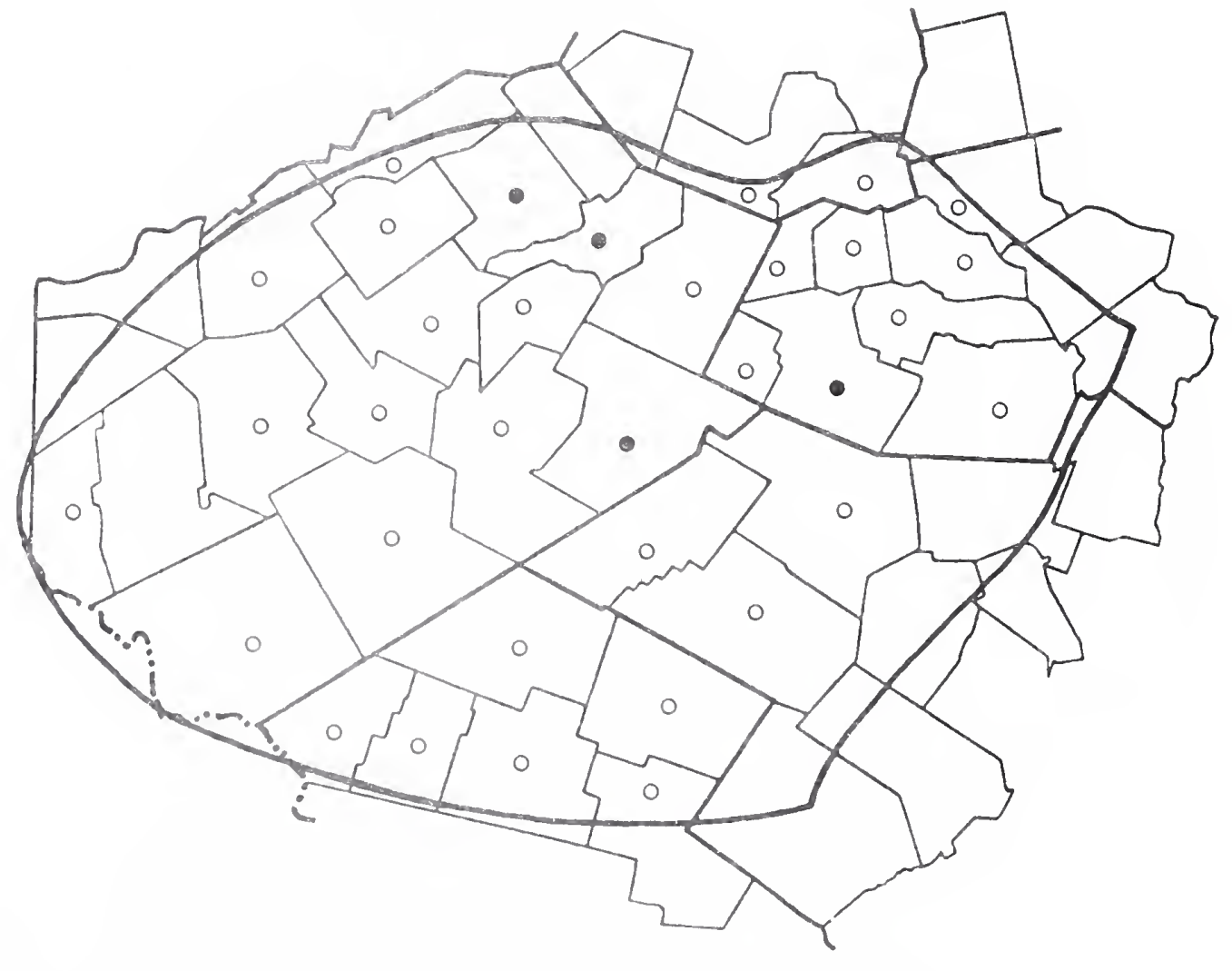


Flora of

Geum aleppicum Jacq.

THE CATSKILLS

Yellow Avens

New York State

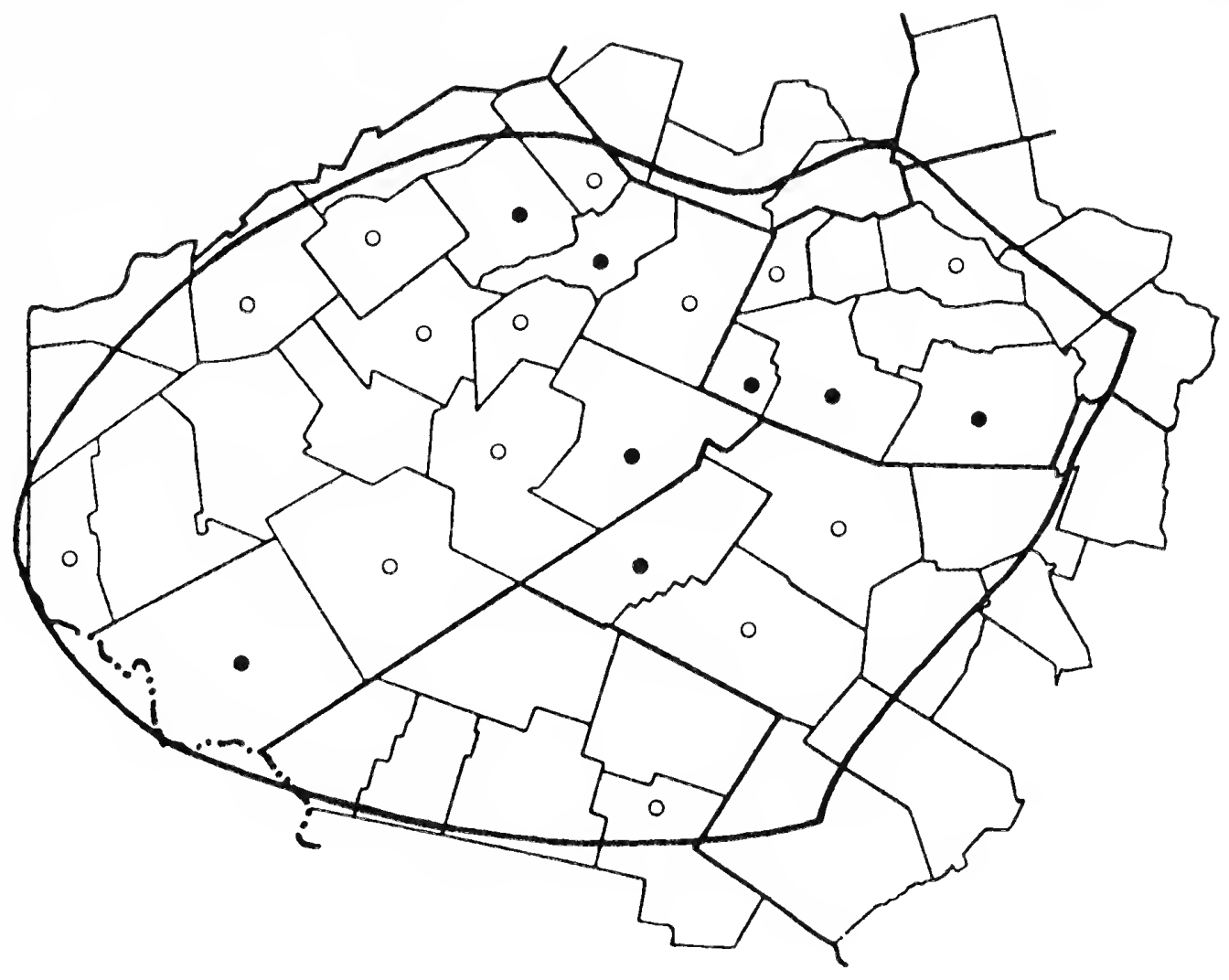

Geum canadense Jacq.

White Avens

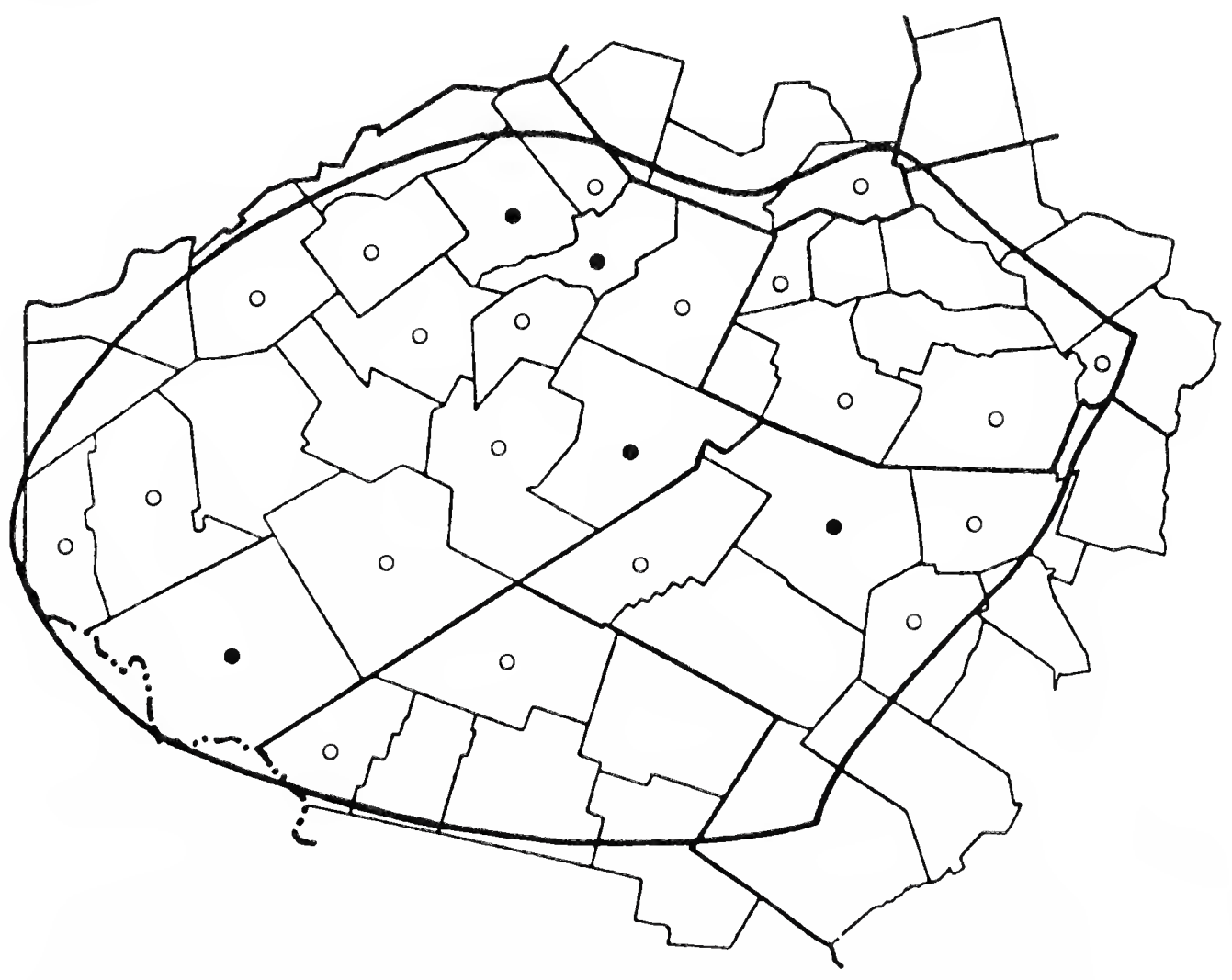




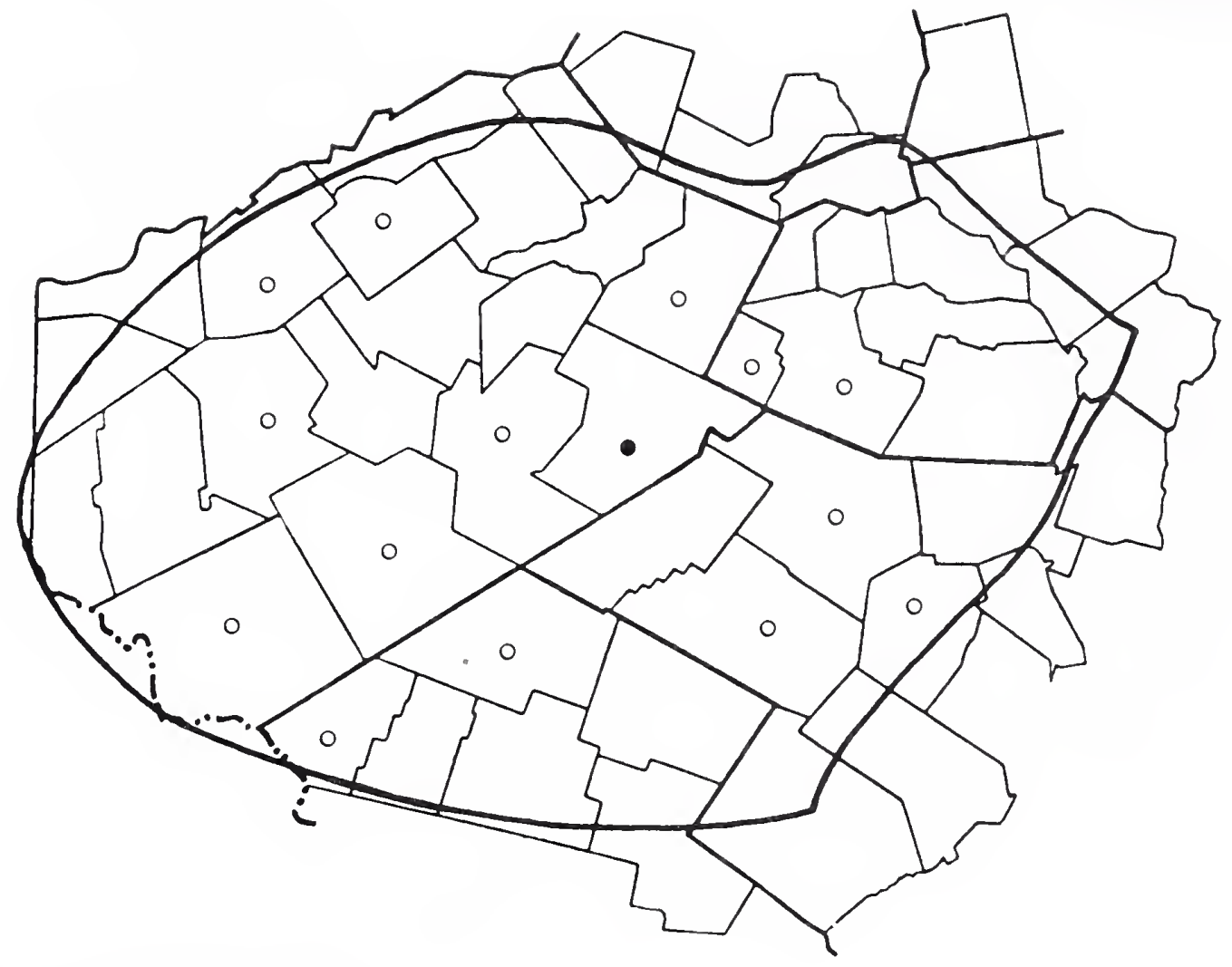

Geum macrophyllum Willd.

Large-leaved Avens

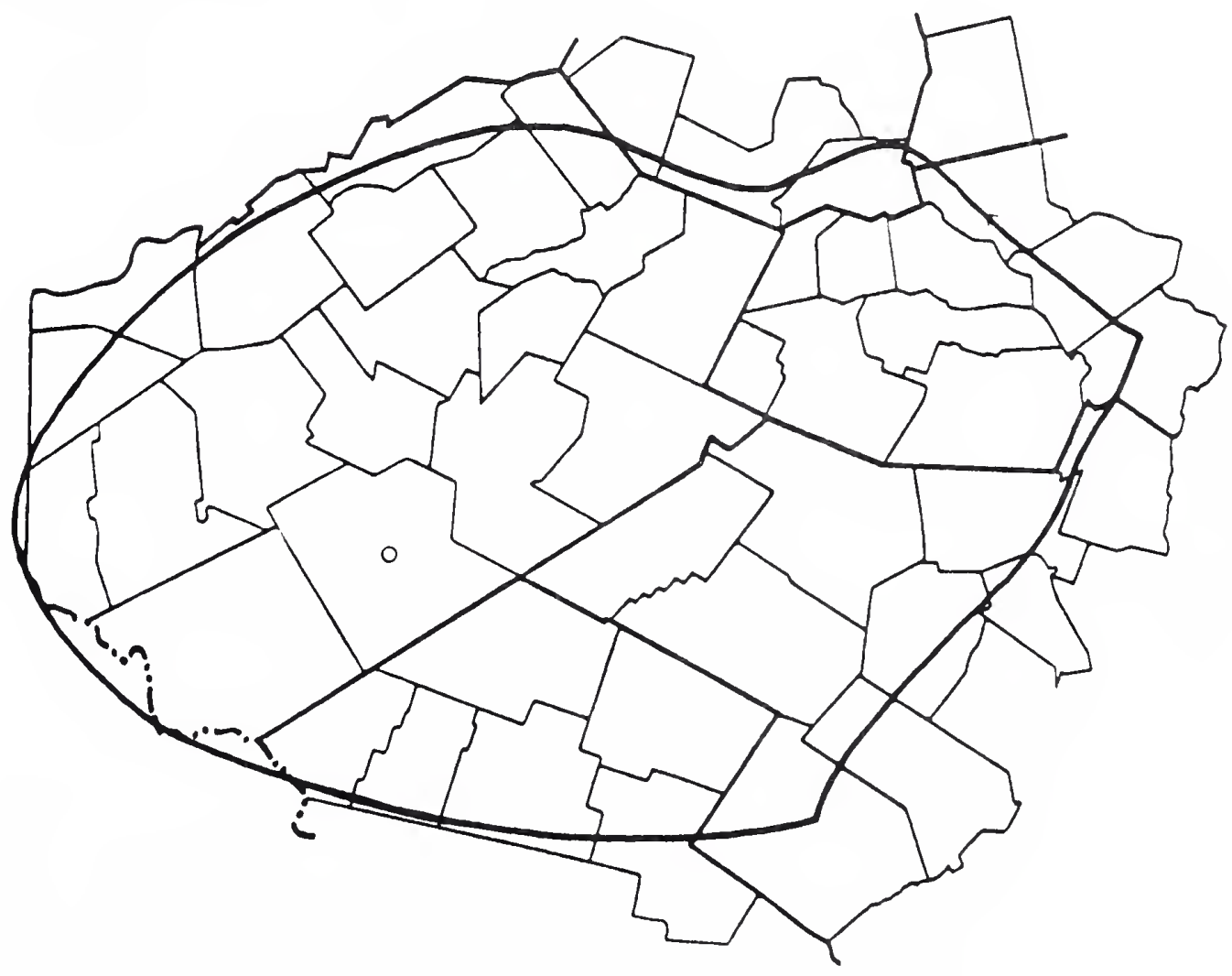


Flora of

Geum rivale I.

THE CATSKILLS

Purple Avens

New York State

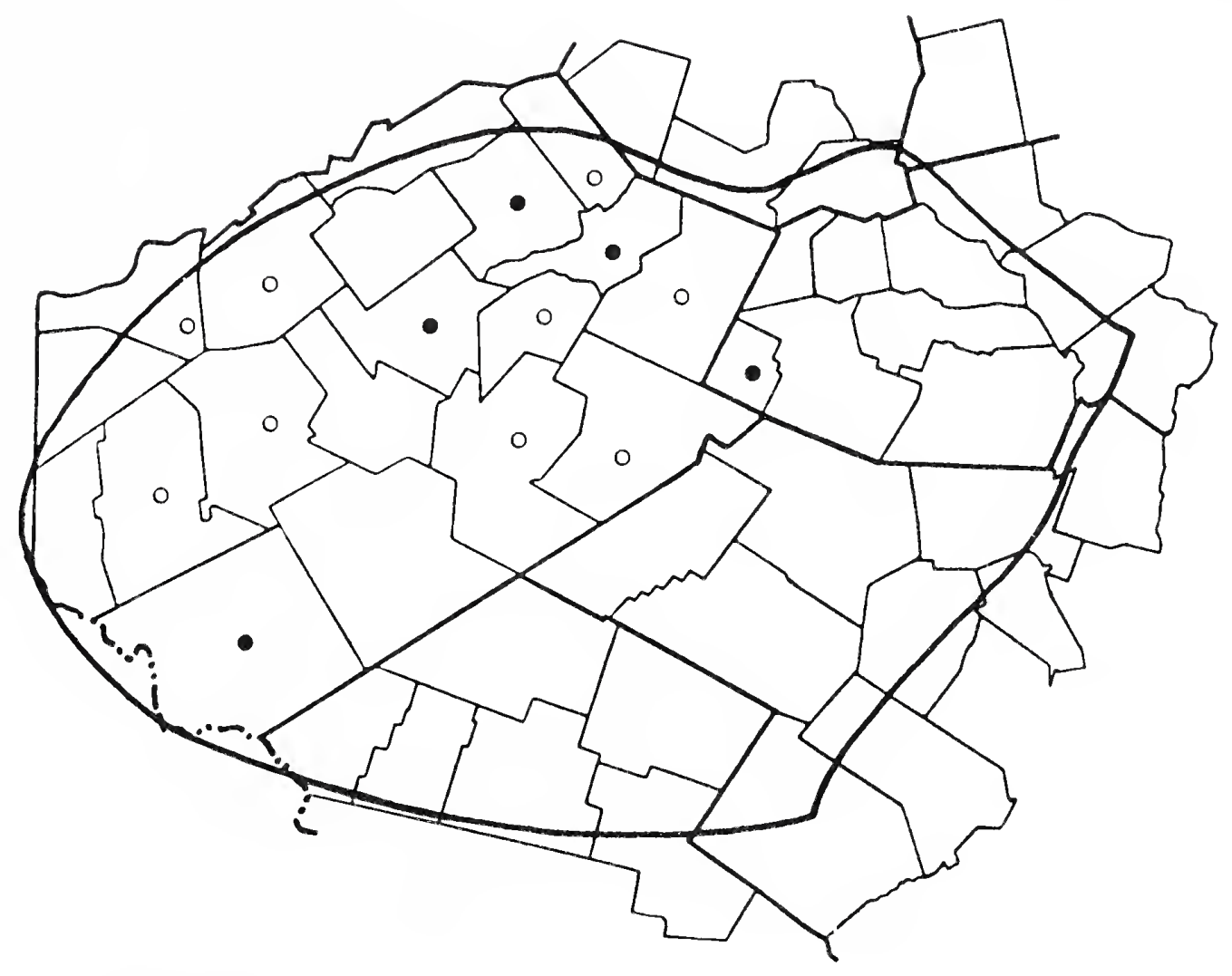

Geum virginianum I.

Rough Avens

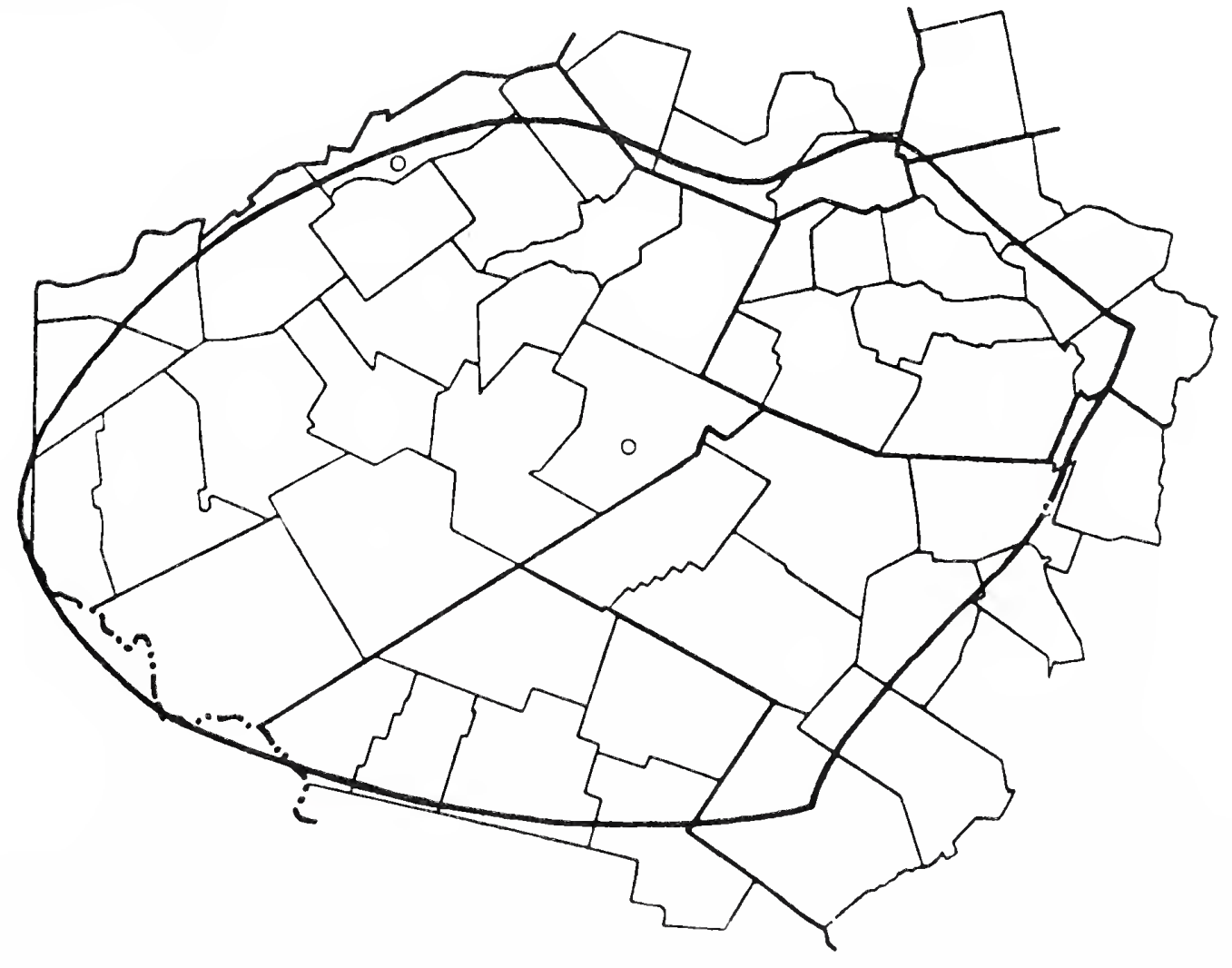




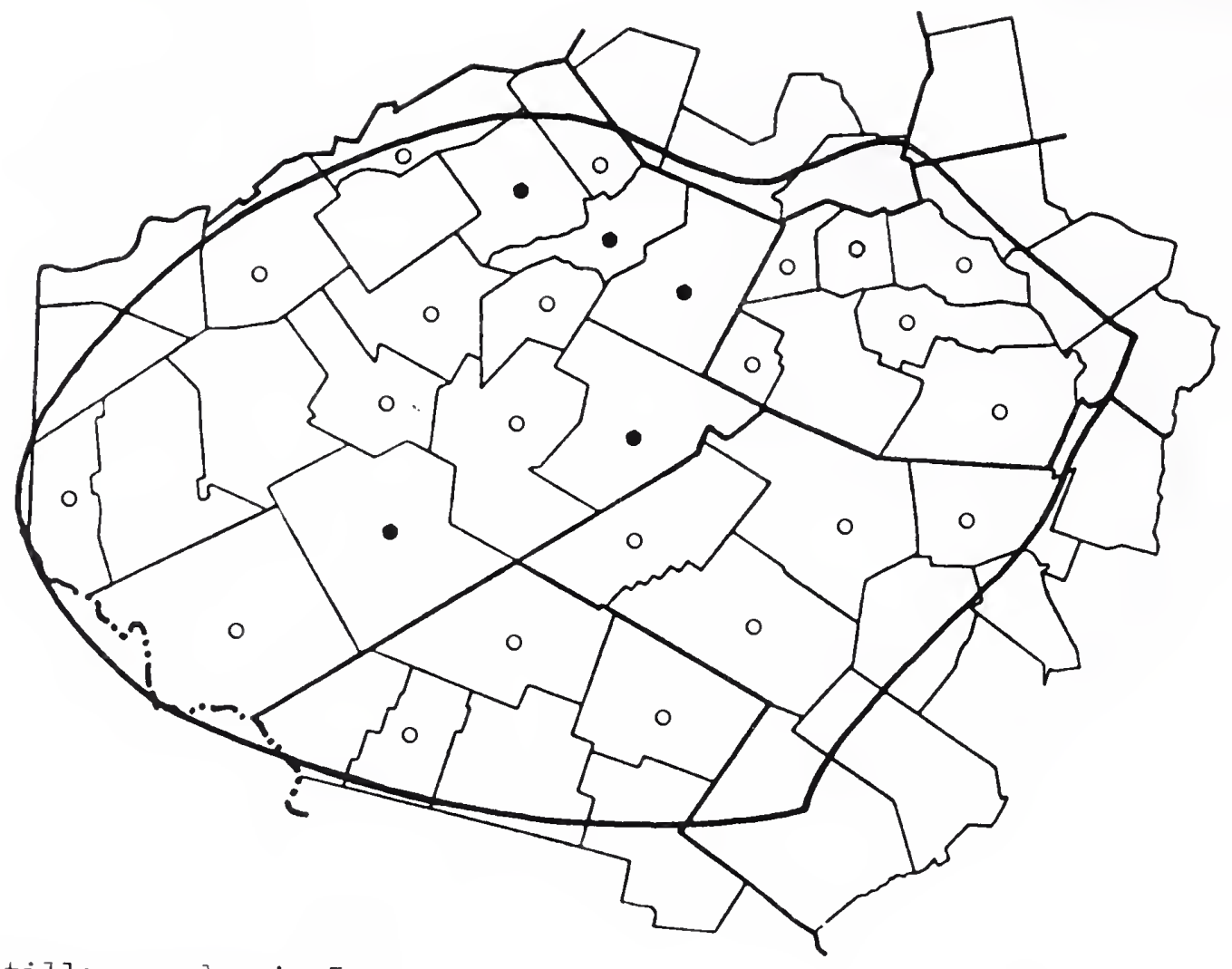

Potentilla canadensis I.

\section{Dwarf Cinquefoil}

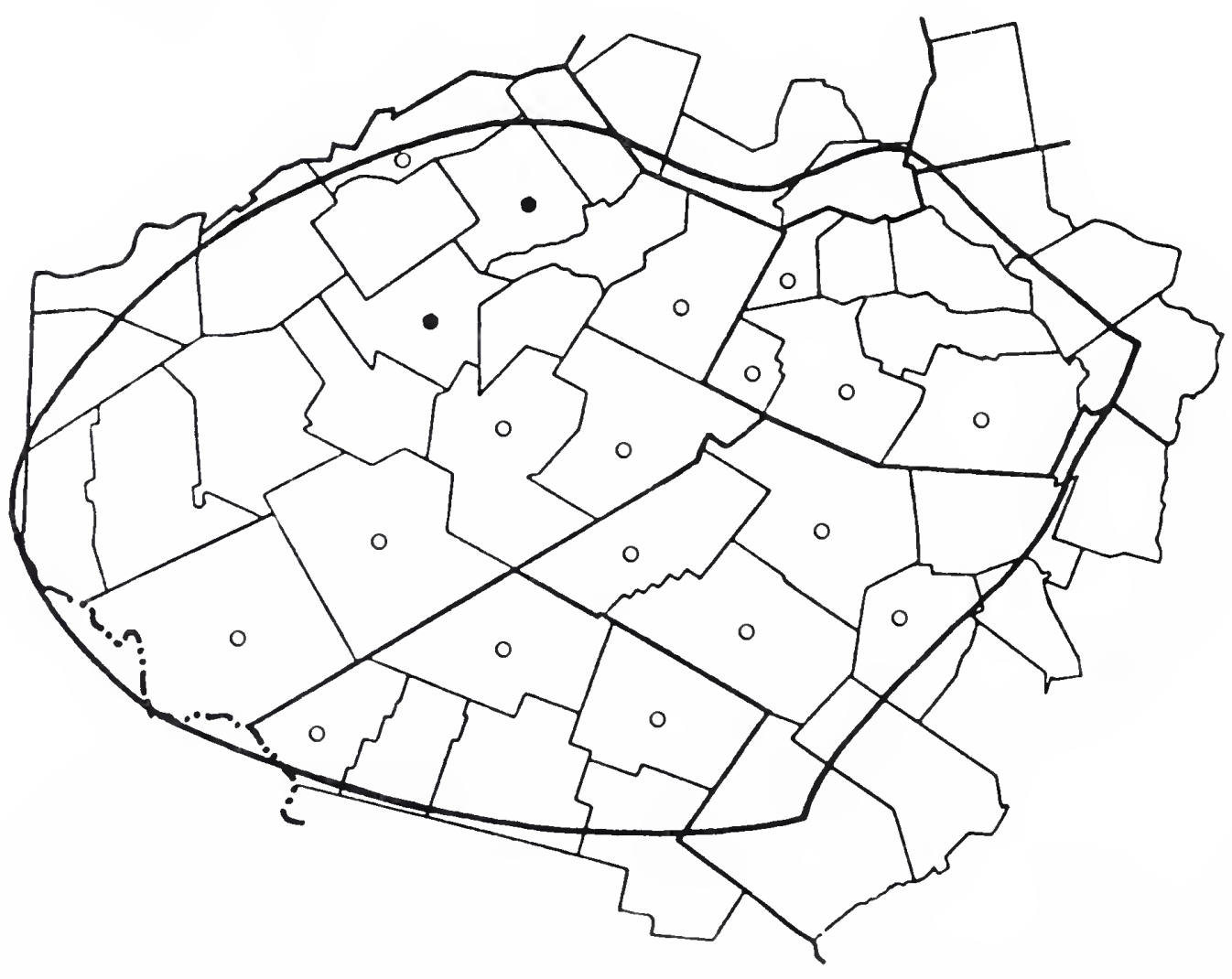


Potentilla intermedia $\mathrm{L}$.

THE CATSKILLS

Downy Cinquefoil

New York State

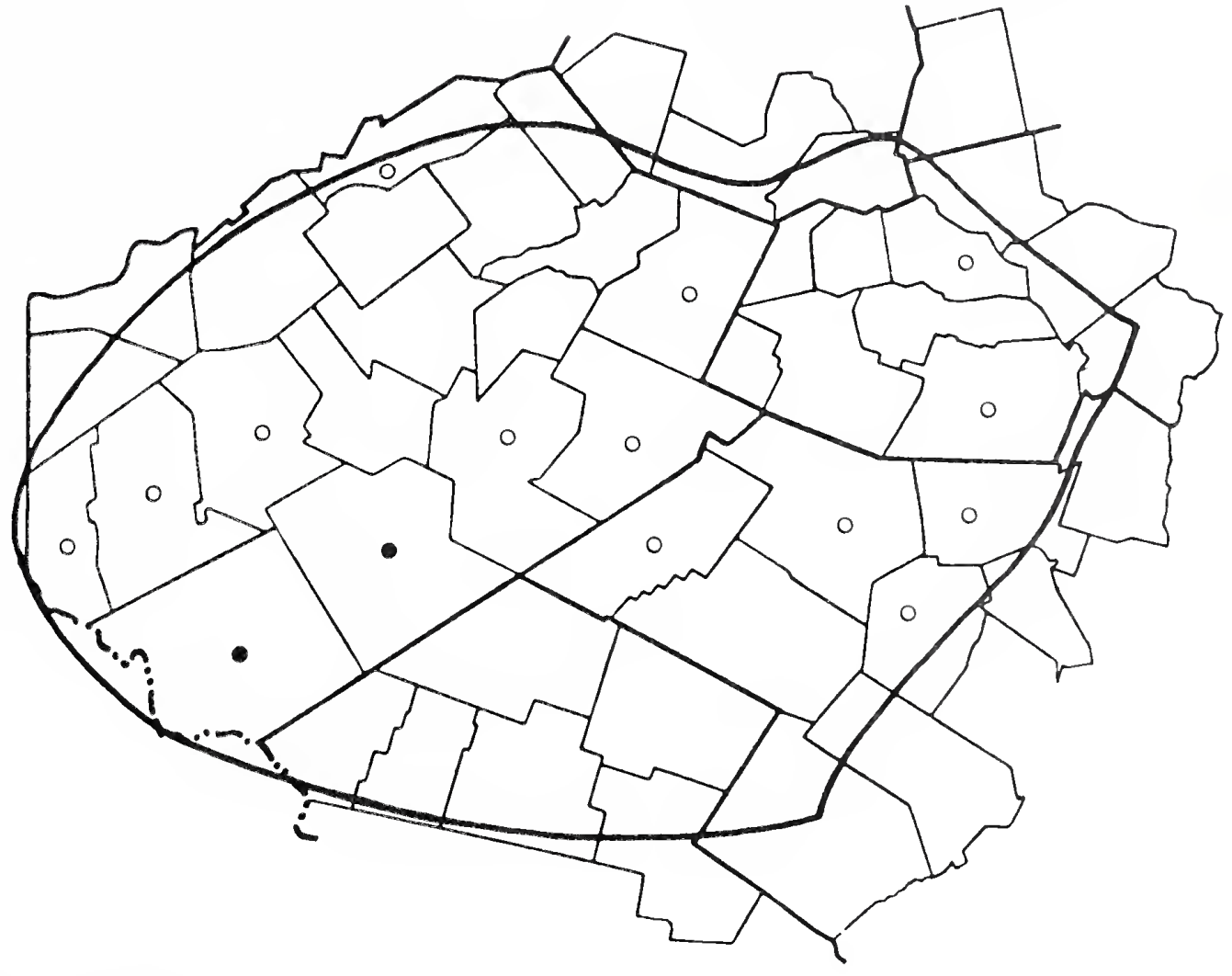

Potentilla norvegica $I$.

Norway Cinquefoil

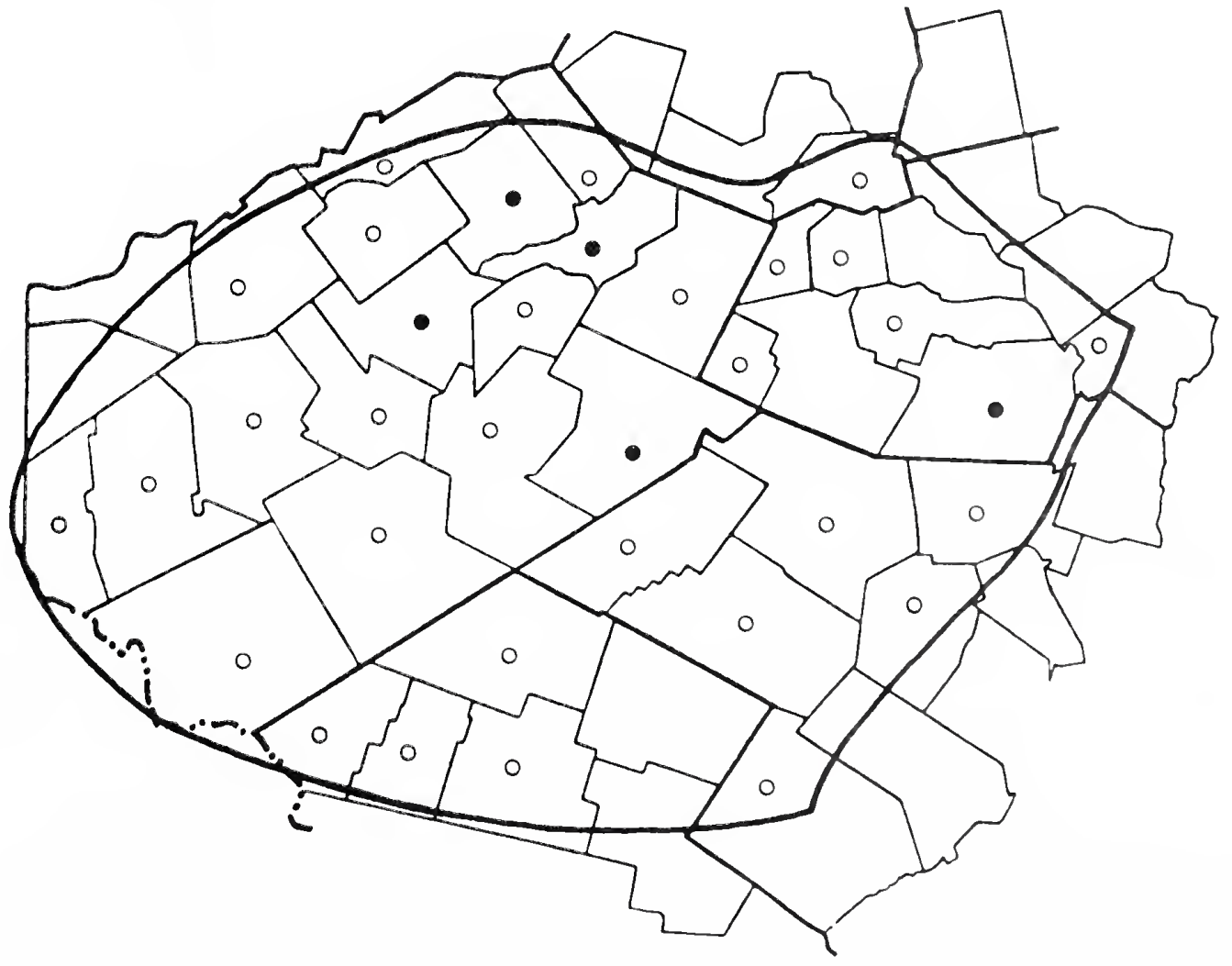




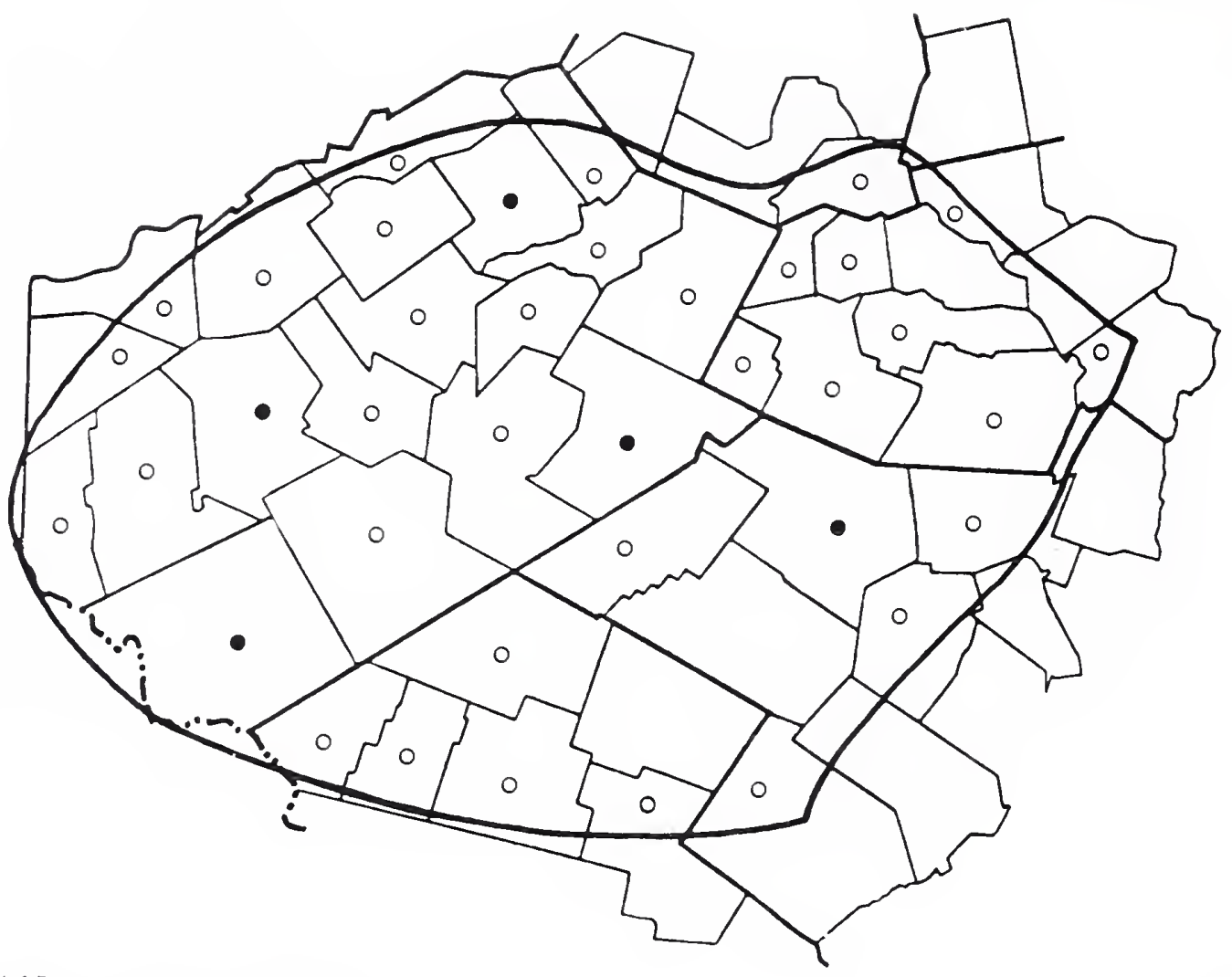

Potentilla simplex Michx.

\section{old-field Cinquefoil}

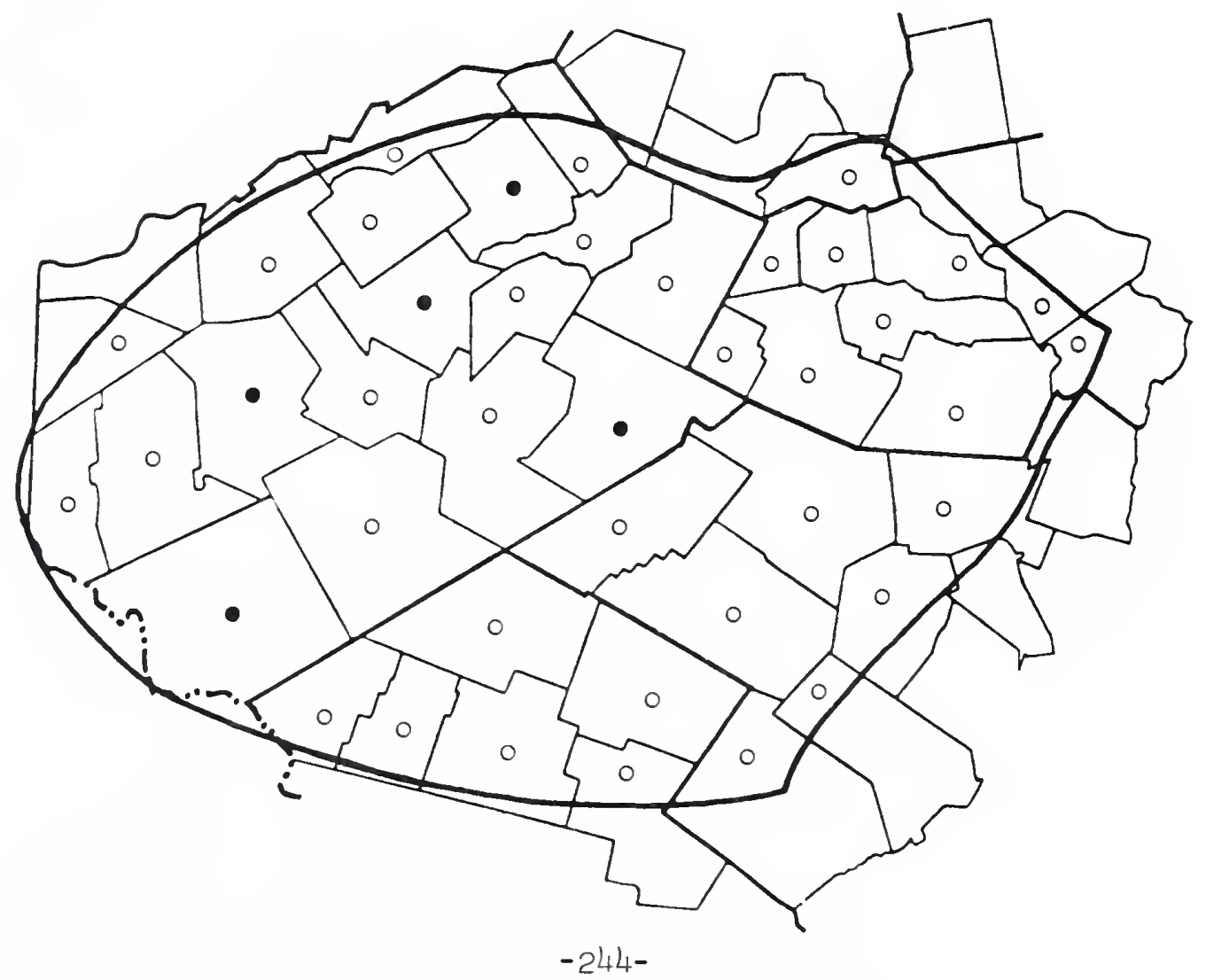




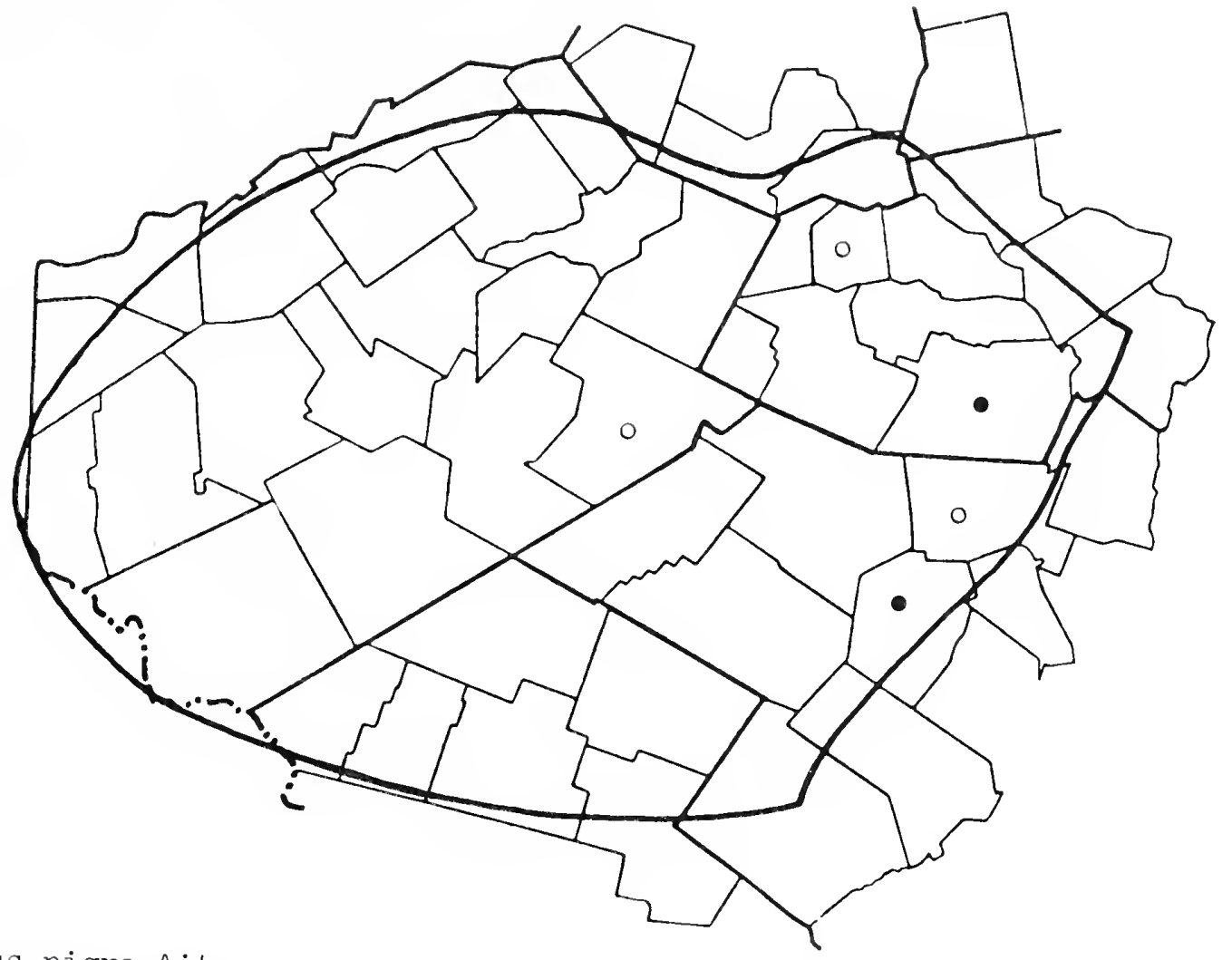

Prunus nigra Ait.

Canada Plum

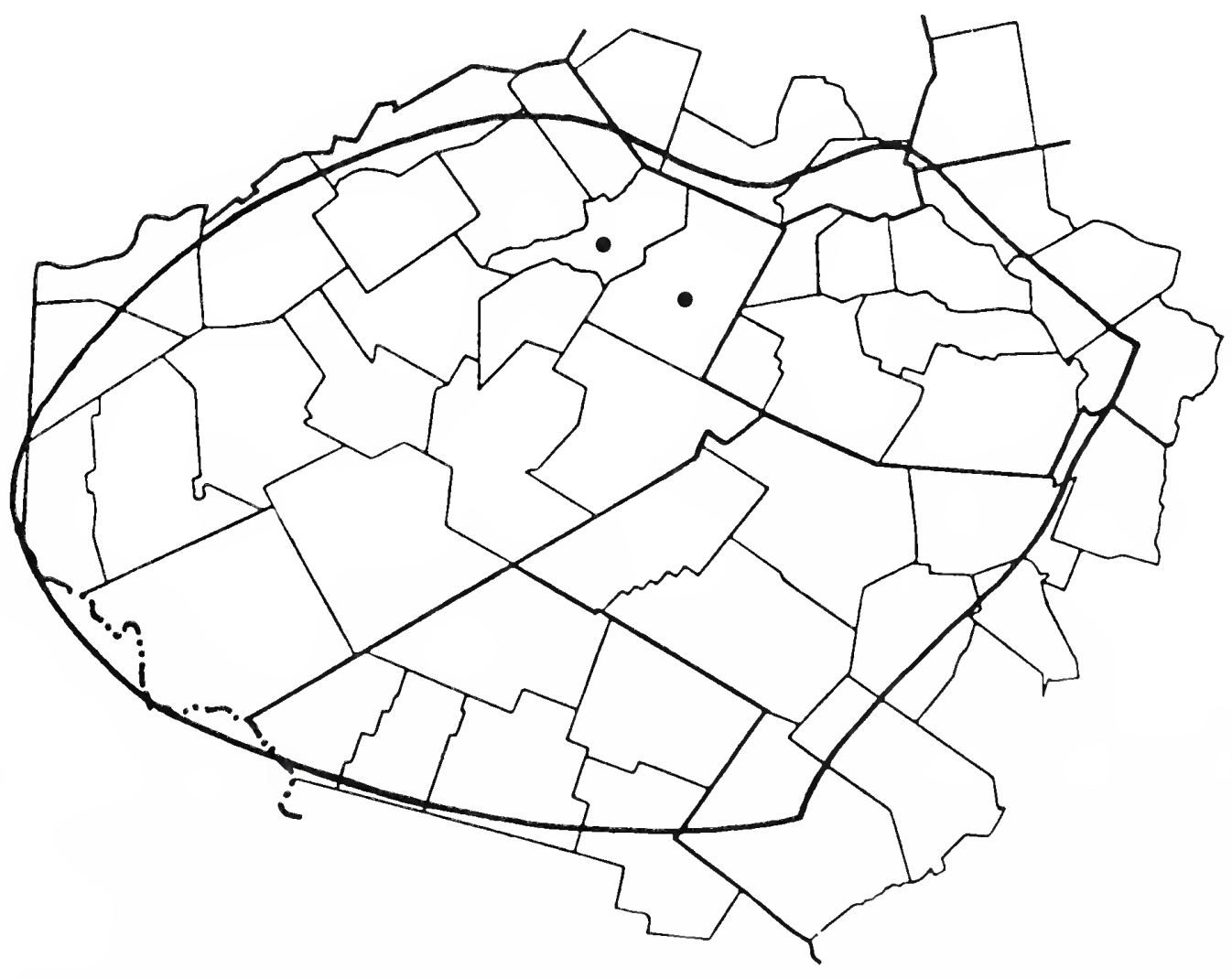




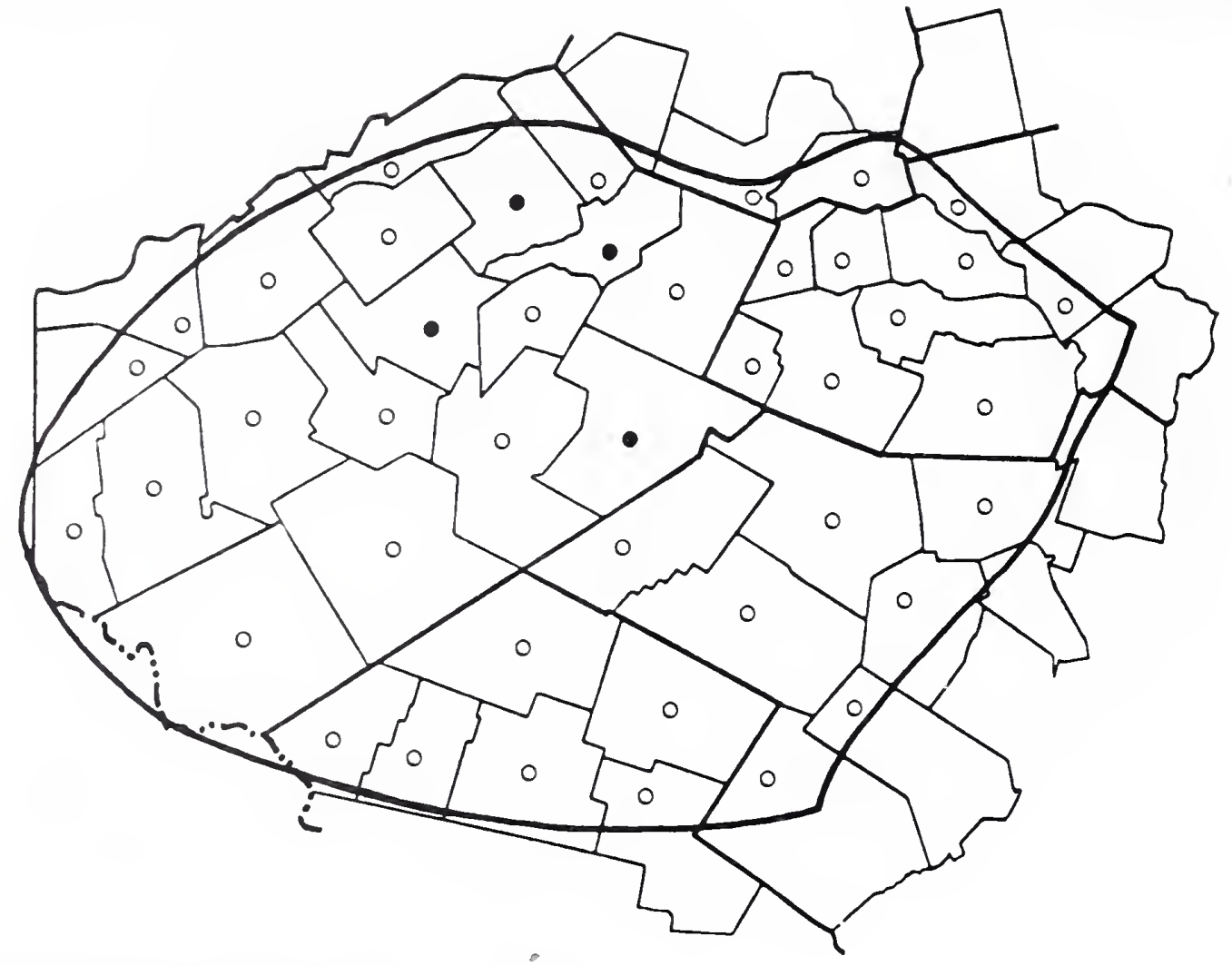

Prunus persica (I.) Batsch.

Peach

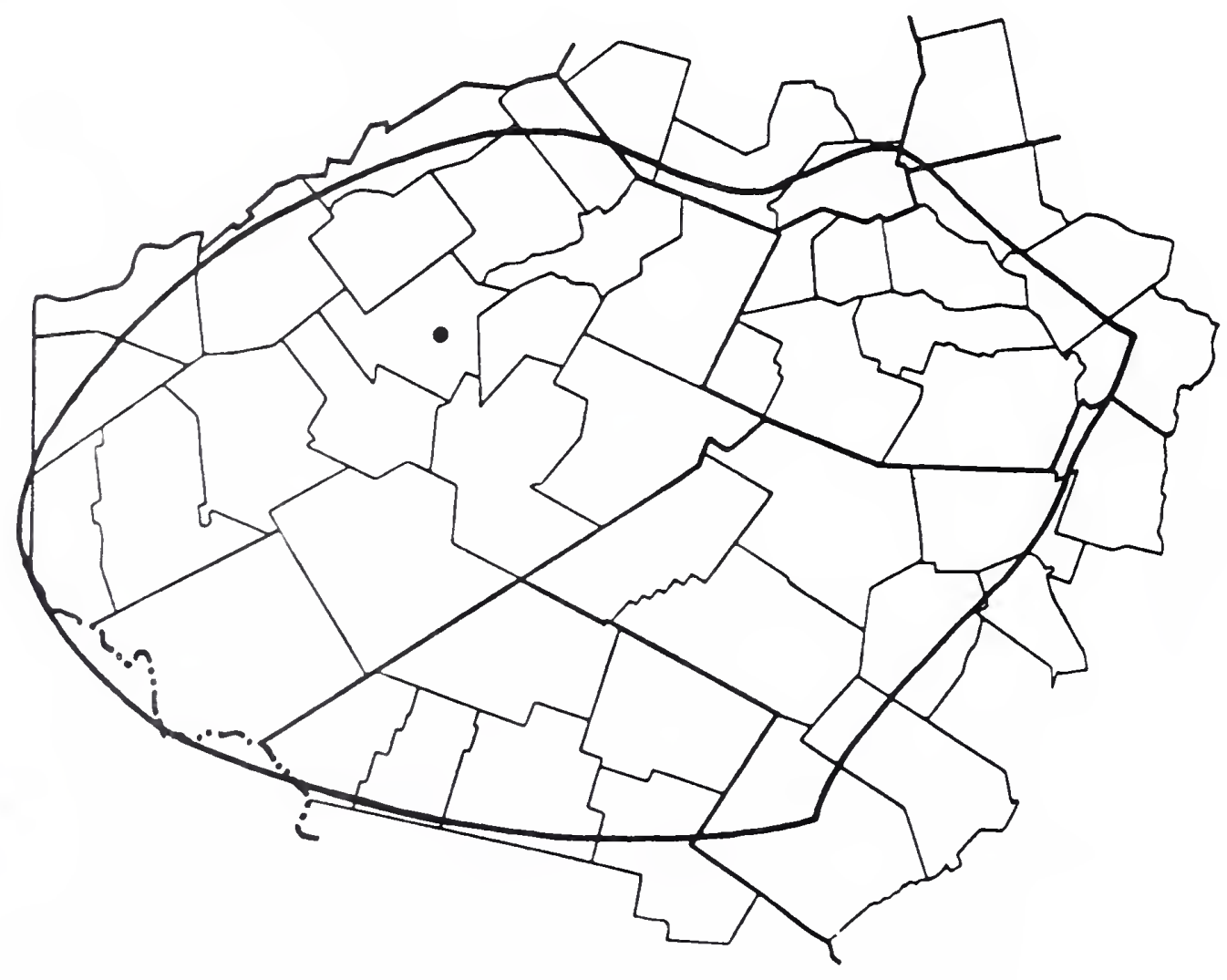




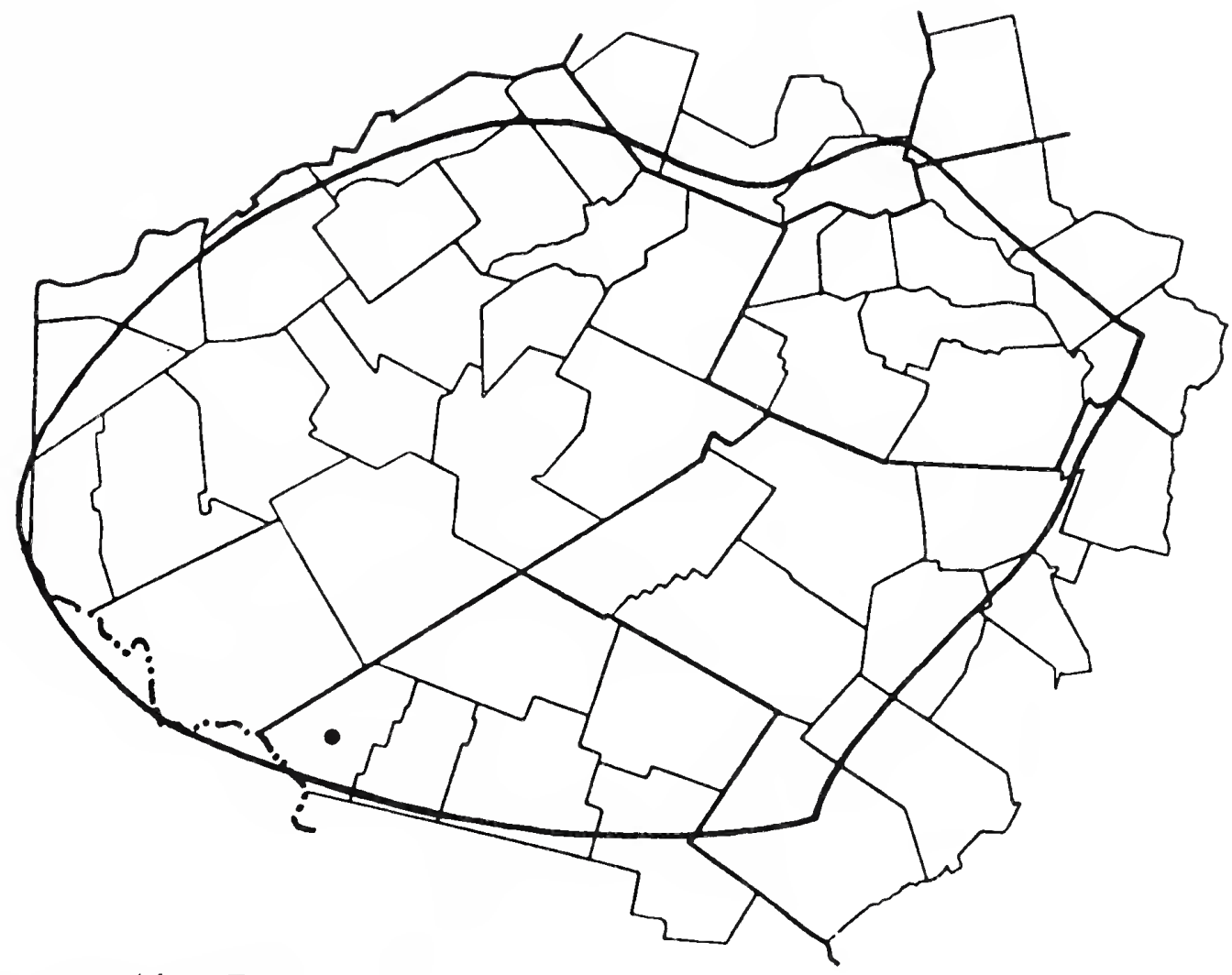

Prunus serotina Ehrh.

Black Cherry

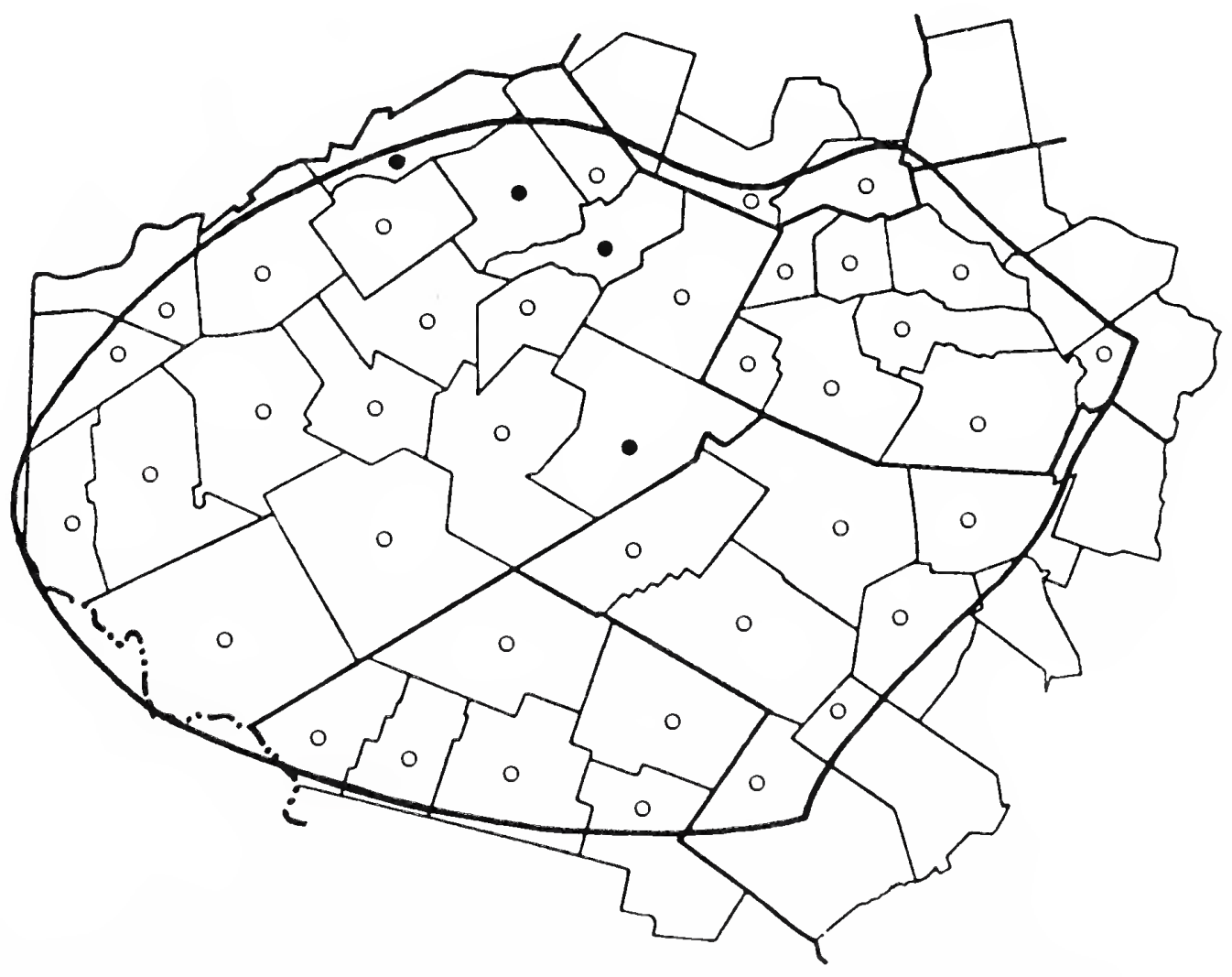


Flora of

Prunus virginiana L. Chokecherry
THE CATSKILLS

New York State

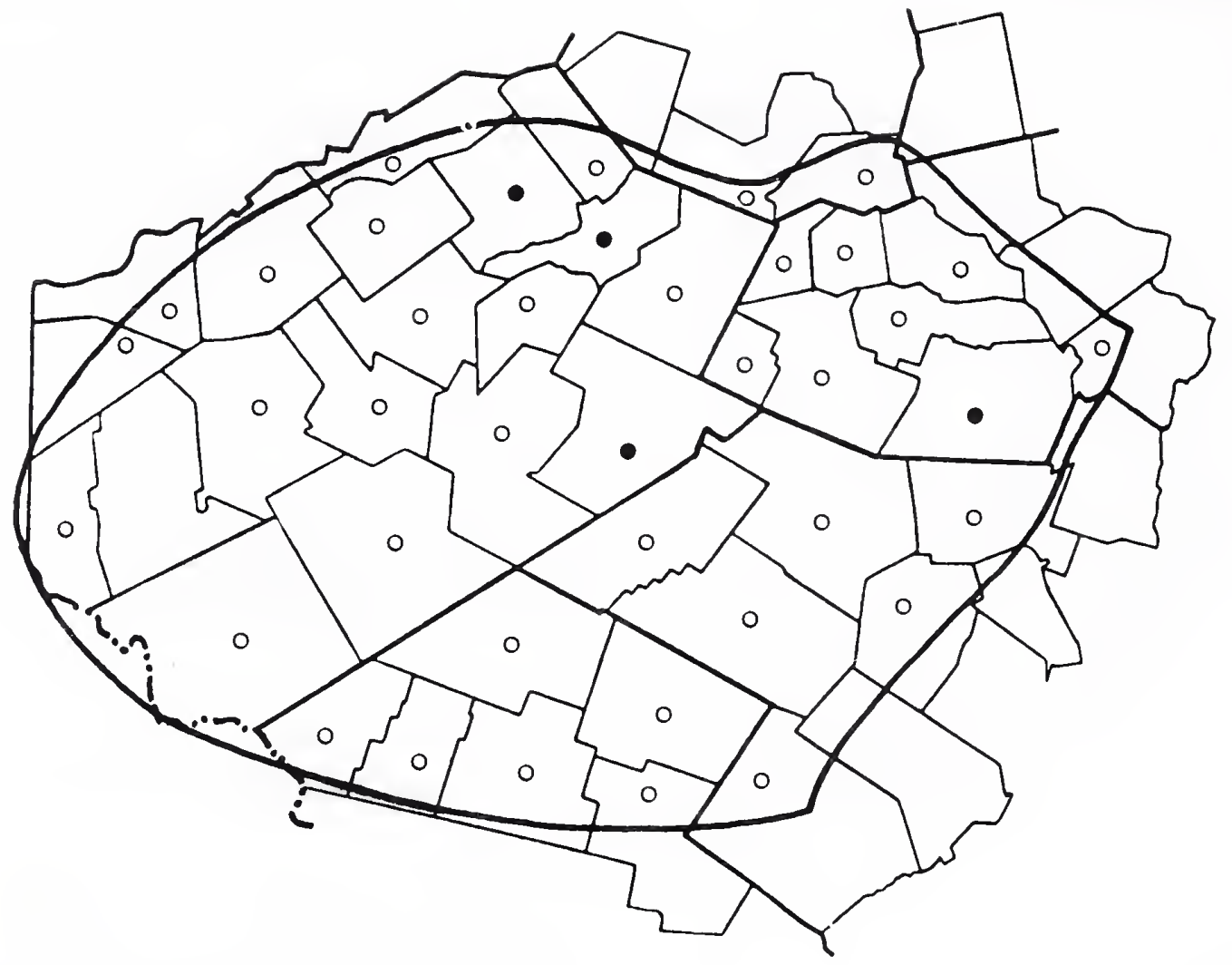

Pyrus americana (Marsh.) DC.

American Mountain-ash

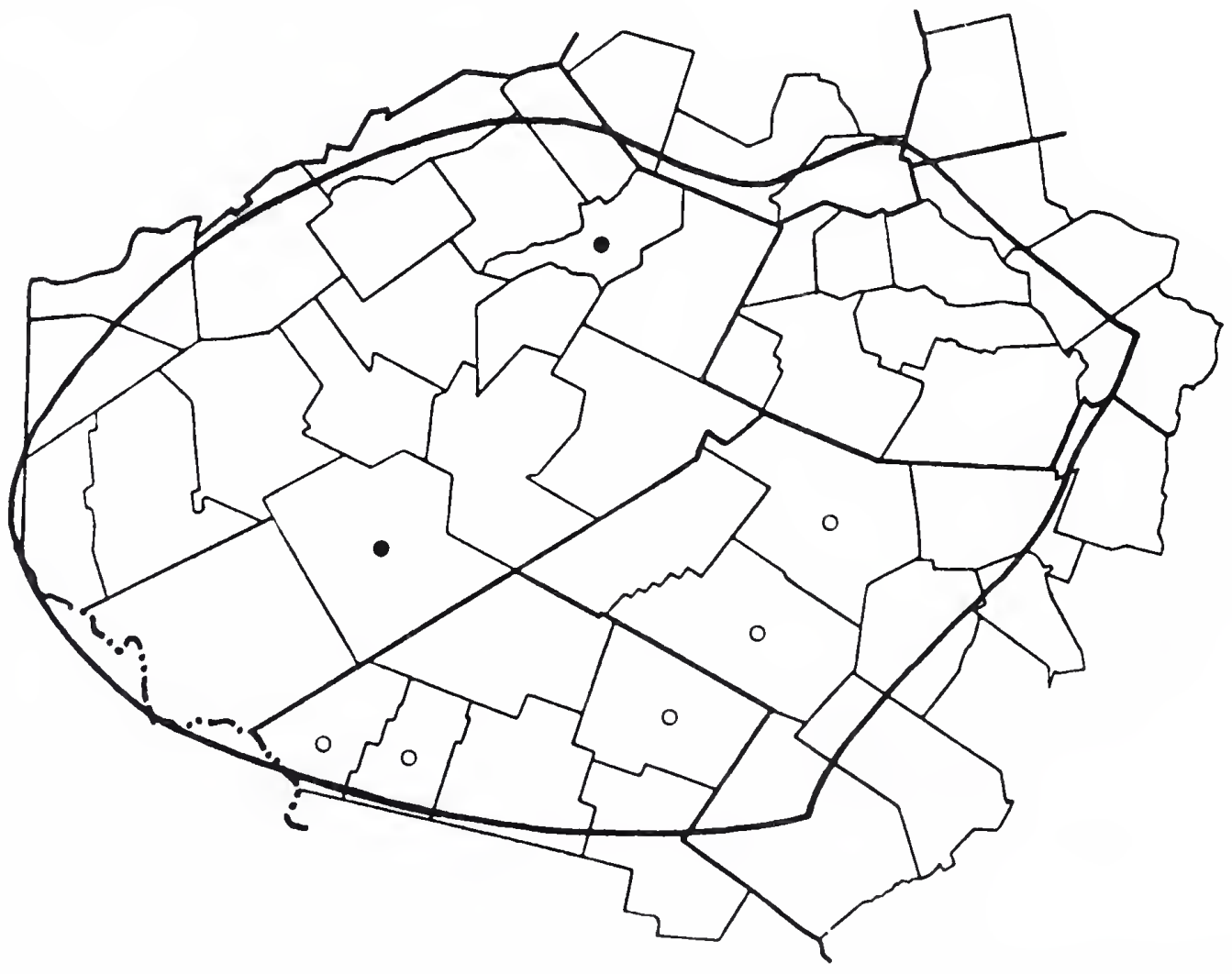


Fiord of

Pyrus communis I.

THE CATSKILLS

Pear

New York State

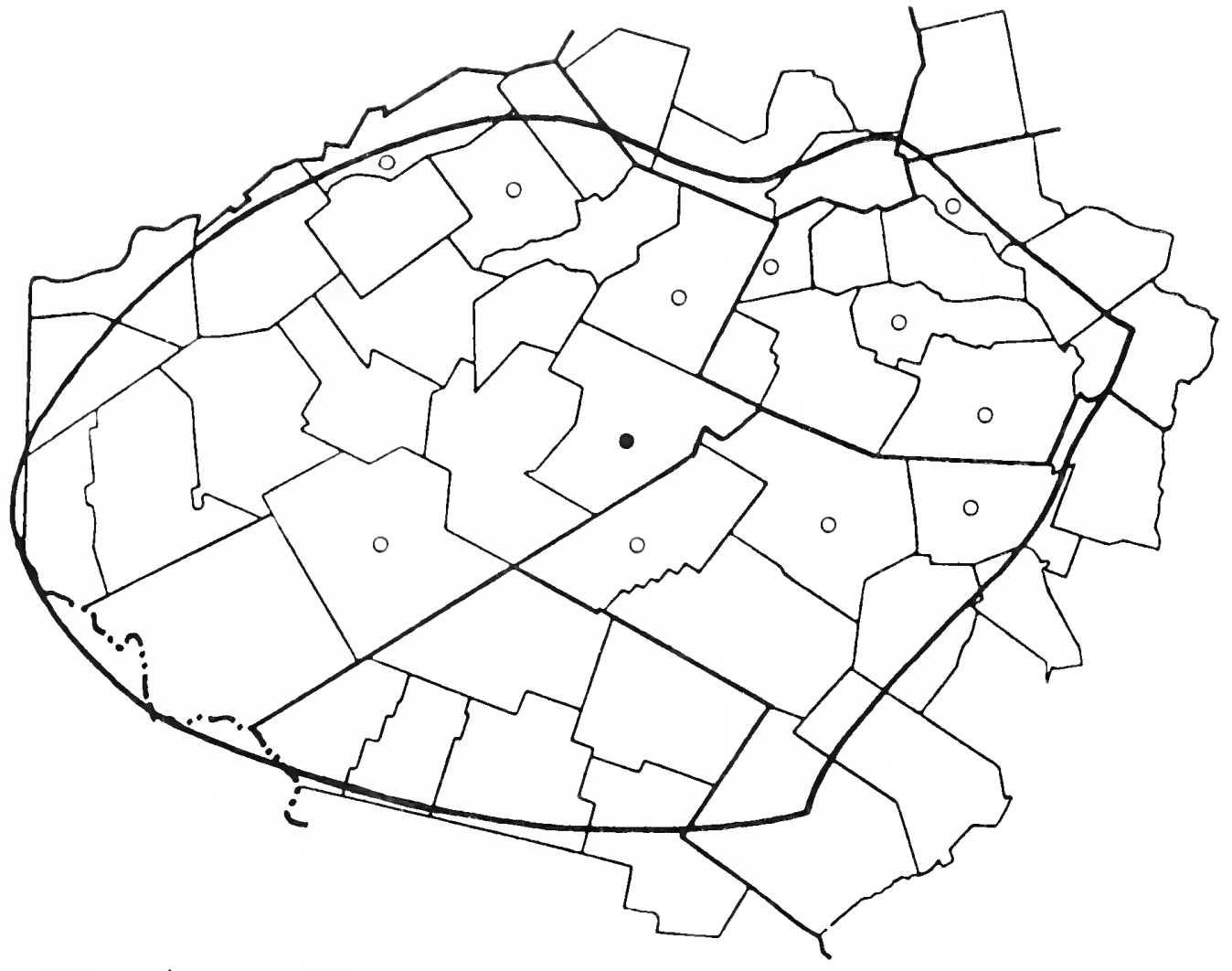

Pyrus decora (Sarg.) Hyland

Showy Mountain-ash

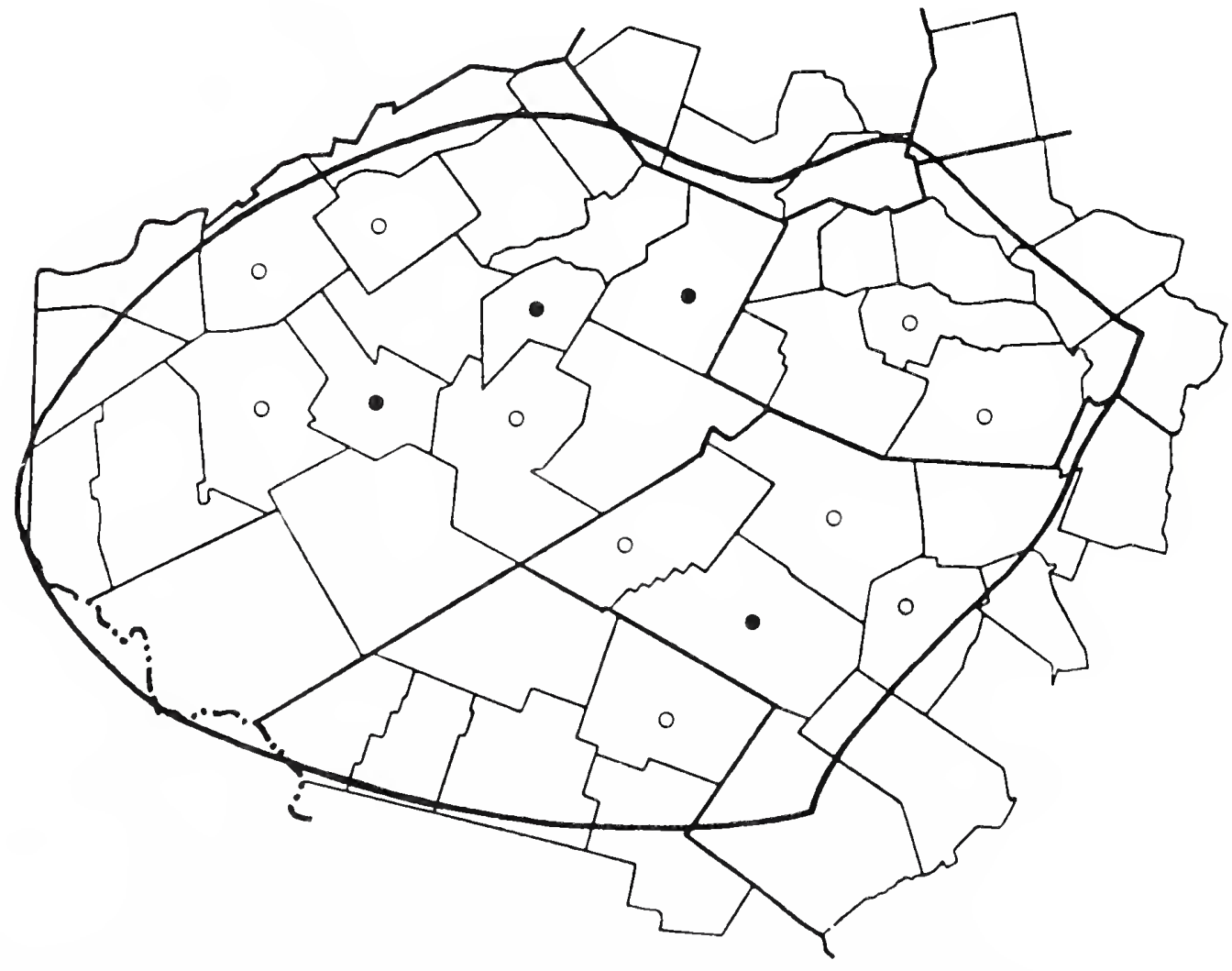




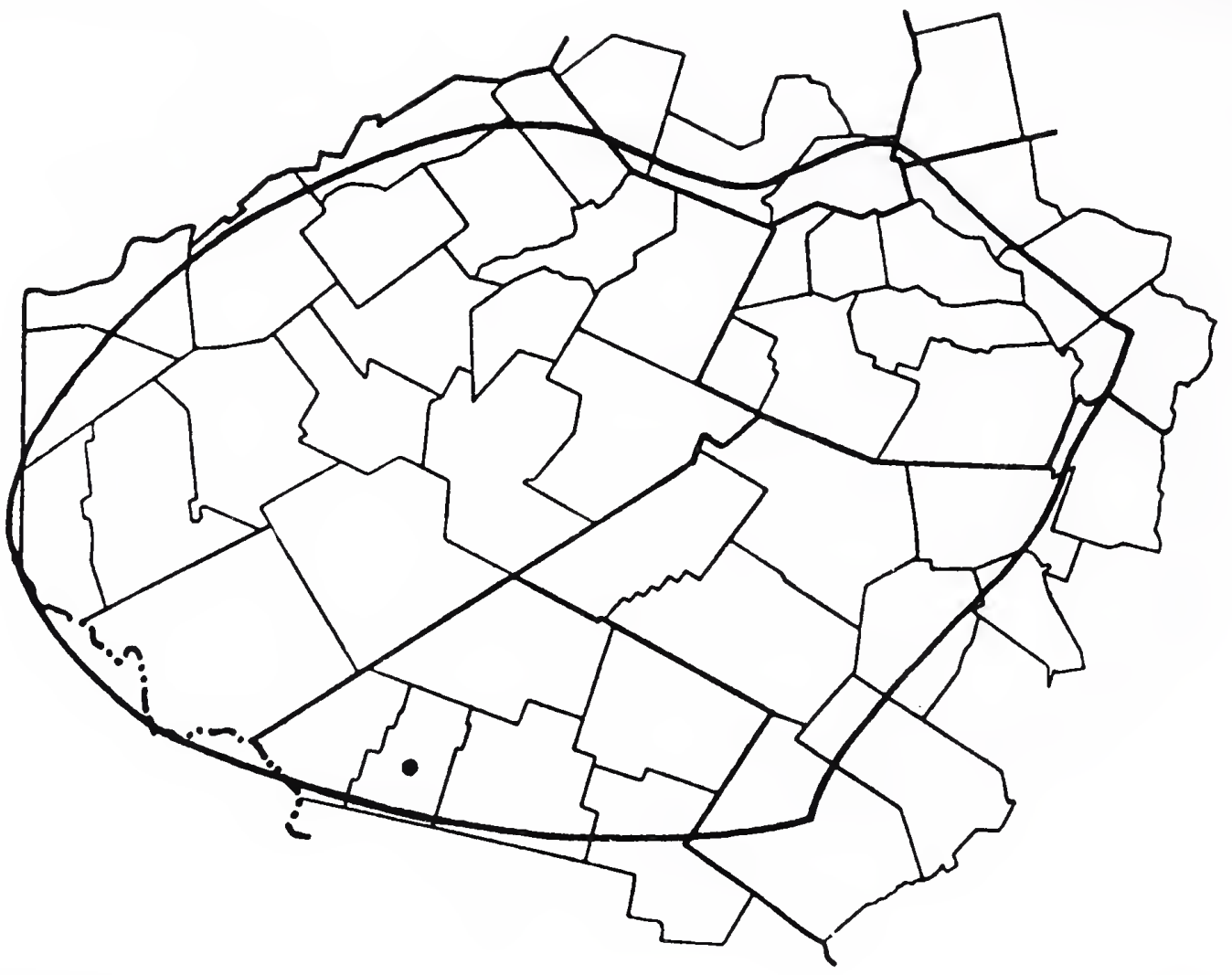

Pyrus malus L.

Apple

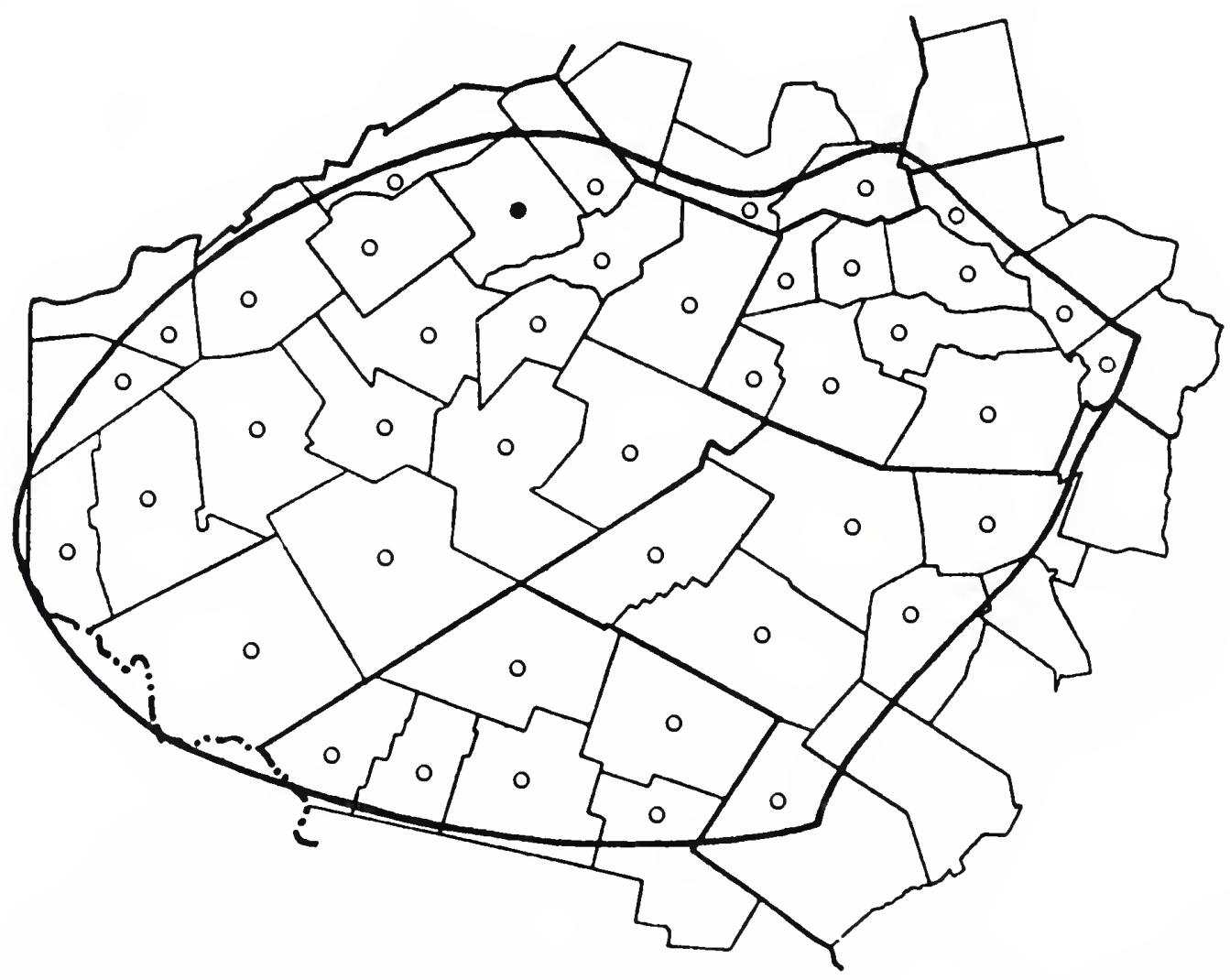


Pyrus melanocarpa (Michx.) Willd.

THE CATSKILLS

Black Chokeberry

New York State

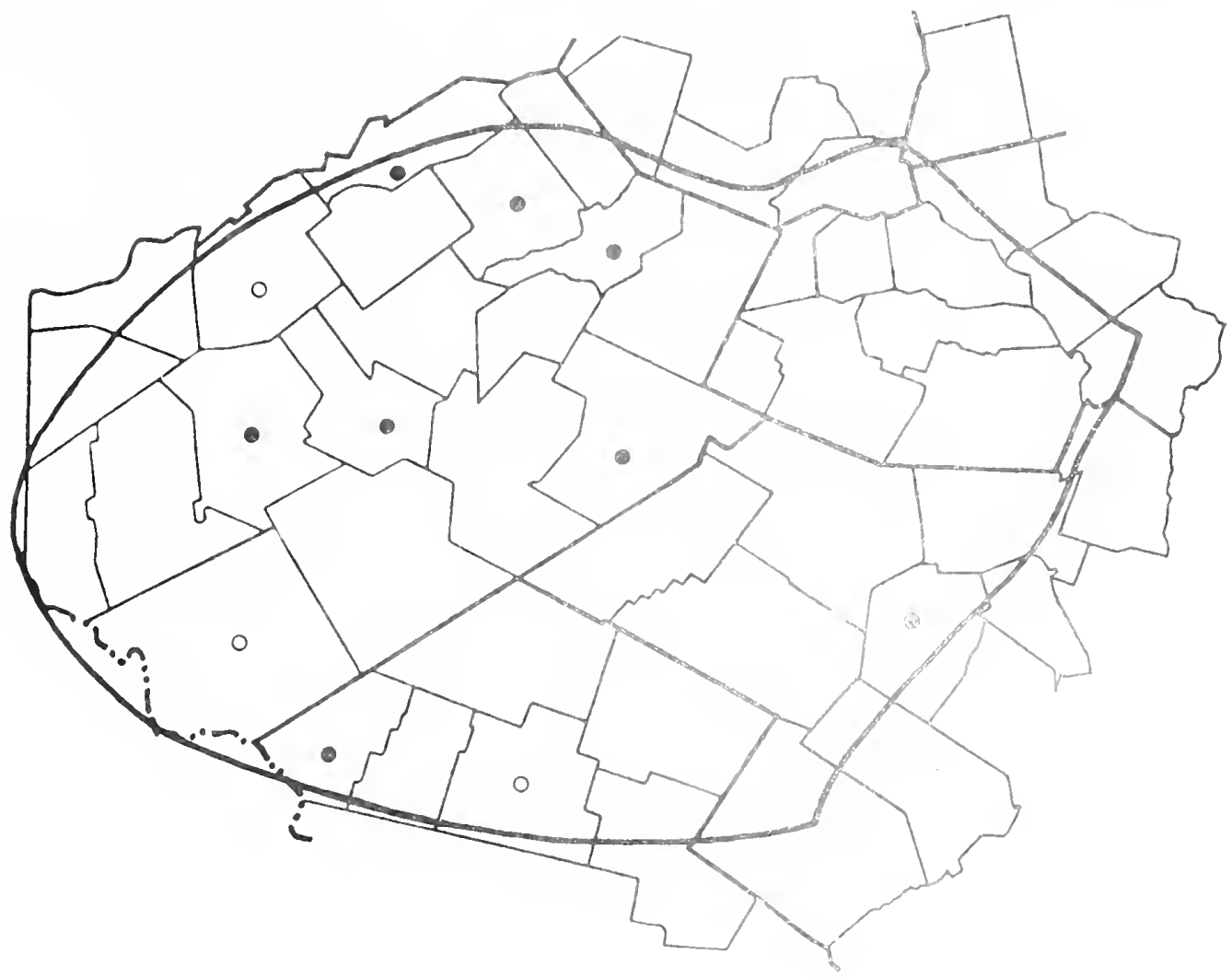

Rosa canina I.

Dog Rose

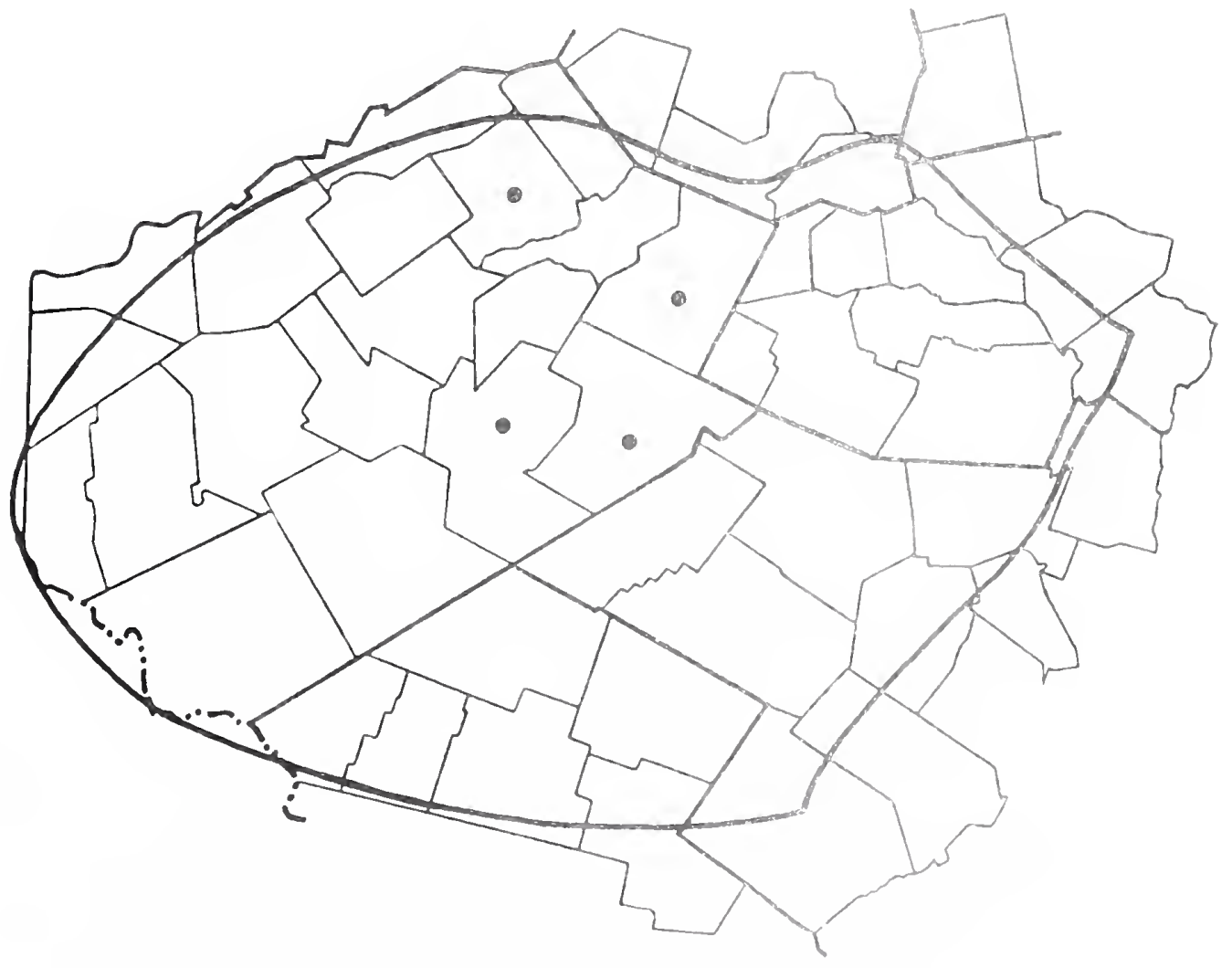




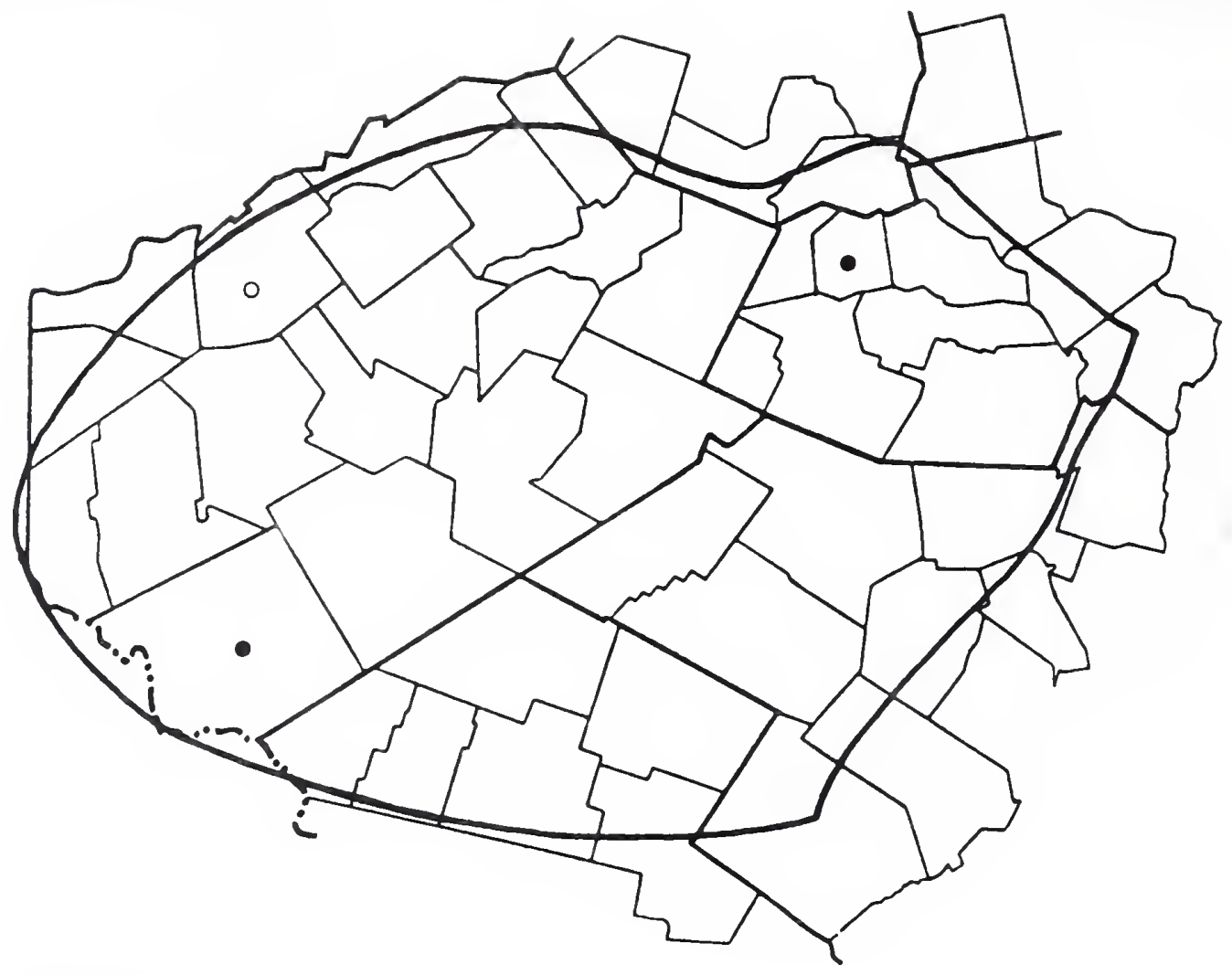

Rosa micrantha Sm.

Small-flowered Sweetbrier

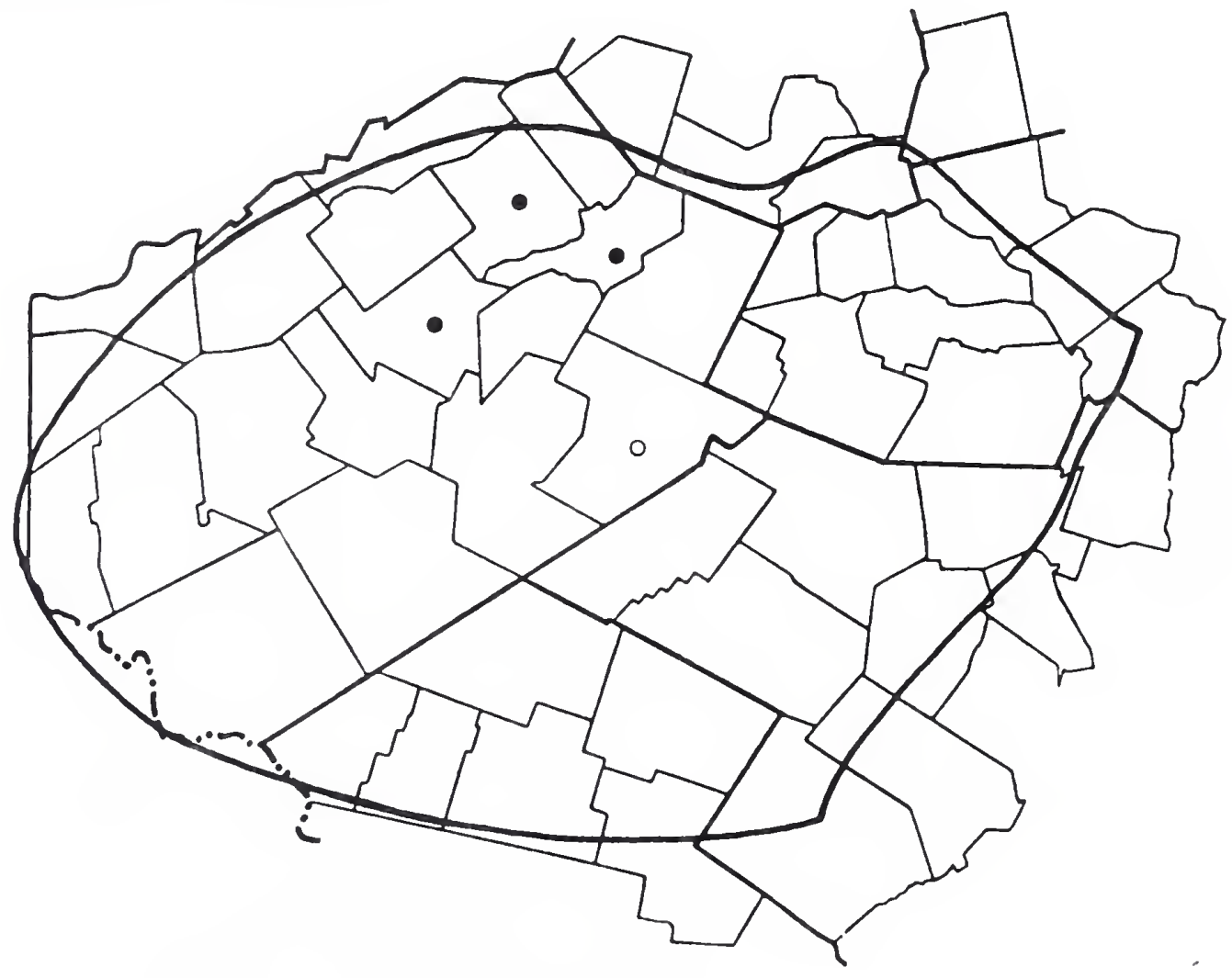


Flora of

Rosa multiflora Thunb.

THE CATSKILLS

Floribunda Rose

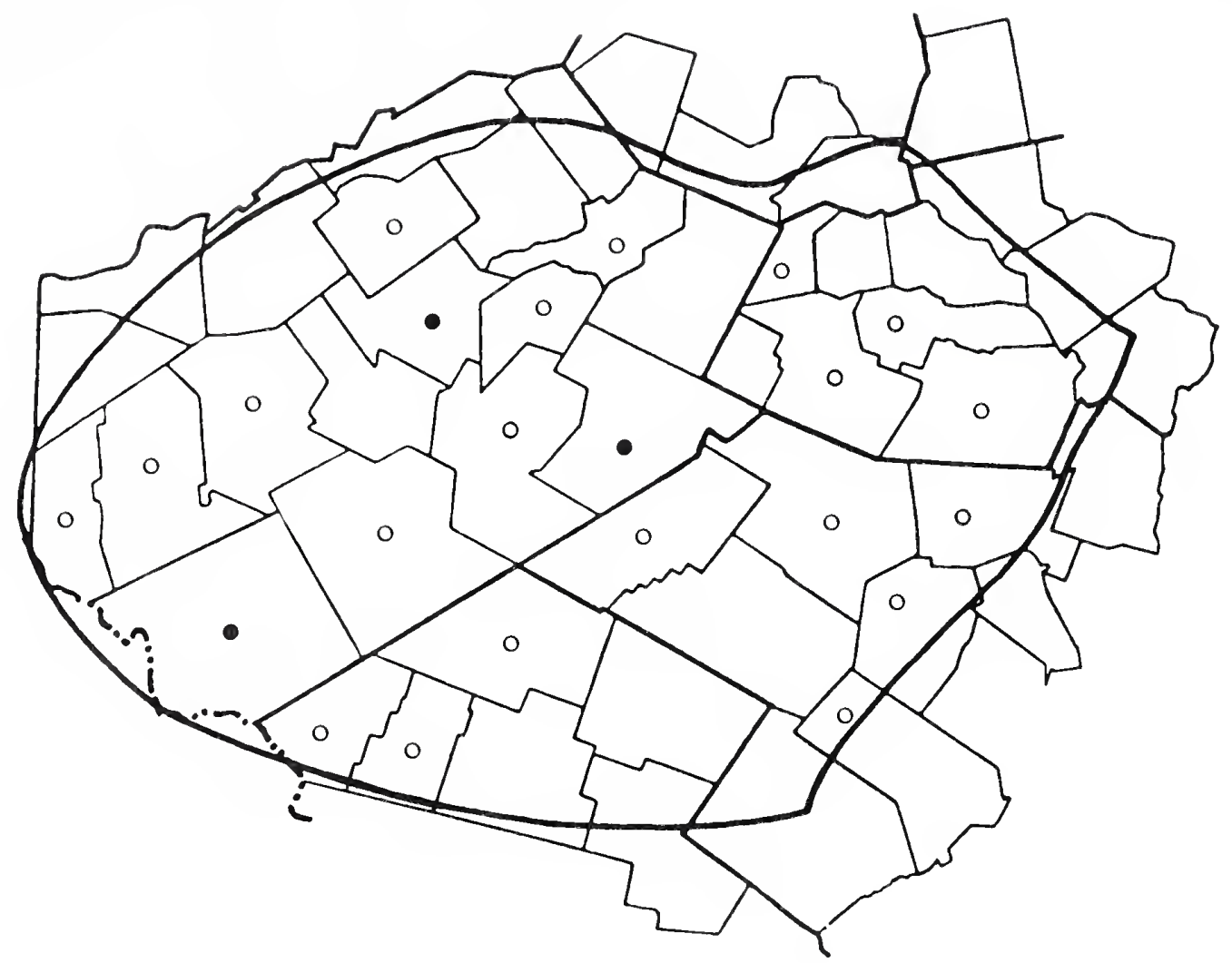

Rosa palustris Marsh.

Swamp Rose

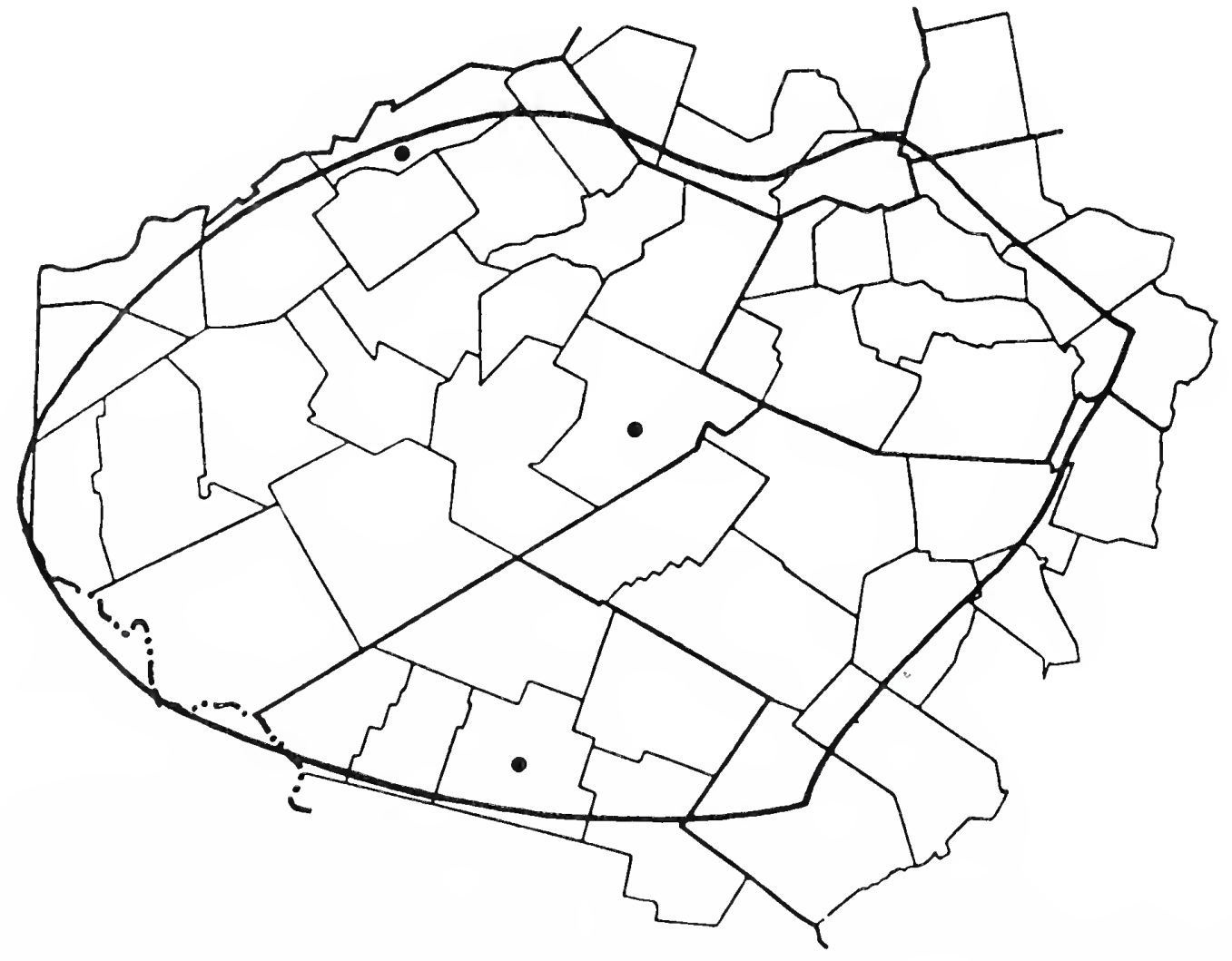




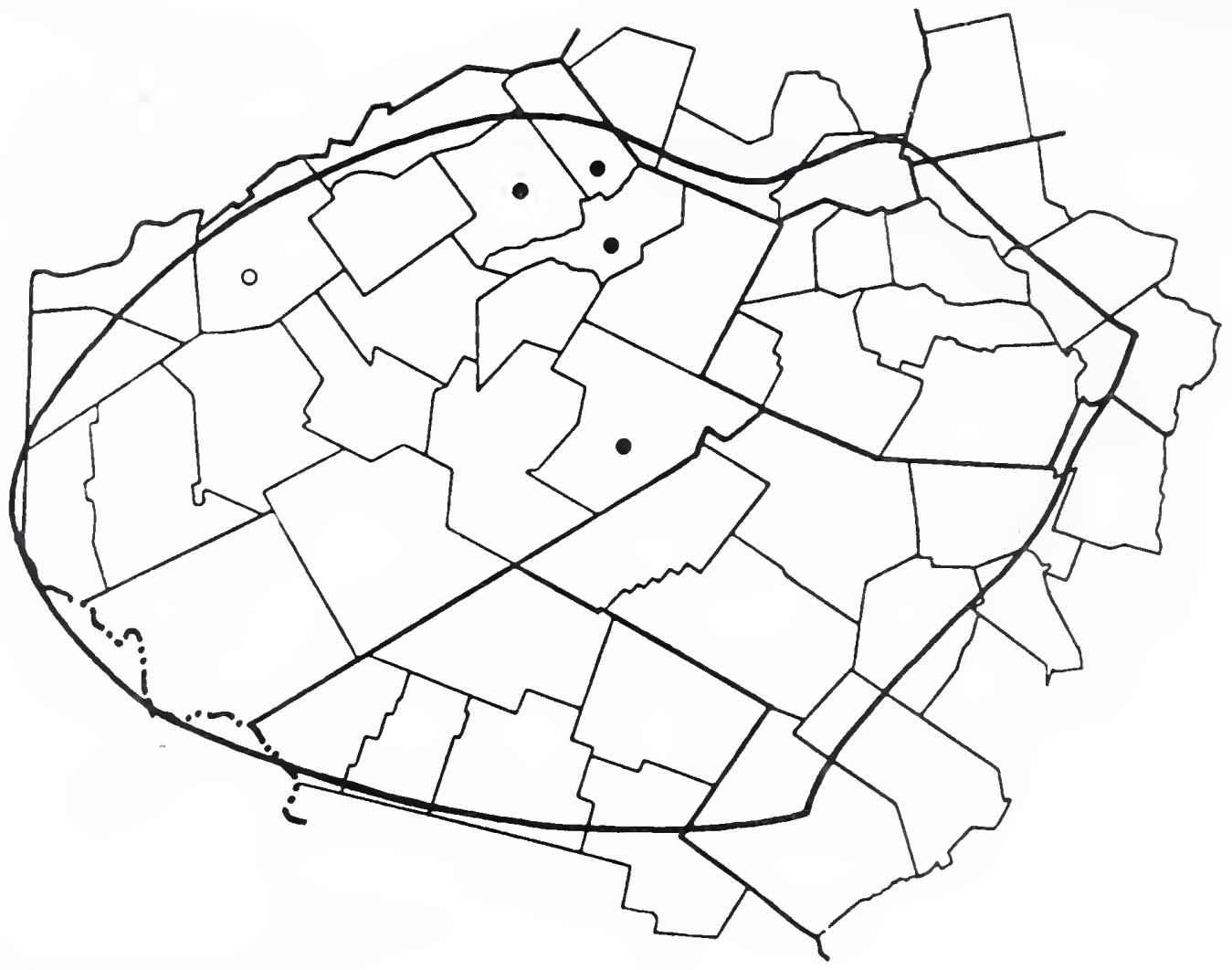

Rosa virginiana Mill.

Tall Pasture Rose

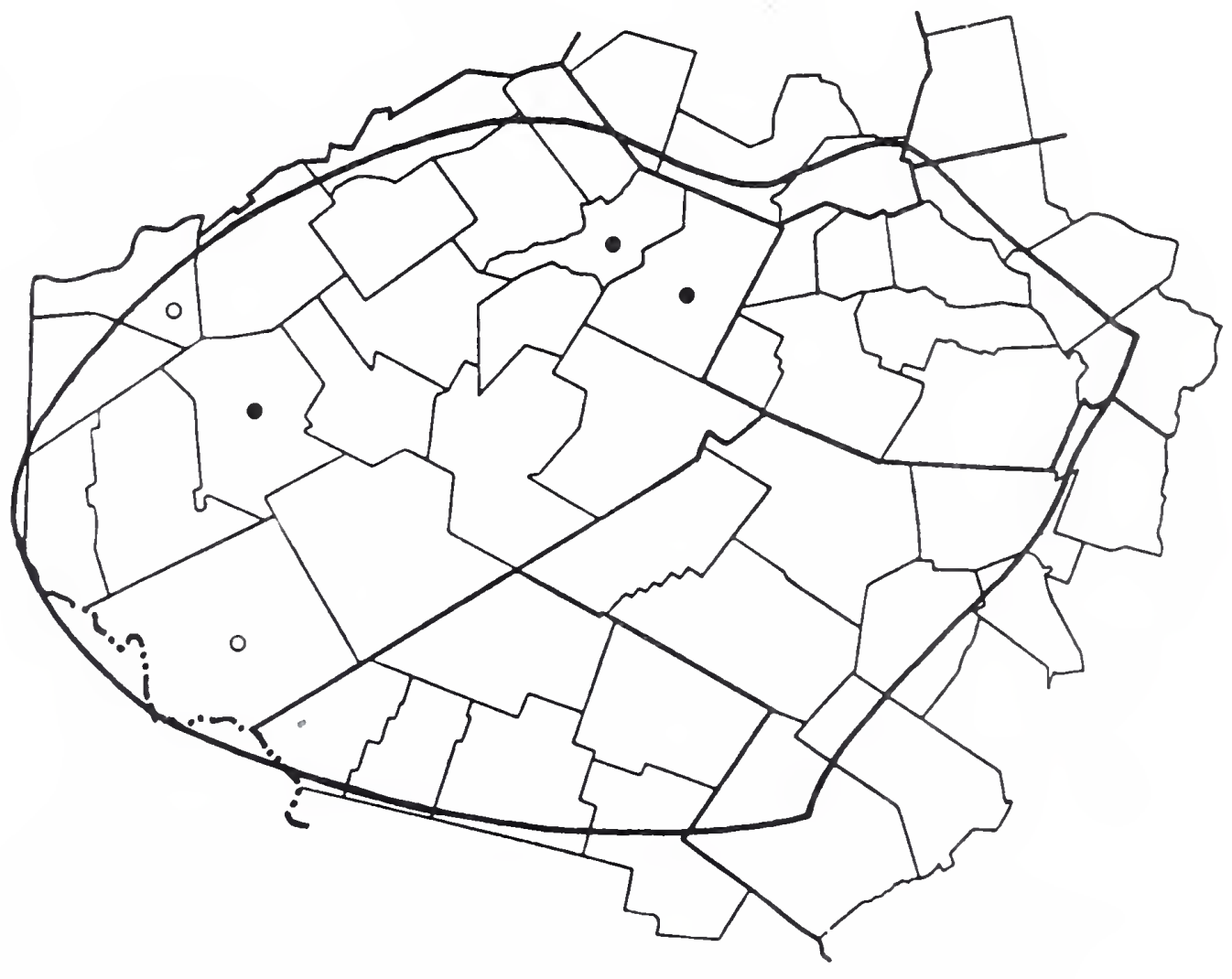




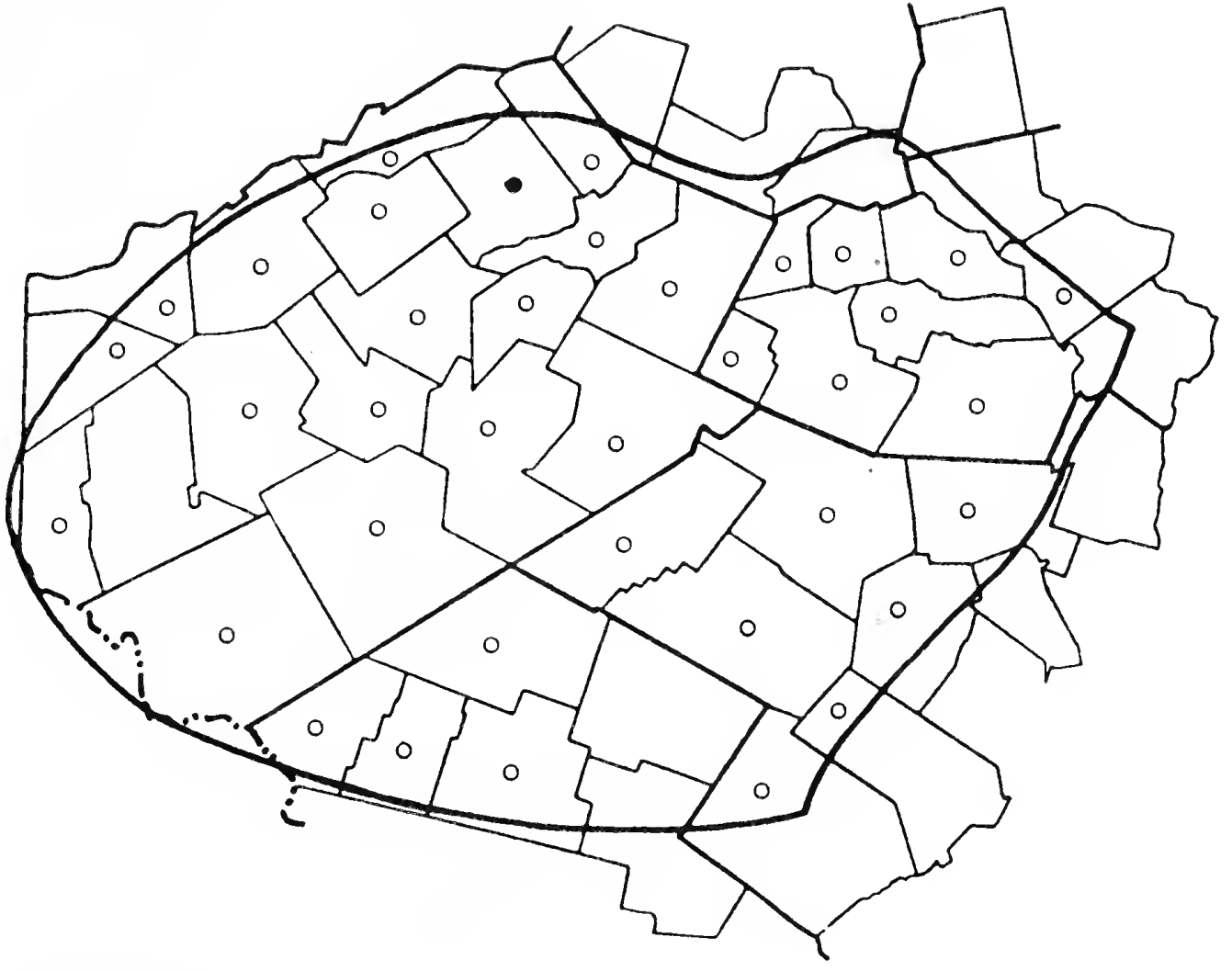

Rubus canadensis L.

Smooth Blackberry

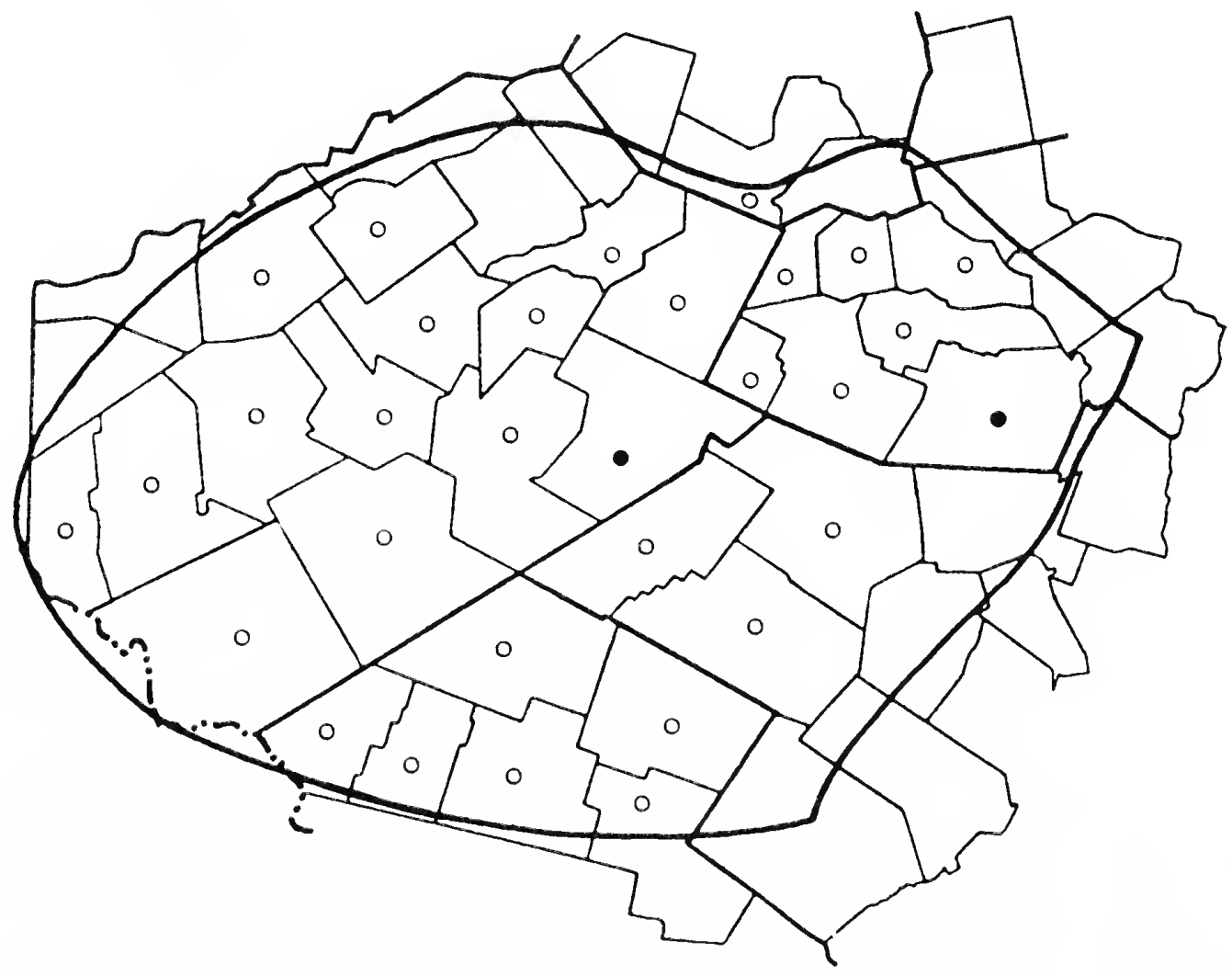




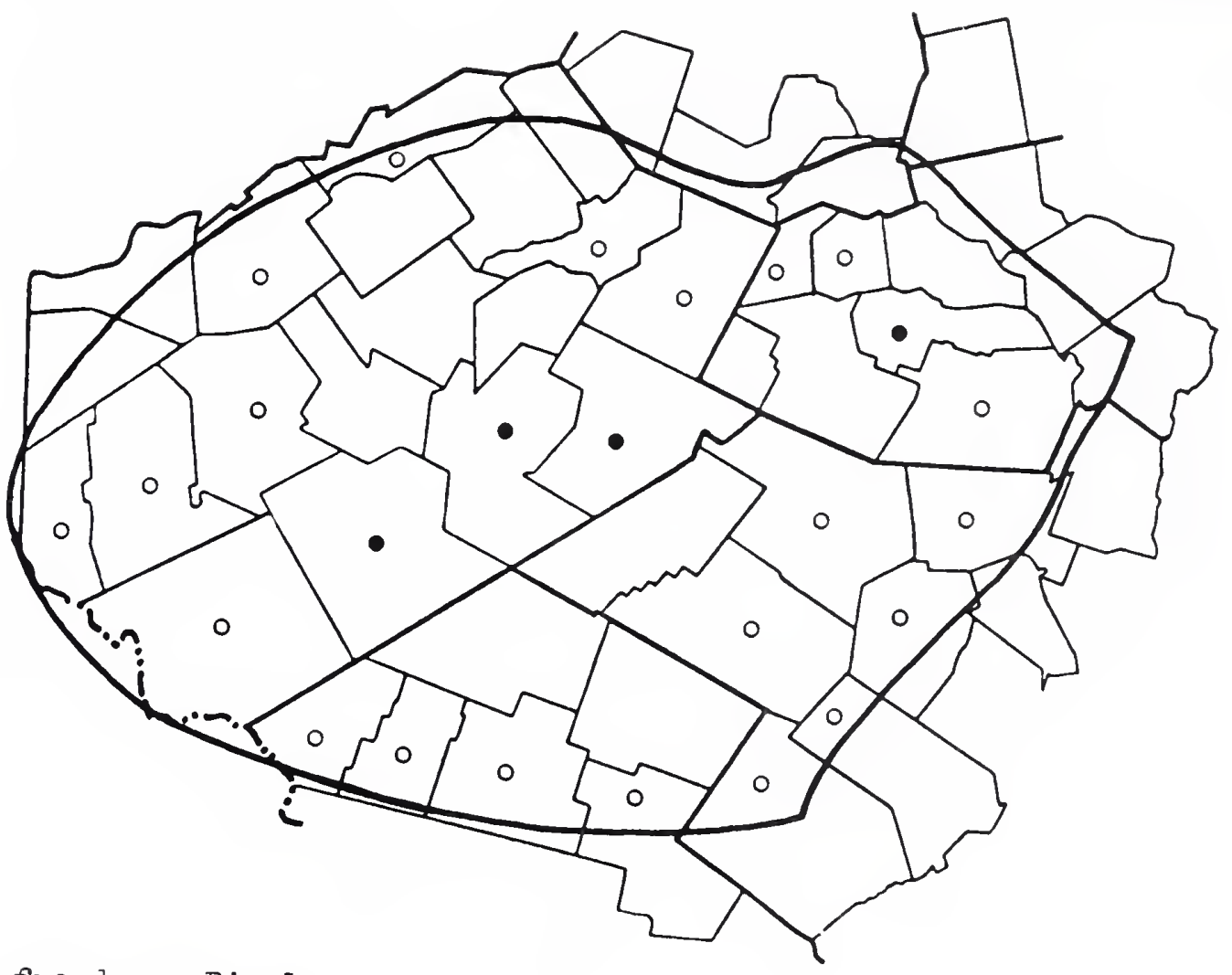

Rubus frondosus Bigel.

Leafy-flowered Blackberry

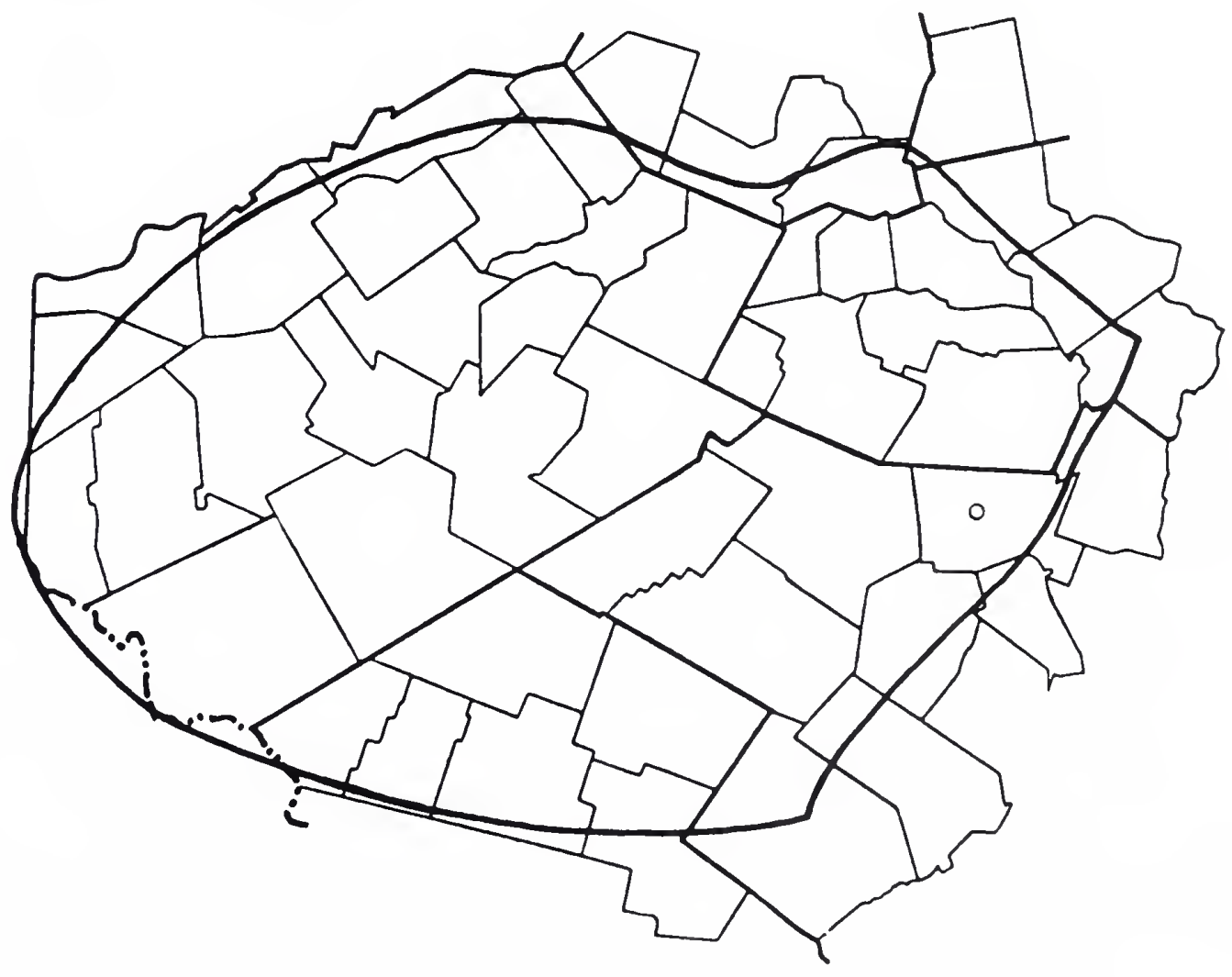




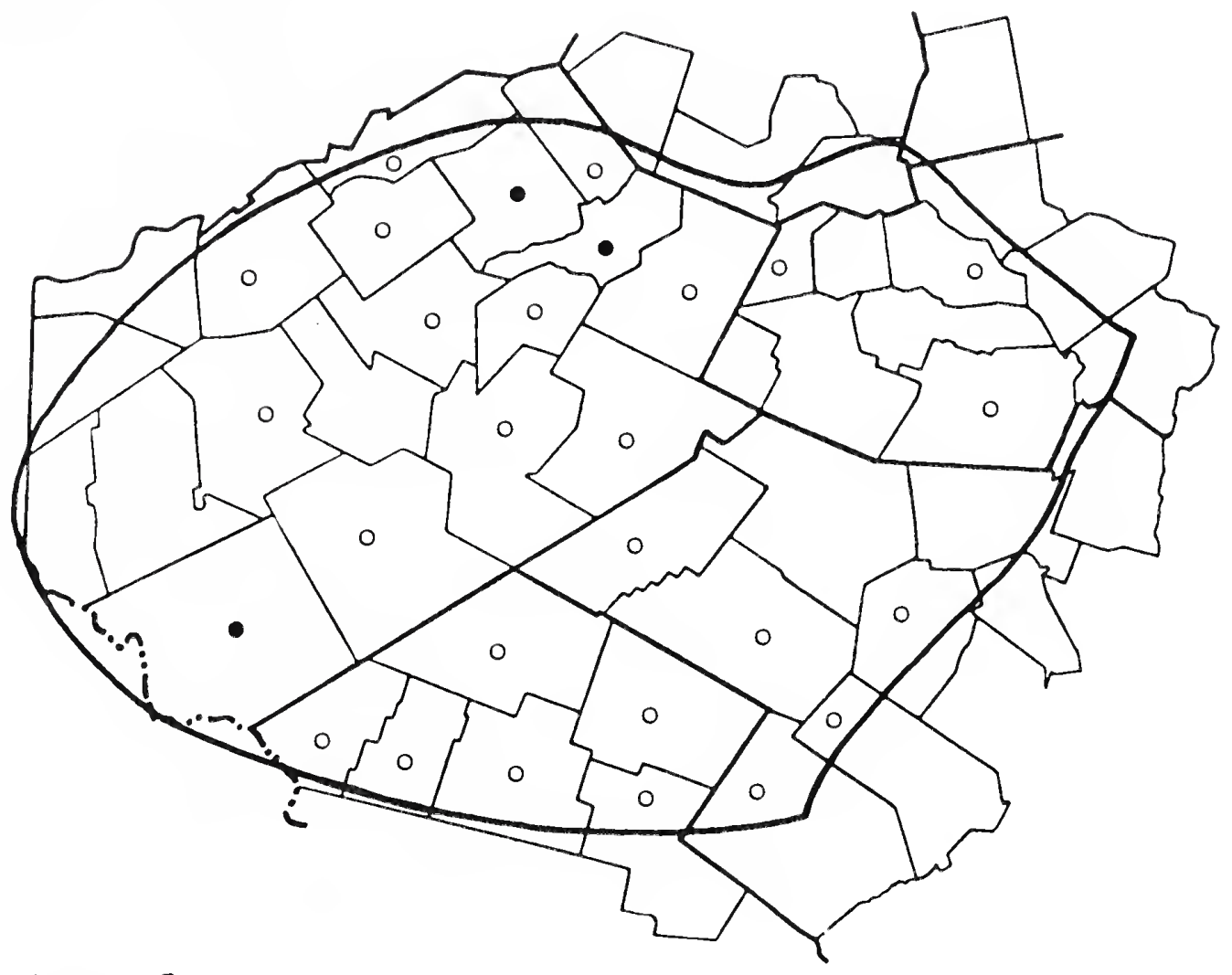

Rubus idaeus I.

ssp. melanolasius Focke Wild Red Raspberry

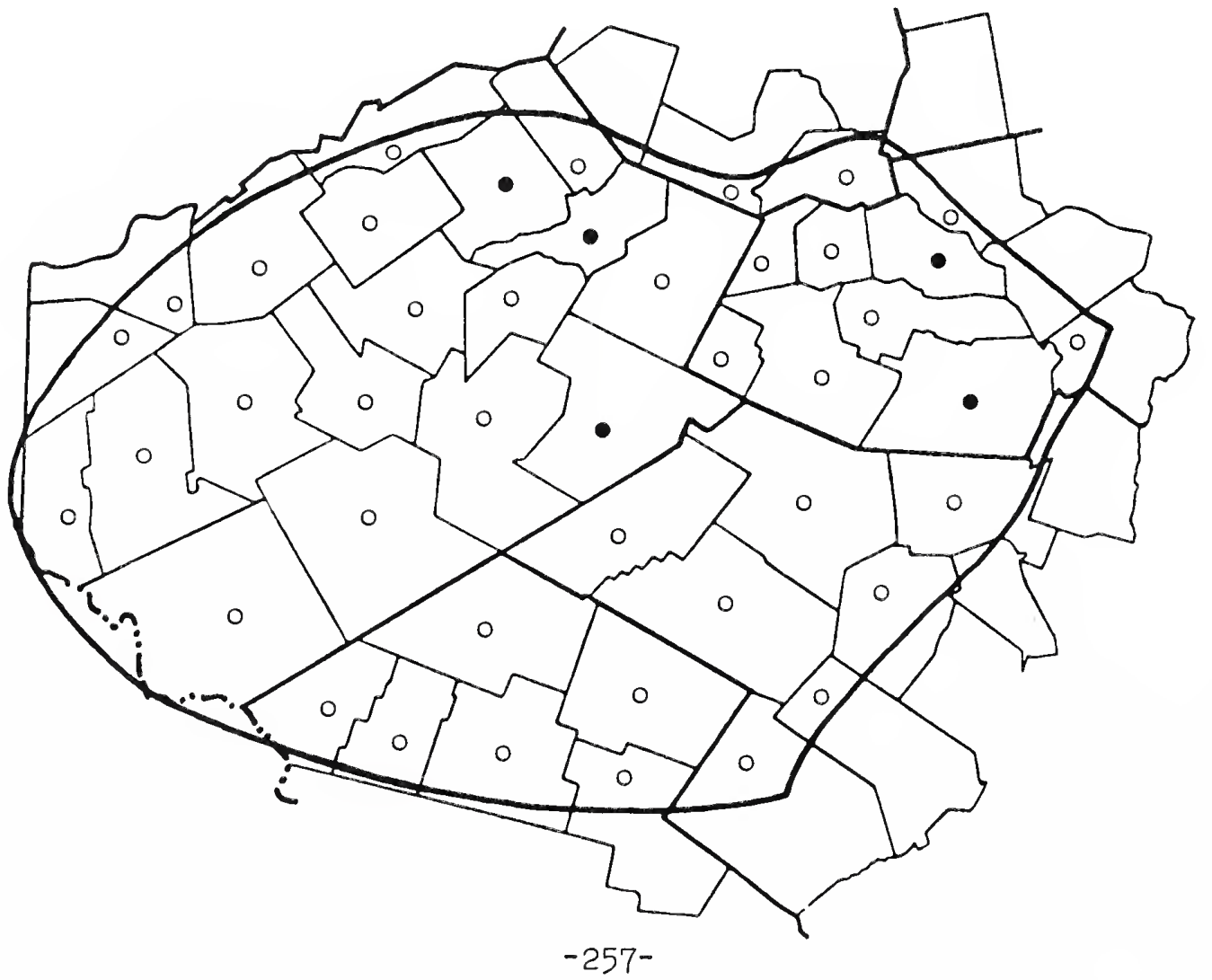




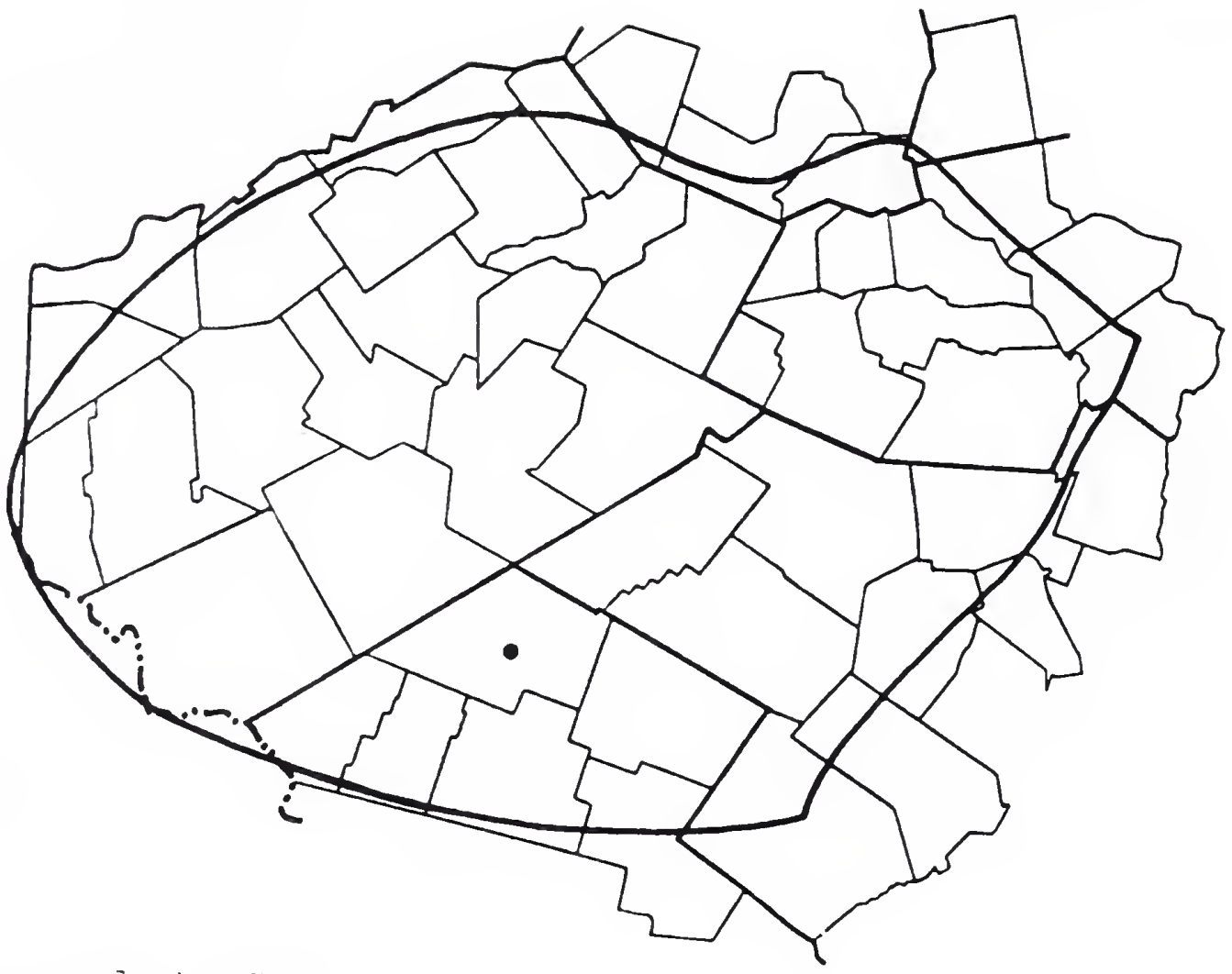

Rubus $\mathrm{x}$ neglectus Peck

Purple Raspberry

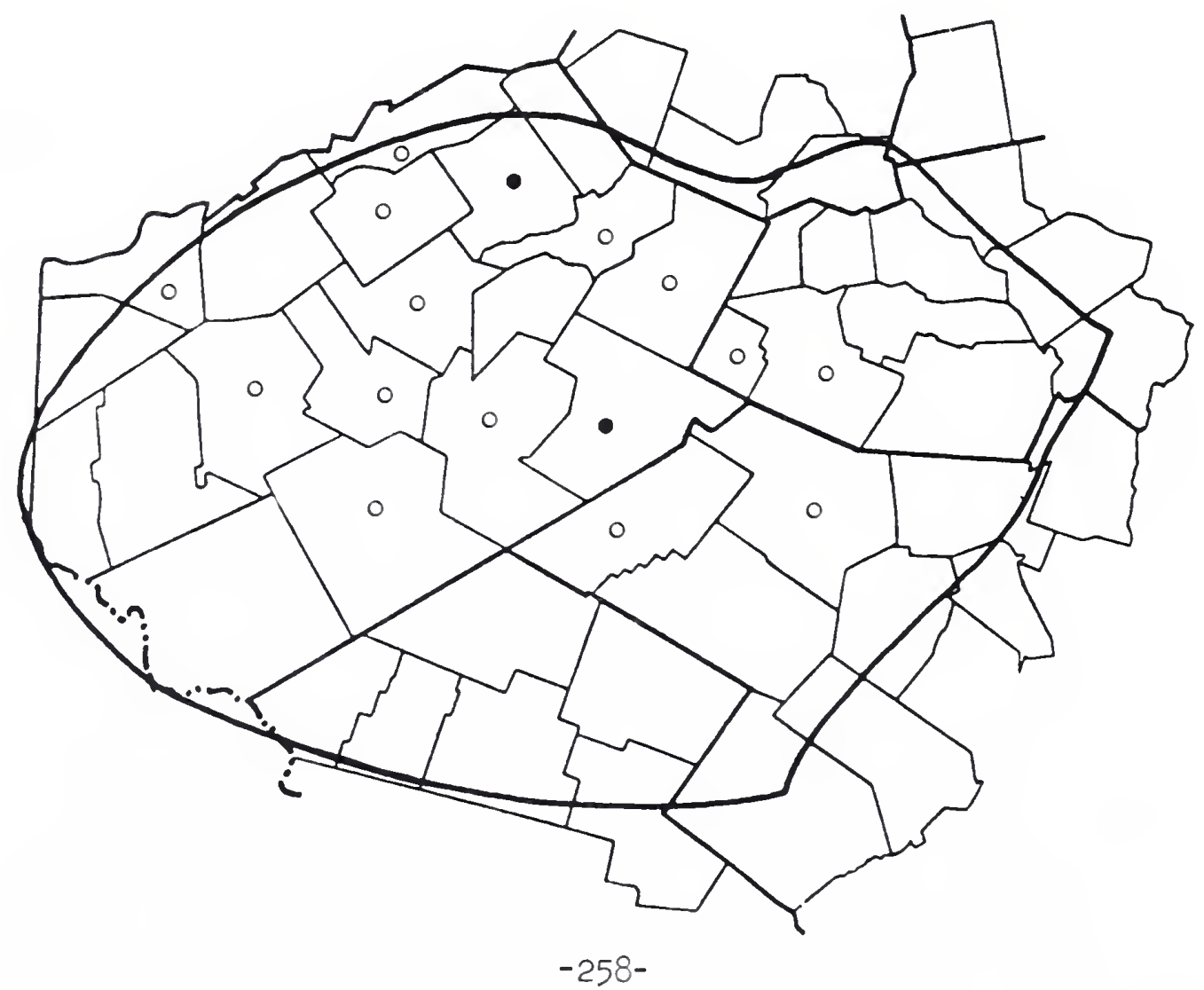


Flora of

Rubus occidentalis I.

THE CATSKILLS

Black Raspberry

New York State

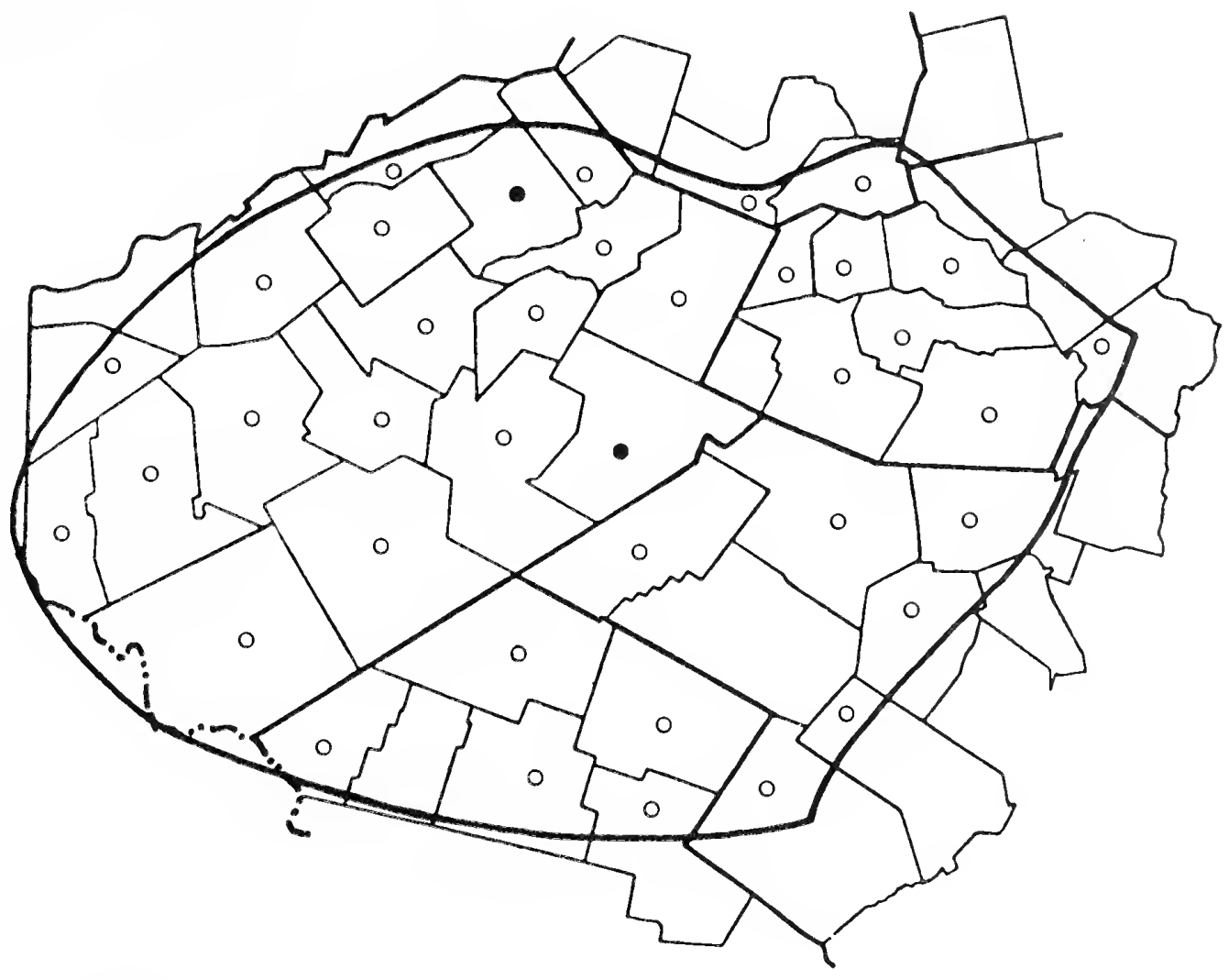

Rubus odoratus $\mathrm{I}$.

Flowering Raspberry

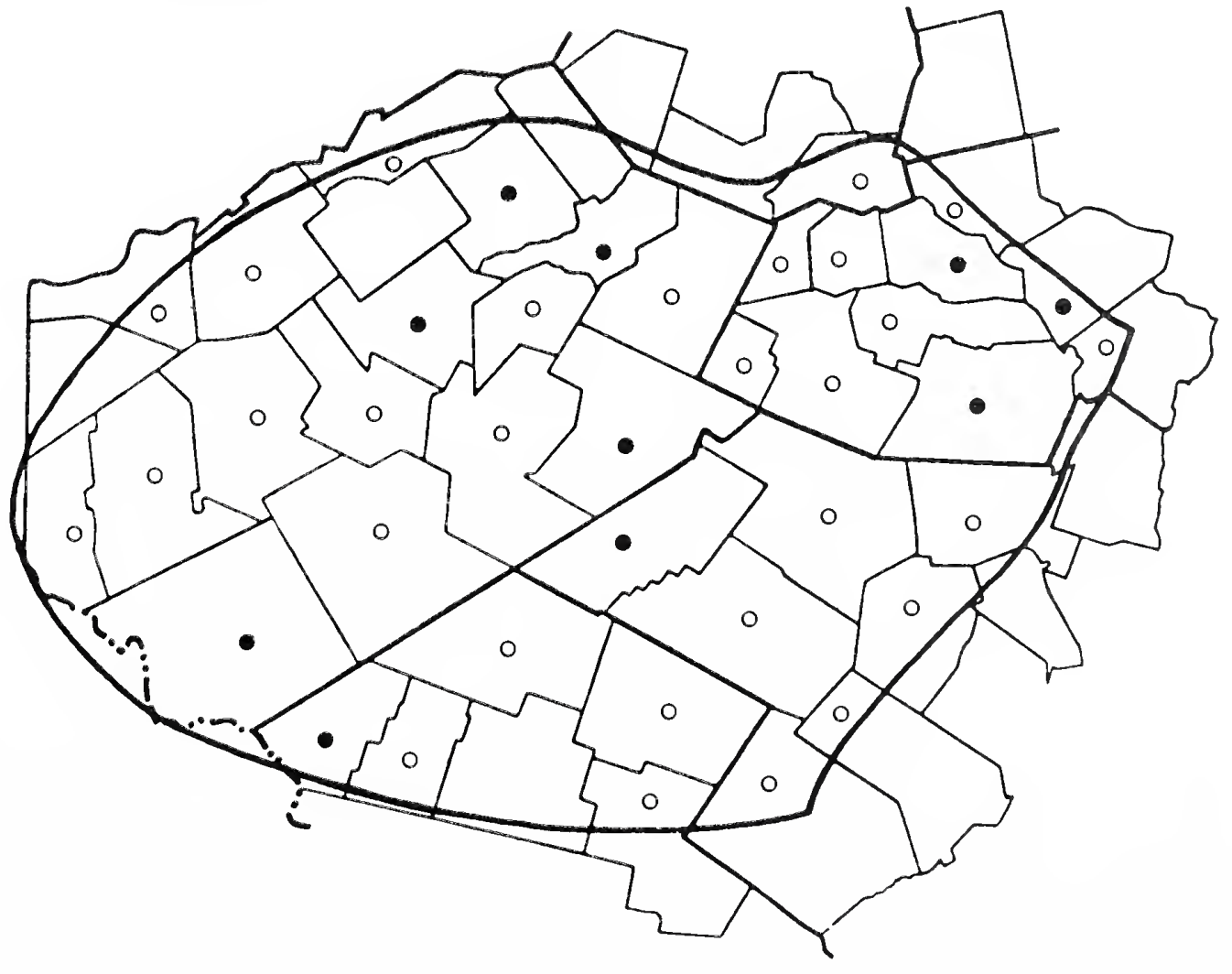




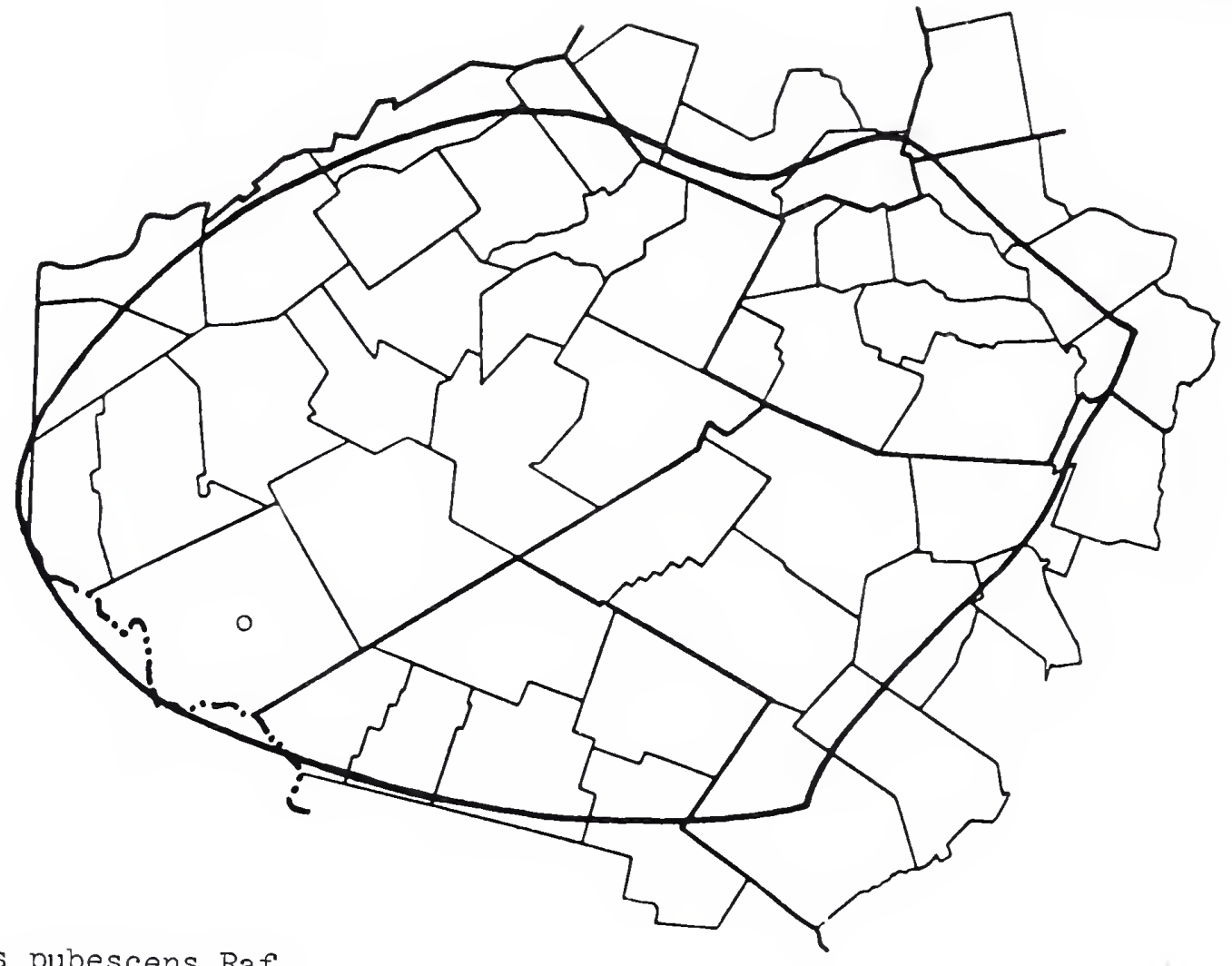

Rubus pubescens Raf.

Dwarf Red Blackberry

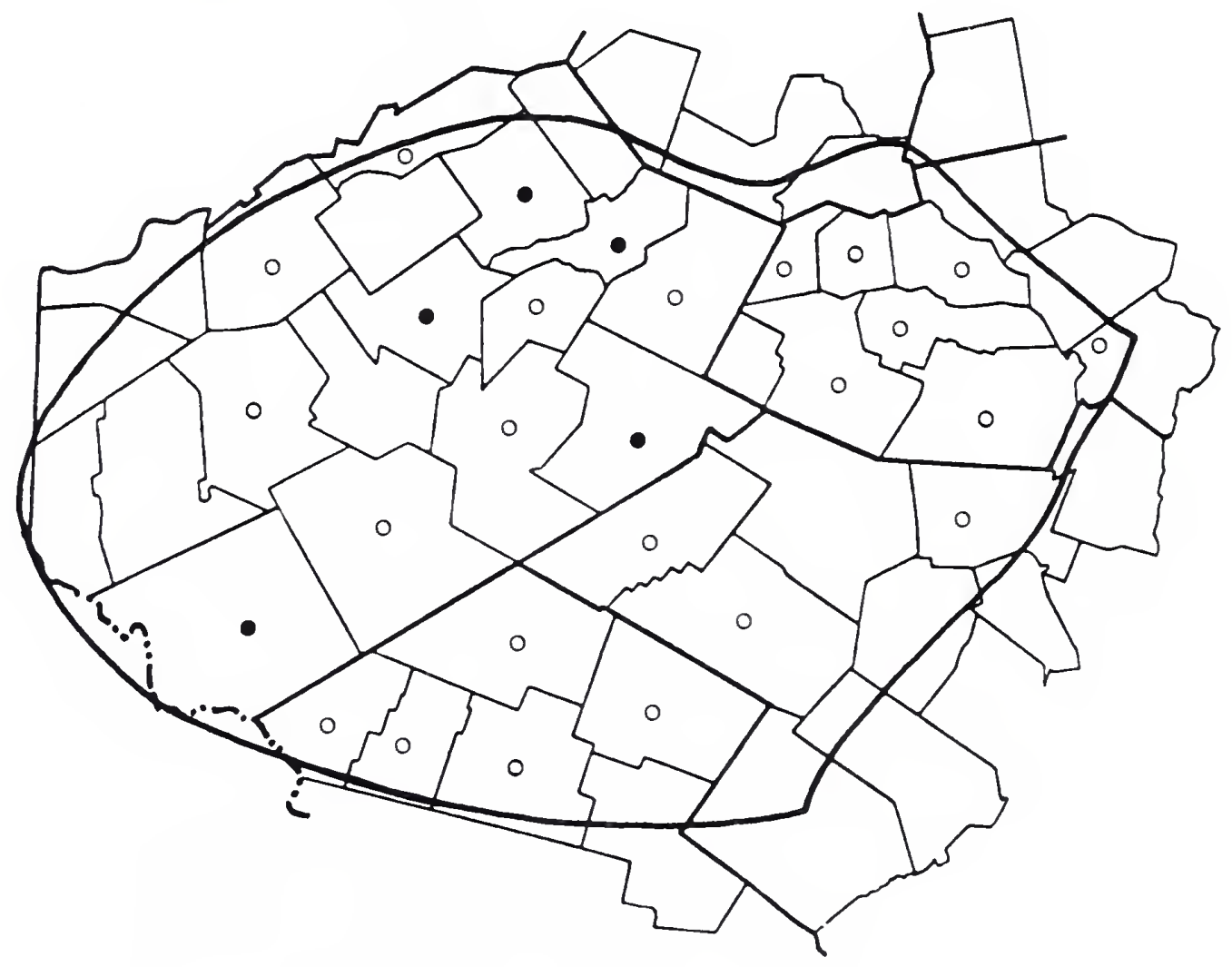




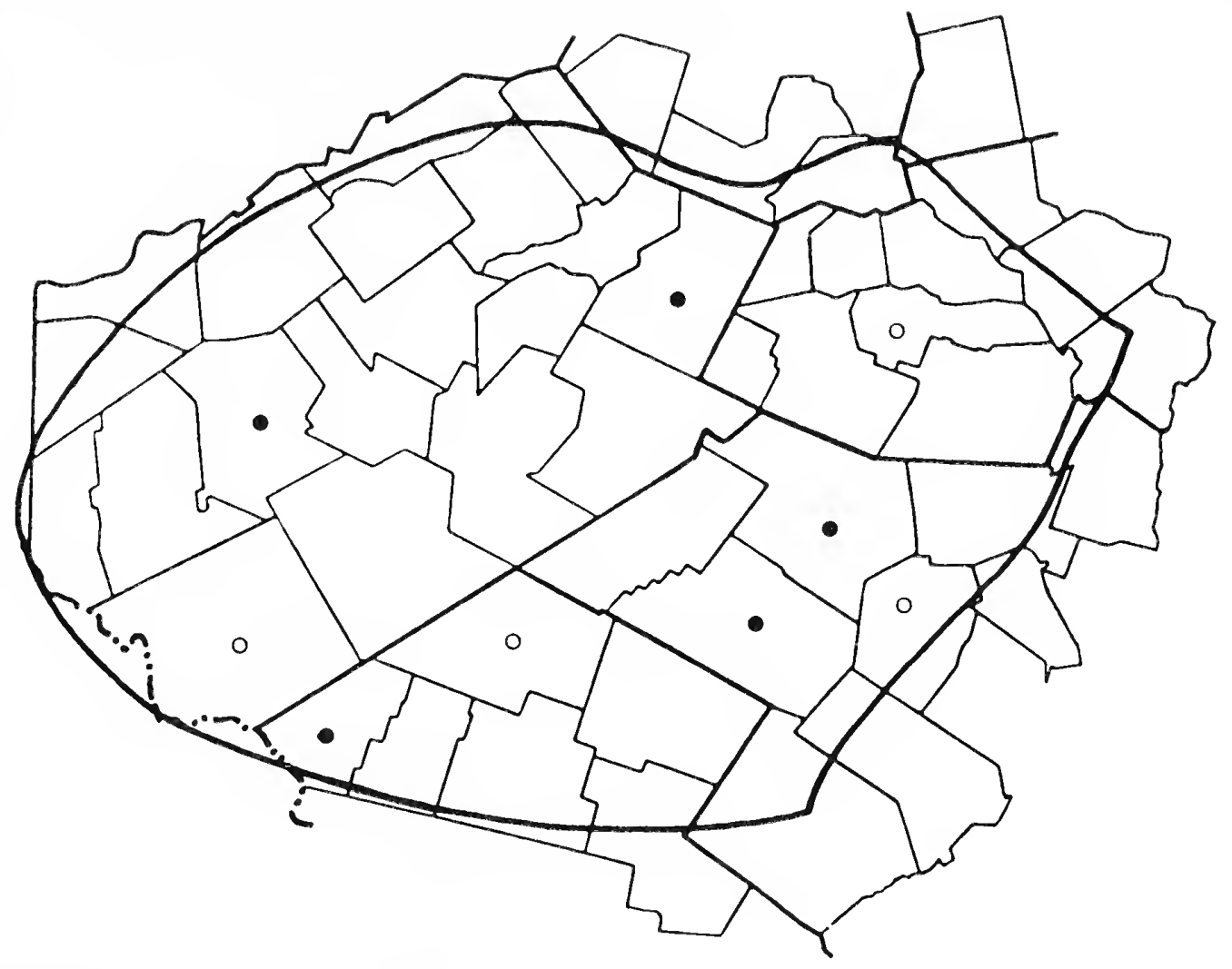

Spiraea latifolia (Ait.) Borkh.

Broad-leaved Meadowsweet

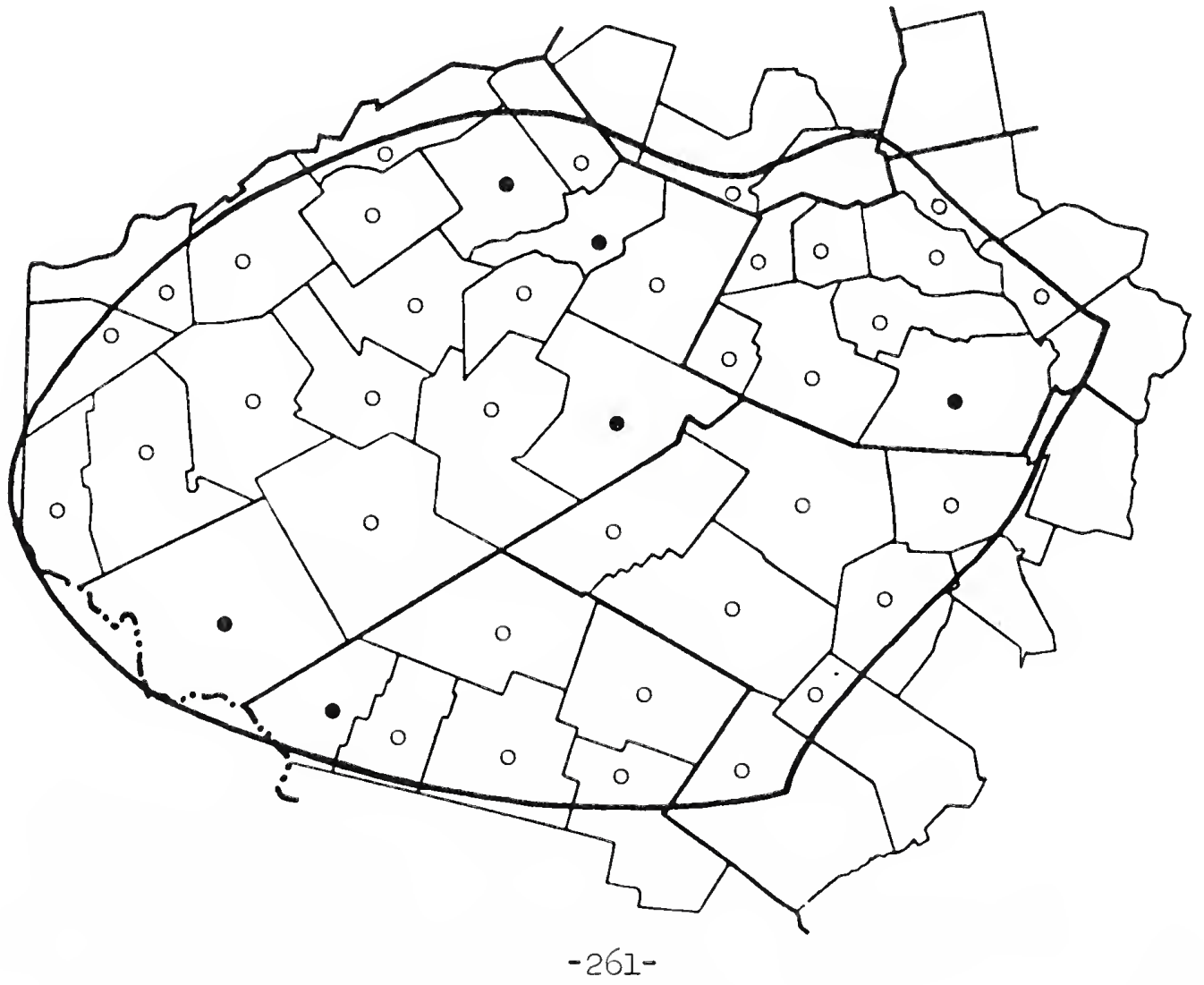




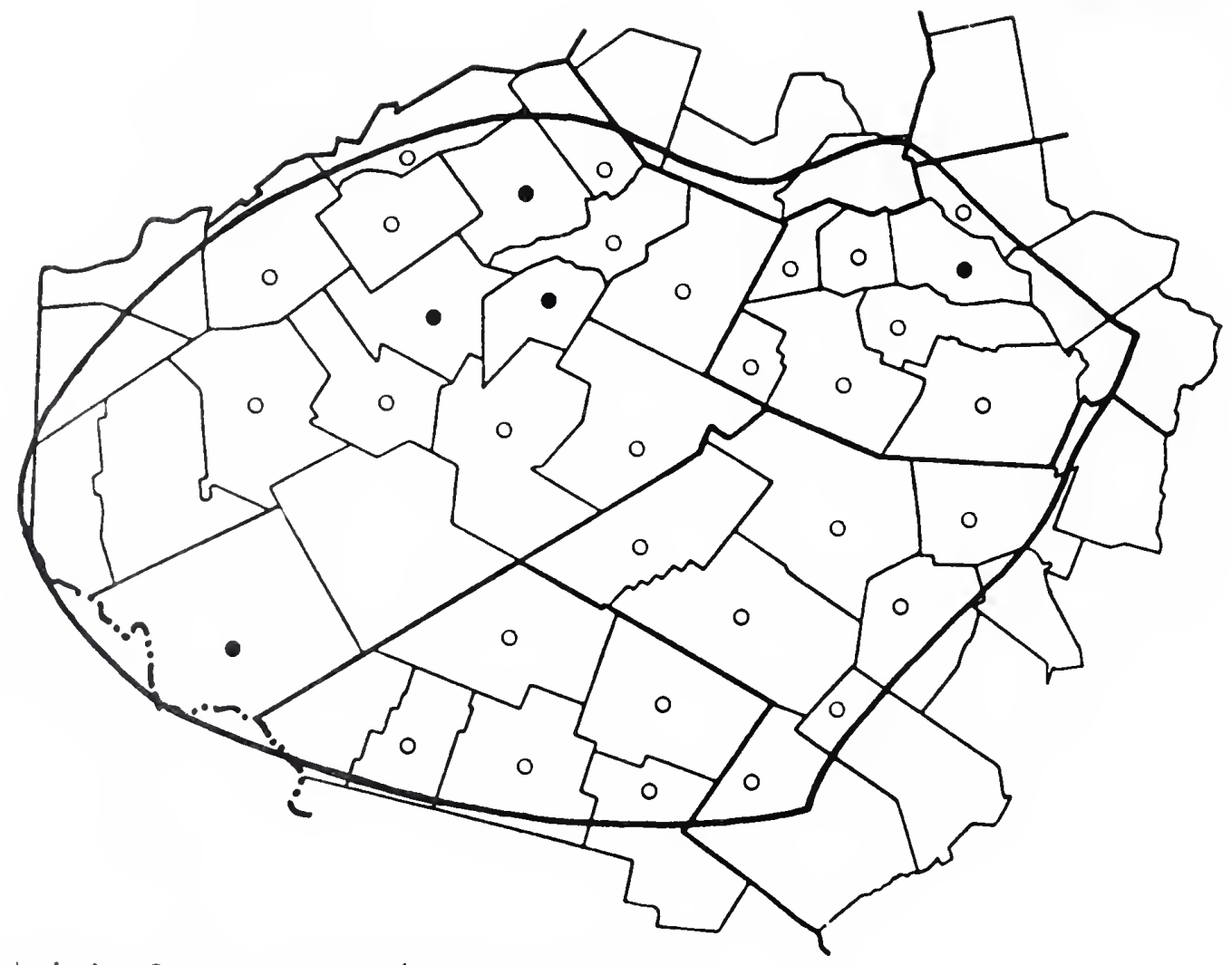

Waldsteinia fragarioides (Michx.) Tratt.

\section{Barren Strawberry}

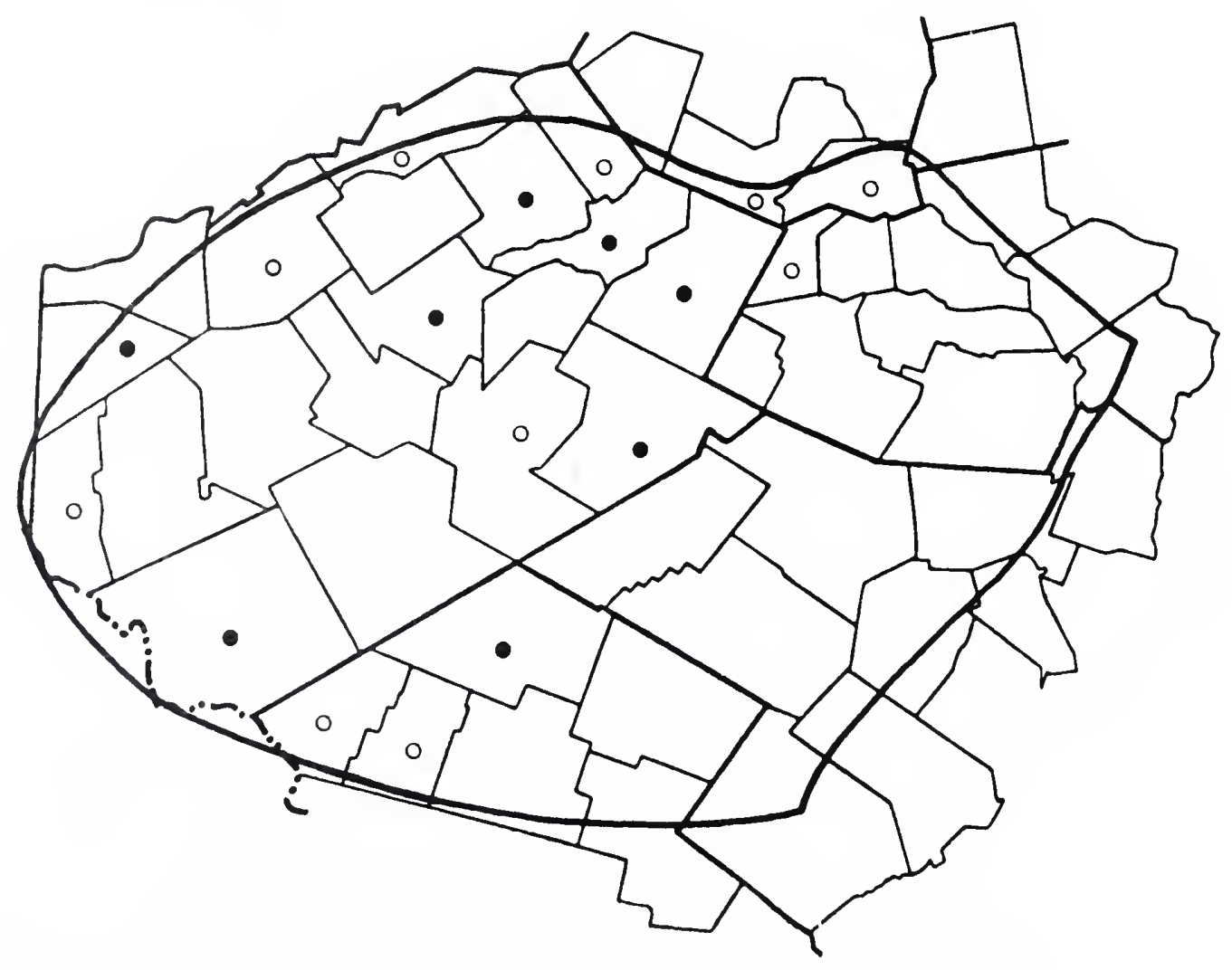


Flora of

Amphicarpa bracteata (I.) Fern.

THE CATSKILLS

Hog Peanut

New York State

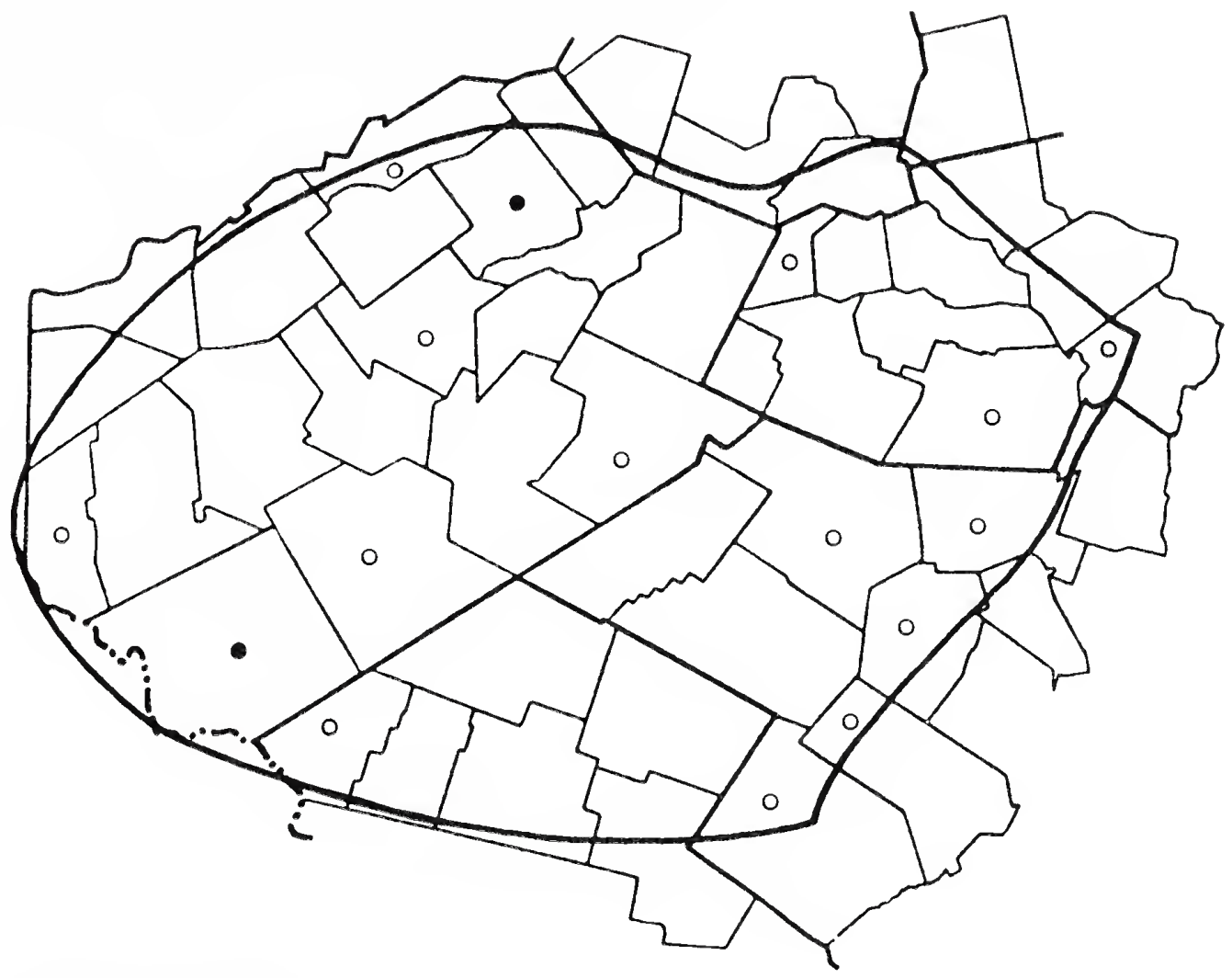

Apios americana Medic.

Ground-nut

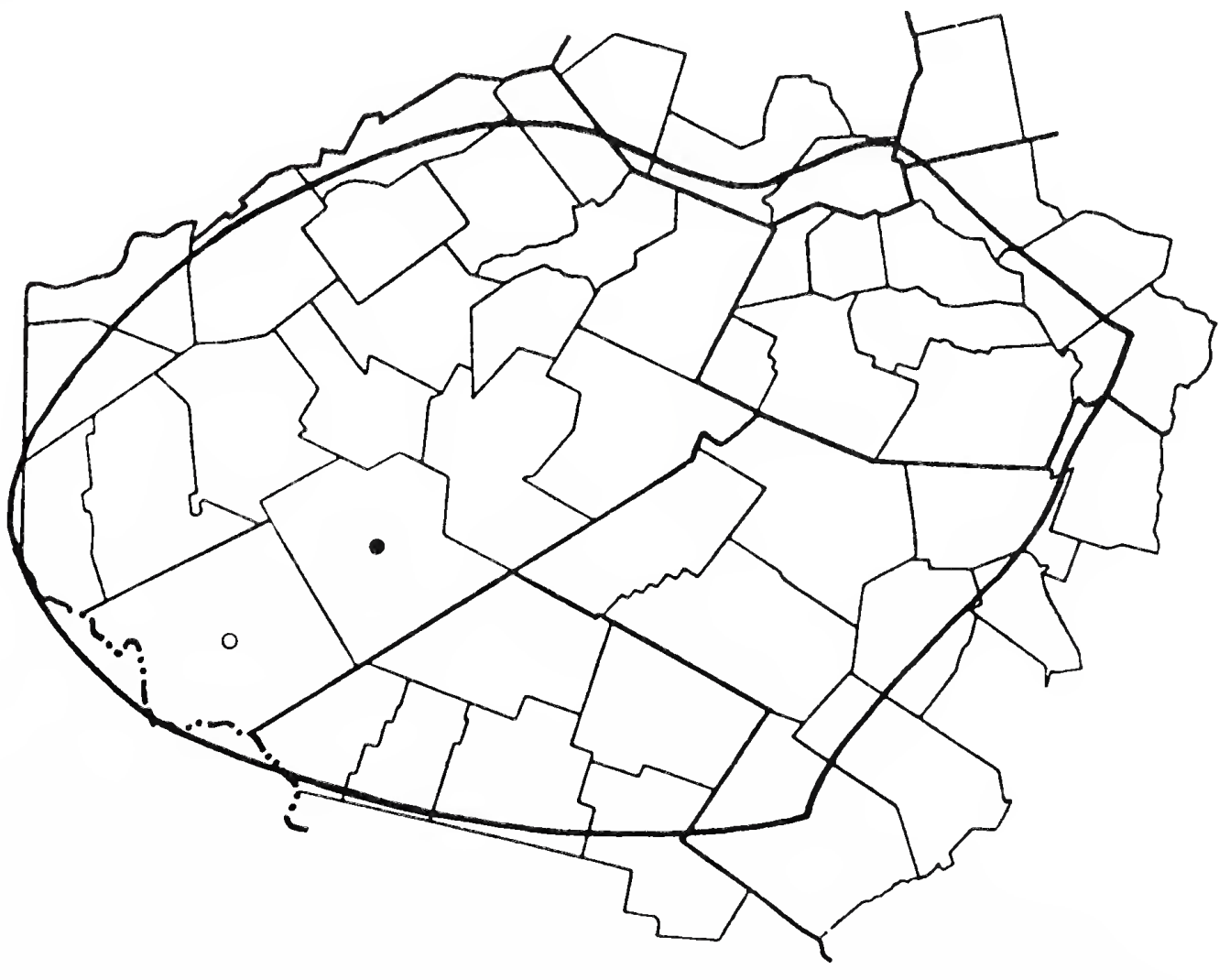




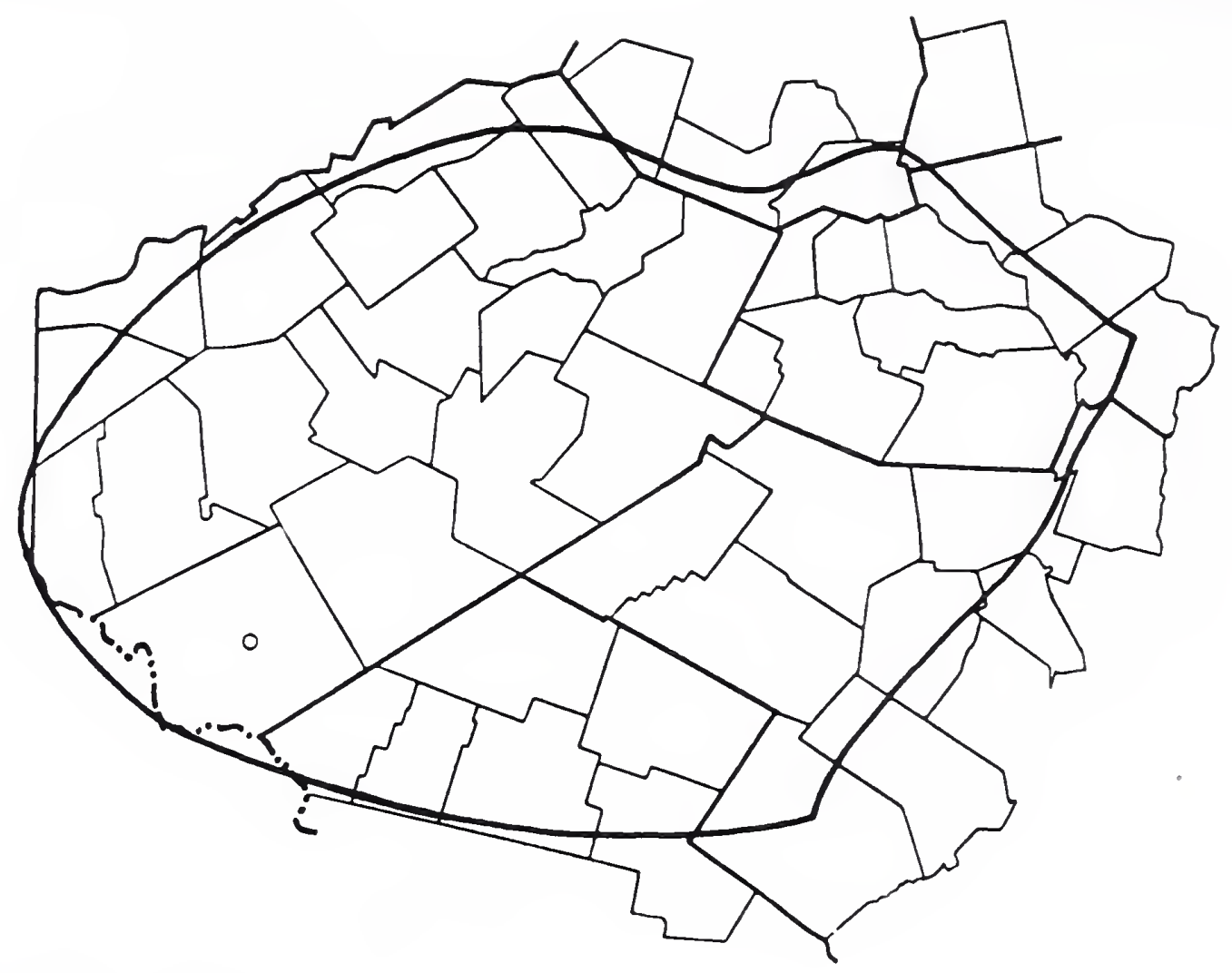

Coronilla varia I.

Crown-vetch

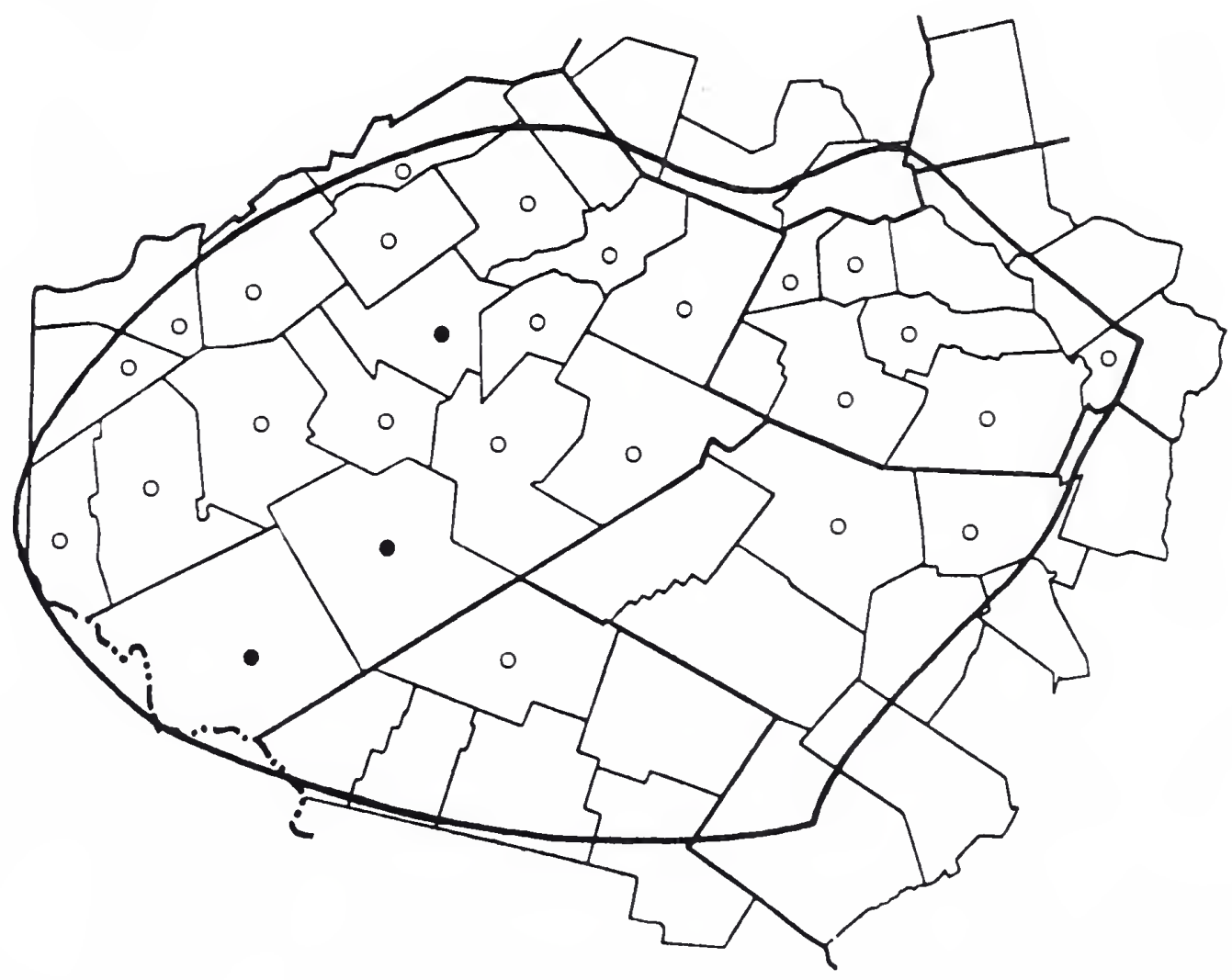




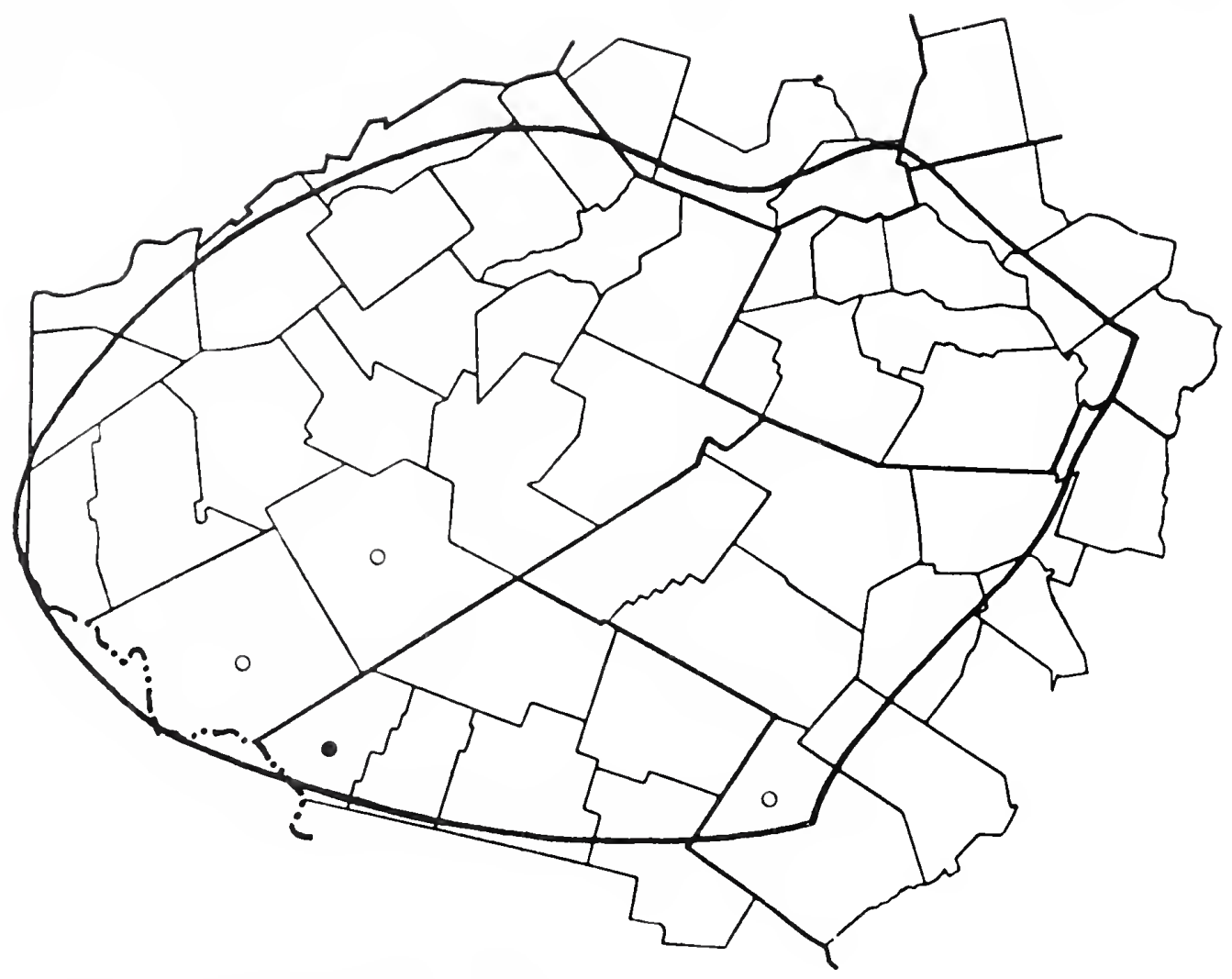

Desmodium glutinosum (MuhI.) Wood

Pointed-leaved Tick-trefoil

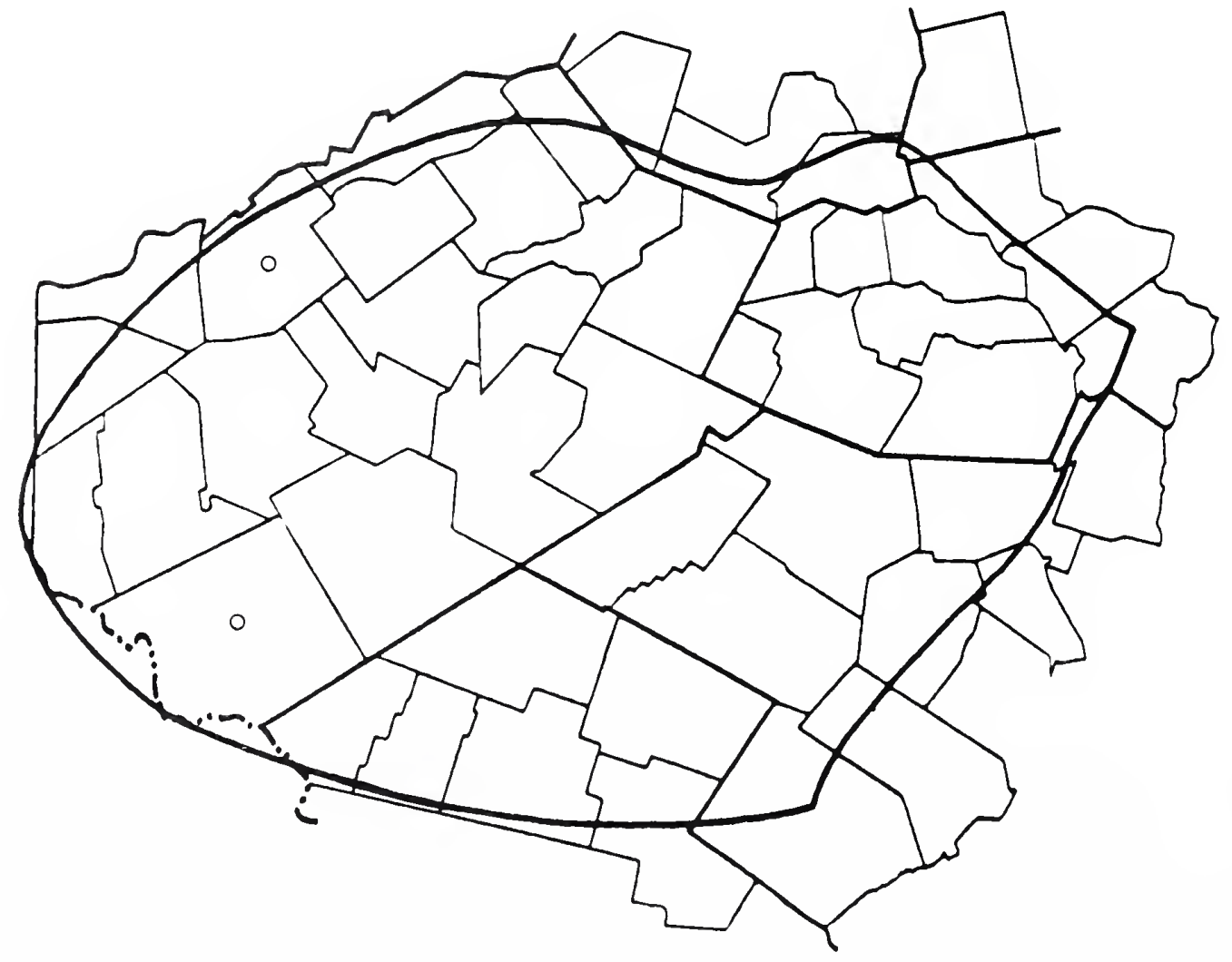




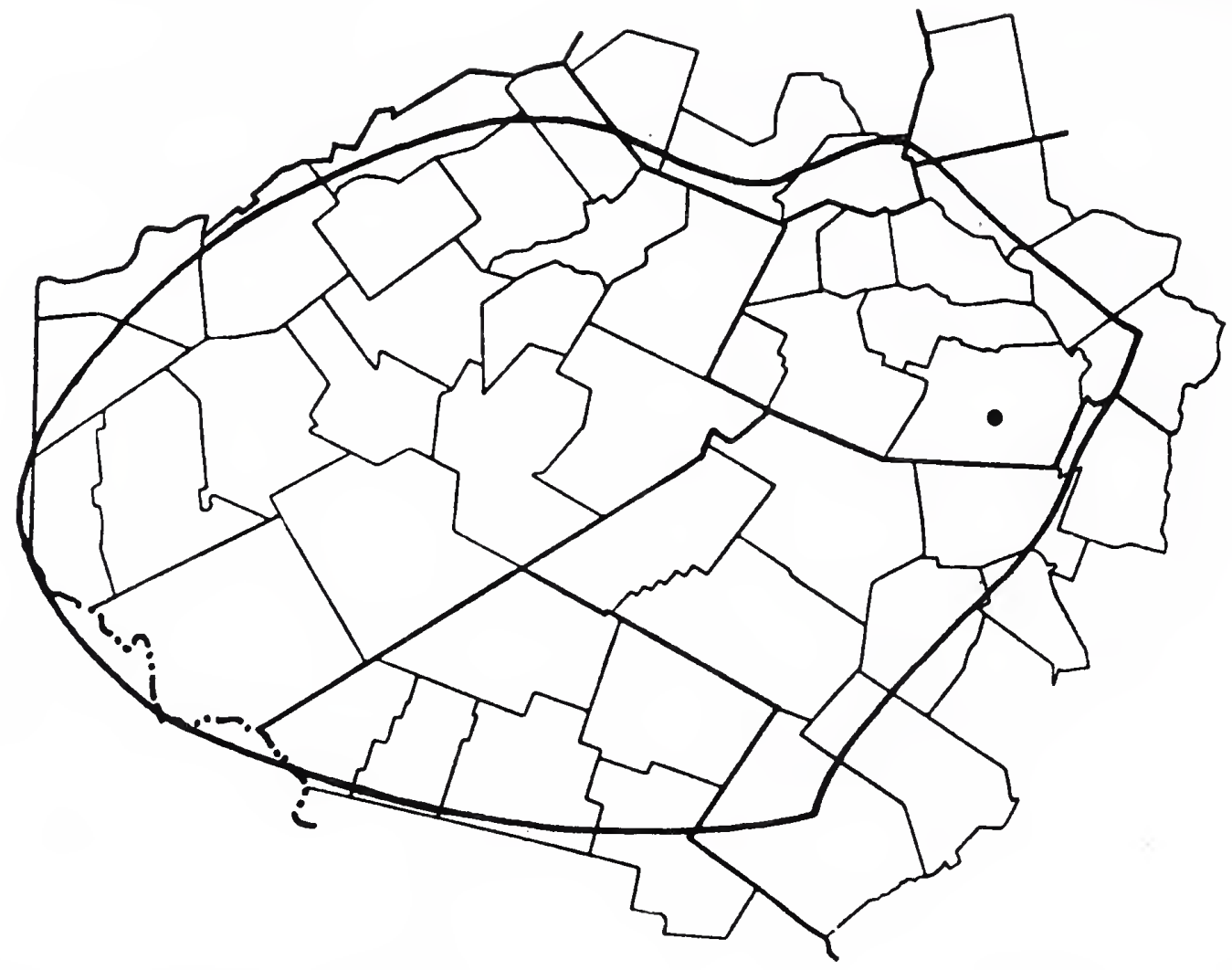

Desmodium paniculatum (I.) DC.

Panicled Tick-trefoil

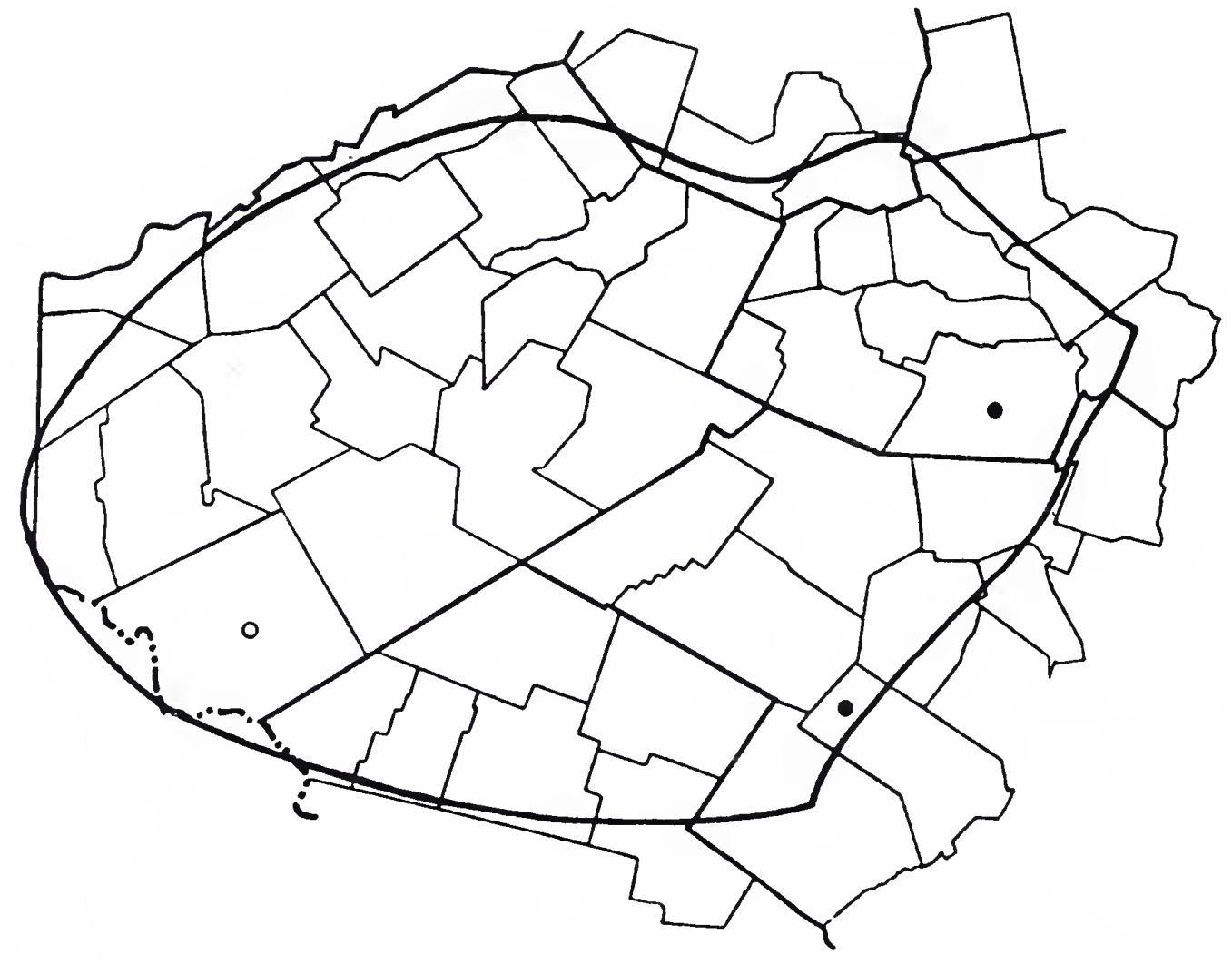


Flora of

Desmodium rotundifolium DC.

THE CATSKILLS

Round-leaved Tick-trefoil

New York State

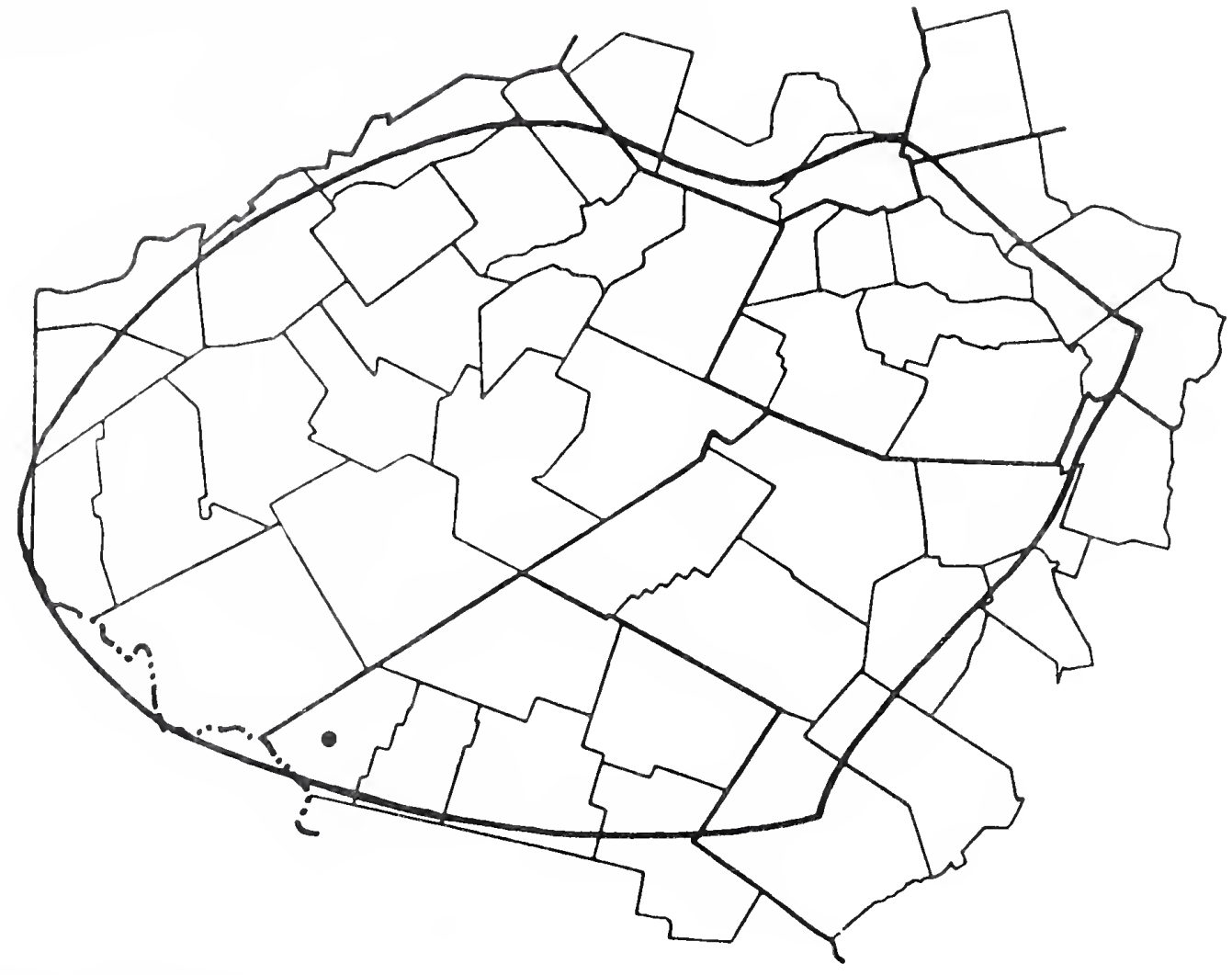

Lathyrus latifolius I.

Perennial Pea

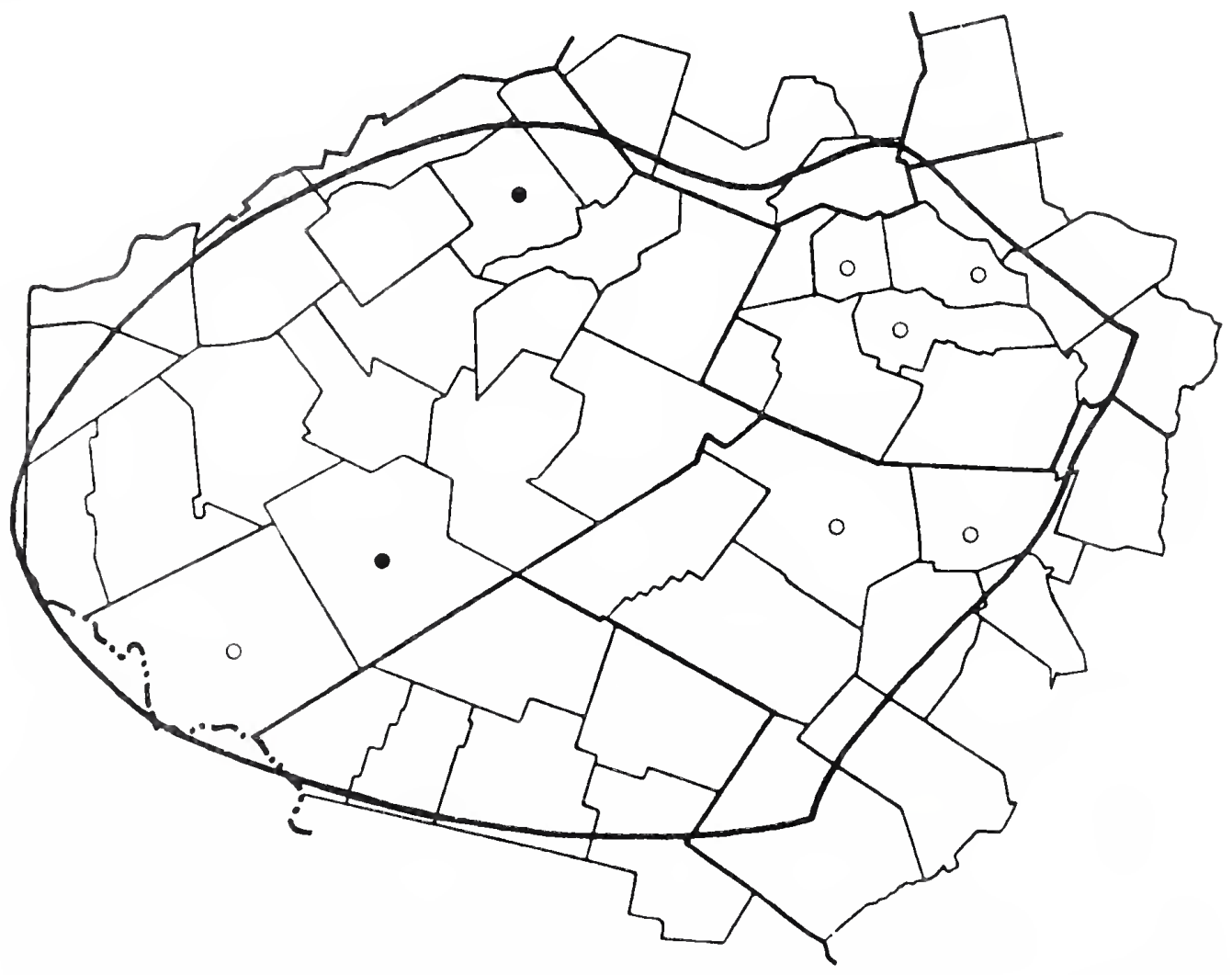


Flora of

Lespedeza capitata Michx.

THE CATSKILLS

Round-headed Bush-clover

New York State

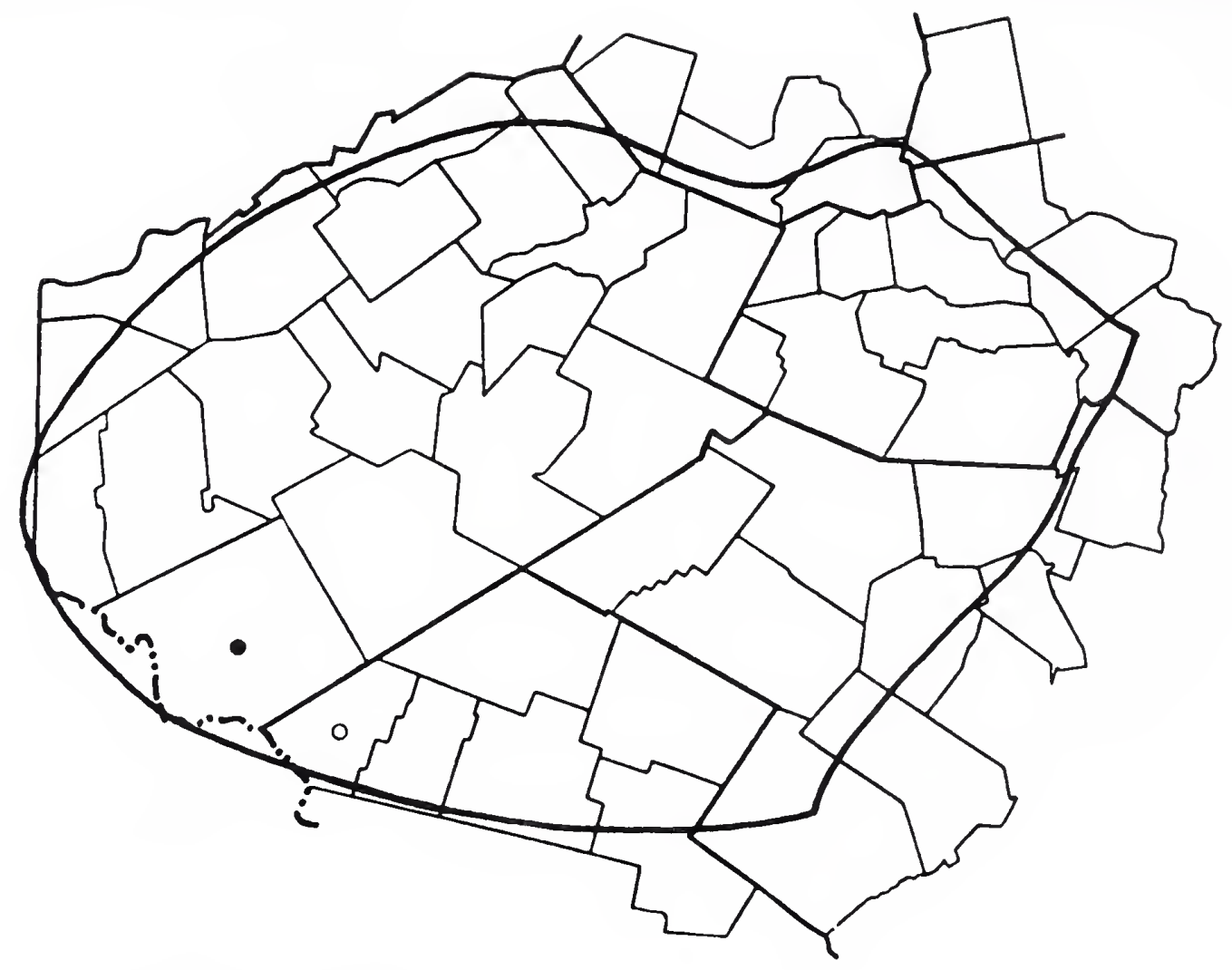

Lespedeza procumbens Michx.

Trailing Bush-clover

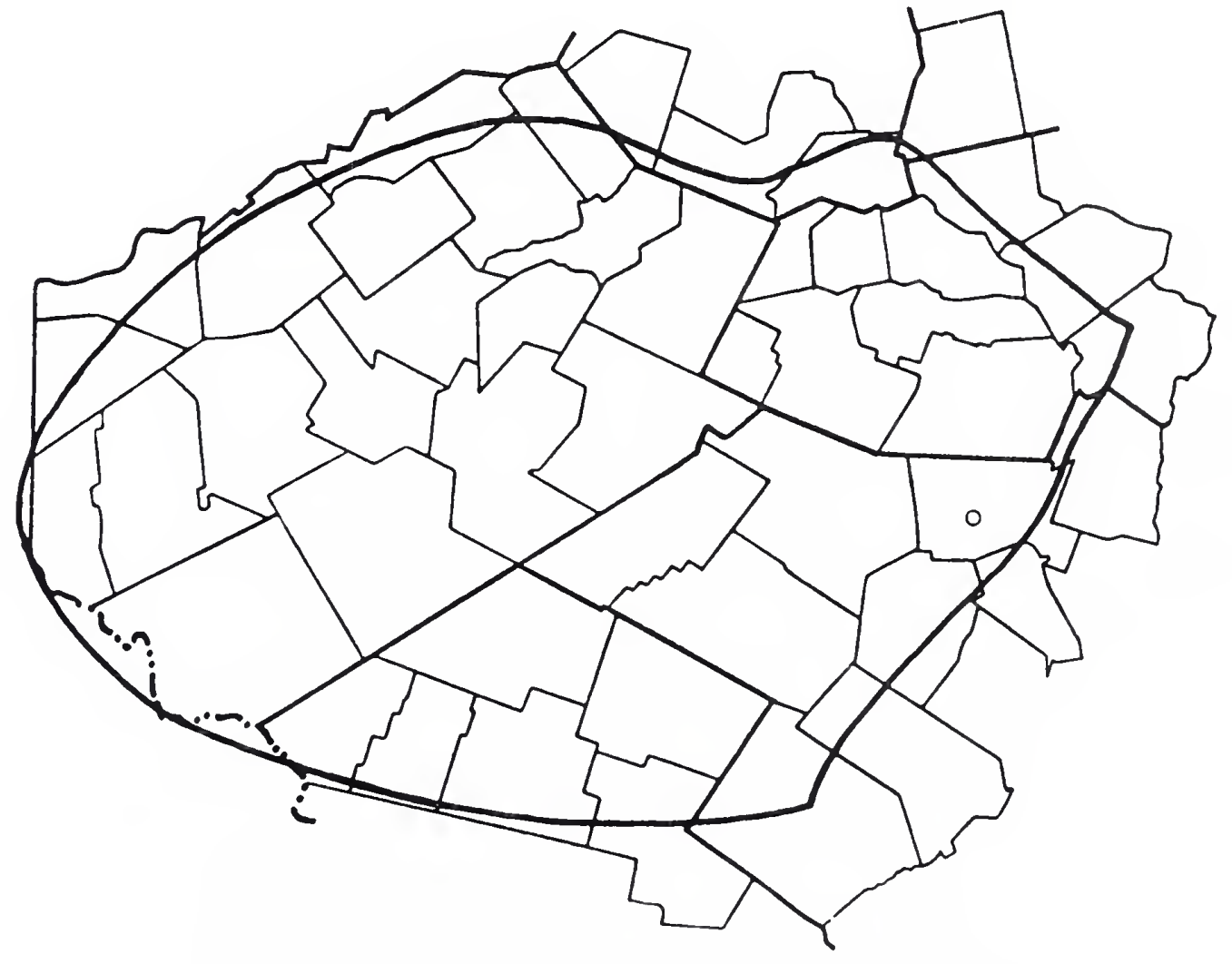


Flora of

Lotus corniculatus L.

THE CATSKILLS

Bird's-foot Trefoil

New York State

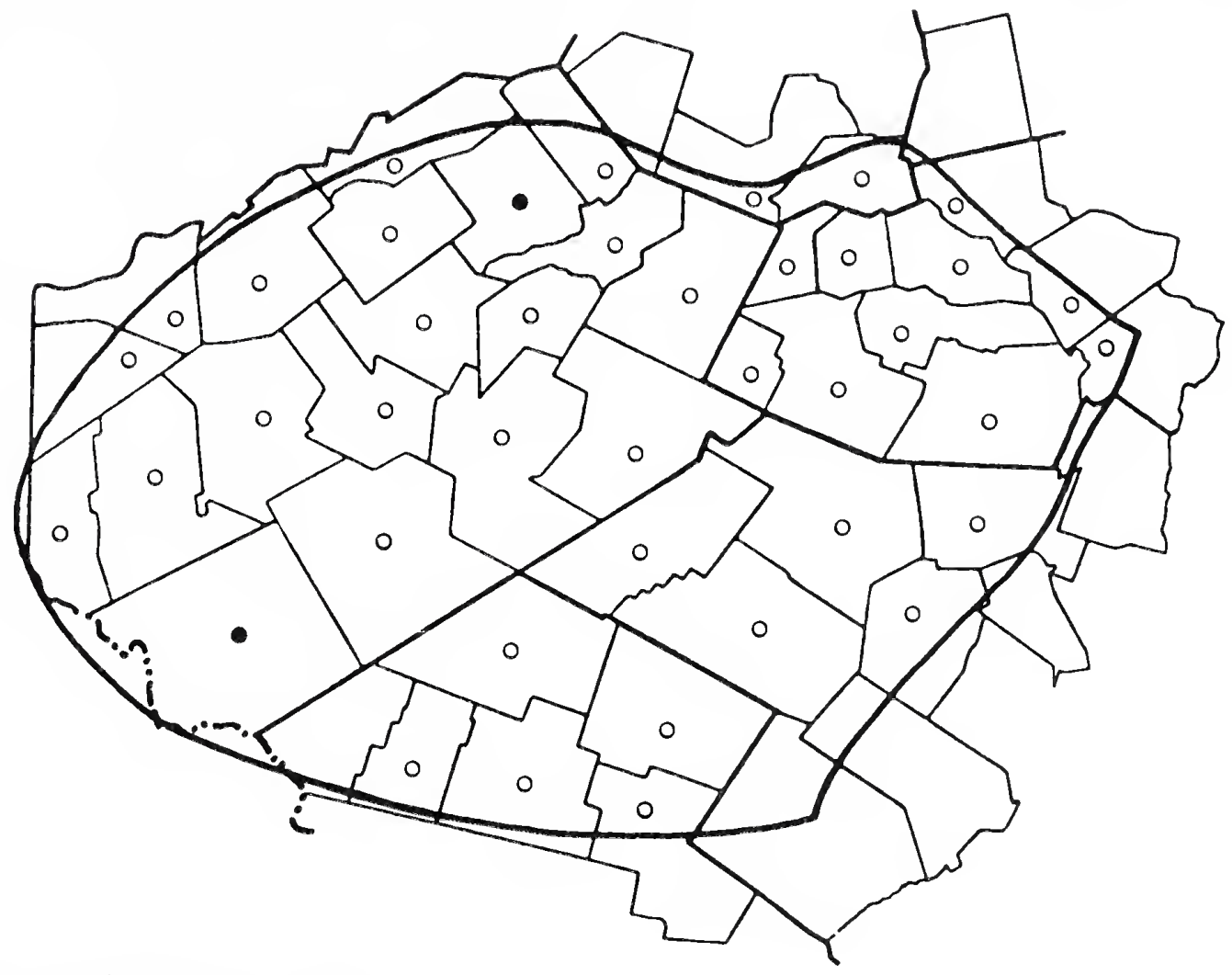

Lupinus polyphyllus Lindl.

Garden Lupine

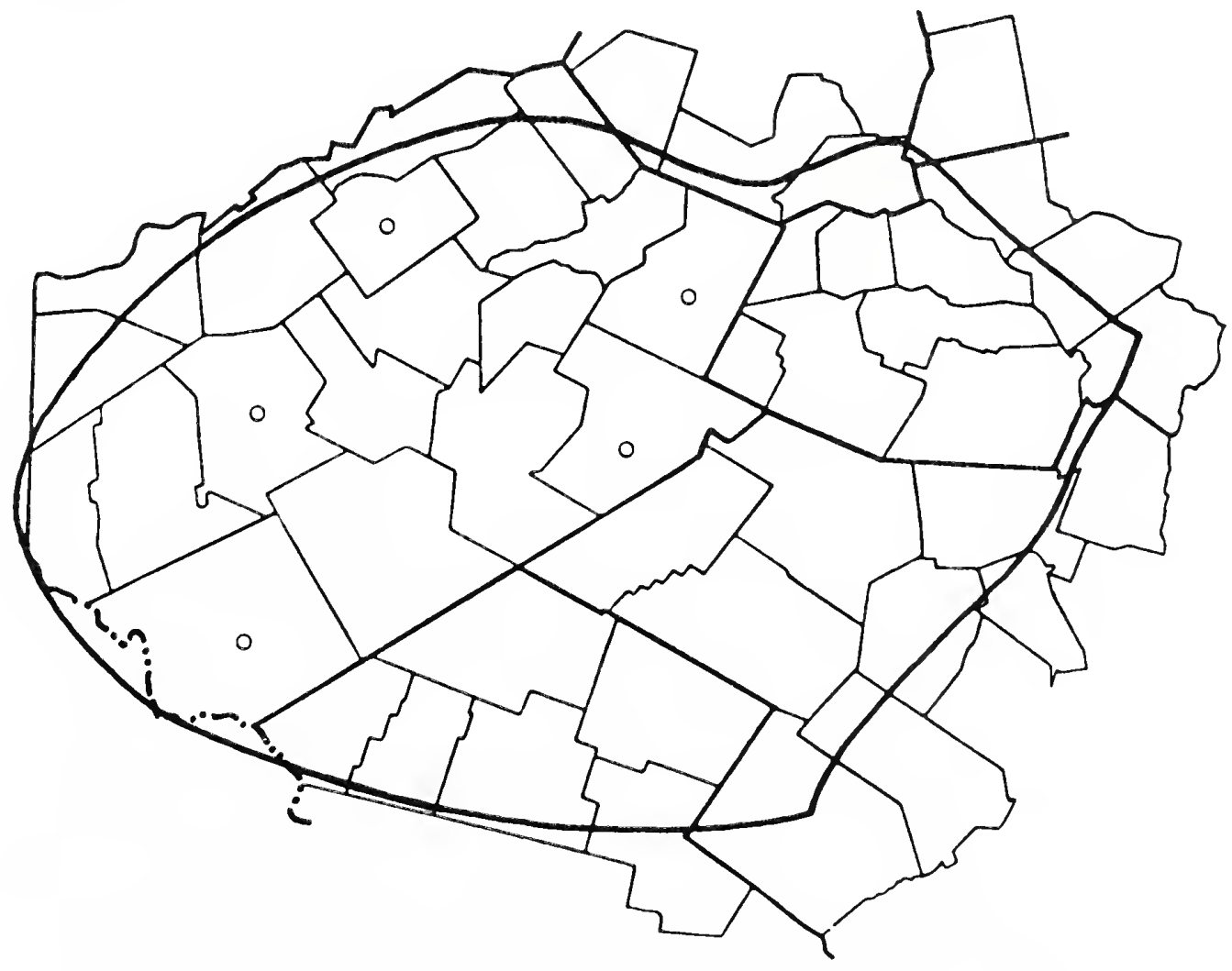




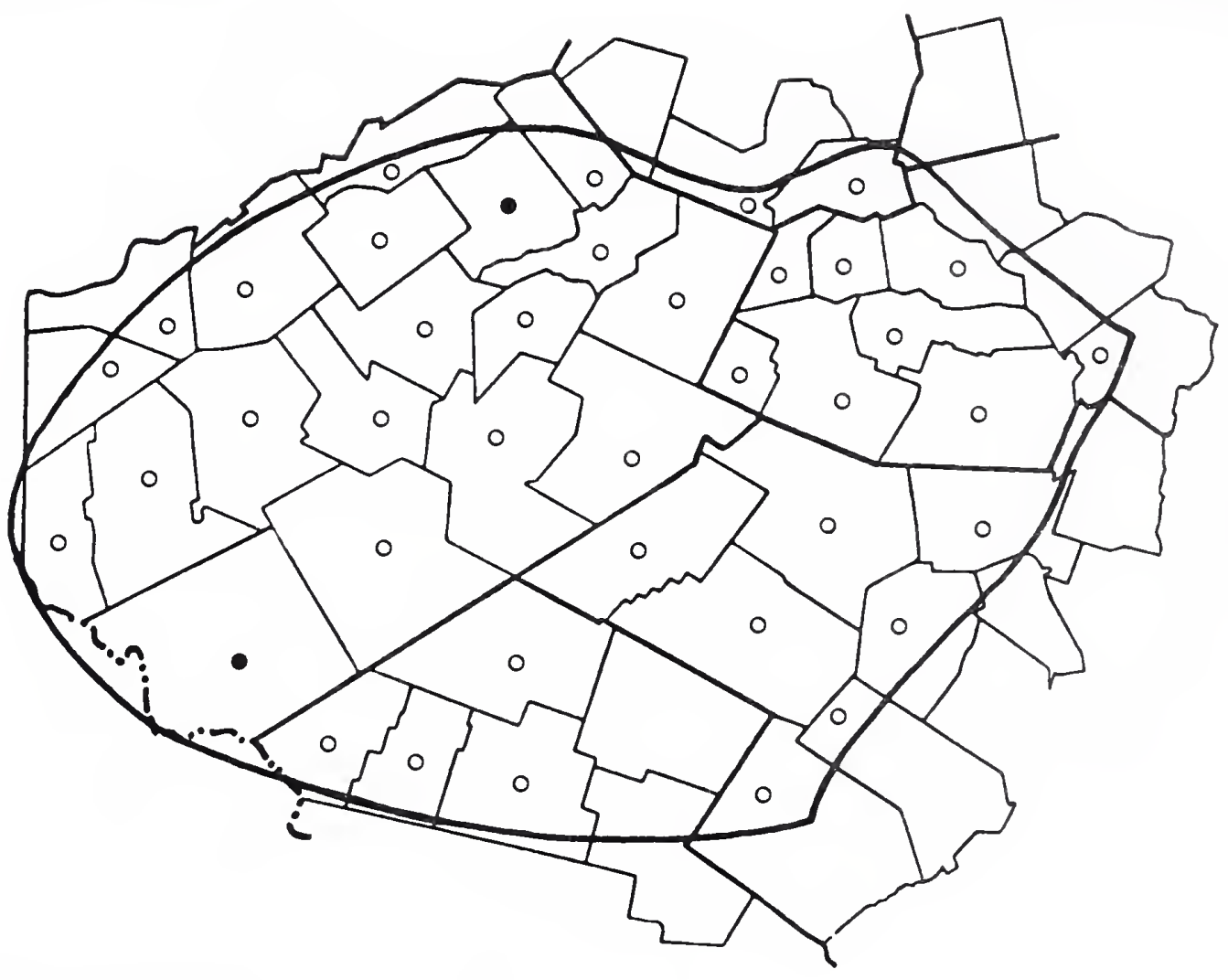

Medicago sativa L.

\section{Alfalfa}

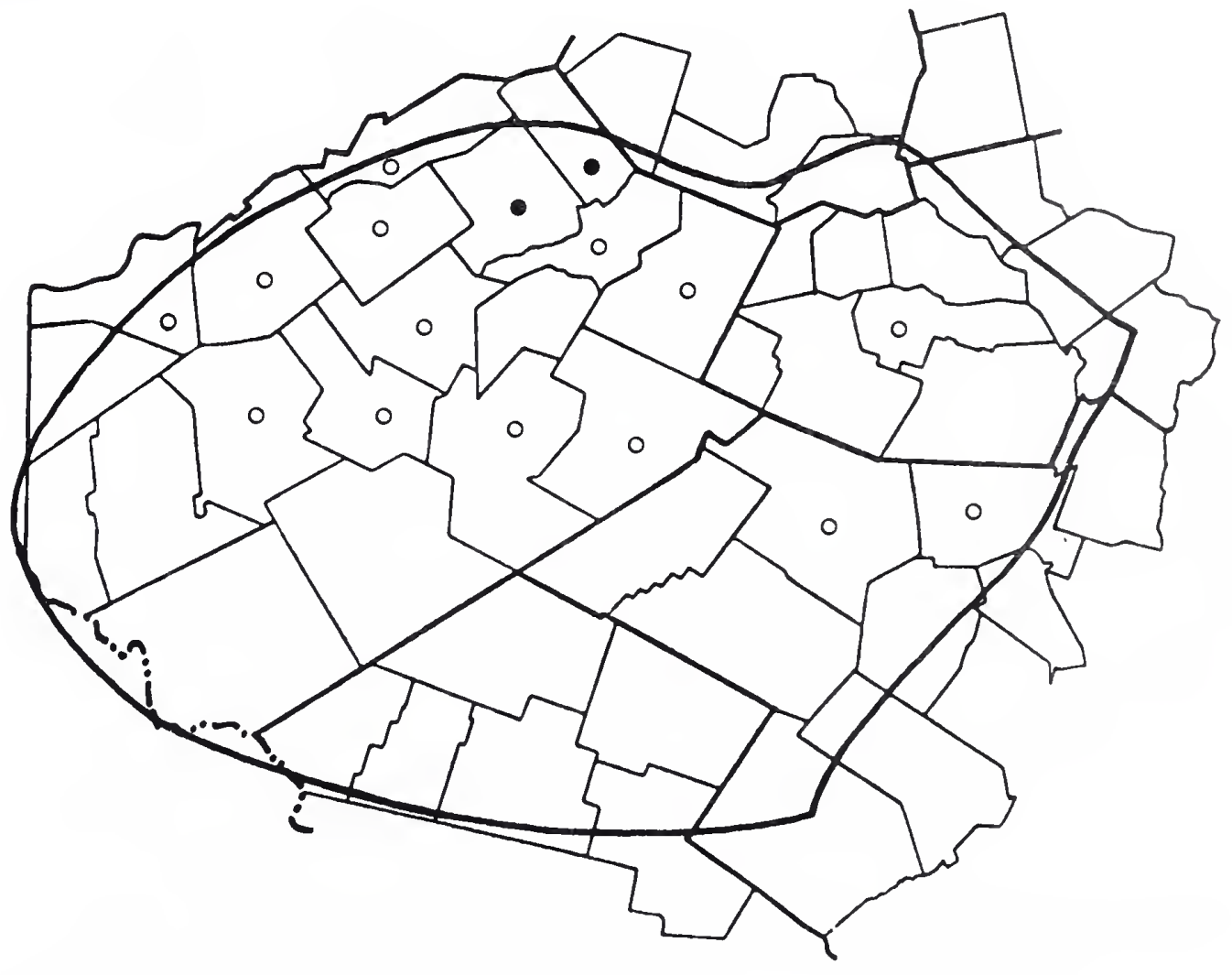


Flora of

Melilotus alba Desr.

THE CATSKILLS

White Sweet Clover

New York State

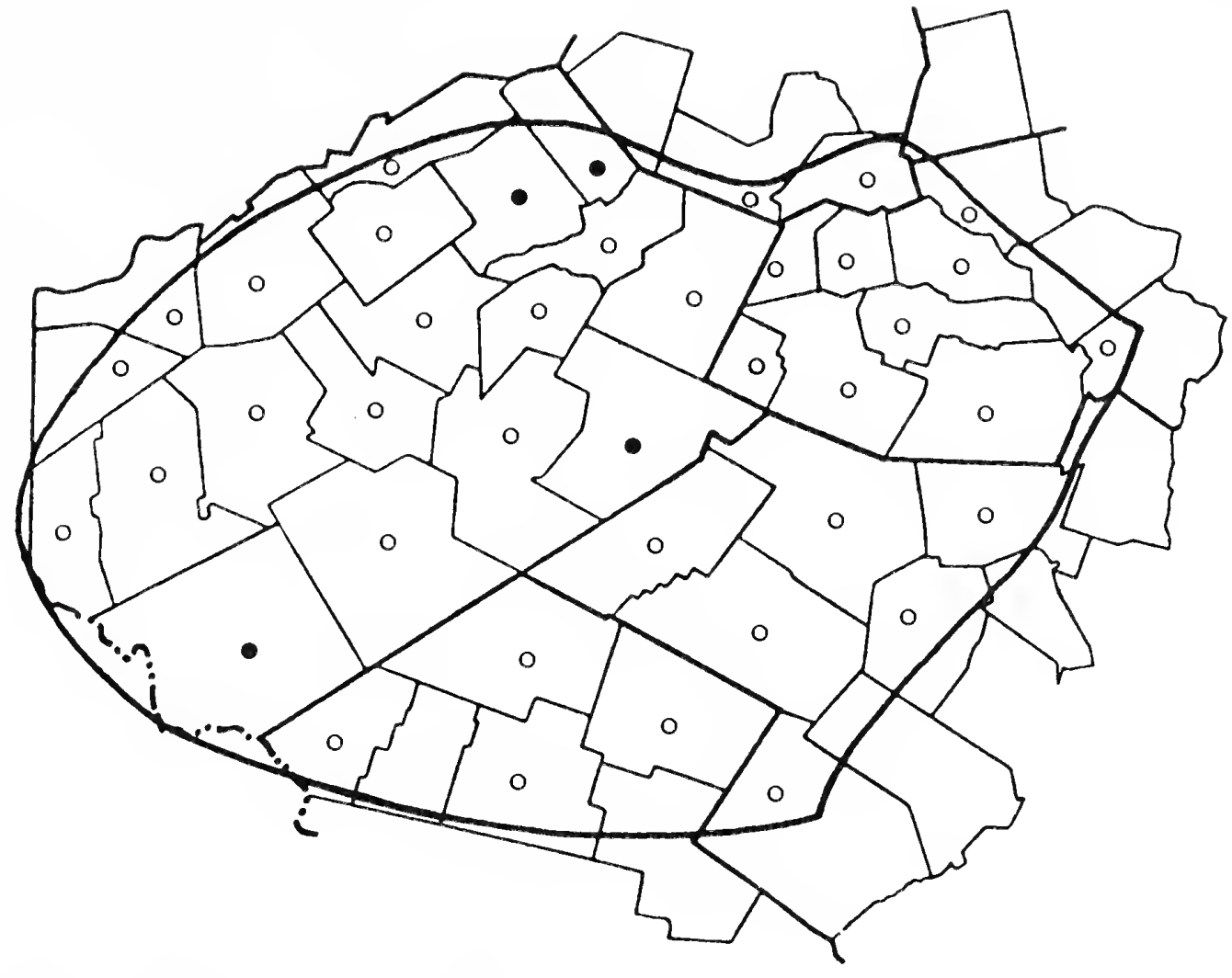

Melilotus officinalis (L.) Lam.

Yellow Sweet Clover

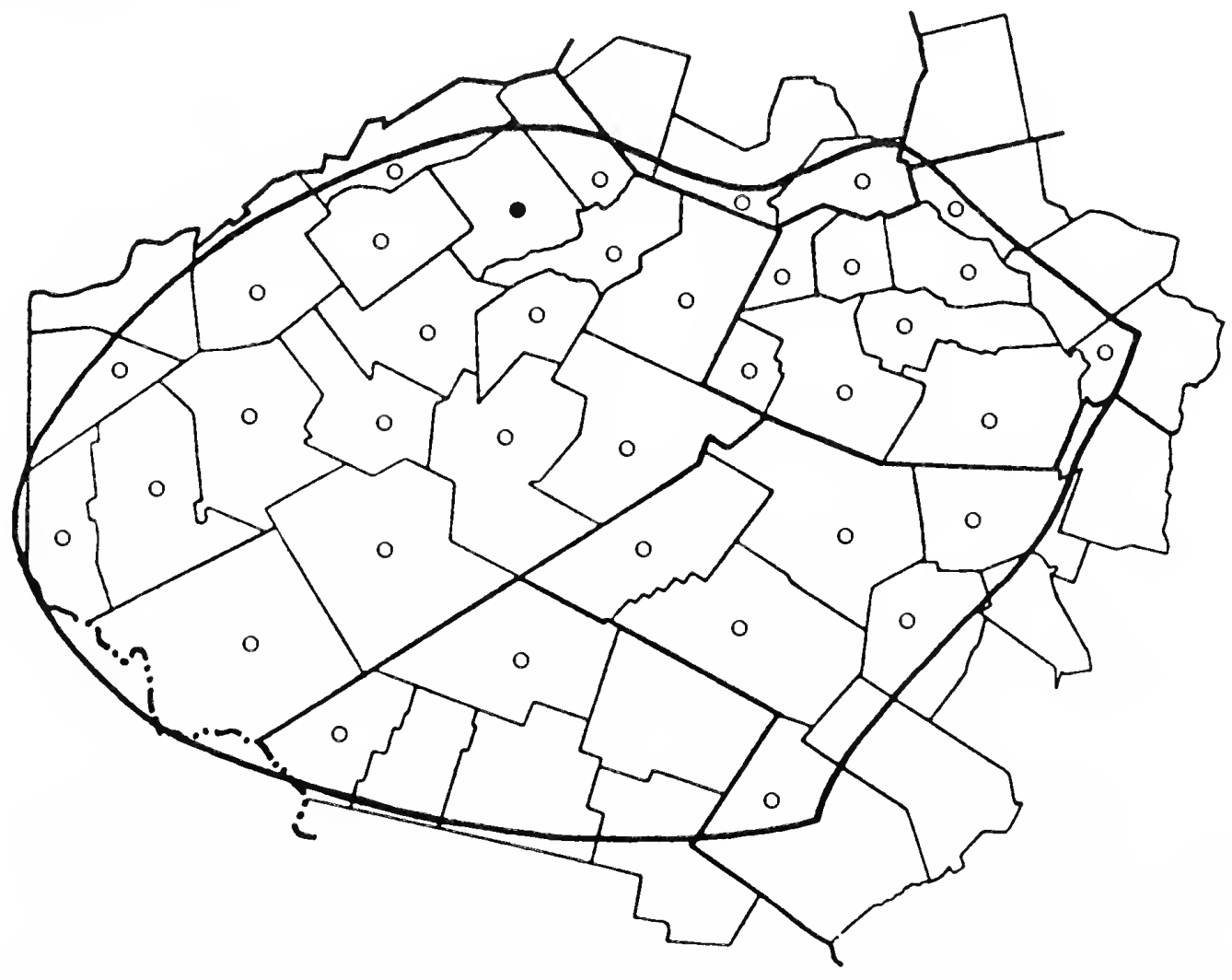


Robina pseudo-acacia I.

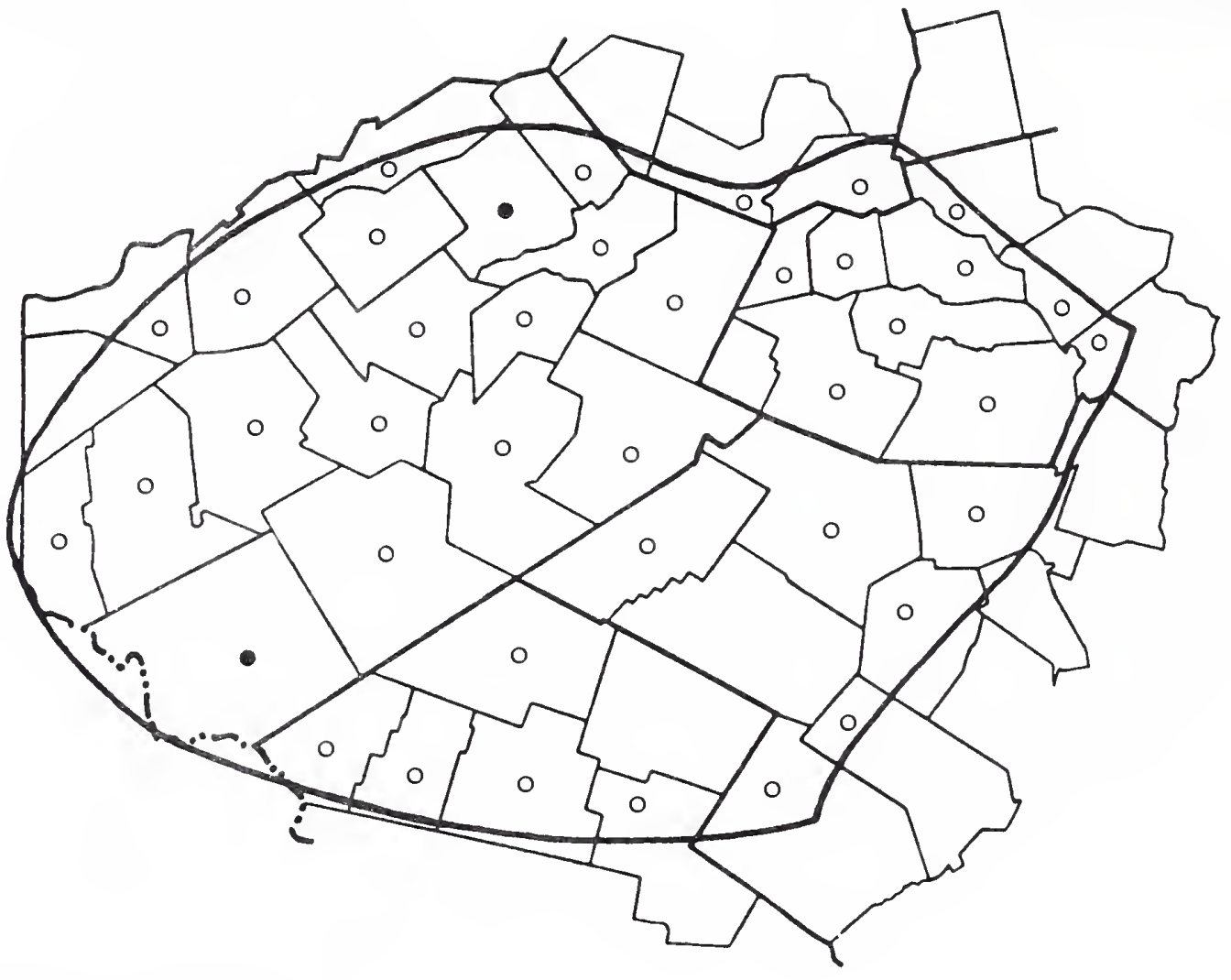

Trifolium agrarium I.

Hop-clover

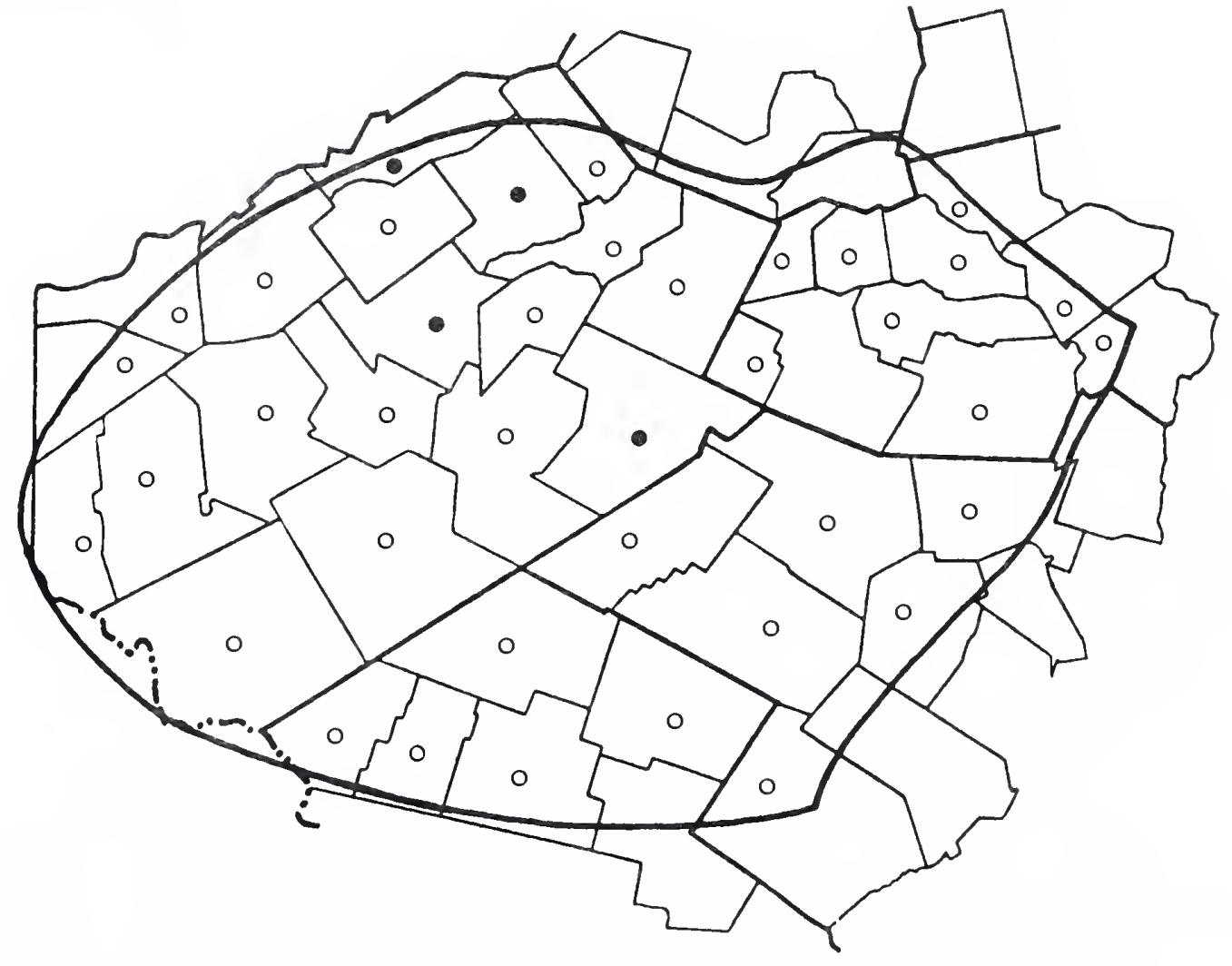


Flora of

Trifolium arvense $\mathrm{I}$.

THE CATSKILLS

Rabbit's-foot Clover

New York State

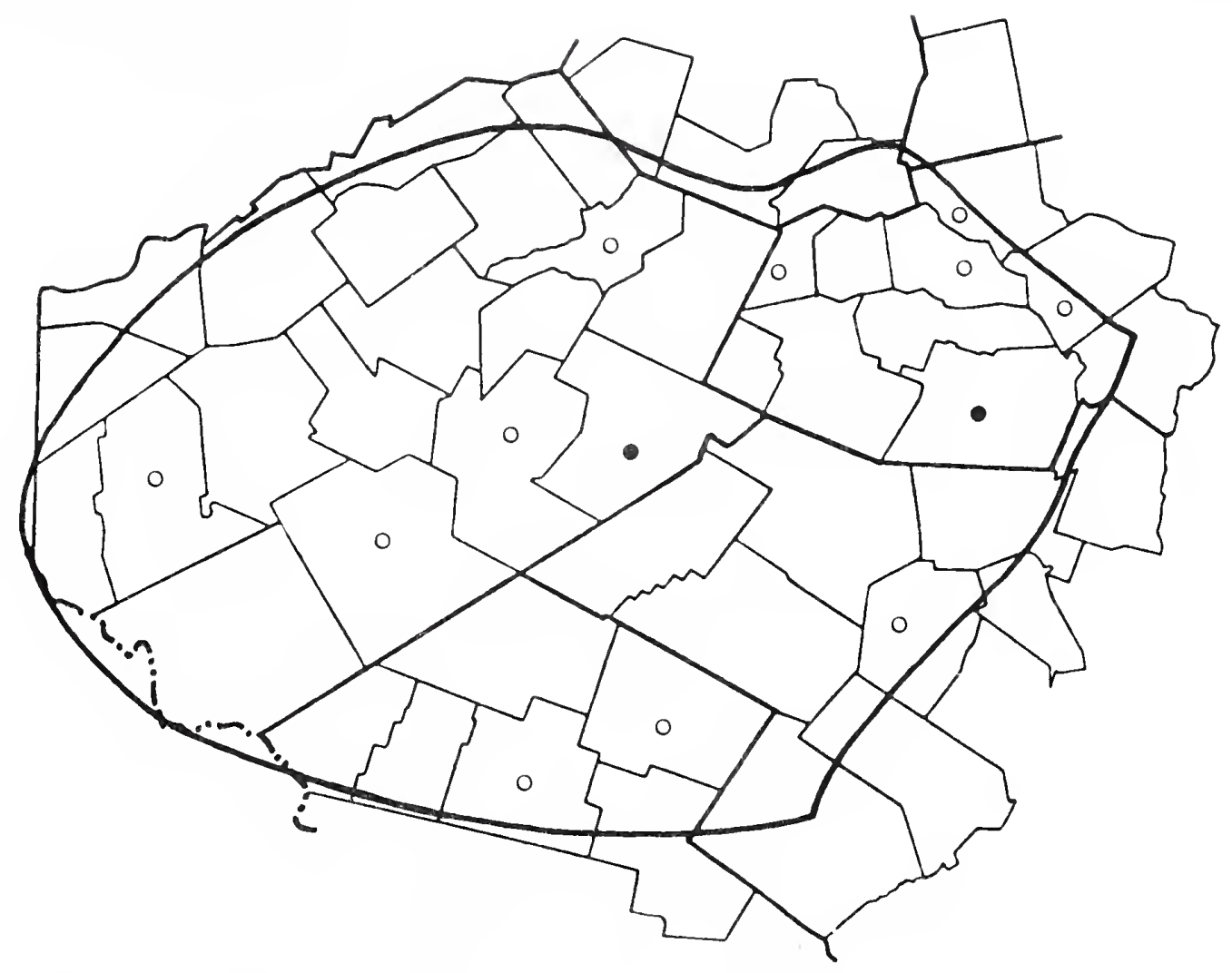

Trifolium hybridum $L$.

Alsike Clover

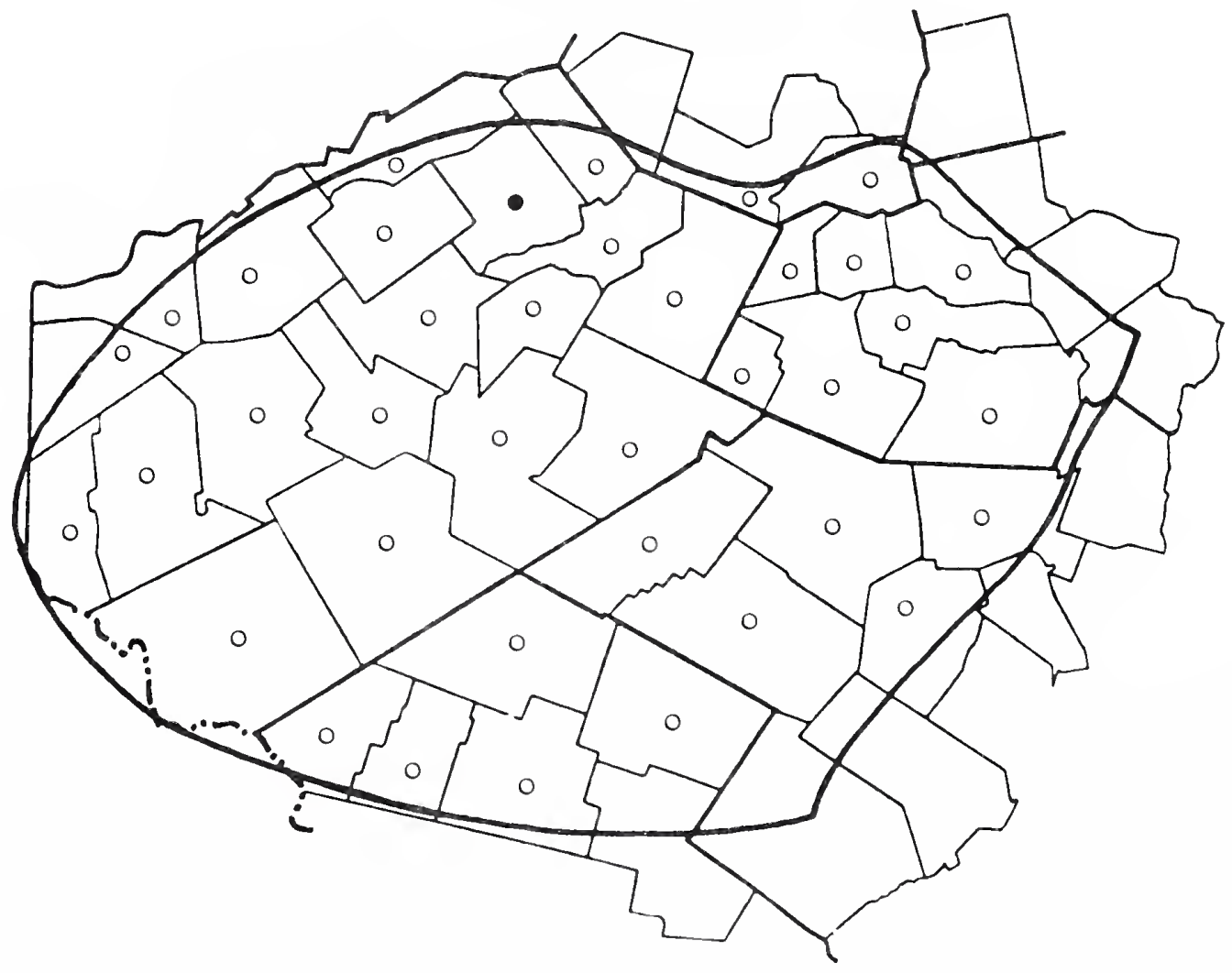




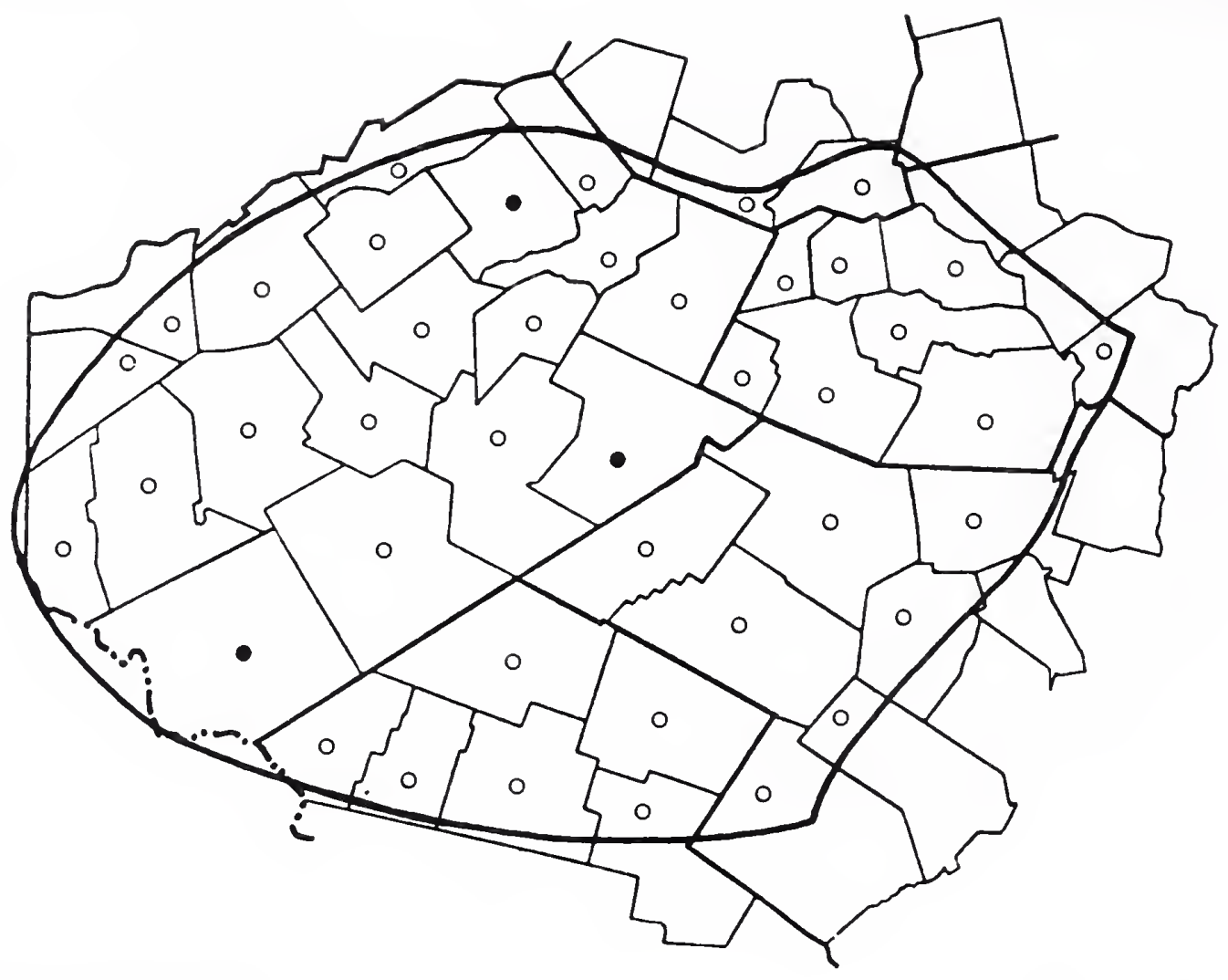

Trifolium repens L.

White Clover

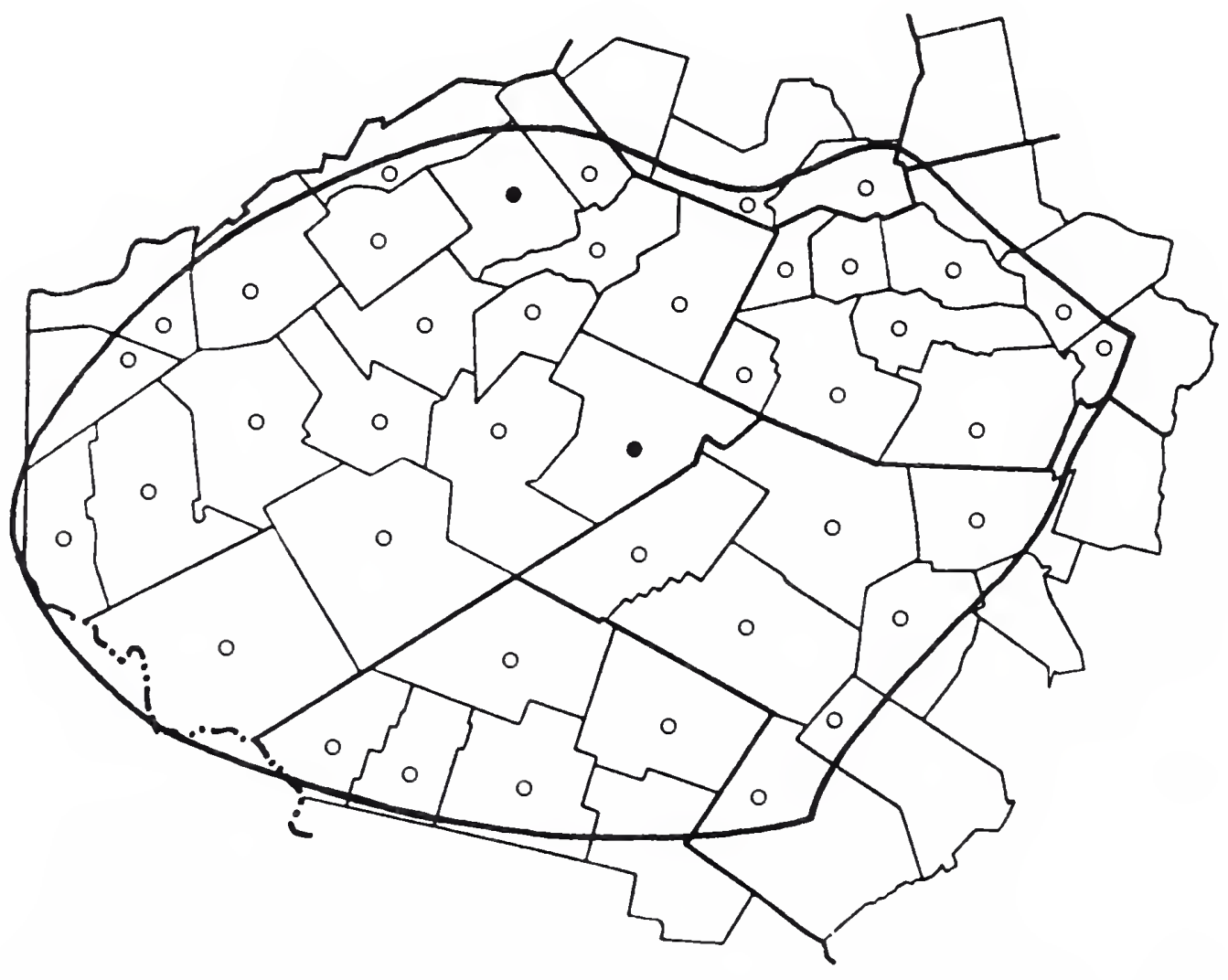




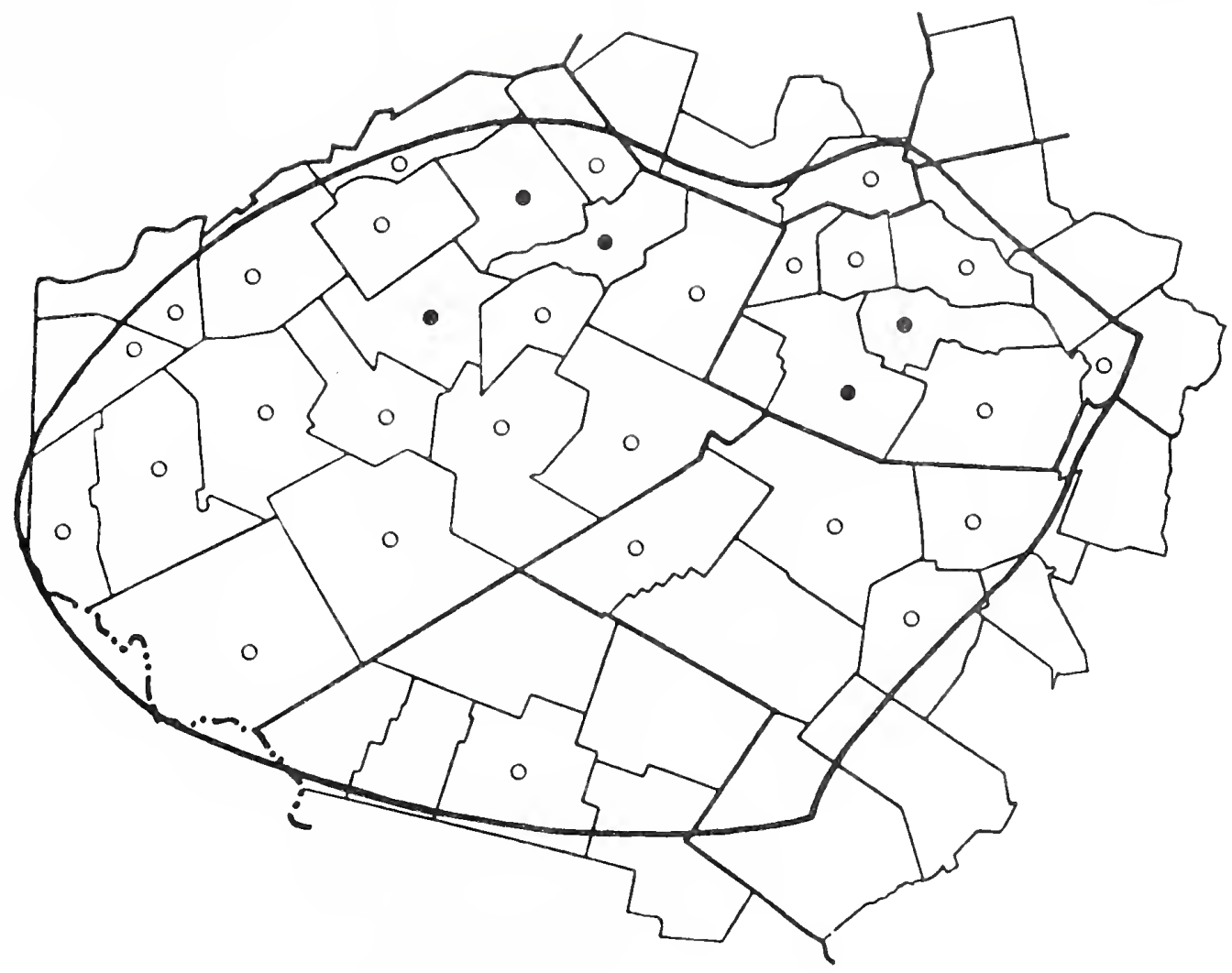

Vicia tetrasperma (I.) Moench.

Four-seeded Vetch

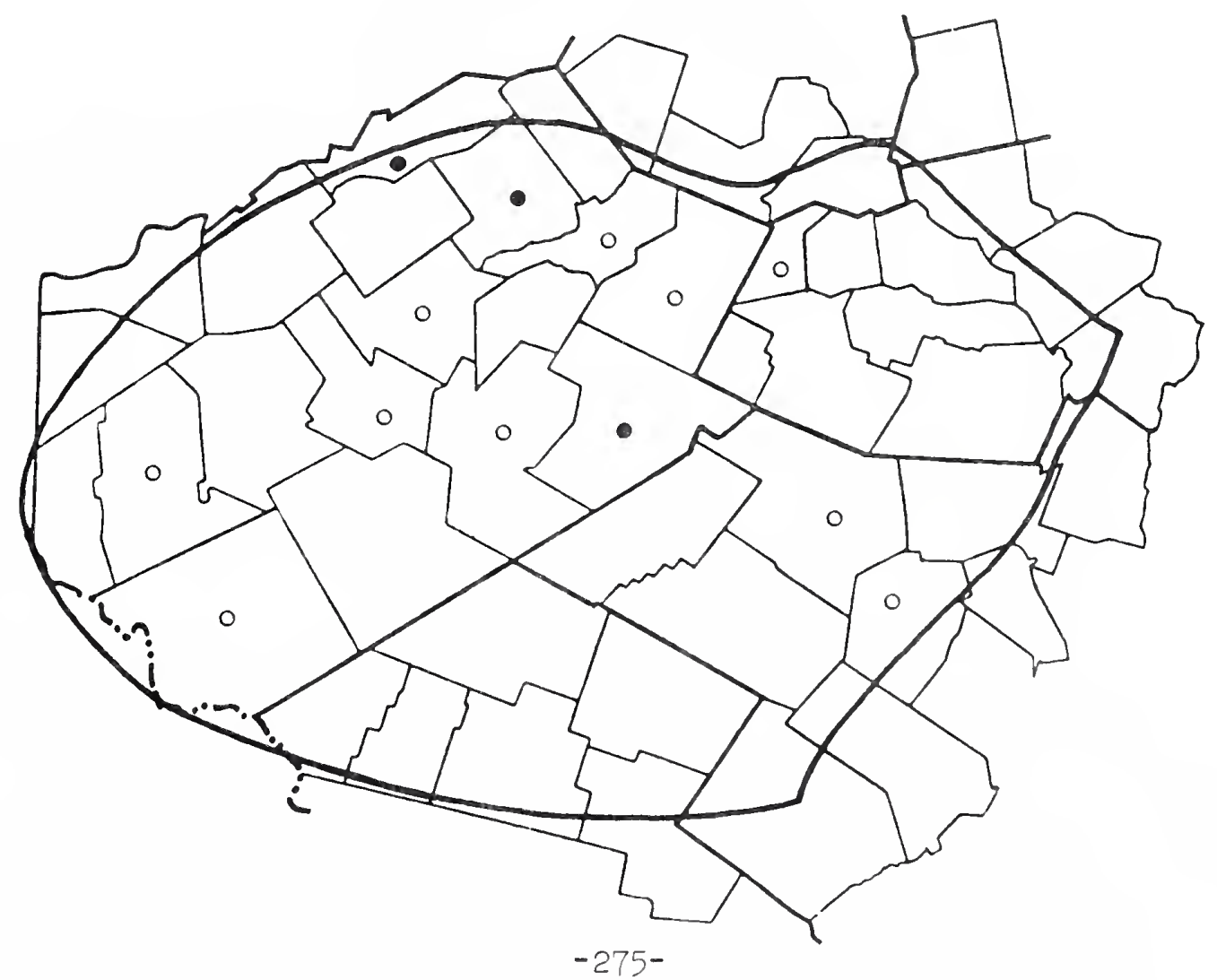


Vicia villosa Roth.

THE CATSKILLS

Hairy Vetch

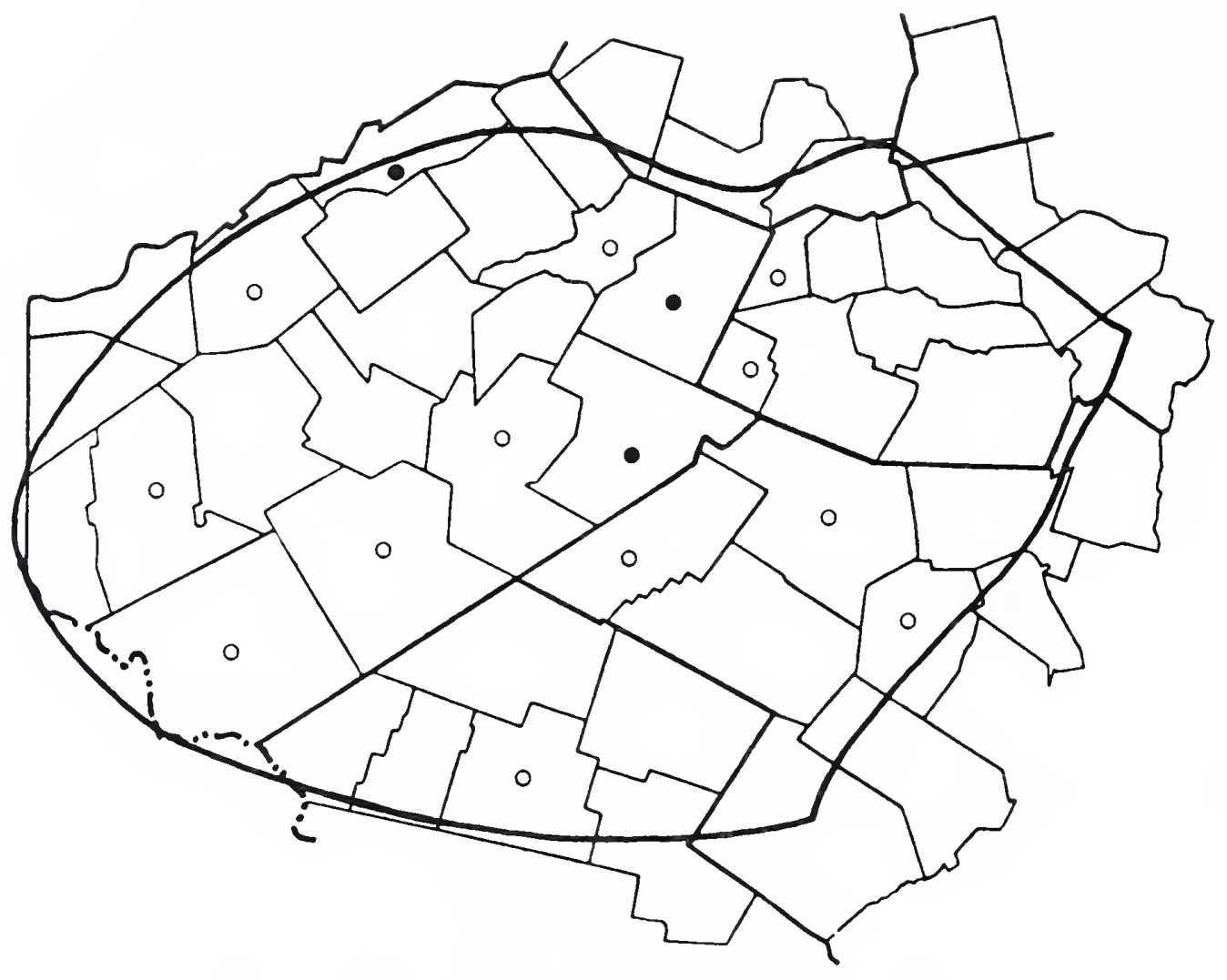




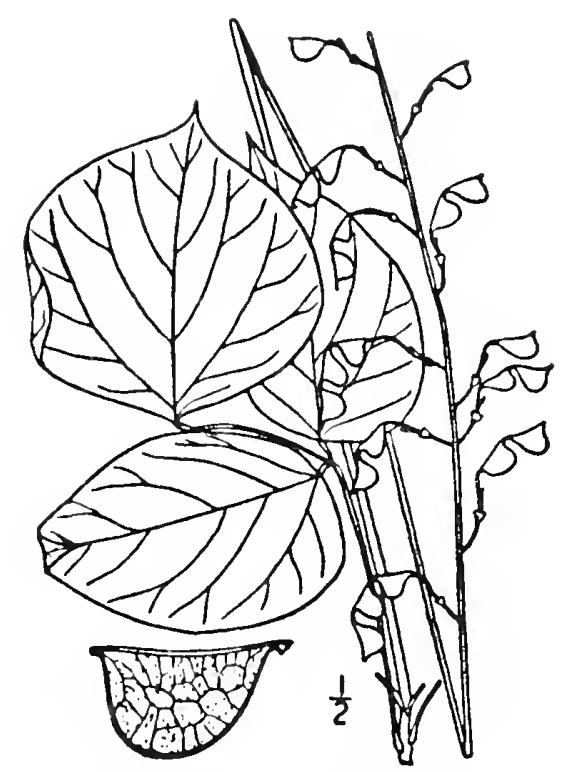

Desmodium glutinosum--Pointed-leaved Tick-trefoil [From Britton \& Brown (1913), Vol. II, p. 396.]

While working on the distribution maps for this volume, the writer became acutely aware that he had inadvertently omitted Desmodium glutinosum both from the keys and from the text. Since cards for the Index had even been nearly completed by the time of this discovery, it seemed to be the sensible thing to put that species in an Addendum instead of retyping and repaging the text itself. This species most resembles $\underline{D}$. nudiflorum, from which it can be distinguished by the terminal leaflet, which is very acuminate and nearly as wide as long, while the leaf-bearing stem is prolonged into an elongate panicle. The terminal leaflet of $\underline{D}$. nudiflorum, on the other hand, is distinctly longer than wide and is usually obtuse or only short acuminate, while the flowers are usually borne on a leafless branch arising from the base of the plant.

Desmodium glutinòsum (Muhl.) Wood. Pointed-leaved Tick-trefoil.

Meaning of Species Name. Glutinous, from the sticky-puberulent rachis of the inflorescence.

Other Names. Pointed-leaved Beggar-ticks.

Type of Plant. A perennial herb.

Habitat. Dry or rocky open woods.

Range. NS and Me to Minn and Sask, $s$ to Fla and Tex. 
Distr in NYS. Locally frequent across the state $s$ of the Adirondacks. Distr in the Torrey Range. Exclusively $n$ of the moraine on II; unknown on SI, scattered up the Hudson valley to the Hudson highlands, thence increasing northw.

Elevation. Sea level-1900 ft in the Torrey range.

Time of Fl. Jul-Aug; Jul l-Aug 15 at Cornell.

Origin. Native. 


\section{INDEX}

Underscored figures indicate pages where illustrations are located.

Agrimonia, 52

gryposepala, 51, 52, 231

Agrimony, 52

tal1, 51, 52, 231

Alfalfa, $173, \underline{175}, 175,270$

Alsike clover, 188, 189, 273

Amelanchier, 52

arborea, 54, 55, 231

bartramiana, 56, 57, 232

laevis, 56, 58, 232

American mountain-ash, 116, 117 , 118, 248

American wood strawberry, 74 , 75, 237

Amphicarpa, 156

bracteata, 156, 157, 263

Apios, 158

americana, 158, 159, 263

Apple, 109, 111, 112, 250

Avens, 77

bristly white, $81,81,240$

large-leaved, $12,82,240$

purple, 80, 83, 241

rough, $82,84,241$

winte, 79, 80, 239

yellow, 78, 79, 239

Baptisia, 161

tinctoria, 161, 161, 264

Barren strawberry, 153, 153, 262

Bean, wild, 158

Bird's-foot trefoil, 170, 171, 269

Bishop's-cap, 19

naked, 19, 20, 223

two-leaved, 19, 20, 222

Blackberry

cut-leaved, 144, 145, 258

dwarf red, 149, 149, 260

leafy-flowered, 141, 141, 256

mountain, 136, 137, 255

smooth, 138, 139, 255

Black chokeberry, 114, 115, 251

Black locust, 180, 182, 183, 272

Blaci medic, 173, 174, 174, 270
Black raspberry, 146, 147, 259

Brainerd's hawthorn, 62, 63, 233

Bramble, 134

Bristly black currant, 29, 30, 226

Bristly dewberry, 142, 142, 257

Bristly gooseberry, 28, 29, 226

Bristly white avens, 81, 81, 240

Broad-leaved meadowsweet, 151, 152, 261

Bush-clover

round-headed, 168, 170, 268

trailing, 169, 169, 268

Canadian tick-trefoil, 164, 166, 265

Cherry, 93

black, 101, 103, 247

pin, 97, 98, 246

sand, 100, 101, 247

Chokeberry, 109, 114

black, 114, 115, 251

purple, $114,115,250$

Chokecherry, 105, 107, 248

Chrysosplenium, 17

americanum, 18, 18, 222

Cinquefoil, 84

downy, 86, 87, 243

dwarf, $85,87,242$

Norway, 88, 89, 243

old-field, 91, 92, 244

rough-fruited, 89, 90, 244

silvery 85, 86, 242

three-toothed, 91, 92, 245

Clover, 185

alsike, 188, 189, 273

hop-, 186, 187, 272

rabbit's-foot, 187, 188, 273

red, 189, 190, 274

white, 192, 192, 274

Clover, sweet

white, 177, 179, 271

yellow, 178, 179, 271

Coronilla, 162

varia, 162, 163, 264

Crassulaceae, the Orpine Family, 10

Crataegus, 59

brainerdii, 62, 63, 233

chrysocarpa, 62, 63, 233

holmesiana, $63,64,234$ 
Crataegus (cont.)

macrantha, 63

macrosperma, $64,65,234$

monogyna, 64, 65, 235

pelicellata, $\underline{66}, 66$

punctata, 67, 68, 235

Crown-vetch, 162, 163, 264

Currant, 23

bristly black, 29, 30, 226

garden $30,31,227$

skunk, 26, 27, 225

wild red, 32, 33, 228

Cut-leaved blackberry, 144, 145, 258

Dalibarda, 69

repens, 69, 69, 236

Deer-vetch, 170

Desmodium, 163

canadense, 164, 166, 265

glutinosum, 265, 277, 277

nudiflorum, 163, 165, 266

paniculatum, 165, 166, 266

rotundifolium, 165, 165, 267

Dewberry

bristly, 142, 142, 257

northern, 140, 140, 256

plaited-leaved, 148, 260

Ditch stonecrop, 20, 21, 21, 223

Dog rose, 128, 129, 251

Dotted haw, 67, 68, 235

Downy cinquefoil, $86,87,243$

Drosera, 4

intermedia, 5, 6, 217

rotundifolia, 5, 7, 218

Droseraceae, the Sundew Family, 4

Dwarf cinquefoil, 86, 87, 242

Dwarf red blackberry, 149, 149, 260

English hawthorn, 64, 65, 235

European gooseberry, 27, 28, 225

European wood strawberry, 75, 75, 238

False violet, 69, 69, 236

Field strawberry, 75, 76, 238

Filipendula, 70

rubra, 70, 71, 236

ulmaria, 70, 71, 237

Flowering raspberry, 147, 148, 259

Foamflower, 36, 37, 229

Four-seeded vetch, 196, 196, 275
Fragaria, 72

vesca ssp. americana, 74, 75, 237

vesca ssp. vesca, 75, 75, 238

virginiana, 75, 76, 238

Garden currant, 30, 31, 227

Garden lupine, 172, 269

Garden mock orange, 22, 23, 224

Geum, 77

aleppicum, 78, 79, 239

canadense, $79, \underline{80}, 239$

laciniatum, $81,81,240$

macrophyllum, 82, 82, 240

rivale, $80,83,241$

virginianum, 82, 84, 241

Golden saxifrage, 17, 18, 222

Gooseberry, 23

bristly, 28, 29, 226

European, 27, 28, 225

prickly, 26, 26, 224

round-leaved, 30, 31, 227

Ground-nut, 158, 159, 263

Hairy vetch, 195, 197, 276

Hamamelidaceae, the Witch-hazel Family, 37

Hamamelis, 38

virginiana, 38, 39, 230

Hardhack, 151, 152, 262

Haw, 66

dotted, 67, 68, 235

scarlet, $\underline{6} 6,66$

Hawthorn, 59

Brainerd's, 62, 63, 233

English, 64, 65, 235

variable, $64,65,234$

Hog peanut, 156, 157, 263

Hop-clover, 186, 187, 272

Indigo, wild, 161, 161, 264

Juneberry, 52

conmon, 54, 55, 231

mountain, 56, 57, 232

Large-leaved avens, 82, 82, 240

Lathyrus, 166

latifolius, 167, 167, 267

Leafy-fllowered blackberry, 141, 141, 256

Leguminosae, the Pea Family, 154

Lespedeza, 168

capitata, 168, 170, 268

procumbens, 169, 169, 268 
Live-forever, 14, 15, 221

Locust, black, 180, 182, 183, 272

Long-spined thorn, 63

Lotus, 170 corniculatus, 170, 171, 269

Low pasture rose, 123, 129, 252

Lupine, 172

$$
\begin{aligned}
& \text { garden, 172, } 269 \\
& \text { wild, } 173 \\
& \text { pinus, } 172 \\
& \text { perennis, } 173 \\
& \text { polyphyllus, 172, } 269
\end{aligned}
$$

Lupinus, 172

Meadowsweet, 70

broad-leaved, I5I, I52, 261

Medic, black, 173, 174, 174, 270

Medicago, 173

Iupulina, 174, 174, 270

sativa, 175, 175, 270

Melilotus, 176

alba, 177, 179, 271

officinalis, 178, 179, 271

Mitella, 19

diphylla, 19, 20, 222

nuda, 19, 20, 223

Mock orange, 22

garden, 22, 23, 224

Mountain-ash, 109, 116

american, 116, 117, 118, 248

showy, 119, 120, 249

Mountain blackberry, 136, 137 , 255

Multiflora rose, 130, 131, 253

Naked bishop's-cap, 19, 20, 223

Naked-flowered tick-trefoil, 163, 165,266

Northern dewberry, 140, 140, 256

Norway cinquefoil, 88, 89, 243

Old-field cinquefoil, 91, 92, 244

Orpine Family, 10

Panicled tick-trefoil, 165, 166, 266

Pasture rose

low, 128, 1229, 252

tall, 129, 132, 254

Peach, 93, 99, 100, 246

Pea Family, 154

Peanut, hog, 156, 157, 263

Pea, perennial, 166, 167, 167, 267
Pear, 109, 119, 120, 121, 2'+9

Penthorum, 20 sedoides, 20, 20, 223

Perennial pea, 166, 167, 167, 267

Philadelphus, 22 coronarius, 22, 23, 224 floridus, 22

Pitcher-plant, 2, 3, 217 family, I

Plaited-leaved dewberry, 148, 260

Platanaceae, the Sycamore Family, 41 Platanus, 44 orcidentalis, 42, 43, 44, 230

Plum, 93 Canada, 95, 96, 245

Podostemaceae, the Riverweed Family, 8 Podostemales, 8

Podostemum, 8 ceratopiyllum, 8, 2, 218

Pointed-leaved tick-trefoil, 265, 277, 277

Potentilla, 84

argentea, 85, 86, 242

canadensis, 86, 87, 242

intermedia, 86, 87, 243

norvegica, $88,89,243$

recta, $89,90,244$

simplex 91, 92, 244

tridentata, 91, 92, 245

Prickly gooseberry, 26, 26, 224

Prunus, 93

nigra, 95, 96, 245

pensylvanica, 97, 98, 246

persica, 99, 100, 246

pumila, 100, I0I, 247

serotina, 101, 103, 247

virginiana, 105, 107, 248

Purple avens, 80, 83, 241

Purple chokeberry, 114, 115, 250

Purple raspberry, 145, 146, 258

Pyrus, 109

americana, 116, 117, 118, 248

communis, 120, 121, 249

decora, 119, 120, 249

floribunda, 114, 115, 250

malus, $111,112,250$

melanocarpa, 114, 115, 251

Queen-of-the-meadow, 70, 71, 237

Queen-of-the-prairie, 70, 71, 236

Rabbit's-foot clover, 187, 188, 273

Raspberry

black, 146, 147, 259 
Raspberry (cont.)

flowering, 147, 148, 259

purple, 145, 146, 258

wild red, 142, 144, 257

Red clover, 189, 190, 274

Ribes, 23

cynosbati, 26, 26, 224

glandulosum, 26, 27, 225

grossularia, 27, 28, 225

hirtellum, 28, 29, 226

lacustre, 29, 30, 226

rotundifolium, 30, 31, 227

rubrum, 30, 31, 227

triste, 32, 33, 228

Riverweed, 8

Robina, 180

pseudo-acacia, 180, 182, 183, 272

Rosa, 122

canina, 128, 129, 251

carolina, 128, 129, 252

micrantha, 130,252

multiflora, 130, 131, 253

palustris, 132, 133, 253

rubiginosa, 132, 133, 254

virginiana, 129, 132, 254

Rosaceae, the Rose Family, 46

Rosales, 9

Rose, 122

dog, 128, 129, 251

floribunda, 130, 131, 253

low pasture, 128, 129, 252

swamp, 132, 133, 253

tall pasture, I29, I32, 254

Roseroot, 13, 14, 220

Rough avens, 82, 84, 241

Rough-fruited cinquefoil, 89, 90 , 244

Round-headed bush-clover, 168, 170, 268

Round-leaved gooseberry, 30, 31, 227

Round-leaved sundew, 5, 7, 218

Round-leaved thorn, 62, 63, 233

Round-leaved tick-trefoil, 165, 165,267

Rubus, 134

allegheniensis, 136, 137, 255

canadensis, 138, 139, 255

flagellaris, 140, 140, 256

frondosus, 141, 141, 256

hispidus, 142, 142, 257

idaeus ssp. melanolasius, 142, 144,257
Rubus (cont.)

laciniatus, 144, 145, 258

$\mathrm{x}$ neglectus, 145, 146, 258

occidentalis, 146, 147, 259

odoratus, 147, 148, 259

plicatifolius, 148, 260

pubescens, 149, 149, 260

signatus, 149

Sarracenia, I

purpurea, 2, 3, 217

Sarraceniaceae, the Pitcher-plant

Family, 1

Sarraceniales, I

Saxifraga, 33

pensylvanica, $34,35,228$

virginiensis, 35, 36, 229

Saxifragaceae, the Saxifrage Family, 17

Saxifrage, 33

early rock, 35, 36, 229

family, 17

golden, 17, 18, 222

swamp, 34, 35, 228

scarlet haw, 66,66

Sedum, 10

acre, 11, 12, 219

albun, 12, 13, 219

rosea, 13, 14, 220

sarmentosum, 13, 14, 220

telephium ssp. purpureum, 14, 15, 221

ternatum, 16, 16, 221

Shadbush, 52

smooth, 56, 58, 232

Showy mountain-ash, 119, 120, 249

Silvery cinquefoil, 85, 86, 242

Skunk currant, 26, 27, 225

Smooth blackberry, 138, 139, 255

Sorbaria, 150

sorbifolia, I50, 150, 261

Spatulate-leaved sundew, 5, 6, 217

Spiraea, 150

latifolia, 151, 152, 261

tomentosa, 151, 152, 262

Stonecrop, 10

creeping, 13, 14, 220

ditch, 20, 21, 223

mossy, 11, 12, 219

white, 12, 13, 219

wild, 16, 16, 221

Straisberry, 72

American wood, 74, 75, 23 ?

barren, 153, 153, 262 
Strawberry (cont.)

European wood, 75, 75, 238

field, 75, 76, 238

Sundew, 4

family, 4

round-leaved, 5, 7, 218

spatulate-leaved, 5, 6, 217

Swamp rose, 132, 133, 253

Sweetbrier, 132, 133, 254

small-flowered, 130, 252

Sweet clover, 176

white, 177, 179, 271

yellow, 178, 179, 271

Sycamore, 42, 43, 44, 230

Tall agrimony, 51, 52, 231

Tall pasture rose, 129, 132, 254

Thin-leaved thorn, $\underline{63}, 64,234$

Thorn, 62

long-spined, 63

round-leaved, 62, 63, 233, 234

thin-leaved, 63, 64

Threadfoot, $8,2,218$

Three-toothed cinquefoil, 91, 92, 245

Tiarella, 36

cordifolia, 36, 37, 229

Tick-trefoil, 163

Canadian, 164, 166, 265

naked-flowered, 163, 165, 266

panicled, 165, 166, 266

pointed-leaved, 265, 277, 277

found-leaved, 165, 165, 267

Trailing bush-clover, 169, 169, 268

Trefoil, bird's-foot, 170, 171, 269
Trifolium, 185

agrarium, 186, 187, 272

arvense, 187, 188, 273

hybridum, 188, 189, 273

pratense, 189, 190, 274

repens, 192, 192, 274

Tufted vetch, 194, 195, 275

Two-leaved bishop's-cap, 19, 20, 222

Variable hawthorn, 64, 65, 234

Vetch, 194

four-seeded, 196, 196, 275

hairy, 196, 197, 276

tufted, 194, 195, 275

Vetchling, 166

Vicia, 194

cracca, 194, 195, 275

tetrasperma, 196, 196, 275

villosa, 196, 197, 276

Violet, false, $69,69,236$

Waldsteinia, 153

fragarioides, 153, 153, 262

White avens, $79,80,239$

White clover, 192, 192, 274

White sweet clover, 177, 179, 271

Wild bean, 158

Wild indigo, 161, 161, 264

Wild lupine, 173

Wild red currant, 32, 33, 228

Wild red raspberry, 142, 144, 257

Witch-hazel, 38, 39, 230

family, 37

Wood strawberry

American, 74, 75, 237

European, 75, 75, 238

Yellow avens, 78, 79, 239

Yellow sweet clover, 178, 179, 271 

